Szegedi Tudományegyetem, Bölcsészettudományi Kar, Történettudományi Doktori Iskola, Medievisztika Program

Kovács Tamás

\title{
Restitutio imperii
}

- Az Anicius család szerepe másfél évszázad legitimációs törekvéseiben -

Témavezető: Dr. Galamb György PhD egyetemi docens 


\section{TARTALOM}

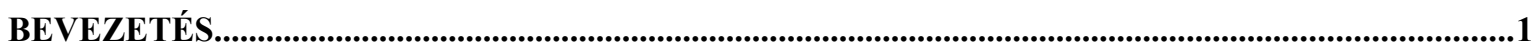

1. HISTORIOGRÁFIA: PROBLÉMÁK ÉS FORRÁSOK..................................................................

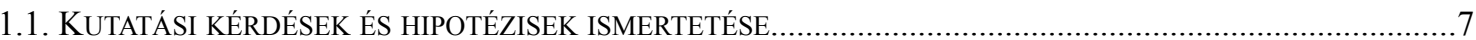

1.1.1. Győzelem hadi siker nélkül.............................................................................................

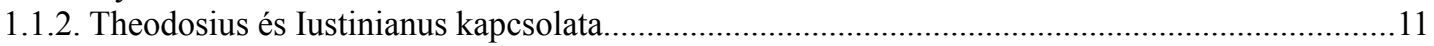

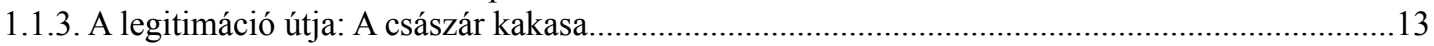

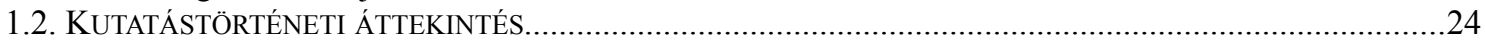

1.2.1. A nacionalizmus hatása a német kutatói szemléletre...............................................................24

1.2.2. A római-gót kapcsolatok a történetírásban...........................................................................27

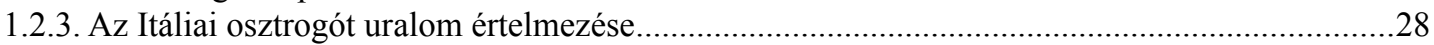

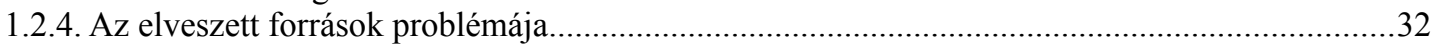

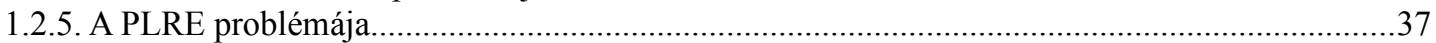

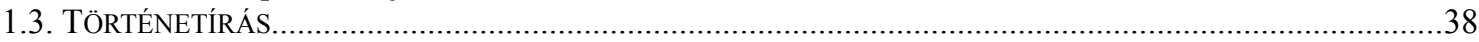

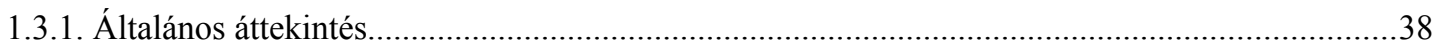

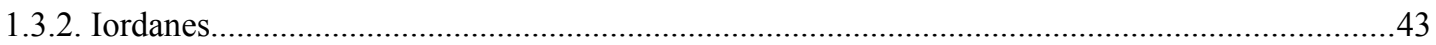

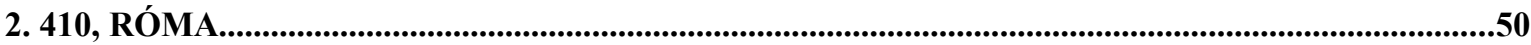

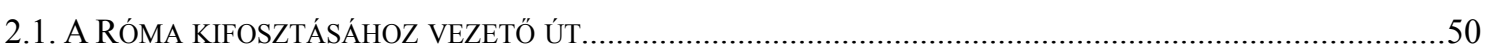

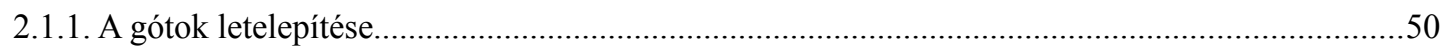

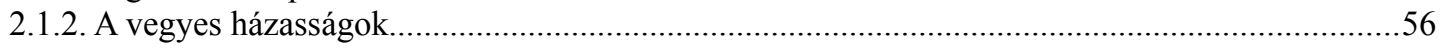

2.1.3. A vegyes házasságok tiltása...............................................................................................57

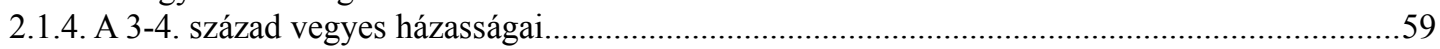

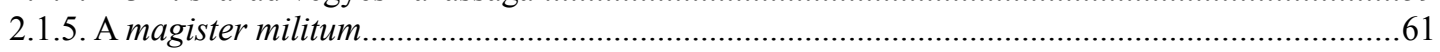

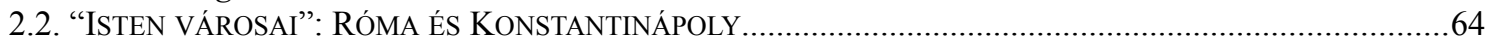

2.2.1. Galla Placidia és Athaulf házasságának képe a kortárs történetíróknál........................................68

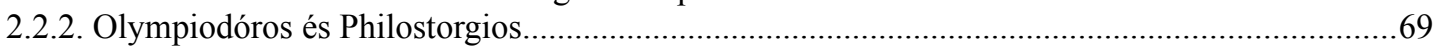

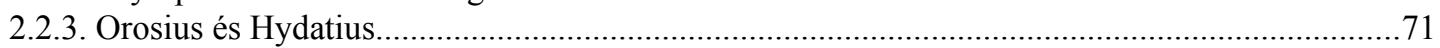

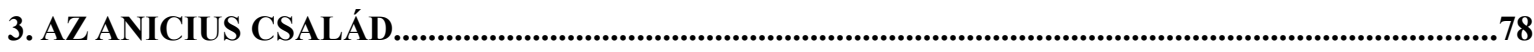

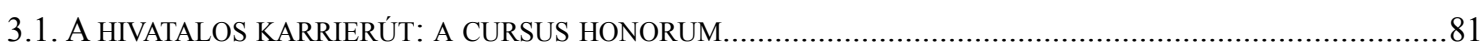

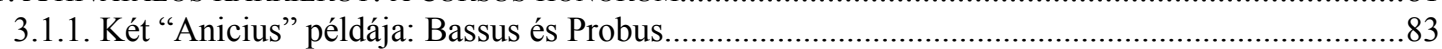

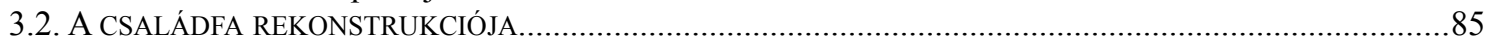

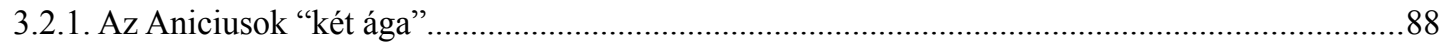

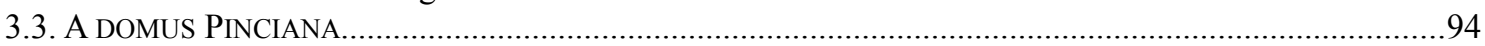

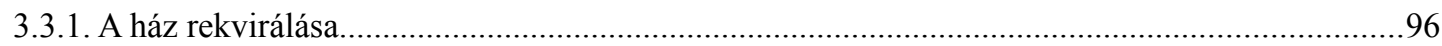

4. 455: A THEODOSIUS-DINASZTIA FOLYTATÁSA...............................................................................99

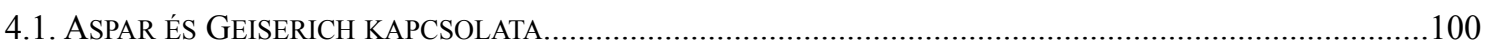

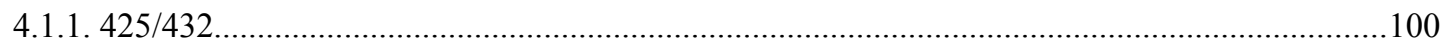

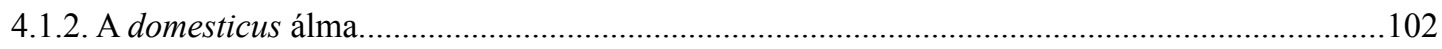

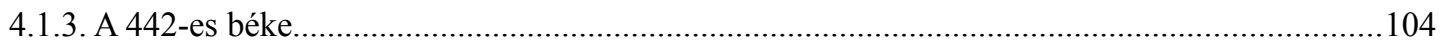

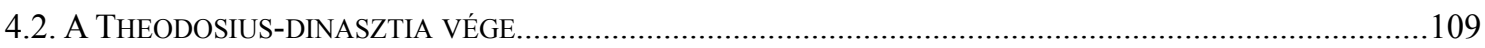

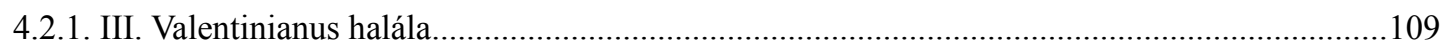

4.2.2. Valentinianus "egyik" lányának "házassága"........................................................................112

4.2.3. Az „elrablás"

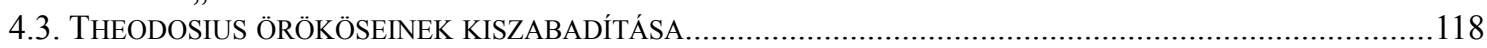

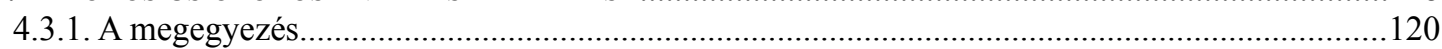

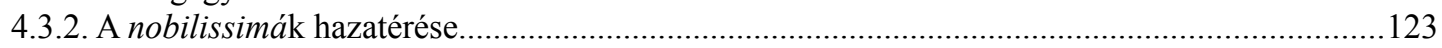

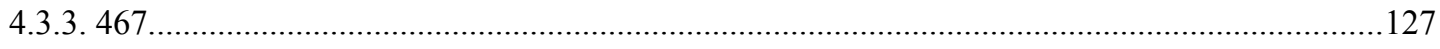

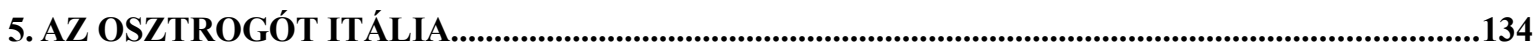

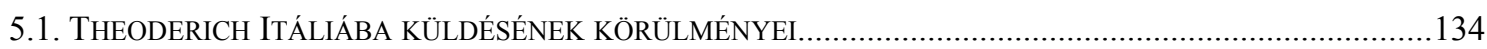

5.1.1. Tárgyalások Zeno és Theoderich között..................................................................................136 
5.1.2. Az itáliai uralkodás ,elismerése”: Az anastasiusi feltétel...................................................139

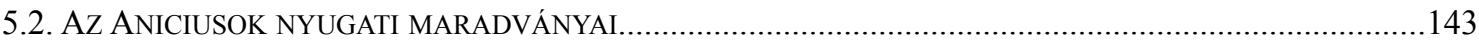

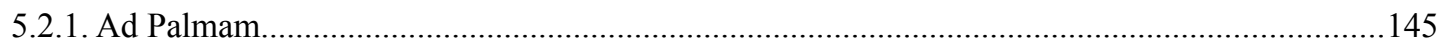

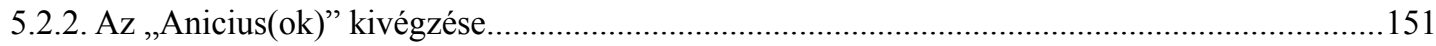

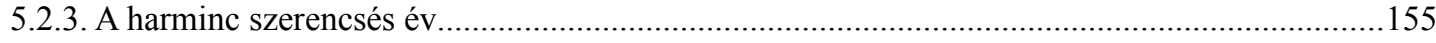

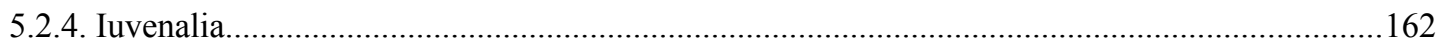

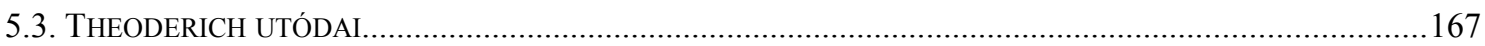

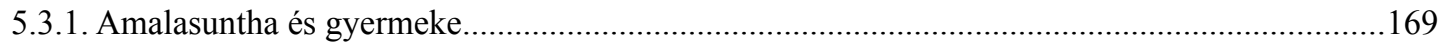

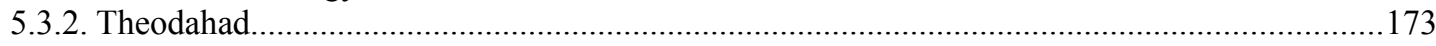

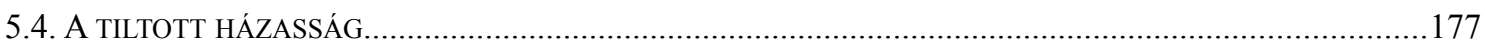

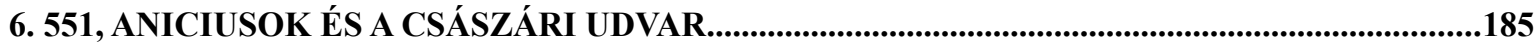

6.1. IUSTINUS ÉS IUSTINIANUS HATALOMRA KERÜLÉSÉNEK KÖRÜLMÉNYEI........................................186

6.2. AZ ANICIUSOK KONSTANTINÁPOLYBAN.............................................................................192

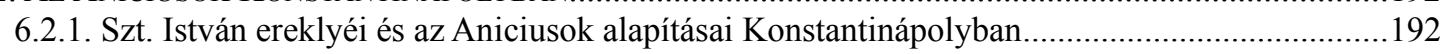

6.2.2. A Szt. Polyeuctus és Iustinianus......................................................................................195

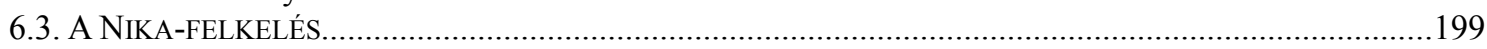

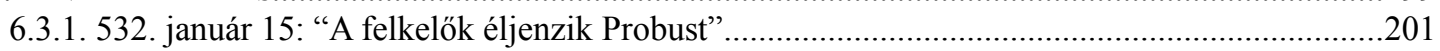

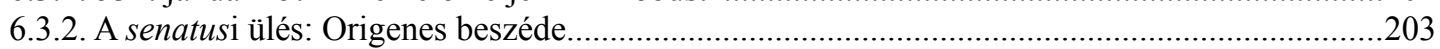

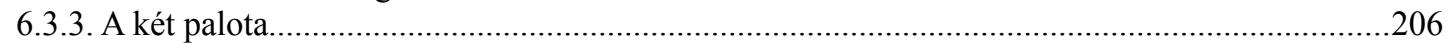

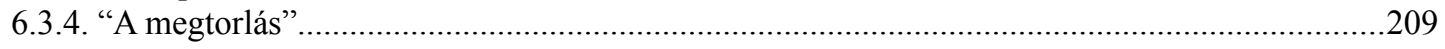

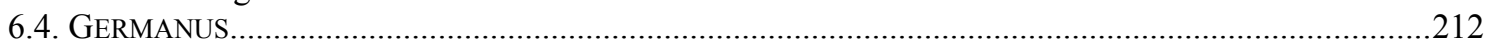

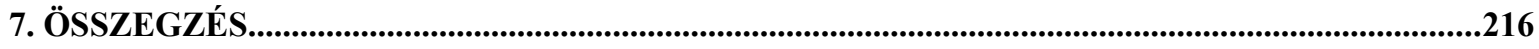

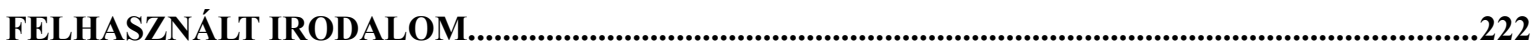




\section{BEVEZETÉS}

A Nyugatrómai Birodalom bukásának körülményei a kezdetek óta izgatja a kutatók fantáziáját. Napjainkra aligha akad olyan tényező, amelyet ne tettek volna már felelőssé a bukásért: területi felosztás; növekvő infláció; demográfiai hanyatlás; kereszténység felvétele; munkaerőhiány vagy éppen a beözönlő barbárok betelepítése. Az elmúlt évtizedek, sőt évszázadok egymást érő monográfiái napjainkra már szinte végeláthatatlannak tünnek, az elméletek mégis mindössze két fö nézet mentén rendeződnek. Az angolszász történetírás Gibbon nyomán arra helyezkedett, hogy a birodalom egész egyszerüen rossz alapokra építkezett, amely a kezdetektől magában hordozta a váratlan összeomlás lehetőségét, ami végül a germánok beözönlésével be is következett. ${ }^{1}$ Ezzel szemben a német történetírás - nem utolsósorban nemzeti megfontolásból - azt igyekezett hangsúlyozni, hogy a germánok nem lerohanták a Nyugatot, hanem szervezett betelepítések révén idővel fölénybe kerültek az őslakosok felett, amit mi sem bizonyít jobban, minthogy a római intézmények és jogrendszer még évszázadokon keresztül zavartalanul müködtek. ${ }^{2}$ De ahogyan a bukás okaiban, úgy annak dátumában sem uralkodott és uralkodik egyetértés. A tetrarchia bevezetésétől kezdődően aligha van olyan jelentős dátum, amit még ne tettek volna meg korszakhatárnak, miközben felmerült annak is a lehetősége, hogy egyetlen évszám helyett talán helyesebb egy hosszan elnyúló fejezetről beszélni, amely végül átvezetett a középkorba.

1 A 18. század végén Edward Gibbon gondolkodását jobbára korának ideológiai vonulatai határozták meg, ennek megfelelően a bukás okait az erkölcsi hanyatlásban fedezte fel. Követve Symmachus gondolatát úgy vélte, hogy a bukásért végső soron a kereszténység okolható, amely elfordította az arisztokrácia figyelmét az államügyektől a transzcendencia irányába (GIBBON 1776). Az angolszász történészhez hasonlóan Váczy Péter is abban látta a hanyatlás okait, hogy az arisztokrácia túlzottan várta Krisztus második eljövetelét, helyüket pedig fokozatosan a beköltöző barbárok vették át (VÁCZY 1935). Napjainkban is többen látják a bukás okait a germánok beözönlésében, így például Peter Heather, aki a hunok okozta népvándorlási hullámban látja a bukás okait (HEATHER 2006), akárcsak a régész Bryan Ward-Perkins, aki kimutatta, hogy a germánok tömeges megjelenését követően a civilizációs fejlettség fokmérőjeként is használt cserépedények eloszlásában törés keletkezett, ennélfogva nem a birodalom, hanem a római civilizáció esett el (WARD-PERKINS, 2006).

2 A kontinuista történetírás 1971-ben vette kezdetét Peter Brown The World of Late Antiquity: From Marcus Aurelius to Muhammad c. munkájával (BROWN 1971), ám a nézet széles körben csak a Brill kiadó Transformation of the Roman World nevet viselö sorozatával vált, amelynek első kötetét Walter Pohl jegyzi (POHL 1997). Két évtizeddel Brown után, Alexander Demandt arra helyezkedett, hogy a Római Birodalom befogadó volt, ami elsősorban jogállamiságából következett, hiszen ennek keretei között bármely nemzet tagjai polgárjogot nyerhettek, amennyiben tiszteletben tartották a római törvényeket (DEMANDT 1989A). De a békés együttélés mellett tette le voksát Patrick Geary is, aki a „Meroving világ” kialakulásáról írott 1988-as könyvében a galliai határvidék példáján keresztül bizonyítja, hogy a határ korántsem jelentett éles váltóvonalat azon népek körében, akik a különböző oldalain éltek (GEARY 1988). 
Kétségtelenül a legjelentősebb választóvonalnak 476. szeptember 4-e bizonyult, amikor Odoacer a ravennai palotában megfosztotta hatalmától a tízes évei elején járó Romulus Augustulust. A Marcellinus comes krónikájára építkező szakmunkák nyomán a dátum később korszakhatár jelentőségüvé vált, majd észrevétlenül, egy szinte áthatolhatatlan fallá alakult, amelyre hivatkozva, az adott kor politikai ideológiának megfelelően mindenki megtalálta a maga igazát. A korszakhatár azonban mindig egy történészi konstrukció, miközben a kor embere talán fel sem fogta a szeme előtt kibontakozó változás jelentőségét, de felfedezhetett olyan szabályszerüségeket és mintázatokat, amelyek párhuzamot mutattak elődei feljegyzéseivel. Így volt ezzel Marcellinus is. Miközben sokan a birodalom végét látták a történetíró caputjában, addig véleményem szerint az auktor egy alig észrevehető párhuzamra irányítja olvasója figyelmét, amelyet körüljárva a késő antikvitás dinamikájának egy fontos mozgatórugójára lehetünk figyelmesek. A korszak kutatói nem tulajdonítottak különösebb jelentőséget annak, hogy a Iustinianus udvarában alkotó szerző közvetve a szkír Odoacert is gótnak nevezte, pedig ezzel a 6. századi politikai gondolkodás egy fontos aspektusára mutatott rá. ${ }^{3}$

A népek homogenizálása korántsem számított új gyakorlatnak a 6. század derekán, hiszen jobbára akkor használja egy történetíró, ha konfrontálódni kényszerül a vele szemben álló kultúrával. Marcellinus valójában az antik örökségből, mindenekelött Hérodotos munkájából merített, aki a görög-perzsa háború történetét egy több népet érintő általánosítással kezdi. Tudni vélte ugyanis a háború okait. Elbeszélése azonban nem a perzsákkal, hanem a phoinikiaiakkal kezdödik. A történet szerint a phoinikiaiak hajóján egy alkalommal, amikor azok Argosban kereskedtek, megjelent Ió, a király leánya, akit rövid tanakodást követően az őt kísérő asszonyokkal egyetemben elraboltak. Egy nemzedékkel az argosi események után még mindig nem perzsákat, hanem trójaiakat találunk. Hérodotos szerint ugyanis éppen az efféle történetek indították arra Parist, hogy maga is Hellászból raboljon asszonyt. De azt is tudni véli, hogy ezek közül a barbárok közül az első ismert személy nem is perzsa, hanem a lüd Kroisos (i. e. 560 - i. e. 546) volt, ${ }^{4}$ aki egy félreértelmezett jóslat és egy elvesztett háború okán végül kénytelen volt fejet hajtani a perzsa II. Kyros (i. e. 559 - i. e. 530) seregei előtt. ${ }^{5}$

Hérodotosnál a „mi és ők” mentén elbeszélt történet alapvetően a különbségek, az ellentétek hangsúlyozására szolgál, amely végső soron konfliktusban tetőzik. A Iustinianus

\footnotetext{
3 MARC. COM. 476.2. "Hesperium Romanae gentis imperium, quod septingentesimo nono Vrbis conditae anno primus Augustorum Octauianus Augustus tenere coepit, cum hoc Augustulo periit, anno decessorum regni imperatorum quingentesimo uigesimo secundo, Gothorum dehinc regibus Romam tenentibus."

4 HDT. 1.6.

5 HDT. $1.88-89$.
} 
udvarában alkotó Marcellinus szóhasználata éppen erre a felosztásra irányítja rá olvasója figyelmét, amit csak megerősít azzal a kijelentésével, miszerint a kis Augustulus eltávolításával elveszett a birodalom nyugati (Hesperium Romanae gentis imperium) fele, amely az első augustus (primus Augustorum) óta töretlenül tartotta magát. Éppen ebben a második gondolatban rejlik a korabeli politikai gondolkodás esszenciája, hiszen Augustulusszal szemben Octavianus egyeduralma a birodalom egészére kiterjedt. Marcellinus pedig az azóta eltelt fél évezred során alig néhány uralkodót illetett ezzel a címmel, ezek a császárok pedig a birodalom felosztásáig mind egyeduralkodóként jelennek meg. A birodalom első császárát, a Valentinianus-dinasztia tagja, Gratianus követi, aki kiskorú öccse mellett gyakorlatilag egyeduralkodó volt néhány évig. 379-ben társcsászárává tette Theodosiust, aki elődje halála utána maga is egyedül igazgatta a birodalom egészét. Változásra 395-ben, Theodosius halálos ágya mellett került sor, mikor a császár felosztotta birodalmát fiai között. ${ }^{6} \mathrm{Az}$ idősebbik Arcadius a birodalom keleti, míg az ifjabbik Honorius a birodalom nyugati területeit kapta meg. A felosztást követően Marcellinus csak a birodalom keleti uralkodóinak esetében alkalmazza az augustus címet, Theodosius gyermekeinek esetében azonban még így is kivételt tesz. Egyiküket sem nevezi augustusnak, minden bizonnyal származásuk miatt, ugyanis mind Arcadius, mind Honorius apjuk korábbi, dinasztikus kapcsolatokat nélkülözö házasságából születtek. Galla Placidiát ellenben, ${ }^{7}$ aki a birodalom nyugati felén, a kiskorú Honorius mellett régensként uralkodott augustaként nevezi meg. Theodosius lánya ugyanis a császár második, Gallával kötött házasságából született, így a családjában egyedül ö, valamint leszármazottai (III. Valentinianus és lányai, Eudocia és Placidia, valamint Iusta Grata Honoria) rendelkeztek Valentinianus-dinasztiabeli felmenőkkel. Ennélfogva a birodalom területi feletti legitimáció is csak a család tagjain keresztül valósulhatott meg. Weber hatalomról alkotott értelmezésben legitimnek számít egy uralom, ha az adott társadalom elfogadja azt. ${ }^{8}$ Ennek alapját a késő antikvitásban a dinasztikus kapcsolat jelentette, amely nem feltétlenül jelentett vérségi kapcsolatot. A tetrarchia idejében bevett szokássá vált, hogy a caesarok a dinasztia nevét illesztették a saját nevükbe, vagy egyszerüen csak kicserélték a saját nemzetégnevüket. Az elgondolás mögött hasonló elv húzódhatott, mint az adoptio során, amikor a gensen kívülálló személy került a nemzetségbe, így létrehozva egy fiktív leszármazást. ${ }^{9}$ Ebben az esetben

\footnotetext{
MARC. COM. 395.3. „Arcadius et Honorius germani utrumque imperium divisis tantum sedibus tenere coeperunt".

„Placidia mater Valentiniani Augusta nuncupata est."

WEBER 1987, 221-225.

Ennek megfelelően Diocletianus caeasarja, Galerius Maximus, a C. Galerius Valerius Maximianus, míg Maximianus caesarja az M. Flavius Valerius Constantius nevet kapta, így két mesterséges dinasztia, a C. Valerii (signo Iovii) és az M. Valerii (signo Herculii) jött létre.
} 
névcserélés elsődleges célja az uralkodó osztály külső reprezentációja volt. De természetesen a dinasztikus vérségi kapcsolat állt az uralkodói legitimáció első helyén.

Hogy Marcellinus mennyire tudatosan nyúlt a hérodotosi mintához, azt jól mutatja, hogy Iustinianus háborújának előzménytörténete is bővelkedett az asszonyrablásokban, ezek azonban szorosan kapcsolódtak az Itáliát éppen uraló dinasztia tagjaihoz és így a birodalom egésze feletti legitimációhoz. 410-ben előbb a vizigótok dúlták fel Rómát és hurcolták magukkal Galla Placidiát, annak érdekében, hogy nyugati uralkodásukat biztosítsák. Negyvenöt évvel később hasonló célok vezették a vandál Geiserich-ket, aki hajójának fedélzetén Eudociával és Placidiával hagyta el a Rómát, akiket csak hosszas alkudozás árán sikerült visszaszereznie a konstantinápolyi kormányzatnak. 540-ben látszólag ismét a görögök diadalmaskodtak, amikor Matasunthát, Nagy Theoderich unokáját hurcolták el Itáliából. Az Amal-dinasztia utolsó leszármazottjának elrablása egyben az osztrogót uralkodó dinasztia végét is jelentette. Az események mellett kivétel nélkül egy római nemzetség neve bukkan fel. A gens Anicii tagjait rendre megtaláljuk a lányrablások fősodrában. Prokopios szerint 410-ben a vizigótok az Anicius család egyik tagjának segítségével jutnak be Rómába. Több keletrómai forrás szerint III. Valentinianus 455-ben elhurcolt lányainak egyike már házasságban, de legalábbis jegyben járt a gens Anicii egyik tagjával. Matasunthát pedig egy olyan személy vette feleségül Konstantinápolyban, aki Iordanes szerint maga is Anicius volt. Ezek az egybeesések talán nem véletlenek, talán éppen ez a család jelenti a kapcsolatot a korábbi, Itáliát is uraló dinasztiákkal. Értekezésemben az előbb említett három esküvő történetén keresztül szeretnék választ adni arra a kérdésre, hogy valójában mi, pontosabban kik jelentették a valódi legitimációt a birodalom számára.

A késő antikvitás bármely részterületének kutatása rendkívül szövevényes, ami elsősorban a gazdag forrásbázisnak köszönhető. A látszólagos hátrány azonban egyúttal előny is, hiszen a források gazdag motívumrendszere és az alig észrevehető intertextuális utalások remek és egybefüggő olvasatokat adnak. Napjaink történészeihez hasonlóan az antik auktorok is lándzsát törtek azon nézet mellett, amellyel a rómaiak és barbárok közötti kapcsolatot magyarázták. Prokopios és keletrómai udvar környezetében alkotó társai, a nagy elődeik - Hérodotos és Thukydidés - nyomán elsősorban feloldhatatlan civilizációs különbségeket láttak a gót és római nép kapcsolatában. Ezzel szemben a „kontinuista” Iordanes és más, a birodalom nyugati félén alkotó társa úgy vélte, hogy a barbárok nem lerohanták a birodalom nyugati felét, hanem egész egyszerüen új hazát és oltalmat keretek, akárcsak a városuk vesztett trójaiak. Miközben ez a két történetírói pólus a maga ideológiája mentén magyarázta az eseményeket, addig az egyházi auktorok különböző kinyilatkoztatások és kommentárok nyomán egyre biztosabbak voltak abban, 
hogy a végítélet napja már közel jár. A források ezen hármas tagolása teszi rendkívül bonyolulttá a korszak értelmezését, mégis adódik egy közös pont, amelyhez jobbára csak formailag, de tartották magukat az egyes történetírók. Ez pedig az a jóslat, melynek alapvetéseit Prokopios örizte meg, $\mathrm{s}$ melyet az első fejezetben fogunk tárgyalni. A dolgozat első oldalain a korábban már vázolt összefüggéseket helyezem 6. századi kontextusba. Majd az ezt követő kutatástörténetben elsősorban a korábbi egyetemes monográfiákat ért ideológiai hatásokat kívánom bemutatni, annál is inkább, mert ezek napjainkban is töretlenül meghatározzák az egyes értelmezéseket. A fejezet végén röviden ismertetem a források kapcsolódási pontjait és látni fogjuk, hogy a mitológiai utalások más történetíróknál is jelen vannak változatlan céllal.

A második fejezetben az első házasság körülményeinek elemzését olvashatjuk, de azt is látni fogjuk, hogy a vegyes házasságok korántsem számítottak kirívó esetnek a korban. Az egyházi történetírók mindenesetre az ószövetségi Dániel próféciájának beteljesedését látták Galla Placidia és Athaulf házasságában, amely formailag rokon vonásokat mutat a Prokopiosnál megőrzött hagyománnyal.

A harmadik fejezetben részletesen bemutatom az Anicius családot és kijavítom a hibás családfákat, amelyek a későbbiekben, így Theodosius-dinasztia nyugati ágának kihalása és az osztrogótok itáliai politikájának tárgyalása kapcsán is fontos szerephez jutnak majd.

A negyedik fejezetben a második asszonyrablásra és a Theodosius-dinasztia leszármazottaira helyeződik a hangsúly. Itt szembetűnő, hogy a keletrómai források a dinasztia férfiágának kihalása után mekkora bizonytalanságról tanúskodnak, legalábbis ami Valentinianus lányainak jegyesi vagy házassági kapcsolatát illeti. Marcellinus szóhasználatának elemzése kapcsán látni fogjuk, hogy III. Valentinianus halála után, keletrómai szempontból, az 5. század zavaros időszakának nyugati uralkodói csupán statisztaszerepet játszhattak az események menetében.

Az ötödik fejezetben, az osztrogótok itáliai uralkodásának legitimációja kapcsán ismét kitapintható lesz a források bizonytalansága. A keletrómai történetírók továbbra sem tudják megfelelően magyarázni és eltakarni Zeno azon hibás lépését, amellyel Itáliába küldte az osztrogótokat, akik Theoderich vezetésével és a császári rendelkezéssel összhangban birtokba vették a félszigetet. A fejezet tárgyalása során látni fogjuk, hogy 30 évvel megérkezése után hogyan vált Theoderich a keletrómaiak szemében trónbitorlóvá és - a római törvényekkel összhangban hogyan tudta megtartani hatalmát. Az évek elörehaladtával azonban az osztrogótok hatalomgyakorlásának mozgástere egyre csak csökkent, amit Theodahad kísérelt meg új alapokra helyezni, egy nyugaton maradt Anicius leszármazotton keresztül. 
Az utolsó fejezetben, Iustinianus uralkodásának eseményei kapcsán látni fogjuk a korábbi események és kapcsolatok kiteljesedését, ami végül megteremti az alacsony származású császár számára a birodalom mindkét felét érintő, egyetemes legitimációt. Reményem szerint egy olyan új olvasattal járulhatok hozzá az 5-6. század tanulmányozásához, amely segít megérteni számos apró és eddig megmagyarázhatatlannak tűnő kérdéseket. 


\section{HISTORIOGRÁFIA: PROBLÉMÁK ÉS FORRÁSOK}

\subsection{Kutatási kérdések és hipotézisek ismertetése}

\subsubsection{Győzelem hadi siker nélkül}

543-ban, a körülményekre való tekintettel, meglehetősen szokatlan lépésre szánta el magát a konstantinápolyi udvar. Miközben Itáliában a harcok még javában tartottak, a palota és a Hagia Sophia székesegyház közé a késő antikvitás minden bizonnyal legmagasabb győzelmi emlékművét emelték. ${ }^{10} \mathrm{~A}$ rézlemezekkel borított oszlop egy hatlépcsős márvány talapzaton állt, tetején Iustinianus lovasszobrával. A császár a mitológiai hős, Thetis istennő és a hős Péleus gyermekének, Achilleusnak a páncélját viseli pávatollas sisakkal. Fegyvertelen kezével Perzsia irányába mutat, bal kezében a földkerekséget szimbolizáló glóbuszt tartja, amelynek immár teljesen urává lett. ${ }^{11} \mathrm{Az}$ emlékmüről beszámoló Prokopios Achilleus páncéljának említésével egyértelmű utalás tesz a trójai mondakörre, és talán az emlékmü felavatásának időpontja is arra utal, ugyanis éppen egy évtizeddel korábban indultak el Konstantinápoly kikötőjéből Belisarius seregei a vandál királyság felé, hogy az egykor elszakított területeket ismét a császár uralma alá vonják. Homéros művében, mint ismeretes, ugyancsak a tizedik év bizonyult sorsfordítónak, hiszen a görögöknek ekkor sikerült bevenniük Trója városát. A 6. században azonban korántsem a hősi eposz mintájára alakultak az események. Belisarius ugyan a vandálok felett már 534-ben győzelmet aratott, azonban a császár gótokkal vívott háborúja közel sem alakult ilyen sikeresen, a félszigeten dúló harcok ugyanis egészen az 550-es évek elejéig elhúzódtak. Így felmerül a kérdés, hogy ha az emlékmű felállítására egyértelmủen nem a csatamezőn szerzett végső győzelem adott okot, akkor mégis mi indokolhatta elhelyezését keletrómai főváros legkitüntetettebb pontján már az 540-es

10 GURlitt 1912, 44, Gerola 1931, 273 MAJESKA 1984, 237-239, Az oszlop pontos magassága ismeretlen. Cristoforo Buondelmonti 70 könyökre (cubitus) tette, ami közel megegyezik a korábbi császárok emlékmüveivel, hiszen Traianus oszlopa 38,4 méter, Marcus Aureliusé 39,72 méter, Constantinusé pedig 35 méter volt. Buondelmonti azonban azt is közli, hogy ez csak csupán az oszlop a mérete, amelyre a szobrot helyezték, továbbá azt is közli, hogy az oszlop egy talapzaton állt. Maljeska orosz utazókról írott müvében - Buondelmontin kívül - végigveszi azokat az orosz utazóknak a számadásait, amelyek még eredeti pompájában láthatták Iustinianus szobrát. A beszámolók hatalmas emlékmüről számolnak be, amely már a kikötőtől messze, a nyílt tengeren is magára vonta az utazók figyelmét. Figyelembe véve az emlékmüvet körülvevő épületek méretét, így például a Hagia Sophia 56 méteres magasságát, valamint a hajósok alacsony perspektíváját minden bizonnyal csak az oszlop volt 35 méter. Jobbára Cornelius Gurlitt is ez az elgondolás vezethette az 1912-es rekonstrukció megalkotásakor, hiszen vázlatán az emlékmü talapzata és a lovasszobor csaknem együttesen olyan magas, mint az oszlop.

11 PROCOP. AED. 1.2.11. 
évek elején.

A kérdés megválaszolásában - a mitológiai hivatkozáson túl - különös jelentősége van egy alig észrevehető utalásnak, amelyet a korszakkal foglalkozó kutatás következetesen figyelmen kívül hagyott, és ami jelen dolgozat gerincét adja. Ez pedig nem más, mint az emlékmű alapjául szolgáló ló története és az általa szimbolizált összefüggések sorozata. Iustinianus lovának eredetével kapcsolatban már a korabeli történetírók véleménye is megoszlott, noha az eltérés csak abban mutatkozott meg, hogy a Theodosius-dinasztia mely tagjának állított emlékhez tartozott. Malalas szerint a szobor eredetileg a Theodosius fórumán, a Forum Taurin állt, és a keletrómai Arcadius császárt (395-408) ábrázolta. ${ }^{12}$ Marcellinus ezzel szemben arról számol be, hogy a fórumon már 390-ben volt egy szobor, amelyet a dinasztiaalapító Nagy Theodosiusnak állítottak, ${ }^{13}$ sőt egy későbbi szöveghelyen azt is megemlíti, hogy 447-ben egy földrengés következtében ennek kivételével a Forum Tauri valamennyi szobra megsemmisült. ${ }^{14}$ A szobrot a század végén, a tartószerkezetek hibája miatt ideiglenesen eltávolították, majd Anastasius uralkodása után ismét visszakerült eredeti helyére. ${ }^{15}$ A kérdést egy 15. századi mügyüjtő, bizonyos Ciriaco de’ Pizzicolli gyüjteményében felbukkanó vázlat dönti el, melyen a "THEO | DOSI” felirat látható. Ennek értelmében az emlékmű eredetileg Nagy Theodosiusnak állíthatott emléket. ${ }^{16}$

A szobrok újrafelhasználása kapcsán az utóbbi évtizedekben többen felhívták a figyelmet a spolia kettős, történeti és müvészettörténeti értelmezés problematikájára. ${ }^{17}$ Mindenképpen említést érdemel a jelenség, mert esetenként téves értelmezéshez vezet. A müvészeti és történeti megközelítés közötti különbség elsősorban a jelentésvesztésben fogható meg. A latin spolium főnév lenyúzott állatbőrt, zsákmányolt ruhát, fegyverzetet vagy más holmit jelent. A 16. században azonban a múvészettörténet is alkalmazni kezdte, ám korántsem ugyanabban az értelemben, ahogyan azt a latin használja. A spolia elöször egy 1510-ben alkotó firenzei kanonok, bizonyos

12 A 6. század elején, amikor követek érkeztek a császári városba, az Aranykapun áthaladva, az oszlopokkal szegélyezett úton előbb Forum Taurira vezető hatalmas diadalív alatt haladtak el, amit két oldalról Honorius és Arcadius szobrai támasztottak, uralkodásuknak megfelelöen Honorius nyugati irányba, Arcadius pedig keleti irányba tekintett. A forum középpontjában Theodosius oszlopa állt, ami a császár gótok felett aratott katonai győzelmét hirdette.

13 MARC. COM. 390.3

14 MARC. COM. 447.1 vö. 480.1. Az is elképzelhető, hogy 447-ben leomlott, de restaurálták.

15 MARC. COM. 480.1, MARC. COM. 506, 512.5 Theodosius szobrának helyére Anastasius császár állíttatta saját szobrát, amit azonban az 510-es lázadások alkalmával leromboltak. JANIN 1950, 69-72, CROKE 2010, 259. Janin szerint ez ugyanaz a szobor lehetett, Croke szerint a szobor még a Nika-felkelést követően is állhatott.

16 NicEPH. GREG. Hist. BYz. 1.7.12, az oszlop sokáig fennmaradt, még Niképhoros Grégoras is beszámol róla. A szoborról készült metszetet Budapesten őrzik, elsőként Rodenwaldt publikálta 1923-ben. Lásd részletesen DEWING 1940, 395.

17 Frey 2016, 17-19, DeY 2012, 298-307, KINNEY 2001, 138, WARD-PERKINS 1999, 225-244. 
Francesco Albertini Rómáról szóló leírásában akkor kerül elő, amikor a szerző arról értekezik, hogy a Sixtus-kápolna porfírkőzet oszlopai a Diocletianus fürdöböl kerültek új helyükre. Kilenc évvel később egy, a pápának írott levelében Raffaello már arról kesergett, hogy a Constantinusi diadalív 4. századi alkotásai a nyomába sem érhetnek azoknak a spoliáknak, amelyek a 2. századból származnak. ${ }^{18}$ A 16. században a spolia alatt tehát a korábbi korból származó (lehetőleg klasszikus) újrafelhasznált dombormüveket értették. A kifejezés elsősorban a múvészettörténeti szakmunkákban mai napig örzi ezt a szük értelmezést. Ezzel szemben a modern szakmunkák már három kategória mentén közelítik meg a kérdést. Nem mindegy ugyanis, hogy mi volt az újrafelhasználás vezérlő elve: a gazdaságosság, az esztétika vagy esetleg az ideológia. Az újrafelhasznált elem típusa egyúttal meghatározta a felhasználás mikéntjét is. Egy egyszerü márványtömb aligha volt alkalmas ideológiai célok kifejezésre. Bár ezzel kapcsolatban már 1984ben érdekes felfedezésre jutott Bryan Ward-Perkins, kimutatta ugyanis, hogy az 5-6. századi konstantinápolyi és ravennai építkezéseknél a frissen kifejtett és megmunkált márványtömbök mindig az épületek felső részénél kerültek beépítésre, míg az újrafelhasznált elemek alul, az utcafronton kaptak helyet azzal a céllal, hogy a hajdani korok dicsőségét idézzék az egyszerü járókelők emlékezetébe. ${ }^{19}$

Az újrafelhasználással kapcsolatban jellemző példa Constantinus diadalíve, amelynek kapcsán az utóbbi években már több kutató is arra a következtetésre jutott, hogy az emlékmü újrafelhasznált elemei valójában ideológiai funkciót töltöttek be, arra sarkallva nézőjét, hogy Constantinust a közelmúlt híres császárainak sorában láttassa. Pensabene és Panella levezette, hogy a diadalívben felhasznált 2. századi domborművek és szobrok az elődökkel történő azonosulás, a legitimációs igény, és nem utolsósorban a dinasztikus nagyravágyás kifejeződései. ${ }^{20}$ A 20 . század végén amellett érveltek, hogy a diadalívhez felhasznált dák hadifoglyok nem a Traianus fórumról kerültek az emlékmüre, ezzel kapcsolatban néhány éve Meischberger, a DAI munkatársa bizonyította, hogy egy márvány depóból kerültek átszállításra. ${ }^{21}$ A Constantinus diadalív elemeit tehát ízlés szerint válogatták össze. Breat Brenk találó antropológiai hasonlattal, a kannibalizmussal vonta párhuzamba a dolgot, hiszen a kannibál sem azért eszi meg ellenségét, mert éhes, hanem mert azt reméli, hogy így megszerezheti áldozata erejét. ${ }^{22} \mathrm{~A}$ constantinusi példánál maradva talán

MAIER 2007, 2-8

19 WARD-PERKINS 1984, 214-217, LIVERANI 2004, 383-434. Ward-Perkins nyomán több kutató, többek között Liverani érvelt amellett, hogy a korábbi emlékmüvekről származó dombormüvek és épületelemek újrafelhasználása nem tekinthető egyszerüen gazdasági szükségszerüségnek.

20 Pensabene-PANELla 1993-94, 111-283, COATES-STEPHENS 2003, 339-358,

21 MAISCHBERGER 1997, 119-121.

22 BRENK 1987, 103. 
mindennél beszédesebb a császár saját emlékmüvén elhegyezett felirata, hiszen ha elfogadjuk azt, hogy az emlékmüvet a Mulvius-hídi csata, illetve Maxentius legyőzése ihlette, akkor azt is meg kell magyarázni, hogy a feliraton záró sorában miért többes szám (triumphis insignem) szerepel. ${ }^{23}$

A 4. századi emlékmű tehát az osztrogót uralkodók ősei felett győzedelmeskedő császárnak állított emléket. Theodosius 380-as konstantinápolyi látogatásával egyidejűleg nagyszabású építkezési program kezdődött, melynek csupán egyik eleme volt a Forum Tauri. A hispániai származású császár konstantinápolyi emlékműve számos vonatkozásban hasonlóságot mutat Traianus diadaloszlopával. Ikonográfiai szempontból szinte teljesen megegyeznek, ${ }^{24}$ de talán fontosabb további két párhuzam, melyek alapján Traianus oszlopa mintaként szolgálhatott Theodosius számára. Mindketten hispániai származásúak voltak, ugyanakkor mindkét emlékmü egy olyan nép felett aratott császári győzelmet hirdetett, amelynek tagjai Thracia területére törtek be. ${ }^{25}$ Traianusnak a 2 . század elején sikerült győzelmet aratni a dákok felett és így biztosítania a Dunai határszakaszt, míg Theodosius egységeinek a 386-ban Dunán átkelő a greuthungiakra sikerült megsemmisítő vereséget mérniük. ${ }^{26} \mathrm{~A}$ 4. század végén betörő nép első ismert királya Hermanarich (370 k.) volt, akit Iordanes az Amal nemzetséghez (nobilissimus Amalorum) sorol, ${ }^{27}$ és aki Nagy Theoderich szépapjának testvére volt. ${ }^{28}$ A konstantinápolyi udvar számára bizonyára nem financiális okok indokolták Theodosius lovának újrafelhasználását, hanem annak egyértelmúen reprezentációs célja volt. Az uralkodó fegyvertelen keze nem Perzsia, hanem a közös ellenség irányába mutatott.

Iustinianus emlékmúvének alapját egy olyan szobor adta, amely Nagy Theodosius Amalok feletti győzelmét hirdette. A fenti analógia mentén világos, hogy a császár azért használta fel 4. századi elődjének szobrát, mert 543-ban is a Hermanarich és Theoderich dinasztiája feletti győzelmet ünnepelték. Az előbbiek tükrében elmondható, hogy az 543-ban felavatott emlékmüvön a iustinianusi éra legalapvetőbb politikai üzenetének kinyilvánítása került sor. Azzal, hogy a császár Theodosius egykori lovas szobrát használta fel diadaloszlopához, nemcsak azt fejezte ki, hogy Theodosius örököseként tekint magára, hanem egyúttal az Amal-dinasztia feletti gyözelmét is

23 CIL 06.1139.

24 Ikonográfiai elemzésre lásd FAEDO 1998, 315-328.

25 ERRINGTON 2006, 145-146.

26 Heather 1996, 144-145, Philostor. Hist. eCCl. 9.8., PLRE1 379-380, "GAinas”, PLRE2 1125-1126, “Tribigildvs". Tizenhárom évvel később a gót származású ám római zsoldban álló Tribigild, aki a túlélők élén állt fellázadtak a római uralom ellen. A felkelés elfojtására egy másik gót vezért küldtek, Gainas magister militum személyében, aki gyorsan gyorsan kiegyezett a felkelőkkel és mozgalmukat saját céljaira igyekezett felhasználni. A felkelés a 4. század végi gótellenes mozgalom alapjául szolgált.

27 JORD. GET, 116.

28 JORD. GET, 79-81. A Getica alapján rekonstruál Amal családfához lásd HEATHER 1995, 147. 
hangsúlyozta.

\subsubsection{Theodosius és Iustinianus kapcsolata}

Az emlékmüállítás konkrét körülményeinek a körüljárása után fontos részletesebben is megvilágítanunk a Theodosius és Iustinianus közötti kapcsolat jellegét. Alapvetően feltételezhető, hogy a kettejük közötti viszony alapját közvetett vagy közvetlen vérségi kötelék szolgáltathatta, vagy pusztán politikai azonosulás, esetleg valamilyen rokoni kapcsolat és utóbbi kombinációja.

A Theodosius és Iustinianus politikája közötti párhuzam viszont már annál nyilvánvalóbb. Mindketten a birodalom peremterületének számító területről verekedték fel magukat a császári székbe. Pseudo-Zacharias rhétor megjegyzése, miszerint Iustinianus egyenesen egy trágyadomb mellől került a fővárosba. ${ }^{29}$ Egyikőjük sem volt ősi arisztokrata család sarja, így hatalomra kerülésüket követően kritikus jelentősége volt annak, hogy elérjék egy stabil támogató kör kiépülését. Ebben elsősorban az egyre nagyobb kiterjedéssel és befolyással rendelkező egyház jóindulatára számíthattak. Támogató bázisának megszilárdítása érdekében Theodosius első dolga volt, hogy erős, keresztény alapokra helyezze uralkodását. Ennek jegyében már rögtön megválasztása után lemondott a pogány pontifex maximus címröl. A pogány császárok közül elsőként, rögtön beiktatását követően megkeresztelkedett. Elképzelhető ugyanakkor, hogy a császár halál elötti eseményként tekintett a rítusra, mert súlyos betegsége alkalmával kérte meg Thessaloniké püspökét a szertartás végrehajtására. Ugyanakkor az egyháziak kérésére rendre jóváhagyta a pogány templomok bezáratását és keresztény templomokká alakításukat. ${ }^{30}$ Egy évvel később, 380 februárjában pedig Gratianusszal és II. Valentinianusszal közösen kiadott dekrétumában, az ún. Cunctos populosban a nicaeai kereszténység mellett foglalt állást, ami ezzel a birodalom államvallásává vált. ${ }^{31} 381$ kora nyarán az első konstantinápolyi zsinaton szentesítették a nicaeai hitvallást. Ezen a zsinaton valósult meg Konstantinápoly azon igénye is, hogy a keleti egyházak között vezető szerepet tölthessen be. A zsinat harmadik kánonja kimondta, hogy a római egyházfö után a konstantinápolyi püspököt illeti meg a legmagasabb rang a keresztény

29 Ps.-ZACH. RHET. CHRON. 8.61. A szerző a bederianai születésü Iustinusszal kapcsolatban teszi ezt a megjegyzését, aki a maurianai katonai táborban szolgált az 5. század második felében, majd a 470-es évek végén innen került a fóvárosba, ahol társaival a palotaőrség tagjaivá vált (PROCOP. ARC. 6.2.). Ezek a területek azonban egymástól karnyújtásnyira helyezkednek el.

30 MEYENDORFF 2001, 22.

31 COD. THEOD. 16.1.2. Theodosius először 380-ban novemberében ment Konstantinápolyba. WHITBY 1989. 50, 156 lj, A korábbi történeti szakirodalomban 378 szerepel, ennek oka, hogy a Chronicon Paschale hibás kronológiájára alapoznak. 
egyházban, ${ }^{32}$ ami viszont Damasus és az öt követő pápák ellenállásába ütközött. Mindenesetre Theodosiusnak ezek a szimbolikus lépései egyértelmüen szélesítették a császár hívő támogatóinak körét, ugyanakkor éppen ezek a döntései okoztak megbotránkozást a senatori arisztokrácia soraiban, akik között még jó néhányan szimpatizáltak a régi vallással.

Iustinianus vallási kérdésekben Theodosius nyomvonalán haladt. Iustinus hatalomra kerülését követően intenzív levelezés kezdődött Hormisdas (514-523) pápával. Előbb a császár, aki már hetekkel a megválasztása elött levelet küldött a pápának, melyben kifejezte szilárd elköteleződését az egyházi kérdések rendezése mellett, és támogatását kérte nem csak az egyházi ügyekben, de saját személyét és családját illetően is. ${ }^{33}$ Ezt követően 518. szeptember 7-én kelt levelében Iustinianus is megerősíti szándékát az Akakios-féle skizma rendezését illetően. ${ }^{34}$ Iustinianus és nagybátyja kiemelt jelentőséget tulajdonított annak, hogy uralkodásukat a római egyház is elfogadja. Hormisdas Iustinianusnak írt levelében biztosítja a császár unokaöccsét arról, hogy elkötelezett a családjuk mellett. ${ }^{35}$ Iustinianus aktív egyházpolitikájának köszönhetően egy évvel később véget vetettek az Akakios-féle egyházi szakadásnak, így a chalcedoni zsinat rendelkezéseit váltak általánosan elfogadottá a birodalom mindkét felében. Theodosiushoz hasonlóan a pogányok üldözése is megjelenik Iustinianus politikájában. ${ }^{36}$ Nagy Theoderich, a pápa és más egyháziak mellett, senatorokat is küldött az 520-as évek közepén Konstantinápolyba, mert a császár bezáratta az ariánus templomokat. ${ }^{37}$

A hispániai születésü Theodosius először 380 novemberében járt Konstantinápolyban, Iustinianusnak pedig még több évtizedes konstantinápolyi uralkodása során sem sikerült rendesen megtanulnia görögül. ${ }^{38}$

A 6. században a császár háborúinak elsődleges célja a birodalom területi integritásának helyreállítása volt, Iustinianus előtt Theodosius volt az utolsó uralkodó, aki - noha csak nyolc hónap erejéig - a teljes Imperium Romanum egyedüli uralkodójává vált. Még ha 395. január 17-én két részre is osztotta birodalmát, a császár halálos ágyán született döntés nem bontotta meg a keleti és nyugati részek egységét, hiszen a császár fiai kerültek egy-egy birodalomrész élére. Theodosius idősebbik fiát, Arcadiust helyezte a keleti birodalomrész élére, kisebbik fiának, Honoriusnak a birodalom másik fele jutott. A császár 395-ös döntésével a Nagy Constantinus óta töretlenül

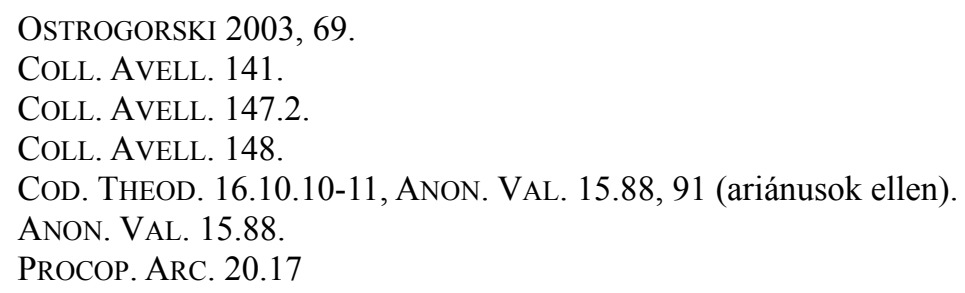


fennálló dinasztikus kontinuitás továbbra is biztosított volt, legalábbis a Theodosius-dinasztia 455ös kihalásáig. Nyilvánvaló, hogy Iustinianus alapvető döntéseiben követte Theodosius politikáját, egy dolgot viszont nem tudott felmutatni, ez pedig a dinasztikus kapcsolat 5. századi elődjével és annak uralkodóházával. Néhány oldallal korábban láthattuk, hogy Malalas és Marcellinus ellentétes állásponton volt az egykor a Forum Taurin álló szoborral kapcsolatban, de talán nem is az a lényeg, hogy kié volt a szobor, hanem az, hogy mindenképpen a Theodosius-dinasztiához kapcsolódott.

A két császár közötti kapcsolat jellegét az emlékmủ mitológiai utalásai is megvilágítják. A császár Theodosius egykori lován ült, de nem szokványos páncélt és sisakot viselt, hanem Achilleus felszerelését. A szobor ikonográfiai jelentése az, hogy mivel a császár a görög hős páncéljában jelenik meg, minden bizonnyal tetteiben is hasonlatos hozzá.

Homéros eposzában a trójaiak és a görögök háborúját, mint ismeretes, a legszebb földi asszonynak, a spártai király feleségének az elrablása váltotta ki, ez a motívum pedig mind a Theodosius-dinasztia, mind Iustinianus idejében újra felbukkan. A görög világ egy évtizedig húzódó harca tehát egy végzetes döntés, egy asszonyrablás miatt kezdődött, melyben kiemelt szerep jutott Achilleusnak, hiszen, ahogyan azt Agamemnón madárjósa is megjövendölte, a görögök az ő segítsége nélkül soha nem lesznek képesek győzedelmeskedni a trójaiak felett.

Az előbbiek tekintetében az a véleményem, hogy Iustinianus emlékmüvének mitológiai utalása a trójai háborúra vonatkozik, azon belül is az asszonyrablás motívuma lehet figyelemre méltó, hiszen Trója és a görögök harcát is éppen ez okozta. A asszonyrablás motívuma Theodosius életében még nem, de az általa alapított dinasztia idejében már megtörtént. 410-ben, Alarich ugyanis Róma feldúlása után a kincsek mellett Theodosius lányát, Galla Placidiát is magával vitte, így minden bizonnyal ez az esemény lehet az összekötő kapocs Theodosius és Iustinianus között.

\subsubsection{A legitimáció útja: A császár kakasa}

A következőekben Prokopios Háborúkról írott müvének egy caputját kívánom elemezni, ${ }^{39}$ ugyanis figyelemre méltónak tartom, hogy a vandál háborút tárgyaló kötetet nem a vandálokkal kezdi a szerző, hanem a vizigótokkal, illetve Róma 410-es ostromával. Ráadásul ennek elbeszélése során egész egyszerủen megfeledkezik Galla Placidia elhurcolásáról, és valamiért nagyobb jelentőséget tulajdonít annak a ténynek, hogy hogyan jutottak be a gótok az örök városba, mintha csak a barbárok elleni háború is ebben gyökerezne. Olvasójának gyanúját csak fokozza, hogy Róma ostromának leírása során két, egymással ellentétes történetet mesél el a város elestéről. Az elsőben

39 Procop. De Bellis. 3.2. 
a vezér ügyességének tulajdonítja a sikert, a másodikban viszont már egy római asszony "árulása" jelenik meg. A két történet között a Honorius császár különös szórakozottságáról szóló elbeszélés kap helyet. Kétségtelenül szokatlan az elrendezés, hiszen a szerző egy látszólag már lezárt történetet mesél el újra, ráadásul egyazon szakaszon belül. Éppen ezért úgy gondolom, hogy a császár különös viselkedése, valamint Alarich sikerének második története mögöttes jelentést hordoz.

A vizsgált szakaszban Prokopios archaikus etnonímekkel nem csupán klasszikus mủvekre utal, így kiemelve mondanivalójának lényegi jelentését, és elbeszélését is keretezve. A caput elején, még mielőtt hozzákezdene az ostrom tárgyalásához, felsorolja azokat a népeket (gótok, vandálok, vizigótok és gepidák), amelyek ekkor a birodalom területén éltek, ${ }^{40} \mathrm{de}$ azt is megjegyzi, hogy ezek a népek csak nevükben különböznek egymástól, tetteikben azonosak. Sőt, azt is megemlíti, hogy ezeket a népeket egykoron sauromatáknak vagy melankhlainosoknak vagy éppen getáknak nevezték, ezzel is utalva Hérodotos munkájára, amelyben ezek a nevek először feltüntek. ${ }^{41}$

Hérodotos elbeszélésében a görögökkel szemben álló barbárok szokásai meglepő hasonlóságot mutattak. Miután a szerző számot vetett a mitológiai asszonyrablások (phoinikiaiak, trójaiak) egész sorával, az általa ismert világba vezeti olvasóját, amelyben a lüd Kroisos bukását sem a véletlen, hanem egy asszony szeméremének megsértése okozza, amelyet még elödje követett el. ${ }^{42}$ De a thraciai geták értékrendje is meglehetősen hasonló volt. Lányaikra ők sem vigyáztak és azt sem bánták, ha azok idegen férfival háltak. A nép sorában a legnagyobb erényének egyébként is a rablás számított. ${ }^{43}$ Talán ezek az egyezések is kiemelt szerepet játszottak abban, hogy legyőzésüket követően mind a lüdek, mind a geták csatlakoztak a perzsa sereghez. De talán az sem mellékes, hogy ezek a népek jobbára két nép keveredéséből jöttek létre, így például a sauromaták, a szkíták és az amazonok vegyesházasságából születtek. Prokopios tehát Hérodotos nyomán, bár névleg elkülönítette a különböző népeket, szokásaik és tetteik révén elöbb-utóbb valamennyien az ismert világ perzsa, és egyúttal barbár oldalán találták magukat.

Mindezek után Prokopios egy újabb archaizáló népnevet is bevezet a taulantok szó alkalmazásával, ${ }^{44}$ amelyet mindössze két alkalommal használ a teljes korpuszban. A szóval előbb a

40 Procop. De Bellis. 3.2.1-2.

$41 \quad$ HDT. 4. 21., 4.57., 4.102., 4.110., 4.116-117., 4.119-120., 4.122-123., 4.128., 4.136. (sauromaták), HDT. 4.20., 4.100-102., 4.107., 4.119., 4.125. (melankhlainosok), HDT. 4.93-94., 4.96-97., 4.118.; 5. 3-4 (geták)

42 HDT. 1.8-14. vö. 1.91.

43 HDT. 5.5.

44 WiLKES 1992, 174-175. A taulantok fénykora az i. e. 4. századra tehető, utolsó említésükre Prokopiost megelőzően i. e. 168-ban kerül sor, így valószínüsíthető, hogy a taulantok népe már rég nem volt fellelhetö az adott területen. 
vizigótok, majd az osztrogótok tárgyalása során találkozunk, ráadásul akkor, amikor a szerző ezeknek a népeknek az Itáliába indulásáról értekezik, ezzel is erősítve a két nép közötti kapcsolatot. ${ }^{45}$ Ugyanakkor 410 tárgyalása kapcsán a caputon belül a vizigótokról megjegyzi, hogy Thraciából indultak útnak, hogy egész Európát fenyegessék, ${ }^{46}$ majd azzal zárja a caputot, hogy az osztrogótok szintén Thraciából indultak a nyugati területek meghódítására ${ }^{47}$ A két nép történetének egy mondatos, szinte szó szerint azonos leírása arra szolgál, hogy keretbe foglalja az elbeszélni kívánt történet. Prokopios ezzel, valamint a taulantok szó megfontolt használatával ismét azt érzékelteti, hogy ezek a népek csak a nevükben különböznek egymástól, tetteikben azonosak.

Prokopios hérodotosi és thukydidési allúziója az elözménytörténetek irányába mutat, amely közös vonása a jogtalan uralkodás. Hérodotos különböző népek homogenizálásával kezdi munkáját, de azt is megjegyzi, hogy az ösbünt Kandaulés testőre, Gygés követte el. Hérodotos története szerint az utolsó Hérakleida uralkodó bukását egy asszony szeméremének megsértése okozta. Kandaulés ugyanis rendszeresen kérkedett felesége szépségével. Sőt, egy alkalommal még azt is felajánlotta testőrének, hogy titkon lesse meg az asszonyt, mikor az a hálószobában megszabadul ruháitól. Az asszony azonban észrevette az őt megleső testőrt, akit másnap választás elé állított: vagy megöli férjét és őt feleségül veszi, vagy őt ölik meg. Gygés az előbbit választotta, így nemzetsége (Mermnadák) szerezte meg az uralmat. ${ }^{48}$ Delphoi megerősítette hatalmát, annyit azonban hozzátett, hogy a Hérakleidák majd bosszút állnak Gygés ötödik utódján (Kroisos). ${ }^{49}$

Hérodotoshoz hasonlóan Thukydidés története is a Hérakleidák uralkodói jogához kapcsolódik. A szerző a peloponnésosi háború előzménytörténetének elbeszélésekor az alapkonfliktus kulcsszerepét osztja a taulantokra. A történet szerint a gyarmati Epidamnosban a város növekedésével együtt a belső ellentétek is fokozódtak, mígnem a lakosok elüldözték a város arisztokráciáját, akik a közeli taulantok népéhez menekültek és segítségükkel a város megregulázásába kezdtek. ${ }^{50}$ A kétségbeesett epidamnosiak követséget menesztettek Kerkyrába, hogy gyarmattartójuktól kérjenek segítséget, próbálkozásuk azonban üres fülekre talált. A városiak ezt követően jóslatot kértek arra vonatkozóan, hogy felajánlhatják-e a várost a korinthosiaknak,

45 Procop. DE BELlis. 3.2.9. (vizigótok esetében), 5.1.13. (osztrogótok esetében).

46 Procop. De Bellis. 3.2.7.

47 Procop. De Bellis. 3.2.39-40.

48 HDT. 1.8-14. vö. 1.91.

49 HDT. 1.8-14. vö. 1.91.

50 THUC. 1.24. A 408-as római események szoros párhuzamot mutatnak a epidamnosi arisztokrácia menekülésével. Zósimos szerint ugyanis Stilicho kivégzése után több ezer gót katonát, nőt és gyermeket mészároltak le Itáliában. A túlélök Alarich-hoz menekültek, aki immár az elüldözött gótokkal kiegészülve indult Róma ellen, akárcsak a taulantokkal kiegészült arisztokrácia Epidamnos ellen. 
annál is inkább, mert a város alapítója is Hérakleida volt. ${ }^{51}$ A prokopiosi allúzió tehát két olyan előzménytörténetre mutat, amely szorosan kapcsolódik a Hérakleidák hatalmi legitimációjához. Hérodotos esetében egy asszonyrablással egybekötött hatalomgyakorlás veszi kezdetét, Thukydidés esetében pedig kiderül, hogy az epidamnosi gyarmatváros jogosan Hérakleida alapítójához tartozik.

A történetíró ezt követően elbeszéli, hogyan is vették be Alarich katonái Róma városát. Az első történet szerint miután Alarich sok időt vesztegetett az ostrommal, kitalálta, hogy csellel veszi be a várost. A seregéből összehívott háromszáz olyan fiatalt, akiknek még nem sarjadt ki a szakálla, ám kellően erősnek bizonyultak. Ezt követően beavatta őket tervébe, miszerint a város patriciusainak szánja öket ajándékként, mintha csak rabszolgák lennének. Utasításba adta a fiataloknak, hogy tanúsítsanak annyi kedvességet amennyit csak tudnak és buzgón szolgálják kijelölt urukat mindenben, de csak egy bizonyos ideig. A megjelölt napon déltájban, amikor a gazdáik az ebéd utáni sziesztájukat tartják, valamennyiüknek ki kellett mennie a Salaria kapuhoz és egy váratlan rohammal végezniük kellett az örökkel. ${ }^{52}$ Így is tettek, majd kinyitották Alarich elött a kapukat. A második történet szerint már egy arisztokrata asszony, egy bizonyos Proba nyittatta ki Róma városának kapuit. Az asszony a történetíró szerint annyira szánta Róma népét, amely már éhezett, és kannibalizmusra is vetemedett, hogy inkább megparancsolta a szolgáinak, hogy az éj leple alatt nyissák meg a kapukat a gótok előtt. ${ }^{53}$ Alapvető különbség a két történet között az időpont, hiszen míg Alarich ifjú katonái a szieszta idején, az őrök megölése után nyitották ki a Salaria kaput, addig Proba szolgái az éj leple alatt, az őrök sérelme nélkül tárják ki a kapukat, mintha nem is egy eseményről lenne szó. Az első történet kapcsán Benedicty Róbert már rámutatott arra, hogy ennek legkorábbi allúzióját Hérodotos szolgáltatja Babilon ostromának leírásakor. ${ }^{54} \mathrm{~A}$ másik történet azonban megválaszolatlan. Az asszony elárulta a várost, ennek a súlyát azonban tompítja Prokopios azzal, hogy megemlíti a római lakosok szenvedését.

A kulcsot a két történet közé ékelődő mese rejti. A szerző a ravennai udvarba kalauzolja olvasóját, ahol továbbra is megmarad a Thukydidés elbeszélésével fennálló párhuzam. Az ostromlott epidamnosiak ugyanis előbb gyarmattartójukhoz, Kerkyrához fordultak azzal a kéréssel, hogy ne nézzék közönyösen pusztulásukat, inkább próbálják meg összebékíteni öket a számüzöttekkel és vessenek véget a háborúnak. Zósimos szerint miután Alarich ostrom alá vette a

\footnotetext{
ThUC. 1.24. vö. Procop. De Bellis. 3.2.25-26.

Procop. De Bellis. 3.2.14-22.

PROCOP. DE BELLIS. 3.2.27-28.

54 BENEDICTY 1960, 76-77. A csellel bevett város különböző előzménytörténeteire lásd. uő. vö. HDT. 4.93, 4.97; 4.118 Benedicty elgondolását kiegészítheti az előszóban már látott gondolatmenet, hiszen Hérodotos leírásában a gótok elődei, a geták, nem csak szokásaikban voltak azonosak a perzsákkal, hanem éppen akkor csatlakoztak a nőrabló perzsákhoz, amikor azok Babilon ostromára indultak.
} 
várost, egy háromtagú senatusi követség indult Ravennába, amelynek Priscus Attalus is tagja volt. ${ }^{55}$ Noha Prokopios egy szót sem ejt a követségröl, a lényegi mondanivaló azonban megegyezik, hiszen a 6. századi auktor szerint a császár az egyik eunuchtól, nevezetesen a baromfiak őrzőjétől értesült Róma pusztulásáról. A uralkodói baromfik őrét akár a császári javak őrzőjének vagy comes sacrarum largitionumnak is nevezhetjük, hiszen a tisztségviselő elsődleges feladata a császári javak igazgatása volt. ${ }^{56}$ Zósimos szerint ugyanis Priscus Attalust éppen ezen látogatása alkalmával nevezte ki a császár comes sacrarum larigitionumnak. ${ }^{57}$ A hír hallatán keservesen így szólt: "Hiszen nemrég még a kezemböl evett!" 58 . A történet szerint ugyanis a császárnak volt egy nagy kakasa, amelyet, akárcsak a várost, Rómának neveztek. A meglepett „eunuch” világossá tette a császár előtt, hogy bizony nem a szárnyas, hanem a város pusztult el. A történetíró szerint, amikor a császár meghallotta, hogy a kakas életben van, megkönnyebbülten így sóhajtott fel: “Már azt hittem, barátom, hogy a kakasom, Róma pusztult el", ${ }^{59}$ és mit sem törődve a római eseményekkel folytatta napját. A leírásában szereplő császári érdektelenségében a kerkyraiakéhoz hasonló közöny tükröződik, hiszen utóbbiak szóra sem méltatták az epidamnosiakat. ${ }^{60}$ Ennél azonban különösebb a kakas, amelyet immár a kezéből etet az uralkodó.

Az előző két allúzióhoz hasonlóan Prokopios kakas motívuma is egy jóslatra utal, s ahogyan az előzőekben, most is a legitimáció kerül előtérbe. A Honorius által dédelgetett kakas ugyanis az elkövetkező uralkodás szimbóluma. A motívum a 11. század fordulóján alkotó Ióannés Zónaras munkájából fejthető vissza, aki a korai bejegyzéseit kortárs történetírók felhasználásával formálta. ${ }^{61}$ A történetíró beszámolója szerint Valens (328-378) uralkodása végén a császárhoz közel álló Libanios és Iamblichos (Proclus tanára) egy alkalommal kakasjóslást végzett, amely a következőképpen zajlott. A görög ábécé huszonnégy betüjét a porba írták, majd mindegyikre búzamagot helyeztek, ezt követően szabadjára engedtek egy kakast. A szárnyas előbb a théta, majd az epszilon, omikron és a delta betúkről csipegette fel a magot, így rajzolódott ki a „Theod” szó. Amikor a császár tudomására jutott a jóslás eredménye, minden ok nélkül összegyüjtötte azokat, akiknek a neve ezzel az öt betüvel kezdődött, így a Theodosiusokat, Theodotusokat és a Theodorusokat, valamint másokat, és egyszerüen kivégeztette őket. A történet magja Prokopios

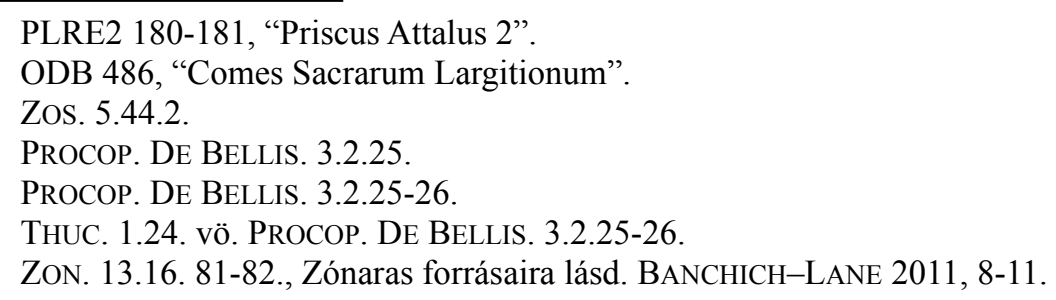


kortársánál, Theodóros Anagnóstésnál is megjelenik némileg pontosabb formában. A Hagia Sophia lektora szerint Valens azért ölte meg öket, mert azt jövendölték róluk, hogy uralkodni fognak. ${ }^{62}$

A történet archetípusát az eseményekkel kortárs Ammianus Marcellinus munkájában találjuk. A történetíró szerint befolyásos tisztségviselők egy csoportja (Fidustius, Hilarius és Patricius) jövendölés útján igyekezett megtudni Valens leendő utódjának nevét. A vádlott Hilarius szerint a jóslás a következőképpen zajlott. A delphoi háromlábú (tripus) mintájára babérfaágakból elkészítettek egy asztalkát, amelyre különféle fémekből készült kerek csészét helyeztek rá, melynek szélére az ábécé huszonnégy betüjét vésték. Egyikünk, aki a ceremóniákat jól ismerte, szerencsehozó zöld ágakkal a kezében az asztalkához lépett és verseket mormolva fohászkodott. Ezt követően meglóbált egy fonálra erősített gyürüt, ami a megjelölt közökben, ide-oda ugrálva hozzáért az egyes betűkhöz, hexameterek jöttek létre, amelyek választ adtak a föltett kérdésekre. Hilarius szerint mikor azt kérdezték, hogy ki lesz az utódja a mostani uralkodónak, az ugráló gyürü ezt a két szótagot súrolta: „Theo”, és hozzátoldotta még a következő betüt (d). A résztvevők egy ideig azon tünődtek, hogy ki múlja felül jelenleg a többieket, mígnem valaki fölkiáltott, hogy a jóslat Theodorusra értendő. ${ }^{63}$ Miután Hilarius az egész dolgot elbeszélte, hozzáfüzte, hogy Theodorus semmit sem tudott erröl. A Valens a bírák előterjesztésére kivégzéseket rendelet el, amelyek nem csak a jóslás résztvevőit érintette, hanem sokan másokat, hiszen a történet értelmében valamennyi „Theod” kezdőnevü személy veszélyes lehetett az uralkodásra.

Ammianus története a 29. könyv elején kapott helyet, amelyben a szerzö figyelme - a perzsa fenyegetés időszakos csillapodásával - az állam belső ellenségei irányába fordul. A Theodorus elleni per mintegy bevezeti id. Theodosius comes üstökösszerü karrierjét, amelynek a kötet végén váratlanul vége szakad. ${ }^{64}$ Noha Ammianus nem említi, de id. Theodosius halálát is koncepciós per okozta. A comes I. Valentinianus legfőbb bizalmasának számított. Egyre növekvő elismertsége természetszerủen udvarbeli irigyeinek számát is gyarapította, de a császár életében pozíciója biztosított volt. 373-ban Afrikába vezényelték a helyi lázadás leverése érdekében, amin sikerrel úrrá lett, azonban két évvel később, amikor I. Valentinianus tragikus hirtelenséggel elhunyt, a védőháló, amely eddig gátat vetett a Theodosius-ellenes udvari intrikáknak, eltünt. A császár helyét fia, az alig tizenhat éves Gratianus vette át, aki a hozzá közel álló udvari tanácsadók ${ }^{65}$

62 ThEOD. LECT. EPIT. 209. Anagnóstés beszámolója szerint azokat végezték ki, akiknek a neve thétával kezdődött.

63 AMM. MARC. 29.1.29-33 vö. 29.1.8. Ammianus már jóval a történet leírása elején (29.1.8) megemlíti, hogy a jóslást végző személyeknek időbe tellett rájönni, hogy ki lehet a megfelelő utód: „,atque cunctantibus, quisnam ea tempestate omnibus vigore animi antistaret, visus est aliis excellere Theodorus, secundum inter notarios adeptus iam gradum".

64 AMM. MARC. 29.5.16.

65 Elsősorban a magister officiorum Maximinus, Romanus és Petronius Probus (cos. 371) javaslatára. 
hatására koholt vádak alapján felségárulással vádolta meg az idősebbik Theodosiust. A vádlók közül a történetíró kiemeli Probust, aki szerinte ritka gyanakvó ember volt, a "Kétarcú Fortuna kegyeltjeként" hol jóindulatúnak mutatkozott, hol gonosz ármánykodónak. A Theodosius comesszel szembeni vizsgálatot gyorsan és titokban folytatták le már hetekkel Gratianus megválasztása után, a kivégzést pedig legkésőbb 376 januárjában végre is hajtották Karthágóban. ${ }^{66}$

Alapvető különbség Ammianus és Zónaras történetében a résztvevők személye és a jövendölés módja. A nevek azonban árulkodóak, és nem mellékesen szoros kapcsolatban vannak a módszerrel is. A 11. századi történetíró leírásában szereplő Iamblichost (Proclus tanára) nem találjuk a kortárs leírásokban, minden bizonnyal nem véletlenül, hiszen a szerző a diák megnevezésével kétségtelenül a neoplatonista Iamblichosra (245-325) és tanítványára Proclusra (412-425) utal. Iamblichos a 4. században létrehozta a neoplatonizmus dualista irányzatát, amely megpróbálta szintetizálni a platóni és a pythagorasi tanokat. Éppen ez jelenti a kapcsolatot a két történet között. Pythagoras követői ugyanis úgy gondolták, hogy minden dolog kulcsa megmagyarázható számokkal, éppen ezért a görög ábécé egyes betűihez is számértéket rendeltek. A jóslatban szereplö görög betük számértéke $(T \varepsilon 0 \delta=300+5+70+4)^{67}$ Theodosius társcsászári kinevezésének dátumát (379) rejti. Apja halála után ugyanis az ifjabbik Theodosius, joggal tartva a további retorzióktól, visszavonult a család galiciai birtokára, ahonnan 378-ban maga Gratianus hívta vissza, ráadásul egy évvel később (379) tárcsászárává tette, így a jóslat, noha apja végzetét jelentette, előkészítette Theodosius uralkodását. A kakassal történő jóslás módja ugyancsak ehhez a csoporthoz kötődött. ${ }^{68}$ Prokopios a történetet azzal a velős megjegyzéssel zárja, hogy bizony ily nagy volt Honorius ostobasága, hogy tudniillik összekeverte a várost a kakassal, amivel minden bizonnyal arra, utal - amellett, hogy összefüggésbe hozza a császárt az író korában államilag üldözött Platóni Akadémia tanaival - hogy a gyermektelen Honorius nyilvánvaló utódlási problémákkal küzdött.

Mindazonáltal, az előbbiek nyomán úgy vélem, hogy Prokopios által megőrzött uralkodói közöny annak tudható be, hogy uralkodását biztosítottnak vélte, de legalábbis Prokopios szemszögéből biztosított volt. Zónaras leírásában a kakas azzal jövendölte meg a Theodosiusok uralkodását, hogy a földről felcsipegette a császár nevének első négy betűjét, most viszont már Honorius tenyeréből eszik. Ezt úgy értelmezhetjük, hogy már nem a vakszerencse, hanem a császár

66 OROS. 7.33.7, DEMANDT 1969, 624-625 (datálásra). A kortárs források közül Ammianus Marcellinus, Zosimos és az ismeretlen szerzőtől származó Epitome de Caesaribus egyáltalán nem említi az idősebbik Theodosius kivégzésének tényét. Symmachus, Pacatus, Libanios, Themistios és Claudianus még az utalást is elkerüli. A kortársak közül csak Jeromos és Orosius tesz említést az eseményről.

67 AST - LOUGOVAYA, 2015, 83-84.

68 BOYANCÉ 1972, 141-143. 
kezében van dinasztia sorsa. Valóban, 410-ben, Róma kifosztása után, Galla Placidiát is magukkal vitték a vizigótok. A fogságból csak évekkel később sikerült kiszabadítaniuk a nyugatrómai csapatoknak Theodosius lányát, aki hazaérkezését követően, Honorius parancsára, Constantius senatorral kötött házasságot. A házasságból született III. Valentinianus, akivel 455-ben férfiágon kihalt a nyugati Theodosius-dinasztia.

A dinasztikus kontinuitás egy senatori családdal, az Aniciusokkal folytatódott, amikor Anicius Olybrius feleségül vette III. Valentinianus lányát, Placidiát. Ennek a családnak a fontosságát őrizte meg Prokopios második története, amely egy asszony árulásának tulajdonította Róma elestét. A történetíró szerint Proba nem azért nyittatja ki a város kapuit, mert el akarja árulni

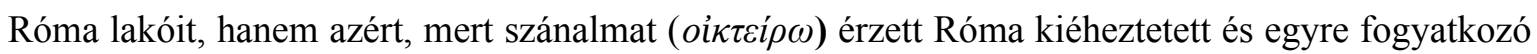
lakossága iránt, helyzetüket reményvesztettnek értékelte. ${ }^{69}$ Thukydidésnél az epidamnosi lakosok is csak azt követően fordultak a korinthosiakhoz, hogy követjárásuk zátonyra futott a gyarmattartó Kerkyránál. Prokopiosnál az asszony Latium népének biztos pusztulása helyett az egyetlen lehetséges megoldást, a fennmaradást választotta. Prokopios a thukydidési mintával szemben már nevesíti a „felajánlást tevő" Probát, aki ezáltal közvetítő funkciót nyer a történetében. Olyan személyként értelmezhetjük, aki a gótok és rómaiak közötti kapcsolatot szimbolizálja.

Prokopios szövegében már nem az asszony személyének van jelentősége, hanem nemzetségnek, az Aniciusoknak. Proba történetét Prokopios az "Egyesek azt mondják..." formulával vezeti be. ${ }^{70} \mathrm{~A}$ tartalmat tekintve ezt a ki nem mondott párhuzamot ismét Zósimos nyújthatja, aki Historia Nova című munkájában ugyancsak egy asszonynak tulajdonítja Róma "elárulását". ${ }^{71}$ Az 5. század végén alkotó auktor történetében Theodosius unokahúgát, Serenát ${ }^{72}$ gyanúsítják azzal, hogy a vizigótokat a város ellen hívta. Alapvető különbség a két asszony között, hogy míg Serenáról csupán annyit gyanítanak, hogy ő hívta a gótokat a város ellen, addig Probához már a gótok bejutása és így közvetve a két nép keveredése kapcsolódik. Ez a keveredés azonban házassága révén Serenában is megvan, és éppen ez jelenti a kettejük közötti hasonlóságot. Az asszony ugyanis Honorius unokatestvéreként feleségül ment Stilichóhoz, ${ }^{73}$ a vandál származású magister militumhoz. ${ }^{74} \mathrm{~A}$ dolog jelentőségére már Prokopios kortársa, Iordanes világít rá.

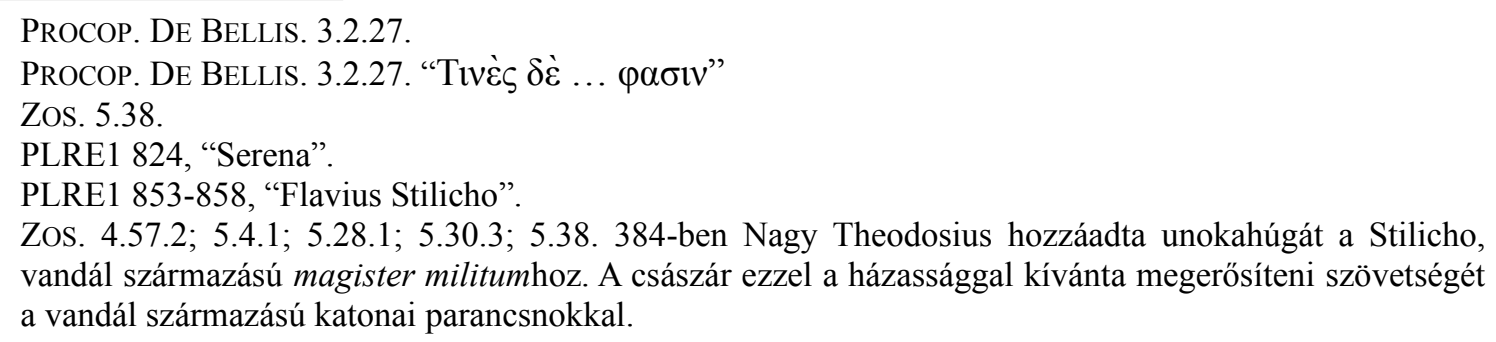
vandál származású magister militumhoz. A császár ezzel a házassággal kívánta megerösíteni szövetségét a vandál származású katonai parancsnokkal. 
Beszámolója szerint ugyanis 550-ben Iustinianus császár unokatestvére házasságot kötött Matasuntha osztrogót hercegnővel.

“Matasunthát a császár unokatestvéréhez, Germanus patriciushoz adta feleségül [...] az Anicius-nemzetség egyesült az Amallal" 75

Iordanes szerint tehát, a 6. század közepére Iustinianus unokatestvére éppen ahhoz a nemzetséghez fog tartozni, amelynek az egyik tagját Prokopios is megemlíti a Theodosius-dinasztia kontinuitását jelképező kakas után, mindezt olyan kontextusban, ami a két nép keveredésére utal. Prokopiosnál történetében tehát a császárt azért nem zaklatja fel Róma pusztulása, mert tudja, hogy Probán, illetve nemzetségén keresztül a dinasztia fennmaradása biztosított lesz. Prokopios történetében Honorius kakasa, amely immár a császár kezéböl eszik, allúzió Iustinianus 6. századi tevékenységére, amit tökéletesen mutat Galla Placidia és Matasuntha történetének párhuzama. Mindkettőjüket elhurcolják a birodalom ellenében fellépő barbárok, ám a császároknak hadvezéreik útján mindkettőjüket sikerül visszaszerezni és saját jelöltjükkel összeházasítani.

Prokopiosnál a tárgyalt caputot a vizigótok és az osztrogótok egymondatos története fogja közre, ennek a jelentősége domborodik ki ebben az értelmezésben. A történetíró ezért homogenizálta ezt a két népet, ezáltal biztosítva az olvasót, hogy a vizigótok és az osztrogótok tetteikben is azonosak. Hérodotos elbeszélésében a hellének és barbárok egy dologban biztosan különböztek, ez pedig a lányrabláshoz való hozzáállásuk volt. Utóbbiak ugyanis úgy vélték, hogy ha már egyszer megtörtént, talán helyesebb nem bánkódni, háborúzni pedig egyenesen oktalanság lenne. Nem így a hellének, akik előbb csak hasonló tettekkel válaszoltak, majd háborút indítottak. ${ }^{76}$ A fordulópontot az eseményekben Helené elrablása hozta, ami Trója tíz éves ostromához, Helené visszaszerzéséhez és a város pusztulásához vezetett. Hérodotos szerint a perzsák ettől a ponttól vallották ellenségüknek a hellén népet. ${ }^{77}$

410-ben, Róma kifosztása után, a kincsek mellett Theodosius lányát, Galla Placidiát is magukkal vitték a vizigótok. A fogságban az asszony házasságot kötött Athaulf vizigót királlyal.

75 JORD. GET. 314.: "Mathesuentham vero iugalem eius fratri suo Germano patricio coniunxit imperator. De quibus post humatum patris Germani natus est filius idem Germanus. In quo coniuncta Aniciorum genus cum Amala stirpe spem adhuc utriusque generi domino praestante promittit." A Getica magyar fordításában a fratri-t pontatlanul testvérként adták vissza a fordítók. A dolgozat későbbi szakaszában világossá fog válni, hogy Germanus a császár unokatestvére volt.

76 Előbb Ió elrablásának hatására egy csapat krétai Türoszig hajózott, ahonnan Európéval tértek haza. Nem sokra rá pedig, egy másik csapat hellén a kolkhiszi király leányát, Médeiát rabolta el. Az uralkodó erre követséget küldött Hellaszba, ahol azonban elutasításba ütközött, mivel az argosziak sem kaptak elégtételt Ió elrablásáért, így ő se várjon semmit. Ez idáig a hellének két asszonyrablást tudhattak magukénak, míg a barbárok csak egyet.

77 HDT. 1.4. 
Néhány évvel később a nyugatrómai csapatoknak sikerült kiszabadítaniuk Galla Placidiát, aki hazaérkezését követően a gyermektelen Honorius parancsára Constantius senatorral kötött házasságot. Galla Placidiához hasonló sors várt Theoderich unokájára is. 536-ban Witiges, miután magához ragadta a hatalmat, egy kisebb csapat élén Ravennába vonult és elhurcolta Matasunthát, akit nem sokkal később erőszakkal feleségül is vett. ${ }^{78}$ Néhány év múlva a keletrómai csapatoknak sikerült kiszabadítaniuk Theoderich unokáját, aki Konstantinápolyba érkezését - és Witiges halálát - követően a gyermektelen Iustinianus utasítására Germanushoz ment feleségül. ${ }^{79}$ Ezt a párhuzamot Prokopios megfontolt szóhasználata újfent megerősíti. A taulantokhoz hasonlóan a szerző a geta szót is mindössze két szöveghelyen alkalmazza, ám ezúttal egy lényegesen tágabb keretet kapunk. Első ízben a 410-es ostrom bevezető szakaszában találjuk, ezt követően azonban csak 536-ban bukkan fel, a város sikertelen osztrogót ostroma alkalmával, amely után Belisariusnak sikerült foglyul ejtenie Matasunthát és Witigest. ${ }^{80}$ Látható, hogy szinte tökéletes párhuzam felfedezhető Galla Placidia és Matasuntha házasságában, egy különbség mégis adódik. A Galla Placidia második házasságából született gyermek III. Valentinianus néven egészen 455 márciusáig igazgatta a birodalom nyugati felét, míg a Matasuntha második házasságából született Germanus postumusszal kapcsolatban ez korántsem mondható el.

Galla Placidia férjének korai halála, illetve Valentinianus kiskorúsága miatt az asszony évekig régensként uralkodott fia helyett. Matasuntha férje, Iustinianus unokatestvére ugyancsak korai halált halt, azonban az asszony a császár túszaként élt Konstantinápolyban, így ha akart volna sem gyakorolhatott régensi pozíciót. A gyermek véréhez kapcsolódó legitimáció azonban nagyon is jelen volt. Iordanes így ír erről:

“Öbenne egyesült az Anicius-nemzetség az Amallal, s ö most mindkét nép reménysége, ha az Úr élteti." $"$

A történetíró szerint a 6. század közepére az osztrogót Amal-dinasztia és a római Aniciusnemzetség házassága egyensúlyt hozhat a két nép kapcsolatába és véget vethet a háborúskodásnak. A 6. század közepére ez tehette lehetővé, hogy két nemzetség egyesülése, az Aniciusok és az Amalok házassága képes egyensúlyi helyzetet teremteni a birodalom területén. Mindezek alapján úgy gondolom, a másfél évszázad végére kialakult hatalmi legitimáció minden fél számára

\footnotetext{
$78 \quad$ PROCOP. DE BELlis. 5.11.27.

79 PROCOP. DE BELLIS. 7.39.14-15.

80 Procop. DE BELLis. 2.2.2. (első megjelenés a vizigótok esetében) vö. 5.24.29-30. (második megjelenés az osztrogótok esetében).

81 JORD. GET. 314.
} 
elfogadott közös nevezője az Anicius-nemzetség volt, eszköze pedig a házasság. Véleményem szerint Iordanes megjegyzésében az uralkodói hatalom legitimációjának egyetemesen elfogadott alapvetése rejlik. A történetíró szerint az Anicius-nemzetséggel kötött házasság, illetve az ebből született gyermek egyszerüen felmenői útján képes arra, hogy véget vessen csaknem két évtized véres összecsapásainak és egyesítse a birodalmat. Iordanes leírásából kitünik, hogy ez a házasság tabula rasát jelent a két nép kapcsolatában.

Ez a gondolat Prokopios munkájában is megjelenik, még ha kevésbé szemmel látható módon. A 6. század közepén alkotó szerző jól tudta, hogy Matasuntha elhurculása végső győzelmet jelentett az osztrogót Itália felett, amelyet nem csak a thukydidési Epidamnos allúziójával tárt olvasója elé, hanem a geta szó precíz használatával is, amely keretezte a vizigótok és az osztrogótok történetét. Iustinianus emlékmüvét 543-ban tehát azért emelték, mert Matasuntha személyében az Amal-dinasztia utolsó tagját sikerült Konstantinápolyba vinnie a keletrómai erőknek. Azzal, hogy Iustinianus utasítására Theodosius császár egykori lovasszobrát használták fel diadaloszlop elkészítéséhez egyértelmü kinyilatkoztatást tett amellett, hogy Theodosius örököseként tekint magára. Ugyan a közvetlen bizonyítékot még nem láthattunk arra, hogy pontosan kin keresztül is kapcsolódik Iustinianus a Theodosius-dinasztiához az már nyilvánvalóvá vált, hogy a köztes kapcsolatot az Anicius-nemzetség hordozhatja. Az emlékmủ mitológiai utalása a trójai háború történetére utal, azon belül is az asszonyrablás motívuma lehet meghatározó, amely már Hérodotosnál is jelen volt. Az 5-6. században az asszonyrablás motívuma először 410-ben a Theodosius-dinasztia idején jelenik meg Galla Placidia esetében, ugyanakkor az 530-as évek végén is történt hasonló esemény, amikor Witiges elrabolta, majd házasságra kényszerítette Matasunthát. Mindkét esetben az uralkodó vér hordozója, a dinasztia egyenes ági leszármazottja esik fogságba. Kiszabadításuk után, második házasságukat már egy rómaival kötik. Az első esetben csak felsejlik az Aniciusok képe, amit Honorius kakasának története magyaráz, a második esetben pedig in concreto kimondásra kerül, hogy az Anicius-nemzetség egy tagjával történik a házasságkötés. Prokopios 410-es leírásában szemléletesen utal a vizigótok és az osztrogótok közötti párhuzamra. A dinasztia folytonosságát jelképező kakas immár a császár kezéből eszik, ekképpen az asszonyok második házassága mindkét esetben a császár döntése volt.

Az elkövetkező fejezetek központi kérdése tehát, hogy kik voltak az Aniciusok, illetve, hogy a velük kötött házasság, hogyan teremthetett egyetemes legitimációt egy uralkodó számára a birodalom egésze felett. A kutatástörténeti áttekintés és a források alapvető kapcsolatainak ismertetését követően a meghatározó asszonyrablások történetén keresztül fogom feltárni az Aniciusok legitimációs szerepét. 


\subsection{Kutatástörténeti áttekintés}

Iordanes idézete három fő kérdést vet fel, amelyeket vizsgálat alá kell vennünk. Kik voltak az Aniciusok, illetve a velük kötött házasság, vagy éppen a velük fennálló rokoni kapcsolat hogyan teremthetett legitimációs igényeket a birodalom határain belül. Általánosságban elmondható, hogy az Anicius-nemzetség szerepe az uralkodók legitimációs törekvéseiben vakfolt a kutatásban, így hagyományos értelemben vett kutatástörténetről sem beszélhetünk. Az előzőekben már rámutattunk, hogy az Aniciusok szerepe elsősorban házasságok útján, a rómaiak és germánok közötti kapcsolatokban domborodik ki, amelyeket elsősorban a német történetírás hangsúlyozott. Ezért mindenekelött a német történetírást ért ideológiai befolyásról kell beszélnünk, amely még valamivel a 20. század felén túl is éreztette hatását.

\subsubsection{A nacionalizmus hatása a német kutatói szemléletre}

A nacionalizmus a 19. század elejétől a 20. század közepéig jelentőst hatást gyakorolt a német történetírásra és az ebben a rendszerben felnövekvő kutatói generációkra, amely így ebből a szemszögböl közelítette meg a germán - római kapcsolatok kutatását, jelentősen befolyásolva az értelmezést. A következőekben a német nacionalizmus ismertetésén keresztül szeretném megvilágítani a szakirodalomban rejlő torzulások okát.

A 19. században a német nacionalizmus egyik központi munkájának Jacob Grimm (17851863) filológiai munkája számított. Napjainkban nevéről többeknek a testvérével kiadott hét kötetes mesegyűjtemény jut eszébe, noha Grimm nyelvészként, irodalom- és jogtudósként a 19. században kibontakozó német nacionalizmus egyik központi alakja volt. Akadémiai székfoglalójának címe "Liebe zum Vaterland", melyben egy latin kifejezés elemzése során arra jutott, hogy mindenhol ahol germán nyelvet beszélnek vagy beszéltek, az Germania. ${ }^{82}$ A német hazaszeret a Monumenta Germaniae Historica 1819-es alapítását is áthatotta. A német történelem legfontosabb forrásainak kiadásául szolgáló sorozat címerében ugyanis a "Sanctus amor patriae dat animum" feliratot találjuk. ${ }^{83}$ Az alapító Heinrich Friedrich Karl vom und zum Stein (17571831) és Johann Friedrich Böhmer (1795-1863) fejében a patria nem Németországot, hanem a Habsburg birodalmat jelentette, ${ }^{84}$ a 19 . század elején Németország ugyanis nem mint politikai

\footnotetext{
LEERSSEN 2006, 119-126, 145-158, GEARY 2014.

LEERSSEN 2006, 143.

WOOD 2008, 69, JONG 1996, 63-72.
} 
egység, hanem mint kulturális entitás értelmezödött, így a német befolyás és kulturális övezet határai lényegesen tágabbak voltak, miközben Itália nem volt több, mint földrajzi fogalom. ${ }^{85}$

A 19. század második felében helyzet alapjaiban változott meg. Előtérbe kerültek a barbárokkal foglalkozó történeti kutatások, valamint annak kérdése, hogy a késő antikvitás germán népeinek története vajon meghatározhatóvá teszik-e az akkori Németországot. A váltás oka az 1870-ben kirobbant porosz-francia háború volt, melynek jogosságát a német történészek megkísérelték alátámasztani. Jacob Grimm már 1848-ban amellett érvelt, hogy Schleswig-Holsten területének az új germán állam keblében lenne a helye, hiszen bizonyos nyelvjárásbeli jellemzöi arra mutatnak, hogy a területen élők az egykori germán népek leszármazottai, ${ }^{86}$ így 1870-ben Alsace (a későbbi Elzász) elfoglalása után Mommsennek nem kellett messzire nyúlnia az igazolásért, hiszen a területen élők nyelve (Elsässerditsch) egy felső-alemann dialektusból kialakult nyelv volt. ${ }^{87}$ A porosz-francia háború végén, az 1871-ben létrejövő német egység nyomán a nacionalizmus még inkább előtérbe került.

A 19. század végén intézményesedni látszott a nézőpont. 1875-ben a teutoburgi erdő közelében fekvő Detmold településén hatalmas szobrot állítottak a nemzeti hősként tisztelt Arminiusnak, aki 9-ben visszaverte Varus légióit. Az esemény szimbolikus jelentőséggel bírt, hiszen a porosz-francia háború kirobbanása után a franciákat a propagandagépezet gyakorta hasonlította Varus-féle betolakodóknak. ${ }^{88}$ Miután Felix Dahn befejezte germán királyokról, ${ }^{89}$ valamint Prokopiosról írott munkáját, ${ }^{90}$ hozzálátott a monumentális Ein Kampf um Rom c. történelmi regényéhez, amely öt évvel a német egység megvalósulása után, 1876-ban jelent meg. A történész és publicista az 5-6. századi germánokról az a túlzottan leegyszerüsített képet rajzolta meg, hogy a hanyatló rómaiak felett a győzedelmes germánok veszik át az uralmat. A német egység okozta eufóriában Dahn munkájának hatása felerősödött. 1876-tól a német történészek érdeklődése a korábbi politikailag semleges témák irányából a germán népek Európára gyakorolt hatására tevődött át. 1875-ben kezdték meg az MGH új sorozatának az Auctores Antiquissiminek a

85 ISBELL 1994, 1-9, WOOD 2008, 69. A kutatástörténet ezen szakaszában a filológia és a kora középkori jog kutatása kapott kiemelt szerepet.

86 LEERSSEN 2006, 183-1.

87 WOOD 2008, 73.

88 MARChAND 1996, 159, 12. lj., KULIKOWSKi 2007, 47, FRÖHLICH 2008, 185.

89 DAHN 1861-1908 (Die Köngige der Germanen). Dahn tizenegy kötetes munkájának első hat kötete 1871-ig megjelent és a Das Wesen des ältesten Königthums der germanischen Stämme und seine Geschichte bis auf die Feudalzeit alcímet víselte, míg 7-11. kötetek 1894-ben indultak Das Wesen des ältesten Königthums der germanischen Stämme und seine Geschichte bis zur Auflösung des karolingischen Reiches alcímmel.

90 DAHN 1865 (Prokopius von Cäsarea. Ein Beitrag zur Historiographie der Völkerwanderung und des sinkenden Römerthums). 
munkálatait, amelynek első kötetei 1877-ben jelenhettek meg. Az új sorozatban már tematikus bontásban vizsgálták azokat a forrásokat, amelyek a Római Birodalom germánok lakta területein születtek, így az Auctores Antiquissimi részét képezte a rómaiak és gótok itáliai együttélését tárgyaló Variae is. ${ }^{91}$

1914-ben Németország lerohanta Belgiumot. Bár a támadás pillanatában Jacob Grimm már ötven éve halott volt, szellemisége továbbra is jelentős hatással volt a kor gondolkodóira. 1915-ben Karl Lamprecht (1856-1915), noha fö kutatási területe a német gazdaságtörténet volt, Drezdában tartott előadásában amellett érvelt, hogy a flamandok etnikailag a germánokhoz tartoznak, így Németország fellépése jogos és szükséges, amikor flamandokat elnyomják a Belgium területén élő francia ajkú vallonok. ${ }^{92}$ A 20 . század első harmadában a német nacionalizmus egyre csak erősödött, mígnem a második világháborúban elérte csúcsát. ${ }^{93}$

1940 szeptemberében Siegfried Fuchs (1903-1978), az Abteilung Rom des Deutschen Archäologischen Instituts (DAI Rom) igazgatóhelyettese egyik memorandumában így emelte ki a német kutatások irányvonalát:

“Végső soron az egész programnak arra kell törekednie, hogy kiemelje a germán világ a mai olasz kultúrában és nemzetben játszott döntö szerepét. Meg kell mutatnunk a germánok és a rómaiak közötti keveredés és kultúra mélységét és történelmi értékét; meg kell vizsgálnunk ezeket a történelmi körülményeket, és hangsúlyoznunk kell a germán elem fontosságát."

Fuchs memoranduma remekül mutatja a német kutatás hozzáállását a germán-római kapcsolatokhoz, amely meghatározta a 20. század első felének akadémiai irányvonalát. Az ezekben az időkben kialakult német tudományos diskurzus hatása még az '50-es évek tudományosságán is érződött, ami nyomot hagyott az ekkor keletkezett doktori disszertációkban is. ${ }^{95}$

91 Wood 2013, 174-176. 1898-ig tizenhárom kötet látott napvilágot, amelyek közül Mommsen szerkesztette a Geticát, a Variae-t, valamint további három krónikát.

92 WoOD 2008, 73. Lamprecht 1915. március 4-én tartott elöadást Über Belgien. Nach geschichtlichen und persönlichen Erfahrungen címmel, melynek teljes szövege a következö linken érhető el: http://www.zum.de/psm/1wk/lamprecht.php.

93 FRÖHLICH 2008, 183, WOOD 2008, 77. Az 1920 októberében megalapított Deutsche Forschungsgemeinschaft (DFG) a kezdetekben azokat a kutatásokat támogatta, amelyek az egykori germán településtörténetet kutatták. A nácik hatalomra kerülését követően pedig teljesen kiszolgálták a hatalom igényeit. 1937 és 1943 között a Deutsches Archäologisches Institut (DAI) római intézete 60200 birodalmi márkát (RM) biztosított az osztrogót és langobard kutatásokra, ami mai értéken valmivel több mint 430000 eurónak felel meg.

94 Archiv des Deutschen Archäologischen Instituts, Abteilung Rom (ADAIR I), Germanische Hinterlassenschaften id. FRÖHLICH 2008, 198.

95 KULIKOWSKI 2007, 48-49., WeNSKUS 1961. Paradigmaváltásra csak jóval a második világháború lezárását követően került sor 1961-ben Reinhard Wenskus Stammesbildung und Verfassung címmel megjelent monográfiájával, amely már nem a német nemzettel megegyező, homogén csoportokként ábrázolta a germánokat, hanem azok polietnikus voltára hívta fel a figyelmet. Wenskus tézisének 


\subsubsection{A római-gót kapcsolatok a történetírásban}

A 19. századtól a 20. század közepéig, elsősorban a már említett nacionalista szemlélet következtében prekoncepciók egész sora rögzült a német történetírásban, amelyek elsősorban a germán-római kapcsolatok értelmezését és az uralkodói legitimációt érintették. Ezeknek az elméleteknek a többsége igen hosszan hatott, sőt néhányuk még napjainkban is töretlenül tartja magát. Jellemző példaként említendő, hogy az osztrogótok itáliai jogállásával és berendezkedésével kapcsolatban sem uralkodott egyetértés. Ez a bizonytalanság pedig valamennyi kapcsolódó kutatásban kifejtette hatását, így nyomott hagyott a gót-római kapcsolatokat vizsgáló munkákon is. $^{96}$

A második világháborús német történetírás a Siegfried Fuchs által is kinyilvánított nyomvonalon haladt akkor, amikor a 410-es évek fö forrásaként szolgáló Orosiust belekényszerítette az Eusebios-féle hagyományba és kijelentette, hogy Orosius Ágostonnal ellentétes szemléletet képvisel, hiszen nála nem különül el élesen a civitas terrena a civitas deitől. ${ }^{97}$ Ez alól üdítő kivételt jelent Diesner, Fabbrini, O’Daly és Nuffelen munkája, amelyek éppen Orosius fölényét hangsúlyozzák Ágoston munkájával szemben, hiszen neki már nem célja, hogy Róma történelmi sorsát elválassza a vallástól. ${ }^{98}$ A német kutatók többsége igyekezett erősíteni azt a nézetet, hogy Ágoston azért hallgat Orosius munkájáról, mert teljességgel elvetette a hispániai pap értelmezését és az Isten városának későbbi könyveiben arra törekedett, hogy megcáfolja Orosius értelmezését. ${ }^{99}$ Orosius kedvezőbb volt a korai német történetírás számára, hiszen míg Ágoston magyarázkodik 410-ről, addig Orosiusnál már korántsem szerepel központi helyen Róma kifosztása. Sőt, Orosius említi meg a vizigót Athaulf kereszténnyé válását is, aki már arra is képes, hogy házasságot kössön a császár lányával.

A 20. század második felének német kutatása, illetve az erre építkező szakirodalom így következetesen egyenrangú felekként tekintett a gótokra. Ez a nézet elsősorban Adolf Lippold

alapvetése, hogy az egyes germán törzsek leszármazását egy szük csoport, az uralkodóház (Stirps Regia) hordozza, amelynek sorsa egybeforr népe sorsával.

96 Kiterjedt kutatástörténeti áttekintést Prostko-Prostyński készített. Lásd PROSTKO-PROSTYŃSKI 1994, 3361. A fejezet elsősorban a német kutatástörténetre fókuszál, mindenesetre említést érdemel, hogy a magyar kutatásban két kutató is alaposabban foglalkozott Theoderich itáliai berendezkedésének kérdésével: Váczy Péter (1904-1994) és Várady László (1926-2013). Váczy szerint a birodalom határain belül letelepített foedusszal rendelkező népek idővel kliens-királyságokká emelkedtek (VÁCZY 1935). Az ő nézeteire építkezett Várady László álláspontja, amely szerint Theoderich állama kliens királyság volt a birodalom berkein beül, egy olyan monarchia, amelynek uralkodói a konstantinápolyi uralkodó kliensei (VÁRADY 1984, 14, 37-60).

97 Lásd. NUFFELEN 2012, 197-205. Ez a szemlélet tükröződik az alábbi munkákon: LIPPOLD 1952, 1-42, PASCHOUD 1967, 276-278, GOETZ 1980, 136-146.

98 DiesNer 1963, 102, FABBRINI 1979, 428-429, O’DALY 1990, 29, NuFFELEN 2012.

99 Ezen a nézetet képviselik a kettővel korábbi jelzetben felsorolt kutatók. 
nyomán vált széles körben elterjedtté, amely minden bizonnyal nem így történt volna, ha a kutatók többsége kézbe vette volna a szerző doktori disszertációját, melyből világossá válik, hogy Ensslin útmutatásait követte nézetei kialakításakor. ${ }^{100}$

\subsubsection{Az Itáliai osztrogót uralom értelmezése}

A német nacionalizmus befolyásának hullámzása az osztrogótok itáliai uralkodásával foglalkozó munkákon is nyomott hagyott. A fő kérdés az volt, hogy Theoderich vajon a keletrómai császár szövetségeseként, vagy alattvalójaként uralkodott-e Itáliában? Míg a 18. századi Angliában alkotó Edward Gibbon (1737-1794) monumentális munkájában még nyitva hagyta ezt a kérdést, ${ }^{101}$ addig a német történetírás elsősorban az erősödő nacionalizmus miatt már egész Itália királyaként tekintett a gót vezérre. A gondolat Georg Friedrich Sartoriustól (1765-1828) származott, ${ }^{102}$ amit előbb Rudolf Köpke (1813-1870) fogadott el. ${ }^{103}$ Sartorius nézete a politikailag felfokozott hangulatban futótüzszerüen terjedt. Ebben az időszakban az osztrogótok itáliai joghatóságának kiterjesztése a német kutatók munkáiban felülreprezentált. Köpke már úgy gondolta, hogy Theoderich királyként, Itália valamennyi lakosa felett uralkodott. ${ }^{104}$ Felix Dahn már azt a nézetet vallotta, hogy miután Anastasius elküldte a felségjelvényeket Itáliába (amelyeket az osztrogót uralkodó el is fogadott) Theoderich kinyilvánította igényét a többi germán királyságra is. ${ }^{105}$

Sartorius és Köpke támogatói elfogadták, hogy Theoderich római eredetü tisztséggel felruházva érkezett Itáliába, és úgy gondolták, hogy álláspontjukat még inkább megerősíti mindaz, amit Anonymus Valesianus ír a 493. év eseményeiről. A kérdéses részletet úgy értelmezték, hogy a gótok Itália királyává tették Theoderich-et. ${ }^{106} \mathrm{~A}$ nemzeti érzelem áthatotta a forrásértelmezést, hiszen Anonymus a megadott szöveghelyen csak annyit közöl, hogy a gótok (exercitus Gothorum) a maguk részére megerősítették Theoderich uralkodását, ráadásul mindezt a keletrómai uralkodó jóváhagyása (praesumptione regni) nélkül. Német kollégái elfogultságával szemben kitűnő példát nyújt az olasz Augusto Gaudenzi (1858-1916), aki ugyanekkor már kevésbé elfogultan szemlélte

104 KÖPKE 1859, 182, RANKE 1883. Ezzel szemben Leopold von Ranke a gótok királyának és Itália hercegének nevezte, aki a "dominus rerum" cím birtokosa.

105 DAHN 1881, 241, Dahn egy néhány évvel későbbi munkájában már ellentmondott ennek a nézetnek DAHN 1866, 162.

106 KÖPKE 1859, 182. Ezzel szemben Anonymus Valesianus csak annyit közöl, hogy a gótok a maguk részére megerősítették Theoderich uralkodását. ANON. VAL. 11.57.: "Gothi sibi confirmaverunt Theodericum regem" vö. ANON. VAL. 12.64. "Facta pace cum Anastasio imperatore per Festum de praesumptione regni".
} 
Itália kora középkori eseményeit. Vizsgálatai során arra a megállapításra jutott, hogy Anastasius ugyan elismerte uralkodótársának Theoderich-et, de alacsonyabb jogokat biztosított neki. ${ }^{107}$ Nézete szerint Anastasius Theoderich-kel kötött megállapodása kizárólag Theoderich-re vonatkozott, így utódainak hatalomra kerülésüket követően el kellett érniük Konstantinápoly elismerését. ${ }^{108}$ Bár Gaudenzi elmélete állt legközelebb a napjainkban is elfogadott szemlélethez, az előbb említett kutatók valamennyien egyetértettek abban, hogy Theoderich uralkodását szentesítenie kellett a konstantinápolyi uralkodónak. Úgy gondolták ugyanis, hogy a Római Birodalom oszthatatlanságának szemszögéből a császár továbbra is a nyugati részek uralkodója is maradt, mert arról I. Theodosius akkor sem mondott le, amikor fiai között felosztotta a birodalmat.

Mommsen sem tért le az elödei által kijelölt útról. Megközelítésének egyik alapvető vonása a római történelem egységének hangsúlyozása volt, amely tanítványaira, Otto Seeckre (1850-1921) és Ludo Moritz Hartmannra (1865-1924) is nagy hatást gyakorolt. ${ }^{109}$ Mommsen szerint Theoderich consuli beiktatását (484) követően Zeno patriciusként és magister militumként küldte Itáliába a germán hadvezért, ${ }^{110}$ továbbá úgy gondolta, hogy Odoacer és Theoderich csak a saját germán alattvalóiknak a királyai voltak, a római polgárok felett pedig mint a császár küldöttei uralkodtak, ezen felül a magister militum tisztséget birtokolták. Mommsen szerint Theoderich a császár helyetteseként uralkodott Itáliában, így joga volt a császári felségjelvények viselésére, miközben a római consul, patricius és magister militum tisztségekkel is rendelkezett, ami bővebb jogkört biztosított számára, így megválaszthatta a nyugati tisztségviselőket. A birodalom tisztségviselőjeként pedig, akárcsak elődje, Odoacer, római polgárnak számított, amit - véleménye szerint - a „birodalmi gentilicium”, a Flavius biztosított. ${ }^{111}$

107 GAUDENZI 1888, 30.

108 GAUDENZI 1888, 27-34.

109 Mommsen tevékenységéről részletes összefoglalóként szolgál CROKE 1990. munkája.

110 Mommsen 1910, 444, PROSTKO-ProstyŃSKI 1994, 34. A kutatásban csak Prostko-Prostyński kérdőjelezte meg ezeknek a tisztségeknek az érvényben maradását azt követően, hogy Theoderich megérkezett Itáliába. A forrásokban ugyanis csak a rövid életű Armatus példája áll rendelkezésre, aki élete végig viselte magister militum praesentalis tisztséget. A magistratusok ettől a kivételtől eltekintve időszakos jellegüek voltak. Mommsen véleménye szerint az osztrogót uralkodó területi minőséggel rendelkezett, tehát magister militum per Italiam volt, annak ellenére, hogy Zeno 483-ban magister militum praesentalis tisztségbe nevezte ki, ez a méltóság ugyanis csak a fővárosban állomásozik. JORD. ROM. 348, MARC. COM. 483, Forrásaink szerint Theoderich még azt követően is betöltötte a hivatalt, hogy 486-ban fellázadt Zeno ellen. A szakirodalom nem vette figyelembe, hogy Theoderich vajon ezt a pozíciót a lázadása után is birtokolta bármelyik formában is.

111 MommSEN 1910, 449, 476-477. A kutató szerint formális szempontból pozíciója hasonló volt Stilichóéhoz vagy éppen Odoaceréhez. MOMMSEN 1910, 481 vö. 477. Mommsen munkája sem mentes az ellentmondásoktól. Miközben igyekezet meghatározni Theoderich hatáskörét az osztrogótok felett, ellentmondásba került saját elméletével. Azt állította ugyanis, hogy a római magister militum nagyobb hatalommal rendelkezik a foederati csapatok felett, mint a germán király az harcosai felett, máshol ennek ellenkezőjét állította. Mivel Mommsen nem következetesen vezette le elgondolásait, a 20. század 
Mommsen Flavius címmel kapcsolatos tézisét Cameron 1988-as frappáns cikke cáfolja. Az angol kutató úgy magyarázta a Flavius megnevezést, mint egy udvariassági formulát, amit a rövidített névalakok mellett használtak. A cognomen elé beszúrt Flavius "úr" jelentéstartalommal bír. ${ }^{112}$ Például: Anicius Probus Faustus niger neve rövidített alakban elsősorban papiruszokon Fl. Faustus niger, vagy csak Fl. Faustus alakban jelenik meg. ${ }^{113}$ Cameron nyomán bizonyos, hogy csupán a Flavius név birtoklásától nem lesz senki római polgár, így Odoacer és Theoderich sem volt az. Mommsen további fontos megjegyzése, hogy Theoderich soha nem használta magára sem a "rex Gothorum" sem a "rex Romanorum" megnevezést, egyszerüen király (rex) volt, ez pedig mindkét közösség, tehát a rómaiak és a germánok együttes felhatalmazását (Doppelstellung) jelentette. ${ }^{114}$ A Konstantinápoly és Theoderich uralma alatti kapcsolatot Mommsen foedusként értékelte, miközben hangsúlyozta, hogy Itália továbbra is a Római Birodalom szerves része maradt, ugyanakkor kételkedett abban, hogy bármiféle római-germán állam létrejött volna akár Odoacer, akár Theoderich uralkodása alatt. ${ }^{115}$

Siegfried Fuchs korábban említett memorandumának tükrében korántsem meglepő, hogy a néhány évvel Mommsen után alkotó történészek többsége már ismét inkább hitt egy germán, vagy római-germán állam képében, amely már Odoacer alatt kialakult és utódai alatt is fennállt. A náci Németország időszakában Ernst Stein (1891-1945) és Wilhelm Ensslin (1885-1965) - visszatérve a 19. századi nézethez - módosította Mommsen nézetét, mégpedig úgy, hogy Theoderich immár minden itáliai alattvalójának királya volt, ugyanakkor viselte a magister militumi tisztséget és hatalmát a keletrómai uralkodóval kötött megállapodása korlátozta. Az általánosan elfogadott nézet szerint az Odoacer és Theoderich által kinevezett consulokat keleten elfogadták. Theoderich itáliai jogköre nagyszerüen körvonalazható Cassiodorus formuláiból, amit gyüjteményének hatodik könyve tartalmaz. Ennek értelmében Theoderich kinevezhette a consult, a patriciust, Róma városának praefectusát, a quaestort, a magister officiorumot, a comes sacrarum largitionumot, a rerum privatarumot, a comes patrimoniit, a provinciák kormányzóit. ${ }^{116} \mathrm{Ez}$ azonban csak annyit jelent, hogy azokat a személyeket, akiket nyugaton consullá tett az uralkodó, azokat

közepén alkotó történészek számára éppen munkájának ezen részei jelentettek támadási felületet.

112 CAMERON 1988-as cikke ellenére rendre felbukkannak olyan tanulmányok, amelyek a Flavius cím mommseni alapjaira építkeznek. Problémát okoz ugyanakkor az is, hogy a The Prosopography of the Later Roman Empire szerkesztöi is következetlenül jártak el, így hol szerepel Flavius cím egy-egy senator elött, hol nem.

113 PLRE2 454-456, "Fl. Anicius Probus Faustus iunior Niger 9". Az alábbi példa rosszul szerepel a PLREben.

114 Mommsen 1910, 479.

115 MOMMSEN 1910, 383.

116 CASSIOD. VAR. 6.1-15. Többek között: 6.4 (városi praefectus), 6.5 (quaestor), 6.6 (magister officiorum), 6.7 ( comes sacrarum largitionum), 6.8 (rerum privatarum), 6.9 (comes patrimonii). 
Konstantinápolyban is el kellett fogadnia a császárnak. ${ }^{117}$ Minden bizonnyal olyan megállapodás volt kettejük között, hogy a császár minden évben csak egy consult nevez ki, a másikat pedig fenntartja a nyugati jelölteknek, azonban a végső döntés az ő kezében volt. Ez jelenik meg azokban az években, amikor csak keleti consul jelenik meg a fastiban, mint például 499-ben, ${ }^{118}$ de erre mutat az 519. év is, amikor Eutharicus kinevezése esetében a Variae rögzíti, hogy a császár tette consullá. ${ }^{119}$

Miközben Mommsen úgy látta, hogy Theoderich hatalmának alapját elsősorban a magister militum tisztség adta, addig Ensslin, az általa életre hívott, ún. katonai patricius tisztségben vélte felfedezni azt. A kutató szerint, mivel a tisztség birtokosai kombinálták a patricius címet a magister militum praesentalis tisztséggel, a magistratus nem csupán a legmagasabb katonai pozíció birtokosa volt, hanem - közvetlenül a császár után - a legmagasabb polgári pozíció birtokosa is. ${ }^{120}$ Ernst Stein (1981-1945) elismerte, hogy Theoderich birodalmi küldött volt és magister militum, azonban elutasította, hogy az uralkodó a patriciusi címet is viselte volna. ${ }^{121}$ Véleménye szerint ugyanakkor Theoderich mindkét nép felett királyként uralkodott, amivel Mommsen elméletét teljesen tarthatatlanná tette, hiszen pusztán a keletrómai elfogadás elegendőnek bizonyult ahhoz, hogy mindkét nép felett uralkodjon.

Herwig Wolfram szerint Theoderich római polgárként, birodalmi magister militumként, patriciusként, ex-consulként, valamint a gótok királyaként érkezett Itáliába. Királyi címét azonban nem fogadta el a császár, noha 493-ban serege (exercitus Gothorum) a gótok és az itáliaiak királyaként ünnepelte. Wolfram szerint ezek a tisztségek Theoderich uralkodásától egészen Witiges hódoltatásáig érvényben maradtak. ${ }^{122}$ Wolfram érveit a kutatók többsége elfogadta, elsősorban azok, akik nem kételkedtek abban, hogy Itália továbbra is az Imperium Romanum része maradt. Az angolszász szakirodalom jelentős része azonban továbbra is kitartott amellett, hogy Theoderich nem lehet a gótok és a rómaiak uralkodója, hiszen az Anastasiusszal kötött megállapodás részletei

17 PROCOP. DE Bellis. 6.6.20.

118 CLRE 499, MARC. COM. 499, Ioannes qui est Gibbus consuli éve.

119 CASSIOD. VAR. 8.1.

120 ENSSLIN 1947, 76-79. Ensslin szerint ebből következett, hogy az utolsó nyugatrómai császár, Romulus Augustulus eltávolítása után ez a méltóság vált Odoacer és Theoderich uralkodásának formális alapjává. Mommsennel szemben Ensslin már vizsgálta Theoderich 493-as gótok általi elfogadása és Anastasius 498-as megállapodása közötti különbségeket. Úgy vélte, hogy Anastasius 498-ban a felségjelvények megküldésével elfogadta Theoderich uralkodói státuszát, melyet a gótok előzetesen 493-ban kinyilvánítottak.

121 STEIN 1949, 17.

122 ANON. VAL. 11.57, WOLFRAM 1990, 279-284. 
nem rekonstruálhatók, ugyanakkor Theoderich itáliai berendezkedése a forrásokban nincsen pontosan definiálva. ${ }^{123}$

\subsubsection{Az elveszett források problémája}

A historiográfiát böngészve mai szemmel úgy tünik, mintha a kutatás megfeledkezett volna arról, hogy a latin nyelvü források többsége, amelyek bármilyen módon is említést tesznek Theoderich itáliai pozíciójáról, Konstantinápolyban, erős keletrómai befolyás alatt született. Mi okozhatta ezt a feledékenységet?

A 19. század végén, a nagy forráskiadások időszakában a hangsúly Marcellinus munkáján és annak forrásain volt. Ennek oka elsősorban az volt, hogy Marcellinus comes 476-os bejegyzése nyomán kialakult a Nyugatrómai Birodalom végét jelző korszakhatár, ${ }^{124}$ ami csaknem másfél évszázadon keresztül alapjaiban határozta meg a korszakkal foglalkozó kutatók hozzáállását az 5-6. század eseményeivel kapcsolatban. A korábbiak tükrében egyáltalán nem meglepö, hogy a német nacionalizmus térnyerése itt is tetten érhetö.

19. század első felében Marcellinus krónikájának vizsgálata során Kaufmann felfigyelt arra, hogy a szerző csupán néhány nyugati eseményről számol be krónikájában, amelyek annyira általános jellegúek, hogy akár konstantinápolyi évkönyvekből is származhattak. ${ }^{125}$ Kaufmann-nal ellentétben Holder-Egger azt igyekezett alátámasztani, hogy Marcellinusnak a birodalom nyugati feléből származó értesülései az ún. ravennai évkönyvekből származnak. ${ }^{126}$ Mommsen tanítványa, Otto Seeck, hasonlóan Kaufmannhoz arra az álláspontra helyezkedett, hogy a Marcellinusnál megőrzött nyugati események olyannyira általánosak, hogy azokkal Konstantinápolyban is tisztában lehettek. ${ }^{127}$ 1894-ben, amikor Mommsen a Monumenta Germaniae Historica (MGH) részeként kiadta Marcellinus krónikáját, tanítványa megfontolásai alapján elvetette, hogy Marcellinus a ravennai évkönyvekböl vette volna értesüléseit. Marcellinus és Iordanes szövegkiadásaiban így IGN (ignotus) jelzéssel látta el azokat a szöveghelyeket, amelyek mögött

123 BARNWELl 1992, 136, THOMPSON 2002, 65-72, O’DONNELL 1979, 100.

124 CROKE 1983, 1, MARC. COM. 476.2. "Hesperium Romanae gentis imperium, quod septingentesimo nono Vrbis conditae anno primus Augustorum Octauianus Augustus tenere coepit, cum hoc Augustulo periit, anno decessorum regni imperatorum quingentesimo uigesimo secundo, Gothorum dehinc regibus Romam tenentibus."

125 KAUFMANN 1884, 471-510.

126 HOLDER-EGGER 1877, 47-111.

127 SEECK 1889, 601-635. 
azonos forrást, vagy forráscsoportot sejtett, elsősorban egy konstantinápolyi krónikát, hiszen Iordanes hivatkozik a Romanában egy bizonyos annales consulumque series-re. ${ }^{128}$

A korban a Getica pongyola latin nyelvezete ugyanis korántsem vívta ki a kutatók elismerését. Mommsen és társai, különösen a klasszikus irodalom tükrében úgy gondolták, hogy Iordanes gyenge latinja hasonlóan gyenge intellektusra vall, így munkájának eltérő színvonalú részei és tévesztései egész egyszerüen más munkákból kerülhettek a Geticába, miközben nem vették figyelembe, hogy Iordanesnek a latin már a harmadik beszélt nyelve lehetett. ${ }^{129} \mathrm{Az}$ MGH kutatóinak Iordanesről alkotott véleménye alapvetően határozta meg a 20. század kutatását. Bergmüller 1903-ban írt doktori disszertációjában "Kompilator ersten Ranges"-nek nevezte Iordanest, ${ }^{130}$ a kutatói hozzáállás pedig a későbbiekben sem változott. ${ }^{131}$

A 20. század közepén, Holder-Egger után Ensslin volt az első, aki amellett érvelt, hogy Mommsen IGN jelzése nem egy helyi konstantinápolyi krónikát takar, hanem egy nyugati történeti munkát. A német kutató munkásságának tagadhatatlan előnye volt, hogy ráirányította a figyelmet arra, hogyan is dolgozott Marcellinus és Iordanes ugyanabból a forrásból. A kutató érvrendszerének alapját hat szöveghely adta (III. Valentinianus és Licinia Eudoxia házassága, ${ }^{132}$ Bonifatius ÉszakAfrikába hívja a vandálokat, ${ }^{133}$ Thracia osztrogót/hun inváziója, ${ }^{134}$ Basiliscus halála, ${ }^{135}$ Krisztus születése, ${ }^{136}$ Iosephus és Claudianus ${ }^{137}$ ), melyek mindegyikével azt kívánta bizonyítani, hogy nyugati munkákból származtak. Elemzése végén arra jutott, hogy a Getica nem más, mint Cassiodorus elveszett gót történetének felületes kivonata, ugyanakkor - a szerző gyenge latinja miatt - a Romana sem tekinthető Iordanes saját munkájának. Ensslin szerint a történetíró ebben az esetben ugyancsak egy elveszett munkát kivonatolt. A kutató úgy gondolta, hogy a Romana nem más, mint a Theoderich által 525-ben kivégzett Q. Aurelius Memmius Symmachus (cos. 485) elveszett Historia Romanának kivonata. ${ }^{138}$

Ensslin hipotézisére alapozta nézetét Marinus Antony Wes, aki arra hívta fel a figyelmet, hogy Romulus Augustulus 476-os eltávolításáról csak Marcellinus és Iordanes számol be. Wes meggyőzően érvelt amellett, hogy az információt mindketten Q. Aurelius Memmius Symmachus

128 JORD. ROM. 388.

129 CROKE 1987, 117.

130 BERGMÜlLER 1903, 3, GALDi 2010, 357.

131 Iordanes Geticájának morfológiai és szintaktikai sajátosságaira lásd GALDI 2010, 357-375.

132 JORD. ROM. 329, MARC. COM. 437, ENSSLIN 1949, 71.

133 JORD. GET. 167, JORD. ROM. 330, ENSSLIN 1949, 71.

134 JORD. ROM. 331, MARC. COM. 442.2, ENSSLIN 1949, 73.

135 JORD. ROM. 342, MARC. COM. 471.1, ENSSLIN 1949, 79.

136 JORD. ROM. 258, ENSSLIN 1949, 19-28

137 JORD. ROM. 57, JORD. GET. 29, ENSSLIN 1949, 23-24, 67.

138 ENSSLIN 1949. 
(cos. 485) elveszett Historia Romanájából vették. A kutató véleménye szerint a korban egyedül a szónok ősökkel rendelkező Symmachus bírt olyan tudással, amivel felismerhette Romulus eltávolításának jelentőségét. ${ }^{139}$ Wes szerint Iordanes és Marcellinus nem tett mást, minthogy egyszerüen megismételte Symmachus véleményét, aki felismerte 476 jelentőségét, ${ }^{140}$ immár nem csak a Geticát, de a Romanát is egyszerü kivonatnak tartották. Wes arra épített, hogy Symmachus ugyan 518-ban befejezte munkáját, de kiegészítette azt, egészen 519-ig, mert ebben az évben olyan események történtek, amelyek alapjaiban változtatták meg Konstantinápoly és Ravenna kapcsolatát: Eutharicust Theoderich utódjának jelölte a császár, illetve Akakios-féle skizma is véget ért. A kutató szerint azzal, hogy a császár hivatalosan is elfogadta Eutharicust, egyet jelentett azzal, hogy a keletrómai kormányzat nem ideiglenes megoldásként tekint az osztrogótok itáliai uralkodására, miközben a római arisztokrácia bízott abban, hogy a régi rend helyreállításra kerül. Ebben a kontextusban Romulus Augustulus eltávolítása különös jelentőséggel bírt, hiszen ő volt az utolsó nyugatrómai uralkodó. Symmachust ezek a történések arra indították, hogy megírja a Historia Romanát, ami egyfajta politikai irat volt az osztrogótok itáliai uralkodásával szemben. A kutató elgondolása szerint Theoderich erre megbízta Cassiodorust, hogy egyfajta elleniratként, készítse el a gótok történetét. ${ }^{141}$

A kutató elgondolásának alapját az a feltételezés adta, hogy Marcellinus már 518/519-ben készen volt krónikájának első verziójával, valamint, hogy Symmachus Historia Romanájának pontos keletkezési ideje nem ismert, de meghatározható. Wes szerint a 476-ról szóló bejegyzés Symmachus munkájából került Marcellinushoz, következésképpen a Historia Romanának még Marcellinus krónikája előtt el kellett készülnie. A kutató azzal igyekezett bizonyítani feltételezését, hogy a Historia Romana keletkezési idejét 519-re helyezte, azonban ebben az évben jelent meg Cassiodorus Eutharicus consulságának tiszteletére írt krónikája is, aki ekkor még egy szóval sem említi 476 jelentőségét, de később a Geticában, ami - Ensslin szerint - Cassiodorus elveszett gót történetének másolata, már megjelenik az információ. Wes ebböl azt a következtetést vonta le, hogy 519-ben kortársai előtt ismeretlen volt Symmachus munkája.

A kutató szerint, mivel Symmachus 519-ben már elkészült a Historia Romanával, ezért a Iordanesnál Theoderich uralkodására vonatkozó harminc évet is innen kell visszaszámolni, így 489-hez jutunk. Mivel Marcellinus műve 489 után nem tartalmaz nyugati bejegyzést, ezért a Historia Romana a 489-519 között készült. Továbbá úgy gondolta, hogy bár az 551-ben alkotó Iordanes ugyan tisztában volt Theoderich pontos uralkodási idejével, de mivel a szerző saját

139 WES 1967, 54-81.

140 Jord. ROM. 344, JORD. GeT. 242, MARC. COM. 476.2.

141 WES 1967, 110-122. 
bevallása szerint is agramatus ${ }^{142}$ volt, Wes szerint éppen ezért nem tudta helyesen kezelni az uralkodó dátumokat. Demandt, Várady és Croke szerint ezért Symmachus Historia Romanájának 519-es keletkezési dátuma tarthatatlan. ${ }^{143}$ Croke szerint azért is, mert a kutató nem vette figyelembe, hogy Marcellinus és Symmachus ugyanabban az időben alkottak, ám a birodalom különböző pontjain. Croke cáfolatában arra az álláspontra helyezkedett, ha sikerül bizonyítani, hogy Marcellinus értesülése nem nyugati munkából származik, akkor ezzel sikerül megcáfolnia Ensslin tézisét, ami Wes elméletének alapját adta. ${ }^{144}$ Problematikusabb azonban a Romanában, Theoderich uralkodására vonatkozó harminc év, amit a szerző Odoacer legyőzésétől (493) számítva ad meg. ${ }^{145}$ Wes nézetével szemben, azonban ez nem tényleges uralkodási éveket jelent, hiszen a szerző azt közli, hogy Theoderich "körültekintően és békében harminc éven át" (prudenter et pacifice per triginta annos continuit) uralkodott, ami így minden bizonnyal egy minőségi jelző a szerző szemében.

Ensslin és Wes hipotézisét mindenesetre csak tovább erősítette Arnaldo Momigliano, aki Iordanesben a dél-itáliai Cortona (Crotone) püspökét vélte felfedezni. Momigliano véleménye szerint Konstantinápolyban kialakult egy itáliai emigráns arisztokráciát tömörítő kör, amelynek Cassiodorus és Iordanes is tagjai voltak. Ez a csoport egy olyan megoldáson dolgozott, ami az osztrogót Itália számára, a háború lezárását követően, egy kedvező rendezést tett volna lehetővé. Momigliano úgy gondolta, hogy 551-ben Germanus és Matasuntha házassága alkalmából Cassiodorus kiegészítette gót történetét, és Iordanes már ezt az átdolgozott verziót használta a Geticához. Momigliano szerint Matasuntha és Germanus, vagyis az Amal és Anicius házasság jelentőségét csak Cassiodorus ismerhette fel. ${ }^{146}$ Momigliano úgy gondolta, hogy Iordanes Cassiodorus kérésére összegezte munkáját, annak érdekében, hogy a konstantinápolyi emigráns rómaiak számára könnyebben hozzáférhetővé tegyék a politikai üzenetet tartalmazó munkát, ${ }^{147}$ Momigliano ezen nézet kifejtésekor figyelmen kívül hagyta azt a tényt, hogy Iordanes csak három napra kapta meg Cassiodorus gót történeti munkáját, ${ }^{148}$ miközben szerinte együtt dolgoztak azon, hogy a gótok számára kedvező rendezést segítsenek elő Konstantinápolyban. Az olasz kutató feltételezése szerint Cassiodorus azért érezte szükségét a kiegészítésnek, mert Germanushoz hasonlóan, ő maga is az Anicius-nemzetséghez tartozott, hiszen az Ordo Generis Cassiodorumban

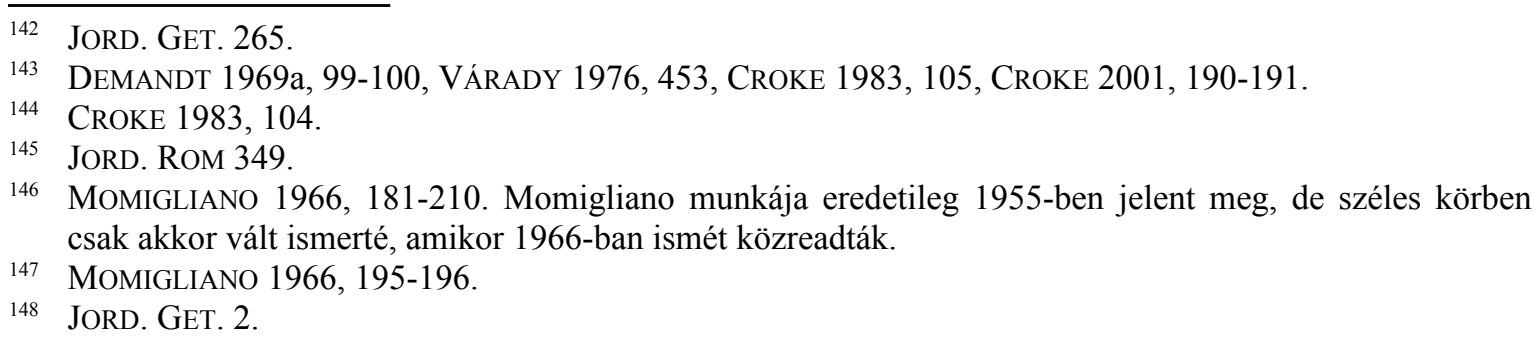


(Anecdoton Holderi) ${ }^{149}$ elődjének nevezi Boëthiust és Symmachust. Momigliano ezen állításával az a probléma, hogy az Ordo Generis Cassiodorum szövege éppen azon a ponton sérült, amelyből megállapítható lenne a tényleges rokonság, ezért a kutatás ugyan valamilyen kapcsolatot feltételez az Ordó-ban említésre kerülő személyek között, de nem rokonit. ${ }^{150}$ Ennek ellenére Momigliano elméletét a 20. század végének szinte valamennyi kutatója átvette, például Wolfram ${ }^{151}$ is, pedig jobban belegondolva, az olasz kutató Ensslin és Wes kettős hipotézisére építette elgondolásait. A kutatás számottevő része az 1970-as évek végétől a '90-es évek elejéig a szisztematikusan igyekezett bizonyítani, hogy Momigliano interpretációja teljességgel valószínütlen, hiszen Mommsen óta az egész elgondolás azon alapul, hogy Iordanes egyszerủ másoló. ${ }^{152}$ A század végére így kezdett általánosan elfogadottá válni, hogy Iordanes nem következetlenül másolta Cassiodorus gót történeti munkáját, általánosan elfogadott megközelítés azonban nem alakult ki. ${ }^{153}$

Goffart ezzel szemben úgy gondolta, hogy a Getica "happy enddel"154 végződik, Matasuntha és Germanus házasságának leírása nem más, mint propaganda, amelynek célja, hogy a latinul beszélő gótok és itáliai senatorokat meggyőzze arról, hogy Iustinianus gótok elleni hadjárata jogos és szükséges lépés volt. A házasság pedig nem másra szolgált, mint annak hangsúlyozására, hogy a gót nemesek egyenrangúvá váltak a rómaiakkal. ${ }^{155}$ Goffart olvasatában a Getica két szerelmes története, a beteljesedés útjába pedig csak a császár és a gót királyság háborúja áll. A szerző szerint a Getica tévesztései mind azt a célt szolgálják, hogy a cselekmény elkerülhetetlenül sodródjon a házasság és a két nép egyesülésének irányába. De mi van abban az esetben, ha Iordanes nem egyszerü másoló, ha műve nem propaganda és ha Theoderich téves 30 éves uralkodásának is megvan a maga jelentése.

149 A szöveget 1977-ben publikálta A. Holder, így kiadójáról gyakran Anecdoton Holderiként is nevezik.

150 Momigliano 1966, 205, O’Donnell 1979, 262, Gallonier 1996, 305. A kérdéses szövegrész Gallonier kiadásában: “ordo generis Cassiodororum: qui scriptores extiterint ex eorum progenie vel + ex quibus eruditis + Symmachus patricius et consul ordinarius [...] Boethius [...]. Usener a quibus helyett civibus-t javasolt, míg Mommsen ingadozott a vel qui eruditi és vel ex quibus eruditis profecerint között, amit a Mommsen-féle Iordanes-kiadás előszavának 41. oldalán találhatunk meg. A vel qui eruditi javítás biztossá tenné, hogy Boëthius és Symmachus mint rokonok, nem pedig mint tanárok; mesterek szerepelnek az Ordo Generis Cassiodorumban. Momigliano ezt a javítást fogadta el, az ex cuibus eruditis profecerint-et pedig csupán annyival magyarázta, hogy aligha elképzelhető, hogy Boëthiust tanárként említette volna Cassiodorus. A kézirat bizonytalan a kutatás a '70-es évek végétól arra helyezkedik, hogy nincs bizonyítható vérségi kapcsolat Cassiodorus, Boëthius, Symmachus és az Ordo címzettjeként szereplő Rufius Petronius Nicomachus Cethegus között.

151 WOLFRAM 1990, 15, WOLFRAM 1997, 26.

152 VÁrady 1976, 441-487, CAMERON 1981, O’DONNell 1982, 223-240, BARNish 1983, CroKe 1987, 117-134, GOFFART 1988, 20-111, WOLFRAM 1990, HEATHER 1991B, 3-67, AMORY 2003, 291-307.

153 CROKE 1987, 117-134, CROKE 2003, 365-366.

154 GOFFART 1988, 68. A szerző nyolcadik fejezetének címe: „The Getica: History with Happy Ending”.

155 GOFFART 1988, 62. 


\subsubsection{A PLRE problémája}

1971-ben indult útjára a Prosopography of the Later Roman Empire (PLRE) sorozata, amely a különböző forrásokban fellelhető személyeket igyekezett rendszerezni Gallienus császár uralkodásának kezdetétől egészen 641-ig. Az egyébként kitünő adattárat ma is széles körben használják, azonban a római senatus tekintetében kritikával kell kezelnünk.

Nagyjából egy évtizeddel ezelött ugyanis Silvia Orlandi Olaszország egyik vezető epigráfusa rámutatott, hogy André Chastagnol a 20. század közepén elmulasztotta elemezni a Flavium Amphitheatrum feliratainak tipográfiai jellemzőit, ugyanakkor sok esetben a márványtömbök kapcsolódási sorrendjét sem vette figyelembe. ${ }^{156} \mathrm{~A}$ felfedezés jelentősége abban rejlik, hogy Amphitheatrum Flavium senatori ülőhelyeinek feliratait az 5. század végén nem a központi kormányzat gondozta, hanem az egyes senatori családok, valamelyik helyi iparos megbízásával, aki a már meglévő márványtömböket használta, így azoknak mind a négy oldalára írhattak. Amennyiben egy senator utódja ugyanazt, vagy hasonló nevet viselt egész egyszerủen betoldották az új nevet a már meglévő elé vagy mögé. Éppen azért 480 után az Amphitheatrum Flavium feliratai rendkívül változatos képet mutatnak.

Mivel a Chastagnol nem elemezte a tipográfiát, valamint a kapcsolódási sorrendet, könnyen előfordulhat, hogy egyes feliratokat rosszul értelmezték, pontosabban a rajta szereplő senatorok neveit rossz időszakra helyezték, mint pl. Fl. Valila esetében, aki a francia kutató munkája szerint Odoacer és Theoderich uralkodása alatt is élt, ${ }^{157}$ holott biztosan tudjuk, hogy a senator 483-ban már halott volt. ${ }^{158}$ Ez azért problematikus, mert éppen Chastagnol elemzésére épülve készült el 1980-ban Martindale Proposography of Later Roman Empire c. kötete, amit a korszakkal foglalkozó kutatók előszeretettel használnak a családi kapcsolatok feltárásakor. Így azokat a senatorokat, akiket a kötet 480 utánra datál, mindenképpen alaposan kell ellenőrizni. Orlandi munkájának jelentősége számunkra abban áll, hogy a dolgozat 5 . fejezetében éppen az osztrogótok itáliai uralkodása idején fogunk egy családi szálat rekonstruálni.

156 ORLANDI 2004, 11-15, 167-523.

157 ChastagnOL 1966, 39.

158 ORLANDI 2004, 320, 513-514. 


\subsection{Történetírás}

\subsection{1. Általános áttekintés}

A 6. század első felében a birodalom legtöbb helyén továbbra is a latin nyelv funkcionált közös nyelvként. ${ }^{159}$ Prokopios ugyan túloz, amikor rosszalló megjegyzést tesz a császár görög tudásával kapcsolatban, ${ }^{160}$ de kétségtelen, hogy születése révén Iustinianus is inkább a latinban jeleskedett. Ezek tükrében érthető, hogy Iustinianus idejében a konstantinápolyi udvar közvetlen közelében is több latinul beszélő udvaronc is akadt. Ilyen volt a császár szülőföldjéről származó Marcellinus comes is, aki már az 510-es évek végén Iustinianus cancellariusaként tevékenykedett, később pedig latin nyelvü krónikájában állított emléket a 6. századi eseményeknek egészen 534-ben bekövetkezett haláláig. Marcellinus krónikáját, amely Theodosius hatalomra kerülésével kezdődik, és Iustinianus uralkodásával záródik két évtizeddel később már Cassiodorus ajánlotta olvasásra a Vivarium lakóinak. ${ }^{161}$

Marcellinus krónikája egyike volt azoknak a munkáknak, amelyeknek másolatát Cassiodorus magával vitte, amikor az 550-es évek elején elhagyta Konstantinápolyt. A latinul beszélő közösségek múltértelmezése megegyezett, ezt azonban az egyes szerzők más-más irányból világították meg. A 6. század latin nyelvü történetírói a múltban folyamatosan ismétlődő motívumkincsének értelmezéséhez a korábbi keresztény szerzők által kidolgozott modellekre építettek. Ezek egyike volt a 4. század végén Caesareai Eusebios, illetve a következő század elején Szent Ágoston. A két szerző közötti kapcsolatot Jeromos ${ }^{162}$ jelentette, aki Eusebios krónikájának fordítója és kiegészítője is volt, miközben aktív kapcsolatot ápolt Szent Ágostonnal és annak hippói kolostorával, ahova több hispániai szerzetes is elzarándokolt. Ezek között volt az 5. század elején Orosius és Hydatius ${ }^{163}$ is, akik már Jeromos és Ágoston útmutatásainak megfelelően jártak el saját

159 A latin-görög használatának mértékéről lásd ADAMIK 2001.

160 PROCOP. ARC. 20.17

161 CASS. INST. DiV. LITT. 1.17

162 ADAMIK 2009, 778. Jeromos az 5. század közepén, minden bizonnyal 345-348 között született mélyen vallásos és tehetős vidéki földbirtokos családba. Területeik, a családi birokok a Pannonia és Dalmatia provinciák határán fekvő terültek el, egyes vélemények szerint Stridon (Strido Dalmatiae) városának közelében.

163 A dolgozatban az Hydatius szöveghelyeket elsőként a Burgess-féle kiadás jelzéseit használom, majd ()ben közlöm a Mommsen-féle hivatkozást. A kettősséget indokolja, hogy a korábbi korszakkal foglalkozó szakirodalom is eltérő kiadásokat használ, ugyanakkor a Mommsen-féle kiadásban a párhuzamos sorok, idézőjelek és zárójelek következetlen használata nehézkessé ezen használatát. Széll Gábor remek jegyzetapparátussal rendelkező fordítása ugyancsak mindkét helyet jelöli (SzÉLL 2005, 11). Hydatiusról részletesebben lásd BURGESS1993, 1-68; SzÉLL 2005, 5-12. 
műveik elkészítésekor, éppen ezért érdemes röviden áttekintenünk Jeromos életútját, az őt ért hatásokat, hiszen tudása és tapasztalatai minden bizonnyal tanítványaira is hatással voltak.

Tehetős vidéki arisztokrata lévén, Jeromos az elemi tanulmányok elvégzése után Rómába utazott, ahol a híres Aelius Donatus grammatikusnál tanult szónoklattant, filozófiát, grammatikát, görög és latin nyelvet. ${ }^{164}$ Tanárán keresztül megismerte a latin irodalom klasszikusait, különösen Terentius és Vergilius alkotásai nyerték meg tetszését. Ebben az időben szenvedélyesen gyüjtötte és tanulmányozta a klasszikus irodalmat, ami későbbi művein és stílusán is jól látható nyomokat hagyott. Cicero stílusát és gördülékenységét olyannyira megszerette és magáévá tette, hogy a Vulgata munkálatainak kezdetén komoly kényelmetlenségeket okozott számára a nép egyszerü nyelvének használata. Tanulmányai befejezését követően, az ekkor húszas évei elején járó Jeromos Treviribe utazott. Itt ismerkedett meg poitiers-i Szent Hilarius ókeresztény író munkáival, amelyekből még barátja és egykori padtársa, Tyrannius Rufinus számára is másolt. ${ }^{165}$

A hétköznapok nyugalmából az ebben az időben trieri számüzetését töltő Szent Athanasios előadásai billentették ki. Az egykori alexandriai püspök az arianizmus harcos ellenfeleként elsősorban a nicaeai hitvallást propagálta a császárvárosban, de emellett sok szót ejtett a szerzetesi eszményképről, az egyiptomi remeték életéröl is. Ez utóbbiak annyira fellelkesítették Jeromost, hogy néhány éves trieri tartózkodás után elhagyta Valentinianus székhelyét, ahonnan előbb hazautazott a családi birtokra, majd 373-ban, többek társaságában, kelet felé, a Szentföldre indult. ${ }^{166}$ Döntésére kétségtelenül hatással volt, hogy a 370-es évek második felében családjának a Pannonia határán fekvő birtokai gyakorta megszenvedték a környéket érő gót portyázásokat. Jeromosnak így nem maradt más választása, minthogy megváljon birtokaitól.

379-ben visszament Konstantinápolyba, ahol megismerkedett az alexandriai iskola egykori legkiemelkedőbb teológusának, Órigenésnek a munkáival. Ugyanebben az időben kezdte alaposabban tanulmányozni Eusebios műveit, aki elsősorban az Ószövetség és az Újszövetség szövegkritikáival tünt ki. Eusebios krónikáját ebben az időben fordította le és egészítette ki.

\footnotetext{
JER. ADV. RUFIN. 1.16.

ADAMIK 2009, 778-779.

166 ADAMIK 2009, 780. Egy év leforgása alatt felkereste a birodalom keleti felének legjelentősebb városait, járt Athénban és Konstantinápolyban is, végül Kis-Ázsiában antiochiai barátjánál, Evagriusnál állapodott meg egy időre. Szüksége is volt a pihenésre, mert az előző év fáradságos, gyakran erőltetett utazásai egészségét is megviselték. Ebben az időben készíti el első szövegmagyarázatát is, majd elvonul az antiochiai sivatagba remetének. Már majd egy éve visszavonultan élt, amikor 376 nagyböjtjén álmában elérte a felismerés, hogy eddigi életében nem követte teljes szívéből Krisztus tanítását. Ekkor legalább akkora szenvedéllyel, mint ahogyan jó tíz évvel korábban Rómában gyüjtötte a klasszikusokat, belevetette magát a héber nyelv tanulmányozásába, ami ideje és energiája nagy részét felemésztette. Egy évvel később visszament Antiochiába, ahol pappá szentelték az ekkor harmincas évei elején járó Jeromost, aki kikötötte, hogy a papi funkciókat nem kívánja ellátni.
} 
Jeromos a két évvel későbbi első konstantinápolyi zsinaton (381) személyesen is részt vett. A zsinatot követő évben az antiochiai és a cyprusi püspök társaságában Rómába utazott, ahol még közelebbi kapcsolatba kerülhetett Damasus pápával (366-384), akivel egy ideje már levelezett. ${ }^{167}$ Damasusnak imponált Jeromos széles körü olvasottsága és a nem sokkal korábban megszerzett héber tudása, így csakhamar a pápa titkára lett. Ebben a munkakörben látott neki az Újszövetség és a zsoltárok latin fordításainak revíziójához. ${ }^{168}$

Rómában komoly közösségi és tanítói életet élt. Arisztokrata özvegy és hajadon nők egy csoportjának kezdte magyarázni a Bibliát, amit ök maguk is lelkesen tanulmányoztak az özvegy arisztokrata Marcella vezetésével, akinek villájában hétről hétre összegyültek. ${ }^{169}$ Tehetsége, valamint az arisztokrata nök körében elért sikerei - legalábbis ami a szüzességi fogadalmak gyarapodó számát illeti - számos ellenlábast szültek. Legfőbb támogatója, Damasus pápa halála után ellenségeinek nem telt sok időbe telt, hogy kikezdjék. Állítólag már fiatal római lányok temetésén is azt rebesgették, hogy a szigorú böjtölés okozta halálukat. ${ }^{170} 385$ nyarán megelégelve mindezt öccsével hajóra szállt, és kelet felé indult. Betlehembe érve társaival két kolostort hozott létre, egyet a nők, és egyet a férfiak számára. ${ }^{171}$ Utóbbiak mellett egy iskola és egy fogadó is helyet kapott. ${ }^{172}$ Kiterjedt levelezése és a fogadóban megforduló zarándokok miatt szinte minden hírt hallott a birodalom minden tájáról, de különösen Rómából, aminek sorsát továbbra is szívén viselte. Akár személye, akár munkája révén, de Jeromos kötötte össze az 5. század legtöbb történetíróját.

Jeromos, Ágoston, Orosius és Hydatius munkáját pedig kivétel nélkül ismerték és használták a 6. századi latin nyelvű történetírók. Marcellinus maga is Eusebios krónikájának folytatójaként lépett fel. A kutatók időről időre igyekeztek bizonyítani, hogy ezek a források a nyugatrómai birodalomfél hanyatlását és bukását jelenítik meg. ${ }^{173}$ Sokkal valószínűbb azonban, hogy a történetírói megközelítés középpontjában a folytonosság állt, amit igyekeztek a saját szemszögükből megvilágítani, miközben alkalmazkodtak ahhoz a hatalmi és egyensúlyi

167 JER. EP. 15, 16.

168 ADAMIK 2009, 781.

169 JER. EP. 47.3. Jeromos fennmaradt levelezésének számottevő része is ebből az időszakból datálódik. Csak Marcellával 19 levélváltása volt, ami kiemelkedő szám a majd 150 levelet tartalmazó gyüjteményben. Marcellának írt levelek: 23-29, 32, 34, 37-38, 40-44, 46, 59, 97.

170 JER. EP. 39.6

171 JER. EP. 39.6. Cypruson csatlakozott hozzájuk néhány római arisztokrata asszony, így például Paula és lánya, akikkel még római előadásai során kötött barátságot Jeromos. Az özvegy Paula vagyonából, valamint Jeromos családi birtokainak korábbi eladásából származó összegbool.

172 ADAMIK 2009, 782.

173 HEATHER 1997, 65-82. 
rendszerhez, amelyben éppen éltek. ${ }^{174}$

Ebben az alkalmazkodásban kitünt Cassiodorus, aki a 480-as évek végén született a délitáliai Squillacensis (Squillace) városában, így aligha emlékezett arra az időre, amikor Theoderich és gótjai Itáliába vonultak és megdöntötték Odoacer uralmát. Ha a gótok uralkodásának kezdeteire nem is, de azokra a történetekre mindenképpen emlékezhetett, amelyeket apja és nagyapja meséltek neki családjuk történetéről és hősies helytállásukról, azokról a cselekedetekről, amelyeket az 5. század közepén a szülőföldjüket fosztogató vandálok ellenében vittek véghez. ${ }^{175} \mathrm{Az}$ arisztokrata családban nevelkedett Cassiodorus előtt apja és nagyapja példája lebegett, amikor a 6. század elején ő maga is az állam szolgálatába lépett. ${ }^{176}$ Előbb apja mellett tanácsos, majd 507 után quaestor sacri palatii lett. Nem véletlenül esett rá Theoderich választása. Cassiodorus azzal hívta fel magára az uralkodó figyelmét, hogy egy panegyricust írt neki a kinevezése előtti évben. ${ }^{177}$ Míg élete első 25 évében a családi birtok környékén klasszikus nevelésben részesült, addig kinevezését követően a ravennai udvarban már megismerkedhetett a gót kultúrával és szóbeli hagyománnyal, ezek többségébe ráadásul éppen Theoderich vezette be, akivel rendszeresen emlékezetes beszélgetéseket folytattak. ${ }^{178}$ Cassiodorus azonban elsősorban római volt, aki elfogult volt a birodalom igazi római uralkodóival szemben. Tiszteletre méltó régi időkről (antiquitas honora) beszél még akkor is, amikor III. Valentinianus gyengülő hatalmát említi. ${ }^{179}$ Valentinianus halála után azonban aligha akadt igaz római uralkodó.

Az arisztokrata és keresztény háztartásban felnövő Cassiodorus megtanulta, hogy a római múlt hogyan illeszkedett a világtörténelem azon kontextusába, melyet a keresztény történetírás más múvei, így Jeromos krónikája és Orosius munkája világítottak meg. Ez érhető tetten abban a krónikában, amelyet 519-ben készített Theoderich sógorának, Eutharicusnak. ${ }^{180}$ Cassiodorus Chronicájának 5721 éve jobbára Prosper, és az őt követő krónikások bejegyzéseinek összefoglalása, mellőzve azok egyházi vonatkozású bejegyzéseit, nehogy valamiféleképpen is megsértse az ariánus duxot. A szerző másik módosítása, hogy a Prosper bejegyzései közé beilleszti saját családjának történetét, így például a vandálok 440 és 441-es dél-itáliai támadását, másrészt pedig elkendőzi a gótok számára szégyenletes eseményeket, és fölnagyítja sikereiket. Cassiodorus

174 HEATHER 1997, 65-74.

175 CASSIOD. VAR. 1.4.14.

176 CASSIOD. VAR. 1.4.10-11, Cassiodorus nagyapja a 430-as években Aëtius fiának, Carpiliónak a társaságában követséget vezetett a hunokhoz, ahol Attilával is tárgyalt. CASSIOD. VAR. 1.3.4, Apja pedig Odoacer és Theoderich alatt praefectus praetorióként tevékenykedett.

177 CASSIOD. VAR. 9.24.3.

178 CASSIOD. VAR. praef. 8, 9.24.8.

179 CASSIOD. VAR. 11.1.9-12.

180 CASS. CHRON. 
megfeledkezik Athanarich meghunyászkodásáról és konstantinápolyi haláláról (382), a pollentiai gót vereség dicsőséges győzelemmé válik kezei között (402), Alarich véráldozat nélkül fosztja ki Rómát (410), és a vandálok Hispániából történő kiűzésében is kiemelt szerep hárul a gótokra (427). Noha 455-el Prosper krónikája abbamaradt, Cassiodorus tovább folytatta gótok számára előnyös beszámolóját egészen Eutharicus consuli évéig (518). A szerző nem tett mást, minthogy a lehető legjobban kiszolgálta megrendelőjét, miközben saját felmenőinek érdemeit is beleszőtte elbeszélésébe.

Néhány évvel a Chronica elkészültét követően ismét megtisztelő ajánlatot kapott. Ezúttal maga Theoderich kérte fel arra, hogy készítse el a gótok történetét. Cassiodorus minden bizonnyal örömmel látott munkához, müve azonban nem maradt az utókorra. Az elveszett gót történetről csupán a szerző egyik későbbi (537) írásából, az Ordo Generis Cassiodorumból értesül az olvasó. ${ }^{181}$ Az Ordóból kiderül, hogy munkája 12 kötetböl állt és központjában a gót történelem, földrajz és néprajz állt. ${ }^{182}$ Az írást minden bizonnyal rögtön elkezdte, az azonban bizonytalan, hogy az Ordo Generis Cassiodorum mikor fejeződött be. ${ }^{183}$ A keltezéshez támpontot adhatna, ha ismernénk annak pontos terjedelmét, hiszen korántsem mindegy, hogy Livius történeti munkájához, vagy Eutropius Róma rövid történetéhez állt-e közelebb, azonban erre történő utalás sem szerepel más müveiben, de a kortársaknál sem.

Cassiodorus elveszett történetének néhány eleme Iordanes Geticájában (De origine actibusque Getarum) is feltünik. Iordanes maga számol be arról, hogy éppen a Romanán dolgozott, amikor felkérést kapott egy bizonyos Castaliustól, hogy készítse el Cassiodorus 12 kötetes történeti munkájának összefoglalását. ${ }^{184}$ Egyesek hitelt adtak annak a feltételezésnek, hogy Iordanes képes volt teljes egészében átmásolni Cassiodorus történeti munkáját. ${ }^{185} \mathrm{~A}$ feladat azonban nehézséget okozott Iordanesnek, mert nem rendelkezett saját példánnyal, ráadásul csak három nap erejéig kapta kölcsön Cassiodorus inasától az eredeti példányt. Iordanesnek tehát 72 órája volt arra, hogy jegyzeteket készítsen Cassiodorus munkájáról. ${ }^{186}$ Ilyen rövid idő alatt szó szerinti másolásról szó sem lehetett, így minden bizonnyal egy-két fontosabb részt átvehetett, de inkább a szerkezet és Cassiodorus gondolatmenetének átültetése lehetett az elsődleges célja. Goffart szerint Iordanes jól

181 Az Ordo Generis Cassiodorum (Anecdoton Holderi) legutóbbi kritikai kiadása: GALONNIER 1996.

182 Cassiodorus részletesen a Variae egyik levelében ír az elveszett gót történetről lásd CASSIOD. VAR. 9.25.

183 Datálásról: KRAUTSCHICK 1983, 21-40, GOFFART 1988, 21.

184 JORD. GET. 1-3.

185 Ezek a modern munkák többnyire együttesen említik a két szerzőt Cassiodorus-Iordanes alakban. Többek között Wolfram is ilyen alakban említi WOLFRAM 1997, 26.

186 JORD. GET. 1-3. 
láthatóan sietett a Getica elkészítésével, mert az a Romanához képest sok hibát tartalmaz, ${ }^{187}$ ami véleménye szerint az utómunka hiányáról árulkodik. Ezen tévesztések egyike, hogy Iordanes szerint 410-ben Alarich nem egyedül, hanem Athaulffal közösen fosztotta ki Rómát. ${ }^{188}$

\subsubsection{Iordanes}

A korábbi kutatás álláspontjával szemben úgy gondolom, hogy minden történetíró alapvető igénye volt, hogy a lehető legteljesebb munkát adja ki kezei közül, így Iordanes hibái sem magyarázhatóak pusztán a sietséggel. Véleményem szerint Iordanes, annak ellenére, hogy elkötelezett a császár iránt, szándékosan tartózkodott attól, ${ }^{189}$ hogy bármiféle személyes megjegyzést tegyen. Iordanes Geticája nem tör pálcát egyik nép felett sem, hiszen a szerző számos olyan, a rómaiak és a gótok között lezajlott összecsapást tárgyal, amelyek végeredményben a rómaiak győzelmével értek véget. Ezeknek a vereségeknek a leírásakor azonban soha nem mulasztja el, hogy erkölcsi oldalról is alátámassza a két nép konfliktusát. Philippus császárral a gótok azért szakítanak, mert az uralkodó visszatartotta a szokásos ajándékot. ${ }^{190} \mathrm{~A}$ rómaiak hadrianopolisi csatavesztése ugyancsak a császár hibájából következett be, mert Valens megsértette a gótoknak tett vállalását, ugyanakkor megpróbálta megöletni a gót vezetőket. ${ }^{191}$ Iordanes munkája végén mégis Iustinianus háborúját és győzelmét igazolja. ${ }^{192}$ Iordanes szerint a két nép hosszú együttélése során kiegészítette egymást. A szerző szerint éppen ezért volt nehéz a rómaiaknak a gótok ellen harcolniuk, hiszen egykor még éppen ez a nép védte meg őket. ${ }^{193}$ Constantinust is a gótok segítették Licinius ellenében. ${ }^{194}$ De a gótok voltak azok is, akik parthusok ellen vonultak a rómaiak segédcsapataiként. ${ }^{195}$

Természetesen a gótok és rómaiak viszonya közel sem volt békés, Iordanes mindazonáltal igyekszik csökkenteni a két nép közötti ellenségeskedésnek a látszatát. Éppen ezért teljesen

187 JORD. GET. 145, Többek között összemossa a Eugenius és Maximus trónbitorlókat. JORD. GET. 153, 165, Geiserichet 407-ben Hispánia területére helyezi, akit 416-ban már Észak-Afrikában találunk. Ezek a hibák nem szerepelnek a Romanában.

188 JORD. GET. 159-60.

189 JORD. GET. 313-315, Iordanes elkötelezettségére. JORD. GET. 38, 68, A történetíró Konstantinápolyt következetesen a "mi városunknak" (nostro urbe) nevezi.

190 JORD. GET. 89.

191 JORD. GET. 132-133, 136-138. További példák: JORD. GET. 76, Domitianusszal azért szakítottak a gótok, mert a császár kapzsivá vált. JORD. GET. 154-155, Iordanes szerint Alarich itáliai portyázásai ugyan nagy károkat okozott a rómaiaknak, de ebben az esetben ugyancsak az utóbbiakat terhelte a felelösség, hiszen előbb szerződést kötöttek a gótokkal, majd megtámadták őket.

192 JORD. GET. 307, 314-315.

193 JORD. GET. 111.

194 JORD. GET. 111-112.

195 JORD. GET. 111-112. Iordanes megjegyzi, hogy a római hadvezérek mindig bölcsen döntöttek, amikor a germán népre bízták a védelmüket. 
kihagyja Valens gót háborúját, ami részletesen szerepel Ammianus Marcellinusnál, akinek munkáját Iordanes ismerte és használta is. ${ }^{196}$ Szó sem esik a római csapatok 540 -es években elszenvedett sorozatos vereségeiröl, ahogyan a Konstantinápolyban tomboló pestisjárványról is megfeledkezik a szerző. A Getica végére érve az a benyomása támad az olvasónak, hogy a dicsőséges gót uralomnak vége szakadt.

A Geticával szemben a Romana már pótolja ezeket a mulasztásokat, így a 6. század közepét érintő természeti katasztrófák is megjelennek. ${ }^{197}$ A szaporodó sorscsapások miatt Iordanes zárása a Geticában joggal volt borús, a szerző meg volt róla győződve, hogy a birodalom a végéhez közelít, és ezt ki is nyilvánította azokban a levelekben, amelyeket a kész munkákhoz csatolt. Vigiliusnak írt levelében János apostolt idézi, aki szerint a világ szeretete hiábavaló, hiszen egyszer véget ér, és minden megszünik, ami benne van. ${ }^{198}$ Hasonlóan borúlátó üzenet ahhoz, amellyel Orosius fejezte be hét kötetes pogányok ellen írt munkáját (Historiarum adversum paganos libri VII) ${ }^{199}$ Miközben Iordanes bizonyíthatóan használta Orosius munkáját, sem a Getica sem a Romana nem tekinthető kereszténységet védelmező apologetikus munkának. Mindkettő történeti munka, ami a klasszikus kultúra hagyományait folytatja.

Iordanes minden bizonnyal idős korában kezdte az írást. Attila birodalmának felbomlását követően Iordanes nagyapja Candac jegyzöje volt, ${ }^{200}$ Iordanes pedig kezdetekben Candac unokaöccsének, Bezának a jegyzöje volt. Iordanes minden bizonnyal akkor kezdte írni müveit, amikor már járatos volt a latin irodalomban. Motivációjában a 6. század virágzó irodalmi élete is szerepet játszhatott. A korszakban a klasszikus irodalmi müfajok közötti határ kezdett elmosódni, nem érvényesültek a korábbi szigorú megkötések. ${ }^{201}$ Iordanes írása azt mutatja, hogy miközben biztosan barbár származású volt, szinte teljesen romanizálódott, büszke volt gót származására. Valószínüleg érezte, hogy valami probléma van ebben a kettősségben. Minden bizonnyal ezek az érzések fordíthatták a történelmi kutatások és történetírás irányába. ${ }^{202} \mathrm{~A}$ Romanában megnyilvánul, hogy a történet, amit ír, az egyben a saját története is, lehetséges jó rómainak lenni úgy, hogy nem adja fel gót örökségét. A Getica egyfajta személyes bocsánatkérés, ez természetesen csak azokra a szakaszokra érvényes, ahol saját magát mutatja be, hiszen a többi nem saját tapasztalatán alapul. A

196 HEATHER 1989, 102-128. JORD. GET. 298-292 vö. MALCH. 15; 18. Theoderich a birodalom hüséges szövetségeseként jelenik meg és egy szó sem esik a 480-as években a birodalom ellenében vívott harcairól.

197 JORD. ROM. 376-388.

198 1JÁN. 2.15

199 OROS. 7.39.

200 JORD. GET. 265-266.

201 CAMERON 1985, 24-28.

202 LIEBESCHUETZ 2011, 300 
Getica meghatározó gondolata a rómaiak és gótok kapcsolata. Iordanes elbeszélésének tanulsága, hogy amikor mindkét fél tisztességesen viszonyult egymáshoz, akkor kapcsolatukból mind a rómaiak, mint a gótok profitáltak.

Iordanes munkájának felépítése és a szerző iránymutatása rávilágít arra, hogy - szemben a korábbi nézetekkel - a Getica egy tudatosan felépített egész, így hibáinak is célja van. A bevezetést követően Órigenés kommentárja található, majd a gótok földrajzi eredetével foglalkozik, ${ }^{203}$ amit vándorlásuk követ. ${ }^{204}$ Ezután már mint egyesült nép kerülnek tárgyalásra egészen a 4. század végéig. ${ }^{205}$ Ezt követően két szálra válik az elbeszélés: a vizigótokéra ${ }^{206}$ és az osztrogótokéra, ${ }^{207}$ amit az utószó zár. A Getica egészében az alkalmi ,jelzőtáblák” irányítják az olvasót előre és hátra. A kitérők szépen bevezetettek és befejezettek. ${ }^{208} \mathrm{Ha}$ az olvasó nem hagyja figyelmen kívül a szerző útbaigazításait, akkor nem érzi kuszának Iordanes elbeszélését, és nem kételkedhet abban sem, hogy Iordanes kiegészítette Cassiodorus munkáját más görög és római írókkal, amit már jelezett a bevezetőben. Éppen ezért biztosak lehetünk abban, hogy azok a források, amelyeket Iordanes név szerint említ, nem Cassiodorustól származnak, hanem Iordanes kiegészítésként illesztette be őket.

Iordanes következetesen adja meg forrásait is. Már munkája elején beismeri, hogy a kezdeti földrajzi leíráshoz szükséges forrás Orosius volt, Britannia leírása pedig Liviustól származik. ${ }^{209}$ Iordanes tehát pontosan azt csinálja, amit az elöszóban megadott. ${ }^{210}$ Kiegészítő információkat közöl Cassius Diótól, ${ }^{211}$ Orosiustól, ${ }^{212}$ Pompeius Trogustól, ${ }^{213}$ de megemlíti Vergiliust ${ }^{214}$ és Lucanust ${ }^{215}$ is, vagyis azokat a költőket, akik saját idejében jól ismertek voltak. Miután végigvezeti olvasóját a 2. század eseményein, Ablabiustól származó értesülései alapján ismerteti az osztrogótok és vizigótok

JORD. GET. 1-24.

204 JORD. GET. 25-81.

205 JORD. GET. 82-130.

206 JORD. GET. 131-245.

207 JORD. GET. 246-316. Az osztrogótok történetének részletes beszámolója a 268. résztől indul, ezt megelőzően a szerző az elötörténetüket és a gót csoportok szétválását tárgyalja.

208 JORD. GET. 16 (reliquimus, redeamus), 19 (nobis sermo est), 22 (sequitur deinde) 39 (propositum redeamus), 52 (mentio est) 75 (mentio facta est), 82 (redeamus doceamusque; unde agimus), 88 (unde agimus), 90 (quid multa?) 172 (ad propositum redeamus), 243 (de quo in subsequentibus dicturi sumus, obtenuit), 245 (nam pari tenore, ut de Augustis superius diximus; "quod nos interim praetermisso sic ut promisimus omnem Gothorum texamus originem”), 252 (sed nobis, ut ordo, quem coepimus, decurrat), 268 (ergo, ut ad gentem, unde agimus, revertamur).

209 JORD. GET. 10.

210 JORD. GET. 38, Scythia leírásával kapcsolatban nem nevezi meg forrását, azt azonban közli, hogy releváns értesülésből származnak információi.

211 JORD. GET. 40, 58, 65.

212 JORD. GET. 44, 58.

213 JORD. GET. 48, 61.

214 JORD. GET. 41.

215 JORD. GET. 44. 
eredetét. ${ }^{216}$ Ezt Maximinus Thrax, az első gótnak tekinthető császár bemutatása követi. Iordanes ekkor közli, hogy a császárról származó értesülése Symmachus Historia Romanájának ötödik könyvéből származnak. ${ }^{217}$ Iordanes tehát továbbra sem tesz mást, mint kiegészíti Cassiodorus munkáját a saját forrásai és elgondolásai alapján. A Maximinustól Constantinusig terjedő részben nem említ más forrást, így ezek minden bizonnyal Cassiodorustól származhattak. ${ }^{218}$ Azonban, amikor a gótok történetét egy másik nép elbeszélése keresztezi, ismét más forrásokhoz nyúl, amelyeket ugyancsak megnevez. A vandálok ismertetésekor Dexippiushoz nyúlt, ${ }^{219}$ a hunok esetében pedig Orosiushoz ${ }^{220}$ és Priskoshoz. ${ }^{221}$ A Getica csaknem felét teszi ki a vizigótok és az osztrogótok történetének ismertetése. ${ }^{222}$ Munkájának ezen részében csak három külső forrásra hivatkozik, melyek közül az egyik Priskos. ${ }^{223}$ Iordanes minden bizonnyal intenzíven használta Priskost, hiszen a konstantinápolyi udvar diplomatájának történeti munkája 430 és 474 között az 5. század csaknem egészét lefedi. Mikor Priskos munkájának végére ér, életkora révén már képes arra, hogy szóbeli hagyománnyal és saját tapasztalatával egészítse ki munkáját. Ezeken a helyeken kapnak helyt változatos értékítéletei és itt érhetők tetten saját gót identitásával kapcsolatos megnyilvánulásai is. ${ }^{224}$ Ennek értelmében nyugodtan kijelenthető, hogy a szerző megfelelő, önálló és koherens módon dolgozta össze forrásait, így számítani lehet arra, hogy valamilyen cél vezette a szerzőt, valamilyen irányba fejlesztette a történet.

216 JORD. GET. 82.

217 JORD. GET. 83.: "Nam, ut dicit Symmachus in quinto suae historiae libro, Ensslin nézetének, miszerint a Iordanes Romanája Symmachus elveszett történetének kivonata legföképpen erre a passzusra épült.

218 JORD. GET. 89-112.

219 JORD. GET. 113.

220 JORD. GET. 121.

221 JORD. GET. 123.

222 Vizigótok: JORD. GET. 131-245, osztrogótok: 246-314.

223 JORD. GET. 178, 183, 222, 254, 255.

224 Elődeiröl: JORD. GET. 43, 59, 116, 148, 246, 316, identitásáról: JoRD. GET. 28, 43, 72, 79, 116. Cassiodorus minden bizonnyal nem mondott el számadásában ilyen történeteket, hiszen római származású volt. A kiegészítő írott forrásokon kívül Iordanes beszámol arról, hogy számos dolgot ad hozzá saját szavaival. Amennyiben ilyen szöveghelyek azonosíthatóak, úgy három nagy csoportba sorolhatóak: felszólalások és vélemények, kortárs hivatkozások és összekötő kifejezések. Ezek többnyire személyes vélemények, vagy értékítéletek, mint például, hogy a barbárok hajlamosabbak polgárháborúra. JORD. GET. 169, vagy 29, 218. Ez a kategória számos nyelvvel és földrajzzal kapcsolatos megjegyzést tartalmaz. JORD. GET. 119, 134, 157. 193. 197, 214, 217, 218, 245, 259; etimológiai megjegyzések JORD. GET. 27, 48, 70, 71, 72, 95; és személyes állítások 12, 14, 31, 37. 38, 45, 52, 57, 70, 74, 75, 104, 120, $125,169,261.266,316$. A második csoportot a kortárs megjegyzések alkotják: JORD. GET. 7, 21, 25, 27 , 51. 67. 69. 74, 96, 103, 104, 107, 112, 113, 119, 168, 172, 264, 265, 266, 267, 273, 303. ilyen például a pestisjárvány (104). A harmadik nagy csoportot azok a kötőszavak alkotják, amelyek jelzőtáblaként funkcionálnak az elbeszélés során: JORD. GET. 9, 10, 16, 39, 42,48, 52, 54, 61. 74, 83, 94, 95, 96, 107, $114,119,129,130,133,147,152,161,169,174,176,184,197,200,240,243,245,251,263.268,290$, 295, 299. O’DONNELL 1982, 230. Ezek célja elsősorban, hogy előre és hátrafelé mozgassák az olvasót a megfelelő témacsoporthoz, és azt az érzetet keltik, hogy a szerző tökéletes uralja a müvét. 
A Getica egy a vizigótokat tárgyaló rész kezdetén ${ }^{225}$ Fritigern népének vándorlásával kezdi elbeszélését. Iordanes szerint az egyre terjeszkedő hun hatalom miatt indultak útnak. Követeket küldtek Valenshez annak érdekében, hogy bebocsátást nyerjenek a birodalomba. A császár engedett a kérésnek és Thracia és Moesia területén telepítette le őket. ${ }^{226}$ Majd úgy folytatja, hogy ezekkel a barbárokkal is az történt, ami azokkal szokott, akik rossz helyen telepedtek meg. ${ }^{227}$ A történetíró szerint a frissen megtelepült menekült tömegeket egy idő után gyötörni kezdte az éhség, ezért kereskedelmi lehetőséget kértek a helyi római vezetőktől, elsősorban Lupicinustól, aki kapva a vizigótok kiszolgáltatott helyzetén, sokszoros áron kínálta nekik a különféle húsokat. ${ }^{228}$ Iordanes szerint a rómaiak kapzsisága olyan méreteket öltött, hogy a gótok egy idő után már egy rabszolgáért is csupán egy darab kenyeret, vagy tíz font húst remélhettek. Amikor már a vizigótok rabszolgái is elfogytak, a kereskedők gyermekeiket kezdték követelni. ${ }^{229}$ Ekkor történt, hogy Lupicinus meghívta Fritigernt udvarába, ám kelepcét állított a vizigót vezérnek, akinek azonban sikerült túlélnie a merényletet. Az inzultusra a vizigótok fegyverrel válaszoltak, és már nem vendégként, hanem saját jogon kezdték birtokba venni az Thracia környéki területeket. ${ }^{230} \mathrm{~A}$ lázadó gótok ellen az ekkor még Antiochiában tartózkodó Valens vonult, a gótok azonban Hadrianopolis mellett (378) megsemmisítő vereséget mértek a császárra, ami végső soron Theodosius visszahívásához vezetett. A Valens helyére kinevezett Theodosius, miután helyreállította a meglazult katonai fegyelmet, Thraciába vonult seregével és egészen a provincia határáig üzte a gótokat. ${ }^{231}$

Az imént említett történet mesélését Iordanes egy nevezetes intertextus található. Fritigern népének kizsákmányolásának részletezése kapcsán a szerző Vergilius Aeneis-ének egy részletét használja a rómaiak aranyéhségének (auri sacra fames) leírására. ${ }^{232}$ Erre az allúzióra már maga Mommsen is felhívta a figyelmet, különösebb jelentőséget azonban nem tulajdonított neki elsősorban a már részletezett okok miatt, hiszen a szöveghely meglehetősen rövid, így akár azt is gondolhatnánk, hogy Iordanes korábbi olvasmányaiból emlékezett erre a kifejezésre. ${ }^{233} \mathrm{Az}$

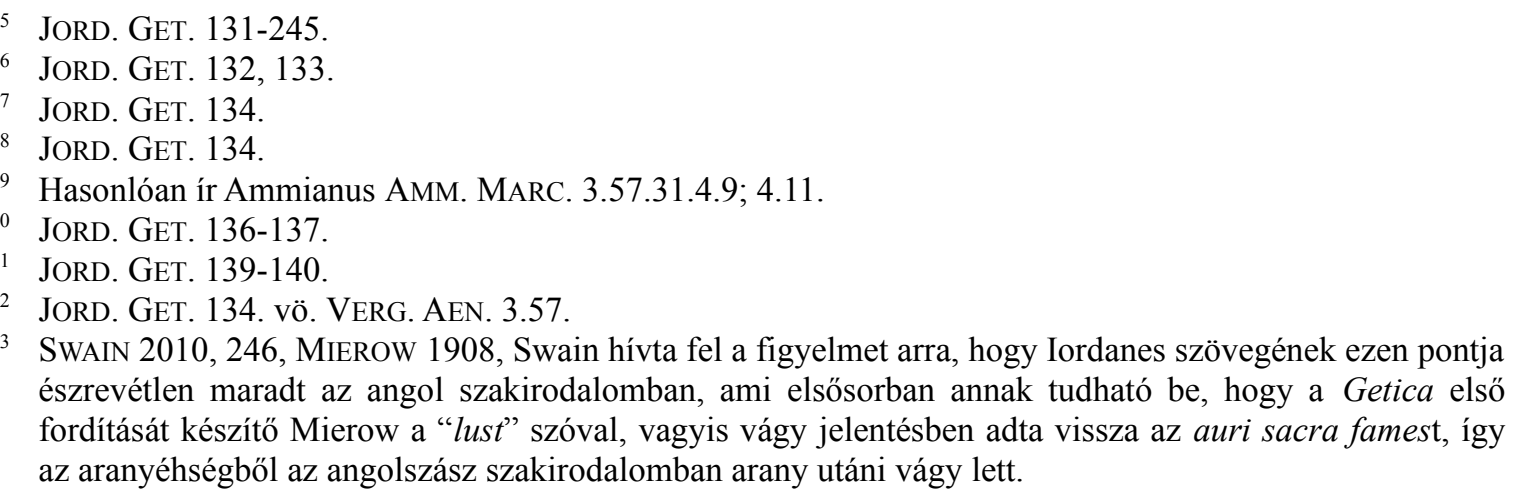
észrevétlen maradt az angol szakirodalomban, ami elsősorban annak tudható be, hogy a Getica első fordítását készítő Mierow a “lust” szóval, vagyis vágy jelentésben adta vissza az auri sacra famest, így az aranyéhségből az angolszász szakirodalomban arany utáni vágy lett. 
elözőekben láttuk, hogy Iordanes következetesen megnevezte azokat a történetírókat, akiket használt és éppen ott, ahol felhasználta öket. Ebben az esetben azonban eltekint ettöl, így valószínüsíthető, hogy a szöveghely Cassiodorus Historia Gothorumából származhat. Erre utalhat a szerkezetbeli egyezés is, hiszen Vergilius mủve is 12 énekből áll, ahogyan a Historia Gothorum is. Cassiodorus munkájával kapcsolatban azonban ez minden, ami kimutatható.

Sokkal érdekesebb az a iordanesi kontextus, amelyben Vergilius részlete helyt kapott. A hun támadás következtében a gótok elhagyták eredeti szálláshelyüket, akik a rómaiak földjére menekültek. A szánalmasan menekülő nép képe megegyezik az Aeneis 3.57-el, amit Iordanes allúzióként használ. ${ }^{234}$ A gótok, ahogyan trójaiak is, új haza keresésére indulnak. Vergilius intertextusa Iordanes narratívájának szerves részét képezi. A rómaiak "aranyéhsége" azonnal az olvasó emlékezetébe idézi Fritigern népének éhezését, ezáltal szembeállítja a két népet és kiemeli pozícióbeli különbségüket. Vergilius, miután a második énekben beszámol Trója bukásáról, a menekülők történetével folytatja elbeszélését. A két narratíva tematikus egyezést mutat, ráadásul mindkettő kapcsolódik Thraciához. Iordanes azonban más ponton is követi Vergilius munkáját. A harmadik ének elején Aeneas elhagyja Tróját és új otthont keres népének. Miután hajókat építenek, útnak indulnak. Első városalapítási kísérletükre éppen Thraciában kerül sor, ami ugyan sikertelennek bizonyul, de egy érdekes jelenet rajzolódik ki az olvasó előtt. Aeneas áldozatot készül bemutatni, de a felhasználni kívánt cserjék alatt, ahogy kiszakítják öket a földböl vérezni és beszélni kezd a mélység:

\section{"Hagyd a halottat, tiszta kezed kíméld. Nem a kóró \\ Vére csepeg - te pedig jól ismersz, trójait engem! \\ Fuss e kegyetlen földröl, fuss, jaj, e kapzsi vidékröl.“235}

A mélyböl a halott Polydóros hangja szólt, akit még a trójai háború idején Priamos király küldött tengernyi arannyal vejéhez, a thrákok királyához, hogy biztonságba helyezze gyermekét. A kapzsi Polyméstor azonban Trója eleste után megölette az oltalmat kereső Polydórost, hogy megkaparintsa kincseit. Korábban láthattuk, hogy Prokopios előbb Iustinianus emlékmüvének kapcsán tett világos utalást a trójai mondakörre, majd a Háborúkról írott múvében is utalt rájuk Róma 410. évi ostromának leírása kapcsán. A Getica szerzője ezzel az egyértelmü párhuzammal világosan azonosítja a gótokat a trójaiakkal, a rómaiakat pedig a görögökkel. ${ }^{236} \mathrm{~A}$ korábbi kutatás ismeretében azt is mondhatnánk, hogy ezek a részek Cassiodorus Historia Gothorumából kerültek a Geticába,

\footnotetext{
234 JORD. GET. 134. vö. VERG. AEN. 3.57.

235 VERG. AEN. 3.42-44. Lakatos István fordítása.

236 JORD. GET. 134. vö. VERG. AEN. 3.57.
} 
mindenesetre csak annyi bizonyos, hogy Iordanes és Prokopios személyében egy latin és egy görög nyelven alkotó szerzőnél is felbukkan a gótok trójaiakkal történő párhuzamba állítása, így ez a kép mindenképpen általánosan ismernek számított a 6. században. A gótok Hadrianopolis után továbbindulnak Nyugat felé, akárcsak Aeneas, és a trójaiakhoz hasonlóan, nőrabláshoz folyamodnak.

Iordanes csupán a 160. caput környékén hibázik, de ott sokszor. Mulasztásai éppen Galla Placidia elrablásának körülményeit érintik, ahol meglehetősen furcsa kronológiát alkalmaz. A kortárs krónikákban, így Hydatiusnál négy évvel azt követően, hogy a gótok feldúlták Rómát, Narbo városában Athaulf feleségül vette az elhurcolt Galla Placidiát. 416-ban pedig Honorius parancsára Constantinus indult az asszony kiszabadítására. ${ }^{237}$ Annak ellenére, hogy Galla Placidia szabadon bocsátására 416-ban került sor, ${ }^{238}$ Iordanes közvetlenül Iovinus 411-413 közötti trónbitorlása elé helyezi, így azt az érzetet erősíti, mintha a szabadon bocsátásra rögtön az elrablása után, tehát még 410-ben sor került volna. ${ }^{239}$ Iordanes a környező eseményeket is úgy módosítja, hogy azt az érzetet erősítse, mintha Galla Placidia elrablása és szabadulása szorosan összefüggne Róma kifosztásával.

Láthattuk, hogy Prokopios és Iordanes eltérő módon közelítette meg a gótok történetét. Prokopios a népnevek használatával nemcsak keretezte a történetet, de rámutatott arra is, hogy a probléma gyökerét az asszonyrablások jelentették. Ezzel szemben Iordanes vergiliusi allúzióval a trójaiakkal azonosította a birodalom nyugati felébe érkező gótokat, akik Aeneashoz hasonlóan új haza keresésére indulnak, előbb Thraciában telepednek meg, de maradásuk nem lévén, onnan is továbbállnak Itália irányába. Jellemük azonban nem változik, és ismét asszonyt rabolnak, de a végén mégiscsak a görögök győzedelmeskednek. A következő fejezetben azt fogom vizsgálni, hogy miért lehetett fontos a történetírók számára, hogy összekapcsolják Nagy Theodosius lányának elrablását Róma kifosztásával.

237 HYD. CHRON. 49 (57).

238 HYD. CHRON. 52 (60). JORD. GET. 164. Athaulf hatalmát ekkorra már Valia örökölte. A senatornak nem kellett harcba bonyolódnia a gótokkal, mert elődjével szemben - és a Geticában egyedülállóan - Valia már igen "bölcs" volt, így szövetséget kötött Constantiusszal, megegyezésük fejében pedig Galla Placidia szabadon távozhatott.

239 JORD. GET. 164 vö.165, illetve JORD. ROM. 325-326, ahol a kronológia rendben szerepel. Constantinus és Valia megállapodása az alapját jelentette annak, hogy két évvel később a gótokat Aquitániában telepítették le. A jelentősége ennek az események, hogy alapjában véve ennek folyománya volt a vizigót királyság megalakulása Galliában. 


\section{410, RÓMA}

\subsection{A Róma kifosztásához vezetõ út}

\subsubsection{A gótok letelepítése}

382 öszén Theodosius utasította Saturninus magister militumot, hogy kössön békét a vizigótokkal és gondoskodjon letelepítésükről a Dunától délre eső területen. Jobbára a 20. század első felének német történetírásának hatása érhető tetten még a század végén is azokban az írásokban, amelyek gyávaságként vagy éppen megalkuvásként tekintenek a gótok letelepítésére, ${ }^{240}$ ami egészen érthetetlen, hiszen a római hadsereg gyakorlatilag nem létezett, csak Hadrianopolisnál 40000 római halt meg. A helyzet érzékeltetéseképpen, amikor Konstantinápoly elöször találta szembe magát a hunokkal és reflexíjukkal, évtizedekbe került olyan római íjászok kiképzése, akik hatékonyan fel tudták venni velük a versenyt, hiszen nekik is hasonló kiképzésen kellett átesniük, mint azoknak, akik már gyermekkoruk óta forgatták a fegyvert. ${ }^{241} 480$ elején, a probléma mértékéhez képest nemhogy speciális harcászatra nem volt kit kiképezni, hanem még az egyszerü sorozás is problémákat okozott. A császár kétségtelenül nehéz helyzetben volt, ami más, a korábbiaktól eltérő hozzáállást kívánt. A fejezet első részében rámutatok arra, hogy a 4. század végén hogyan magyarázták a vizigótok letelepítését, ezt követően rátérek arra a kérdésére, hogy a letelepítettek házasodhattak-e a provinciabeli őslakosokkal. A fejezet záró szakaszában pedig a barbár Galla Placidia és Athaulf házasságának történetírói értelmezését fogom ismertetni

Annak ellenére, hogy közel másfél évig dolgoztak Theodosius megbízottjai, elsősorban a Saturninus magister militum és az általa vezetett csoport a 382-es gót megállapodás (foedus) részletein, a dokumentum nem maradt fenn, így a megállapodás pontos részleteit is homály fedi, még csak nem is utalnak rá későbbi forrásokban. Elsősorban Herwig Wolfram kutatásai nyomán, a 382-es szerződés néhány alapvető elemét tekintve, megegyezik a kutatás számottevő része. ${ }^{242}$ Ezek

240 Ezen nézet képviselőire lásd Holum 1989, 8. 7. lj.

241 LUTTWAK 2011, 71. A római hadszervezet kihívásaira és a rájuk adott válaszra lásd: LUTTWAK 2011, 149.

242 Heather 1996, 150, Wolfram 1990A, 133-134. A szerződéssel kapcsolatos további megállapítások: 1. 382-ben elsődleges feladatuk a határvidék védelme volt, ezért Dacia és Thracia dioecesisek északi részén, a Duna és a Balkán hegyei között telepítették le öket, ahol adómentességet élveztek. 2. A gótok rendelkezésére bocsátott terület továbbra is a birodalom szerves része maradt, annak ellenére, hogy a gótok bizonyos fokú autonómiáját élveztek ezeken a területeken. 3. A gótok kötelesek voltak katonai segítséget nyújtani a rómaiaknak, de csak a saját törzsi vezetöiktől kapott parancsot fogadták el. De 394ben Alarich már egy római tábornok parancsnoksága alatt állt. 4. Együtt éltek a provincia lakosságával, 
egyike szerint a gótok nem leigázott és nem alávetett népnek minősültek, hanem a birodalom alattvalói és szövetségesei lettek, de barbárok maradtak, így nem rendelkeztek a római házassághoz füződő joggal, a ius conubii-val. Ennek a nézetnek az alapját az adja, hogy a forrásokban nem találunk római és szövetséges közötti házasságot. Ezt a képet némileg árnyalhatja a kortárs történetírók véleménye.

A gótokkal kötött foedus Themistios, Pacatus (389) és Synésios (De Regno) munkájában fordul elö, ${ }^{243}$ de részletesebben csak Themistios tárgyalja a tizenhatodik és a harminckettedik szónoklatában. ${ }^{244}$ Müfaji sajátosságaik miatt Themistios szónoklataiban és Pacatus panegyricusában is kifejezetten kedvező kép tárul az olvasó elé a császárról, nem így Synésios De Regno c. munkájában, ami elsősorban Theodosiust és az általa életre hívott megállapodást támadja. ${ }^{245}$

Elsősorban Themistios igyekszik hangsúlyozni, hogy a 382-es foedus külsőségeiben a deditio (meghódolás) formalitásainak felelt meg, tehát valamilyen módon alárendelt csoportot lát a gótokban. ${ }^{246} \mathrm{~A}$ deditio fogalma meglehetősen változékonynak bizonyult a római történelem során. A királyság időszakában olyan idegen (peregrinus) népekre vagy törzsekre alkalmazták, amelyek önként helyezték magukat Róma fősége alá. Az ilyen jellegü meghódolás legkorábbi példáját Livius említi a szabinok deditiójáról, ami a rómaiakkal folytatott harcok után köttetett Tarquinius és a hozzá küldött követek útján egyszerü kérdés-felelet formájában. ${ }^{247}$

A 4. század végén kötött gót szerződés tehát, ha elfogadjuk Themistios megjegyzését, ehhez a korai liviusi példához állhatott közel. A meghódoltatás másik módja ugyanis háború, az imperium erőszakos terjeszkedése útján történt (deditio in dictionem), ebben az esetben a megállapodás célja a legyőzöttek saját célokra történő hasznosítása. Ezeknek a népeknek a jogállása meglehetősen széles skálán mozgott, a szabadságukban részben vagy egészben

megélhetésüket kezdetben az a föld biztosította, amit a rendelkezésükre bocsátottak és amit megmüveltek. Ennek a megoldásnak azonban nem sokáig volt jövője, ezt tükrözi a későbbi galliai és itáliai gót berendezkedés (lásd. GOFFART 2010). 5. Szövetségesként jogosultak voltak éves fizetésre, ennek pontos rendszere és összege azonban ismeretlen.

243 PACAT PANEG. 12.12.3-5, SyN. Ep. 19-21.

244 THEM. OR. 16, 32.

245 A békemegállapodás modern rekonstrukciói: STALlKNECHT 1969, ChrYsos 1989, WOLFRAM 1990, HEATHER 1996.

246 THEM. OR. 16, 199c.

247 LIV. 1.38. "Collatia et quidquid citra Collatiam agri erat Sabinis ademptum; Egerius-fratris hic filius erat regis-Collatiae in praesidio relictus. Deditosque Collatinos ita accipio eamque deditionis formulam esse: rex interrogavit: "Estisne vos legati oratoresque missi a populo Collatino ut vos populumque Collatinum dederetis?"-_"Sumus."-Estne populus Collatinus in sua potestate?"-"Est."-"Deditisne vos populumque Collatinum, urbem, agros, aquam, terminos, delubra, utensilia, divina humanaque omnia, in meam populique Romani dicionem?"-_"Dedimus. "_"At ego recipio." Bello Sabino perfecto Tarquinius triumphans Romam redit." 
korlátozottól a félszabadokon keresztül egészen a bizonyos függetlenséget élvező népekig. A deditio in dictionem esetében Róma rendelkezett mindenről: az alárendelt nép autonómiájának mértékéről, a vallási szokások megtartásáról. A kulcskérdés a meghódoltatás során valójában az, hogy Róma szóban vagy szerződésben lefektetett feltételei mennyire vannak összhangban a realitásokkal, hiszen elnyomó feltételek alapján nem valószínű a nép tartós behódoltatása. ${ }^{248}$

A 6. században, a római jogi oktatás alapját képző gaiusi Institutionesben érdekes kontextusban említik a peregrinusokat. Róma öt minősített jogtudósának egyike a 2. században csak azokat nevezte peregrinus dediticiusnak, akik fegyvert ragadva küzdöttek a római nép ellen, majd legyőzetvén megadták magukat. ${ }^{249}$ Néhány évtizeddel később Caracalla reformja (constitutio Antoniniana) nyomán a birodalom határain belül élő peregrinusok megkapták a polgárjogot, a dediticiusok azonban nem. A rendelet kibocsátásakor a városok megmaradtak korábbi helyzetükben, noha ez az autonómia a 4-5. századi központosítások időszakában megszünik.

A constitutio Antoniniana kibocsátása után a 4. századi Aelius Sentius törvénye megtartotta Gaius dediticius értelmezését. Olyan felszabadított rabszolgáknak tartotta őket, akik egykor fegyverrel harcoltak a római nép ellen, majd legyőzöttként behódoltak. Az ő szabadságuk a legkorlátozottabb, mert semmilyen törvény, vagy rendelet nem adhat nekik római polgárjogot. ${ }^{250}$

Ammianus Marcellinus Róma történetéről írott munkájában öt alkalommal bukkannak fel dediticiusok, ${ }^{251}$ számunkra azonban csak egynek van jelentősége. 360 februárjában Iulianust augustusszá kiáltják ki a lutetiai téli szálláson, amit levélben közöl II. Constantiusszal. Levelében kifejti, hogy igáslovakon túl, olyan leaetusokat ${ }^{252}$ fog küldeni uralkodótársának, akik a Rajnán inneni barbár szülőktől származnak, illetve fiatalokat a meghódoltak (dediticiis) soraiból. ${ }^{253}$

Az acclamatióját megelőző években Iulianus több hadjáratban a frankok és az alemannok ellen indult a nyugati területeken jobbára a Rajna mentén. 356 nyarán, első germán hadjáratában Augustodonum (Autun) és Antissiodorum (Auxerre) mellett több várost is felszabadított. Ammianus megemlíti, hogy miután 359-ben összeesküvés vádjával kivégezték Barbatiót, ${ }^{254} \mathrm{a}$ katonái Iulianushoz kerültek. Az egy évvel későbbi levél meghódolt ifjai (dediticiis), így vagy tőle

248 LIV. 42.8.4, 7.27.9, AMM. MARC. 17.12.13, SHERWIN-White 1973, 60.

249 GAI. INST. 1.14.: "Vocantur autem peregrini dediticii hi, qui quondam adversus populum Romanum armis susceptis pugnaverunt, deinde victi se dediderunt."

250 GAI. INST. 1.14-15, 26.

251 AMM. MARC. 20.8.13, 21.4.8, 24.2.22, 27.12.6, 29.5.35, 31.6.5.

${ }^{252}$ Alemann nép, akik a római segédcsapatok egy részét alkották. Lásd AMM. MARC. 16.11, 20.8, 21.13.

253 AMM. MARC. 20.8.13.: "Equos praebebo currules Hispanos et miscendos Gentilibus atque Scutariis adulescentes Laetos quosdam, cis Rhenum editam barbarorum progeniem, vel certe ex dediticiis qui ad nostra desciscunt".

254 PLRE1 146-147, "Barbatio". 
kerültek Iulianushoz, vagy - és ez a valószínübb - a 359-es alemann hadjárat során a szövetséges (amicum nobis) Suomarius királytól, akinek a területei a Rajna mindkét partjára átnyúltak. Ammianus szerint bár vonakodott átengedni a Rajnán Iulianus seregeit, arra végül nem került sor, hogy feldúlják a meghódolt törzsek földjét (pacatorum terrae). ${ }^{255}$ Gaius és Ammianus műveinek tükrében a dediticiusok tehát egyrészt lehettek azok az idegen népekhez tartozó egyének, akik behódolást követően katonáskodni kezdtek a római seregben, vagy e kifejezés jelölhette felszabadítottak egyes kategóriáit.

382-es megállapodás kapcsán Themistios 16. szónoklatát azzal kezdi, hogy a legyőzöttek, akárcsak a korábbi ábrázolásokon, önkéntesen átadják fegyvereiket. ${ }^{256}$ Majd a mitológiai Thetishez hasonlítja öket, aki azzal igyekezett elkerülni házasságát Péleusszal, hogy folyamatosan alakot váltott. Bár végül egybekelnek, az idáig vezető út inkább hasonlít elnyújtott harcok sorozatához semmint harmonikus kapcsolathoz. ${ }^{257}$ Az előző fejezetben a mellett érveltem, hogy a 6. században a gótokat a trójaiakkal azonosították, ezzel szemben a 4. század végén Themistios még csaknem egyenrangúan kezeli öket, olyan félként, amellyel a rómaiak képesek az egyesülésre, azonban Thetis és Péleus említésével olvasója emlékezetébe idézi Thetis átváltozásainak sorozatát, amely a házasság elodázását szolgálta, így Themistios mégis deditióként írja le az eseményt. ${ }^{258} \mathrm{Nem}$ különben Pacatus, vagy éppen Libanios, aki Theodosiushoz írt panegyricusában szolgaként, szolgálatba fogadottakként említi a gótokat. ${ }^{259}$ Synésios pedig már egyszerü könyörgőként írja le őket. ${ }^{260}$ A kor történetírói nem a foedusra jellemző egyenlő feltételeként írják le az eseményt, hanem behódolásként. ${ }^{261}$

255 AMM. MARC. 18.2.8-9, “Alamanni tamen omnes, quos petebat exercitus, confine periculum cogitantes Suomarium regem amicum nobis ex pactione praeterita monuerunt minaciter ut a transitu Romanos arceret. Eius enim pagi Rheni ripis ulterioribus adhaerebant. Quo testante resistere solum non posse, in unum coacta barbara multitudo venit prope Magontiacum prohibitura viribus magnis exercitum ne transmitteret flumen. 9 Gemina itaque ratione visum est habile quod suaserat Caesar, ne pacatorum terrae corrumperentur, neve renitente pugnacissima plebe pons cum multorum discrimine iungeretur, iri in locum ad conpaginandum pontem aptissimum".

256 THEM. OR. 16.199c, HEATHER-MonCUR 2001, 265, 189. 1j. Heather és Moncur szerint Themistios ikonográfiai emlékekre történő utalásai, amelyek kivétel nélkül a császár győzelmét hangsúlyozzák, azt mutatják, hogy Theodosius győzelmi menetet tarthatott, minden bizonnyal 382. október 3-án. Ezzel szemben lásd. MCCORMICK 1990, 42-43. Ugyanakkor kiemelendő, hogy Heather és Moncur ennek alátámasztását nem kortárs forrásokból nyeri, hanem a 6. századi krónikástól, Marcellinus comestól.

257 THEM. OR. 16.210d. vö. HOM. IL. 1.528.

258 Orosius szerint valamennyi gót törzs behódolt. OROS. 7.34.7: "universae Gothorum gentes rege defuncto aspicientes virtutem benignitatemque Theodosii Romano sese imperio dediderunt”. Az 5. század második felében Hydatius már csak látszólagosnak (infida) nevezi a békét, ezzel utalva Alarich későbbi tevékenységére: HYD. CHRON. 7. (7): “Gothi infida Romanis pace se tradunt".

259 PACAT. PANEG. 2.22.3, LiB. OR. 9.16.

260 SYN. EP. 21.50.12.

261 A keletrómai történetírók szemléletmódjáról, illetve az identitás kérdéséről lásd. KALDELLIS 2011, 45-60, 82-99, 121-130, KALDELLIS 2017, 185-198, 
Ezzel szemben a 20. század első felében elterjedt az a nézet, hogy a béke kiegyensúlyozott és egyenrangú szövetségkötés volt, aminek különlegessége abban rejlett, hogy immár letelepítéssel is járt, melynek során a telepesek a római földet használták. Ennek a nézetnek az alapját azonban nem kortárs szerzők, hanem Iordanes 6. századi munkája, a Getica szolgáltatta. ${ }^{262}$ Mivel a Geticát ebben az időben hiteles forrásnak ismerték el, könnyen kialakulhatott az a nézet, hogy a 382-es megállapodás az első azoknak a békéknek a sorában, amelyben egy idegen félnek sikerült arra kényszerítenie a római államot, hogy hivatalosan is elismerje befolyási körzetének és stratégiai hatalmának visszaszorulását. ${ }^{263}$ Ennek azonban ellentmondanak a kortárs beszámolók, valamint az a tény, hogy a birodalom csak fél évszázaddal később kezd el tudatosan tervezni a barbár vezetők és népük eltartásához szükséges évi adóval (annona foederaticiae). ${ }^{264}$ De erre utal Theodosius halálát kötően Alarich felkelése is.

Themistios maga is elismerte, hogy a gótok, akik Hadrianopolisnál legyőzték és megölték Valenst, nem pusztultak el a következő négy év harcaiban sem. ${ }^{265}$ A gótok ráadásul, miután feldúlták a területet, még földet is kaptak. Themistios ezért azt igyekszik hangsúlyozni, hogy a gótok a föld után kötelezettségekkel is rendelkeznek, hiszen meg kell mủvelniük azt, így az adóbevételeket is gyarapították. A földmüvelés mellett ugyanakkor jelentős emberállománnyal egészítették ki a római hadsereget. A szónok azzal próbált közönségének megfelelni, hogy számos olyan érvet terjesztett elö, amelyek együttesen azt sugallták, hogy az adott helyzetben a lehetö legjobb eredményt érte el a császári vezetés. A 16. beszédében a mezőgazdasági termények után befizetendő adó mértékét emelte ki, ugyanakkor arra is kitért, hogy Thracia ismét benépesülhet a pusztító háború után. A későbbi 34. szónoklatában pedig már tényként közli, hogy az adóbevételek emelkedése valóban megtörtént.

A letelepítésből származó előnyök felsorolása után figyelemre méltó gondolat következik. Themistios szerint, még ha a rómaiak nem is irtották ki teljesen a gótokat, munkával és egyéb kötelezettségekkel ugyanúgy elnyomták őket mintha ténylegesen megsemmisültek volna. ${ }^{266}$

262 JORD. GET. 141-146.

263 Ezen a véleményen STALLKNECHT 1969, 25-26, aki éppen Iordanes miatt gondolta úgy Stallknecht, hogy már Constantinus is ezt próbálta alkalmazni 332-ben a Duna mentén. Ezzel a vélekedéssel szemben lásd HEATHER 1991B, 17.

264 NOV. THEOD. 24.2.

265 THEM. OR. 16.211a.

266 THEM. OR. 16.210a-211a, 34.32. THEM. OR. 15.190c-191a, ERRINGTON 1996, 11-14. Errington mutatott rá, hogy Themistios egyik korábbi szónoklatában, amelyben megörökítette az idős és beteg Athanarich Konstantinápolyba érkezését egy hosszú betoldás található. Ha összeolvassuk a betoldás nélküli részt, tökéletesen mutatja, hogy mit gondolt Themistios a megtört Athanarichról: Az ellenség sokkal jobban legyőzhető meggyőzéssel, mint erővel. Athanarichot 381. január 12-én megérkezett Konstantinápolyba 13 nappal később meg is halt. 
Themistios leírása tökéletesen egybecseng a deditio in dictionem, vagyis a háborúban legyőzött fegyveres nép maradványainak saját célokra történő felhasználásával. A dedito ilyen irányú értelmezése tökéletesen alkalmas volt arra, hogy a római nép számára azt az üzenetet közvetítse, hogy a Római Birodalom az Isteni gondviselés legfőbb haszonélvezője, ami képes arra, hogy tökéletességre juttassa az emberiséget. ${ }^{267}$ Ebben a sémában az idegenek a rómaiaknál alacsonyabb státuszban vannak, így velük szemben a helyenként durva eljárásokat (390-es mészárlás) ${ }^{268}$ is tökéletesen helyénvalónak tartották, mert ez is egyrészt azt erősítette, hogy alacsonyabb rangban vannak, ${ }^{269}$ másrészt azt, hogy büntetésüket az isteni rend ellen elkövetett tetteik miatt kapják. Ebből a nézőpontból csak a teljes és feltétel nélküli megadás jöhetett szóba az uralkodó és a barbárok között.

Themistios feladata egyértelmü volt, ugyanazt csinálta, amit Theodosius elődei idején, ${ }^{270}$ egyszerüen kiszolgálta megrendelőjét. Themistios elsősorban azért lehetett fontos Theodosius számára, mert jelentős szerepet játszott a fiatal konstantinápolyi senatus feltöltésében (355-ben II. Constantius (337-361) őt magát is közvetlenül, adlectio útján tette senatorrá). Themistios ezen feladat elvégzése során évekig járta a Balkán-félsziget déli csücskét, hogy érdemes aspiránsokkal töltse fel a - római társához képest kétségtelenül - fiatal szervet. A fiatal filozófus szónok, ha nem is a legnépszerübb, de annyi bizonyos, hogy a legismertebb tagja volt a keleti elitnek, hiszen a senatorok többségéhez közvetlen kapcsolat füzte, így amit leírt, a többség készséggel elfogadta. Kiszolgálta az uralkodói érdekeket. Székfoglalója után nem sokkal már hangos szavakkal dicsérte II. Constantiust társainak. ${ }^{271}$ A császár nem maradt hálátlan, hamarosan már egy bronzszobrot állíttatott Themistios tiszteletére és patriciussá tette. ${ }^{272}$ 361-ben Constantius halála után nem kellett hozzá sok idő, hogy a szónok az utód Iulianus bizalmát is elnyerje, ahogyan az elkövetkező uralkodókét is, egészen 379 januárjáig. ${ }^{273}$ Theodosius beiktatásának alkalmával Themistios első

267 A győzelem iránti elvárásra általánosságban lásd MCCORMICK 1990.

268 A mészárlás körülményeiről részletesebben lásd SPEIDEL 1998.

269 AMM. MARC. 30.6.3, Ammianus Marcellinus a Valentinianushoz érkező kvád követeket nevezi silány; alacsony rendủ embereknek (vilibus). Hasonló példák Themistiosnál: THEM. OR. 14.181c, 15.197b.

270 Themistiost már Iulianus, Iovianus, Valens és Gratianus idejében is kitüntetett figyelem övezte, aminek oka elsősorban oktatásában rejlett. Themistios Anatóliában, a Fekete-tenger partján fekvő Paphlagoniában született 317-ben. Apja Eugenius, a kor elismert gondolkodója volt, már korán bevezette fiát filozófia tanulmányozásába, aki elsősorban Aristotelésben, a platonikus tanokban, valamint az általuk közvetített hellenisztikus értékrendszerben találta meg a kiteljesedést. Aristoteléshez már igen korán kommentárokat készített. Themistios a húszas évei elején érkezett Konstantinápolyba, ahol ideje nagy részét a filozófia tanulmányozásának szentelte.

271 THEM. OR. 3.4.

272 COD. THEOD. 6.4.12.

273 THEM. OR. 31. 
dolga volt, hogy egy hosszú beszédben dicsérje az új uralkodót. ${ }^{274}$ Constantius, Iulianus, Iovianus, Valens és Gratianus után Theodosius számára nyilvánvaló volt, hogy mit várhat el Themistiostól, ahogyan a szónok számára is egyértelmü volt, hogy mit vár el tőle a császár.

A legelőnyösebb színben kellett feltüntetnie a császár által életre hívott megállapodást, amit úgy oldott meg, hogy deditio in dictionemként írta le a 382-es megállapodást, így kialakította Theodosiusról a győzedelmes császár képét, miközben nyilvánvaló volt, hogy a birodalomnak egyszerüen nincs meg a megfelelő ereje ahhoz, hogy megoldja a gót problémát. A gótok provinciában egy tömegben történő letelepítése két kockázatot hordozott: a gót autonómia kibontakozását, amelynek legjobb példája Alarich fellépése lesz, és a részleges asszimilációt vegyes házasság útján, amire maga Themistios is célzott amikor Thetis és Péleus házasságához hasonlította a gótok és rómaiak kapcsolatát.

\subsubsection{A vegyes házasságok}

A germánok és a rómaiak asszimilációja nem a 4. század végén kezdődött, ahogyan a harcuk sem. Legyen elég csak Arminius esetére utalni, aki az egyik germán törzs, a heruszkok vezetőjeként néhány évvel Teutoburg előtt még római polgárjog birtokában a császári seregben teljesített szolgálatot, kiválóan beszélt latinul, a teutoburgi csatában azonban ő okozta Varus vesztét. Példája mutatja, hogy a germánok gyorsan Róma legfontosabb szomszédjaivá váltak. ${ }^{275}$ Az idegenek beáramlása a Birodalomba egy idő után természetszerủen vegyes házasságokhoz vezetett. Az ezekből született gyermekek azonban már nem csak a latin nyelvet tanulták meg, mint Arminius, hanem legalább félig már rómaiakká is váltak.

A Constitutio Antoniniana kihirdetéséig a római polgárokat nemcsak a határvidékeken húzódó limes választotta el az idegenektől, hanem egy egészen meglepő jogi szabályozás is. A római jog ugyanis csak a polgárjoggal rendelkező lakosok közötti házasságot ismerte el. Ennek értelmében egy római törvényesen nem házasodott össze a limes túloldalán élő alárendelt vagy más nép egyik tagjával (peregrinus) sem. Az ilyen házasságból született gyermek ugyanis törvénytelennek számított, így még az apja akarata értelmében sem örökölhetett. Más volt a helyzet azonban, ha a római félhez hasonlóan a külhonból származó szülő is rendelkezett a ius connubiival. Nem véletlen, hogy a polgárjog megszerzése erős motivációt jelentett mindazok számára, akik idegen származásuk ellenére a birodalom területén dolgoztak. ${ }^{276}$ Egy, a bithyniai Prusa (ma Bursa)

274 THEM. OR. 14.

275 WOLFRAM 1997B, 41-47.

276 MiLlar 1977, 486. 
városából származó orvos a feliratán megörökítette, hogy a polgárjogot szülei, testvérei, valamint saját maga számára is Traianus császár adományozta. ${ }^{277}$ 212-ig az uralkodói kegygyakorlás része volt a polgárjog adományázása, ezt azonban Constitutio Antoniniana alapjaiban változtatta meg.

\subsubsection{A vegyes házasságok tiltása}

A 4. század második felében három meghatározó esemény történt a birodalom történetében, valamennyi a birodalommal szomszédos népekhez kötődött. 360-ban Iulianus császár váratlan halála után Iovianus arra kényszerült, hogy békét kössön Shapurral, amelynek értelmében a rómaiak elveszítették Mezopotámia jelentős részét, Nisibis, Castra Maurorum és Singara városaival együtt. A jelentős területvesztés kétségtelenül megroppantotta a hadseregen belüli magabiztosságot és morált, amit csak tetézett a római sereg csaknem teljes pusztulását okozó hadrianopolisi csatavesztés. E két esemény együttes hatása vezetett oda, hogy 382-ben Theodosius arra kényszerült, hogy a vizigótokat a birodalom határain belül telepítse le. ${ }^{278}$ Jobbára emiatt terjedt el a kutatásban, hogy Valentinianus egyik rendeletében a birodalom egész területen tiltotta a barbárok és rómaiak közötti házasságkötést, ${ }^{279}$ amit minden bizonnyal csak erösíthetett, hogy a forrásokban néhány kivételtől eltekintve nyoma sincs vegyes házasságnak. A rendelet első sora alapján halál járt azoknak a férfiaknak, akik barbár asszonnyal házasodtak. Hasonló büntetés járt azoknak az asszonyoknak, akik külföldiekkel (gentilis) egyesültek. ${ }^{280} \mathrm{~A}$ kutatásban gótellenes rendeletként rögzült a szabályozás, noha kibocsátására, Iovianus perzsákkal kötött 30 éves békéjét követően, 373-ban került sor, tehát még a vizigótok letelepítése előtt.

Gótellenes rendeletként történő értelmezése igencsak meglepő, hiszen a vegyes házasság gyakorlatára igen korai emlékek is rendelkezésre állnak, és a források tükrében is úgy tünik, hogy Róma igen nyitott és befogadó hatalom volt. Livius szerint a város nagysága éppen abban rejlett, hogy Romulus mindenkit meghívott az újonnan alapított Rómába. ${ }^{281}$ Szent Ágoston szerint Rómában minden bevándorlót, legyen az szökött rabszolga, vagy éppen gladiátor, a menedékjog

277 CIL 11.3943.: "C(aius) Calpurnius Ascl(a)epiades Prusa ad Olympum medicus | parentibus et sibi et fratribus civitates VII a divo Traiano | impetravit natus III Non(as) Mart(ias) Domitiano XIII co(n)s(ule) eadem die | quo et uxor eius Verona Chelidon cum quo(!) vixit annis LI | studiorum et morum causa probatus a viris clarissimis adsedit magis|tratibus populi Romani ita ut in aliis et in provincia Asia custodiar(ius?) | [tabellarum(?)] in urna iudicum vixit annis LXX".

278 ChrYsos 1989.

279 Többek között ezen a véleményen: Blockley 1982, 63-79, BiANCHINI 1988, 225-249, DeMANDT 1989, 76-77, SIVAN 1996, 136-145 81.

280 COD. THEOD. 3.14.1. "nulli provincialium, cuiuscumque ordinis aut loci fuerit, cum barbara sit uxore coniugium, nec ulli gentilium provincialis femina copuletur".

281 LIV. 1.8.5. 
egyesített egymással. ${ }^{282}$ Éppen a rendelet születésének idején jegyezte meg Aurelius Victor, hogy az idegen származású császárok általában alkalmasabb férfiak voltak, mint a született rómaiak. ${ }^{283} \mathrm{~A}$ hispániai Prudentius a 4. század végén úgy gondolta: ahogyan a városfal körülöleli és egyesíti a polgárait, úgy egyesülnek házasságok útján a városba érkező más-más népek. ${ }^{284}$

Róma hozzáállása minden idegen számára nyitott volt. Augustus óta a germánok számítottak a környező népek közülük a legfontosabbnak, földrajzi és demográfiai okokból kifolyólag. Az idegenek beáramlása a birodalomba egy idő után természetszerüen vegyes házasságokhoz és a népek egyesüléshez vezetett. A Codex Theodosianus rendelkezése, keletkezési körülményeinek figyelembevételével, minden bizonnyal egy szükebb csoportra vonatkozhatott. A gentiles elnevezést két esetben alkalmazzák a joggyüjteményben: Egyrészt vallási értelemben a pogányok jelölésére, ez azonban nem áll összhangban Valentinianus toleráns politikájával. ${ }^{285}$ Másrészt azoknak az idegen törzseknek a tagjaira, akiket a hadszervezet részeként a határ mentén telepítettek le, azért, hogy védelmi feladatokat lássanak el. ${ }^{286}$ Esetleg olyan személyek jelölésére, akik a határ mentén élnek, bábkirályok (reguli) fösége alatt. ${ }^{287}$ A rendelkezés fókuszában tehát a határ mentén élők vannak. Természetesen nem lehet kizárni annak a lehetőségét, hogy a rendelet a házasságot akarta tiltani, ennek azonban ellentmond a szabályozás második mondata, ${ }^{288}$ amelynek értelmében nem maga a házasság büntetendő, hanem a házasságból eredő negatív következmények. Tehát a jogalkotó szemében a házasság akkor vált büntethetővé, ha bebizonyosodott, hogy valamiféle összeesküvésre készülnek azok a személyek, akik barbár rokonokkal, házastárssal rendelkeznek. Véleményem szerint ilyen, a központi hatalom számára hátrányos tett lehetett a kémkedés.

Noha a rendelet nem került át Iustinianus joggyüjteményébe, azonban a Novellák között felbukkan egy hasonló rendelkezés. Az 535-ben keletkezett dokumentum megtiltotta Mesopotamia és Osroene provinciák lakóinak, hogy idegenekkel házasodjanak. ${ }^{289}$ Prokopios megemlíti, hogy a Citharizum és a töle háromnapi járásra lévő Osroene-beli Theodosiopolis (ma Ras al-Ayn) között fekszik egy Chorzanēnek nevezett régió, amit nem választanak el tavak vagy hegyek Perzsiától,

282 August. De CIV. D. $1.34 ; 4.5$

283 DEMANDT 1989, 76.

284 PRUDENT. C. SYMM. 2.598-614.

285 Az elnevezés használata még nem feltétlenül gátja a toleráns politikának.

286 COD. THEOD. 7.15.1. "terrarum spatia, quae gentilibus propter curam munitionemque limitis atque fossati antiquorum humana fuerant [...]"

287 COD. THEOD. 12.12.5. "Cum legati gentilium venerint, obsignari eorum tabulas oportet, ut ad mansuetudinem nostram fides earum, quae a regulis profectae fuerint [...]"

288 "quod in iis suspectum vel noxium detegitur, capitaliter expietur."

289 NoV. 154. 
amelyek megakadályoznák az átkelést a két ország között. Emiatt a helyi lakosok, legyenek azok rómaiak, vagy perzsák, nem félnek egymástól és nem tartanak támadástól a másik részéről. Közös piacokat tartanak, és közös gazdaságot müködtetnek. Söt még házasodnak is egymással. Az auktor szerint olyan egyetértés honol az itt élő népek körében, hogy ha bármelyik hatalom katonai parancsnoka támadást a másik országa ellen, biztos, hogy ezeken a területeken akadálytalanul haladhatnának át. ${ }^{290}$

A határproblémákra már Ammianus Marcellinus is felhívta a figyelmet. A 4. századi auktor beszámolója szerint a római határforgalmat szigorúan ellenőrizték a perzsa határszakaszon, nehogy rómaiak meneküljenek idegen területekre és így információkat szolgáltassanak idegen hatalomnak. Érdekes analógiát szolgáltat Antoninus esete, aki korábban jómódú kereskedő volt, majd később Mesopotamia kincstárnoka vált belőle, amikor is kémkedni kezdett a hadsereg állomáshelyei után. Nem kellett sok idő hozzá és a teljes keleti államigazgatást megismerte. Később, annak érdekében, hogy a határörök figyelmét ne vonja magára, a Tigris folyása mellett Hiaspis községben egy kis telket vásárolt. Esténként pedig az úszni tudó szolgái közbenjárásával tanácskozott a túlpart satrapájával, Tamsaporral, akit már régebbről ismert. Később pedig egész családjával átszökött a perzsákhoz, ahol töviről hegyire elmesélte az elmúlt négy évtized történéseit és másban is felajánlotta segítségét. ${ }^{291}$ Ha Antoninust nem állította meg a Tigris folyása, akkor nem nehéz elképzelni, hogy egy szabadon átjárható területen, mint Chorzanē milyen információáramlás zajlott, különösen, ha a kereskedö a felesége révén is a területhez kötődött.

Mindezek alapján valószínüsíthető, hogy mind a 373-as rendelet, illetve a Iustinianuskorabeli Novella a határ menti aktív kémkedés lehetőségét igyekezett minimalizálni. Még ha a szövetségesekkel köttetendö házasság ellen irányult is volna, ahogyan azt a szakirodalom egy része tartja, bizonyosan nem érte el célját, ugyanis egyetlen ezzel kapcsolatos kivégzést sem említenek a források. A továbbiakban számos példát látunk majd vegyes házasságokra, amelyek tovább fogják erősíteni ezt az álláspontot.

\subsubsection{A 3-4. század vegyes házasságai}

A 3. századból négy vegyes házasságról tudunk. Gallienus császár (253-63) és Pipa, a markomannok vezetőjének lánya között kötött házasság elsődleges célja a birodalmat sorozatosan zaklató germánok megbékítése volt. ${ }^{292}$ A hispániai születésủ Bonosus, aki 281-ben lépett fel trónbitorlóként, Hunila gót hercegnőt vette feleségül, ettől remélte ugyanis a gótok támogatását. A

\footnotetext{
290 Procop. AED. 3.3.9-12.

291 AMM. MARC. 18.5.3
} 
harmadik házaspárt a frank Proculus és a germán Vituriga alkotta, fiuk Herennianus később maga is trónbitorló lett. A 3. század utolsó dokumentált vegyes házasságát Tiranes, Bosporus királya kötötte a római Aeliával. Ez a négy házasság meglehetősen csekély számú ahhoz, hogy komoly következtetéseket lehessen levonni, annyi mindenesetre kiolvasható az adatokból, hogy a házasságokat jobbára trónbitorlók kötötték, minden bizonnyal szövetségkeresés céljával. ${ }^{293}$

A 4. században a vegyes házasságok száma az tizenegy ismert házassággal közel háromszorosára nő a korábbi időszakhoz képest. A concordiai katonai temetőben felbukkant felirat tanúsága szerint Alatancus Victoriával kötött házasságot. ${ }^{294}$ Szintén egy feliraton bukkan fel Ursinianus és Ludula neve, utóbbi minden bizonnyal gót eredetü név. ${ }^{295}$ A század közepén Armenia királya, III. Arsaces (378-387) feleségül vette Constantinus praefectus praetoriójának, Ablabiusnak (cos. 331) a lányát, Olympiast. Ablabius korának egyik legismertebb embere volt, egy időben még a senatus vezetését is ellátta. Constantinus fiának támogatását is rá bízta. Synésios szerint Ablabius korának legfontosabb írói közé tartozott, ${ }^{296}$ így lehetséges, hogy ő írta a gótok elveszett történetét, amit később Cassiodorus és Iordanes is felhasznált. ${ }^{297}$ Később azonban már azt gyanították róla, hogy uralomra akar törni, ezért törbe csalták majd kivégezték. ${ }^{298}$ Javait minden bizonnyal rekvirálták, mert a konstantinápolyi palota mögötti háza ebben az időben került Placidiához. ${ }^{299}$ Hormisdas a hasonló nevủ perzsa herceg fia volt, aki 324-ben a Rómába menekült, ahol meg is házasodott. ${ }^{300}$ Theodosius császár első feleségének, Flaccillának az unokaöccse is idegen nőt választott. Nebridius ugyanis a berber Gildo lányát, Salvinát vette feleségül. Gildo Mauretania királyának fia volt. ${ }^{301}$

A galliai születésű Magnentius a század közepén Constans zsoldjában állt testőrparancsnokként, 350-ben azonban, kihasználva a császár népszerütlenségét, megölte őt és magához ragadta a hatalmat. Hároméves trónbitorlása során feleségül vette Picenum kormányzónak fiatal lányát, Iustinát. ${ }^{302} \mathrm{~A}$ frank származású magister peditum, Merobaudes (cos. 377, 383) szintén római feleséget szerzett magának. A 443. év azonos nevü magister milituma

292 BLOIS 1976, 4. 254-ben a markommanok előbb lerohanták Pannoniát, majd mélyen benyomultak Itáliába. Négy évvel később ismételt támadással fenyegettek, ami Pannoniában Ingenuus felkeléséhez és trónbitorlásához vezetett. Gallienus előbb legyőzte a trónbitorlót, majd feleségül vette Pippát, ami átmeneti stabilitás hozott a pannoniai hadszíntéren.

293 BLOCKLEY 1982, 66, SORACI 1974, 1-2.

294 CIL 5.8783.

295 CIL 13.3787.

296 SYN. EP. 61.4.

297 JORD. GET. 28. "Ablavius descriptor Gothorum gentis egregius verissima adtestatur historia."

298 ZOS. 2.40.3.

299 SYN. EP. 61.4

300 AMM. MARC. 26.8.12, PLRE1 443, "Hormisdas 2", PLRE1 443-444, "Hormisdas 3".

301 Jer. EP. 79.2.1, 123.17, AMM. MARC. 29.5.2, 29.5.6, PLRE1 620, "Nebridius 3”, BlockLey 1982, 66. 
minden bizonnyal az ö leszármazottja. ${ }^{303}$

Agilo, az alemann származású magister peditum Araxius (PPO 365/366) praefectus praetorio Vetiana nevủ lányát vette el. ${ }^{304} \mathrm{~A}$ frank származású magister militum Bauto (cos. 385) ${ }^{305}$ is római feleséget szerzett magának. A különböző kortárs szerzők eltérően vélekednek az asszony származásáról. Zósimos szerint római volt, Philostorgios azonban barbárnak gondolja. ${ }^{306}$ Házasságukból született Eudoxia, aki később Arcadius császár felesége lett. Fravitta (cos. 401), a vizigót származású keleti magister militum még kinevezése előtt Theodosius jóváhagyását kérte házasságához, amit meg is kapott. ${ }^{307}$ Szintén vegyes házasságból született Stilicho (cos. 400, 405) magister militum, mert Orosius semibarbarusnak nevezi, így vandál származású apja, aki lovassági parancsnokként Valens alatt szolgált később pedig római nőt vett feleségül. ${ }^{308}$

Azokat a házasságokat leszámítva, amelyeket csak feliratos emlékek dokumentálnak, jól látható, hogy a fennmaradó 9 házasság között találunk a 3-4. században is előforduló, szövetség biztosítására törekvő házasságokat (Arsaces, Hormisdas, Nebridius). A fennmaradó 5 házasságot azonban már kivétel nélkül magas rangú katonai vezetők, magister militumok kötötték.

\subsubsection{A magister militum}

A vegyes házasságok kérdéséhez szorosan kapcsolódik az 5. századi magister militumok, illetve más magas rangú katonai vezetők házassági gyakorlata, hiszen az előbbiekben láthattuk, hogy a pozíció birtokosai 4. században során egyre inkább dominálják a vegyes házasságokat. Pozíciójuk révén később pedig már alakíthatták is öket. A neve ellenére a magister militum feladatköre nem korlátozódott kizárólag a hadsereg vezetésére, még ha a források elsősorban ezt a feladatkörüket domborítják is ki. $^{309}$ A tisztségviselők azonban szük feladatkörükön túllépve, a császári

302 PLRE1 488-489, "Iustina". A keleti források egybehangzó véleménye szerint Iustina ekkor még túl fiatal volt a házassághoz, így gyermeke sem született. Az asszony azért állt a források érdeklődésének középpontjában, mert Magnentius megölését követően második férje Valentinianus (364-375) lett. Ebből a házasságból született Galla, Grata és Iusta.

303 PLRE1 598-599, "Flavius Merobaudes 2".

304 AMM. MARC. 14.10.8, 26.7.6, 26.10.7, PLRE1 28-29, “Agilo", PLRE1 94, “Araxius".

305 PLRE1 159-160, "Flavius Bauto".

306 ZOS. 4.33.2, PHILOSTOR. HIST. ECCL. 11.6.

307 EUNAP. FR. 60, PLRE1 372-373, "Flavius Fravitta".

308 OROS. 7.38.1, JER. EP. 123.16, PLRE1 853-858, "Flavius Stilicho".

309 Not. Dign. OCC. 5, 6, 42, A 4. század végén keletkezett hivatali jegyzék. A Notitia Dignitatum szerint a palotaőrség és a császári testőrök kivételével a birodalom nyugati felének teljes fegyveres ereje elsősorban a gyalogsági parancsnok (magister peditum) és a lovassági parancsnok (magister equitum) joghatósága között oszlott meg, esetleg néhány egység a galliai lovasparancsnok (magister equitum per Gallias) alá tartozott. Ez utóbbi esetében látható, hogy a magister peditum irányítja a római hadszervezetben szolgáló idegeneket (laeti), valamint a flottát is. Az 5. század elején, Constantius magister militum (411-421) hivatalviselésétől kezdődően a gyalogsági és lovassági feladatkör 
közigazgatás más szintjein is rendelkeztek hatáskörökkel. A magister militum háborús időszakban közvetítő szerepet játszott a császár és az ellenség között. 455-ben Petronius Maximus magister militumát, Avitust küldte II. Theoderich vizigót uralkodó udvarába, minden bizonnyal azzal a céllal, hogy Theoderich pozíciójának megerősítéséért cserébe a vizigótok támogatásukról biztosítsák Petronius Maximust. ${ }^{310}$ 459-ben a magister militum például békekövetséget küldött a szvévekhez, akik hírül vitte, hogy Maiorianus és II. Theoderich megerösítették egymás között a tartós béke létrehozására tett esküjüket. ${ }^{311}$ Nem véletlenül nevezte még Prokopios is a császár jobbkezének a magister militumot. ${ }^{312}$

Az 5. század során a magister militum folyamatosan arra törekedett, hogy még inkább kitágítsa hatáskörét. A hadsereg feletti parancsnokság fontos eszközt adott a kezébe, amiért is rendkívül befolyásos személynek számított a pozíció birtokosa. Már Constantius, az első comes et magister utriusque militiae azért vált fontossá a Prosper szemében, mert 412-ben megpróbálta befolyásolni az arles-i püspökválasztást annak érdekében, hogy saját barátját, Patroclust juttassa a pozícióba. ${ }^{313} \mathrm{Az}$ őt nem sokkal magister militumi tisztségben követő Felix pedig éppen Patroclust ölette meg, hogy saját emberét ültethesse a helyére. ${ }^{314} \mathrm{~A}$ püspökválasztások befolyásolása azonban eltörpül a visszaélések sorában, ha figyelembe vesszük, hogy Castinus arra használta magister militumi pozícióját, hogy Honorius halála után hatalomra segítse a trónbitorló Ioannest (423-

összeolvadt és egy személy kezében összpontosult. COD. THEOD. 1.7.3, BARNWELL 1992, 41-44, Az 5. század comes et magister utriusque militiae tisztség birtokosai: Constantius (411-421), Castinus (422425), Felix (425-430), Bonifacius (431-432), Sebastianus (432-433), Aëtius (433-454), Avitus és Remistus (455-456), Ricimer (456-472), Gundobad (472-473), Ecdicius Avitus (475), Orestes (475-476). Ettől kezdve a magister equitum egyszerüen csak a lovassági csoportokért felelt, míg a magister peditum pedig már nem csak a gyalogság felett parancsnokolt, hanem valamennyi katonai comes és dux felett, továbbá a légiók és a segédcsapatok is hozzá tartoztak. A magister militum a központi adminisztráció tisztségviselöje volt, nem pedig a provinciális igazgatásé, erre világítanak rá a neki címzett rendeletek. A tisztségviselö feladatköréhez tartozott többek között a katonaszökevények felkutatása COD. THEOD. 7.20.12, 7.18.17., a hadszervezeten belüli előléptetések COD. THEOD. 7.1.18., elbocsátások és a toborzás COD. THEOD. 7.20.12, 7.13.8., a hadiadó begyüjtésével kapcsolatos igazgatási feladatok COD. THEOD. 7.5.1., a katonák általi eröszakos birtokbavételek intézése COD. THEOD. 2.23.1., a veteránok leszármazottaival kapcsolatos ügyek COD. THEOD. 7.22.12., a tisztek ellátása COD. THEOD. 7.4.37., valamint az afrikai comes (comes Africae) hivatalával kapcsolatos ügyintézés, ugyanis ennek a hivatalnak az állományát is a magister militum biztosította COD. THEOD. 1.7.3, NOT. DIGN. OCC. 4. Név szerint ismert hivatalnokok (comes Africae): Gratianus Funarius (420-as évek), Gaius Annius Tiberianus (325-327), Romanus (363-377), Gildo (393-398), Gaudentius (399), Bathanarius (401-408), Ioannes (408), Heraclianus (408-). A rendeletek világosan körülhatárolt feladatkörök ismeretében látható, hogy a magister militum a hadsereg teljes körü parancsnokai voltak. SID. APOLL. CARM. 7.375-8, 392-4, 399-402, 425-36, 464-8.

311 HYD. CHRON. 192. (197).

312 Procop. De Bellis. 3.4.28.

313 PROSP. TIRO. 1247.

314 Prosp. Tiro. 1292. 
425). ${ }^{315}$ Constantius, Felix és Castinus tevékenysége már világosan elörevetítette a század fennmaradó részének politikai eseményeinek fő vonalát is. Aegidius a galliai származású magister militum, akit még Aëtius nevezett ki a század közepén Gallia katonai vezetőjének, kihasználta a Maiorianus eltávolítása időszakában keletkezett ürt, és megalapította a soissons-i királyságot (457486), ami több mint két évtizedig fenn tudott maradni. ${ }^{316}$ A szvév származású Ricimer pedig már arra használta a magister militumi pozícióját, hogy kihasználja, majd megbuktassa "császárok" egész sorát, így Avitust, Maiorianust, Libius Severust és Anthemiust, ${ }^{317}$ míg végül teljesen irányítása alá nem vonta a birodalom nyugati felét. 457 és 472 . között egymaga birtokolta a magister militumi pozíciót. Világos, hogy Ricimer elsődleges célja az volt, hogy olyan uralkodót nevezzen ki, aki egyáltalán nem zavarja érdekköreit. Avitus vesztét éppen az okozta, hogy szemet hunyt II. Theoderich hispániai tevékenysége felett cserébe azért, hogy a vizigót uralkodó támogassa császári pozíciójában. Hispániában azonban a vizigótok a szvévek rovására kezdtek terjeszkedni, miközben Ricimer a szvév király fia volt. ${ }^{318}$

Nyilvánvalóvá, hogy a magister militumok saját céljaik érdekében visszaéltek a hatalmukkal, ami anomáliákat okozott a nyugati uralkodói központ életében. A ravennai központi adminisztráció ilyen körülmények között könnyüszerrel vált az egymással szembeálló érdekcsoportok csataterévé, ahol az ellentétekből általában azok kerültek ki győztesen, akik jó kapcsolatot ápoltak a katonai igazgatás vezetőjével. A mindennapos udvari intrikák miatt a császár képtelen volt a nyugati birodalomrész sorsát érdemben irányítani. A császárnak választott személy gyenge volt, ez azonban nem jelenti azt, hogy a pozíció is gyenge volt. A ravennai udvarban pereskedő tisztségviselők tevékenysége azonban éppen annak a személynek a tevékenységét lehetetlenítették el, akitől a saját szükségleteik is függtek.

A vegyes házasságok kérdéséhez kapcsolódik az 5. századi magister militumok, illetve más magas rangú katonai vezetők házassági gyakorlata. Néhány kivételtől ${ }^{319}$ eltekintve az 5 . század 12 ismert vegyes házasságában az idegen származású katonai vezetők elsősorban az arisztokrácia felső köréből választottak maguknak feleséget. Bonifatius comes például a vizigót származású Pelagiát

\footnotetext{
PROSP. TIRO. 1282.

HYD. CHRON. 218-224. (221-224).

SID. APOLL. CARM. 5.266-268.

318 BARNWELL 1992, 41-44. Ricimer halála után ez az érdekcsoport a burgundokhoz került részben fiatalabbik nővére miatt, aki Gondioc burgund király felesége lett, másrészt mert a következő magister militum éppen Gundobad lett, aki 473-tól már a burgundok királya lett.

319 PLRE2 511, "Gessius 3", A petrai születésủ Gessius, aki megbecsült orvosnak számított Zeno idejében barbár asszonyt vett el, akitöl több gyermeke is született. PLRE2 145-146, "Fl. Ariobindus 2", MALCH. 18, A gót származású Ariobindus (cos. 434) egy ismeretlen nevủ római nőt vett feleségül, a szintén gót Gentóhoz hasonlóan.
} 
vette el, aki a comes halála után Aëtiusszal kelt egybe, a magister militum így megszerezte Bonifatius birtokait. ${ }^{320}$ Aspar gót származású apósának, Plintának (cos. 419) a fia szintén római nőt vett feleségül. ${ }^{321}$ Sokkal érdekesebb azonban a katonai vezetők azon törekvése, hogy az uralkodó lányával vagy valamelyik közelebbi hozzátartozójával kössék össze magukat. Az 5. század ismert vegyes házasságainak felében éppen ez történik. Ricimer magister militum, aki Anthemius császár lányát, Alypiát vette feleségül. ${ }^{322} \mathrm{~A}$ csak királycsinálóként emlegetett alán Aspar egyik fiát Leo császár fiatalabbik lányához adta, másik fiát pedig Isauriában Zeno törvénytelen fiának lányával házasította össze. ${ }^{323}$ Ez a tendencia 414-ben Athaulf vizigót király (410-415) és Honorius császár nővérének, Galla Placidiának Narbóban kötött házasságával kezdődött.

\section{2. “Isten városai”: Róma és Konstantinápoly}

Theodosius halála után azonnal felkeltek a vizigótok, Iordanes szerint ugyanis megfosztva érezték magukat a szokásos ajándékoktól. ${ }^{324}$ A 6. századi történetíró hangzatosan azt mondja, hogy a gótok féltek, hogy a hosszú békében vitézségük megfogyatkozik, valójában azonban semmi különös nem történt. Ehhez elég csak végignézni az 5-6. század megmozdulásait. A gótok 382-es letelepítését követően mindig felkelés követte egy-egy uralkodó halálát egészen addig, amíg ismét megállapodtak a császárral. Így volt ez III. Valentinianus halála után folyamatosan, de ez történt akkor is, amikor a császár germán szokásoknak megfelelően, előbb Theoderich-et, majd kijelölt utódját Eutharicust is fogadta fegyverrel fiává.

A vizigótok Alarich vezetésével előbb a birodalom keleti felét, majd nyugati részeit fosztogatták végig. ${ }^{325}$ 408-ban, Arcadius halála után nem sokkal ideiglenes megoldás született azzal, hogy Stilicho magister militum egész Illyricumot átengedte nekik. A megállapodás rövid életünek bizonyult, mert a katonák ura az udvar engedélye nélkül cselekedett, jobbára ezzel szokták magyarázni, ${ }^{326}$ hogy hamarosan megölték. Bukásában nagy szerepe volt Olympius ${ }^{327}$ magister officiorumnak, aki azt terjesztette, hogy a vandál származású magister militum, tizenéves fia,

PLRE2 232-240, "Bonifatius 3", PLRE2 856-857, "Pelagia 1".

321 PRISC. FR. 14, PLRE2 892-893, "Fl. Plinta".

322 PLRE2 942-945, "Fl. Ricimer 2".

323 PLRE2 164-69, "Fl. Ardabur Aspar", PLRE2 840-842, "Fl. Patricius 14", PLRE2 594, "Herminericus", Aspar Patricius nevü fia Leontiával házasodott össze, Herminericus pedig Zeno ismeretlen nevü unokájával.

324 JORD. GET. 147.

325 402-ben Itália irányába indultak, ahova 405-ben már vandál, burgund és szvév csapatokkal - nőket és gyerekeket is beleértve - mintegy 40000 föt számláló népesség vonult végig.

326 WOLFRAM 1990A, 139-161.

327 PLRE2 801-802, "Olympius 2". 
Eucherius számára akarja megszerezni a trónt. ${ }^{328}$ Noha Stilicho megölésének okai és körülményei között korántsem uralkodik egyetértés a történetírók között, ${ }^{329}$ annyi bizonyos, hogy házassága révén komoly veszélyt jelenthetett. A vandál származású magister militum ugyanis Theodosius unokahúgát, Serenát ${ }^{330}$ vette feleségül, akit a császár korábban lányává fogadott. Noha a házasság ötlete Theodosiustól származott, a császárhoz füződő rokoni kapcsolatát (adfinitas) feliratában is büszkén hirdette a magister militum. ${ }^{331}$ Theodosius kiváló családi, vagy inkább stratégiai szövetségesi kapcsolatait (kedesteia) Themistios is hangosan dicsérte, ${ }^{332}$ ennek a családnak volt része immár Stilicho is. Talán Illyricum átadása, de sokkal inkább az adfinitas okozta a magister militum vesztét. Utóbbit támasztja alá, hogy Stilicho bukását nem sokkal később felesége és fia kivégzése követte, lányai pedig egymás után lettek Honorius feleségei. Maria halála után, Thermantia lett a császár felesége egészen 415-ben bekövetkezett haláláig.

Stilicho halála után annak csaknem 30000 katonája átállt Alarich-hoz, aki korábban maga is magister militumként szolgált, 408-ban azonban már Róma falai alá vonult, ahol két évig várakozott a Salaria kapu és a város más belépési pontjai közelében, mire végül a betörés mellett döntött. Nyolcszáz évvel korábban Brennus galljai korántsem voltak ilyen türelmesek, ráadásul eljárásuk is alapjaiban különbözött, hiszen míg a gallok felégették szinte az egész várost, ${ }^{333}$ addig az ariánus gótok Róma több szent helyével is tisztelettel bántak. A Szent Péter és Pál bazilikákat, amelyek a legnagyobbak voltak a városban, menedéknek nyilvánították, így azokat, akik ide menekültek, semmilyen bántódás nem érthette. Jeromost ugyan megrendítette Róma kifosztása, de maga is meglepődött azon, hogy Alarich gótjai milyen kíméletesen bántak azokkal az asszonyokkal, akikkel közeli viszonyt ápolt. Marcellát, Jeromos barátjának és támogatóját előbb elkísérték a Szent Pál-bazilikába és csak azt követően fosztották ki a villáját. ${ }^{334}$ A Szent Péterbazilikából egy hatalmas ezüst cibóriumot ugyan elemeltek, de a liturgikus ereklyéket érintetlenül hagyták. 410-ben a három napos gót “dúlás” során a város legtöbb müemléke és épülete érintetlen

328 PHILOSTOR. HIST. ECC. 11.3.

329 Zos. 5.32-35; 5.44-46.1, Oros. 7.38.5, Philostor. Hist. ECC. 12.1. Kétségeit az esettel kapcsolatban Philostorgios is megosztja.

330 PLRE1 824, "Serena".

331 CIL 6.1730: "Fl(avio) Stilichoni v(iro) c(larissimo) | Flavio Stilichoni inlustrissimo viro | magistro equitum peditumque | comiti domesticorum tribuno praetoriano | et ab ineunte aetate per gradus claris| simae militiae ad columen gloriae | sempiternae et regiae adfinitatis evecto | progenero divi Theodosi comiti divi | Theodosi Augusti in omnibus bellis | adque victoriis et ab eo in adfinitatem | regiam cooptato itemque socero d(omini) n(ostri) | Honori Augusti Africa consiliis eius | et provisione liberata ex s(enatus) c(onsulto)". THEM. OR. 4.59; 16.203d. Theodosius kiváló családi, vagy inkább stratégiai szövetségesi kapcsolatait (kedesteia) Themistios is dicséri.

332 THEM. OR. 4.59; $16.203 \mathrm{~d}$.

333 POLYB. 2.18.

334 JER. EP. 127.12-13. 
maradt, még ha a mozdítható drága holmik el is tủntek. A szerkezeti károsodások is túlnyomórészt a Salaria kapu környékét és a régi senatusi épületet érintették. ${ }^{335}$

A 408-410. közötti események feltárásának elkerülhetetlen végkövetkeztetése az, hogy Alarich elsődleges szándéka egyáltalán nem Róma kifosztása volt, hiszen gótjai már 408 késő őszétöl a város falainál voltak, és ha akarta volna, bármikor betörhettek volna. Ezért arra kell gondolnunk, hogy Alarich elsősorban arra törekedett, hogy a római állam gótokkal fennálló, a 382. évi megállapodásban szabályozott kapcsolatát átalakítsa. A legfontosabb az volt számára, hogy a császártól garanciákat és legitimációt kapjon, miután 401-ben elvonult Konstantinápolytól. Róma ostroma egész egyszerüen arra szolgált, hogy szándéka megvalósítása érdekében nyomást gyakoroljon Honoriusra és tanácsadóira, ám sikertelenül. Heather szerint Alarich egész egyszerủen túlbecsülte a város jelentőségét és a ravennai székhelyü nyugati császárság befolyását. 410-ben, három napra, valamelyest szabadjára engedte katonáit, majd csalódottan távozott, hiszen nem kapta meg a római államtól azt a megállapodást, amire vágyott. Róma "kifosztását" nem szimbolikus csapásként kell értékelni, hanem Alarich kudarcaként. ${ }^{336}$

Úgy gondolom, hogy Heather véleménye vitatható. Az valóban helyénvaló, hogy a helyzet egyértelmüen Alarich kudarca volt, azonban, véleményem szerint Róma szimbolikus jelentőségét nem lehet túlbecsülni és a kortárs keresztény történetírók nem is becsülték túl. A pogányok szerint Alarich fosztogatásánál nem is lehetett volna világosabb jele az új államvallás alkalmatlanságának. Szerintük a várost egész egyszerüen azért érte támadás, mert eltávolították a pogány szobrokat. Mint tudjuk, ez a vélekedés késztette Szent Ágostont az Isten városáról (De civitate Dei) c. munkájának megírására. Az első három kötettel már az Alarich távozását követő harmadik évben készen volt. A második könyvben sommásan azzal válaszol pogány kortársainak, hogy még Róma történetét sem ismerik rendesen, így azzal sincsenek tisztában, hogy Krisztus születése elött mennyi katasztrófától szenvedett a város. ${ }^{337}$

Az első három kötet elkészítéséhez Livius Róma történetéről írott munkájának gyors újraolvasása elegendő muníciót adott Ágostonnak, hogy válaszoljon a pogányok vádjaira. Az első három kötetének központjában a római történelem egy teljesen újszerü megközelítése állt, ami rögzítette az egy és oszthatatlan birodalom ideológiáját. ${ }^{338}$ A keresztények azonban a Jelenések könyve alapján már régóta ismerték a két város és az új Jeruzsálem fogalmát. ${ }^{339}$ Ágoston érvelésében a mennyei Jeruzsálem az a város volt, ahová a keresztények azon része, amely

335 HEATHER 2006, 227-228.

336 HEATHER 2006, 228-229.

337 August. De Civ. D. 2.19-20, HeAther 2006, 230.

338 HEATHER 2006, 230.

339 JEL. 21:2-3. 
üdvözülésre van predesztinálva valójában tartoztak, függetlenül attól, hogy a birodalom melyik városában éltek. Úgy gondolta, hogy Róma csak egy az oikumené sok városa közül, semmi ok sincs arra, hogy bárki is összekeverje a mennyei Jeruzsálemmel. ${ }^{340}$ Ágoston értelmezésében élesen elkülönül a mennyei (civitas Dei) és a földi város (civitas terrena), és védekezésének alapját és éppen ez adja. Ágoston értelmezésében az emberiség történelme elhanyagolható semmiség a mennyei királyság mellett, amely folyamatosan növekszik és gyarapodik. A hippói püspök számára így a földi város történelméből csak a szentek életrajzainak van valós értéke, mert ök világos kapcsolattal rendelkeznek az igaz erények és a világi sikerek között. Az Isten városáról legfontosabb célja, hogy szétválassza egymástól Róma történelmi végzetét a kereszténységtől vagy bármilyen más vallástól, ${ }^{341}$ és arra szorítja olvasóját, hogy a tiszavirág életü földi királyság helyett inkább a valódi mennyei királyságra koncentráljon.

Hogy ezt mennyire nem így gondolták a Róma keresztény arisztokráciájának tagjai, az világosan kiderül Jeromos levelezéséből. Egy Rómában élő arisztokrata asszonynak a következőképpen fogalmaz közös barátjukról:

“[Marcella] életmódjának köszönhetöen Róma Jeruzsálemmé vált. Szüzek számos monostora, monachusok megszámlálhatatlan sokasága; az Istennek szolgálók nagy serege, ami korábban gyalázat tárgya volt, most dicsőséges lett." ${ }^{3^{42}}$

Az idézet levél egyike Jeromos azon írásainak, amely betlehemi tartózkodása alatt született, ${ }^{343}$ de ebből is a levéből kiviláglik, hogy az arisztokrácia soraiban 410 elött erősen élt az a gondolat, hogy Róma megannyi templomával és aktív hitélettel nem más, mint a földi Jeruzsálem. Ezt az eszményen ejtettek súlyos sebet Alarich gótjai, és ezt az eszményt rombolták tovább az 5. század során az átviharzó vandálok. Ennek azonban előfeltétele a biztonság, ami Alarich tevékenységével 410-ben egyértelmüen sérült, a későbbi fosztogatások pedig csak fokozták Róma bizonytalan helyzetét, amit kérlelhetetlenül kihasználtak a konstantinápolyi történetírók. Egy évszázad sem kellett hozzá, hogy a forrásokban Konstantinápoly új Jeruzsálemként tünjön fel, és ez a kép tünik föl Hagia Sophia építése kapcsán is. Iustinianus uralkodása alatt, a költő Rhómanos Melódos elismerően méltatta az megújuló székesegyházat, amely szerinte nem csak Nagy Constantinus jeruzsálemi templomán tesz túl, hanem Salamon templomán is. Három évtizeddel

\footnotetext{
340 August. De CIV. D. 2.19-20.

341 O'DALY 1990A, 29

342 JER. EP. 127.8.

343 Jeromos legtöbb levele betlehemi tartózkodása idejéből hiányzik, ez nagyjából a jelenleg ismert szövegkorpusz 1/3-át teheti ki (CAIN 2009, 220-222).
} 
később újabb elemmel gazdagodott az értelmezés, amikor egy névtelen himnusz szerint Salamon temploma csak egy embernek épült, addig a Hagia Sophia egyetemes alkotás a föld valamennyi lakója számára. ${ }^{344}$ Iustinianus uralkodására Róma helyett már Konstantinápoly vált az új Jeruzsálemmé. Látható, hogy Konstantinápoly az 5-6. század folyamán fokozatosan átvette Róma szimbolikus szerepét, azonban ahhoz, hogy elérje ezt, nem csupán templomokra és aktív hitéletre volt szüksége, hanem magába kellett olvasztania mindazokat a képzeteket, amelyeket az 5. század elején élt írók 410-hez társítottak. Hogy melyek voltak ezek a dolgok, arra nem Ágoston fog választ adni, hanem Orosius. Ágoston védekezésével szemben ugyanis Orosius már nem arra törekedett, hogy függetlenítse a mennyei királyság gondolatát a testi és a földi léttől, hanem Galla Placidia és Athaulf házasságán keresztül igyekezett magyarázni az eseményeket.

\subsubsection{Galla Placidia és Athaulf házasságának képe a kortárs történetíróknál}

Iordanes tárgyalása kapcsán láthattuk, hogy a történetíró úgy alakította a Róma kifosztását övező események sorrendjét, hogy azt az érzetet keltse mintha a házasságra és fosztogatásra ugyanabban az évben került volna sor. De vajon miért volt fontos másfél évszázaddal később összekapcsolni a két eseményt? Véleményem szerint a válasz elsősorban Galla Placidia személyében rejlik, az okokat pedig a kortárs történetírók világítják meg.

Nagy Theodosius kétszer házasodott. Arcadius és Honorius, a későbbi kelet- és nyugatrómai uralkodók, valamint lánya, Pulcheria, aki később Marcianus keletrómai császár felesége lett, valamennyien Theodosius első feleségétől, egy hispániai nemes lányától, Aelia Flaccillától születtek. Az asszony azonban 386-ban meghalt. A következő évben II. Valentinianus családja Thessalonikében keresett menedéket, ami ekkor már Theodosius székhelyéül szolgált. ${ }^{345} \mathrm{~A}$ helyzet kapóra jött Theodosiusnak, aki még ebben az évben összeházasodott Valentinianus egyetlen lányával, Gallával, ezzel pedig kapcsolatot létesített a Valentinianus-dinasztiával. Házasságukból három gyermek született, ${ }^{346}$ de hármójuk közül csak Galla Placidia (392-450) élte meg a felnőttkort. Féltestvéreivel szemben Placidia dinasztikus szempontból hatalmas előnyt tudott felmutatni: vérében a Valentinianus és Theodosius-dinasztia együttesen élt tovább.

Athaulf és Galla Placidia házasságáról több szerző is beszámol, a szövegek keletkezési sorrendjében Olympiodóros, Philostorgios, Orosius, Prosper, Hydatius, Marcellinus comes,

34 MAGDALINO 1993, 11-12.

345 Zos. 4.43.2.

346 Első fiuk, Gratianus gyermekkorában meghalt, a második fiú pedig anyjával együtt születésekor halt meg 394-ben. 
valamint mindkét munkájában Iordanes. A felsorolt szerzők közül azonban csak a keleti Olympiodóros és Philostorgios, valamint a nyugati Orosius és Hydatius ad részletes leírást az eseményröl, a többiek megelégszenek a házasság tényének rögzítésével. A keleti és a nyugati szerzők ugyanakkor egy-egy párost is alkotnak, hiszen egyháztörténeti munkájában Philostorgios részben Olympiodórosra támaszkodott. Orosius és Hydatius között pedig az összekötő kapocs Szent Jeromos, akivel mindketten személyes kapcsolatot ápoltak. Jeromos fordította le Caesareai Eusebios (265k.-339) püspök krónikáját, amelyet 378-ig ki is egészített. A következöekben az ö nézöpontjukon keresztül világítom meg az eseményeket és mutatok rá Orosius magyarázatának különlegességére.

\subsubsection{Olympiodóros és Philostorgios}

Thébai Olympiodóros töredékesen fennmaradt munkájában, melyet eredetileg II. Theodosius (401450) keletrómai császárnak dedikált, részletes képet fest Galla Placidia esküvőjének körülményeiről. A szerző elárulja, hogy Athaulf 413. január elején egy bizonyos Candidianus tanácsára házasodott össze Galla Placidiával Narbo egyik vezető hivatalnokának, Ingenuusnak a házában. Candidianus életének nagy részét homály fedi, de minden bizonnyal azonos lehet a 424. év keleti magister militumával. ${ }^{347}$ A házasságkötés helyszínéül szolgáló épület tulajdonosáról pedig még ennyi információ sem áll rendelkezésre. Olympiodóros kiemeli, hogy a házat római szokásoknak megfelelően díszítették fel, Placidia uralkodói öltözetben volt, mellette foglalt helyet Athaulf, aki római hadvezéri köpenyt, és más, római stílusú ruhákat viselt. Az ünnepség során Athaulf ötven, selyembe öltözött, jó kiállású fiatal férfit ajándékozott feleségének. A férfiak egyenként két nagy tálat tartottak, az egyik tele volt arannyal, a másik pedig felbecsülhetetlen értékü drágakövekkel, amelyeket Róma feldúlása során zsákmányoltak. Ezt követően a gót és római vendégsereg szórakoztatására lakodalmi himnuszok következtek, az elsőt Priscus Attalus énekelte, öt Rusticius és Phoebadius követte. ${ }^{348}$ A házasságot követően hamarosan megszületett Galla Placidia és Athaulf közös gyermeke, aki anyai apja és nagyapja után a Theodosius nevet kapta. Nem sokra rá azonban a gyermek meghalt, akit hamarosan apja is követett. Athaulf halálát egyik alattvalója, Dubius okozta, aki Olympiodóros szerint már régóta leste az alkalmat, hogy bosszút állhasson Athaulfon, aki megölte korábbi mesterét. ${ }^{349}$

347 PLRE2 594, "Ingenivs (? Ingenuus)" vö. PLRE2 176-78, “Athaulfus”, Ingenuus a PLRE szerzőinek feltételezése szerint azonos lehet azzal a katonával, aki a szentföldön elmesélte Jeromosnak Athaulf és Galla Placidia házasságát.

348 OLYMP. FR. 24.

349 OLYMP. FR. 26. 
A kevéssel Olympiodóros után alkotó ariánus egyháztörténésznél, Philostorgiosnál az esküvő leírásának számottevő része elveszett, a modern kommentárok tükrében annyi azonban bizonyos, hogy a házasságban Dániel ószövetségi próféciájának beteljesedését vélte felfedezni. ${ }^{350} \mathrm{~A}$ prófécia az i. e. 2. században keletkezhetett, története II. Nabû-kudurri-uṣur (i. e. 605-562) újbabiloni uralkodóval kezdődik, később pedig II. Kyros (i. e. 559-530) és Dareios (i. e. 522-486) idejében folytatódik. ${ }^{351}$ Dániel könyve részben azt az időszakot öleli fel, amelyben a lüdek és geták már egyesültek a perzsákkal. ${ }^{352}$ A prófécia kezdetén II. Nabû-kudurri-uṣur (i. e. 605-562) álmában egy hatalmas szobrot látott, amelynek feje színtiszta aranyból volt, melle és karjai ezüstből, hasa és ágyéka bronzból, lábszárai vasból, lábai pedig részben vasból és agyagból. Egy égből lehulló hatalmas kő azonban összezúzta a szobrot, amelynek elemei - az arany, az ezüst, a bronz és a vas porrá váltak és az enyészetté lettek, a kő pedig, amelyik elpusztította a szobrot, egy heggyé változott, ami beborította a földet. Az álom megfejtésével az uralkodó Dánielt bízta meg, aki a következőképpen magyarázta a jelentését. Az arany fej II. Nabû-kudurri-uṣurt szimbolizálja, az ezüst testrészek az utána következö, de nálánál kisebb birodalmat jelképezik, amit a bronz birodalma követ, ami uralma alá hajtja az egész földet. A vas lábszárak a negyedik birodalmat szimbolizálják, ami szilárd, akárcsak a vas, így mindent törni-zúzni fog. A lábak és a lábujjak részben agyagból, részben vasból vannak, így ez a birodalom részben szilárd, részben törékeny lesz. Meg fog oszlani, de azért marad benne valami a vas szilárdságából. Ha a vas összekeveredik az agyagos sárral, akkor házasságok útján fognak összekeveredni, de nem tudnak összeforrni, miként az agyag sem vegyül a vassal. Ezeknek a királyoknak az idejében az Isten olyan birodalmat hoz létre, ami örökkévaló, nem szünik meg soha, nem száll át másik népre és elpusztítja az összes többi birodalmat. ${ }^{353}$

Jeromos 407-ben kiadott, Dánielhez írt kommentárjában felfedi, hogy az arany fej és a szárnyas oroszlán a babiloni birodalmat jelképezik, az ezüst mellkas és kezek, valamint a medve az óperzsa birodalmat szimbolizálják, a bronz has, ágyék és a négyfejü párduc Nagy Sándor birodalmát jelképezi, a félig vas és agyag lábak és a legfélelmetesebb szörny pedig a Római Birodalmat. Jeromos minden bizonnyal ismerte a történeti előzményeket, mindenekelőtt a különböző barbár népek Hérodotoson alapuló egységesítését.

350 Philostor. Hist. ECCL. 12.4, AMIDON 2007, 157-158.

351 ODB 583-584, „Daniel”, DAN. 1.1., 10.1., 11.1.

352 HDT. 1.88-89 (lüdek), 4.97. (geták).

353 DAN. 2.31-2:43. Dániel hetedik könyvében leírja, hogy Baltazárnak, Bábel királyának uralkodása idején álmot látott. A tengerből négy vadállat emelkedett ki: Az első egy szárnyas oroszlán, a második medvéhez hasonló volt, a harmadik egy négyfejü párduchoz hasonlított, akinek hátán négy szárny volt. A negyedik állat volt a legfélelmetesebb mind közül. Különbözött az előbbi háromtól, szörnyen erős volt, vas fogai voltak és tíz szarva. 


\subsubsection{Orosius és Hydatius}

A címben szereplő szerzők szorosan kötődtek Jeromoshoz, éspedig elsősorban annak betlehemi kolostora miatt, amely menedéket biztosított a szentföldre induló zarándokoknak, mint amilyen Orosius és Hydatius volt. Témánk szempontjából korántsem mellékes, hogy Jeromos nem sokkal látogatásuk előtt fejezte be Dániel könyvének kommentárját.

Az exegézisében meglehetősen sokat késett, jobbára Tyrannius Rufinus tevékenysége miatt. A 4. századi Róma utolsó évtizedének hitéletében minden rendben is ment, egészen 397-ig, amikor Tyrannius Rufinus, Jeromos egykori római barátja és tanulótársa, Rómába érkezve ki nem adta Órigenés Peri arkhónjának meglehetősen szabadosan fordított latin nyelvű változatát De principiis címmel. ${ }^{354}$ A századforduló végén Jeromos jelentős energiáit kötötte le, hogy orvosolja a Rufinus okozta zavarokat. Az 5. század elején Jeromos egyik, nolai Paulinusnak küldött levelében szabadkozik, mert ígérete ellenére még mindig nem készítette el a Dániel könyvéhez írt szövegmagyarázatát. Töredelmesen vallja be, hogy munkái sorában elöre kellett vennie Pammachius és több római gyülekezet kérését, ami Órigenés Peri arkhón c. munkájának fordítására vonatkozott. Nem akarta ugyanis, hogy az Órigenés-vita közepette Rómában egyesek tévtanok felé forduljanak, ezért inkább lefordította a keresztény dogmatika első rendszerezését tartalmazó órigenési munkát. ${ }^{355}$ Annak ellenére, hogy Paulinus korábbi levelével együtt egy köpenyt is küldött Jeromosnak, az egyházatya még egy jó darabig halogatta a munka befejezését, ${ }^{356}$ amellyel végül csak 407-ben történt meg, ${ }^{357}$ éppen akkor, amikor a nyugaton maradt hittársak és barátok életét Alarich gótjai már alaposan felforgatták.

Jeromos első látogatói között volt egy hispániai pap, aki 415 végén, szentföldi zarándoklata során felkereste őt betlehemi monostorában. A szerzetest Paulus Orosiusnak hívták, aki az Ibériaifélsziget északnyugati részén csücskében elterülő Bracara Augusta (Braga) városában született jó harminc évvel korábban. ${ }^{358}$ Mélyen elkötelezett pap volt, állomáshelyén nem csak a Priscillianus tanításaival szemben vette fel a harcot, hanem az Órigenés-vitákból is kivette a részét. Elkötelezettségét remekül példázza, hogy a birodalom csaknem legnyugatibb pontjáról indult keletre, az imperium éppen átellenes pontjára. Eredetileg nem is Jeromoshoz ment, hanem

354 JER. EP. 127.6 .

355 JER. EP. 85.3.

356 JER. EP. 85.6, JER. ADV. RUFIN. 1.8-10, Jeromos 402-ben még kiadta a Rufinus ellen írt értekezését (Adversus Rufinum), amelyben azzal vádolta, hogy a fordítás során helyenként megmásította az eredeti görög szöveget, annak érdekében, hogy Órigenés pozitívabb színben tüntesse fel. A vitát azonban nem lehet egyik fél javára sem eldönteni, mert az eredeti szöveg elveszett.

357 ZECCHINI 2003, 319.

358 OROS. 7.22.8, ADAMIK 2009, 806. 
valamivel korábban, talán 409 és 411 között ${ }^{359}$ érkezett Hippo (Annába) városába, annak érdekében, hogy kikérje Szent Ágoston tanácsait ezekkel a vitákkal kapcsolatban. Az Órigenés-vita kulcskérdései a lélek eredetéhez kapcsolódtak. ${ }^{360}$ A téma komolysága és komplexitása Orosius hippói tartózkodását néhány év erejéig tartóssá tette, ${ }^{361}$ de a lélekkel kapcsolatos kérdések megválaszolását Ágoston inkább Jeromosra bízta. ${ }^{362}$ A szerzetes ezért Betlehembe indult Ágoston ajánlásának kíséretében, ${ }^{363}$ a Jeromossal történt találkozó után Hispánia felé vette útját. ${ }^{364}$ Szülőföldjét azonban nem érte el, mert Menorca szigetén értesült a városát is érintő vandál támadásról, ezért visszafordult. 416 második felére már ismét Hippóban volt, ahol Ágoston kérésére nekilátott hét kötetes történeti munkájának (Historiarum adversum paganos libri VII), ${ }^{365}$ melynek gyakran idézett hetedik kötetében többek között visszaemlékezik Jeromosnál tett látogatására is. Ebben a kötetben a szerző a Krisztus születése utáni időszakot tárgyalja egészen 417-ig, így megelevenedik benne Róma kifosztásának története, valamint Galla Placidia és Athaulf házassága is, gyakori idézettségét is éppen ez az esemény adja.

Az esemény leírásával kapcsolatban néhány dolog igencsak megfontolandó, amire az eddigi szakirodalom talán nem szánt elég figyelmet. ${ }^{366}$ Az egyik ilyen, hogy Orosius egyszerủen összemossa Róma kifosztását (410) a házassággal (414), mintha egyszerre vagy éppen közvetlenül

359 OROS. 3.20.6-7, 5.2.1.

360 JER. EP. 131.2 .

361 Ebben az időben írja meg Orosius a Commonitorium de errore Priscillianistarum et Origenistarum (414) c. munkáját, ami általános tájékoztatást adott a viták állásáról. Orosius munkájának hatására született Jeromos Ad Orosium contra Priscillianistas et Origenistas c. müve.

362 JER. EP. 131.2-3. (Ágoston levele Jeromosnak): "Nam inde ad nos usque ab oceani littore properavit, fama excitus, quod a me posset de his, quae scire vellet, quidquid vellet audire. [...] Accipe igitur quae mihi, peto, aperire ac disserere non graveris. Quaestio de anima multos movit, in quibus et me esse confiteor."

363 JER. EP. 134.1.(Ágostonnak): "Virum honorabilem fratrem meum, filium dignationis tuae, Orosium Presbyterum, et sui merito et te iubente suscepi."

364 EP. SEVERI. 4.2.

365 ADAMIK 2009, 807, Munkájának a Történelem hét könyvben a pogányok ellen (Historiarum adversum paganos libri VII) címet adja. Az egyházatya kérésének alapját az adta, hogy ebben az időben már befejezte a De civitate Dei első tíz könyvét, de elégtelennek találta a Krisztus születése elötti katasztrófák számát. Orosius elsődleges feladata tehát az volt, hogy a világtörténelem katasztrófáinak során keresztül bizonyítsa, hogy már a kereszténység kezdete előtt is érték Rómát katasztrófák. Hétkötetes munkájának első könyvében az addig ismert világ ismertetését követően Ádám bünbeesésével kezdi történetét, amit a világtörténelem háborúinak felsorolásával míg el nem jut Róma megalapításáig. Második könyvében Róma és Perzsia történetét ismerteti. Rómát I. e. 390-ig, Perzsia történetét pedig I. e. 401-ig vezeti le. Harmadik könyvében Nagy Sándor birodalmával és az ezzel párhuzamos római történelmet ismerteti. Negyedik könyvében Karthágó elpusztításáig ismerteti az eseményeket. Ötödik könyvében a Spartacusfelkelésig beszéli el a katasztrófák sorát, majd a következő, hatodik könyvében Krisztus eljöveteléig ismerteti az eseményeket. A hetedik könyvben saját koráig, egészen 417-ig folytatja a világ katasztrófáinak ismertetését.

366 A korábbi szakirodalom kritikájára: NUFFELEN 2012, 197-205. 
egymást követően történtek volna. ${ }^{367}$ De nem ez az egyetlen jelentős változtatás, amivel a szerző él. Az ezt követő elbeszélésében ugyanis megemlékezik arról, hogy Jeromosnál tett látogatása alkalmával személyesen hallott egy beszélgetést Jeromos, és egy, korábban Theodosius alatt szolgáló egykori katona, egy jámbor, józan és komoly ember között. A katona ráadásul maga is az esküvő helyszínét adó Narbo városából érkezett, hogy Athaulf szavait tolmácsolja a betlehemi szerzetesnek. A vizigót uralkodó üzenetében kinyilvánította, hogy a gótok féktelen természete miatt ragaszkodik a római törvények megtartásához, azok sértetlenségének és tiszteletének biztosításához. ${ }^{368}$ Athaulf szavait egy olyan katona tolmácsolja, aki korábban Nagy Theodosius megbízható embere volt, ráadásul maga is Narbo városából, tehát az esküvő helyszínéről származott. Mủvében Orosius egyedülálló módon azzal megerősíti meg a történet hitelességét, eredetiségét, hogy saját magát helyezi a hiteles elbeszélő szerepébe. Ö maga hallotta a dolgokat, nem pedig elődei szavait önti új köntösbe, amire műve korábbi szakaszaiban egyáltalán nincs példa. ${ }^{369}$

A katona által elmesélt történet fő mondanivalója, hogy a vizigót uralkodó alárendeli magát a római törvényeknek. Ezt azonban nem önszántából teszi, hanem Galla Placidia hatására. Ezt az elgondolást támasztja alá Alarich végzete. Orosius ugyanis Olympiodórostól eltérően számol be Athaulf haláláról. Nála már nem személyes bosszú okozza a vizigót király vesztét, hanem népének akarata. A vizigótok ellenzik Athaulf Róma-barát politikáját, amelynek gondolatát Galla Placidia ültette el Athaulf fejében. ${ }^{370}$ A történet központi szereplője nem Athaulf, hanem maga Placidia. A történetíró azért hozza szóba a Róma kifosztását és azért mossa azt össze a házassággal, mert Róma sorsát így össze tudja kötni Placidia sorsával. ${ }^{371}$ Theodosius lánya és a Gondviselés hatására a barbár uralkodó, népének szokásával szembefordulva, tisztelni kezdi a római törvényeket, amelyeket már alkalmazni is akar. Placidia pedig Athaulf halála után épségben visszakerül Rómába, így mind az asszony, mind a város megmenekül. Ez a gondolat ugyanakkor alapjaiban értelmezi át Athaulf és Placidia házasságának leírását.

Orosius a házasság leírásakor egyértelmúen Dániel könyvére utal, mondván, hogy a vizigót uralkodó már-már azt tervezte, hogy a házasság révén a gótok és a rómaiak földje is egybeolvad,

367 Oros. 7.40.2. "in ea inruptione Placidia, Theodosii principis filia, Arcadii et Honorii imperatorum soror, ab Athaulfo, Alarici propinquo, capta atque in uxorem adsumpta." vö. 7.43.2. "Gothorum tunc populis Athaulfus rex praeerat: qui post inruptionem urbis ac mortem Alarici Placidia, ut dixi, captiua sorore imperatoris in uxorem adsumpta Alarico in regnum successerat." OROS. 7.43.2.

369 OROS. 7.43.4.

370 OROS. 7.43.7-8.

371 Oros. 7.40.2.: "capta atque in uxorem [Galla Placidia] adsumpta, quasi eam diuino iudicio uelut speciale pignus obsidem Roma tradiderit" 
így az egykori "Romania" is "Gothia" része lesz, melynek élén ő fog uralkodni. ${ }^{372}$ Az elbeszélés érdemi mondanivalója megegyezik Dániel könyvének következő részletével:

“Elöször dél királya erösödik meg. De az egykori vezérek közül egy másik még nála is erösebb lesz, s hatalmasabb birodalmat szerez, mint a többi ország. Évek múlva szövetségre lépnek: dél királyának lánya a béke érdekében feleségül megy észak királyához."

A kutatás jobbára a fenti idézet és Orosius hetedik könyve alapján a vizigótok és a rómaiak békés közeledéseként értékeli Galla Placidia házasságát, ez azonban csak a felületes szemlélő számára tünhet így. Részint azért, mert, mint ahogyan azt Nuffelen kimutatta, Orosius nem a 7. könyvben kezdi el a 410-es események tárgyalását, ${ }^{374}$ hanem már a másodikban utal rájuk, amit viszont a kutatók többsége figyelmen kívül hagy, hiszen konkrétumok után kutatva csak a 7. könyvben találnak érdemi információkat Alarich "pusztításáról”. ${ }^{775}$

Orosius második könyve egyfajta szerkezeti útmutató, amely hétkötetes munkájának felépítését tartalmazza. A szerző miután sorra veszi a korábbi birodalmakat, Róma ismertetése kezdetén felemlegeti Tróját, de Ágostonnal szemben nem von párhuzamot a két város között. A hippói szerzetes ugyanis az Isten városának harmadik kötetében a trójai háború eseményeit egyértelmüen párhuzamba állítja Rómával. ${ }^{376} \mathrm{Az}$ ő szemében ugyanis Trója bukása csupán annak az egyértelmü bizonyítéka, hogy egy város, amennyiben azt pogány istenek védik, bizony elbukik, ami éppen ezeknek az isteneknek az alkalmatlanságát bizonyítja, ezzel szemben az igaz keresztény város még a legzivatarosabb időszakokat is képes túlélni. Orosius ebben a nézetben nem osztozik mesterével. Ugyan utal Trójára, de nem állítja egyértelmü párhuzamba Róma városával, csupán annyit közöl, hogy Rómát Trója bukása után 414 évvel alapította két testvér. Nincs tehát

372 OROS. 7.43.5.: "se [Athaulf] inprimis ardenter inhiasse, ut oblitterato Romano nomine Romanum omne solum Gothorum imperium et faceret et vocaret essetque, ut vulgariter loquar, Gothia quod Romania fuisset et fieret nunc Athaulfus quod quondam Caesar Augustus."

373 DAN. 11.6-7. Dániel könyvének ezt a részletét exegézisében Jeromos nem a Római Birodalom és a gót királyság összetüzésével azonosítja, hanem a Szeleukida birodalom és Egyiptom viszályával. i. e.281-ben a I. Seleucusszal a Szeleukida birodalom alapítójával gyilkosság végzett. A merénylet miatt kirobbanó örökösödési háborúba Egyiptom is beavatkozott II. Ptolemaius Philadelpus (i. e.282-246) vezetésével. I. Antiochus (i. e.281-261) szeleukida uralkodó számos hadjáratot vezetett Egyiptom ellen, amitől Ptolemaius úgy igyekezett szabadulni, hogy Berenike nevü lányát hozzáadta Antiochushoz. Egy korábbi helyen azonban megtörténik az azonosítás. Ahogyan korábban Philostorgios esetében - a romlott szöveg ellenére - már láthattuk, a szerző Placidiát az agyag szubsztanciájával azonosította. Jeromos pedig a tengerből kiszálló négy szörnyet birodalmakkal azonosítja, amelyek közül a negyedik a Római Birodalom, amely uralma alá hajtja az egész földet. Következésképpen Jeromos felfogásában a negyedik szörny és a szobor agyag része a Római Birodalom.

374 OROS. 7.39-40.

375 NUFFELEN 2012, 45.

376 OROS. 2.4. 
egyértelmü kapcsolat, csupán annyi észlelhet az olvasó, hogy miképpen Trója elbukott úgy Róma is esendő. ${ }^{377}$

Róma bukását különleges szerkezettel készíti el a szerző. Trója említése után felsorolja Romulus bűneit, majd a szabin nők elrablását és szégyenletes házasságukat. Ennek leírásához Vergilius Aeneisének egy részletét használja, ${ }^{378}$ éppen azt, amely Aeneas pajzsának egy részletét adja. ${ }^{379}$ Orosius művében tehát ezzel kezdődik Róma története, végét pedig Galla Placidia elrablása és házasságra kényszerítése jelenti. ${ }^{380}$ Orosius ezzel keretezi Róma történetét, és ez volt az, amit Iordanes és Cassiodorus is felismert, hiszen Iordanesnél is Galla Placidia és Athaulf házasságával kezdődik a gótok és a rómaiak kapcsolata, műve végén pedig Matasuntha és Germanus házassága szerepel. ${ }^{381}$ Orosiusnál Róma története egy asszonyrablással kezdődött és saját idejében is ez ismétlődik meg Galla Placidia elrablásával. Az előző fejezetben láthattuk, hogy az Orosius után egy évszázaddal alkotó szerző Alarichot és gótjait Aeneashoz és a trójai néphez hasonlította, ezt a nézöpontot valójában Orosius adta a későbbi történetírók kezébe, ennélfogva a dánieli idézet sem tekinthető a két nép egyesülésének jelképeként.

Ebből kifolyólag úgy gondolom, hogy Orosius egy eszkatológiai visszaszámlálást indított. A házasság ugyanis, véleményem szerint a Nabû-kudurri-uṣur álmában megjelenő szobor pusztulásának utolsó elötti jelenetének feleltethető meg. Az égből lehulló hatalmas kő azonban összezúzta a szobrot, amelynek elemei - az arany, az ezüst, a bronz és a vas - szétporladnak. A vas ekkor keveredik össze az agyagos sárral, ekkor keverednek a népek házasságok útján, de nem tudnak összeforrni, miképpen Galla Placidiának sem lehet gyermeke Athaulftól. Ezt követően Isten létrehozza saját birodalmát, amely örökkévaló. Orosiusnál tehát korántsem pozitív a házasság leírása, hiszen valójában a világvége-várást indított el.

A világvége-várás jelentőségére Hydatius (397k-469) ${ }^{382}$ is felhívja a figyelmet. A hispániai születésủ szerzetes Orosiusszal közel egy időben kereste fel Jeromost, ${ }^{383}$ aki saját bevallása szerint

377 OROS. 2.4.1.

378 NUFFELEN 2012, 53-54. OROS. 2.4.2. "parique successu crudelitatis sine more raptas Sabinas" vö. VERG. AEN. 8.635: "sine more raptas Sabinas"

379 VERG. AEN. 8.635, Aeneas pajzsának részletes leírása, rendszerezve Vergilius kivonataival: VELLA 2004, 7-9.

380 Oros. 7.43.2

381 JORD. GET. 159-163. vö. 314.

382 Hydatius születési dátuma bizonytalan, általában a 4. század végére helyezik (MUHLBERGER 1990, 193266, BROWN 2013, 99).

383 Hyd. Chron. 33. (40) vö. BROwn 2013, 99, Peter Brown legfrissebb monográfiája szerint Hydatius anyja társaságában kereste fel a Szentföldet, ezt azonban semmilyen adat nem erősíti meg. Aquae Flaviae későbbi püspöke alig tíz évesen elzarándokolt el a Szentföldre minden bizonnyal egyik közeli hozzátartozójának kíséretében. 
is nagy hatást gyakorol későbbi életére. ${ }^{384}$ A hispániai szerzetes karrierje elsősorban elhivatottságának köszönhetően gyorsan ível felfelé, alig harmincéves korában már püspöknek választották a Hispánia északi részén fekvő Aquae Flaviae városában. Krónikáját csak élete végén kezdte el írni, amellyel valójában Eusebios munkáját folytatta, amit, mint említettük, Szent Jeromos ültetett át latin nyelvre és 378-ig ki is egészített. Hydatius ettől a 378-as időponttól egészen halálának évéig jegyezte fel meglepő részletességgel az eseményeket, ezzel a korabeli Hispania egyik legrészletesebb forrását adva, amely egyedülálló módon mutatja be a provinciabeli rómaiak és barbárok szembenállását.

Hydatius Galla Placidia és Athaulf házasságában - Philostorgioshoz hasonlóan - Dániel próféciájának beteljesedését látta, aminek in concreto hangot is ad. "Athaulf feleségül vette Placidiát Narbo közelében. Ebben Dániel jövendölését látták beteljesedni, miszerint a déli király lánya egybekel az északi királlyal." 385 A szerző dánieli allúzióját csak még magabiztosabbá tette Galla Placidia és Athaulf gyermekének korai halála, miképpen Dániel könyvében sem lehet észak királyának és dél királya lányának gyermeke. ${ }^{386}$

Ahogyan korábban láthattuk, Orosius a házasságban Gothia és Romania egyesülését látta, Róma megmenekülését pedig Galla Placidiának tulajdonította, ezzel szemben Hydatius már egy lépéssel tovább ment. ${ }^{387} \mathrm{~A}$ korábbi értelmezés tükrében korántsem meglepő, hogy míg Orosius esetében a házasság leírása hétkötetes munkájának legvégén kapott helyet, addig Hydatius esetében a krónika elején (57. caput a 253-ból) jelenik meg, világosan összekapcsolva Dániel jövendölésével. ${ }^{388}$ Hydatius művében azonban még egy konkrét utalás történik Dániel próféciájára. A 110. (118) caput esetében Hydatius jelzi, Dániel már megjósolta, hogy a vandál Geiserich el fogja üldözni Carthago püspökeit és papságát, feldúlja a szentek nyughelyeit, a templomaikat pedig az ariánusok rendelkezésére bocsátja. ${ }^{389}$ Hydatius ezzel apró lépésekben halad a világvége felé.

Hydatius halálának pillanatáig (469) írta mủvét, így kétségtelen, hogy ha módja lett volna rá, még folytatta volna. Egy szélesebb keresztény nézőpontból Dániel próféciája az idővonal közepén helyezkedik el, a kezdet és a végítélet között félúton. Azzal, hogy Hydatius két ponton is

4 HYD. ChrON. 31-33. (38-40).

385 HYD. Chron. 49. (57): “Ataulfus apud Narbonam Placidiam duxit uxorem, in quo prophetia Danielis putatur impleta, qui ait filiam regis Austri sociandam regi Aquilonis".

386 DAN. 11.6.: “Évek múlva szövetségre lépnek: dél királyának lánya a béke érdekében feleségül megy észak királyához. De karjának nem lesz elég ereje, még ivadéka se marad."

387 OROS. 7.43.5.: "se [Athaulf] inprimis ardenter inhiasse, ut oblitterato Romano nomine Romanum omne solum Gothorum imperium et faceret et uocaret essetque, ut uulgariter loquar, Gothia quod Romania fuisset et fieret nunc Athaulfus quod quondam Caesar Augustus"

388 HYD. CHRON, 50. (58).

389 DAN. 9.27.: “A templom szárnyán vészt hozó undokság lesz, egészen végig, míg a kiszabott büntetés rá nem zúdul a pusztítóra." 
hivatkozott Dániel próféciájára, világosan mutatja, hogy várta az idők végét. Nála negatív események sora Athaulf és Galla Placidia házasságával veszi kezdetét. Gyermekük halála pedig jelzi, hogy a császári és barbár vérnek nem lehet közös gyermeke: “házasságok által össze fognak keveredni, de eggyé nem fognak összeforrni. A vas ugyanis nem vegyül az agyaggal. " ${ }^{\prime 390}$ A vas viszont vegyül a vassal. Szabadulása után házasságot kötött Constantinus patriciussal, a későbbi nyugati társuralkodóval (421), akitől két gyermeke született III. Valentinianus és Honoria személyében. Ugyanez figyelhető meg az első fejezetben látott Witiges-Matasuntha és GermanusMatasuntha házasságok kapcsán. Prokopios mozaik-leírása, Theoderich egész alakos portréjának összeomlása egy Dániel könyvére történő allúzió. Ahogyan Nabû-kudurri-uṣur álmában megjelenő szobor pusztulása előrevetítette Észak és Dél népeinek keveredését, úgy “jövendölte meg” Prokopios Germanus és Matasuntha házasságait. Ezért zárja Iordanes reményteljesen a sorait, hiszen számára - Orosius és Dániel könyvének tükrében - bizonyos, hogy a gyermek csak abban az esetben lehet reménység, ha az Úr élteti. ${ }^{391}$ Germanus postumus azonban életben marad, ez azonban nem a véletlen mủve. Iordanes azért tartja fontosnak közölni, hogy Matasuntha és Germanus házasságában az Amal-dinasztia és az Anicius-nemzetség egyesült, mert vélhetően az Aniciusnemzetség lesz Galla Placidia vérvonalának hordozója.

A fejezetben láthatóvá vált, hogy az uralkodói család idegenekkel történő keveredését csak a történetírók nézték ferde szemmel. Themistios a rómaiak és a gótok egymáshoz való viszonyát az istennő Thetis és a hős Péleus vívódásaként írta le. A későbbi történetírók pedig dánieli allúzióval igyekeztek semmissé tenni bármiféle keveredést. Míg azonban Alarich fosztogatása után Szent Ágoston még azzal érvelt, hogy a birodalmat számtalan sorscsapás érte már Krisztus előtt is, ráadásul Isten városa, a mennyei Jeruzsálem nem földi város, addig Orosius egy merőben új védekezéssel állt elő. A bragai szerzetes Jeromossal folytatott gyakori eszmecseréi folytán maga is tisztában volt azzal, hogy Rómát gazdag hitélete miatt gyakran Jeruzsálemhez hasonlították. Éppen azért Ágoston és Jeromos ellentétét azzal oldotta fel, hogy egyszerüen összemosta Róma kifosztását a házassággal, így a város sorsát össze tudta kötni Placidia sorsával.

DAN. 2.43 .

391 JORD. GET. 314.: “Mathesuentham vero iugalem eius fratri suo Germano patricio coniunxit imperator. De quibus post humatum patris Germani natus est filius idem Germanus. In quo coniuncta Aniciorum genus cum Amala stirpe spem adhuc utriusque generi domino praestante promittit." 


\section{AZ ANICIUS CSALÁD}

Az előző fejezetekben többször felmerült az Anicius-nemzetség neve, hol Róma elfoglalása, hol Theodosius-dinasztia legitimációja kapcsán, érdemes hát jobban megismerni a gens történetét, annál is inkább, mert a ma is széles körben használt névmutató, a Prosopography of Later Roman Empire esetükben pontatlan családfákat közöl, ${ }^{392}$ így az erre építkező szakmunkák többsége is magában hordozza ezeket a hibákat. ${ }^{393}$ A fejezetben a kortárs források és az epigráfiai anyag alapján megrajzolom a senatori arisztokrácia általános képét, rekonstruálom az Anicius család felépítését és kettészakadását, valamint felfedem a család egyik hiányzó tagjának kilétét, hiszen ezeknek a későbbiekben különös jelentősége lesz.

372 után Valentinianus reformjának egyenes következménye volt, hogy a 4. század végétől Rómát és annak senatusát néhány nagyobb család dominálta, amelyek egy idő után, különböző rokoni szálakon keresztül, de kapcsolódtak egymáshoz. A renden belüli erős koncentráltság elsősorban a pozíció, tekintély, és természetesen a vagyon megtartására irányult, ebben kétségtelenül az Aniciusok voltak a legkiemelkedőbbek, mellettük a többi család eltörpülni látszik. ${ }^{394}$

A 4. század végére az immár több mint ezer éves senatus túlélte a köztársaság korát, átvészelte a császárkor valamennyi politikai változását, és kétségkívül idősebb volt, mint maga a birodalom. Ennek megfelelöen alkalmazkodott a különböző korszakok kihívásihoz. Már 379-ben, Theodosius kinevezésének évében egy konstantinápolyi követség érkezett Thessalonikébe Themistios vezetésével, ${ }^{395}$ amely a keletrómai senatus jókívánságait tolmácsolta az újonnan kinevezett uralkodónak. Az a tény, hogy egy költő vezette a konstantinápolyi senatus követségét az újonnan megválasztott uralkodóhoz, rögtön rávilágít a testület legnagyobb gyengeségére, a nemességre. A fiatal konstantinápolyi senatus ugyanis nélkülözte azoknak az ősi nemesi

392 PLRE1 1133, "7. Stemma of the Anicii".

393 A család története jól kutatott, azonban éppen az Aniciusok belpolitikai szerepével foglalkozó tanulmányok következtetései váltak megkérdőjelezhetővé pusztán azért, mert a PLRE hibás adataira alapozzák mondanivalójukat: CLOVER 1978, 169-196, MOORHEAD 1978, 125-136, ZECCHINI 1981A, 123-138, MOORHEAD 1983, 106-120, MOORHEAD 1984, 107-115, RUGGINI 1988, 69-85, hasonlóképpen megkérdőjelezhetőek az ezekre a szakmunkákra épülő genealógiai megállapítások többsége, mint például SETTIPANI 2000.

394 MATTHEWs 1975. 329-51. Az északi és galliai családok tagjai jobbára az legalacsonyabb clarissimus rangban ragadtak. Ugyanakkor az északi uralkodói központoknak köszönhetően - mint Trier vagy Arles - egy-egy uralkodó regnálásának idején kapcsolódni tudtak a római családokhoz. Sidonius Apollinaris jó példa erre. Apollinaris unokája praefectus praetorio volt Galliában 408-9 között, valamint Avitus császár veje, ennélfogva vezető családhoz tartozott még Maiorianus uralkodása alatt is, udvari tisztséget is birtokolt. Vir illustris volt és 468-ban praefectus urbinak is kinevezték, ő volt az egyetlen galliai az elmúlt 40 évben, aki megkapta ezt a tisztséget.

395 Datálásra: HEATHER-MONCUR 2001, 218. 
családoknak a sarjait, akik a birodalom másik felében jószerével már alig fértek be a Curia épületébe, okkal, ezt világítja meg Themistios beszéde.

A senatusi üzenet nem követte a szokásos sablonokat, így teljes egészében elmulasztotta Theodosius őseinek említését, még apját is kihagyták belöle. Talán tapintatból, talán nem, mindenesetre tény, hogy az idősebb Theodosius bevádolásával és kivégzésével gyanúsított tisztségviselők közül ekkorra már csak Petronius Probus élt, valamint Gratianus császár. Themistios mindenesetre kiemelte, hogy míg a korábbi uralkodók győzelmi oszlopok, szobrok és vízvezetékek sokaságával gyarapították Konstantinápolyt, addig Theodosius a valódi problémára legalábbis a senatorokat illetően - talált gyógyírt. Valóban, elődeivel ellentétben, akik dinasztikus kapcsolataik révén a senatus támogatását élvezték, Theodosiusnak ez nem adatott meg, így különösen nagy hangsúlyt fektetett arra, hogy kitüntetések és címek adományozásával a senatorok támogatását is elnyerje. ${ }^{396}$

A konstantinápolyi senatus legnagyobb problémája, amire Themistios utalt, leginkább a hirtelen felduzzasztott méretéből származott. A 300-as évek elejére ugyanis Diocletianus és Constantinus hivatali reformja az arisztokrácia egészét becsatornázta a közhivatalokba, ezzel megnyitottak egy új birodalmi, bürokratikus karrierutat a vidéki arisztokrácia előtt, ami a senatus méretének exponenciális növekedéséhez vezetett. ${ }^{397}$ A 4. század közepére a rend soraiban már nem csupán a városi arisztokrácia tagjai kaptak helyet, hanem a vidéki elit képviselöi is. Számokban kifejezve ez azt jelentette, hogy míg a 3. század közepén alig kétszáz közigazgatási pozíció létezett birodalom szerte, addig a 4. század végére ezeknek a száma a birodalom mindkét felében elérte a háromezret, ráadásul szinte valamennyivel elérhetővé vált a senatori pozíció. Sok senator, kevés ülöhely, így alakult a rend helyzete a század végére.

372-re már olyan mértékben felduzzadt a senatus, hogy Valentinianus és Valens fontos változtatásra kényszerült. Egy megkülönböztető címet vezettek be a senatorok között: az adminisztráció alacsonyabb szintjein helyet foglaló hivatalnokok a vir clarissimus címet, a középen található méltóságviselők (proconsulok, a négy comes, a duxok, magasabb katonai tisztségviselők) a vir spectabilis, az adminisztráció vezető pozícióit elfoglaló tisztségviselők (praefectus praetorio, városi praefectus, consulok, magister militumok, és a hadvezérek) pedig a vir illustris jelzöt kapták. ${ }^{398}$

\footnotetext{
396 THEM. OR. 14.183c. Constantinus középületekkel, Valens vízvezetékekkel járult hozzá Konstantinápoly gyarapodásához. További példákra lásd: MANGO 1985, MACHADO 2012.

397 BARNES 1993, 43.

398 JONES 1964, 143-4, 528-9. A fejlődés ezen irányába mutató félig hivatalos címek már a 4. század közepén megjelentek, amikor a praefectus praetoriók neve mellett a korábban szokványos clarissimus helyett megjelent a clarissimus et illustres cím.
} 
A senatori renden belüli átjárhatóságot és a társadalmi mobilitást jól érzékelteti a költő Ausonius (310-395), aki 379-es consuli beiktatási beszédében kiemelte, hogy elödei közül néhányan katonai érdemeik miatt váltak érdemessé a pozícióra, mások adminisztratív szolgálataik révén, megint mások pedig egyszerủen azért, mert ősi családok leszármazottai voltak. ${ }^{399}$ A senatori családok közfeladatok iránt elkötelezett fiai gyors előrehaladások révén hamar a senatus teljes jogú tagjaivá válhattak, ezért a hivatali adminisztrációt érintő változtatások Theodosius után is folytatódtak. A vir illustris címmel rendelkező senatorok joghatósági és fiskális privilégiumai növekedtek, miközben a clarissimusok és a spectabilisek egyre inkább háttérbe szorultak. Az 5. század közepére Marcianus császár drasztikus megoldást választott a helyzet kezelésére. Egyszerúen elzárta a senatusi belépőt jelentő praetori pozíciót a clarissimusok és a spectabilisek elöl. Ez az intézkedés azonban csak még jobban kinyitotta az ollót a senatorok között, hiszen csak a vir illustris címmel rendelkező senatorok vehettek részt a senatusi üléseken. Az 5. század közepére aktív senatusi tagsággal tehát már csak az illustrisok rendelkeztek. Ők vehettek részt az üléseken, ők szólalhattak fel és ők intézhettek beadványokat. Az illustris címet azonban csak aktív karrierrel lehetett elérni, amelyet az ösi arisztokrata családok kapcsolataik, valamint gazdagságuk révén könnyüszerrel el tudtak érni.

A rangban legalacsonyabb szinten lévő clarissimus családok tagjai ezért folyamatosan keresték annak lehetőségét, hogy valahogyan magasabb szintre kerüljenek. Ennek egyik új lehetősége az egyház lett, hiszen az uralkodói támogatásnak köszönhetően az egyház folyamatosan erősödött, ráadásul a 4. század végére a senatori arisztokrácia soraiban is egyre több keresztény bukkant fel, egy századdal később pedig abszolút többségbe kerültek. Az I. Leo pápa (440-461) tevékenységével egyre erősödő római egyház, noha eltérő hierarchiával rendelkezett, alapjaiban azonban nagyon is egyezett az állammal. A senatori rendhez hasonlóan az egyház tagjai is kiváltságokkal rendelkeztek, így például mentesültek az adófizetés alól, ráadásul kuriális feladatokat sem kellett ellátniuk. A sorozatos adományok gyarapították az egyház birtokállományát, a püspökök pedig egyre nagyobb befolyásra tettek szert előbb székhelyükön, majd az azt tágabban körülölelő régióban. ${ }^{400}$ Korántsem meglepő, hogy az idősebb vagy az alacsonyabb sorban lévő senatorok egyre inkább keresték annak a lehetőségét, hogy az egyházi hatalomban is befolyással

399 AUSON. GRAT. ACT. 4.

400 450-re a püspökök helyzete annyira megerösödött, hogy a kiöregedő senatorok keresték annak a lehetőségét, hogy püspökök lehessenek. Ez a fejlődés elsősorban Galliában látható, ahol a birodalmi hatalom már válságba jutott. A 6. század közepén hasonló helyzet figyelhető meg Hispániában és Itália legnagyobb részében is. 500 után a nyugati arisztokrácia egyre inkább katonai jellegüvé vált, az arisztokratikus kultúra pedig egyre inkább egyházi. Ebben az időben figyelhető meg, hogy a müvelődés egyre inkább egyházi jelleget ölt. Ez a folyamat nem fejeződött be Venantius Fortunatus (535-600) és Nagy Szent Gergely (540-604) idején, a 6. század végén, de már közel járt. 
rendelkezzenek. Már a 4. század végén azt mondta Róma egyik vezető senatora Damasus (366-

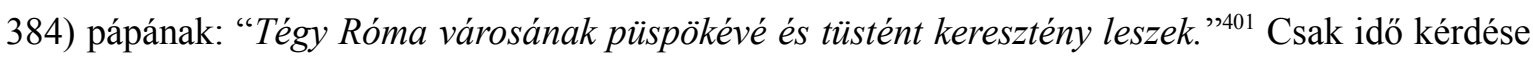
volt, hogy mikor alakul ki az egyházi karriertípus, ahogyan azt majd a későbbi fejezetekben látni fogjuk.

\subsection{A hivatalos karrierút: a cursus honorum}

A cursus honorum, vagyis a senatori rend hivatalviselési sorrendjének történetére számtalan felirat és törvényi rendelkezés szolgál alapul. Egy senator pontos cursusának ismeretében nemcsak a születési idejére lehet következtetni, hanem házassági és kollegiális kapcsolataira is, ami a senatori családfák rekonstrukciójának szempontjából különös jelentőséggel bír. Mivel a dolgozat során több alkalommal is találkozni fogunk ezekkel a rekonstrukciókkal, érdemes röviden áttekinteni öket. A 4. század végére a legjelentősebb különbség a korábbi korokhoz képest a demográfiai eltolódás, hiszen míg a köztársaság korában a consuli hivatalviselés alsó határa 43 év volt (ráadásul csak tíz év elteltével lehetett ismételten viselni), addig a constantinusi rendelkezések értelmében a quaestori, praetori és a consul suffectusi pozíció már a tizenhatodik életév betöltése elött nyitott volt az aspiránsok számára. ${ }^{402}$ A cursus csúcsát jelentő consuli székben, amit egykor a legidősebbek birtokoltak, a 4-5. századra már kezdtek megjelenni a fiatal felnőttek. A helyzetet súlyosbította, hogy a rendes consulok és a patriciusok csupán egy igen szük csoportját alkották az elitnek, hiszen consult csak évente választottak, a patriciusi címet pedig még az 5. század második felében is meglehetősen szükmarkúan osztották. Leginkább csak egykori consulok, városi praefectusok, esetleg leköszönő praefectus praetoriók kaphatták meg a címet, akikböl szintén csak egy volt évente.

A cursus legelőkelőbb helyét így a consulok helyett az egykori consulok vették át. Megítélésüket pedig csak javította, ha korábban már viseltek valamilyen praefecturát, esetleg magister militumi tisztséget, hiszen így automatikusan a korábbi időszakok consuljai fölé kerültek, akik nem rendelkeztek hasonló előnyökkel. Ez elégedetlenséghez vezetett, hiszen megvolt az esélye annak, hogy egy fiatalabb ex-consul és patricius előnybe kerül egy idősebb consullal szemben, aki nem rendelkezett kiterjedt cursusszal. Ezekben az esetekben a rangidősség döntötte el a kérdést. Ugyanakkor az is elöállhatott, hogy valaki egynél több alkalommal lett consul. Ez annyira gyakorivá vált a korban, hogy a korábbi gyakorlatot, miszerint a kettős consulság csupán

\footnotetext{
401 JER. C. IOA. 8.

402 COD. THEOD. 6.4.1.
} 
megerősíti az adott személyt a pozíciójában, felváltotta a kettős consul elsőbbségének gyakorlata. ${ }^{403}$

A senatusi belépőt, a hagyományos római cursus honorum kezdetét a quaestor és a praetor hivatala jelentették. Noha ezek súlytalan pozíciónak számítottak, beiktatási ceremóniájuk ünnepélyes kereteket kapott azáltal, hogy az ifjú aspiráns családjának cirkuszi játékokat kellett rendezniük. Noha a fényüzés nem volt szükségszerü, a játékok mégis évről évre egyre nagyobb összegeket emésztettek fel, hiszen az esemény remek alkalmat nyújtott a család társadalmi státuszának kinyilvánítására. Olympiodóros 5. század eleji római látogatása alkalmával megemlékezett arról, hogy egy bizonyos Maximus 4000 mérő aranyat költött fia beiktatási játékaira. Egy másik senator, Symmachus pedig 2000 mérő aranyat költött, ${ }^{404}$ miközben birtokaiból éves szinten csupán 1500 mérő arany folyt be. ${ }^{405}$ Ez az összeg már-már erőn felüli költésnek hathat, azonban figyelembe kell venni, hogy ez befektetés volt az ifjú elkövetkező karrierjébe. A meghívottak többsége prominens tisztségviselőkből és vezető senatorokból állt, ráadásul Róma népe is ezen a formális eseményen keresztül ismerte meg a fiatal senatort. Kétségtelen, hogy ez az első benyomás meghatározó volt a későbbi személyes és üzleti kapcsolatok szempontjából, máskülönben aligha költötték volna rá bevételük számottevő részét.

Róma lakosságának támogatását legegyszerübben az amfiteátrumban rendezett játékokon útján lehetett megnyerni. A senatoroknak ugyanis lehetősége nyílt arra, hogy patrociniumot, azaz védnökséget vállaljon a cirkuszi pártok valamelyikében. ${ }^{406}$ Függetlenül attól, hogy volt-e formális szerződés a felek között, a kötelezettségek mindkét fél számára világosak voltak. ${ }^{407}$ A patronus védte a párt érdekeit, cserébe annak tagjai népszerüsítették támogatójukat különböző eseményeken. Ez meglehetősen hatékony módja volt a senator és családja reprezentációjának, ha figyelembe vesszük, hogy a játékok közben került rá sor, hatalmas nézősereg előtt. Minden bizonnyal különös jelentősége volt egy-egy párt patronálásának, hiszen több senator is fontosnak tartotta, hogy megemlékezzen erről, amikor a cursusát részletezte. ${ }^{408}$

403 JONES 1964, 534. II. Theodosius törvényei alapján a második consulátus csak megerősítette a személy érdemeit, nem pedig tovább fokozta azokat. Ezzel szemben III. Valentinianus Novellae-ja, amit 443-ban bocsátott ki, Petronius Maximus második consulsága alkalmából kinyilvánította, hogy a kettős consul elsőbbséget élvez a többi consul elött.

404 OLYMP. FR. 41.2.

405 MatTHEws 1975, 17-18, Lim 1999, 272, A 372-es törvénykezés említést tesz olyan gyakorlatról is, amikor kettő vagy három szerényebb jövedelmủ senator felosztotta egymás között a játékok kiadásait. COD. THEOD. 6.4.21, JONES 1964, 538, Ez azonban egyáltalán nem aratott tetszést a befolyásos senatorok sorai között.

406 Patrociniumot bármilyen szervezet, vagy csoport számára biztosíthatott egy senator. Anicius Paulinus például a bördíszmüvesek, Valerius Proculus pedig a pékek védnöke volt (CIL 6.1682, CIL 6.1692).

407 CAMERON 1976A, 21.

408 Chastagnol 1960, 461-2. 


\subsubsection{Két "Anicius" példája: Bassus és Probus}

A 4. század második felében aktív Petronius Probus (cos. 371) ${ }^{409}$ és Anicius Auchenius Bassus (PVR 382) (10 $^{410}$ tevékenysége is remekül példázza a korábban említett változásokat. Mindkettőjük figyelemre méltóan hosszú karriert futott be. A senatusi belépöül szolgáló hármas (quaestor, praetor, corrector) valamelyikét már huszadik életévük elött betöltötték. Noha ezek formális és súlytalan pozíciónak számítottak, a római senatus tagjai ezt követően sem szorultak a politika peremterületére, hiszen helytartóként, vagy praefectus praetorióként, aki a birodalom csaknem negyedét ellenőrzése alatt tartotta, valós hatalommal rendelkeztek. A hivatali idő egyik tisztség esetében sem haladta meg az egy évet, mindegyiket meg kellett újítani, amelyek maximális ideje egy évtized körül alakulhatott. Probus és Bassus már a harmincadik életévük elött proconsulok lettek, ${ }^{411}$ Probus Africa provinciáé (358), ami hosszú idő óta az egyik legrangosabb provinciának számított Illyricum mellett, ${ }^{412}$ Bassus pedig a Rómával szomszédos Campania proconsulja (379/382). ${ }^{413}$ Mindkét területnek megvolt a maga előnye. Africa az egyik leggazdagabb provincia volt, ami Róma gabonaellátásának szilárd bázisát jelentette hosszú évtizedek óta. Itt, távol a senatustól és bármilyen váratlan ellenőrzéstől a proconsul szabadon tevékenykedhetett, tökéletes terep volt a gazdagodásra. Előnye ugyanakkor hátrányául is szolgált, hiszen ekkora távolságból az észak-afrikai tartomány proconsulja aligha szólhatott bele aktívan a birodalom életébe. Ez az előny megmaradt Campania proconsuljánál, akit a déli irányba húzódó via Appia gyorsan összekötött Rómával.

Bassus cursus honorumának második jelentősebb szakaszában ez az előny még nyilvánvalóbbá válik, hiszen alig 27 évesen praefectus urbi (382) lett. Egyéb kötelességei mellett a senatus vezetését is ellátta, ebben a pozícióban pedig az uralkodóval való kommunikáció is hozzá tartozott. Feladatköre nemcsak Róma városán belüli adózásra, hanem a jogszolgáltatásra is

409 PLRE1 736-740, "Sex. Claudius Petronius Probus 5".

410 PLRE1 152-154, "Anicius Auchenius Bassus 11".

411 A senatori karrierút ezen szintjén a másik, valamivel szerényebb lehetőségét a correctori pozíció jelentette. A tisztség először Traianus (98-117) uralkodása alatt jelent meg, feladatuk az egyes provinciákban az adminisztratív reformok végrehajtása. A Notitia Dignitatum szerint az 5 . század elején 5 corrector müködött a következő területeken: Apulia és Calabria (Dél-Itália), Lucania (Dél-Itália) és Bruttinum, Savia, Augustamnica (Egyiptom), Paphlagonia (Asia Minor). Probus kortársa Quintus Aurelius Symmachus ebben az időben volt corrector a dél-itáliai Lucaniában, ezt követően proconsuli minőségben szolgált Africában (373). A senatorok számára a másik lehetőséget csak az achaiae-i proconsuli méltóság lett volna, mivel a 3. században az Asia provincia gyakorlatilag megszünt.

412 WICKHAM 2005, 10, 17-22, BARNES 1985, 144-153. Africa és Illyricium különös történelmi jelentőséggel bírt már császárkor kezdetén is. Octavianus ugyanis miután a birodalom proconsuljaként az Imperium 22 provinciája közül tizenkettőt megtartott magának, ezek jobbára a határ menti provinciák voltak, ahol a harcok miatt a hadsereg java állomásozott. A maradék tíz senatori provincia közül csak kettő rendelkezett sereggel, ez pedig éppen Africa és Illyricum volt.

413 CIL 6.1679. 
kiterjedt. Míg Bassus elsősorban Rómában és az udvarban mozgott otthonosan, addig Probus egészen más utat választott karrierje kiteljesítésére. Africa után adta magát az azzal egyenrangú Illyricum, amelynek 364-ben lett praefectus praetoriója, ami az adminisztratív pozíciók csúcsának számított. A tisztség hierarchiában betöltött szerepét talán az hangsúlyozza a legjobban, hogy a császár köszöntését (salutatio) közvetlenül a praefectus praetorio után fogadhatta. Hatalma elsősorban a területi igazgatásban érvényesült, adóbeszedések és igazságszolgáltatás formájában. A tisztséggel könnyűszerrel visszaélhetett az, aki betöltötte, ahogyan arról több későbbi forrás is beszámol. Keleten, Ióannés Lydos szerint a praefectus praetorio pénzt csalt ki a kincstárból azért, hogy saját céljaira használja, ${ }^{414}$ nyugati kollégája pedig duplán szedte be az adót Liguria területén. ${ }^{415}$ Probus ezt a hivatalt viselte 364-ben, és minden bizonnyal olyannyira megkedvelte, hogy a későbbiekben sem akart elszakadni tőle: 366-ban Galliáért, majd hét évig (368-375 között) megszakítás nélkül ismét Illyricumért felelt. Hétéves illyricumi tisztségviselése különösen szembetünő annak tükrében, hogy kortársai átlagosan másfél évig viseltek ezt a pozíciót. Kétségtelen, hogy Probus a császár kegyeltjének számított, amit hosszú méltóságviselésén túl az is bizonyít, hogy 371-ben consultársa lett az alig 12 éves Gratianus császárnak. Probus szerencséjének és illyricumi tevékenységének 375-ben Iphicles, az epirusiak követe vetett véget, aki felfedte Valentinianus elött Probus illyricumi visszaéléseit. ${ }^{416}$ Probus kegyvesztett lett, és bár Valentinianus még az év öszén meghalt, pozícióját csak nyolc év elteltével, 383-ban tudta visszaszerezni, amikor II. Valentinianus (371-382) kinevezte Africa praefectus praetoriójává.

Dacára annak, hogy Probus és Bassus között közel húsz éves korkülönbség volt, hivatali karrierjük egy ponton érdekes egyezést mutat. A 370-es évek elején valamiért mindketten fontosnak érezték hangsúlyozni, hogy egy és ugyanazon időben (uno eodemque tempore) több tisztséget is viseltek. Bassus még csak ekkor kezdte karrierjét, ilyenformán a ranglétra első fokait jelentő quaestor és praetor tisztségeket viselte egy időben. Probus ezzel szemben már a karrier csúcsát jelentő consulságot (371) kapta meg praefectus praetoriói (368-75) hivatalviselése idején. ${ }^{417}$ Minden bizonnyal élénk rivalizálás lehetett a két tisztségviselő között, mert Cameron

4 LYDUS MAG. 3.75.1.

415 ENNOD. VITA EPIPH. 107.

416 AMM. MARC. 30.5.4-11.

417 A Probus részére állított római felirat, CIL 6.1751: “Dedicata |VI Idus Aug(ustas) | dd(ominis) nn(ostris) | Valente VI et | Valentiniano II | Augg(ustorum) cons(ulibus) || Nobilitatis culmini | litterarum et eloquentiae lumini $\mid$ auctoritatis exemplo | provisionum ac dispositionum magistro | humanitatis auctori $\mid$ moderationis patrono | devotionis antistiti | Petronio | Probo v(iro) c(larissimo) proconsuli Africae | praefecto praetorio | per Illyricum Italiam et Africam | consuli ordinario | ob insignia erga se remediorum genera |Veneti adque Histri peculiares eius | patrono praestantissimo" vö. Bassus Apulia és Calabria tartományban megtalált feliratával, CIL 9.1569: "Anici Bassi | Anicio Aucenio v(iro) c(larissimo) | proc(onsuli) Camp(aniae) s(acra) v(ice) [i]ud(icando) | praestantissimo [pa] tro|no e[t] in 
szerint az "uno eodemque tempore" kifejezés csak kettejük feliratában fordul elö. A kutató feltételezése szerint a fiatal Bassus campaniai proconsulsága idején látta Probus egyik tartománybeli feliratát, ami megörökítette senior kortársa illusztris pozícióját ezért a sajátját is ennek mintájára készítette el. ${ }^{418}$

A senatorok rivalizálásának hátterében egy leszármazásukkal kapcsolatos vita állhatott. A 4. században sok család úgy próbálta presztízsét növelni, hogy igyekezett visszavezetni családfáját minél korábbra, lehetőleg a köztársaság időszakára. ${ }^{419}$ Bassusnak ilyenfajta hivalkodásra nem volt szüksége, mert apja Amnius Anicius Paulinus (cos. 334) volt, ${ }^{420}$ akinek nevében több köztársaságkori nemzetség neve, így az Amnius és az Anicius is szerepelt. Éppen az a két név okozta a Bassus (PVR 382) és Probus (cos. 371) közötti versengést, ugyanis annak ellenére, hogy Bassus volt az egyenes ági leszármazott, a nála csaknem húsz évvel idősebb Probus (cos. 371) az Amnius család megújítójának (stirpis novator Amniae) nevezte magát. Bassus erre válaszul az Anicius család helyreállítójának kezdte nevezni magát, ${ }^{421}$ ezzel is utalt arra, hogy apját követően sikerült visszaállítania a család régi fényét. A senatorok közötti rivalizálás kezdete egy Ausoniushoz füződő esemény tükrében pontosan datálható. A költő ugyanis nem sokkal 371 után egy mesekönyvet ajándékozott barátjának, Probusnak, melyben az Amnius család megújítójának és az Aniciusok családfájának díszítőjeként jellemzi, ezzel utalt Anicia Faltonia Probától született fiára. ${ }^{422}$ A kettejük közötti versengés gyökere tehát abban rejlett, hogy mindketten ugyanarra az ősi családra vezették vissza magukat. Egy olyan hierarchikusan szerveződő társadalomban, mint a Nyugatrómai Birodalom, a család és annak története, valamint a származási hely, alapvető eleme volt az arisztokrata identitástudatnak. Probus pedig, aki Ammianus szerint meglehetősen ingatag jellemü ember volt, ${ }^{423}$ minden bizonnyal a legjobb családba akart beházasodni.

\subsection{A családfa rekonstrukciója}

A szakirodalomban általánosan elterjedt nézet, hogy az Aniciusok a Rómával szomszédos

om[n]i[b]us si[ngu]lari | eximium munus et pecu|liare praeter [ce]teros ho|nores insigne regio [E]squi| lina recte factorum | omnium memor(iam) loca|vit".

418 CAMERON 1984, 193-196, CAMERON 2012B, 142.

419 NOVAK 1979, 120-21, SYME 1971, 23.

420 Teljes neve: PLRE1 679, "Amnius Manius Caesonius Nicomachus Anicius Paulinus iunior signo Honorius 14".

${ }^{421}$ ILS 1263, CIL 10.5651, két feliratán is megjelenik a "restitutor generis Aniciorum” kifejezés.

${ }^{422}$ CAMERON 2012B, 136-37, AUSON. EP. 16.2.31.: "stirpis novator Amniae | paribusque comit infulis | Aniciorum stemmata"

${ }^{423}$ AMM. MARC. 27.11. 
Palestrina azaz Praeneste városából származnak, ez az értesülés azonban retrospektív szemléleten alapul. A szakirodalom a köztársaságkor és korai császárkor esetében Novak 1979-es cikkére támaszkodik, ${ }^{424}$ ő Meiggsre, ${ }^{425}$ Meiggs pedig az 1869-es RE Anicius szócikkére, ${ }^{426}$ ami ebben az esetben Anicius Auchenius Bassus (cos. 431) Palestrinában előkerült feliratára alapoz. A kutatás tehát a köztársaságkor és korai császárkor esetében egy 5. századi senator feliratára támaszkodik. Más azonosítások köztársaságkori Aniciusokat Rómába helyezik, ez erősíti a Via Anicia elnevezése, ami napjainkban a Trasteverét szeli ketté. Ezzel az azonosítással az a probléma, hogy az utca az 5. században épült Santa Cecilia in Trastevere templomtól (a forrásokban Titulus Ceciliae néven bukkan fel) tart dél felé a Via di Porta Portese irányába. ${ }^{427}$ Elmondható tehát, hogy a kutatók később élt senatorok alapján próbálják lokalizálni a családot, tévesen, ami nem feltétlenül pontatlan, azonban, véleményem szerint, egy nemzetség pontos lokalizációjához minden esetben a család egyenes leszármazását kell követni.

Az Anicius név már igen korán megjelenik a forrásokban. 44-ben Cicero egy bizonyos $\mathrm{C}$. Anicius érdekében közbenjárt a proconsulnál, mert az üzleti tevékenységet akart folytatni a Africa provinciában. ${ }^{428}$ A kezdeti időszakban, császári provincia lévén, az uralkodó közvetlenül, a senatus jóváhagyása nélkül nevezte ki a provincia elöljáróját. A 3. század végén Diocletianus három kisebb provinciára osztotta Africa proconsularist: Zeugitana Karthágó központtal alkotta az északi részt, ami egyben a proconsul székelyeként is szolgált, tőle délre megalapították Byzacenát, központjában Hadrumetum (ma Sūsa) városával, a harmadik provincia pedig Tripolitania lett, központjaként Leptis Magna szolgált, ami lényegesen délebbre volt Byzacenától.

Noha Cicero igen távoli példát nyújt, és kiváló epigráfiai adottságok ellenére C. Anicius leszármazottai nem rekonstruálhatóak teljes bizonyossággal, tény, hogy a nemzetség egy későbbi tagjának, Anicius Paulinus (cos. 334) kilenc közeli rokonának több mint fele rendelkezett valamilyen pozícióval Észak-Afrikában. ${ }^{429}$ Septimius Severus császár például Numidia provincia legatus Augusti pro praetorenak (197-201) választotta Quintus Anicius Faustust (cos. 198). ${ }^{430}$ Legalább fél évtizedes provinciabeli tartózkodása tükrében nem meglepő, hogy Uzappától nem messze előkerült felesége, Vesia Rustica felirata is, amely megőrizte mindkettőjük nevét. ${ }^{431}$ Uzappa

424 NOVAK 1980, 129-130.

425 MeIGGS 1973, 212.

426 RE 2196-2208, "Anicius".

427 CAPIZZI 1997, 19.

428 CIC. FAM. 12.21.

${ }^{429}$ CHRISTOL 1986, 163.

430 CIL 8.2550.

431 A feliratot Beschaouch publikálta, Beschaouch 1969, 213: "Vesia Rustica $\mid$ Q(uinti) Anici Fausti $\mid$ de suo posuit. | D(ecreto) d(ecurionum)". 
Byzacena provincia egyik központi városa, amely püspöki központként is szolgált. A közelben egy további felirat is előkerült, ami egy másik rokon, bizonyos Sex. Anicius Saturninus és feleségének nevét örzi. ${ }^{432}$ A feleségek feliratai bizonyítják a család aktív jelenlétét Byzacena térségében. ${ }^{433}$ Bassus ükapja, a 3. században élő Sex. Anicius Faustus Paulinianus ${ }^{434}$ pedig nem egyszerüen egy mesterség patronusa volt, ahogyan sok más kortársa, hanem a Byzacenában található Uzappáé, ${ }^{435}$ ami az africai proconsul székhelyeként szolgált egészen a 3. század végéig.

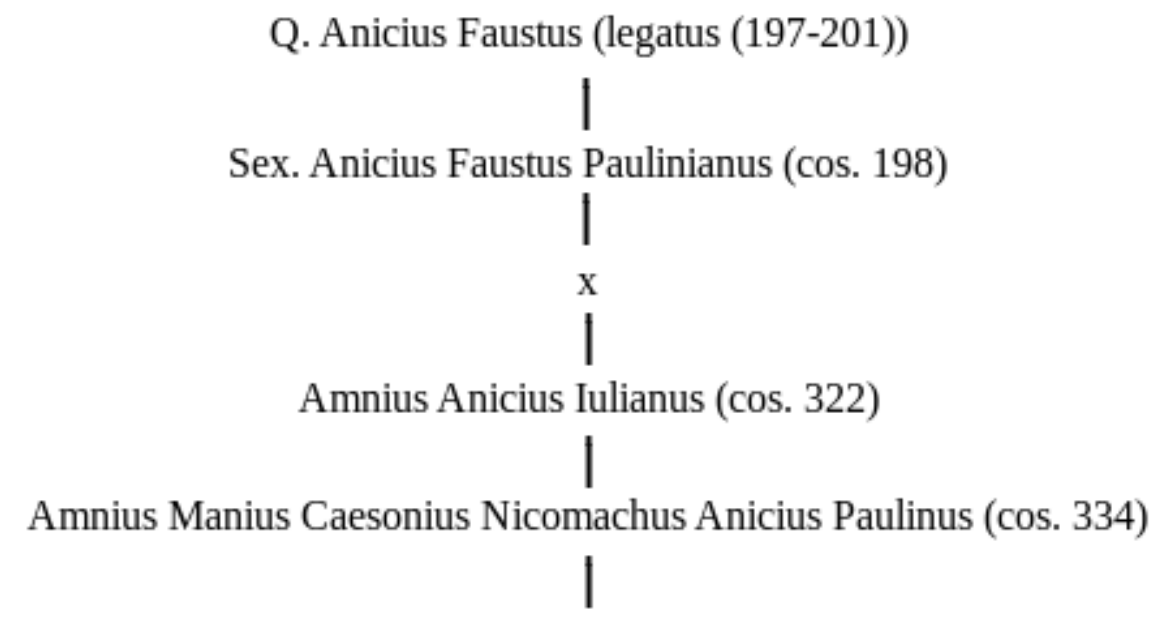

\section{Anicius Auchenius Bassus (PVR 382)}

1. Stemma: Anicius Auchenius Bassus (PVR 382) felmenői ${ }^{436}$

A nemzetség gazdagsága érthető, hiszen a birodalom éléstárát jelentő Észak-Afrika hosszú idő óta az egyik legszerencsésebb provincia volt. Határait nem fenyegették barbár törzsek, és az uralkodói központoktól való távolsága miatt kimaradt a birodalom polgárháborúiból. A birodalom fontosabb politikai eseményei máshol zajlottak, miközben az afrikai provinciák egyre csak gyarapodtak. Védelmére elegendő volt egy legio és egy alig több mint ezer föt számláló sereg a legfontosabb kikötőnél, Karthágónál. Az adószedők számadásainak tükrében Africa gazdasága a 4.

432 AE 1969/70: "Seia Maxima | Sex(ti) Anici Saturnini | de suo posuit |d(ecreto) d(ecurionum)".

433 NovaK 1976A, 21. Ezt csak erősíti, hogy Novak további harminc Aniciust eredeztet az észak-afrikai Cirta városából, amelynek éppen Q. Anicius Faustus volt a patronusa. Faustus patronusságára: CIL 8.19495 (Cirta) illetve CIL 8.6048 (Arsacal).

434 PLRE1, 330. A senatornak a PLRE csak a nevét ismeri.

435 CIL 8.11933: "Sex(to) Anicio Fa|usto Paulini|ano c(larissimo) i(uveni) patro|no patroni f(ilio) | ordo [c]ivita|[t] is Uz[ap]pen|[sis s]tatuam | [f]acere cu|[ra]vit idemq(ue) | [d] edicavit".

436 A stemmában az $\mathrm{X}$ jelzés ismeretlen nemü hiányzó generációt jelöl. 
században különösen virágzott. A század végén Quintus Aurelius Memmius Symmachus, a római senatus egyik vezető személyisége már Anicius Paulinus (cos. 334) apját, Amnius Anicius Iulianust (cos. 322) állította példaként kortársai elé. Symmachus szerint Iulianus testesítette meg a tökéletes arisztokratát, akinek gazdagsága, előkelősége vagy éppen hatalma messze túltett mindenki máson, és akinek gazdagságát éppen korábbi hivatalai alapozták meg. ${ }^{437}$ Ezen hivatalok egyike éppen az africai proconsulság volt, amit öt éven keresztül (315-320) viselt. ${ }^{438}$

Az Aniciusok kiterjedt észak-afrikai birtokállományának egyenes következménye, hogy Ostiában a Tiberis torkolatánál fekvő legfontosabb kereskedelmi kikötőben is rendelkeztek érdekeltségekkel. Szent Ágoston megemlékezik arról, hogy mielőtt 387-ben visszautazott volna anyjával Észak-Afrikába, néhány napot még Ostiában töltöttek baráti körben. ${ }^{439}$ Minden bizonnyal az egyházatya barátai közé tartozott Amnius Anicius Iulianus (cos. 322) unokája, Bassus (PVR 382) és családja is, mert néhány évvel később a házigazda fia emléket állított a szent anyjának. ${ }^{440}$ Ráadásul Bassusnak (PVR 382) és feleségének a felirata is megtalálható a kikötőben. ${ }^{441}$

\subsubsection{Az Aniciusok "két ága"}

\section{Anicius Auchenius Bassus és örökösei}

Az elődök tárgyalása során nyilvánvalóvá vált, hogy a szakirodalomban elterjedt nézettel szemben a család fő területei századokon keresztül Észak-Afrikában, mégpedig elsősorban Byzacena területére koncentrálódtak.

Bassus (PVR 382) Africa korábbi proconsuljának, Anicius Paulinusnak (cos. 334) ${ }^{442}$ későn született fia volt. ${ }^{443}$ A Traianus-forum közelében talált felirat tanúsága szerint meglehetősen

437 SYMM. EP. 1.2.5.

438 Paradoxon, de az 5. század elején nem használta ki ezeket az előnyöket a nyugati kormányzat, sőt. CoD. THEOD. 10.10.31. A Codex Theodosianus szerint egy 422-ben kiadott törvény teljes adómentességet biztosított Africa és Byzacena császári tartományaiban, amelyek egyenként 7700 négyzetkilométert tettek ki. A kormányzat túlzott bőkezüségére talán magyarázat lehet a müveletlen terület nagysága, de törvénytelen gazdasági haszonszerzés is állhat mögötte. Részletesebben lásd WEBER 1989.

439 AUGUST. CONF. 9.12.31 barátokra: 9.11.28

440 ANTH. LAT. 1.670, PLRE1 152-154, "Anicius Auchenius Bassus 11".

${ }^{441}$ CIL 14, 1875.

442 Teljes neve: Amnius Manius Caesonius Nicomachus Anicius Paulinus. Fia, PLRE1 152-154, "Anicius Auchenius Bassus 11".

443 Bassus (PVR 382) viszonylag későn 355 táján születhetett. RE 2196-2208, “Anicius.”, CHASTAGNOL 1956., Seeck és Chastagnol úgy gondolta, hogy azért mert Bassus (PVR 382) majd fél évtizeddel apja consulsága után lett Róma városának praefectusa, a család számára előnytelenül alakult ez az időszak. CAMERon 2012B, 141, Ezzel szemben Cameron úgy gondolja, hogy Anicius Paulinus (cos. 334) a század elején születhetett és viszonylag sokat várt a házassággal, esetleg első házassága sikertelen lehetett, ezért Bassus (PVR 382) csak később a 4. század közepén születhetett. 
ambiciózus férfi volt, cursus honoruma kezdetén quaestor, majd praetor, később Campania proconsulja, így már húszas évei közepén Róma városának praefectusa lehetett. ${ }^{444}$ Turrenia Honoratával ${ }^{445}$ kötött házasságából Anicius Auchenius Bassus (cos. 408) és Anicia Iuliana ${ }^{446}$ született. ${ }^{447}$

Bassus (PVR 382) azonos nevet viselő fia, Anicius Auchenius Bassus a 408. évben töltötte be a consulságot. A PLRE nem említi, ${ }^{448}$ de minden bizonnyal volt egy fia. ${ }^{449}$ Egy azonos nevü senator ugyanis felbukkan egy röpiratban, amelyet század végén kezdődő egyházi szakadás az ún. Laurentius-skizma (498-506) idején készítettek a pápai udvarban. A Gesta de purgatione Xysti III, amint a neve is mutatja III. Sixtus pápa (432-440) idejében játszódik. A történet szerint két senator, a római Bassus és a dél-itáliai Marinianus együttesen támad a pápára. A senatorok könnyen azonosíthatóak, hiszen a szerző közli, hogy Marinianus patricius volt, Bassus pedig volt consul. Ezen információk alapján Anicius Auchenius Bassusról ${ }^{450}$ (cos. 431) és Avitus Marinianusról ${ }^{451}$ (cos. 423) lehet szó. A történetben szereplö Bassus tehát Anicius Auchenius Bassus (PVR 382) és Turrenia Honorata unokája és minden bizonnyal a 408. év consulának fia. Ettől kezdve azonban nincsen genealógiai adat a senatorokra. Valószínüsíthető, hogy mindkét család kihalt férfiágon, hiszen az 5. század második felében nem bukkan fel senator ezen a néven. A gens Anicii így a 42030-as évek környékén nőágon folytatta útját, az egyik lehetséges beházasodó Acilius Glabrio Sibidius lehetett. A senator nevét ugyanis megőrizte egy emlékmü, amit fia, Anicius Acilius Glabrio Faustus (cos. 438) állított apjának. ${ }^{452}$ Látható, hogy a 438. év consulának nevében már ismét feltűnik a nemzetségnév, így a 6. századi Rómában megjelenő Aniciusok minden bizonnyal ettől az ágtól származnak.

${ }^{444}$ CIL 6.1679.

445 PLRE1 437, "Tvrrenia Honorata 3".

446 PLRE2 468, "Anicia Iuliana 2".

447 PLRE1 152-54, "Anicius Auchenius Bassus 11".

448 PLRE2 219-220, "Anicius Auchenius Bassus 7".

449 PLRE2 220-21, "Anicius Auchenius Bassus 8.".

450 PLRE2 220-221 "Anicius Auchenius Bassus 8".

451 PLRE2 723-724, "Fl. Avitus Marinianus 3".

${ }^{452}$ CIL 6.1678. "Spedii. | Acilio Glabrioni Sibidio, v(iro) c(larissimo) et omnibus $\mid$ meritis inlustri, legato in provincia Achaia, | consulari Campaniae, vicario per Gallias | septem provinciarum, sacri adiutori cogni|tori, fori huiusce inventori et conditori pri|mo, patri reverentissimo Anicius Acilius | Glabrio Faustus, v(ir) c(larissimus), loci ornator, togatam |statuam offerens piae non minus quam de|votae mentis religione, ponendam | erigendamque curavit". 
Anicius Auchenius Bassus (PVR 382)

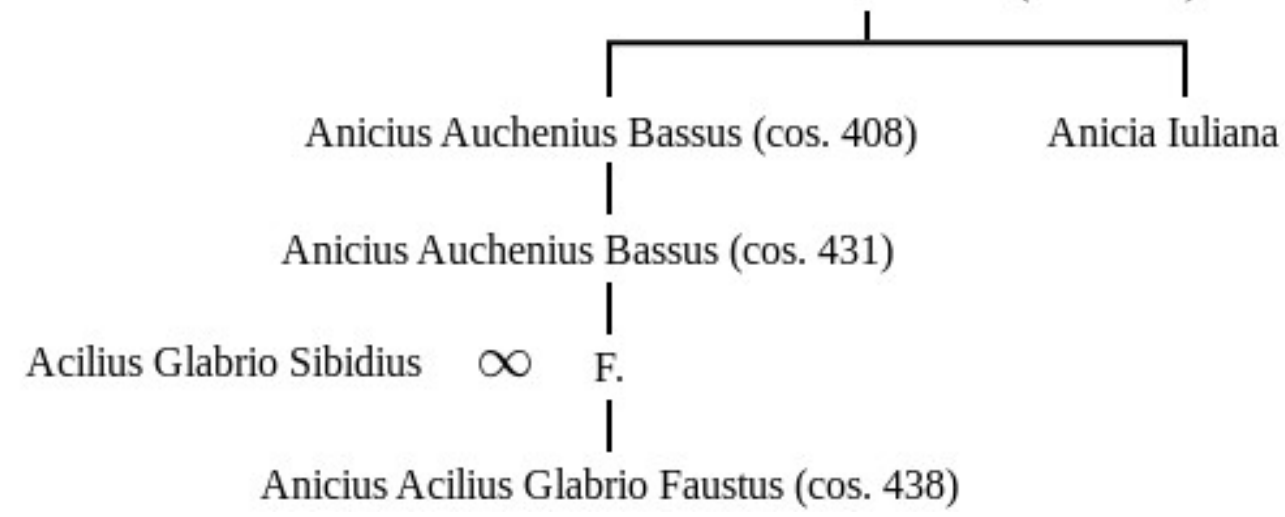

2. Stemma: Anicius Auchenius Bassus (PVR 382) leszármazottai

\section{Sextus Claudius Petronius Probus (cos. 371) és örökösei}

“Előkelő származásánál, tekintélyénél és óriási vagyonánál fogva az egész római világban ismerték, hiszen a birodalomnak csaknem minden részében voltak birtokai. Jogosan szerezte-e azokat vagy sem, annak megitélése nem rám tartozik"453

A veronai születésű Sextus Claudius Petronius Probus (cos. 371) $)^{454}$ kétségtelenül a 4. századi római politikai elit legfigyelemreméltóbb tagja. Cursus honoruma kezdetén quaestor, majd Róma praefectusa, 358-ban Africa proconsulja, ezt követöen pedig négy alkalommal praefectus praetorio (per Illyricum 364-ben, per Galliarum 366-ben, per Italiae, Illyrici et Africae 368-375, majd ezt követően még egy alkalommal 383-384), 371-ben pedig consul Gratianusszal közösen. 375-ben I. Valentinianus idején korrupció vádjával perbe fogták. II. Valentinianus idején továbbra is vezető tisztségviselő volt, sőt követte a császárt Thessalonikébe, amikor az Nagy Theodosiusnál keresett menedéket. A személye körüli sok legenda közül a Vita Ambrosii arról számol be, hogy egy perzsa követség tagjai, miután tiszteletüket tették Theodosiusnál, rögtön Probushoz siettek, mert a saját szemükkel akarták látni a kor egyik legsikeresebb emberét. ${ }^{455}$

Annak ellenére, hogy a kutatás napjainkig Aniciusnak tartja, valójában Probusnak házasságáig semmi köze nem volt az Anicius-nemzetséghez. ${ }^{456}$ Ezt mutatja, hogy a senator saját feliratában soha nem nevezi magát Aniciusnak, a nemzetség neve először utódai felirataiban jelenik meg, amelyek Probust az Anicius-ház kiemelkedő személyiségének (culmen) nevezik. Ez azonban

\footnotetext{
453 AMM. MARC. 27.11.

454 PLRE1 736-740, "Sex. Claudius Petronius Probus 5".

455 PaUl. MEDiolanensis, V. AMBrosit. 25.

456 Chastagnol 1956, 124. vö. CAMERON 2012B, 137.
} 
elsősorban azt mutatja, hogy Probus gyermekei Aniciusként tekintettek magukra. de nem apjuk, hanem anyjuk után. ${ }^{457}$ Probus Aniciusként történő azonosítása Chastagnol nyomán terjedt el a szakirodalomban, aki szerint a senator apja, Petronius Probinus (cos. 341) egy azonosítatlan Anicius családból származó nőt vett feleségül, ennek azonban ellentmond Ausonius mesekönyve, amit költő ajándékképpen küldött Probusnak, amikor fia született Anicia Faltonia Probától. Ebben a senatort az Amnius család megújítójának (stirpis novator Amniae) nevezi, ${ }^{458}$ minden bizonnyal azért, mert az egyetlen élő Amnius leszármazott lehetett. Mindazonáltal Ausonius alapján bizonyos, hogy Probus eredetileg az Amnius nemzetség tagja volt, és csupán házassága révén kerül kapcsolatba az Aniciusokkal. A senator Anicia Faltonia Probát ${ }^{459}$ vette feleségül, akitől három fia és egy lánya (Anicia Proba) ${ }^{460}$ született. Probus 390 körül bekövetkező halálakor az Anicius család ezen ága számított Róma legbefolyásosabb családjának, de halálát követően gyors hanyatlás figyelhető meg a család életében.

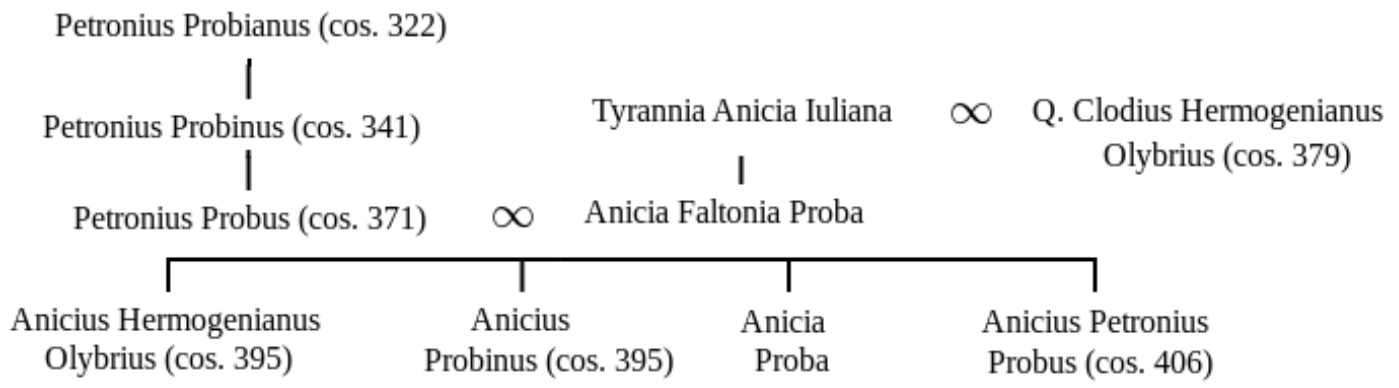

3. Stemma: Sextus Claudius Petronius Probus (cos. 371) családja

Idősebb fiai, Anicius Probinus ${ }^{461}$ és Anicius Hermogenianus Olybrius ${ }^{462}$ 395-ben együtt viselték a consulságot. Ebből az alkalomból Claudius Claudianus egy panegyricust szentelt nekik. A legfiatalabb, Anicius Petronius Probus ${ }^{463}$ pedig 406-ban töltötte be ugyanezt a pozíciót. A

$\overline{457}$ Fia, Anicius Hermogenianus Olybrius (cos. 395) és felesége Anicia Iuliana állította 395 tájékán. CIL 6.1753: Sexto Petronio Probo, | Anicianae domus $\mid$ culmini, proconsuli $\mid$ Africae, praefecto $\mid$ praetorio quater | Italiae, Illyrici, Afri|cae, Galliarum, con|suli ordinario, con|sulum patri. Anicius Hermogenianus | Olybrius, v(ir) c(larissimus), consul | ordinarius, et Ani|cia Iuliana, c(larissima) f(emina) eius, | devotissimi filii, | dedicarunt. A senatori önreprezentáció módozataira lásd NIQUET 2000.

458 CAMERON 2012, 137.

459 lásd. PLRE1 732-733, "Anicia Faltonia Proba 3".

460 lásd. PLRE1 731-732, "Anicia Proba 1".

461 lásd. PLRE1 734-735, "Anicius Probinus".

462 lásd. PLRE1 639-640, "Anicius Hermogenianus Olybrius 2".

463 lásd. PLRE2 913-914, "Fl. Anicius Petronius Probus 11". 
rendelkezésre álló kútfők szerint Probus fiai azonban nem örökölték apjuk habitusát, ugyanis 410 körül egész egyszerủen eltünnek a történetírók szeme elöl. A három fiú közül csak Olybriusról (cos. 395) és az ő családjáról lelhető fel érdemi információ, ami egyben a hiátus okát is magyarázhatja.

\section{Anicius Hermogenianus Olybrius (cos. 395)}

Probus idősebbik fia, Olybrius (cos. 395) ${ }^{464}$ még apja életében feleségül vette Anicia Iulianát. ${ }^{465} \mathrm{~A}$ PLRE szerint csak egy gyermeke volt Demetrias ${ }^{466}$ személyében, ez az információ azonban téves, a senatornak ugyanis volt még egy gyermeke. Szent Ágoston 414-ben Anicia Iulianának ajánlott De bono viduitatis c. munkájából ugyanis kiderül, hogy az asszonynak lánya mellett még legalább egy fia volt. ${ }^{467}$ A gyermek neve azonban nem derül ki a forrásból, születési idejére is csak következtethetünk.

414-ben Jeromos Demetriasnak küldött leveléből kiderül, hogy a lány éppen házassága előestéjén tett szüzességi fogadalmat, így cserbenhagyva hitvesét. Ha a római jognak megfelelően 12 éves korban került sor a házasságkötésre, ${ }^{468}$ akkor Demetrias minden bizonnyal 401-ben vagy 402-ben született. Jeromos ugyanakkor azt is közli, hogy Demetrias apja szerencsére már nem élhette meg Róma pusztulását, tehát 410 előtt halhatott meg. Ennek alapján valószínüsíthető, hogy Demetrias öccse 402 és 410 között születhetett. Jeromos Demetriasnak küldött leveléből további értékes információk derülnek ki a családdal kapcsolatban. ${ }^{469}$

A levélben Jeromos a szüzességi fogadalom előnyeiről, Róma helyzetéről, de ami a legfontosabb, a fiatal lány családi kapcsolatairól is sokat elárul. Az egyházatya a lány három felmenőjét említi. Probust, Olybriust és az Anicius-nemzetséget. ${ }^{470}$ A levél keletkezési évében Demetrias apja már halott volt, így Jeromos - noha később kitér a lány apjára is - egy generációval korábbról kezdi a felmenők ismertetését. Előbb nagyapját, Petronius Probust (cos. 371), majd dédapját, Q. Clodius Hermogenianus Olybriust (cos. 379) említi. Az anya nemzetsége, az Anicius az utolsó helyen szerepel. Ez támasztja alá Olybrius (cos. 395) anyja tiszteletére készíttetett felirata,

464 lásd. PLRE1 639-640, “Anicius Hermogenianus Olybrius 2".

465 lásd. PLRE1 468, "Anicia Iuliana 2".

466 lásd. PLRE2 351, "Demetrias".

467 Cameron 2012B, 148, August. De Civ. D. 8.11. "Augustinus Episcopus [...] religiosae famulae dei Iulianae in Domino Dominorum Salutem [...] Tu autem, quae et filios habes et eo saeculi fine vivis...".

468 HARPER 2012, 685.

469 JER. EP. 130.

470 JER. EP. 130.3. "Rhetorum disciplina est, ab avis et atavis, et omni retro nobilitate, ornare quem laudes, ut ramorum sterilitatem, radix foecunda compenset, et quod in fructu non teneas, mireris in trunco. Scilicet nunc mihi Proborum et Olybriorum clara repetenda sunt nomina: et illustre Anicii sanguinis genus, in quo aut nullus, aut rarus est, qui non meruerit Consulatum." 
melyet feleségével, Anicia Iulianával közösen állítottak. ${ }^{471}$ A szüz nagyapjának és dédapjának említését követően emlékezik meg az apjáról. Jeromos Olybrius (cos. 395) méltatásakor ismét fontos információt közöl a családdal kapcsolatban. Megemlíti ugyanis, hogy Olybrius (cos. 395) boldogan halhatott meg, hiszen egyrészt nem látta Róma pusztulását, de lánya azonos nevű nagyanyja után kapta a nevét. ${ }^{472}$ A rekonstruált családfa (4. stemma) szemléletesebben mutatja az előbbieket.

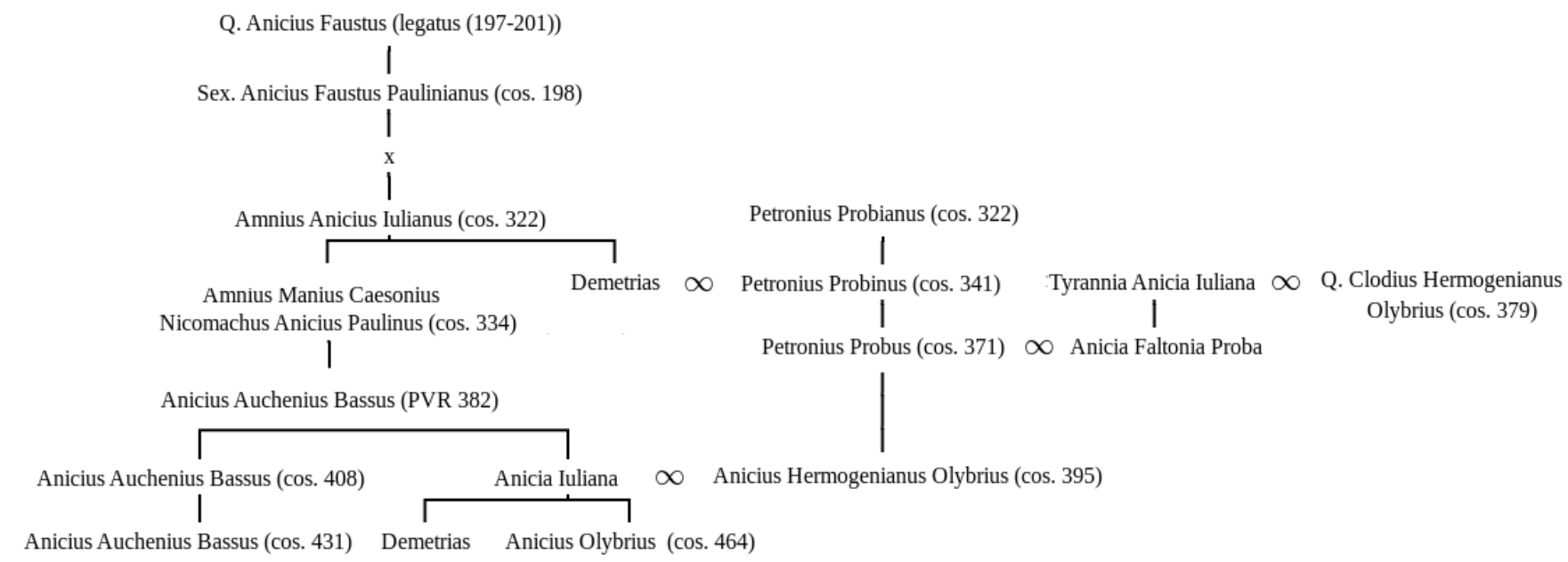

4. Stemma: A két család egyesülése

Látható, hogy Demetrias dédanyját (proavia) a megfelelö helyre illesztve érdekes minta rajzolódik ki. Olybrius (cos. 395) minden bizonnyal apai nagyanyja után nevezte el lányát és minden bizonnyal fia esetében is hasonló módszerrel élhetett. Míg a lány az anyai nagyanyja nevét kapta, addig a De bono viduitatisban szereplő ismeretlen nevü fiú az anyai nagyapa után kapta a nevét,

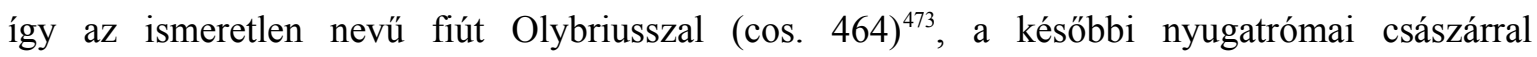
azonosítom. Ezt a megfeleltetést több dolog is alátámaszthatja. Egyrészt, amint láttuk Olybrius (cos. 464) születését 402 és 410 közé helyeztem. A senator idős korban, 472-ben került a nyugati

471 CIL 6.1755. "Aniciae Faltoniae | Probae, fidei nobilita|tis antiquae, orna|mento Anicianae | familiae, servandae ac | docendae castitatis | exemplo, consulum | proli, consulum ma|tri. Anicius Hermoge| nianus Olybrius, v(ir) c(larissimus), | consul ordinarius, | et Anicia Iuliana, c(larissima) f(emina), | eius, devotissimi filii, | dedica(ve)runt."

472 JER. EP. 130.3. "Olybrius virginis nostrae pater [...] Felix morte sua, qui non vidit patriam corruentem; imo felicior sobole, qui Demetriadis proaviae nobilitatem, insigniorem reddidit, Demetriadis filiae perpetua castitate."

473 vö. PLRE2 796-800, “Anicius Olybrius 6". 
birodalom élére, tehát közel 70 évesen és néhány hónappal később mégis természetes halállal halt. ${ }^{474}$ Másrészt pedig lányát, saját anyjához hasonlóan, Anicia Iulianának ${ }^{475}$ nevezte el.

Korábban említettem a mesekönyvet, amit Ausonius küldött ajándékképpen Probusnak (cos. 371) és Probának fiuk, Olybrius (cos. 395) születése alkalmából, illetve a kísérőlevélröl, amelyben a szerző Probust az Amnius család megújítójának nevezi. ${ }^{476}$ Mindjárt a levél első sorból kiderül, hogy a költő Sirmiumba küldte ajándékát, ${ }^{477}$ a levél ennélfogva jól datálható, hiszen a senator 370-es évek elején szolgált a területen mint praefectus praetorio. ${ }^{478}$ Ausonius szóhasználata korántsem véletlen, hiszen cursus honorumának figyelembevételével Bassus (PVR 382) ekkortájt még csak 15 éves lehetett, így a senatusi belépöül szolgáló hármas (quaestor, praetor, corrector) egyikét sem töltötte be. Ez az összefüggés rávilágít a fejezet alapvetésére és magyarázza Bassus (PVR 382) és Probus (cos. 371) egymást utánzó feliratát. Demetrias anyai nagyapja tehát az afrikai Aniciusok leszármazottja, Probus "uno eodemque tempore" "versenytársa", Anicius Auchenius Bassus (PVR 382) volt. A két család végül, minden bizonnyal a hatalom és a gazdasági pozíció megtartása érdekében, Demetrias szüleinek házasságán keresztül egyesült.

\subsection{A domus Pinciana}

A család gazdagságát Jeromos is említi később, aki szerint Demetrias hatalmas gazdagságban, szolgáktól és eunuchoktól nyüzsgő hatalmas háztartásban nőtt fel özvegy anyjával és nagyanyjával. ${ }^{479} \mathrm{Az}$ épület nagysága még a legnagyobb ünnepek alkalmával is könnyűszerrel látta el a vendégeket. Az észak-afrikai szerzetes Demetrias életét az Ószövetség Eszterének palotai életéhez hasonlítja. ${ }^{480}$

Jeromos és Ammianus Marcellinus szerint roppant gazdagságban élt a család, ${ }^{481}$ így háza minden bizonnyal Róma ékessége lehetett. Egy feliraton, melyet a senator fiai állítottak anyjuk tiszteletére, Anicia Faltonia Probát az Amniusok, Pinciusok és Aniciusok díszeként említik. ${ }^{482}$ Ausonius levele kapcsán már rávilágítottunk, hogy Probus az Amniusok megújítója, Proba pedig az

474 Marc. com. 472.

475 PLRE2, 635-636, "Iuliana 3".

476 AUSON. EP. 12.31-34. "qui vincit aevi iniuriam stirpis novator Amniae partibusque comit infulis Aniciorum stemmata."

477 Auson. EP. 12.1. "Perge, o libelle, Sirmium"

478 AMM. MARC. 29.6.9-11. Ammianus egy szarmata és kvád betörés kapcsán említi.

479 JER. EP. 130.4. "inter gemmas et sericum: inter eunuchorum et puellarum catervas, et adulationem ac ministeria familiae perstrepentis, et exquisitas epulas, quas amplae domus praebebat abundantia, appetisse eam jejuniorum laborem, asperitatem vestium, victus continentiam."

480 JER. EP. 130.4. vö. Eszt. 4.17.

481 JER. EP. 130.4, AMM. MARC. 27.11. 
Anicius-nemzetség tagja. De melyik ágról jön a Pincius?

Jeromos Demetriasnak írt levele kapcsán már láthattuk, hogy az egyházatya ugyancsak három nemzetséget említett egymás után. Elsőként Demetrias apai nagyapját, Probust, majd az ö feleségének apját, Olybriust (cos. 379) említette, a sort pedig anyja, Anicia Iuliana nemzetsége zárta. Ugyanakkor azt is láthattuk, hogy Jeromos, Olybrius (cos. 395) korai halála miatt egy generációval fentebbről kezdte az apai oldalról. ${ }^{483}$ Minden bizonnyal a szokás diktálta ezt, hiszen ha nem így lenne, akkor Probustól (cos. 371) kellene kezdenünk a számítást, így azonban a soron következö Olybrius (cos. 379) apja lenne, aki viszont korántsem a gens Pincia tagja. ${ }^{484}$ Figyelembe kell vennünk az elbeszélök szemszögét. Mind Jeromos, mind Anicia Faltonia Proba gyermekei, függetlenül attól, hogy külső vagy belső szemlélöként tekintettek-e a családra, mindketten az apa nemzetsége irányából méltatták. Egy patriarchális társadalomban értelemszerúen az apa nemzetsége áll elöl, és éppen ez történik a gyermekek feliratában is. Az anyjuk tiszteletére készítették a feliratot, de ő, az Anicius, csak mint dísz lehet jelen az apa nemzetségei (Amnius, Pincius) mellett.

Probus (cos. 371) esetében már láttuk, hogy Ausonius az Amniusok megújítójának nevezte öt, ami csak akkor lehetséges, ha szülei közül valamelyik az Amnius nemzetséghez tartozott. Probus (cos. 371) apja, Petronius Probinus (cos. 341), ahogyan neve is mutatja, nem volt Amnius. Házassága révén viszont azzá vált, ahogyan korábban Probus (cos. 371) esetében is láthattuk, hogy gyermekei már az Anicius család fejeként tekintettek rá, noha azt házassága révén, Anicia Faltonia Proba útján érte el. Petronius Probinus (cos. 341) tehát a gyermekek szemében már Amniusként volt jelen, a Pincius pedig - Jeromos analógiája mentén - Probinus apósának nemzetsége volt. Ennek alapján talán nem véletlen, hogy Symmachus hasonlóan festi le Amnius Anicius Iulianust (cos. 322), mint ahogyan Ammianus Marcellinus Probust (cos. 371). Mindkét esetben a tökéletes arisztokrata képe rajzolódik ki, akinek gazdagsága, előkelősége vagy éppen hatalma messze túltett mindenki máson. ${ }^{485}$ Mindazonáltal nem állapítható meg pontosan, hogy a Pincius nemzetség, pontosan mikor és milyen úton kerülhetett be az Amnius-Anicius családba, a fentiek alapján

482 A feliratot Anicius Probinus és Anicius Probus állították Anicia Faltonia Probának. CIL 6.1754: "Consimiles fratrum trabeis gestamina honorum | tertia quae derant addidimus titulis, | dilectae Probus haec persolvo munera matri, | restituens statuis praemia quae dederat. || Aniciae Faltoniae | Probae, Amnios, Pincios | Aniciosque decoranti, | consulis uxori, | consulis filiae, | consulum matri. | Anicius Probinus, v(ir) c(larissimus), | consul ordinarius, | et Anicius Probus, v(ir) c(larissimus), | quaestor candidatus, $\mid$ filii devincti $\mid$ maternis meritis $\mid$ dedicarunt.

483 JER. EP. 130.3. Talán tapintatosságból, talán szokás miatt, mindenesetre Jeromost elsősorban az özvegy iránt érzett empátiáját emeli ki."Vereor plura dicere, ne sanctae matris vulnus exasperem"

484 Olybriust (cos. 379) apja Clodius Celsinus Adelphius (PVR 351) volt.

485 SymM. Ep. 1.2.5. vö. AMm. MARC. 27.11; PAUl. Mediolanensis, V. AMBrosiI. 25. 
azonban bizton kijelenthető, hogy Petronius Probinus (cos. 341) irányából érkezett, és így Probus (cos. 371) örökségének részét képezte.

Az Amnius-Pincius-Aniciusok befolyását talán az szemlélteti a legjobban, ha lokalizáljuk a domus Pincianát. A gens Pinciusról elnevezett "hegy", a Mons Pincius az óváros északkeleti szegletében, az aurelianusi falakon belül található, amelyet a császár a 270-es évek elején épített. Számos római család rendelkezett kerttel és villával a hegyen. Többek között Lucullus és Sallustius, akiknek a nevét ma is kertek viselik. Itt található a 2. században készült Horti Aciliorum, ami a Porta Pinciana és a Spanyol lépcső között kapott helyet, ${ }^{486}$ éppen ott, ahol a Probus fiai által készíttetett felirat is előkerült. Probus márványpalotája, ahova a perzsa követek siettek, a Pincius hegyen, a sallustiusi és pompeiusi kertek között állt, egészen pontosan a mai Villa Borghese helyén, ami napjaink Rómájának is talán a legimpozánsabb helyszíne.

\subsubsection{A ház rekvirálása}

A domus Pincianáról a Liber pontificalis és Prokopios is megemlékezik. Mindkét forrás szerint 537. március 11-én ide vette be magát Belisarius, és amíg a városban tartózkodott, a domus Pincianában fogadta a különbözö követségeket. Prokopios közbevetőleg azt is elárulja, hogy a házról elnevezett kapu jobb oldalán van egy másik kapu, amit Salariának neveznek, ${ }^{487}$ amelyen keresztül Alarich gótjainak sikerült behatolniuk a városba. ${ }^{488}$ De hogyan került egy ilyen impozáns épület a hadvezér kezébe?

Jeromos leveléből kiderül, hogy Róma 410-es "feldúlása" utána, Proba megvált az épülettől. ${ }^{489}$ Az eladásra azonban nem önszántából került sor, hanem ahogyan Jeromos fogalmaz, “a kapzsiság bocsátott áruba hatalmas birtokokat s szerez magának olyan támogatókat a gonosz Mammon révén, hogy azok beköltöznek az örök hajlékba." ${ }^{\$ 90}$ Ezzel az egyházatya Lukács evangéliumának hamis intézőjére utal, ${ }^{491}$ akit a történet szerint azzal vádoltak, hogy eltékozolja ura vagyonát. Rafinált ember lévén töprengett, hogyan kerülhetne ki szorongatott helyzetéből, mitévő legyen, hiszen félt, hogy elveszi munkáját és mivel koldulni nem akart, azt a megoldást eszelte ki,

486 A Horti Aciliorumot északról, nyugatról és keletről opus reticulatum technikával épített fal határolja, vagyis a domb lejtőin épített falak. Az északi és keleti falakat később beépítették az aurelianusi falakba. Az északi rész a híres Ferde fal, a Muro Torto, ami széles félkör alakban húzódik és a nyugati oldalán egy lépcsősor nyílik, ami jelenleg a spanyol lépcső északi oldalához vezet.

487 LiB. Pont. 60.6, 8., Procop. De Bellis. 5.19.14.

488 Procop. De BeLlis. 3.2.27-28.

489 JER. EP. 130.7.

490 JER. EP. 130.7.

491 vö. LK. 16:1-9. 
hogy ura minden adósát magához hívatta és mindegyiktől megtudakolta, hogy mekkora adóssággal tartozik urának. Az intéző minden adós tartozásából lefaragott, így megnyerve ura adósait. A történet tanúsága, hogy "szerezzetek magatoknak barátokat hamis mammonnal, hogy amikor elfogy, befogadjanak titeket az örök hajlékba" "492 A hamis intézö leleményessége tehát abban állt, hogy az urától ellopott, következésképpen "hamis" javakkal barátokat szerzett magának. A mammon itt a jogtalanul felhalmozott vagyon szinonimájaként van jelen, ami nem örök érték, így bölcsebb halál előtt visszaosztani a szegényeknek, vagy az egyháznak, amely nyilvánvalóan nem hamis barát. ${ }^{493}$

A 410-es évek elejére az özvegy Proba kiszolgáltatott helyzetbe került, idősebbik fiának, Olybriusnak (cos. 395) korai halála pedig feltehetően megtörte az asszonyt. A helyzetet csak súlyosbította, hogy a vizigót fosztogatást követően a tehetősek, vagy akár már a kevésbé tehetősek is kihasználták az Alarich utáni bizonytalan helyzetet, és nyomott áron felvásárolták a római ingatlanokat, így Probus és Proba villáját is. ${ }^{494} \mathrm{~A}$ ház eladását kapzsiság és a gonosz vagyon együttese okozta. Probus halála után Proba szüzességi fogadalmat tett, ahogyan lánya is, Olybrius (cos. 395) halála után. Demetrias pedig még azelött elkötelezte magát Istennek, hogy férjhez ment volna. Hasonló helyzetet mesél el Jeromos barátja, Marcella esetében. Miután az asszony elveszítette apját, majd hét hónappal később férjét is, szüzességi fogadalmat tett, vagyonát pedig a szegények között akarta szétosztani. Terve azonban megbicsaklott anyja ellenállásán, aki "fiai és unokái nem lévén, mindent fivére gyerekeire akart átruházni. ${ }^{2495}$ Probának azonban már nem élt sem az anya, sem az apja, lányai pedig - hozzá hasonlóan - önmegtartóztatást fogadtak.

A gonosz vagyon nyomott árat, de akár rekvirálást is jelenthet, amely révén a római állam tette rá a kezét a domus Pinciára. Egyrészt erre utal, hogy az épület stratégiai helyen, a Salaria kapu szomszédságában volt. Néhány évtizeddel 410 után, III. Valentinianus idejében már egy vízvezetékkel kötötték össze a Porta Salariát és a Domus Pincianát. ${ }^{496}$ Másrészt ezt bizonyítja az osztrogótok uralkodása alatt keletkezett két levél is. Az elsőböl megtudjuk, hogy Theoderich utasítást adott arra, hogy Ravennában új épületeket emeljenek. ${ }^{497}$ Ez ezt követő levélből pedig az is kiderül, hogy az ehhez szükséges márványtömböket Rómából, a domus Pincianából fogják

492 LK. 16:9.

493 SPINETOLI 1986, 16. fejezet.

494 JER. EP. 130.7. "Ecclesiastici ministerii gradus, et cassa nomina monachorum emere praedia, tanta nobilitate vendente."

495 JER. EP. 127.4. Marcella anyjának, Albinának a fivére Rufius Caeionius Caecina Sabinus Volusianus Lampadius (PPO 355, PVR 365) fia pedig, Marcella első unokatestvére, Publius Caeionius Caecina Albinus. Albina rájuk akarta hagyni a vagyont.

496 CIL 15.7259, Procop. De Bellis. 6.9.2, NTDAR 18, “Aqua Pinciana.”.

497 CASSIOD. VAR. 3.9. 
elszállítani, az uralkodó ugyanis a római senatus vezetőjét is tájékoztatja döntéséről. ${ }^{498}$ Ez utóbbi arra mutat, hogy az épület állami kezelésbe került. De ezt támasztja alá az is, hogy Belisarius itt rendezte be székhelyét. ${ }^{499}$ Jeromos szemében a domus Pinciana hamis intézője az állam lett, amely később Belisarius képében ölt emberi alakot. Minden bizonnyal ez a történet táplálta a 12 . században Ióannés Tzetzés Belisariusról szőtt legendáját, ami alapján ötszáz évvel később François-André Vincent megfestette városfalnál kolduló Belisarius képét. ${ }^{500}$

414-ben, miután Demetrias az esküvője előtt úgy határozott, hogy anyja és nagyanyja példáját követve, szüzességi fogadalmat tesz, nagyanyja, Anicia Faltonia Proba eladta római birtokait, és lányával és unokájával, valamint az ekkor nagyjából 10 év körüli Olybriusszal a byzacenai családi birtokokra ment, hogy a világtól elvonulva élje le hátralévő életét. ${ }^{501}$ Az Anicius család tehát az 5. század elején két részre szakadt: Anicius Auchenius Bassus (PVR 382) azonos nevet viselő fia és unokája továbbra is Rómában maradt, lánya, Anicia Iuliana azonban, férje halála utána gyermekeivel, anyósával Észak-Afrikába költözött. A család római birtokai az állam tulajdonába kerültek. A Salaria kapu szomszédságában található domus Pinciana stratégiai pozíciója elvitathatatlan, azonban a Jeromosnál szereplő gonosz Mammon erőszakos felvásárlást sejtet. Talán Honorius császár is emlékezett rá, hogy nagyapja, az idősebbik Theodosius halálát is éppen Probus (cos. 371) okozta, így idővel a senator családjának sem lehetett maradása Rómában.

498 CASSIOD. VAR. 3.10.2. "marmora, quae de domo Pinciana constat esse deposita, ad Ravennatem urbem per catabolenses vestra ordinatione dirigantur."

499 Procop. De BELlis. 5.19.14.

500 TzETZES CHIL. III. HIST. 88-91.339-348. (Kiessling 94. old.). vö. GLOR. MART. 102. Az egykori Anicius birtok, a Salaria kapu tövében kolduló Belisarius képe erős analógiát mutat az Anicia Iulianához érkező és adományért könyörgő Iustinianus képével, amit Tours-i Szent Gergely fest le. A kérdéses történethez az utolsó fejezetben fogok visszatérni.

501 JER. EP. 130.7. "Quae de mediomari fumantem viderat patriam, et fragili cymbae, salutem suam suorumque commiserat, crudeliora invenit Africae littora." A rómaiak Észak-Afrikába vándorlásához lásd még V. MEL. GR. 19, 20. 


\section{455: A THEODOSIUS-DINASZTIA FOLYTATÁSA}

Az Anicius család tárgyalása során láthattuk, hogy a Salaria kapu szomszédságába tartozó hatalmas senatori villa az 5. század elején az ő tulajdonukban volt, azonban nem sokkal később már az állam vagyonát gyarapította, hiszen a család elhagyta Rómát és Észak-Afrikába költözött. Az özvegy Proba, menye és gyermekei, köztük az ekkor alig tíz éves Anicius Olybriusszal az egykori családi birtokokra költözött. A fejezetben ennek a költözésnek a jelentősége fog kidomborodni, ezért elsősorban a birodalom és a vandál Geiserich közötti kapcsolatot fogom vizsgálni.

A fejezet első részében a szakirodalomban csak "királycsinálóként" emlegetett ${ }^{502}$ Aspar befolyásának kibontakozását és tevékenységét igyekszem megvilágítani. Úgy gondolom ugyanis, hogy a magister militum már az 430-as évek elejétől egészen halála napjáig jelentős hatással volt a birodalmi politikára, amelyet jobbára Geiserich vandál uralkodóval szövetkezve érhetett el. A magister militum hatáskörének áttekintésekor már láthattuk, hogy a tisztség birtokosa milyen befolyással rendelkezik azokon a területeken, amelyeket a háborús konfliktusok érintenek. Aspar és Geiserich formálódó kapcsolata éppen ezért már a korai időszakban kitapintható több történetíró munkájában is, de látni fogjuk, hogy ez érhető tetten a 442-es vandálokkal kötött megállapodásban is.

Ezen kívül Geiserich és a keletrómai katonai föparancsok, Aspar kapcsolatának vizsgálata sem érdektelen. Az is fontos körülmény, hogy hónapokkal III. Valentinianus 455-ben bekövetkezett halála után néhány hónappal Geiserich megjelent Ostia kikötőjében és Észak-Afrikába vitte a császár özvegyét, Licinia Eudoxiát és lányait: Eudociát és Placidiát. A Theodosius-dinasztia utolsó leszármazottai és Róma talán leggazdagabb családja ezzel egy régióba kerültek, miközben Geiserich III. Valentinianus hozzátartozóinak személyében értékes túszokat szerzett, ráadásul fia házasságot kötött Eudociával. Aspar és Geiserich hallgatólagos szövetsége jelentős károkat okozott az elkövetkező uralkodók, így I. Leo legitimációjában, annál is inkább, mert évekbe telt, amíg a konstantinápolyi kormányzatnak sikerült kiszabadítania az özvegyet és az egyik lányt, Placidiát. A fejezet záró részében azt mutatom meg, hogy a keletrómai források tendenciózusan igazolni igyekeznek Placidia 455 előtti házasságát, miközben a lány ekkor még csak alig tizenkét éves volt. A keletrómai auktorok célja ezzel az volt, hogy a lány szabadulását Leo uralkodásának kezdete elé helyezzék. A dinasztikus ősökkel nem rendelkező császár számára ugyanis az egyetlen legitimáció lehetőséget az jelentette, hogy formális kapcsolatba kerül Valentinianus lányaival.

502 BURY 1889, 229. LEE 2008, 43. Az elnevezés elöször J. B. Bury munkájában jelent meg. 


\subsection{Aspar és Geiserich kapcsolata}

\subsection{1. $425 / 432$}

$\mathrm{Aspar}^{503}$ és Geiserich ${ }^{504}$ kapcsolata már a 442-es vandálokkal kötött szerződés előtt formálódni látszik, amelyre a Chronicon Paschale és Theophanés krónikájának egy különös tévesztése világít rá. Ez a két forrás ugyanis összekever két azonos nevü személyt, ${ }^{505}$ akik között, véleményem szerint, az összekötő szálat éppen Aspar jelentheti. Erre a tévesztésre egy udvarbeli leszámolás hívja fel a figyelmet.

II. Theodosius 450-ben bekövetkezett halála után Chrysapius ${ }^{506}$, aki addig a császár köztiszteletnek és nagy megbecsülésnek örvendő spathariusa volt, támogató nélkül maradt. Végzetét nem a hun uralkodó elleni félresikerült merénylete okozta, hanem az egyik udvaron belüli ellenlábasa, ${ }^{507}$ Iordanes $^{508}$ (cos. 470), aki jó ideje erős ellenérzéssel viseltetett Chrysapius iránt. Öt okolta ugyanis apja, Ioannes haláláért, akit 441-ben ölt meg egy bizonyos Arnegisclus. Ioannesről kevés információ áll rendelkezésre, a Marcellinus comes által leírtak tükrében azonban bizonyos, hogy vandál származású (natione Vandalus) volt, így minden bizonnyal Észak-Afrikából érkezett, ${ }^{509}$ talán éppen a 430-as években. Néhány hónappal azt követően ugyanis, hogy a vandálok 429-ben átkeltek Észak-Afrikába, II. Theodosius felismerte a területfoglalásukban rejlő veszélyeket és azonnal megtette a szükséges ellenlépéseket: 432-ben az egyik, alán származású magister militumának, Asparnak a vezetésével flottát küldött Észak-Afrikába.

Asparnak nem ez volt az első útja nyugatra. Hét évvel korábban ugyanis még apja társaságában vonult Itáliába. A hadjárat célja az volt, hogy kiköszörülje a II. Theodosius becsületén

503 PLRE2 164-169, "Fl. Ardabur Aspar”.

504 PLRE2 496-499, "Geisericus".

505 A kérdéses szöveghelyek CHRON. PASCH. 441., THEOPH. AM. 5938.

506 PLRE2 295-297, "Chrysaphius qui et Ztummas".

507 PRISC. Fr. 7, 8, 12., THEOPH. AM. 5943. Attila félreállítására már a 440-es évek végén törekedtek a konstantinápolyi udvar belső köreiben. Legföképpen Chrysapius. 449-ben terve nemcsak kudarcba fulladt, de a célpont is tudomást szerzett róla. Attila erélyesen követelte a spatharius kiadását, sikertelenül. Az udvarból Anatolius és Nomus vezetésével követség indult Attila megbékítésére. II. Theodosius ekkor még kiállt spathariusa mellett, azonban 450-ben bekövetkezett halála után az özvegy Pulcheria meghajlott az ifjú Iordanes kérése elött és elrendelte Chrysapius kivégzését.

508 PLRE2 620-621, "Fl. Iordanes 3".

509 MARC. COM. 441. 
esett csorbát, illetve ${ }^{510}$ hogy eltávolítsa a trónbitorló Ioannest ${ }^{511}$ (423-425). A császári udvarba menekült Galla Placidiát a császár Ardabur, Aspar, Candidianus és Helio magister officiorum támogatása mellett visszaküldte Itáliába. A szárazföldi erőket Aspar és Candidianus vezette, míg a császári flotta Ardabur irányítása alatt állt. Philostorgios tükrében a flotta Itália partjainál hajótörést szenvedhetett, Ardabur pedig a trónbitorló Ioannes fogságába esett. Philostorgios szerint Ardabur azt színlelte, hogy egyezséget köt vele, de a fogsága idején, viszonylagos szabadságát kihasználva felbujtott egy korábbi hadvezért, hogy szervezzen merényletet Ioannes ellen, közben pedig tájékoztatta Aspart a fejleményekröl. A terv sikerült. Az Ardabur által megbízott tisztségviselö és emberei elfogták Ioannest, akit aztán Placidiához és Valentinianushoz küldtek. Usurpatiója csúnya véget ért, elöször a kezét vágták le, majd le is fejezték. Philostorgios mellett egy-két nyugati krónika is arról tesz említést, hogy a trónbitorlót Aquileiában végezték ki. ${ }^{512}$

Ezt követően a keleti magister officiorum és a magister militumok közremüködésével hozzáláttak a ravennai udvar újjászervezéséhez. A harmadik napon érkezett meg Aëtius, akit még Ioannes küldött a hunokhoz, hogy szorult helyzetében támogatást szerezzen. ${ }^{513}$ Aëtius és Aspar seregei összecsaptak egymással, de mivel nem bírtak egymással, fegyverszünetet kötöttek. Aëtius a keletrómai küldöttek hathatós közvetítésével megállapodott az új ravennai vezetéssel. ${ }^{514}$ Katonai karrierje is ekkor indult el igazán. 425-ben comesszé és Gallia magister militumává tették, majd hogy hun zsoldosai is kellöen megszolgálják a fejpénzüket - a vizigótok által ostromlott Arles alá küldték. ${ }^{515}$ Miután stabilizálták Galla Placidia helyzetét, Aspar és a keletrómai sereg többi vezetője visszatért Konstantinápolyba.

431-ben Aspar ismét elindult Konstantinápolyból, immár magister militumként, mely tisztséget innentől kezdve 471-ben bekövetkezett haláláig viselt. ${ }^{516}$ A császár ezúttal ÉszakAfrikába küldte Bonifatius ${ }^{517}$ comes domesticorum et Africae megsegítésére, aki azzal érdemelte ki

510 Olymp. FR. 34, THEOPH. AM. 5913. A keletrómai császár nagybátyja ugyanis Athaulf halála után önállósította magát. Honorius előbb mindenféle konzultáció nélkül házasságra kényszerítette Galla Placidiát az idős Constantiusszal, akit ráadásul 421 február 8-án augustusszá is tett. Honorius tette egyértelmü dinasztikus célokat szolgált. Erre válaszol II. Theodosius - azon túl, hogy Constantinust nem fogadta el keleten - még az év júniusában feleségül vette Eudociát, hogy maga gondoskodjon méltó utódról a dinasztia számára. 421. szeptember elején azonban meghalt Constantinus, férje halála után Placidia gyermekeivel Honoriával és Valentinianusszal Konstantinápolyba menekültek. 423-ben augusztusában meghalt Honorius, három hónapra rá Ioannes kezdte bitorolni a nyugati trónt.

511 PLRE2 594-595, “Ioannes 6".

512 Philostor. Hist. Eccl. 12.13-14, Chron. Gall. 452, 99. vö. Hyd. Chron. 75 (84). Hydatius ezzel szemben Ravennába helyezi Ioannes kivégzését.

513 Prosp. Tiro. 425, Philostor. Hist. ECCL. 12.14.

514 Olymp. Fr. 43, Philostor. Hist. Eccl. 12.13-14, Prosp. Tiro. 425.

515 PROSP. TIRO. 425.

516 PLRE2 164-169, "Fl. Ardabur Aspar".

517 PLRE2 232-40, "Bonifatius 3". 
nem mindennapi címét, hogy Ioannes trónbitorlásának idején biztosította az afrikai provinciákat. A comes már 430 tavaszán megütközött Geiserich seregével, amelyet akkor még sikerült megvernie, majd visszavonult Hippo Regius városába. Geiserich ostrom alá vette a várost, ahova a következő év végén érkezett meg a konstantinápolyi flotta, azonban Aspar és Bonifatius egyesült serege sem bírt a vandálokkal. ${ }^{518}$ Ráadásul 432 elején Bonifatiust hazahívta Placidia. ${ }^{519}$

Aspar ezzel szemben nem vonult vissza, amit több forrás is alátámaszt. ${ }^{520} 434$-ben consullá választása alkalmával ő töltötte be a nyugati, míg Ariobindus magister militum pedig a keleti consul szerepét. ${ }^{51}$ Aspar legalább egy évig biztosan Észak-Afrikában volt, ahol magister militumként tárgyalásokba bocsátkozott Geiserich-kel, éppen úgy ahogy Aëtiusszal is tette. Minden bizonnyal ekkor került kapcsolatba a vandál Ioannesszel ${ }^{522}$ is, aki később magister militum lett a konstantinápolyi udvarban, és aki nyilván nem azonos a trónbitorló Ioannesszel. Ezzel szemben Theophanés és a Chronicon Paschale összemossa a két személyt mondván, hogy a trónbitorló "vandál” Ioannest Konstantinápolyba vitték, ahol - ahelyett hogy megbüntették volna kitüntetéseket kapott. ${ }^{523}$

Mindezek alapján feltételezhető, hogy a történetírók egész egyszerüen azért keverik össze a trónbitorló Ioannest a vandál származású magister militummal, mert kettejük között az összekötő kapocs Aspar magister militum volt. Aspar vonult 425-ben Ravennába a trónbitorló likvidálására, és ő ment alig tíz évvel később Észak-Afrikába is. Aspar - és talán Geiserich - közvetítésével kerülhetett a vandál Ioannes Konstantinápolyba, ahol szép karriert futott be, hiszen, mint láttuk, pár éven belül magister militum lett. Ioannes és így fia, Iordanes is Asparnak köszönhették Konstantinápolyba kerülésüket. Az igazi trónbitorló pedig nem ment Konstantinápolyba, se magától, se úgy, hogy vitték. Egyetlen helyre ment 425-ben, a vesztőhelyre. A Geiserich és Aspar között feltételezett kapcsolatot a következő történet fogja alátámasztani.

\subsubsection{A domesticus álma}

Aspar 431-es észak-afrikai hadjáratával kapcsolatban különös történetröl számolnak be a

518 Procop. De Bellis. 3.3.32-35.

519 CLRE 434, LiB. PROMISs. 6.9. Mindenekelött consulsága, ugyanakkor Quodvultdeus szerint "Nostris quoque temporibus, Aspero vi cos. Carthagini constituto".

520 HYD. CHRON. 89 (99).

521 PLRE2 232-40, "Bonifatius 3", Nov. THEOD. 7.4, CLRE, 402, Aspar missoriumára: ZACCAGNinoBEVAN-GABOV 2012. MARC. COM. 441. Kérdéses, hogy meddig volt Észak-Afrikában, annyi azonban bizonyos, hogy 441-ben már a hunok ellen vezényelték.

522 PLRE2 597, "Ioannes 13".

523 THEOPH. AM. 5938. 
keletrómai történetírók. 432-ben, miközben tovább folytatódott a Geiserich elleni harc, egy vereséget követöen többen vandál fogságba estek. ${ }^{524} \mathrm{~A}$ foglyok között volt Aspar egyik, Marcianus nevezetü domesticusa is.

Az történet szerint a vandál katonák a keletrómai foglyokat egy tisztásra vezették, hogy Geiserich megszemlélhesse őket. ${ }^{525}$ Az uralkodó a seregszemle után elrendelte a foglyok szabadon bocsátását, de Aspar domesticusa időközben elaludt a napon. Ahogy lehunyta a szemét, egy sas jelent meg az égen, és úgy repült, hogy szárnyaival eltakarta a nap sugarait, hogy azok ne zavarják a domesticus pihenését. Geiserich, amint megpillantotta a szokatlan jelenséget, ráeszmélt, hogy isteni beavatkozásról van szó. Utasította katonáit, hogy azonnal vezessék elé a foglyot. Amikor kilétét megtudta, Geiserich rájött, hogy az égi jelenség Aspar domesticusának kedvezett.

A sas világos jelkép volt. Suetonius szerint Augustus halálát éppen az jelezte elöre, hogy a sas elpártolt tőle

“Halálát [...] egészen nyilvánvaló megnyilatkozások hozták tudomására. A Mars-mezőn, mikor nagy tömeg elött az ötévenkénti tisztító áldozat szertartását végezte, feje fölött sas keringett, majd átszállt a szomszédos templomra [...]. Mihelyt ezt Augustus észrevette, megparancsolta hivatali tiszttársának, bizzák meg ünnepélyesen Tiberiust, hogy a következö tisztító áldozatra tegye le a szokásos fogadalmat, mert ö, noha a feliratos fogadalmi táblák készen állanak, nem óhajt olyasmit megfogadni, amit már be nem válthat." ${ }^{, 526}$

Prokopios szerint Geiserich-nek azonnal eszébe jutott, hogy Aspar mily nagy hatalmat gyakorol Byzantionban, és tüstént világossá vált számára, hogy ez az ember egyszer még császár lehet. ${ }^{527}$ Emiatt - ahogyan a történetíró folytatja - a vandál király megeskette Marcianust, hogy ha valaha császár lesz, hatalmát soha nem fogja az övéi ellen használni, majd szabadon engedte őt. ${ }^{528}$

A korszakkal foglalkozó kutatók nem foglalkoztak a mese történeti hátterével, ${ }^{529}$ minden bizonnyal csak annyit láttak benne, hogy a szerzők ezzel magyarázzák Marcianus későbbi katonai passzivitását. Természetesen ez a magyarázat is helyénvaló lehet, de úgy gondolom, hogy létezhet ennél mélyebb értelmezése is a szóban forgó szövegnek. Prokopios azzal folytatja a történetet, hogy Geiserich attól tartott, hogy megfogyatkozik ereje és jó szerencséje, ezért jobbnak látta, ha

524 PlRe2 232-40, "Bonifatius 3.”, Procop. De Bellis. 3.3.35-36, Evagr. HE. 2.1, Theoph. AM. 5931, 5943.

525 Procop. De Bellis. 3.4.3-11, Evagr. HE. 2.1, Theoph. AM. 5943, Nic. Call. HE. 15.1, Zon. 13.24.419.

526 SUET. Aug. 97.1. Kiss Ferencné fordítása.

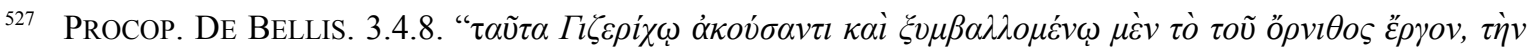

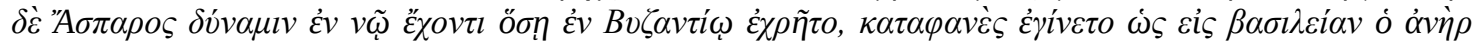

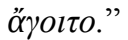

528 PROCOP. De BELLIS. 3.4.9-11.

529 KALDELLIS 2004. Kaldellis legutóbbi, Prokopiost tárgyaló monográfiában sem kerül említésre a történet. 
szövetséget köt III. Valentinianusszal, és vállalja, hogy minden évben tributumot fizet, a megállapodás záloga pedig fia, Hunerich lesz. ${ }^{530}$ Csakhogy ez az esemény nem 432-ben történt, hanem tíz évvel később. A szerző azzal, hogy összemossa a 432-es eseményeket az egy évtizeddel későbbi, 442-es békével és túszadással, miközben Marcianus szabadon engedése kapcsán az isteni tényezö mellett kiemeli Aspar hatalmát, csak még jobban ráirányítja a figyelmet a hadvezér 432-es és 442-es szerepére. ${ }^{531}$ Prokopios szerint Marcianus hatalomra kerüléséhez nem volt elegendő az isteni kegy, ehhez szüksége volt Aspar hatalmára és befolyására is. A történetíró leírásában Marcianus szabadon engedéséhez nem az isteni jel vezetett: Geiserich azért bocsátotta el a domesticust, mert tudta, hogy Aspar beosztottja. A Geiserich és Aspar között húzódó kapcsolat már felsejlett a vandál és a trónbitorló Ioannes történetírói tévesztése kapcsán, Marcianus szabadon bocsátásának története pedig csak tovább erösíti azt a feltételezést, hogy kapcsolat volt a vandál uralkodó és a keletrómai magister militum között. Prokopios ráadásul az események összemosásával sejteti azt is, hogy a magister militumnak tevékeny szerepe lehetett a 442-es megállapodásban, ami mint látni fogjuk, korántsem a ravennai udvar érdekeit szolgálta.

\subsubsection{A 442-es béke}

Geiserich és a ravennai udvar között 442-ben kötött megállapodást több körülménye is Aspar szerepére irányítja a figyelmet. Az elöző oldalon láthattuk, hogy Prokopios úgy informálja olvasóját, hogy Geiserich már 432-ben békét kötött Valentinianusszal, ezzel szemben Cassiodorus arról számol be, hogy a 440-es évek elején vandálok folyamatos dél-itáliai portyázásával szemben nagyapjának kellett felvennie a küzdelmet. ${ }^{532}$ Ráadásul a vandálok ellen felvonuló keletrómai flotta számadatai is érdekes egyezést mutatnak. Theophanés - Prokopiostól független - beszámolója szerint Geiserich, miután olyan földeket és szigeteket kapott, amelyek korábban római adófizető tartományok voltak, királynak kezdte magát nevezni. Theodosius ezt megelégelve egy 1100 hajót számláló flottát küldött Szicília partjaihoz. Furcsamód éppen annyit, mint amennyit I. Leo fog a vandálok ellen küldeni a 468 -ban, ${ }^{533}$ mintha a történetíró szerint a két esemény erősen korrelálna egymással, noha a közös nevezőt ez esetben is csak Aspar személye jelenti.

A Theodosius által indított expedícióhoz szárazföldi seregével Aëtius is csatlakozott. ${ }^{534} \mathrm{~A}$

530 Procop. DE BELlis. 3.4.13-14.

531 Procop. De Bellis. 3.3.35, 3.4.12 vö. 3.4.13, Merobaud. CARM. 1.5.10. Miközben Prokopios a 432-es eseményeket részletezi, egy ponton beleszövi a mesélésbe Hunerich 442-es túszadását.

532 CAssiod. VAR. 1.4.14. vö. HYD. CHRON. 112 (120). Erre utal Cassiodorus, aki apja méltatása kapcsán megemlíti, hogy a 440-es években nagyapja védte Bruttiumot a vandálokkal szemben.

533 THEOPH. AM. 5938. 
keletrómai flottát a rangidős Ariobindus vezette, aki Aspar consultársa volt 434-ben. ${ }^{535}$ Mellette még négy hadvezér érkezett Ansilas, Inobindus, Arintheus és Germanus személyében. Aspar ezúttal a fővárosban maradt. ${ }^{536} \mathrm{Az}$ expedíciós sereg összeállt, készen arra, hogy egy határozott csapással visszaszerezze Észak-Afrikát. A flotta azonban nem indult Afrikába, a támadási parancs ugyanis soha nem érkezett meg Konstantinápolyból.

Theophanés szerint Geiserich valahogy megneszelte az ellene készülődő akciót és tüstént követeket küldött Theodosiushoz, hogy a béke feltételeiröl tárgyaljanak. ${ }^{537}$ Sem a kortárs, sem a későbbi történetírók nem nyújtanak semmiféle támpontot ennek időpontjára. Mindenesetre úgy gondolom, hogy valamilyen elözetes kapcsolatfelvételnek történnie kellett a vandál uralkodó és Aspar között, mert Theophanés a következő év kapcsán azt említi, hogy a flotta Szicília partjainál vár az udvar további utasítására, illetve Geiserich követeinek megérkezésére. ${ }^{538}$ Theophanés meglehetősen tömören közli a tényeket, de későbbi, hasonló események alapján rekonstruálható egy lehetséges forgatókönyv.

Mint Prokopios előadja, hogy amikor 543-ban, a keletrómai-perzsa háború során a felek békére szánták el magukat, előbb egy tájékoztató követség ment Perzsiába, amely arról informálta Chosroést, hogy hamarosan érkezik két követ, akikkel érdemben tárgyalhat. A perzsa uralkodó türelmesen várt rájuk, azonban egyikük az út során megbetegedett, ami hátráltatta előrehaladásukat. Chosroés, elunva a várakozást, utasította Persarmenia körzetének katonai parancsnokát, hogy küldjön egy követet Valerianoshoz, Armenia magister militumához, hogy szemrehányásokat tegyen a követek késlekedése miatt. A követ rendben megérkezett a magister militumhoz, majd a tárgyalást követően (ahol egy titkos megbeszélésre is sor került), visszaindult a perzsa udvarba, hogy tájékoztassa Chosroést a keletrómai követség felől. ${ }^{539}$

Egy másik hasonló esetre 568-ban került sor. Menander beszámolója szerint az avarok és a keletrómaiak közötti béketárgyalásokra során Bonus magister militum, az előzetes tárgyalásokat követően továbbküldte a követeket Konstantinápolyba a császárhoz. A magister militum később kapott egy levelet II. Iustinustól, amelyben az uralkodó alaposan letorkolta a katonai parancsnokot,

534 A források hallgatnak a szárazföldi sereg létszámáról, de a későbbi adatok tükrében annyi bizton állítható, hogy ennyi hajó több tízezer katona elszállítására volt alkalmas.

535 CLRE 434.

536 THEOPH. AM. 5941, CoD. THEOD. 12.8.2, további kommentár CourTOIS 1955, 171-175. Pentadius felelt a logisztikáért, adminisztrációs rémálom volt az expedíció.

537 THEOPH. AM. 5941.

538 THEOPH. AM. 5942.

539 Procop. DE Bellis. 2.24.3-9. Konstantinápolyból két tapasztalt követet küldtek az illír származású Konstantianos és az edessai Sergios személyében. Prokopios szerint mindketten roppant jól képzett és rafinált tárgyalók voltak. Az út során Konstantianos betegedett le. Ráadásul Perzsiában is kitört a pestis. Chosroés egy keresztény papot küldetett követség gyanánt Nabedesszel. 
amiért képes volt igen előnytelen előzetes feltételekkel továbbengedni a követeket az udvarba. ${ }^{540} \mathrm{~A}$ Prokopios és Menander által leírtak tökéletesen mutatják, hogy háborús helyzetben a magister militum nem egyszerün közvetítő, hanem felügyelete alatt tartja a béketárgyalások egész folyamatát egészen a végső megállapodásig.

A fentiek alapján úgy gondolom, hogy a 442-es szerződés előkészületei a következőképpen rekonstruálhatók. Egy időben a keletrómai flotta indulásával tájékoztató követek indultak Geiserich-hez és átadták neki a hadüzenetet. Geiserich erre szintén követeket küldött Konstantinápolyba, hogy egyezkedjen a feltételekről. A fővárosban Aspar vezető magister militum közölhette velük a feltételeket, többek között ekkor állapodtak meg a Geiserich fiának túszként való átadásáról is. ${ }^{541} \mathrm{~A}$ vandál követség ezt követően visszaindult Karthágóba, ahol tájékoztatták Geiserichet a feltételekről, aki egy viszontválaszt küldhetett Konstantinápolyba. Ezt követően Konstantinápolyból követek indultak Szicíliába, hogy tájékoztassák Ariobindust, a koalíciós sereg élén álló magister militumot a fejleményekről. Ezen a ponton jegyzi meg Theophanés, hogy a flotta várja Geiserich követeit - minden bizonnyal a túsz Hunerich-kel - illetve a további utasításokat. III. Valentinianus és magister milituma, Aëtius fogadták a követeket, megállapodtak és átvették Hunerichet. Valentinianus és Aëtius érintettségét az mutatja, hogy haláluk után, amikor a szerződés semmissé vált, Geiserich nyomban Itáliába ment fiáért. ${ }^{542}$ A megegyezést követően a flotta elhagyta Szicília partjait, Aspar pedig Areobindus visszaérkezését követően a hunok ellen indult. ${ }^{53}$ Aspar felügyelő szerepét bizonyítja, hogy 441-ben szinte valamennyi környező néppel békét kötött, így ebben az évben nem is volt más hadmozdulat, talán azért, hogy teljesen a vandálokkal kötendő megegyezésre tudjon koncentrálni. ${ }^{544}$ Egyes források ugyanakkor a flotta hosszas szicíliai időzésének tudják be, hogy nem sikerült egyszer s mindenkorra leszámolni a vandálokkal. ${ }^{545}$

Az eseményeket érdekes fényben tünteti fel Merobaudes, aki másfél évtizeddel a kudarcba fulladt expedíció után írta meg panegyricusát, melyben Aëtius harmadik consulságának állít

540 Men. Prot. 12.6.81-83. Lásd még MEN. Prot. 25.1.46, 25.1.87-88. 579-ben hasonló eset történt. Sethus magister militum megállapodott az Avar kagánnal arról, hogy egy hidat építenek a Dunán. A kagán arra utasította Sethust, hogy ha a követek megérkeznek hozzá, akkor haladéktalanul küldje őket tovább Konstantinápolyba a császárhoz. Vonakodva bár, de Sethus eleget tett a kérésnek.

541 Ebbe az irányba mutat az a tény is, hogy később az osztrogót Theoderich hasonlóan Aspar közvetítésével került túszként Konstantinápolyba.

542 Lásd I. ANTIOCH FR. 224.4.

543 THEOPH. AM. 5942. A két beszámoló 441 vége és 443 elejére datálható. A hunok tevékenységére: MAENCHEN-HELFEN 1973, 94-100. 441-ben a hunok feldúlták Sirmiumot és lakosságát rabszolgasorba vetették, ezzel az évi felvonulás véget is ért. 442-ben nem voltak hadmozdulatok. Aspar magister militum fegyverszünetet kötött 442-ben az éves portyázások megkezdése előtt. A flotta képtelen lett volna elérni a keleti partokat időben, hogy részt vegyenek a 441-es hadmozdulatokban.

544 MARC. COM. 441.1

545 Prosp. TIRO. 441, NiC. CALL. HE. 14.57. 
emléket. A dicshimnusz tartalmaz néhány olyan utalást, amelyben ugyancsak kitapintható Aspar befolyása. Merobaudes Aëtius Duna és Rajna menti harcait, valamint a nyugati gótok ellen folytatott hadjáratát követően tér rá a vandálok elleni sikertelen hadjáratra. Merobaudes szerint Aëtiust egyszerüen félreállították: “Megvetnek, a sors változása folytán hatalmamat nem tisztelik; elüztek a tengerekröl, s a szárazföldön sem uralkodhatom." ${ }^{446}$ Néhány sorral lejjebb Arés kíséröje, Aëtius "védnöke", egy öblös sziklabarlang mélyén élő Enüó veszi át a szót, aki "gyászosnak érezte, hogy gyász nélkül él a föld. "\$47 Nővére, - szintén a hadakozók védnöke - leszáll hozzá és így kezdi buzdítani: "Micsoda szörnyü kábulat bénitotta meg tagjaidat, növérem, e mérhetetlenül hosszú béke idején? [...] Ne legyen fal elég erös dacolni vad dühöddel: | népek és királyok remegjenek iszonyú hangod hallatára. [...] Én pedig ravasz csellel leplezve magam a magas palotába lopódzom. | [...] a legföbb ügyekben ne a kiválóak, hanem a vakvéletlen szava döntsön, s a szivekben eszeveszett mohóság és kíméletlen aranyéhség forrjon. ${ }^{, 548}$ Miközben Aëtius nem másra bízná a háborúkat, hanem ő maga vezetné azokat, "s nem az esztelen pénzvágy késztetné arra, hogy mérhetetlen sok gondot vállaljon magára, hanem fegyvere becsületének szeretete." ${ }^{549}$ Merobaudes e sorai, Aëtius félreállításának ismeretében úgy is értelmezhetők, hogy létezik egy, a hadvezérnél hatalmasabb erő, aki hasonló hozzá, de a palotában, aranyéhségtől hajtva képes elnyomni Aëtiust. Talán éppen az egyre növekvő hatalmú Asparra utal a szerző, hiszen vezető magister militumként ő rendelte el a visszavonulást Szicíliából.

Visszatérve a 442-es tárgyalásokhoz, Aspar befolyására utal az is, hogy 425-ben - amint arról már beszéltünk - III. Valentinianus az ő segítségével szerezte vissza trónját. De ezt az elgondolást támasztják alá a 442-es megállapodás részletei is, amelyek egyértelmüen kedvezőtlenek voltak a nyugati birodalomrész számára. Victor Vitenses a vandálok alatti keresztényüldözésekröl írott munkájában (Historia persecutionis Africanae provinciae sub Geiserico et Hunirico regibus) arról számol be, hogy a felek területcserében állapodtak meg. $442-$ ben Geiserich megkapta Byzacena, Africa proconsularis provinciákat, valamint Numidia egy részét is, vagyis a gazdaság gabonatermelő vidékeinek központjait. ${ }^{550}$ Ezzel szemben Ravennának be kellett érnie az értéktelenebb Tingitania, Mauetania Caesariensis, Mauretania Stifensis provinciákkal, illetve Numidia Cirtensis, és Numidia nyugati részével, ${ }^{551}$ vagyis azokkal a

\footnotetext{
546 Merobaud. PAN. 2.51-55, Olajos 1966. Merobaudes műveinek magyar fordítását Olajos Terézia készítette el. Valamennyi idézett szövegrész az általa készített magyar fordításból származik.

547 Merobaud. PAN. 2.61-62.

548 Merobaud. PAN. 2.72-73, 84-86, 89-91, 95-97.

549 MEROBAUd. PAN. 2.98-104.

550 VICT. VIT. 1.13. A vandál vezér örökletes birtokként Zeugitanát adta katonáinak, ez lesz az ún. sortes Vandalorum.

551 Procop. De Bellis. 3.4.12.
} 
területekkel, amelyek a 435-ös megállapodáskor kerültek a vandálokhoz. Az alapvető különbség a 442-es és a korábbi megegyezés között, hogy ezzel a vandálok elfoglalták a birodalom fó gabonaraktárát, innen már csak egy lépés volt, hogy Szicília és Szardínia fosztogatásával megbénítsák a birodalom nyugati felének gabonaellátását. ${ }^{552}$ Ez a megállapodás tehát egyáltalán nem szolgálta Ravenna érdekét.

További érdekes párhuzamot szolgáltat a 442-es tárgyalásokkal kapcsolatban a hadrianopolisi összecsapást megelőző követjárás. Ammianus Marcellinus beszámolója szerint 378. augusztus 9-ének előestéjén Fritigern egy keresztény papot és más alacsonyabb rendü embereket küldött a császár táborába, akik átnyújtották Valensnek a vezér levelét. Fritigern azt kérte, hogy a császár engedje át neki lakóhelyéül Thraciát, annak összes állatával és terményével együtt, mert ha ez megadatik nekik, akkor örök békére kötelezi magát. A követ egy másik bizalmas levelet is átnyújtott, melyben Fritigern, mintha rövidesen jó barátja és szövetségese lenne (amicus futurus et socius) a császárnak, ismertette, hogy csak akkor tud a birodalom számára kedvező feltételeket a saját népével elfogadtatni, ha megmutatja nekik teljes fegyverzetben a római sereget, így ébresztve félelmet bennük és lohasztva le harci kedvüket. ${ }^{553}$ Míg Hadrianopolis elóestéjén nem teljesült, amit Fritigern titkos levelében állítólag kért, 442-ben II. Theodosius felvonultatta teljes seregét, ami meghunyászkodásra és békére kényszerítette Geiserichet. A vandál uralkodó 442-ben megkapta a legfejlettebb észak-afrikai tartományokat, azok minden ingóságával együtt. Fritigernnel szemben ö már valóban a császár barátja és szövetségese lett, amit eljegyzéssel pecsételtek meg.

A képet Merobaudes első carmenje árnyalja még annak ellenére is, hogy a költemény első sorai elvesztek.

“... a müvészien ékesitett ebédlő ajtószárnyait Concordia képmása dísziti [...] ahol ünnepi lakomákon fogyasztják a halhatatlan uralkodó ételeit [...] Amott a mi védnökünk [III. Valentinianus] színe elött siratja váratlanul veszni látszó örökségét az éppen megérkezö számüzött [Hunerich]. ${ }^{554}$ Ám aztán a gyözelem visszaadta a birodalmat annak, aki születése révén örökölte azt, és a fényes császári udvar hozzáadta a távolról kért feleséget [Eudocia]. [...] Ha egykor férje lesz majd, elmondhatni, hogy Péleus és Thetis, Nereus leánya lépett nászra a thessaliai nyoszolyán."

Merobaudes kétszeresen is élesen szembeállítja egymással a vandál királyfit és a császárt, hiszen utóbbit az istenekre jellemző halhatatlansággal ruházza fel, de ez köszön vissza akkor is, amikor

\footnotetext{
552 NVAL. 34. (451. június 13).

553 AMM. MARC. 31.12.19.

554 PLRE2 572-573, "Hunericus".
} 
Thetis és Péleus násza kerül szóba, hiszen előbbi istennő volt, míg Péleus görög hős. Hunerich és Eudocia házasságának tervét azonban korántsem gondolja komolyan a ravennai udvar, erre utalhat Concordia (Harmonia) említése, aki a görög mitológiában Aphrodité és Arés házasságtörő nászából született. ${ }^{555}$ Hasonló esküvőre akkor került sor, amikor az istennő Kadmos és a hős Harmonia kelt egybe. Az istenek nászajándékai: a peplos és a nyaklánc azonban végzetesnek bizonyultak az utódok számára. Kadmosnak és Harmoniának négy lánya és egy fia született, de előbb vagy utóbb valamennyien meghaltak. A lányok halála után ${ }^{556}$ Thébai trónja Polydórosra maradt, és a nemzetség a végzetes Labdakos-Laios-Oidipus ágon folytatódott. ${ }^{557}$ Az Eudocia és Hunerich házasságból született gyermek, Hilderich uralma jelenti a vandál királyság végét és így teljesül be ez esetben is a végzet. Bizonytalan, hogy hány sor hiányozhat a carmen elejéről, mindenesetre valószínüsíthető, hogy Concordia, valamint Thetis és Péleus nászának említése egy gondolati egységet fog közre. Merobaudes mondatainak első elhangzásakor pontosan hatvan év telt el a gótok 382-es letelepítése óta. Themistios óta semmi sem változott. A deditio deditio maradt.

\subsection{A Theodosius-dinasztia vége}

\subsubsection{Valentinianus halála}

Alig három hónap volt hátra III. Valentinianus harmincötödik születésnapjáig, amikor március közepén az egyik reggel kilovagolt a palotához közeli Mars mezejére. A Konstantinápolyban alkotó 6. századi történetírók számára a helynek szimbolikus jelentése volt. ${ }^{558}$ Augustust itt hagyta el a sas, és itt állt a Pantheon szomszédságában a Saepta Iulia hatalmas szavazócsarnokával, ahol fél

555 Merobaud. CARM. 1.5.10., RoBerts 2003, 44-95, 297-299, 343-347. A késő antikvitásban a concordia intézménye korántsem tekinthető együttmüködést ösztönző eljárásnak, hiszen az uralkodói és katonai csoportok gyakran ellentétben álltak egymással. Roberts értelmezésében sokkal inkább tekinthetőek patronus-cliens viszonynak.

556 KERÉNYI 1977, 144. Zeus villáma agyonütötte Semelét és a tüzben Kadmos palotája is megsemmisült. Agaué örületében széttépte saját fiát, Inó fiával a tengerbe vetette magát.

557 KERÉNYI 1977, 144-145. Polydóros unokáját, Laiost végül saját fia, a kitagadott Oidipus ölte meg. A Thébai uralkodóház, a Labdakidák családjának történetéből sok költő merített, többek között Sophoklés és Euripidés. Kadmos dédunokája, Laios nyugtalanító jóslatot kapott, mely szerint fia fog életére törni. A Kithairón hegyre kitetette a fiút. A szolga azonban, ahelyett, hogy végrehajtotta volna a parancsot, a fiút Polybos korinthosi király pásztorának adta, akit a király sajátjaként nevelt. Laiost újra és újra nyugtalanította jóslat, ezért elindult Delphoi felé, hogy a jóshelyen kérdezősködjék kitett fia után. Ugyanebben az időben fia, Oidipus is Delphoi felé indult, mert megsejtette, hogy nem Polybos az apja. Útközben találkoztak. Laios kocsija nem fért el az úton gyalogló Oidipustól. Szó szót követett, mire Laios szolgája védelmére kelt, a feldühödött Oidipus pedig mit sem sejtve, hogy valódi apja áll vele szemben, megölte.

558 Marc. COM. 455, Jord. Rom. 334, Evagr. HE. 2.7, ezzel szemben Prosp. Tiro. 455. 
évezreddel korábban még több ezren gyültek össze, hogy megválasszák a birodalom vezető tisztségviselőit. A Saepta ötlete még Caesar fejében fogalmazódott meg, de megvalósítása már unokaöccsére és kijelölt utódjára, Octavianusra hárult. ${ }^{559}$ Akárcsak a Krisztus születését követő tizennegyedik évben, 455. március 16-án is az utolsó princeps fellépésének helyszínévé lett. Valentinianus éppen csak kikötötte lovát, amikor kíséröi, Aëtius egykori bucellariusai rátámadtak és néhány kardcsapással végeztek vele. ${ }^{560} \mathrm{~A}$ császárt két lánya, Eudocia és Placidia, valamint özvegye, Licinia Eudoxia siratta. A sas pedig immár a birodalom keleti felébe, Marcianus fölé szállt. ${ }^{561}$

Két évtizeddel korábban, 437-ben még fényes külsőségek közepette ünnepelték Valentinianus és II. Theodosius egyetlen lányának esküvőjét, amelytől a dinasztia felvirágoztatását remélték, hiába. Fiú örökös híján - a keleti ág után - Valentinianus halálával vége szakadt a Theodosius-dinasztia nyugati ágának is, annak a dinasztiának, amely I. Theodosiusszal, még ha rövid időre is, de vallási és területi egységet teremtett. Ha nem is érdemelt volna ilyen kegyetlen leckét, Prokopios szerint meggondolatlanságával és naivitásával Valentinianus maga hívta ki a sorsot egy évvel korábban, amikor egy tanácskozás alkalmával Petronius Maximus sugalmazására saját kezével végzett legfőbb katonai parancsnokával, Aëtius magister militummal. ${ }^{562}$ Pontosan hat évtizeddel Theodosius halála után hasonló helyzet állt elő Valentinianus megölésével. Ezúttal azonban a dinasztikus kontinuitás a császár lányain múlott, pontosabban csak az ifjabbik Placidián, mert nővére, Eudocia néhány éve már jegyben járt a nyugatrómai udvar “túszával” Hunerich-kel, a fiatal vandál királyfival.

A szálakat Petronius Maximus mozgatta. Tágabb családja fián, Palladiuson ${ }^{563}$ kívül ismeretlen, ${ }^{564}$ annyi azonban bizonyos, hogy rendkívül agilis ember volt, hiszen két ízben Róma városának praefectusa, majd ugyancsak duplán viselte a praefectus praetoriói tisztséget, ahogyan a consulatust is. ${ }^{565}$ Ö állt nem csak Aëtius, de III. Valentinianus meggyilkolása mögött is. ${ }^{566}$

559 Részletesen a Saepta Iuliáról lásd NTDAR 340-341, "Saepta Iulia.”.

560 I. ANTIOCH FR. 224.4, PRISC. Fr. 30.3. = JORD. ROM. 334. A merényletet Optelas és Thraustelas hajtotta végre.

561 PROCOP. De Bellis. 3.3.35-36

562 Procop. DE BELLIS. 3.4.28. A kialakult ingatag helyzetet a császár elsősorban magának és meggondolatlan politikájának köszönhette. Valentinianus úgy érezte, hogy Attila halála után a hun fenyegetés is elmúlt, így a továbbiakban már nincsen szükség Aëtius támogatására.

563 PLRE2 821, “Palladius 10.” vö. HYD. CHRON. 155 (162). Palladiusról, a nevén, valamint azon kívül, hogy Petronius Maximus előző házasságából született jóformán semmilyen információval nem rendelkezik a kutatás.

564 OLYMP. FR. 41.1-2, Feltételezett felmenőiröl Olympiodóros egy kurta töredékén kívül nem tesznek említést a források.

565 CIL 6.1794.

566 Procop. De Bellis. 3.4.17-36. 
Intrikáinak alapját maga Nagy Theodosius szolgáltatta második házasságával. A 390-es évek elejére ugyanis, II. Valentinianus halálával Galla maradt az egyetlen összekötő kapocs a korábbi dinasztiával. Theodosius számára a Gallával kötött házassága biztosította a legitimációt és a dinasztikus kontinuitást Valentinianusszal. Hatalomra kerülésével mindenki számára nyilvánvalóvá vált, hogy egy dinasztia nőágon is fennmaradhat.

Antiochiai János szerint a császár gyilkosai az uralkodó lovával és a fejéről lehulló diadémmal rögtön az ötvenes évei végén járó Petronius Maximushoz siettek, ${ }^{567}$ aki már a császár halálának másnapján elfoglalta a trónt. A hatalom megszervezésére azonban nem maradt ideje. Megfelelő legitimáció nélkül úgy akart jogalapot teremteni uralkodására, hogy házasságra kényszerítette Valentinianus özvegyét, Licinia Eudoxiát. ${ }^{568}$ Ám Hydatius szerint ennél még tovább ment. Miután összeadta ${ }^{569}$ Palladiust Valentinianus lányával, még caesarrá is kinevezte. ${ }^{570}$

Aëtius és Valentinianus halálával a vandálokkal kötött 442-es megállapodás érvényét vesztette. Petronius Maximus uralkodásának elismertetése lehetetlennek bizonyult, ingatag pozíciója pedig már az udvarban tartózkodó Hunerich életét is veszélyeztette. Geiserich felismerve a helyzetben rejlő veszélyt, hamarosan Róma felé indult csapataival. A vandál sereg érkezésének híre gyorsan véget vetett Petronius Maximus tiszavirág életü, hetvenöt napos uralkodásának, miközben megkísérelt elmenekülni a városból, a zendülő katonaság fiával együtt elfogta és megölte. ${ }^{571}$ Miután a vandál sereg kifosztotta Rómát, Geiserich visszatért Karthágóba Licinia Eudoxia és lányai, Hunerich és talán Aëtius fiának, Gaudentiusnak a társaságában. A későbbiekben látni fogjuk, hogy míg a források többsége csak abban egyezik, hogy a vandál uralkodó Valentinianus özvegyét és lányait vitte magával, valamint nyilvánvalóan, fiát, Hunerichet, addig az eseményekkel kortárs Hydatius kiegészíti a felsorolást Gaudentiusszal, ami bizonyára nem véletlen. A történetírók hallgatása meghatározott célt szolgált.

567 I. ANTIOCH FR. 224.2.

568 PLRE2 410-412, "Licinia Eudoxia 2.".

569 BURY 1923, 324; vö. WES 1967, 305, PLRE2 407-408, "Eudocia 1." Bury nyomán elterjedt az a nézet a modern történetírásban, hogy Petronius Maximus Eudocia és Hunerich eljegyzését bontotta fel. Ezt a feltételezést azonban nem támasztják alá a források, mivel nem nevezik nevén a hercegnőt, akit feleségül vett Gaudentius. Ugyanakkor az események korábbi folyásának ismeretében logikátlan is lenne, hiszen Placidia korábbi eljegyzését még Valentinianus bontotta fel, így az ő keze szabad volt. Petronius Maximus ingatag helyzetében Eudocia eljegyzésének felbontásával csak még egy ellenséget szerzett volna.

570 HYD. CHRON. 155 (162).

571 Hyd. CHRON.155 (162), PLRE2 749-751, "Maximus 22”, PLRE2 821, "Palladius 10" Halálát változatosan írják le a különböző források. Marcellinus szerint például feldarabolták. A PLRE feltételezése szerint fia, Palladius is ekkor veszthette életét, ezzel a család vérvonala is megszakad. 


\subsubsection{Valentinianus "egyik" lányának "házassága"}

Hydatius az egyetlen szerző, aki arról számol be, hogy Petronius Maximus összeadta fiát Valentinianus lányával. ${ }^{572} \mathrm{~A}$ római jogban az eljegyzés alsó korhatára nyolc év volt, a házasságé pedig tizenkettő. ${ }^{573} \mathrm{Az}$ arisztokrácia tagjai igyekeztek a lehető leghamarabb férjhez adni gyermekeiket, hiszen a szüzesség erény volt, ${ }^{574}$ amit a források közül Malalas több ízben is kiemel Eudocia esetében ${ }^{575}$ A házasság esetében a jog adta kereteket azonban nem szabad túl komolyan venni, azok ugyanis elvi határok. Ugyan az eljegyzést az apa akár már lánya születése után megtarthatta. A házasság esetében elsősorban a lányok biológiai érettsége volt az irányadó. Shorter szerint a Római Birodalom fennállása idején tizennégy éves kor körül alakulhatott az átlag. ${ }^{576}$ Ezt az elgondolást támasztja alá Eudocia és Placidia szüleinek házassága is. Licinia Eudoxia ugyanis tizenöt éves korábban ment feleségül III. Valentinianushoz, ${ }^{577}$ viszont már kétéves korában sor került eljegyzésükre. ${ }^{578}$

Prosper szerint 454-ben III. Valentinianus és Aëtius megegyeztek abban, hogy összekötik gyermekeik életét ${ }^{579}$ éppen akkor, amikor Gaudentius elérte a római jogban házassághoz szükséges tizennégy éves, hivatalos korhatárt. ${ }^{580}$ Mivel Eudocia a 442-es megállapodás óta Hunerich jegyese volt, így Gaudentius párja Placidia lett. Feltételezések szerint Gaudentius eljegyzésének házasságba fordulását addig nyújtotta Valentinianus, ameddig csak tehette, hiszen nem akarta, hogy magister militum a "fejére nőjön", Aëtius meggyilkolása pedig egyedül azt a célt szolgálta, hogy a házasságot megakadályozza. ${ }^{581}$ Véleményem szerint nem feltétlenül erről van szó.454. szeptember 21/22-én ugyanis nemcsak a magister militumot ölték meg, hanem a praefectus praetoriót is, így vezető tisztségviselők lemészárlása inkább a palotai klikkek közötti szembenállást sejtet, nem pedig Aëtius fiának házassága ellen irányult. Ezt megerősíti az a tény is, hogy Priskos és Hydatius szerint

572 HYD. CHRON.155 (162).

573 RAWSON 1999, 21.

574 HALLETT 2014, 141-142.

575 JOH. MAL. 14.26 (366).

576 SHORTER 1991, 18. Ez azonban számos tényező módosíthatja: öröklődés, betegség vagy akár a diéta is.

577 MARC. COM. 437 vö. SOCRATES, HIST. ECCl. 7.44. Házasságukra 437. október 29-én került sor Konstantinápolyban. Az eredeti tervek szerint Thessalonikébe tervezték, mert Socrates szerint az volt a birodalom két részének a határa.

578 MARC. COM. 424. Minden bizonnyal azért csak két évvel később került sor az eljegyzésre, mert kivárták, hogy túléli-e a korai gyermekkort. Ugyanez történt Hunerich és Eudocia esetében is. A PLRE-t átvizsgálva világossá válik, hogy a tényleges házasságkötés után 1 éven belül megszületik az első utód, a második gyermek pedig 2-3 éven belül, ezért az ismeretlen házasságok meghatározásánál a legjobb támpont az első gyermek születésének meghatározása.

579 PROSP. TIRO. 454: "pactum de coniunctione filiorum"

580 Merobaud. CARM. 4.29-40. Gaudentius születését Merobaudes 4. carmenja alapján határozható meg. A szerző egy verssel ünnepelte Aëtius fiának születését.

581 Ezen a véleményen OOST 1968, 239, HeATHER 2006, 372. 
Gaudentius később is életben volt, ráadásul éppen Geiserich udvarában. ${ }^{582}$ 454-ben Gaudentius már házasodhatott volna, így minden bizonnyal Placidia nem érte el a minimális 12 éves korhatárt sem akkor, sem a következő évben.

Wes úgy gondolta, hogy Maximus Hunerich és Eudocia házasságát bontotta fel. ${ }^{583}$ 455-ben a lány 16 éves korával már bőven házasulandó korban volt, Malalas azonban azt közli, hogy amikor Geiserich Afrikába vitte őket, még szűz volt. ${ }^{584}$ Ugyanakkor az is kétségtelen, hogy Hunerich és Eudocia eljegyzésének felbontása igencsak meggondolatlan lépés lett volna Petronius Maximustól, figyelembe véve rendkívül ingatag helyzetét. Az adott körülmények között korántsem lett volna bölcs döntés kivívni egy olyan ember haragját, aki az elmúlt évtizedben számtalan alkalommal bizonyította, hogy képes ráerőltetni akaratát a nyugatrómai vezetésre, aki éppen a Rómában túszként tartózkodó fiának korábbi menyasszonyát megcsonkítva küldte vissza apjához, a vizigót királyhoz. Ezt támasztja alá Priskos is, aki szerint Maximus csak az özvegyet kényszerítette házasságra. ${ }^{585}$ Eudoxia kapcsolati állapotáról azonban nem tesz említést, ahogyan más keleti források sem. A gallaeciai krónikáson kívül más forrás egyáltalán nem említi, hogy akár Eudocia, akár Placidia eljegyzése felbontásra került volna, jó részük megelégszik azzal, hogy az "elrablás" tényét rögzíti. ${ }^{586}$

Hydatius maga közli, hogy Geiserich az özvegyen, illetve lányain kívül még Gaudentiust is magával vitte, tehát valamennyi jegyespárt. ${ }^{587} \mathrm{Ha}$ lett volna bármi alapja is annak, hogy Petronius Maximus felbontotta valamelyik lány eljegyzését, akkor nem valószínü, hogy Gaudentius még életben lett volna, amikor Geiserich megérkezik. Hydatius és Priskos után ezt az értelmezést Antiochiai János is alátámasztja, aki a 460-as évek elejével kapcsolatban azt közli, hogy Geiserich azért támadja Itáliát, mert korábban nem sikerült megszereznie Valentinianus és Aëtius örökségét. A történetíró szerint ugyanis előbbihez Eudocia nevében lett volna joga, aki fia felesége lett, utóbbihoz pedig Gaudentius révén, akit - az Antiochiai János által írottak értelmében is - magával vitt 455-ben és talán fiává is fogadta. ${ }^{588}$ Gaudentius tehát élt, és jegyessége is érvényben volt még azt követően is, hogy Geiserich magával vitte Észak-Afrikába. A vandál uralkodó ezzel kettős legitimációt szerzett Valentinianus örökségére. Egyiket fia és Eudocia 442-es eljegyzésével, a

582 Hyd. Chron. 160 (167), Prisc. Fr. 38.2. = I. Antioch Fr. 227. vö. Procop. De Bellis. 3.6.6. = Prisc. FR. 53.3.

583 WES $1967,132$.

584 JOH. MAL. 14.26 (366).

585 PRISC. FR. 30.1. = I. ANTIOCH FR. 224.4.

586 Hyd. Chron. 155 (162). vö. Jord. Rom. 335, Jord. Get. 235, Procop. De Bellis. 3.4-5, Chron. PASCH.

587 HYD. CHRON. 155 (162).

588 I. ANTIOCH FR. 227. 
másikat pedig Gaudentius örökbefogadásával, aki 454-ben Placidiát jegyezte el. Mindez tökéletes alkupozíciót jelentett a vandál uralkodó számára.

\subsubsection{Az ,elrablás"}

A 455-ös események értékelésével kapcsolatban ellentmondásosak a források. A Iustinianus korabeli számadásokkal szemben a kortárs források nem azt mondják, hogy Geiserich elrabolta (rapio) az asszonyokat, hanem azt, hogy visszatért (redeo) velük és ez óriási különbség. ${ }^{589} \mathrm{Az}$ emberrablás (raptus) ugyanis az egyik legfőbb bủn volt a római jogban, elsősorban negatív társadalmi hatásai miatt, ezért 326-ban Constantinus császár szigorúan szabályozta. ${ }^{590}$ A raptio, ahogy neve is mutatja, az alany akaratával ellentétes elhurcolást jeleni, ami magában foglalta a menyasszonyrablást, a kényszerházasságot és az ezzel járó testi erőszakot is. ${ }^{591} \mathrm{~A}$ házasságot megelőző jogi aktus az eljegyzés, amit a menyasszony és a vőlegény családja (apa) köt. Az eljegyzés bizonyos jogi szempontokból ugyanolyan megítélés alá esett, mint a házasság, éppen ezért felbontásának komoly következményei voltak. Ha a férfi szakítja meg az eljegyzést, azzal tönkreteszi a lány jövőjét, mert a közösség szemében könnyen kialakul az a kép a nőről, hogy valamilyen testi, vagy egyéb fogyatékosságban szenved, és a férfi ezért megszakította a kapcsolatot. Abban az esetben, ha a lány családja (apa) szakítja meg az eljegyzést, nyílt támadást követ el a jegyes becsülete ellen, amit annak meg kell bosszulnia, ha továbbra is a társadalom elismert tagja akar maradni. Éppen ezért az eljegyzések felbontása indikátora egy esetleges elrablásnak. Menyasszonyrablásra akkor is sor kerülhet, ha a lány családja családi vagy pénzügyi okok miatt folyamatosan halasztja a házasságot, a férfi pedig elunva a várakozást, a saját kezébe veszi a dolgok irányítását. ${ }^{592}$

Az menyasszonyrablás azonban csak akkor valósul meg, ha az idegen férfi, a kiskorút a törvényes képviselőjének hozzájárulása nélkül hurcolja el. 455-ben egyik lány sem volt már kiskorú, apjuk halott volt, és nem rendelkeztek más férfi rokonnal sem, viszont mindketten jegyben jártak, és jegyesükkel, valamint anyjukkal hagyták el Itáliát, ami nem minősül menyasszonyrablásnak. Ezt az elgondolást Malalas anekdotája teszi teljessé. A történetíró szerint

589 Hyd. Chron. 155 (162) vö. MARC. COM. 455, JORD. GET. 159. Ezzel szemben Marcellinus már az abduco igét használja, ahogyan Iordanes is. ProcoP. DE BELLIS. 3.5.3. vö. HDT. 6.79, 134. Prokopios pedig a fogoly ( $\alpha i \chi \mu \alpha ́ \lambda \omega \tau o v)$ szót használja.

590 COD. THEOD. 9.24.1.

591 COD. THEOD. 9.1.1, 9.2.5, 9.8.1, 9.14, 9.25, 9.38.4, 9.38.6-7. Történhetett váltságdíjért cserébe, de az is szóba jöhet, hogy a lány összejátszik elrablójával, hogy megszökhessen a szüleitől vagy a jegyesétől/férjétől.

592 Az emberrablás társadalmi hatásairól lásd EvANS-GRUBBS 1989. 
amikor Theodosius megtudta, hogy a vandál uralkodó Eudoxia biztatására tört Itáliára és fosztotta ki Rómát, mélységesen csalódott lányában, és a továbbiakban nem beszélt vele. Nem is beszélhetett, ugyanis 455-ben II. Theodosius már öt éve halott volt. Malalas "elszólása" azonban felfedi a konstantinápolyi propaganda esszenciáját. A konstantinápolyi udvar célja II. Theodosius "feltámasztásával" az volt, hogy igazolja: a családnak volt élő férfi rokona, amikor Geiserich elvitte a lányokat és anyjukat. Roger Scott Malalas személyében a konstantinápolyi udvar egyik hivatalos történetíróját tartja számon. ${ }^{593}$ Ebből már sejthető, hogy a konstantinápolyi udvar megkísérli menyasszonyrablásnak beállítani a történteket. Úgy gondolom, hogy nem Eudocia miatt teszik ezt, hiszen III. Valentinianus idősebbik lánya már jó ideje jegyben járt Hunerich-kel, ráadásul a történetírók abban is egyetértenek, hogy a pár házasságára nem sokkal azt követően került sor, hogy 455-ben visszatértek Észak-Afrikába. ${ }^{594}$

A problémák inkább Valentinianus kisebbik lánya, Placidia köré csoportosulhatnak, akivel kapcsolatban a keletrómai történetírók tendenciózusan igazolni igyekeznek egy 455 elötti házasságot, miközben láttuk, hogy Placidia a jegyesével hagyta el Itáliát, ugyanakkor távozásakor alig volt tizenkét éves. Alapvetően gyanúra ad okot, hogy a keleti auktorok a fiatalabb testvér házasságát az idősebbik elé helyeznék, de ami számunkra még furcsább lehet, az inkább az, hogy a keletrómai auktorok még csak nem is Gaudentiusszal házasítják össze Placidiát, hanem éppen azzal az Olybriusszal, akivel kapcsolatban az Aniciusok bemutatása kapcsán már említettük, hogy a 410es évek elején családjával Észak-Afrikába költözött. Ráadásul túlbuzgóságukban annyi hibát vétenek, hogy tovább erősíti azt a gyanút, hogy tudatos történetírói konstrukcióról van szó, amelynek egyetlen célja, hogy a vandál akciót menyasszonyrablásként állítsa be. De talán többröl is lehet szó. Talán a cél nem Geiserich tevékenységének befeketítése, hanem az, hogy Placidia legalább a források szintjén már Konstantinápolyban legyen, mire I. Leo hatalomra kerül.

A kútfők közötti különbségek ugyanis elsősorban a házasság idöpontjára vonatkoznak. Prokopios úgy állítja be Eudocia és Hunerich, valamint Placidia és Olybrius házasságát, mintha egymást követték volna. ${ }^{595}$ Evagrios szerint Olybrius elöbb eljegyezte Placidiát, majd összeházasodott vele. A történetíró szerint Marcianus parancsára történt az eljegyzés és a házasság,

593 SCOTT 2012A, 147-164. Elmondható, hogy a kutató szinte teljes munkássága ennek alátámasztására irányul, lásd részletesebben SCOTT 2012.

594 Forrásokra lásd. PLRE2 407-408, "Eudocia 1", PLRE2 564-565, "Hildericus", Procop. DE BELLIS. 3.9.10. Ezt az álláspontot Eudocia és Hunerich fiának életkora is igazolhatja. Hilderichet ugyanis Prokopios egy 530-as esemény kapcsán már nagyon öregnek nevez. Ha hitelt adunk a történetírói álláspontnak, akkor Hunerich 455-456-ban születhetett, így a Prokopios által leírt eseménykor már a hetvenedik életéve felett járhatott.

595 PROCOP. De BeLlis. 3.5.6. 
ezt azonban Aspar befolyásának fényében igencsak fenntartással kell kezelni. ${ }^{596}$ Malalas szerint, mialatt Eudoxia és Placidia vandál fogságban volt, Olybrius Konstantinápolyban élt, de sem az eljegyzéssel, sem a házassággal kapcsolatban nem közöl érdemi információkat. ${ }^{597}$ A 8. századi Theophanés már színesebben adja vissza a történetet. A történetíró szerint ugyanis Geiserich, miután megtudta, hogy Placidiának "már van férje", Licinia Eudoxiát és Placidiát is szigorú őrizetben tartotta, de Marcianus halálának évében szabadon engedte őket. ${ }^{598}$ Zónaras már viszonylag józanabbul igyekszik előadni a történetet. A 12. századi auktor szerint Geiserich Afrikában nem azt tudta meg, hogy Placidia házas, hanem azt, hogy jegyben jár. ${ }^{599}$ A történetírók csak egy dologban értenek egyet, nevezetesen, hogy Licinia Eudoxia és Placidia szabadon bocsátására két évvel "elrablásuk" után, még Marcianus idejében sor került. ${ }^{600}$

Az előbbi auktorok állításával szemben figyelemre méltó, hogy Olybrius nevét a kortárs Priskos és Hydatius első ízben 462-ben, azaz Leo uralkodása alatt említi. ${ }^{601}$ A kortársak hitelességét támasztja alá az is, hogy Olybrius és Placidia házasságából éppen 463 körül született egy lány, Anicia Iuliana ${ }^{602}$ néven. Közvetlenül ez előtt kerülhetett sor a házasságra, majd valamivel utána a fogantatásra. ${ }^{603}$

Látható, hogy érdekes ellentét feszül a két forráscsoport között, hiszen míg a kortársak a 460-462 közé helyezik a menyegzőt, addig Prokopios, Evagrios, Malalas, Theophanés és Zónaras igyekeznek Marcianus halála elé, Leo uralkodása elé pozicionálni Olybrius és Placidia házasságát. ${ }^{604}$

596 EVAGR. HE. 2.7.

597 JOH. MAL. 14.26 (365-366).

598 THEOPH. AM. 5947, 5949.

599 ZON. 13.25.26-28.

600 vö. Clover 1978, 177-178, ZON. 13.25.26-28. vö. CYr. SCYTH. V. EUTH. 30, Frank Clover perdöntő forrásként vezette be, hogy Olybrius még a 6. század eleji görög hagiográfus Kyrillos Skythopolités Megas Euthymios (377-473) örmény remete életrajzában is felbukkan. Skythopolités szerint II. Theodosius halálának időpontja (450. július 28.) és Iuvenalios jeruzsálemi pátriárka újbóli beiktatása között (452) Theodosius felesége, Athenais, vagyis császári nevén Aelia Eudocia elfordult el az ortodoxiától és Eutychés tanításában keresett menedéket. Skythopolités szerint nem sokkal ez után leveleket kapott "lányának vejétôl", vagyis Olybriustól, aki kérte, hogy csatlakozzon ismét az egyetemes egyházhoz. Skythopolités leírása értelmében Olybrius a leveleket 453 vége és 455 június között írhatta nagyanyósának, Eudociának. Ez a feltételezés azonban ugyancsak sérül Placidia fiatal kora miatt.

601 PRISC. FR. 38, HYD. CHRON. 211 (216).

602 PLRE2 635-636, “Anicia Iuliana 3.” vö. PLRE1 468, “Anicia Iuliana 2.”. A lány apai nagyanyja, Anicius Hermogenianus Olybrius (cos. 395) felesége után kapta a nevét.

603 PLRE2 635-636, “Anicia Iuliana 3.”, PLRE2 795, “Olybrius 3.” Anicia Iulianának egy fia született, aki 491-ben töltött be a consulságot, ez is 460 után időpontot valószínüsíti.

${ }^{604}$ MARC. COM. 455.3, JORD. ROM. 335. De olyan beszámolók is akadnak, így például a 6. századi Marcellinus comes és Iordanes, akik teljesen elhallgatják a házasságot, illetve szabadon bocsátásuk körülményeit. 
Véleményem szerint a 6 . századi, és az ezt követő időszak keletrómai történetíróinak eljárása kettős célt szolgált. Egyrészt azt, hogy Geiserichet a menyasszonyrablóként tüntessék fel, másrészt azt, hogy legitimációt biztosítsanak I. Leo uralkodásához A 457. februárjában hatalomra kerülő császár és elődje között volt egy lényegi különbség. Leóval szemben Marcianus, felesége révén, már kapcsolatban volt a Theodosius-dinasztiával, hiszen számára a legitimációt az özvegy Pulcheria augusta jelentette. Az eset tökéletesen összhangban van Nagy Theodosius hatalomra kerülésével, aki ugyanezt Galla révén érte el, míg azonban Theodosius második felesége több gyermekkel is megajándékozta az uralkodót, ráadásul korábbi házasságából is születtek gyerekei, addig Marcianus nem tudott felmutatni egyenes ági leszármazottat dinasztiabeli feleségétől. Pulcheria ugyanis 414-ben szüzességi fogadalmat tett, amit élete végéig meg is tartott. ${ }^{605}$

A korszakra jellemző dinasztikus kapcsolatkeresés jelentőségét és a Theodosius-dinasztia jelentőségét a legitimáció megteremtése terén szemléletesen érzékelteti Marcianus diadaloszlopának elhelyezkedése, amelyet nem sokkal Pulcheria halála előtt állítottak fel. ${ }^{606}$ Míg a korábbi uralkodók diadaloszlopai a központban, a város fö útvonalai mentén helyezkedtek el, addig Marcianusét a palotaegyüttestöl lényegesen messzebb, Konstantinápoly 11. kerületében állították fel, éppen Pulcheria villájának szomszédságában. ${ }^{607}$ A császárok diadaloszlopai évszázadokon át egyértelmü reprezentációs célt szolgáltak, ennek megfelelően gondosan megválasztották, hogy hova helyezik el őket. ${ }^{608}$ A konstantinápolyi császári diadaloszlopok közül csak Marcianusé áll félreeső helyen, ráadásul Theodosius-dinasztiabeli felesége villájának közelében, ami világos utalás lehetett arra, hogy a dinasztia nélküli császár igyekezett egyesülni felesége családjával, ha már erre természetes módon nem volt lehetősége. Ezt csak megerösíti, hogy 452-ben, amikor a diadaloszlopot felállították, még csak dinasztikus nyomás sem volt, hiszen az emlékmü felállításakor még senki sem sejtette, hogy három év múlva a Theodosius-dinasztia férfiágon kihal, a dinasztia utolsó leszármazottai pedig a vandál uralkodó fogságába esnek.

${ }^{605}$ A 20. századi kutatástörténetben Pulcheriáról kivétel nélkül a jámbor és istenfélő asszony képe uralkodott, ez azonban történetileg csak részben megalapozott. HoLUM 1989, 98-111, Ezt a nézetet elsősorban Holum alakította ki a Theodosius-dinasztia császárnőiről írt monográfiában. Ez alapján kialakult az a nézet, hogy a császárnő jámborsága a legfőbb attribútuma a császárnők hatalmának. A modern kutatás ezzel szemben már azt tartja, hogy ezt az idealizált képet a késő bizánci történetírók festették a császárnőről. A régészet és a Konstantinápollyal foglalkozó topográfia Pulcheria -történetírók által elbeszélt - temérdek vallásos rendeltetésü épülete közül csak egyet tud azonosítani. Részletesebben lásd: Wortley 1980, MANGo 1985, Angelova 2014, Angelova 2015.

606 A diadaloszlopot a város praefectusa dedikálta a császárnak, így minden bizonnyal 452-ben került felállításra. "[Pr]incipis hanc statuam Marciani | cerne torumque | [prae]fectus vovit quod Tatianus | opus" CIL 3.738.

607 MÜLLER-WIENER 1977.

608 Mango 1985, 46, ANGElova 2014, 95. 
Marcianus tanácsadói - akárcsak a császár oszlophelyének kijelöléskor - hasonló gondossággal jártak el a dinasztia utolsó egyenes ági leszármazottainak esetében is. Ahogy Priskostól megtudjuk, mihelyt tudomást szereztek a hercegnők elrablásáról, egy követséget menesztettek Geiserich-hez, azt kérve, hogy engedje szabadon öket. ${ }^{609}$ A követek azonban újra és újra eredmény nélkül tértek vissza Konstantinápolyba. A császár ezt követően levelekben kérte a vandál uralkodót, hogy engedje szabadon túszait, de így sem ért el sikert. Végül egy ariánus püspök, Bleda útján igyekezett rábírni Geiserichet a túszok szabadon bocsátására. A korábbiakkal szemben Bleda már erélyesebben tárgyalt a vandál uralkodóval, de fenyegetései is hatástalannak bizonyultak. Közel egy évig sikertelenül jártak Konstantinápoly és Észak-Afrika között a követségek. Geiserich, felbátorodva a keletrómai udvar tehetetlenségén, 456 első felében feldúlta Szicíliát és Itália szomszédos partvidékét, ezt egészen addig folytatta, ameddig nem született mindkét fél számára megegyezés. ${ }^{610}$ 457. január 27-én, amikor meghalt Marcianus, Licinia Eudoxia, Eudocia és Placidia még mindig vandál király észak-afrikai udvarában voltak.

A 450-es évek végére Konstantinápolyban az egyetlen dolog, ami az embereket Theodosius örökségére emlékeztette, Marcianus diadaloszlopa volt, a város egyik félreeső kerületében. Az évtizedek során mind jobban fakuló emlékezetet kihasználva a 6. század közepére merőben más narratívák keletkeztek.

\subsection{Theodosius örököseinek kiszabadítása}

455 júniusától, attól a perctől, hogy Geiserich partra szállt Karthágó kikötőjében, az elkövetkező két évtized eseményeit ő határozta meg, legalábbis egy pontig. Valós legitimációt a birodalom mindkét felében Theodosius örökösei jelentettek. A vandál uralkodó 435-re elérte, hogy övé legyen Africa termékenyebb területe, majd megszerezte és egyeduralkodóvá tette a helyi római flottát, amellyel fél évtized múlva már Itália déli partjait fenyegette. 442-ben Aspar tevékenysége révén további engedményeket ért el. Nem sokkal visszaérkezését követően ismét hajóra szállt, és Szicília kifosztására indult. ${ }^{611}$ Galliában eközben a birodalom nyugati felének egyetlen ütőképes hadserege császárrá választotta Avitust, akinek az első dolga volt, hogy megkísérelje a vandál probléma

609 PRISC. FR. 31. Priskos az első követséget Avitus uralkodása idején indult Észak-Afrikába, így 455 nyara és a következö év között indulhattak el. Lásd következö lábjegyzet.

610 HYD. CHRON. 169 (176), 170 (177) vö. 171, PRISC. Fr. 31. A vandálok támadását és itáliai partraszállási kísérletét előbb Ricimernek sikerült visszavernie, majd Marcianus serege gyilkolt le egy vandál sereget Corsica szigetén. A szvév Rechiart 456 decemberében halt meg, ezért Ricimer és Marcianus vandálok ellen vezetett hadjáratára is ebben az ében került sor.

611 PRISC. FR. 32. Priskos a következő támadás alkalmával megjegyzi, hogy Geiserich ismét a partvidéket pusztítja, tehát 456 tavasza előtt volt még egy vandál támadás a Szicília és Itália féli partjai ellen. 
megoldását. 456 elején Sidonius Apollinaris a császár tiszteletére írt panegyricusában világossá tette, hogy Avitus terve az, hogy egy vizigót-római koalíció élén Geiserich ellen vonuljon. A tényleges katonai lépések elött követséget küldött Geiserich-hez, amelyen keresztül a 442-es békeszerződés betartatását kérte, de hiába. ${ }^{612}$

A vandál uralkodó tovább folytatta Szicília és Itália déli partvidékének fosztogatását. Megtehette, hiszen a birodalom egyik felével sem történt megállapodás a helyzet rendezéséröl. Így elébe is ment Avitus készülő hadjáratának. Még 456-ban egy hatvan hajóból álló flottát indított Karthágóból Szicília irányába. Katonái Agrigentumnál próbáltak partra szállni, ezt azonban Avitus egyik hadvezérének, Ricimernek sikerült megakadályozni. A vandál flotta ezt követően a partok mentén Gallia irányába indult, minden bizonnyal azzal a céllal, hogy a vizigótokra is figyelmeztető csapást mérjenek. Ricimer azonban üldözőbe vette a rajt, és Korzika szigeténél vereséget mért rájuk. A vandál flotta maradéka visszavonulót fújt. ${ }^{613}$ Ricimer két győzelme ellenére Avitus nem tudta átvenni a kezdeményezést, amelynek okát több tényezőben láthatjuk. Egyrészt Geiserich Róma kifosztása alkalmával Valentinianus utódain kívül a kincstárat is magával vitte, ezen kívül 442 óta ellenőrzése alá vonta a Rómába irányuló gabonaforgalom egészét. Valentinianus és Aëtius halálával az addig érkező gabonaszállítmányok is elapadtak. Megfelelö gabonaellátás hiányában Avitus nem vállalkozhatott nagyobb katonai expedícióra. Az újdonsült nyugati császár gondjait csak tetézte, hogy Róma kifosztásával egyidejüleg Hispániában a szvévek is felbontották Rómával kötött egyezségüket, és elkezdték támadni Hispania Carthaginiensist és Hispania Tarraconensist. ${ }^{614}$ Avitus személyesen ment II. Theoderich király udvarába azzal a céllal, hogy rábírja a vizigót uralkodót egy szvévek elleni hadjáratra, ami ugyan sikerült, azonban a vandálok elleni hadjáratának tervét már figyelmen kívül hagyták a galliai Tolosában. Ez egyben el is döntötte Avitus hadjáratának sorsát, hiszen azzal, hogy a vizigótokat a szvévek ellen küldte, hivatalosan is elismerte II. Theoderich területi igényét Hispániára, ami korántsem talált megértő fogadtatásra Konstantinápolyban. Ennek tükrében korántsem meglepő, hogy Avitus egyike azoknak a nyugati uralkodóknak, akiket a keletrómai udvarban nem fogadtak el hivatalosan. Támogatók híján, egykori hadvezére, Ricimer könnyen fölé nőtt, ráadásul a senatus támogatását is sikerült megszereznie.

Petronius Maximus és Avitus után - Ricimer hathatós közremüködésével - Maiorianus (457-461) szerezte meg a hatalmat, aki folytatta az Avitus által megkezdett utat. Priskos szerint ugyanis, miután szövetségeseivé tette a galliai gótokat, majd alávetette a szomszédságában élő

612 Prosp. Tiro. 455, Sid. ApOll. CARM. 7. vö. PrisC. Fr. 32.

613 Hyd. Chron. 169 (176), PrisC. Fr. 32, Sid. APOLl. CARM. 2.367.

614 HYd. CHRON. 161 (168), 163 (170). 
népeket, egy háromszáz hajóból álló flottát gyüjtve arra készült, hogy Geiserich ellen vonul. A vandál uralkodó ekkor követséget küldött, hogy tárgyalás útján rendezzék a helyzetet. Ez az első jele annak, hogy Geiserich hajlott a megegyezésre. Ennek oka minden bizonnyal abban keresendő, hogy Geiserich Eudociától született unokája ekkorra már elérte az egyéves kort. A ravennai udvarban ilyen idős korban került sor a keresztelőre és az eljegyzésekre, mert a szülők ekkorra már biztosak lehettek benne, hogy gyermekük életben marad. ${ }^{615}$ Maiorianus azonban nem egyezkedett, ezért Geiserich elöbb felégette a mórok földjét, majd megmérgezte a térség kútjait annak érdekében, hogy megakadályozza a nyugatrómai csapatok átkelését Hispániából Észak-Afrikába. ${ }^{616}$ Maiorianus súlyos vereséget szenvedett és visszavonulásra kényszerült. ${ }^{617}$ Itáliába érve elbocsátotta segédcsapatait, és néhány követőjével Rómába indult. Antiochiai János beszámolója szerint útközben Ricimer néhány követője rajtuk ütött, Maiorianust agyonverték, levágták a fejét, elvették a diadémját és a tunikáját majd Ricimerhez siettek. ${ }^{618} 461$ augusztusától, Maiorianus halálával négy hónapos interregnum következett. Ekkor kezdődtek a valódi tárgyalások.

\subsubsection{A megegyezés}

Ahogyan 455-ben és 457-ben, a keletrómai kormányzat most sem szólt bele a nyugatrómai uralkodó megválasztásába, de egyáltalán nem azért, mert Ricimer magister militum megfelelt volna bárkinek is a konstantinápolyi udvarban. ${ }^{619}$ Valójában I. Leo is kritikus helyzetben volt, hiszen elődjéhez képest őt már semmi sem kötötte a Theodosius-dinasztiához, miközben Aspar magister militum gyámkodását, ${ }^{620}$ akárcsak elődjének, úgy neki is el kellett türnie, noha ezt egyre nehezebben viselte. Konstantinápoly számára a prioritást így továbbra is Licinia Eudoxia és

615 lásd MEROBAUD. CARM. 1-2., Gyermekhalandóságra: HARLOW-LAURENCE 2001, 8-10.

${ }^{616}$ PRISC. FR. 36.1

617 Datálásra HYD. Chron. 195 (200).

618 PRisC. Fr. 36.2 = I. ANTIOCH FR. 226, Blockley 1983, 394, 145. lj., MARCELLINUS 461.

${ }^{619}$ CIL 13.2363 vö. CIL 13.2359. A Lugdunumban elökerült felirat, ami csak I. Leo nevét tartalmazza világosan mutatja, hogy Keleten egyáltalán nem fogadták el sem Ricimert, mert az általa megválasztott uralkodókat.

${ }^{620}$ DE CER. 1.91 (R412-416) vö. MARC. COM. 471 "Aspar primus patriciorum". Aspar és I. Leo kapcsolatának legszebb példáját a De Ceremoniis szolgáltatja, amely megőrizte a császár beiktatási ünnepségének részleteit. 457. február 9-én Konstantinápoly Hebdomonnak nevezett külvárosában a sereg közfelkiáltással megválasztotta Leót, aki ezt követően egy hosszú menetben vonul a külvárosból a palota irányába. Miután a palotában felöltötte a császári díszruhát, a császár felszállt egy fogatra, hogy a menet következő részét teljesítse. A kocsin azonban nem egyedül volt. Csatlakozott hozzá - Marcellinus szerint - az "első patricius", Aspar, aki kezet csókolt a császárnak. Amikor a fogat elérte a Constantinus forumát, Leo leszállt, hogy köszöntse a senatust és a városi praefectust, mielőtt felajánlja neki az arany koronát (modiolus) a senatus vezetöje, aki ugyancsak Aspar volt. Az ünnepség ezt követően a forumon, a Hippodromban és a palotában folytatódott, mindenhol kölcsönös közfelkiáltásokkal. Az ünnepség során Aspar egy pillanatra sem távolodott el Leótól. 
Placidia kiadatása jelentette. 461 nyarától Leo aktív diplomáciára kényszerült, miközben Ricimer nyugaton továbbra is folytatta önálló politikáját. Maiorianus halála után előbb elüldözte Maiorianus egyik hadvezérét, Marcellinust, ${ }^{621}$ majd követeket küldött Geiserich-hez és figyelmeztette a korábbi megállapodások betartására, továbbá Valentinianus leszármazottainak elengedését kérte, hiába. A vandálok továbbra is rendszeresen, és egyre hevesebben pusztították Szicília és Dél-Itália partvidékét.

Ricimer 461 novemberében, megunva Konstantinápoly tehetetlenségét, ismét kezébe vette a kezdeményezést és Libius Severust helyezte a nyugati birodalom élére, amit Leo természetesen nem fogadott el. Priskos szerint Geiserich Itália elleni támadásai egyre intenzívebbé váltak, mert a vandál királynak is megvolt a jelöltje a nyugati birodalomrész vezetésére Olybrius személyében. ${ }^{622}$

Ez az első alkalom, hogy a birodalom nyugati része feletti hatalmi igényeket nem Gaudentiusra vagy Hunerich Eudociával kötött házasságával igazolja Geiserich. Priskos 38. töredékében az interregnum alatti hatalmi taktikázást mutatja, azonban figyelembe kell venni, hogy a szerző 461 novemberénél egy lényegesen tágabb időintervallumot tekint uralkodó nélküli állapotnak, hiszen a konstantinápolyi udvarban Libius Severus megválasztását nem ismerték el. Priskos "interregnuma" így túlmutat 461 novemberén. Ebbe a tágabb idősávba már illeszkedik Hydatius leírása, aki szerint Licinia Eudoxia szabadon bocsátása 462-ben történt, lányaival kapcsolatban pedig a házasságkötések tényét rögzíti. ${ }^{623}$

Prokopios Anthemius 467-es megválasztása kapcsán jelzi, hogy Geiserich "továbbra is"

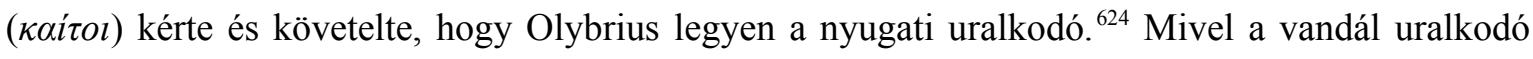
nemcsak Libius Severust, hanem Anthemiust sem ismerte el, feltételezhetően a 462-ben végül bekövetkező szabadon bocsátás feltétele az lehetett, hogy Placidia leendő férje lesz a Nyugatrómai Birodalom uralkodója. Olybrius személye egy kompromisszumos megállapodás eredménye lehetett. Az egyik leggazdagabb római arisztokrata család sarjaként még gyermekkorában Afrikába került anyjával és nagyanyjával. Elképzelhető, hogy a 442-es területcserét előirányzó megállapodás

621 PRISC. Fr. 38, BLOCKLEY 1983, 394, lj. 147. Marcellinus a dalmatiai csapatok katonai parancsnoka volt, aki azt követően lázadt fel III. Valentinianus ellen, hogy a császár megölte barátját Aëtiust. Maiorianusnak (457-461) mindenesetre hüséget fogadott, aki el is küldte Szicíliába, hogy védje a szigetet a vandálok ellen. Priskos szerint Maiorianus halála után Ricimer megnyerte magának Marcellinus osztrogót követöit, akik serege magját alkották. A történetíró szerint ugyanis a hadvezér nem vetekedhetett Ricimer gazdagságával, ezért inkább elhagyta elhagyta Szicíliát és minden bizonnyal visszatért Dalmatiába.

${ }^{622}$ PRISC. Fr. 38.1, BLOCKLEY 1983, 395, lj. 149.

623 Prisc. Fr. 38.1. vö. Procop. De Bellis. 3.6.6. = Prisc. Fr. 53.3., Hyd. Chron. 211 (216). Hydatius pontatlanul adja meg a házastársakat, Hunerich helyett ugyanis Geiserich másik fiát, Gentót jelöli III. Valentinianus egyik lányának házastársaként, míg másik lányát férjének Olybrius jelöli meg.

624 Procop. De BeLLis. 3.6.6. 
előestéjén vagyonukat Konstantinápolyba menekítették, erre utalhat a konstantinápolyi Olybrius körzet elnevezése. ${ }^{625}$ A keletrómai tárgyalófél most is Aspar lehetett. Geiserich-nek vállalnia kellett, hogy félreállítja Gaudentiust. ${ }^{626}$ Olybrius nyugatrómai császárrá történő kinevezése azonban még 467-ben sem történt meg, ráadásul ezt az információt is csak a lehető legkésőbb közölték Geiserich-kel. Priskos beszámolója szerint az itáliai portyázások valódi indoka nem is abban rejlett, hogy Olybrius nem lett császár, hanem abban, hogy Geiserich nem kapta meg Valentinianus és Aëtius után az örökséget, az előbbiét Eudocia miatt, aki fiának felesége lett, a másikat pedig Aëtius fia, Gaudentius miatt, aki vele élt. ${ }^{67}$ Geiserich tehát a Konstantinápollyal kötött megállapodás keretein belül lemondott Gaudentius jegyességéről és az ezzel járó biztos elönyökről, cserébe azt kérte, hogy a férj legyen a következő uralkodó. Ezzel a megállapodással Geiserich úgy érezhette, hogy befolyási körzete egyre csak nő, miközben a keletrómai kormányzat is jól járt, hiszen Valentinianus utódainak érdekeit is megóvta.

Figyelemre méltó, hogy a vandálok elleni tényleges mozgósításra csak azt követően került sor, hogy Valentinianus utódai 462-ben Konstantinápolyba kerültek. A császár követek útján közölte a vandál uralkodóval, hogy nem Olybrius, hanem Anthemius lett a nyugati részek ura, Geiserich a keleti területeket kezdte fosztogatni. ${ }^{628}$ Anthemius 467-es kinevezése a nyugati részek élére összhangban állt a vandálok elleni katonai akció előkészületeivel. Ez azzal kezdődött, hogy a konstantinápolyi követ, Phylarchus kerülővel érkezett a vandál udvarba. Előbb ugyanis Dalmatiába ment, ahol a császár oldalára állította Maiorianus egykori hadvezérét, Marcellinust, majd a vandál uralkodó udvara felé vette az irányt. Hydatius szerint Marcellinus 464 végén már ismét Szicíliát védte a vandál betörésekkel szemben. ${ }^{629}$ Geiserich udvarában azonban sikertelennek bizonyultak a tárgyalások, mert Geiserich még mindig Valentinianus és Aëtius tulajdonát követelte. ${ }^{630}$ Úgy gondolta ugyanis, hogy fia Eudociával kötött házassága miatt még mindig igényt tarthat a birodalom nyugati felére. ${ }^{631}$

Miután Phylarchus közölte Geiserich-kel, hogy a császár Anthemiust helyezte a nyugati

625 Olybrius körzetéröl: MAGDALINO 2001, 58-59.

626 Akár úgy, hogy felbontja az eljegyzést, de akár úgy is, hogy megöli, bár erre csak utalhattak. Az eltünt jegyes/házastárs tünik a legjobb megoldásnak. A római jog szerint a jegyes/férj eltünése esetén a házastárs egy idő után újraházasodhatott.

627 Prisc. Fr. 38.2. = I. Antioch Fr. 227. vö. Procop. De Bellis. 3.6.6. = Prisc. Fr. 53.3. Blockley 1983, 395, lj. 151.

628 Procop. DE BELlis. 3.6.22-24 vö. PrisC. Fr. 39.

629 HYD. CHRON. 223 (227).

630 PRISC. FR. 39 vö. OOST 1968, 307. Ezzel szemben Oost valamilyen keleti területre gondol, ami III. Valentinianus örökölhetett.

631 OosT 1968, 307. Ezzel szemben Oost valamilyen keleti területre gondol, ami III. Valentinianus örökölhetett. 
részek élére, világossá vált a vandál uralkodó számára, hogy Olybrius megválasztására irányuló próbálkozásai megfeneklettek, ezért keleten Illyriát, a Peloponnésos nagy részét és a görög szigetvilágot vette célba, amelyet Prokopios szerint felváltva fosztogatott. ${ }^{632}$

\subsubsection{A nobilissimák hazatérése}

A keletrómai udvar időhúzása érthető, hiszen már 462-ben, Licinia Eudoxia és Placidia Konstantinápolyba érkezésével elérték céljukat. III. Valentinianus lányának és özvegyének jelentősége elsősorban nem csupán az utolsó Theodosius-dinasztiabeli császárhoz füződő vérségi kapcsolatban rejlett, hanem az ehhez kapcsolódó nobilissima címben, illetve az ehhez kötődő udvari gyakorlatban, ami véleményem szerint a dinasztián kívüli uralkodók esetében a legitimáció alapját adhatta.

A nobilissimus/nobilissima kitüntető cím már Constantinus idején megjelent, aki néhány családtagjának juttatta a címet. A császár, apja második házasságából született féltestvéreinek, Hannibalianusnak, Iulius Constantiusnak és Dalmatiusnak adományozta a címet. ${ }^{633}$ Néhány évtizeddel később, Iovianus beiktatásakor (363) a új császár első döntése nyomán nobilissimusszá tette az akkor egyéves fiát, Varronianust. ${ }^{634}$ 421-ben Honorius császár nobilissimus címmel ruházta fel az ekkor alig kétéves III. Valentinianust, aki 423-ban előbb caesar, majd ötéves korában augustus lett. ${ }^{63}$ A kis Valentinianus beiktatására azért volt szükség, mert a császár, saját gyermeke nem lévén, nővére fiát ruházta fel a kitüntető címmel.

Míg a fenti kinevezéseket kivétel nélkül férfiak viselték, addig a Chronicon Paschale merőben más megközelítésből ír a címről. A Húsvéti krónika bejegyzései egyszerủen nobilissimának nevezi a Theodosius-dinasztia nőtagjait, így ők minden bizonnyal nem kinevezés útján jutottak a birtokába, hanem születésüktől fogva nobilissimának minősültek. ${ }^{636}$ Arcadius $397-$

${ }^{632}$ PROCOP. DE BeLlis. 3.6.23.

633 PLRE1 407, "Hannibalianus 2.”, PLRE1 226, "Iulius Constantius 7.”, PLRE1 240-241, “Fl. Dalmatius 6". Constantius Chlorus második feleségétől, Theodorától született hat gyermeke Dalmatius, Iulius Constantius, Hannibalianus, Constantia, Eutropia és Anastasia. Zos. 2.39.2. vö. PHILOSTOR. HIST. ECCL. 2.16a. Philostorgios szerint Constantinus féltestvéreit Dalmatius, Hannibalianus, és Constantiust tette nobilissimusszá. A kutatás szerint a császár nem a féltestvéreit iktatta be a tisztségbe, hanem az azonos nevü unokaöccseit, így természetesen ezt a verziót sem lehet kizárni, de a kérdés nem dönthetö el egyértelmüen.

${ }^{634}$ PhILOSTOR. Hist. ECCL. 8.8. Philostorgios szerint Ancyrába (ma Ankara) érve Iovianus epiphanestatosszá (nobilissimus) tette Varronianus nevü fiát.

${ }_{635}$ PHILOSTOR. Hist. ECCL. 12.12.

${ }^{636}$ Arcadius valamennyi gyermeke a nobilissima/nobilissimus cím birtokosa volt. CHRON. PASCH. 397 (Flaccilla), 399 (Pulcheria), 400, 414 (Eudocia, Arcadia), 401 (Theodosius), 403 (Marina). Flaccilla, Pulcheria és Marina esetében rögtön születésének pillanatában említésre kerül a cím. 
ben született lánya, Flaccilla is a cím birtokosa volt, de a dinasztiába beházasodó Eudocia, Theodosius athéni pogány családból származó felesége is megkapta a címet.

A Chronicon Paschale ugyanakkor fontosnak tartotta megjegyezni, hogy II. Leo a nobilissima Ariadne indíttatására helyezte a koronát Zeno fejére. ${ }^{637}$ Ariadne pontos leszármazása bizonytalan, csupán annyi bizonyos, hogy apja I. Leo volt, anyja pedig Verina. Míg Leo egyszerü családból származott, addig több jel is arra mutat, hogy Verina előkelő felmenőkkel rendelkezhetett. Egyrészt lányát, Ariadnét két egyszerü származású császár is feleségül vette Zeno és Anastasius személyében. Továbbá ezt erősíti az is, hogy Pseudo-Zacharias rétor a nobilissimus szír megfelelőjét ('pypnstss) használja Marcus esetében, aki Basiliscus fia volt. ${ }^{638}$ Az előkelő felmenők tehát Verina és testvére, Basiliscus esetében is fellelhetőek. A család pontos leszármazása adatok híján azonban visszakövethetetlen.

Amint láttuk, 455-ben a Theodosius-dinasztia férfiágának kihalásával érdekes helyzet állt elő a birodalom mindkét felében. Konstantinápolyban Marcianus legitimációját Arcadius lánya, Pulcheria jelentette, miközben a Theodosius-dinasztia nyugati ágának női leszármazottai Karthágóban voltak Geiserich örizete alatt, ahonnan csak 462-ben tértek vissza. Konstantinápolyban ekkor házasodott össze Anicius Olybrius és Placidia, házasságukból pedig megszületett Anicia Iuliana, akit a Chronicon Paschale ugyancsak nobilissimának nevez. ${ }^{639}$ Placidia lánya minden bizonnyal születésénél fogva viselte a címet, ahogyan anyja is.

III. Valentinianus lányának Konstantinápolyba érkezésének jelentőségét a 10. századi De Ceremoniis világítja meg. A nobilissimus beiktatására vonatkozó protokoll az eltelt évszázadok során sokat finomodhatott, a cím mögött húzódó gondolatiság azonban aligha. A nobilissimus beiktatási ünnepségén Konstantinápoly lakossága mellett a senatus tagjai, a Hippodrom pártjai, valamint a scholae palatinae és más katonai alakulatok is részt vesznek. Az uralkodók a Tizenkilenc Akkubita termében foglalnak helyet, jobb és bal oldalukon egy-egy caesar ül. A beiktatási ünnepségen részt vevő magistratusokat fontossági sorrendben hívják a terembe. Elsőként a kouropalatés csoportja érkezik, őket a magistroi követik, végül pedig a patriciusok érkeznek a terembe. Ezt követően megvitatják az aspiránsokkal kapcsolatos kérdéseket, majd távoznak a teremből. A uralkodók is kivonulnak a teremből és a néptől is azt kérik, hogy vitassák meg a jelöltekkel kapcsolatos kérdéseket. Ezt követően, az időközben felállított hordozható oltárhoz lépnek, ahova az első nobilissimust is odavezetik. A pátriárka a hordozható oltár előtt áll, az uralkodók mellette, mögöttük a caesarok, őket pedig a nobilissimus követi. A közös imádságot

637 CHRON. PASCH. 474.

${ }^{638}$ Ps.-Zach. Rhet. Chron. 5.a., Greatrex 2011, 172. 1. lj.

639 ChrON. PASCH. 517. 
követően az uralkodó a nobilissimusra adja az elökészített chlamyst, majd megcsókolja. Az aktust az egybegyültek jókívánságai követik. Az éltetés után az uralkodók, a caesarok és a nobilissimus visszamennek a terembe, ahol az uralkodó és a caesarok leülnek, a nobilissimus pedig jobb oldalukon áll. Ezt követően az udvar is bejön a szokásoknak megfelelően. A senatus kinyilvánítja tiszteletét és csókot ad, a nobilissimusnak kezet csókolnak, majd kivonulnak a teremböl. A nobilissimus beiktatási protokollja záró soraiban felhívja a figyelmet arra, hogy a csók által a uralkodó és a nobilissimus közösségbe került az uralkodókkal, tehát az augustus és az augusta családjának részévé vált. ${ }^{640}$ Nyilvánvaló, hogy ez a kapcsolat fordítva is érvényesült. Nem csupán a nobilissimusok számára lehetett kiváltság, hogy a császárral közösségbe kerültek, hanem egy idegen származású császár számára is fontos lehetett, hogy némelyekkel formális kapcsolatot létesítsen. A dolog jelentőségére Marcellinus comes krónikájának szóhasználata világít rá.

Iustinianus uralkodása idején készült történeti munkájában Marcellinus a római uralkodók megnevezésére elsősorban az augustus, ${ }^{641}$ imperator $^{642}$ és a caesar $^{643}$ szavakat használja. Az előbbi használatával a keletrómai uralkodók elsőbbségét domborítja ki. A sor Octavianusszal kezdődik, akinek szimbolikus jelentősége van, hasonlóan Gratianushoz. A sirmiumi születésü császár

640 DE CER. 1.44 [R226-228].

641 Marcellinus krónikájában 22 alkalommal fordul elő az augustus szó: praef (2), 379.1, 383, 394.1, 414.1 424.1, 431.1, 452.1, 453.2, 462 (2), 476.2 (2), 483, 485, 487, 491, 512.9, 515.6, 519.2, 532, amelyek közöl a következőek köthetők uralkodókhoz: Octavianus (476.2 (2)), Gratianus (379.1), I. Theodosius (383, 394.1), II. Theodosius (431), Pulcheria augusta (414.1, 453.2), Placidia augusta (424.1), Marcianus (452.1), Leo (462 (2)), Zeno (483, 485, 487, 491), Ariadne augusta (515.6), Iustinus (praef., 512.9, 519.2), Iustinianus (praef., 532).

${ }^{642}$ Marcellinus krónikájában az ismeretlen szerzőtől származó kiegészítést is figyelembe véve 72 alkalommal fordul elö az imperator szó: praef, 379.1, 380, 381.2, 383.3, 385, 388.1, 389.1, 389.4, 391.1, 391.2, 392.1, 394.1, 407, 408.3, 416.2, 421.1, 422.1, 423.5, 424.2, 425.2, 430.1, 431.3, 432.2, 434, 435.1, 436, 437, 438.3, 439.1, 443.2, 444.4 (2), 450.1, 453.4, 454.2, 457.1, 458, 467.1 (2), 472.2, 474.1, 475.2, 476.2, 490, 491.1, 494.1, 500.2, 511, 512.4, 512.9, 515.2, 516.1, 516.3, 517, 518.2, 518.3, 519.1, 527, 533, additamentum, 535.1, 537.2, 537.5, 538.1, 540.3, 540.6, 545.3, 546.1, 546.3, 547.1, 548.2, amelyek közül a következőek köthetők uralkodókhoz: Gratianus (383.3), I. Theodosius (praef, 379.1, 380, 381.2, 385, 388.1, 389.1, 389.4, 391, 435.1), II. Valentinianus (391.2, 392), Eugenius (394.1), I. Constantinus (407), Arcadius (408.3, 416.2), II. Theodosius (421.1, 422.1, 424.2, 430.1, 431.3, 436, 439.1, 443.2, 444.4 (2), 450.1), Honorius (423.5), III. Valentinianus (425.2, 432.2, 434, 437, 438.3, 453.4, 454.2), Marcianus (453.4, 457), I. Leo (458, 467, 474.1), Anthemius (467, 472.2), Glycerius (475.2), Zeno (490), Anastasius (491.1, 494, 500, 511, 515.2, 516.1, 516.3, 517, 518.2, 518.3), Iustinus (512.9, 519.1, 527), Iustinianus (533, additamentum, 535.1, 537.2, 537.5, 538.1, 540.3, 540.6, 545.3, $546.1,546.3,547.1,548.2)$.

643 Marcellinus krónikájában 29 alkalommal fordul elő az caesar szó: praef. 387, 392, 402, 408.1, 411.2, 424.2, 457.2, 461.2, 471, 473.1, 474.1, 474.2 (2), 476.1, 507.2, 508, 511 (2), 512.2, 512.4 (2), 512.7, 512.11, 513 (2), 514, 515.3, amelyek közül a következőek köthetők uralkodókhoz: Valens (praef.), Arcadius (387, 393), Eugenius (392), Honorius (394), II. Theodosius (402), Stilicho fia, Eucherius (408.1) III. Constantinus ismeretlen nevü fia (411.2), III. Valentinianus (424.2) Maiorianus (457.2, 461.2), Aspar fia, Patriciolus (471), Glycerius (473.1, 474.2 (2)), II. Leo (474.1), Basiliscus fia, Marcus (476.1), Anastasius (507.2, 508, 511 (2), 512.2, 512.4 (2), 512.7, 512.11, 513 (2), 514, 515.3). 
jelentősége abban rejlik, hogy ő hívta vissza hispániai önkéntes "számüzetéséből" Nagy Theodosiust. A sort tehát Theodosius folytatja, ám fiait - vélhetően a birodalom megosztása miatt Marcellinus nem szerepelteti augustusként. A sor II. Theodosiusszal folytatódik, akit Pulcheria augusta kiemelése követ, utalva arra, hogy a Theodosiust követő, dinasztikus kapcsolatokkal nem rendelkező Marcianus az özvegy révén lehetett császár. A sorban a következő uralkodó Leo, aki azonban már nem rendelkezett dinasztikus kapcsolatokkal, ráadásul házasság révén sem érhette el azt, hiszen Pulcheria 453-ban már halott volt. A helyzetet Marcellinus az imperator és az augustus szavak használatával oldja fel.

A szövegben Leo megválasztásának évében még imperatorként jelenik meg, csaknem két évtizedes uralkodása (457-474) alatt pedig öt alkalommal (458, 462, 466, 471, 473) viselte a consulságot. 462-ben, 466-ban és 473-ban egyedül viseli a consuli címet, mindhárom dátum Leo jelentős diadalát jelképezi, a fennmaradó két eset $(458,471)$ pedig társuralkodói kinevezéseket jelez. ${ }^{644}$ Marcellinus a szövegkörnyezetben következetesen a katonai töltetű imperator szót használja Leo császári hatalmának kifejezésére, jogosan, hiszen a császár uralkodásának szinte egésze vagy a vandálok elleni harcról szólt, vagy arról, hogy valamiféleképpen lerázza magáról Aspar magister militum befolyását. 466-os egyedüli consulságát a vandálok elleni hadjárat előkészületei indokolják. Ekkor küldi rokonát, Anthemiust Rómába, akit ugyancsak imperatornak nevez, utalva arra, hogy kinevezését a készülődő hadjárat indokolta. ${ }^{645}$ 473-as egyedüli consulságának oka, hogy Rómában Ricimer megöli Anthemiust, az uralkodóváltást pedig a császár nem ismeri el. A császár tizenhét éves uralkodása alatt csak egyetlen egyszer, 461/462-ben bukkan fel a caputon belül is augustusként, vagyis abban az évben, amikor III. Valentinianus rokonai visszatérnek Konstantinápolyba, a nobilissimák "közösségbe kerültek" a császárral és feleségével, Verinával. ${ }^{646}$ Licinia Eudoxia és Placidia I. Leo családjának részévé válnak. Marcellinus comes ennek a jelentőségét tehát azzal emeli ki, hogy csak ebben az évben nevezi Leót augustusnak. Minden bizonnyal ennek tudható be, hogy csak 462-ben jelennek meg az első olyan császári solidusok, amelyek mintázatában megjelenik az isteni kéz által tartott korona, amely korábban Arcadius, II. Theodosius és Marcianus feleségeinek érméin már uralkodásuk első évében jelen

644 Társuralkodói kinevezések: MARC. COM. 457-458, 457-ben meghal Marcianus, utódja Leo pedig Maiorianust jelöli caesarnak, ezért 458-ban ők ketten viselik a consulságot. MARC. COM. 471, Leo vandálok elleni hadjáratának sikertelensége miatt Aspar Konstantinápolyi pozíciói ismét megerősödtek, így sikerül elérnie, hogy fia Probianus a császár veje és kijelölt utódja legyen, így 471-ben Leo, Probianus caesarral együtt tölti be a consuli pozíciót.

645 MARC. COM. 466-467.

646 Marc. CoM. 462 vö. De CER. 1.44 [R226-228] 
volt. ${ }^{647}$ Elmondható tehát, hogy Leo legitimációjának központi eleme volt a császári leszármazottak "hazakerülése". A Leót követő Zeno számára a legitimációt már a Leo és Verina lányával, Ariadnéval kötött házassága jelentette, ahogyan Anastasius számára is.

\subsubsection{7}

A fejezet elején még csak sejtéseink voltak Aspar és Geiserich kapcsolatára. Ezt jelezte a történetírók „Ioannes tévesztése”, Marcianus szabadulásának története, illetve a hátrányos 442-es békekötés. Korábbi sejtéseink Aspar túlzott befolyásáról és a vandál uralkodóval folytatott kapcsolatáról a 467-es hadjárat során válnak egyértelmüvé. 467-ben sem indulhatott el önállóan Észak-Afrika irányába a konstantinápolyi flotta. Leónak előbb külső támogatóra volt szüksége a magister militummal szemben, aki Leo hívására meg is érkezett az isauriai Tarais ${ }^{648}$ - a későbbi Zeno császár - személyében, aki egy 300 fóből álló palotaőrséget (excubitores) állított fel. A császárnak szüksége volt Tarais támogatására, mert Aspar, felesége révén kötődött a városfalakon belül letelepített thraciai gót elővédhez, melynek élén Theoderich Strabo állt. ${ }^{649}$

A 467-es vandálok elleni hadjárat története Priskos tolmácsolásában maradt ránk. ${ }^{650} \mathrm{~A}$ későbbi auktorok jobbára az ő leírása alapján tárgyalják a hadjáratot. ${ }^{651}$ A szerző szerint Leo vandálok elleni expedíciója 467-ben lépett következő szakaszába, melynek mérete a korabeli vélemények szerint minden korábbi próbálkozását felülmúlta. Ha Avitus háromszáz hajóból álló flottájára gondolunk, ez talán igaz is lehet, azonban Leo ezeregyszáz hajó formájában ennek csaknem négyszeresét gyüjtötte össze, vagyis pontosan akkorát, mint amekkora flottával 441-ben érkezett Szicília alá a keletrómai kontingens. Leo a tízezer főt számláló legénység iránt is bőkezünek mutatkozott, hiszen összesen 130000 font aranyat költött a vandálok elleni expedícióra. Avitus korábbi sikertelen hadjáratához viszonyítva - csupán a számbeli arányok

647 Az OCRE adatbázis RIC X Leo I 606, 607, 631, 632, 633-as érméi 462-től kelteződnek, csak ezeken az érméken szerepel az isteni kéz. Ezzel szemben Arcadius és az őt követő keletrómai császárok érméin már uralkodásuk kezdetén megtalálható a szimbólum. Lásd RIC X Arcadius 84 (395), RIC X Theodosius II (East) 420 (408), RIC X Marcian 512 (450).

648 Zeno valódi nevéröl lásd HARRISON 1981, 27-28.

649 MARC. COM. 465 vö. CROKE 1995, 97, ZON. 14.14-19. Leo és Aspar szembenállására jó példa volt a 464 szeptember 2-án tartott Szent Mamas ünnepe, mialatt egy hatalmas tüzvész keletkezett a városban (a datálást Croke javította 465-ről 464-re). Aspar feltűnő szerepet játszott abban, hogy életeket és értékeket mentsen a tủzvészben. Ezzel szemben Leo ijedtében áthelyezte a császári udvart a Bosporus túloldalára és hat hónapig innen irányította a birodalmat. Minden bizonnyal nem független az eseményektől, hogy a 464 egyik frissen kinevezett consula éppen Olybrius volt.

${ }_{650}$ PRISC. FRG. 53.3.

${ }^{651}$ EvaGR. HE 2.16. Evagrios maga is megemlíti, hogy az eseményekröl a leghitelesebb beszámoló Priskostól származik. 
figyelembevételével - minden adott volt a sikerhez.

Leo 468-ban indította útjára a flottát Basiliscus föparancsnoksága alatt, aki feleségének, Verinának a bátyja volt. Basiliscus tapasztalt hadvezér hírében állt, hiszen három évvel korábban éppen azzal érdemelte ki a consuli címet, hogy Thraciában legyőzte a gótokat. Priskos azonban azt is tudni véli, hogy Basiliscus rettentően vágyott arra, hogy maga is császár lehessen, amit úgy gondolta, hogy könnyen elérhet, ha Aspar barátságába férkőzik. ${ }^{652}$ Leo még a háborús előkészületek idején értesítette Anthemiust, hogy segédkezzen a vandálok elleni háborúban. Szardínia szigetét pedig Marcellinus tartotta, miután kiverte onnan a vandálokat. Az elöbb felsoroltakon kívül még Heracleiust is Tripolisba küldték, ahol könnyüszerrel megszerezte a környező városokat, majd hajóit hátrahagyva szárazföldön indult tovább Karthágó irányába. ${ }^{653}$

Basiliscus az egész flottájával lehorgonyzott 280 stadionra (nagyjából 60 km) Karthágó felett, Mercurium városánál. Priskos szerint Basiliscusnak meglett volna a lehetősége, hogy harc nélkül elfoglalja a várost, de gyávasága felülkerekedett rajta. Geiserich miután megtudta, hogy Sardinia és Tripolis megadta magát Heracleius csapatai előtt, valamint jelentették neki Basiliscus seregének méretét, roppantul félni kezdett a "legyőzhetetlen császártól”. Basiliscus gyávasága vagy árulása azonban megakadályozta a császár számára kedvező végkifejletet. ${ }^{654}$ Priskos szerint Geiserich-nek sikerült előnyére fordítania Basiliscus hanyagságát. A vandál uralkodó követeket küldött hozzá, és ötnapos fegyverszünetet kért. Azt üzente, hogy tanácskozni fog, hogy olyan dolgokat tegyen, amelyek talán a császár kedvére valóak. Kérését nagy mennyiségü arannyal is nyomatékosította. A történetíró szerint Basiliscus vagy azért, hogy Asparnak kedvezzen, vagy a pénz miatt, de talán csak azért, mert azt gondolta, hogy ez a helyes, engedett Geiserich kérésének és elrendelte az ötnapos fegyverszünetet. Geiserich-nek esze ágában sem volt egyezkedni a keletrómaiakkal, ahogy ütött a fegyverszünet első órája, felkészítette néhány hajóját a gyors indulásra, abban reménykedve, hogy öt napon belül megérkezik a kedvező szélirány és rajtaüthet Basiliscus állásán.

A vandál király számításának megfelelően meg is érkezett a szél, amire várt. Néhány hajóval megindultak az ellenség irányába és mikor a közelbe értek, felgyújtották néhány hajójukat és a parton állomásozó császári flotta közepébe irányították őket. Olyan sürün álltak a hajók az

652 Theoph. AM. 5961 = Prisc. Fr. 53.1 lásd Procop. De Bellis. 3.6.1-2 és 5-25.

653 PrisC. Fr. 53.3, HYD. CHRON. 223 (227), 230 (234), Priskos szerint Marcellinus és Heracleius lépései a háború előzményei voltak, Hydatius tükrében tehát már 465-től történtek vandálok elleni hadmozdulatok.

654 PRISC. FR. 53.3. PRISC. FR. 53.1. vö. THEOPH. AM. 5961. Priskoshoz képest Theophanés már valamelyest kedvezőbben adja vissza a történetet. A 8. századi történetíró rendszeres összecsapásokba bonyolódott Geiserich hajóival és többet közülük a tenger fenekére süllyesztett. A történetíró szerint a hadvezér szerencséje csak később fordult meg. 
öbölben, hogy mindegyik pillanatok alatt lángra kapott, függetlenül attól, hol csapódtak be az égö hajók. A császári tengerészek a nagy káoszban még segítették is a tüz terjedését azzal, hogy evezőikkel, vagy a kezük ügyébe akadó hosszabb fákkal próbálták ellökni saját hajójuktól az égő bárkákat, mert így azok az ellenkező oldalon lévő hajóba csapódtak. ${ }^{655}$ A keletrómai tengerészek pánikba estek és menekülni kezdtek. Ioannes azonban, az egyik Basiliscus alatt szolgáló tábornok a helyén maradt és hösiesen küzdött, ameddig csak ereje és a túlerő engedte. Mikor az ellenség körülvette a hajóját és kezdte ellepni azt, teljes páncélzatban a vízbe ugrott, annak ellenére, hogy vandál uralkodó fia, Gento hosszasan kérlelte a megadásra. Ioannes azt válaszolta, hogy soha nem fogja magát kutyák kezére adni. A harcokat leíró elbeszélésében a történetíró a caput Basiliscus gyávaságával kezdi és Ioannes hősiességével zárja, amivel csak erősíti azt a képzetet, hogy Basiliscus Aspar akaratának megfelelően cselekedett. Ezt csak megerősíti az, hogy Priskos szerint a hős tábornok nem volt ott azon a megbeszélésen, amit Basiliscus a Geiserich követeivel folytatott, ami egyértelműen árulásnak számított. A 467-es vandálok elleni hadjárat a keletrómai flotta szinte teljes pusztulásával ért véget. ${ }^{656}$

Láthattuk, hogy 432-ben Marcianus szabadon bocsátásában döntő szerepe volt annak, hogy Geiserich tisztában volt Aspar befolyásával. A magister militum tíz évvel később, 442-ben egy a nyugat számára sérelmes területcserét eredményező megállapodást hozott tető alá, 467-ben pedig Basiliscus ötnapos fegyverszünetet rendelt el, részben azért, hogy "kedvezzen Asparnak". Aspar évtizedeken keresztül tartó befolyását csak megerősíti, hogy a történetírók szerint 440-442-ben és 467-ban megegyezett a császári flotta létszáma, azonban az előbbit öt hadvezér ${ }^{657}$ irányította, míg az utóbbit csak négy ${ }^{658}$ vezette. Már pusztán a megegyező hajószámmal is az analógiára utalnak, így elmondható, hogy a 442-es sérelmes béke Aspar tevékenységének eredménye volt, ahogyan a 467-es vereség is, ahol a keletrómai flotta csaknem egésze odaveszett.

A 467-es vereség után Aspar hatalma ismét megerősödött, de hatalmának alkonya már közeledett. A magister militum befolyása már igen korán megmutatkozott. Befolyását egyértelmüen jelzi, hogy mindkét fia hamar consuli székben találta magát. Idősebbik fia, Ardabur ${ }^{659}$ 447-ben, a fiatalabbik, Patriciolus ${ }^{660}$ pedig 459-ben töltötte be a pozíciót. Ráadásul Patriciolus I. Leo kisebbik lányát, Leontiát is eljegyezte, és úgy festett, hogy ő lehet Leo utódja. Testvére, Ardabur pedig

655 PRISC. FR. 53.3.

656 PRISC. FR. 53.3.

657 Ansilas, Inobindus, Arintheus, Germanus és Aëtius.

658 Basiliscus, Marcellinus, Heracleius és Anthemius.

659 PLRE2 135-137, “Ardabur iunior 1.”.

660 PLRE2 842-843, “Iulius Patricius 15.”. MARC. COM. 471 vö. JORD. GET. 239, JORD. RoM. 338. Míg Marcellinus és Iordanes Patriciolus alakban őrizte meg a nevét, más forrásokban Patricius néven szerepel. 
Basiliscust ismerte jól, hiszen 453-466 között magister militumként Thraciában szolgált, akárcsak Leo sógora. 466-ban megvádolták Ardaburt, hogy segített apjának rábeszélnie Basiliscust, hogy szabotálják a Geiserich elleni hadjáratot. ${ }^{661}$ Croke szerint Leónak sok időbe telt kiépíteni egy olyan megbízható hatalmi bázist, amivel véget vethetett Aspar túlzott befolyásának. 471-ben császárellenes összeesküvés vádjával apjával együtt kivégezték. Patriciolus Leontiával kötött eljegyzését pedig felbontották, továbbá caesar címétől is megfosztották. ${ }^{662}$ Leo ezzel leszámolt konstantinápolyi ellenzékével és stabilizálta uralkodását. ${ }^{663}$

Az eseményekkel összefüggésben Malalas további adalékokkal szolgál. A történetíró beszámolója szerint Anthemius Itáliába küldését (467) követően valamivel összetüzés bontakozott ki Ricimer és Anthemius között. A császár ezért Itáliába küldte Olybriust azzal, hogy közvetítsen a két fél között, és ha ezzel végzett, folytassa útját Észak-Afrikába, mivel - rokoni kapcsolataiból következően - jobbára már csak neki van szabad bejárása a vandál udvarba. Ebből feltételezhető, hogy Olybrius elküldésére a 467-es hadjárat után kerülhetett sor. Malalas hangsúlyozza, hogy Olybrius úgy hagyta el Konstantinápolyt, hogy feleségét, Placidiát és lányát, Anicia Iulianát a városban hagyta ${ }^{664}$ Véleményem szerint Leo döntésének eredménye lehetett Olybrius feleségének és lányának Konstantinápolyban maradása. Olybrius 464-es consullá választásával egy időben ugyanis heves tüntetés bontakozott ki Konstantinápolyban, melyben Aspar is tevékeny szerepet játszott. Leónak a Boszporusz túloldalára kellett menekülnie, ahol a Szt. Mamas villában rendezkedett be az ideiglenes udvartartás. ${ }^{65}$ Ez a jelenet igencsak kérdésessé teszi, hogy Olybrius megválasztásában Leónak vagy Asparnak volt-e nagyobb szerepe, de minden bizonnyal az utóbbinak, amit csak megerösítenek a 472-es év eseményei.

471-ben, nem sokkal az után, hogy Leónak sikerült megölnie Aspart és Ardaburiust, egy levelet küldött Anthemiusnak, melyben tájékoztatta a konstantinápolyi fejleményekről és arra kérte, hogy végezzen Ricimerrel és Olybriusszal is. Előbbivel elsősorban saját uralkodásának biztosítása miatt, Olybriusszal pedig azért, mert rokonsága miatt könnyen császár lehet belöle Konstantinápolyban. Ricimer és Olybrius halálával így sem Anthemiusnak, sem a császárnak nem maradt volna vetélytársa. Leo terve azonban megfeneklett, a levelet szállító futárt ugyanis a magister militum katonáinak sikerült elfogniuk, ami megpecsételte Anthemius sorsát. Ricimer ezt követően császárrá tette Olybriust, aki azonban néhány hónap múlva megbetegedett és 472 őszén

661 THEOPH. AM. 5951.

662 Croke 2005, 147-203, Marc. CoM. 471, Jord. Get. 239, Jord. RoM. 338. (megölték) vö. Nic. CALL. HE 15.27. (letették).

663 CROKE 2005, 147-203.

664 JOH. MAL. 14.45 (373).

665 Croke 2005, 159. 
természetes halállal eltávozott az élők sorából, nem sokkal később Ricimer is követte. ${ }^{666}$ Leónak sikerült véget vetnie Aspar uralmának, ráadásul Anicius Olybriustól is sikerült megszabadulnia, még ha nem is úgy, ahogy eredetileg tervezte, sőt legitimációja is biztosított volt, egy dolgon azonban nem tudott változtatni: A Theodosius-dinasztiához az egyenes ági kapcsolatot immár Olybrius lánya, Anicia Iuliana jelentette. Aspar az Anicius-Theodosius házasságán kívül még egy kellemetlen örökséget hagyott hátra. Napokkal kivégzése előtt útjára indította Konstantinápolyból az ekkor 18 éves osztrogót Theoderich-et, ${ }^{667}$ aki - akárcsak Hunerich - jó egy évtizeden keresztül a birodalom túsza volt. A következő fejezetben ezért Nagy Theoderich és az osztrogótok itáliai uralkodásán keresztül igyekszem megvilágítani az Anicius család uralkodói legitimációban játszott szerepét.

Az előző oldalakon láthattuk, hogy Aspar és Geiserich kapcsolata az 430-as évek végétől meghatározta az eseményeket. Korán formálódó kapcsolatuk már a Chronicon Paschale és Theophanés krónikájának tévesztésében is kitapinthatóvá vált, hiszen a források összekeverték a vandál származású Ioannes magister militumot az azonos nevü itáliai trónbitorlóval. Az alán Aspar befolyása és a vandál uralkodóhoz füződő kapcsolat jelent meg Marcianus császár szabadon bocsátásának történetében, ugyanakkor a 442-es megállapodás tető alá hozásában is jelentős szerepet játszott. Aspar érintettségét hangsúlyozta Theophanés is, aki nem követjárásnak tudta be a keletrómai udvarral történő kapcsolatfelvételt, hanem egészen egyszerúen annak, hogy Geiserich valahogy megneszelte az ellene készülődő akciót. Az alán származású magister militum szinte halála pillanatáig képes volt arra, hogy érdemben befolyásolja a birodalmi politikát, amit a történetírók 467-es a sikertelen vandálok elleni hadjárat leírásakor már ki is mondanak.

Aspar befolyásának időszakával esett egybe III. Valentinianus megölése is, ami egyben a Theodosius-dinasztia férfi-ágon történő kihalását is jelentette. A Valentinianus helyét elfoglaló Petronius Maximus azzal próbálta meg legitimálni hatalmát, hogy házasságra kényszerítette elődje özvegyét, de ingatag pozícióját nem sikerült stabilizálnia. Ennek egyenes következménye lett, hogy Geiserich Rómába indult, hogy kimenekítse fiát a bizonytalan helyzetből. A vandál uralkodó azonban - talán saját elgondolásból, talán Aspar érdekeivel összecsengő módon - kihasználta a nyugati udvar bizonytalan helyzetét, és fia mellett Valentinianus özvegyét és lányait is magával vitte jegyeseikkel együtt. Geiserich ezzel kettős legitimációt szerzett Valentinianus örökségére,

666 JOH. MAL. 14.45 (373).

667 DE CER. 1.91 (R412-416), MARC. COM. 471. vö. PLRE2 1077-1084, "Fl. Theodericus 7”. A történeti szakirodalomban a PLRE nyomán automatikusan a császárnak tulajdonítják Theoderich szabadon bocsátását, ez azonban meglehetősen kétséges a magister militum befolyásának, valamint a De Ceremoniis és Marcellinus krónikájának ismeretében. Leó ugyanis Aspar katonái választották meg, beiktatása során végig mellette vonult a magister militum, ráadásul a koronát is tőle vette át. 
hiszen a Theodosius-dinasztia leszármazottai immár karthágói udvarában voltak, ráadásul fia, Hunerich csakhamar házasságot kötött III. Valentinianus idősebbik lányával, Eudociával. A kisebbik lány, Placidia pedig Aëtius fiával, Gaudentiusszal járt jegyben. Mindez tökéletes alkupozíciót jelentett a vandál uralkodó számára.

Annak ellenére, hogy 455-ben már egyik lány sem volt már kiskorú, ráadásul mindketten jegyben jártak és jegyesükkel, valamint anyjukkal hagyták el Itáliát a keletrómai történetírók tendenciózusan menyasszonyrablásnak igyekeztek beállítani az eseményeket. Noha a történetírók eltérően számoltak be a házasságokról, egy ponton egyezést mutattak. Valamennyien egyetértettek abban, hogy Licinia Eudoxia és Placidia szabadon bocsátására két évvel (457) “elrablásuk" után sor került, tehát még Marcianus idejében. A kortársak ezzel szemben 462-re helyezték az özvegy és fiatalabbik lányának hazatérését. A keletrómai történetírók részrehajlása és korai dátumának elsődleges célja az volt, hogy legitimációt biztosítsanak I. Leo uralkodásához. Marcianus és I. Leo között ugyanis volt egy lényeges különbség. Ugyan mindketten Aspar katonái, és ha úgy tetszik, „bábjai” voltak, de amíg Marcianus hatalomra kerülése még az özvegy Pulcheria életében sor került, addig Leo számára egy Theodosius-dinasztiabeli asszony sem állt rendelkezésre, hogy elfogadtassa hatalmát.

A keletrómai kormányzat számára ezért vált elsődleges fontosságúvá az özvegy és Placidia visszaszerzése. Az erre irányuló tárgyalások azonban a források szükszavúsága miatt nehezen rekonstruálhatók. Maiorianus halála után interregnum keletkezett, ami keletrómai szemszögböl nem zárult le Libius Severus megválasztásával, hiszen Ricimer jelöltjét nem fogadták el a konstantinápolyi udvarban. Ebbe a tágabb idősávba illeszkedik Hydatius leírása, aki szerint Licinia Eudoxia szabadon bocsátása 462-ben történt, így Placidia szabadon bocsátására is ekkor kerülhetett sor. Az ezt követő időszaktól kezdi a vandál uralkodó követelni Anicius Olybrius megválasztását a birodalom nyugati felének élére. Az Aniciusokat tárgyaló fejezetben láthattuk, hogy Olybrius családja a 410-es években Észak-Afrikába költözött, így Placidiával kötött házassága minden bizonnyal egy kompromisszumos megállapodás eredménye lehetett, amelyet újfent Aspar hozott tető alá. A keletrómai kormányzatnak vállalnia kellett, hogy az özvegy és fiatalabbik lányának szabadon bocsátásáért cserébe Placidia férjét jelölik a ravennai kormányzat élére. Azt, hogy Aspar és Geiserich hallgatólagos megállapodása húzódott meg Placidia és Anicius Olybrius házassága mögött, jól mutatja, hogy az alán származású magister militum eltávolítása után Leo kísérletet tett Olybrius megölésére. De erre mutat az is, hogy amíg Olybrius kinevezése nem teljesült, Geiserich fosztogatni kezdte a birodalom keleti területeit. A keletrómai udvar ráadásul csak azt követően 
kezdhetett a vandálok elleni katonai akció előkészületeihez, hogy biztonságban tudták az özvegyet és fiatalabbik lányát.

III. Valentinianus lányának és özvegyének jelentősége elsősorban nem az utolsó Theodosius-dinasztiabeli császárhoz füződő vérségi kapcsolatban rejlett, hanem az ehhez kapcsolódó nobilissima címben, illetve az ehhez kötődő udvari gyakorlatban, ami a dinasztián kívüli uralkodók esetében a legitimáció alapját adhatta. A Chronicon Paschale tükrében bizonyos, hogy a Theodosius-dinasztia nőtagjai nem kinevezés útján jutottak a cím birtokába, hanem születésüktől fogva nobilissimának minősültek. Az özvegy és Placidia visszaszerzésének jelentőségét a nobilissimus beiktatására vonatkozó protokoll magyarázta, amely felhívta a figyelmet arra, hogy a hivatalos beiktatás során a nobilissimus az augustus és az augusta családjának részévé vált. Értelemszerüen ez a kapcsolat fordítva is érvényesült. A dinasztikus kapcsolatokkal nem rendelkező Leo számára fontos volt, hogy kapcsolatot keressen a korábbi uralkodó dinasztiával, így folytatva a kontinuitást, amire III. Valentinianus leszármazottainak visszaszerzése és a nobilissimus cím biztosított lehetőséget. A dolog jelentőségét Marcellinus comes krónikájának szóhasználata világította meg, amely következetesen a katonai töltetü imperator szót használta Leo császári hatalmának kifejezésére, 461/462-ben azonban augustusnak nevezi, vagyis abban az évben, amikor Licinia Eudoxia és Placidia visszatértek Konstantinápolyba és "közösségbe kerültek" a császárral és feleségével, Verinával.

Aspart ugyan sikerült Leónak eltávolítania, a magister militum korábbi döntéseit azonban már nem tudta megmásítani. 463-tól a Theodosius-dinasztia vére és leszármazása Anicius Olybrius és Placidia lányán, Anicia Iulianán folytatódott tovább. 


\section{AZ OSZTROGÓT ITÁLIA}

A fejezet során az osztrogótok itáliai uralkodásának egyes szakaszait fogom ismertetni, Theoderich Itáliába küldésétől egészen Theodahad uralkodásának kezdetéig. Megkísérlem megmagyarázni a hanyatlás okait, Theoderich és utódai legitimációs lehetőségeit, illetve rámutatok a casus belli okára. Az Anicius család nyugati ágának rekonstrukciója során igyekszem új megvilágításba helyezni Boëthius és Symmachus kivégzésének körülményeit, illetve egy legitimációs kísérletre is látunk majd példát, amelyet Theodahad az Anicius család tagján keresztül igyekezett megvalósítani.

\subsection{Theoderich Itáliába küldésének körülményei}

Aspar magister militum döntése, akárcsak a vandál Hunerich esetében, Theoderich sorsára is hatással volt. 462-ben ugyanis az ekkor alig nyolc éves osztrogót fiúcska Aspar és a pannóniai gótok közötti megállapodás eredményeként került Konstantinápolyba a magister militum túszaként. ${ }^{668}$ A pannoniai gótok a 454 második felében vívott nedaói csata után még Noricum és a Dunántúl vidékén éltek, és csak kilenc évvel később törtek rá a Keletrómai Birodalomra. Iordanes szerint erre azért került sor, mert a gótok nem kapták meg a szokásos ajándékokat. A helyzet azonban sokkal prózaibb volt. A követek ugyanis látták, hogy a gótok másik nemzetségéből származó thraciai gótok Theoderich Strabóval az élükön „a rómaiakkal szoros barátságban" ${ }^{669}$ már Konstantinápoly városfalának tövében rendezkedtek be Aspar segédcsapataként. ${ }^{670} \mathrm{~A}$ helyzetet konszolidálni igyekvő Aspar taktikája a vandálok óta mit sem változott. Előbb rábírta Leót, hogy kezdje meg az évpénz fizetését a gótoknak, majd a megállapodás biztosítékaként a gót vezér fiát kérette az udvarba. Utód híján Valamir saját unokaöccsét küldte Konstantinápolyba. ${ }^{671}$

Theoderich tíz év után 472-ben tért haza, majd népe élére állva előbb az időközben Singidunumot elfoglaló szarmatákat verte meg, ${ }^{672}$ majd a következő év elején már egy 10000 fős sereg élén fokozatosan dél felé nyomult, ${ }^{673}$ véleményem szerint azért, hogy nyomást gyakoroljon a

668 JORD. GET. 270-271, PRISC. FR. 37.

669 JORD. GET. 270.

670 MALCH. 15, 18.2

671 JORD. GET. 270-271, PRISC. FR. 37.

672 JORD. GET. 282.

${ }^{673}$ JORD. GET. 283. Az osztrogót sereg Singidunum után kettévált és az egyik szárnyuk Vidimer vezetésével Itália felé vette útját, a másik pedig Thiudimer és Theoderich vezetésével Thessaloniké irányába. WOLFRAM 1990A, 267. A "bécsi iskola" képviselői elsősorban Herwig Wolfram nyomán - Iordanesre támaszkodva - úgy gondolják, hogy a gótok azért hagyhatták el Pannóniát, mert az a továbbiakban nem biztosított megfelelő életteret nekik. Ez a vélekedés elsősorban azon az elgondoláson nyugszik, hogy a 
keletrómai kormányzatra. ${ }^{674}$ Theoderich ekkor még nem sejthette, hogy Aspart már már kivégezték. A pannóniai gótok érkezésének hírére Leo nyugati irányú átcsoportosítást hajtott végre, ezzel azonban szabad utat engedett Theoderich Strabónak, aki számára ekkor jött el pillanat, hogy maga is revansot vegyen Aspar halála miatt. A kivégzett magister militum harmadik felesége, Sigilda révén ugyanis rokoni kapcsolatot ápolt a thraciai haderő fejével. ${ }^{675}$ Strabónak Arcadiopolis és Philippi felprédálása után sikerült kiharcolnia a magister militum praesentalis címet, valamint évi 200 mérő aranyat, jóllehet már a megbeszélések során nyilvánvalóvá vált, ám ez nem sokban javította a két Theoderich között őrlődő Leo helyzetét, hiszen mindenki számára világos volt, hogy az egykor Aspar testületéböl kikerülő császár Aspar megöletésével már végleg szakított elődei gótbarát politikájával. ${ }^{676}$

A feszült helyzet 474 januárjában, Leó halálát követően csak még inkább eldurvult. A császári széket ugyanis éppen Zenónak sikerült megszereznie. Aspar után újra egy idegen került vezető pozícióba, ám most már császárként, ami az udvari körök heves ellenállásába ütközött. Az elkövetkező éveket belharcok tarkították, amelyekben Strabo Zenóval szemben foglalt állást. A helyzet meglehetősen kényelmetlen volt az új vezetés számára, hiszen Strabo csaknem 13000 gót harcost számláló csapata Konstantinápoly alatt állomásozott. ${ }^{677}$

A szorult helyzetben lévő isaurai vezető így a másik gót vezérnél keresett támogatást, rutinos stratégaként kelepcét állított. A császár lehetséges taktikáját Malchos világítja meg. ${ }^{678}$ Zeno tárgyalásokba bocsátkozott Theoderich-kel, amelynek során megállapodtak abban, hogy osztrogót hadvezér csapataival Strabo ellen indul, Zeno pedig támogatására küldi a thraciai praefectus praetoriót 10000 fös gyalogság, valamint 2000 fös lovasság élén. Majd Hadrianopolis mellett egy újabb császári hadtest csatlakozott volna 20000 fős gyalogsággal és 6000 fős lovassal. ${ }^{679}$ Malchos beszámolójából azonban kiderül, hogy a császári seregek nem jelentek meg az elöre megbeszélt találkozóhelyen, így Theoderich serege csak a szerencsének köszönhette megmenekülését, hiszen a két gót vezér hadtestének létszáma közel megegyezett. Ha egymásnak estek volna, akkor Zeno

Iordanest hiteles krónikásként fogadták el. Mindazonáltal, ha figyelembe vesszük, hogy az üresen maradt központot, Sirmiumot a gepidák Trapstila nevü királyuk vezetésével szinte azonnal elfoglalták, meglehetősen kétséges ez a nézet. A gepidákról nemrégiben Kiss P. Attila írt remek összefoglaló munkát lásd.: KISS P. 2015.

674 JORD. GET. 283.

675 THEOPH. AM. 5964 vö. 5970. I. ANTIOCH FR. 235. Aspar és Strabo rokonságáról csak Theophanés történeti munkája tesz említést. A szerző azonban maga is önellentmondásba kerül, hiszen az egyik forráshely szerint Strabo nővérét, egy másik szerint azonban nagynénjét vette el. Strabo feleségének nevét Antiochai János örizte meg.

676 MALCH. 20.

677 MALCH. 18.

678 MALCH. 18.2.

679 MALCH. 18.2. 
hadtesteinek már csak a maradékkal kellett volna végezni, így Aspar után egy csapásra megszabadult volna a másik két gót vezetőtől is. ${ }^{680} \mathrm{~A}$ helyzet korántsem véletlenül alakult így, hiszen a belharcok lezárása után Zeno elsődleges célja volt, hogy megszilárdítsa hatalmát Konstantinápolyban, ehhez azonban meg kellett szabadulnia megmaradt ellenfeleitől, így attól a nyomasztó tehertől, amit Aspar öröksége jelentett Strabo és Theoderich személyében.

\subsubsection{Tárgyalások Zeno és Theoderich között}

Az előbbiek tükrében nem kérdés, hogy Zeno elsődleges célja az volt, hogy megszabaduljon mindkét Theoderich-től, ami végül sikerült is. A császárra nehezedő nyomáson előbb egy szerencsés véletlen enyhített. Strabót ugyanis Philippi mellett a lova levetette magáról és egy kiálló lándzsába zuhant, ezzel - Iordanes szavai szerint - "ünnepnapot adva a [Keletrómai] államnak" ${ }^{681}$ Strabo halála (481) kétségtelenül pozitív fejlemény volt Zeno számára, de Theoderich is profitált a hadvezér halálából, hiszen így a korábban Strabo alá tartozó thraciai gótok felett is meg tudta szilárdítani hatalmát. A keletrómai uralkodónak így már csak Theoderich-től kellett megszabadulnia, amire kiváló lehetőséget nyújtott a szkír Odoacer itáliai hatalmának megtörése és a számüzött Nepos visszahelyezésének terve, annál is inkább, mert a letett nyugatrómai uralkodó maga is császári rokonságban állt. ${ }^{682}$

Az osztrogótok itáliai uralkodásának feltételei elsősorban a Zeno és Theoderich között zajló tárgyalások során tapinthatóak ki, ám ezekre csak apró utalásokból következtethetünk, hiszen a megállapodás pontos részleteit homály fedi. Theoderich gótjainak konstantinápolyi fogadtatása, különösen a császár két Theoderich összeugrasztására irányuló kísérlete miatt ellenséges volt. A Strabo elleni harcban azonban Zenónak szüksége volt Theoderich-re, ez az egymásrautaltság pedig kényszer szülte szövetséget kovácsolt kettejük között, ami talán nem is volt olyan kényszerü, ha figyelembe vesszük, hogy Theoderich 481 után még majd egy évtizedig Konstantinápoly árnyékában maradt. A Theoderich-kel folytatott tárgyalások során Zeno szinte mindent megígért. Mindenekelött 476 és 478 között, tehát valamivel Romulus Augustulus eltávolítása után rögtön fegyverrel fiává fogadta Theoderich-et. ${ }^{683}$ Többi juttatása azonban már Strabo halála után esett: Zeno előbb 483-ban magister militummá, egy évvel rá pedig consullá tette az osztrogót vezért. ${ }^{684}$

\footnotetext{
${ }^{680}$ MALCH. 20.

681 JORD. ROM. 347.

682 I. ANTIOCH FR. 214.4., MALCH. 14. Iulius Nepos felesége révén rokoni kapcsolatban volt Verinával.

683 MALCH. 20., JORD. GET. 289., PLRE2 1077-1084, „Theodericvs 7”.

684 Malch. 20., MARC. COM. 483, JoRD. Rom. 348.
} 
Theoderich egészen kivételes helyzetben volt, hiszen a gót uralkodók közül csak ő és később kiszemelt utódja, Eutharicus nyerte el a consuli (519) címet. Ez a privilégium különösen szembetünő annak tükrében, hogy a két gót hivatalviselése közé ékelő frank Klodvignak be kellett érnie tiszteletbeli consuli címmel (507). ${ }^{65}$ Malchos beszámolója szerint kivételes helyzetére egy alkalommal még Adamantius császári követ is emlékeztette az ifjú gót vezért: a consuli címet csak azon rómaiak nyerhetik el, akik különösen keményen dolgoznak a birodalom oldalán. ${ }^{686} \mathrm{Az} 5$. század második felében az udvarban tehát rómaiként tekintettek Theoderich-re, jobbára romanitasa miatt kerülhetett napirendre az is, hogy Anicia Iulianát, vagy a város más nemesasszonyát hozzáadják az osztrogót vezérhez. ${ }^{687}$ Theoderich végül nem nyert magának római asszonyt, különösen olyat nem, aki dinasztikus felmenőkkel rendelkezett. A korábbiak tükrében jogosan gondolhatnánk, hogy az udvarban talán már tanultak Geiserich esetéből. Talán így is van, azonban a kortárs Malchos munkájában a consuli cím és a házasság lehetőségégének együttese inkább utal Theoderich Konstantinápoly irányába tanúsított elkötelezettségére.

Még Malchos után fél évszázaddal is megtalálható ez a bizalom, ezúttal azonban már jóval árnyaltabban jelenik meg. Kaldellis rámutatott rá, hogy a Háborúk egy pontján Prokopios Theoderich jellemzését formailag egy olyan allúzióval kezdi, amelyet Thukydidés alkalmazott Periklés bemutatása kapcsán. ${ }^{688} \mathrm{Ez}$ a párhuzam korántsem elhanyagolható, hiszen Prokopios korábban Athén és Kerkyra ellenségeként azonosította a (vizi)gótokat, így az athéni államférfire történő utalás már önmagában Theoderich romanitasának hangsúlyozása, ennél azonban jóval több, hiszen párhuzamot feltételez az athéni államférfi és a gót vezér között. Életének első szakaszában Periklés, akárcsak Theoderich legfontosabb jellemvonása nem politikusként, hanem katonaként mutatkozott meg. ${ }^{69}$ Arisztokrata és nemesi származásuk ellenére mindketten tartózkodtak a politikától, s inkább katonai érdemeket halmoztak, melyben mindketten rendkívül megfontoltnak és sikeresnek bizonyultak. ${ }^{690} \mathrm{Az}$ utókor szemében pedig már a biztonság védőbástyájaként tekintettek rájuk. ${ }^{691}$

Látszólag ez a kép került összeütközésbe a Háborúk egy későbbi szakaszában, ahol Prokopios ismét Thukydidéshez nyúl. Witiges egyik Belisariushoz intézett követsége ugyanis

685 Klodvig tisztségeire: MATHISEN 2012, 82.

686 MALCH. 20.

687 MALCH. 18.3. A romanitashoz: SHEPARD 2006, 139-140, ill. ANON. VAL. 12.60. Theoderich-et uralkodása első szakaszában Traianushoz és Valentinianushoz hasonlították.

688 Procop. De Bellis. 5.1.29-31. vö. ThUC. 2.65.9. KALDELLIS 2014, 254, 446-447. lj.

689 Plut. Per. 7., 18. (Periklésre) vö. AnON. VAL. 12.58., 12.60., 12.72. (Theoderich-re).

690 PLUT. PER. 7. Plutarchos szerint jobbára azért, mert mind megjelenésében, mint beszédében rendkívüli módon hasonlított Peisistratosra.

${ }^{691}$ Plut. Per. 38-39. (Periklésre) vö. AnON. VAL. 10.49. 12.59. (Theoderich-re). 
hasonló felütéssel kezdi mondandóját, mint ahogyan azt a korinthosiak követe tette a peloponnésosi háború idején. ${ }^{692} \mathrm{~A}$ gótok így Theoderich-től Witiges idejére visszakerültek az Athénnal szemben álló oldalra, csakhogy ez a jellemromlás magától Perikléstől indul. Az athéni államférfi ugyanis csak azt követően vált az állam első polgárává és bitorlójává, hogy társa, Ephialtés egy évvel a peloponnésosi hátború kitörése előtt (i. e. 461) politikai gyilkosság áldozata lett. ${ }^{693} \mathrm{Az}$ athéni események analógiát mutatnak a későbbi ravennai történésekkel, hiszen Eutharicus (cos. 519), Theoderich kijelölt és Konstantinápoly által is elfogadott utódja tisztázatlan körülmények között meghalt az 520-as évek elején. ${ }^{694} \mathrm{~A}$ Witiges által küldött követek érvelése arra támaszkodott, hogy Zeno patriciussá és consullá tette Theoderichet, majd Itáliába küldte Odoacer hatalmának megtörésére, ${ }^{695}$ amely után a gótok Itália törvényes uraivá váltak. ${ }^{696}$ Belisarius ezzel szemben arról tájékoztatja őket, hogy bár valóban a császár küldte Itáliába Theoderichet, de azért, hogy felszabadítsa számára Itáliát, nem pedig azért, hogy a maga részére megtartsa. ${ }^{697}$ A keletrómai kormányzat szemében az első törést az jelenthette, hogy Theoderich nem adta át időben a hatalmát utódjának, illetve Eutharicus halála után tovább uralkodott, akárcsak Periklés Ephialtés halála után. 488-ban tehát, amikor az osztrogótok megindultak Itáliába Theoderich még a császár teljes bizalmát élvezte.

${ }^{692}$ Procop. De Bellis. 6.6.14. “ “H

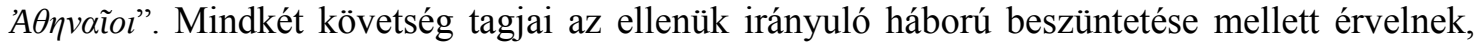
illetve a béke megőrzésére szólítják fel a másik felet.

693 PLUT. PER. 10-11.

694 Procop. De Bellis. 5.2.1., Jord. Get. 304., CAssiod. VAR. 8.1.3., PlRE2 438, „Cilliga”. Euthericust Iustinus fogadta fegyverrel fiává.

${ }^{695}$ MALCH. 20. A követek érvelésében a visszautalás Theoderich és Zeno egyezkedésére ugyancsak párhuzamba hozható Thukydidés munkájával. Malchos nyomán ugyanis bizonyos, hogy Zeno félresikerül kelepcéje után az udvari követ Epidamnosnál tárgyalt Theoderich-kel.

696 Procop. De BELlis. 6.6.14-21. vö. MARC. COM. 491, 523, 526. Hangsúlyozzák, hogy megőrizték a római törvények sértetlenségét, tiszteletben tartották a vallásokat és a római szentélyeket. Ráadásul consuli méltóság egyikét mindig a rómaiak adták, amit évről-évre el kellett küldeni a császárnak. A consulküldés gyakorlata csupán annyit jelentett, hogy nyugatról mindig megküldték keletre a consul nevét, de a császár értelemszerủen megtagadhatta ennek elfogadását, éppen ezért úgy gondolom, hogy a consullisták alapján kitapinthatóak a Konstantinápoly és Ravenna közötti konfliktusok, sőt talán még több minden is. Marcellinus comes consullistájában például megfigyelhető, hogy Theoderich Itáliai uralkodásának föbb pontjait Anicius consulok szegélyezik. Aniciust találunk 491-ben, Itáliába érkezésének évében, de a család tagja tünik fel Eutharicus feltételezett halálának évében (523), de Aniciusszal találkozunk Theoderich halálának (526) évében is. A dolgozat során már láthattuk, hogy a Theodosius-dinasztia az Anicius-nemzetségben folytatódott, éppen ezért a keletrómai döntéshozatalban ezek a kinevezések kettős célt szolgálhattak. Egyrészt Theoderich Itáliába érkezésének esetében arra szolgáltak, hogy megerősítsék Theoderich küldötti státuszát, nevezetesen, hogy újra egységesíti a birodalmat. Az egyes uralkodók halálának évében pedig annak megerősítésére szolgáltak, hogy Itália még mindig a Theodosius-dinasztiához és leszármazottaikhoz, az Aniciusokhoz tartozik.

${ }^{697}$ Procop. De BeLlis. 6.6.23. vö. ANON. VAL. 10.49. A Prokopiosnál megjelenő gondolat tökéletesen megegyezik a Pars Posterior beszámolójával. Lásd. következö lábjegyzet. 


\subsubsection{Az itáliai uralkodás „elismerése”: Az anastasiusi feltétel}

489-ben a Theoderich irányítása alatt álló egyesült gót csapatok, beleértve nőket és gyerekeket megérkeztek Itáliába. Rögtön ezt követően megkezdődött a harc, melynek célja a félsziget feletti hegemónia megszerzése volt. Odoacer az első vereséget követően még tartotta magát, de a 489. szeptember 30-án Verona mellett lezajlott ütközet már jócskán megrendítette ellenállását. Ez követően Ravenna megerősített falai közé vette be magát, ahonnan próbálkozott ugyan meneküléssel, de a 490. augusztus 11-én lezajlott addai csata után végérvényesen elbarikádozta magát az erősségbe. 492 augusztusában Theoderich ostromzárat vont Odoacer búvóhelye köré, amelyet a következö évben be is vett. A szkír uralkodót a bevonulást követő tizedik napon megölték, s ezzel Itáliának új ura lett. ${ }^{698}$ Theoderich uralkodásának első évei Anonymus Valesianus beszámolója alapján rekonstruálható, ez azonban nem nélkülözi a propagandisztikus elemeket. Részrehajlása ellenére Anonymus komoly forrásértékkel bír, amit szerkezeti sajátosságai mutatnak meg.

A névtelen szerző datálási rendszere segít a konstantinápolyi és a ravennai udvar közötti kapcsolatok meghatározásában. Anonymus jól ismerte Eugippius apát Szent Severinus életéröl szóló munkáját, amelyből egy terjedelmes részt ${ }^{699}$ át is emelt saját munkájába. Éppen azt, ahol az apát a Odoacer uralkodásának éveit 13, illetve 14 évben jövendöli meg. ${ }^{700}$ Odoacer 476-ban távolította el Romulus Augustulust, ettől az időponttól kezdve 13/14 évet számolva 489/490-hez jutunk. Ebből következik, hogy Eugippius és az öt idéző Anonymus nem a szkír megölésének dátumát tekinti Odoacer uralkodása végének, hanem már 489-et, amikor Theoderich és csapatai megérkeztek Itáliába és megkezdődnek a harcok. ${ }^{701}$ Ezt követően a 489. év eseményeit hónapra pontosan adja meg, majd Odoacer haláláig a consuli évek szerint datál. Előbb a 490-es évek eseményeit írja le Faustus és Longinus consulok nevének említésével, ${ }^{702}$ majd a 491. évet Olybrius consul nevével jelöli. ${ }^{703}$ Ezt követően jelzi Zeno halálát és Anastasius megválasztását - aki a következő évben a consulságot (492) is betöltötte. ${ }^{704}$ A szerző minden bizonnyal azért a consuli évekkel datálja a 489 és az Odoacer megölése közötti éveket, mert Theoderich ekkor még nem volt

698 ANON. VAL. 11.50-11.55, CASSIOD. CHRON. 493, PLRE2 791-793, “Odovacer”.

699 ANON. VAL. 10.46-48. vö. EUGIPP. V. SEV. 33.

700 ANON. VAL. 10.46, illetve 10.48.

701 Theoderich Itáliába érkezésének eseményei: ANON. VAL. 11.50-55. ProCOP. DE BELlis. 5.1.31 vö. 6.6.14-21. Anonymushoz hasonlóan Prokopiosnál is mindkét dátum $(489,493)$ feltűnik. A keletrómai auktor előbb harminchét évről beszél, tehát 489-től számol, majd 537-ben Witiges követeinek említése során Odoacer legyőzésének éve jelenti Theoderich uralkodásának kezdetét.

702 ANON. VAL. 11.53.

703 ANON. VAL. 11.54.

704 ANON. VAL. 11.56. 
legitim uralkodó, hiszen a névtelen krónikás és mások is leírják, hogy Odoacer legyőzését követően csak addig lesz Itália ura. ${ }^{705} \mathrm{Az}$, hogy a szerző ezt a három évet a consuli évekkel datálja, egyértelmüvé teszi, hogy ezt az időszakot egyfajta interregnumnak tekinti. Ezt erősíti az is, hogy Theoderich már a ravennai ostrom idején követet küldött Konstantinápolyba Zenóhoz feltételezhetően azért, hogy Odoacer sorsáról egyeztessenek. ${ }^{706}$

A következőekben már megmutatkozik a névtelen szerző propagandisztikus jellege. Miközben maga is tökéletesen tisztában van azzal, hogy Ravenna ostroma 490-ben kezdődött, három évig tartott és Odoacer halálával végzödött, ${ }^{707}$ arról ír, hogy a második Theoderich-követ, aki a szkír halála (493) után indult keletrómai föváros felé, csak útközben értesült Zeno két évvel korábbi (491) haláláról, ezért visszafordult. Az, hogy egy követ minden eredmény nélkül visszaforduljon felettébb furcsa. Hasonló eset történt néhány évtizeddel később, amikor Theodahad és a császár követei összefutnak az Adriai-tenger partján fekvő Aulon (ma Vlora) városában. A császári követ fontos információkat tud meg a ravennai követektől, ám ahelyett, hogy visszafordult volna inkább futár útján üzent Konstantinápolyba, a további utasításokig Aulonban maradt. ${ }^{708}$ Anonymus esetében nem is erről van szó. A szerző egyszerủen összemossa az eseményeket, azt az érzetet keltve, hogy a második követség Zeno halála miatt el sem jutott Konstantinápolyba.

A korábbi pontos datálás után szokatlan lenne, ha éppen itt hibázott volna a szerzö. Minden bizonnyal nem is erről van szó. A névtelen krónikás mindenesetre közli a követ nevét, (Anicius) Faustus niger (cos. 490) ${ }^{709}$ akinek a nevét a pápai levelek között is megtaláljuk, amiből világossá válik, hogy a követ feladata az volt, hogy közvetítsen az Akakios-féle skizma megoldása érdekében. A szakadás oka, hogy 482-ben Zeno úgy gondolta megtalálta a tökéletes megoldást a katolikusok és a monofiziták közötti ellentétre. Kompromisszumos megoldását a Henotikon nevü iratban foglalta össze, amelyet Akakios konstantinápolyi pátriárka dolgozott ki. A dogmatikai kérdéseken túl alapvető probléma volt, hogy a császár önkényesen bocsátotta ki, anélkül, hogy

705 Anon. VAl. 10.49., Procop. De Bellis. 6.6.16-18, 23-24.

706 ANON. VAl. 11.55-56 vö. I. ANTIOCH FR. 238 ill. ENNOD. PAN. 10.49, 51. Ez a történet őrződik Antiochiai Jánosnál és Ennodiusnál is. A konstantinápolyi parancs egyértelmü volt, meg kell halniuk. "Ecce iterum ad deditionem sibi cognitam hostium leto debita pars cucurrit [...] libuit eos rursus tendenti inermem dexteram Odovacri regna polliceri [...] mandata est per regiones disunctissimas nex votiva " (ENNOD. PAN. 10.49, 51). Ióannés azt is tudni véli, hogy Odoacert testét egy zsinagóga szarkofágjában helyezték el.

707 ANON. VAL. 11.53.: „Fausto et Longino. His consulibus [490] [...] Odoacrem clausum per triennium Ravenna" vö. 11.55-57.

708 AnON. VAl. 11.57. vö. Procop. De Bellis. 5.4.21, CoD. IUST. 12.49.10.1. Azonban amíg a császári követ a keletrómai oldalon rendelkezett a cursus publicus nyújtotta elönyökkel, ez nem áll a nyugatiak rendelkezésére. A cursus publicus használati engedélyét és más hivatalos okiratot ugyanis a tartomány tractatorának is jóvá kellett hagynia.

709 PLRE2 454-456, "Fl. Anicius Probus Faustus iunior Niger 9". 
bármilyen egyházi gyüléssel megvitatta volna. A római egyházfő ennek hatására 484 júliusában kiközösítette a pátriárkát, így szakadás következett be Róma és Konstantinápoly között. ${ }^{710} \mathrm{~A}$ követ nem az osztrogót uralkodó, hanem Gelasius pápa követeként indult keletre, és nem Zenóhoz, hanem 491-ben megválasztott utódjához, Anastasiushoz. ${ }^{711}$ A követ által kézbesített leveléböl újfent világossá vált a keletiek számára, hogy a Szentatya nem hajlik az egyezségre, s nem fogja elfogadni a Henotikont. ${ }^{712}$ Anonymus ahelyett, hogy közölné a sikertelenség valódi okát, elmondja, hogy a gótok nem várták meg Anastasius jóváhagyását és a maguk részére megszilárdították Theoderich uralkodását. ${ }^{713}$ Ezt az Odoacer legyőzésétől (493) Anastasius jóváhagyásáig (497) terjedő időszakot "praesumptione regni”-nek, vagyis egyfajta elözetes állapotnak tekinti a szerző. ${ }^{714}$ Ezzel azonban önellentmondásba kerül, mert más helyütt közli, hogy Theoderich harminchárom évig uralkodott, ami így Odoacer megölése után automatikusan kezdetét vette, függetlenül Anastasius jóváhagyásától.

A megmerevedett egyházi kapcsolatokban Gelasius 496. november 21-én bekövetkezett halála hozott fordulatot. A klérus tagjai három nappal később megválasztották a római születésű II. Anastasiust. ${ }^{715}$ Majd nem sokra rá egy újabb követség indult keletre, melyet ekkor - a 490-es akcióhoz hasonlóan - ismét a caput senatus, Festus ${ }^{716}$ (cos. 472) vezetett. ${ }^{717}$ Anonymus szerint az uralkodó, akárcsak az első alkalommal, most is a caput senatust küldte, minden bizonnyal azért, mert életkora révén ez a tisztségviselő rendelkezett a legnagyobb tekintéllyel. ${ }^{718}$ A szerző azonban ismét csak küldött nevét említi, miközben tudjuk, hogy a senatus első emberével tartottak az új pápa megbízottjai is. ${ }^{719}$ Anonymus szerint az „egytagú” követségnek csupán politikai célja volt:

710 MEYENDORFF 2001, 211, OSTROGORSKI 2003, 72. A Henotikon valójában az első látható jele volt annak, hogy a keletrómai császár az ókori Római Birodalom egy új, megreformált keresztény változatát akarja létrehozni.

711 A követ a 491-es legátussal szemben már nem a senatus legidősebb tagja volt, hanem a magister officiorum, akit Irenaeus vir illustris kísért.

712 GELASIUS EP. 12.3-4.

713 ANON. VAL. 11.55. vö. 11.56.: Olybrio V. C. Cons. [...] Sic ingressus est Theodericus et post aliquot dies, dum ei Odoacer insidiaretur, detectus ante ab eo praeventus in palatio, manu sua Theodericus eum in Lauretum pervenientem gladio interemit. [...] Et moritur Constantinopolim Zeno imperator, et factus est imperator Anastasius.

714 ANON. VAL. 12.64

715 LIB. PONT. 51-52.

716 PLRE2 467-469 “Fl. Rufius Postumius Festus 5”.

717 ANON. VAL. 64.

718 RICHARDS 1979, 31, CAMERON 2012, 516. A senatus Theoderich és Odoacer uralkodása idején nagyfokú szabadságot évezett. Cameron találóan "vénasszonyok nyarának" nevezi ezt az időszakot, utalva arra, hogy felbomlása már közeledett.

719 AnOn. VAl. 11.57, 12.64. vö. Gelasius Ep. 12, TheOPH. AM. 5992., Procop. De Bellis. 4.5.11-25 vö. PROCOP. DE BELLIS. 5.3.13-15. A kettős, vallási-politikai követségek azonban nem példa nélküliek. Prokopios megemlít egy esetet, amikor Theodahad uralkodásának idején egy ephesosi és egy philippoiból származó pap Rómába járt, hogy hitbéli kérdésekben egyeztessenek II. János pápával. Az 
Theoderich nevében békét kellett kötnie a császárral, mert éveken keresztül a császár jóváhagyása nélkül uralkodott. ${ }^{720}$ A névtelen szerző szerint Festus teljesítette is a megbízatást. ${ }^{721}$ A Hagia Sophia 6. század első felében alkotó lektora ezzel szemben azt is tudni véli, hogy a rangidős senator a palotában folytatott megbeszélésen azt is mondani vélte Anastasiusnak, hogy el tudja érni a Henotikon elfogadását. ${ }^{722}$

A senatus vezető személyének ajánlata korántsem volt légből kapott, hiszen a 496 novembere óta regnáló II. Anastasius, elődjével szemben, lényegesen rugalmasabbnak mutatkozott a Konstantinápoly és Róma közötti kapcsolatokban. ${ }^{723}$ Ez remekül megmutatkozott abban, hogy pontifikátusa kezdetén rögtön alázatos levélben tudatta megválasztását a császárral. Hasonló aktusra Gelasius idejében aligha kerülhetett sor. Az Henotikon elfogadására irányuló ajánlat azonban a követ visszaérkezését követően rögtön okafogyottá vált. Időközben ugyanis elhunyt II. Anastasius, Festus ígérete így nem várt nehézségekbe ütközött. ${ }^{724}$ Rómában nem tudtak megegyezni az új pápa személyében, így 498. november 22-én két, egymással szemben álló pápát választottak. Az egyháziak egy része a Lateráni bazilikában Symmachust, ${ }^{725}$ míg egy másik csoport

egyháziak ekkor a császár levelét kézbesítették, majd nem sokkal később csatlakoztak egy konstantinápolyi senatusból érkezett követhez, aki Amalasuntha miatt érkezett. A Festusszal tartó Cresconius és Germanus pápai legátusok azzal a feladattal érkeztek, hogy elérjék egy ünnepség megrendezésének engedélyezését a császárnál, amellyel Péter és Pál apostolok emlékének tisztelegtek volna.

720 ANON. VAL. 11.53.

721 ANON. VAL. 12.64

722 TheOD. LeCT. EpIT. 2.16-17., TheOph. AM. 5992. ANON. VAl. 12.64 vö. JORD. Get. 295. A forrás szerint megkapta az uralkodói felségjelvényeket (vestis regia), amelyeket még Odoacer küldött vissza Konstantinápolyba, ilyenről azonban szó sincs más forrásokban. Iordanes sem beszél visszaküldésről, csupán annyit mond, hogy Odoacer Zeno tanácsára letette korábbi öltözetét és felségjelvényeket öltött.

723 RICHARDS 1979, 22. Anastasius Konstantinápollyal szembeni engedékenységének jele, akárcsak III. Felix esetében, hogy ö is alázatos levélben tudatta a császárral megválasztását, holott ez ebben a korszakban, s különösen Gelasius pontifikátusa alatt, egyáltalán nem volt jellemzö.

724 THEOD. LeCt. EPIT. 2.16-17, THEOPH. AM. 5993.

${ }^{725}$ A pápa táborát azok a papok erősítették, akik elhagyták II. Anastasiust. Erre azért került sor, mert a pápa érdekközösséget vállalt Photinusszal a thessalonicai diakónussal, így kötődött Akakioshoz, aki a római klérus szemében a Henotikon megfogalmazója volt. Ennek értelmében Symmachus egyértelmüen a 482es rendelkezés ellen foglalt állást, akárcsak Gelasius. II. Anastasius viszont, Gelasiusszal szemben valamivel rugalmasabbnak mutatkozott a Konstantinápoly és Róma közötti kapcsolatokban. Az afrikai születésü Gelasius pontifikátusa alatt a Szentszék sorra utasította el a keleti püspökök kompromisszumos ajánlatait az Akakios-féle skizma kérdésében. Ráadásul, ami leginkább szúrhatta a konstantinápolyi egyház elöljáróinak szemét: „,Gelasius] Az egész egyházra nézve rendeletet bocsátott ki [továbbá] Két könyvet irt Akakiosszal szemben" (LIB. PONT. 51.3). Később éppen emiatt érték Gelasiust sorozatos támadások a konstantinápolyi egyház részéről. Halála után ebből kifolyólag belső átrendeződés történt a kléruson belül, sok pap kivált az egyházból. Ennek legföbb oka Anastasius pápa önálló politikája volt, elődjével szemben ugyanis ő nem kérte ki a papok, püspökök véleményét az egyházat illető kérdésekben. Anastasius Konstantinápollyal szembeni engedékenységének jele, hogy ő is alázatos levélben tudatta a császárral megválasztását, holott ez ebben a korszakban, s különösen Gelasius pontifikátusa alatt, egyáltalán nem volt jellemző. 
a Santa Maria Maggiore bazilikában Laurentiust választotta pápává. Symmachus személyében Gelasius keményvonalas politikáját támogatók leltek képviselőre, míg Laurentius ezzel ellentétes álláspontot képviselt. A két párt összetüzései majd egy évtizedig meghatározták Róma életét, melyet Anonymus elhallgat, ahogyan azt is, hogy Laurentius megválasztása mögött Festus állt.

A fentiek tükrében világos, hogy Anonymus Valesianus következetesen elkendőzte a követségek egyházi motivációját, amely talán csak 490-ben nem volt jelen. Mi több, úgy állítja be őket, mintha csupán világi funkciójuk lett volna, miközben (Anicius) Faustus és Festus követsége szorosan kapcsolódott Akakios-féle skizma megoldásához. Előbbi tisztségviselő Gelasius pápa oldalát erősítve, míg utóbbi a keleti érdekek támogatójaként jelenik meg. Anonymus célja korántsem egyértelmü. Minden bizonnyal semmissé akarja tenni a Zeno és Theoderich közötti megállapodást, ami Odoacer halálával automatikusan lépett életbe és újra akarja definiálni az osztrogótok Itáliai uralkodását oly módon, mint amihez szükségeltetik az új császár jóváhagyása is. Theoderich és Zeno kezdeti viszonya korántsem volt felhőtlen. Az uralkodónak viszont kapóra jött, hogy Aspar korábbi pártfogoltját Itáliába küldje az időközben önállósodott Odoacer hatalmának megtörése érdekében. Ezzel a lépéssel Zeno két legyet ütött egy csapásra, hiszen nemcsak Strabótól, de Odoacertől is sikerült megszabadulnia. Anonymus szerint Theoderich a császár küldötteként addig birtokolhatja Itáliát, amíg a császár jogot nem formál rá. Ezt erősíti Prokopios periklési allúziója is, amely szerint Theoderich uralkodása csak a vége felé vesz negatív fordulatot, nem pedig a szkír halála után. Aligha valószínű, hogy 493 és Anastasius négy évvel későbbi állítólagos elfogadása között érdemi interakció nélkül élt volna egymás mellett Konstantinápoly és itáliai küldötte.

\subsection{Az Aniciusok nyugati maradványai}

Az osztrogót uralom alatt élő római arisztokrácia, így a nyugaton maradt Aniciusok története is elválaszthatatlanul összefonódott a Laurentius-féle egyházi szakadással, amely 498 és 506 között meghatározta Róma jóformán mindennapi életét. Theoderich meglehetősen türelmesnek mutatkozott az egyháziak belharcaival kapcsolatban, hiszen az ő szemében uralkodása nem Anastasiustól és a Henotikon elfogadásától függött, hanem Zenótól és Odoacer legyőzésétől, ami már 493-ban megtörtént. Jól mutatja ezt Cassiodorus Theoderich életében készült krónikája, ami egy szóval sem említi Theoderich Anastasius általi elfogadását, sokkal nagyobb jelentőséget 
tulajdonít annak, hogy Theoderich 489-ben Itália területére lépett. ${ }^{726}$ Theoderich 493-tól nyugodt lehetett saját sorsa felől, legfeljebb Róma nyugalma miatt avatkozott be az egyháziak és a senatorok összetüzésbe.

Az Itália eseményeiről beszámoló Anonymus Valesianus meglehetősen visszafogottnak mutatkozott a Laurentius-féle egyházi szakadás kérdésében. Nem csak az okokról, de a belharcokról sem beszél, pedig Róma utcái 501 tavasza után váltak hangossá, miután a pápákat támogató csoportok összekülönböztek a húsvét ünnepén. A klérus és Symmachus a húsvétot a régi római naptár szerint ünnepelte, így az március 25-re esett. A Laurentiust támogató csoport ezzel szemben azt követelte, hogy az alexandriai időszámítást vegyék figyelembe, amely április 22-re helyezte az ünnepet. Az új időszámítás még az 5. század végén került Rómába Dionysius Exiguus közvetítésével. A szír szerzetes ideje jó részét a nápolyi Castellum Lucullanumban töltötte, amelynek rendfönökével is jó kapcsolatot ápolt. A kolostor élén ekkor az Eugippius állt, aki 510ben megírta Szent Severinus életét, melyből egy jelentős részt Anonymus Valesianus is átvett. Iordanes szerint Odoacer Romulus Augustulust ide számüzte. ${ }^{727}$ A Variae egyik levele szerint Theoderich megerósítette korábbi privilégiumaiban Augustulust, amelyet Liberiustól praefectus praetoriótól nyert el, ${ }^{728}$ vagyis attól a tisztségviselötől, aki az osztrogótok beköltözése során a földosztásért felelt. ${ }^{729}$ Theoderich uralkodásának első szakaszában minden bizonnyal a praefectus praetorio felügyelhetett a Castellum Lucullanumra, ez esetben előbb Liberius, majd 500-tól Theodorus (cos. 505), aki a Decius család tagja volt, ${ }^{730}$ így közvetve ez a tisztségviselő is hozzájárulhatott az alexandriai időszámítás terjedéséhez. Anonymus Valesianus később nem csak őt, hanem testvérét is pozitív színben tünteti fel egy későbbi követség kapcsán, ${ }^{731}$ amely éppen az arianizmus ellen hozott intézkedések enyhítése érdekében indult Konstantinápolyba, miközben a korábbi követjárások során az Anicius családhoz tartozó követ Akakios-féle skizma lezárása érdekében tett próbálkozásait egyszerüen eltussolta. Az Excerpta szerzője meglehetősen elfogult a Deciusok irányába.

726 CASs. Chron. 489 vö. 497, EnNOD. PAN. 10.51. Hozzá hasonlóan Ennodius is nagyobb jelentőséget tulajdonít Odoacer legyőzésének, mint akár Zenónak, akár Anastasiusnak.

727 ANON. VAL. 8.38. IORD. GET. 242.

728 CASSIOD. VAR. 3.35.

729 EnNOD. EP. 9.23; CASSIOD. VAR. 2.15., PLRE 2, 677-681 „Petrus Marcellinus Felix Liberius 3”.

730 ANON. VAL. 12.68., PLRE 2, 1097-1098 „Fl. Theodorus 62”.

731 ANON. VAL. 15.90. „Sed deus, qui fideles cultores suos [Theodorum, Importunum] non deserit, cum prosperitate perduxit." 


\subsubsection{Ad Palmam}

A kettős pápaválasztás okozta harcok már négy éve tartottak, amikor többek kérésére Theoderich végre kitüzte a Symmachus elleni vádakat tárgyaló első ülést 502 nyarára, amely végül csak szeptemberben tudott összeülni. Ez utóbbi ülésnek, pontosabban körülményeinek áttekintése azért jelentős a dolgozat szempontjából, mert ebből rekonstruálható az Anicius család nyugaton maradt ága. Az elemzés annál is inkább szükséges, mert a PLRE Anicius genealógiája ez esetben is kiegészítésre szorul.

A gyülés 502. szeptember 1-jén ült össze a Basilica Sessorianában. Symmachus vádlói azzal érveltek a bünössége mellett, hogy ő és klérusa is szolgákat tart, akik ráadásul vallottak is ellene, ráadásul vallomásuk nemcsak a polgári joggal, de a kánonjoggal is összeütközött. ${ }^{732} \mathrm{~A}$ vád és a helyszín nagyfokú hasonlóságot mutat egy ötven évvel korábbinak mondott perrel, amely III. Sixtus pápa (432-440) és néhány senator között zajlott, legalábbis a 6. századi Gesta de purgatione Xysti III szerint. ${ }^{733}$

A Gesta azért érdekes, mert két, talán nem is annyira fiktív történetet mesél el, sokkal inkább felfedi az Aniciusok skizma alatti politikai irányultságát. Az első történet szerint III. Valentinianus uralkodása idején, Bassus (cos. 431) korábbi consul házában vita bontakozott ki a szabad jogállású Epifanius és a senator szolgája között, amely tettlegességig fajult. A háziúr a szolga védelmére kelt, sőt megtagadta Epifanius szabad státuszát. A sértett III. Sixtushoz sietett támogatásért, aki védelmébe vette a szabadot, majd Bassus házhoz sietett, hogy közbenjárjon az érdekében. A senator nem vette jó néven a közeledést és durván elutasította az egyházfőt, mondván, a pápának semmi köze egy magánház ügyeihez és ahhoz sem, hogy bánik egy nemes a szolgájával. Bassus ezt követően kidobta Epifaniust, és elkobozta valamennyi tulajdonát. A megsértett pápa III. Valentinianusnál keresett támogatást annak érdekében, hogy a császár közbenjárjon és megerősítse Epifanius szabad státuszát.

A másik történet szerint egy szicíliai nemes mindenét az egyházra hagyta. Birtokai szomszédságában Marinianus patricius birtokaitól, aki az egyik szolgájától tudta meg a hírt. Nem sokra rá fel is kereste III. Sixtust (432-440) és arra kérte, hogy az egyház helyett inkább az ő területeit gyarapítsa szomszédja birtokállománya. A pápa azonnal elutasította a senator megkeresését, majd egy felügyelőt bízott meg a birtok felmérésével. A két sértett senator összefogott és a pápa felügyelőjétől megtudták, hogy az egyházfö viszonyt folytat, ezért

\footnotetext{
732 ACTA SYNHOD.HABIT. ROM. 422-423, MOORHEAD 1992, 118.

733 A Gesta de purgatione Xysti III latin szövegét WIRBELAUER 1993, 262-271 publikálta. Általánosságban a Gestáról és keletkezési körülményeiről SESSA 2007, 79-114. A kutatói vélekedések szerint a pápai udvarban készülhetett.
} 
feljelentették a pápát a császárnál. A császár és anyja előbb megszakítottak minden kapcsolatot a pápával, majd a zúgolódás hatására Valentinianus összehívta a senatorokat, Sixtust, valamint az egyháziakat a Sessorium bazilikába. Maximus ex-consul tüstént a pápa védelmére kelt azzal, hogy törvényellenes volt beidézni, de Sixtus jámboran figyelmen kívül hagyta az óvást és részt vett a tárgyaláson, ami azzal végződött, hogy mindkét senatort elmarasztalták és büntetésüket a pápára bízták. III. Sixtus kiátkozta őket. Marinianus és Bassus nem tudod beletörődni a kiközösítésbe ezért megpróbálták lefizetni a pápát, ám mivel bünük a Szentlélek ellen való volt, nem volt számukra megbocsátás. ${ }^{734}$

Az 502. szeptember Symmachus ügyében összehívott ülés körülményei megfelelnek a Gesta történetének. Egyik uralkodó sem támogatta a pápát, bár III. Valentinianus részt vett a gyülésen, míg Theoderich csak egy írásbeli utasítást küldött. ${ }^{735}$ A senatorok ügyesen fogalmazták meg vádjaikat, hiszen Symmachust, Gelasius követőjét, éppen azzal vádolták, amelyeket maga Gelasius is elítélt. Az egyházfő dekrétumai között szerepel ugyanis egy olyan pont, amely szerint ki kell zárni azt, aki szolgákat tart. ${ }^{736}$ Ha a Laurentius-pártiak állításai beigazolódtak volna, a gyülésnek egyértelmủen le kellett volna tennie Symmachust. Egy ilyen súlyú ügyet Cassiodorus hivatali leveleiben megemlített volna, azonban sem Cassiodorusnál sem Ennodiusnál, de még a fennmaradt hivatali papiruszokban sem esik szó a történtekről. ${ }^{737}$ Annak ellenére nem szerepelnek ezekben, hogy 500-ban kiadott Edictum Theodorici kínzást ír elő azoknak a szolgáknak, akik vallanak uruk ellen. ${ }^{738}$ A Symmachus pápa támogatására készített ${ }^{739}$ Gesta de purgatione Xysti III és a valódi ülés jegyzőkönyvének legfontosabb különbsége, hogy míg az előző néven nevezi a pápa vádlóit, addig az Acta Synodorum nem tartalmaz ilyen adatot. A fiktív történetben szereplő senatorok meghatározhatóak, hiszen a III. Valentinianus idejében játszódó történetekben Bassusról például közli, hogy ex-consul és patricius volt, így ebben az időhatárban bizonyos, hogy Anicius Auchenius Bassusról ${ }^{740}$ (cos. 431) lehet szó. A Gesta célja, minden bizonnyal az, hogy figyelmeztesse a senator leszármazottait, máskülönben öket is kiátkozhatja az egyház, ahogyan azt ősükkel történt.

Az Aniciusokról szóló fejezetben már említettem, hogy a család Rómában maradt részének egyik utolsó egyenes ági leszármazottja Anicius Auchenius Bassus (cos. 431) volt. Az Anicius

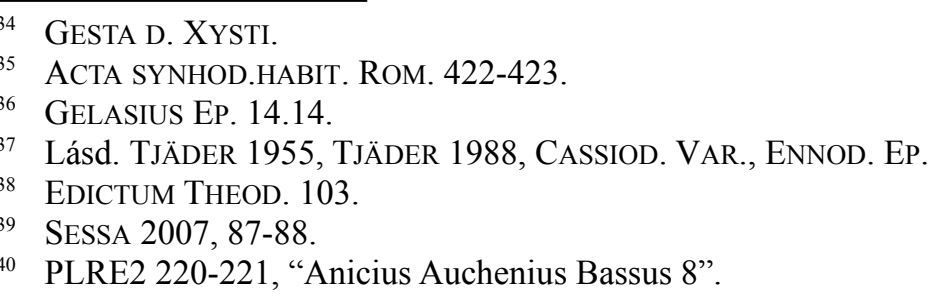


család ezen ága Bassust követően nőágon folytatta útját. Az első kedvezményezett Bassus kortársa, Acilius Glabrio Sibidius lehetett, ${ }^{741}$ nevét ugyanis megőrizte egy emlékmű, amit fia Anicius Acilius Glabrio Faustus (cos. 438) állított. ${ }^{742}$ Ö első ízben a Gesta Senatusban bukkan fel. A 438-ban bemutatott Codex Theodosianus nyugati részekre küldött példányt ő mutatta be, ráadásul saját otthonában, amit a forrás “ad Palmam"-ként jelöl. ${ }^{743}$ A Gesta fiktív történetében a III. Sixtus és Bassus (cos. 431) közötti összetüzés a senator római villájában bontakozik ki, aminek a végén Bassus egyszerüen kidobja az egyházföt.

Lehetséges, hogy a Gesta Senatus és a Gesta de purgationéban szereplö villa egy és ugyanaz. Az ad Palmam épületét ugyanis Theodosius törvénykönyvének bemutatása után éppen a Laurentius-féle skizma következő, 502. október 23-án tartott ülésével kapcsolatban említik újra a források, ${ }^{744}$ amikor Symmachus pápát valamennyi vádpont alól felmentették. Az ott megrendezett ülésen Faustus Albinus (cos. 493) elnökölt. A Gesta Senatus és a Gesta de Xysti purgatione ismeretében feltételezhető, hogy Bassus (cos. 431) és Albinus ${ }^{745}$ (cos. 493) között rokoni kapcsolatban van, illetve az is, hogy az utóbbi senator, vagy családja vonakodhatott a pápa mellé állni, hiszen mi más indokolhatta volna a Gesta de Xysti purgatione létrejöttét? Minden bizonnyal nem Albinus (cos. 493) ellenezte Symmachus pápaságát, hiszen éppen azon az ülésen elnökölt, amely felmentette a pápát valamennyi vád alól, ráadásul néhány évvel később éppen Symmachus pápát kérte meg, hogy a családi birtokon épült bazilikájukat felszentelje. ${ }^{746}$

A PLRE szerint Albinus (cos. 493) apja Caecina Decius Maximus Basilius ${ }^{747}$ (cos. 480) volt, akinek Albinuson kívül még három fia született: Avienus ${ }^{748}(\cos .501)$, Theodorus ${ }^{749}(\cos .505)$ és Inportunus ${ }^{750}$ (cos. 509), miközben korábban arra jutottunk, hogy Bassus (cos. 431) az Anicius család tagja. A Laurentius-féle egyházi szakadást vizsgáló szakirodalom, a PLRE stemmáját elfogadva, azon az állásponton van, hogy mind Basilius (cos. 480) fiai, de éppen ezért nem tudják

741 CAMERON 2012B, 149.

742 CIL 6.1678. Lásd részletesebben az Aniciusokat tárgyaló fejezet 2. stemmáját.

743 G. S. praef.: "Domino [nostro] Flavio Theodosio Aug(usto) [XIV] et Anicio Achillio Glabrione Fausto v. c. consulibus Anicius Achillius Glabrio Faustus v. c. et inl(ustris), tertio expraefecto urbi, praefectus praetorio et consul ordinarius in domo sua, quae est ad Palmam."

744 A gyülés helyszínével kapcsolatban több elmélet napvilágot látott, ezeket Moorhead foglalta össze. Egyesek a Campania provinciában található Palma városával azonosították, Mommsen azonban vonakodik bármiféle földrajzi tartalmat fellelni a „Synodus palmaris” kifejezésben lásd MoORHEAD 1992, 119. 10. 1j. Azt az elméletet, amely szerint a gyülést a Szent Péter bazilika oszlopcsarnokában tartották meg, a kutatók többsége elvetette.

745 PLRE2 51-52, “(?Faustus) Albinus iunior 9".

746 LIB. PONT. 53.10.

747 PLRE2 217, "Fl. Caecina Decius Maximus Basilius iunior 12”.

748 PLRE2 193, "Fl. Avienus iunior 3".

749 PLRE2 1097-1098, "Fl. Theodorus 62".

750 PLRE2 592, "Fl. Inportunus". 
megmagyarázni, hogy a testvérek miért álltak ellentétes oldalon a skizma idején: Albinus és Avienus Symmachus pápát segítette, míg Theodorus és Inportunus az ellenpápát támogatók csoportjához tartozott. Szembenállásuk miatt testvérharcra gyanakodtak, ${ }^{751}$ ami kétségkívül érdekes feltevés, de az ok sokkal pragmatikusabb lehet.

Úgy gondolom, hogy a négy fiú között nem volt testvéri kapcsolat. Sokkal inkább gondolhatunk arra, hogy Albinus és Avienus alkothatott egy testvérpárt, Theodorus és Inportunus pedig egy másikat. Ezt a feltételezést támasztja alá, hogy a kortárs források mindig külön említik a testvéreket. Theodorus és Inportunus I. János pápával együtt ment Konstantinápolyba. ${ }^{752}$ Pápai követségről lévén szó, ez akár az eltérő érdekcsoportok részvételét hangoztató elméletét is alátámaszthatná, amit azonban Cassiodorus levelei cáfolnak. A Variae szerint ugyanis 507-ben cirkuszi játékokat rendeztek az Amphitheatrum Flaviumban, amiben a testvérek is érintettek voltak. $^{753}$ Ahogyan Konstantinápolyban a Hippodrom, Rómában a Colosseum volt a politikai véleménynyilvánítás egyik legmeghatározóbb helyszíne. Cassiodorus leírása szerint kezdetekben négy párt versengett egymással: "zöld, mint a zöldellö tavasz; kék, akárcsak a zord tél; vörös, mint lángoló nyár; fehér akár a zúzmarás ősz" ${ }^{754}$ A késő antikvitásban azonban már csak a zöld és a kék pártokat említik a források. ${ }^{755}$ A Variae egyik levele megerösíti Albinust és Avienust a zöld párt patronusi pozíciójában, ennélfogva a zöldek érdekeit kellett képviselniük, amelynek tagjai panasszal éltek az udvarban. ${ }^{756}$ A Variae egy későbbi levelében, melynek címzettje Róma praefectus urbija, arra utasítják a tisztségviselöt, hogy tartson rendet a városban, mert a pártok összetüzései megbontják a rendet. A levélből kiderül az is, hogy Theodorus (cos. 505) és Inportunus (cos. 509) a zöld párt tagjaira törtek és egy életet már ki is oltottak az összecsapásokban. ${ }^{757}$ A cirkuszi pártok patrociniuma családon belül öröklődött, a fentiek tükrében a zöld párthoz való viszony a két testvérpár egyértelmü különállását mutatja.

Faustus (cos. 438) és Albinus (cos. 493) között azonban legalább egy, de inkább két generáció telt el. Erre mutatnak a consuli évek, az 5. század végére ugyanis, mivel néhány nagy család kezdte monopolizálni a fontosabb tisztségeket, a prosopográfiákban megfigyelhető, hogy

751 Többek között: LLEWELlYN 1976, MOORHEAD 1978, 604-612, RICHARDS 1979, WIRBELAUER 1992 , CAMERON 2012B. A testvérharc elméletének kialakításakor a kutatók a PLRE-ben található stemmát és szócikkeket vették alapul, ami Caecina Decius Maximus Basilius fiának jelölte mind a négy fiút.

752 ANON. VAL. 15.90-91.

753 CASSIOD. VAR. 1.20.

754 CASSIOD. VAR. 3.51.

755 A korábbi felfogással szemben a Zöld pártot a nép, a kéket pedig a senatus, vagy az uralkodó támogatta. CAMERON 1976A, 99. Cameron azonban bizonyította, hogy ez az osztályozás nem mutatható ki egyértelmüen.

756 CASSIOD. VAR. 1.20.

757 CASSIOD. VAR. 1.27. 
egyes családok tagjai szinte menetrendszerúen követték egymást. Az apa consulsága után általában megközelítöleg 20 évvel következett a fia. Ez a minta mutatkozik meg a Deciusok esetében is. Caecina Decius Aginatius Albinus 444-ben töltötte be a consulságot, fia, Caecina Decius Basilius (cos. 463) kinevezése tizenkilenc évvel követte apjáét. Basilius fia, Caecina Decius Maximus Basilius iun. (cos. 480) tizenhét évvel követte apját, az ö fia, Theodorus (cos. 505) pedig huszonöt évre rá következett.

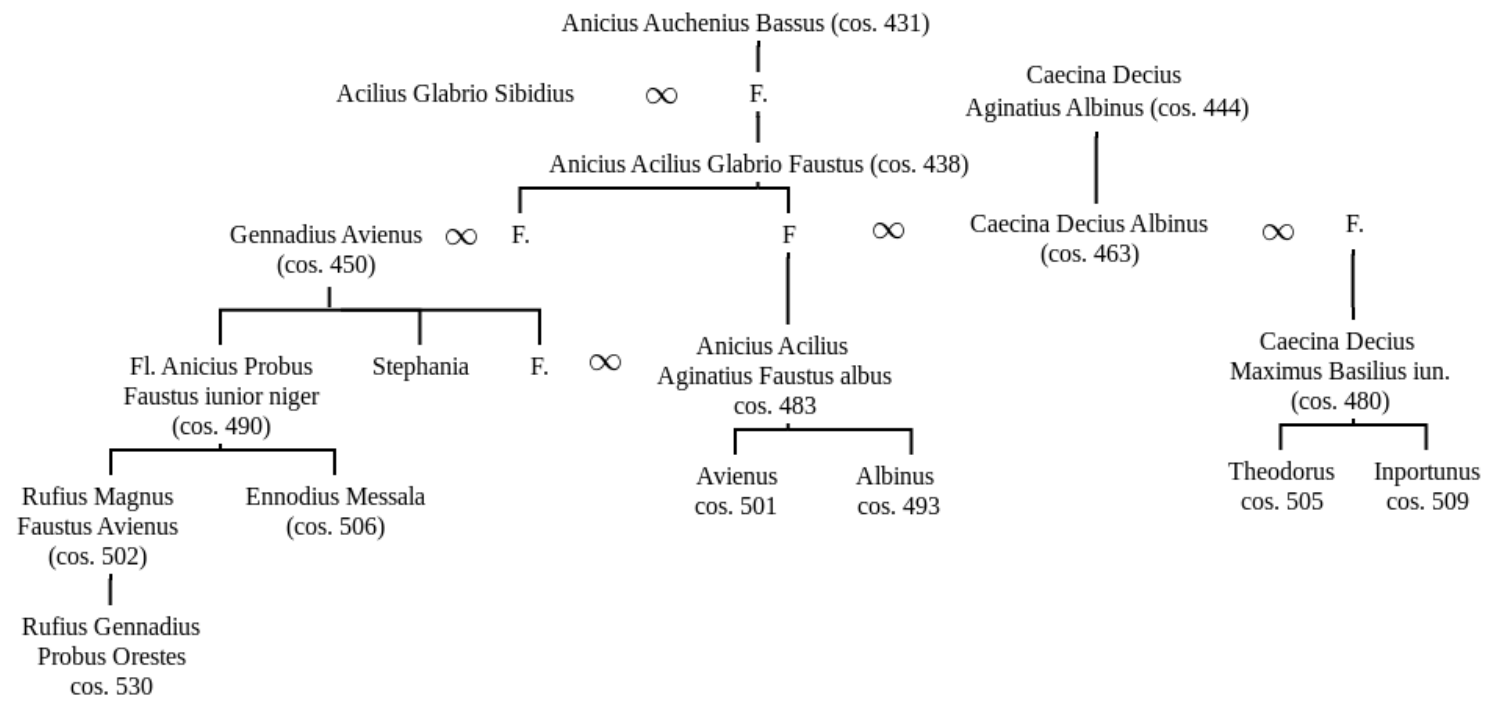

5. Stemma: Az Aniciusok nyugati ága és házassági kapcsolataik

Ami az Aniciusokat illeti, ennek alapján feltételezhető, hogy Anicius Acilius Glabrio Faustus (cos. 434) után, 455 körül, illetve 475 körül hiányzik egy generáció. A PLRE adatbázisa alapján egyetlen senator illeszthető a hiányzó családfa második helyére (475), mégpedig: Anicius Acilius Aginatius Faustus albus ${ }^{758}$ (cos. 483). Az ő esetében az a szerencsés helyzet állt elő, hogy teljes névalakja

758 A rómaiak nevéröl: SALWAY 1994, CASTRITIUS 1997. A római polgárok alapvetően három tagból (praenomen, nomen gentile, cognomen) állt, ezért tria nominának is nevezik, amelyhez néha egy második cognomen is társult, ez lett az agnomen, ami egy még finomabb szüröt, egy pontosabb azonosítást tett lehetővé a családon, nemzetségen vagy egy társadalmi csoporton belül. Az 5. század végén a skizma kapcsán két senator nevében bukkan fel agnomen: Faustus albus (cos. 483) és Faustus niger (490). Az agnomen minden bizonnyal hajszínükre utalt. Albus már igen idős lehetett, míg Faustus niger haja fekete volt. Mindketten senatorok voltak és mindketten aktívan politizáltak, ezért volt szükség megkülönböztetésre. SuNDWALL 1919, 72-83. A két senator jelenlétére nem figyeltek fel a friss útmutatók szerkesztői sem, annak ellenére, hogy erre a lehetőségre a 20. század elején már Sundwall felhívta a figyelmet. ENNOD. EP. 1.7; 1.26. vö. ENNOD. EP. 1.3; 1.4. Ennodius "Faustusnak" írt levelei 
megőrződött. Látható, hogy az Anicius, Acilius és a Faustus névelemek az imént említett Anicius Acilius Glabrio Faustus (cos. 434) nevében is felbukkannak. Új elem viszont az Aginatius, ami egyedül Caecina Decius Aginatius Albinus (cos. 444) nevében található meg. Mindkét senator a dédapja lehetne a skizma idején összetüző testvérpároknak. A megegyező névalakok arra utalnak, hogy a 434. év consulának ismeretlen fia és a 444. év consulának ismeretlen lánya házasságot kötött, amelyből Anicius Acilius Aginatius Faustus albus (cos. 483) született. A senator az anyai nagyapja után kapta az Aginatius nevet, míg a többi névelem apai nagyapja után, az Anicius-ágról származott. A Gesta de purgatione Xystit minden bizonnyal Faustus Albus (cos. 483) Symmachusszal kapcsolatos vonakodása ihlette. Ezt támasztja alá, hogy az 5. század végén Ennodius távoli rokona, vienne-i Avitus levelet küldött a senatus két legidősebb tagjának, Faustus albusnak (cos. 483) ${ }^{759}$ és Symmachusnak ${ }^{760}$ (cos. 485), melyben Symmachus pápa támogatására szólítja fel őket. Avitus minden bizonnyal azért címezte levelét a senatus szeniorjainak, mert azt remélte, hogy idős koruk révén caput senatusként nagyobb befolyással vannak a senatus többségére. Faustus Albus (cos. 483) minden bizonnyal a skizma idején halhatott meg, Ennodius egy 503 öszén ${ }^{761}$ kelt levelében, melyet rokonának, Faustus Nigernek (cos. 490) küldött közli, hogy sikerült rábírnia Symmachus támogatására Albinust (cos. 493). ${ }^{762}$

Egy másik, a Variaeban olvasható levél tanúsága szerint a 6. század első éveiben a domus ad Palmam már Albinus (cos. 493) tulajdonában volt. A senator ugyanis 507-ben egy beadvánnyal fordult a ravennai kormányzathoz, annak érdekében, hogy a háza mellett egy mühelyt nyithasson. ${ }^{763}$ Az engedélyt megkapta. A levél és az átalakítások apropója minden bizonnyal apja nem sokkal ezt megelőző halála lehetett. Ez ugyanakkor azt is jelenti, hogy Anicius Acilius Aginatius Faustus albus (cos. 483) a 6. század elején még életben volt. Fiai csak halála után örökölték meg a zöld párt patrociumát és a házat. Az 1980-as évek végén ásatások zajlottak a környéken, amikor is az olasz

nagy jelentős stílusbeli eltéréseket mutatnak. Ennodius 297 levele közül 54-nek Faustus a címzettje a szerző azonban csak néhány esetben alkalmaz terjedelmes búcsúformulát, ami távolságtartást és tiszteletet jelez.

759 PLRE2 454-456, “Fl. Anicius Probus Faustus iunior Niger 9”. (Anicius Probus Faustus niger (cos. 490)) vö. PLRE2 451-451, “Anicius Acilius Aginantius Faustus iunior (albus) 4” (Anicius Acilius Aginantius Faustus albus (cos. 483)). Lásd ORLANDI 2006. A szakirodalom szerint a levél nem a 483. év consulának szól, hanem a 490. év consulának. Ezt a tévedését az okozza, hogy nem tudják azt, amit még 1980-ban a PLRE készítésekor sem sejtettek, hogy két csaknem azonos nevü senator élt egy időben. PLRE2 1044-1046, "Q. Aurelius Memmius Symmachus iunior 9”.

761 Datálás SunDWALL 1919, 72-83. alapján.

762 ENNOD. EP. 2.22

763 CASSIOD. VAR. 4.30.2.: „Porrecta itaque supplicatione testatus es Curvae porticus, quae iuxta domum Palmatam posita forum in modum areae decenter includit, superimponendis fabricis licentiam condonari, ut et privatarum aedium habitatio protendatur et antiquis moenibus novitatis crescat aspectus." 
régészeknek sikerült kimutatni, hogy a ma is álló SS. Quirico et Giulitta templom alapját egy órási senatori villa adja, ami szinte tapadt a Porticus absidatához. ${ }^{764}$

Az előző oldalakon amellett érveltünk, hogy az egyik 6. század elején tartott egyházi ülésen Symmachus pápát egy olyan ülésen mentettek fel az ellene felhozott vádak alól, amelyet egy Anicius villában tartottak Albinus (cos. 493) elnöklete alatt. Az ún. domus ad palmam Faustus albuson (cos. 483) keresztül Albinushoz (cos. 493) és testvéréhez, Avienushoz (cos. 501) került, ám az 530-as években már egy templom állt az egykori senatori villa helyén.

\subsubsection{Az „Anicius(ok)” kivégzése}

Hogyan került Anicius Albinus (cos. 493) senatori villája az egyház tulajdonába? A századfordulón, a Laurentius-féle egyházi szakadásban, valamint néhány évvel később a cirkuszi összetüzések idején betöltött szerepét követően valamivel több mint tíz évet kellett várni, hogy ismét feltűnjön a forrásokban.

Cassiodorus szerint 514-tôl a klérus és a senatus egyre inkább támogatta a vallási egységet ${ }^{765}$ amelyben elsősorban frissen megválasztott Hormisdas pápának lehetett szerepe. Albinus (cos. 493) nevét nem sokkal később meg is találjuk egy 519 végén, 520 elején kelt levélben, ${ }^{766}$ melyben Hormisdas pápa (514-523) dicséri áldásos tevékenységét Dioscorus diakónusnak. ${ }^{767}$ Albinus, aki a századfordulón még praefectus praetorio volt, majd patricius lett, már a Laurentius-féle egyházi szakadásban is szerepet vállalt, és úgy tünik, hogy az egyház támogatásával a későbbiekben sem hagyott fel. A pápa levelének címzettje ebben az időben apocrisiarius volt a konstantinápolyi udvarban, ahol tevékeny szerepet vállalt az Akakios-féle skizma lezárásában. ${ }^{768}$

518. július 15-e gyakorlatilag a 451-es chalcedoni zsinathoz való visszatérést jelentette. Konstantinápolyban Anastasius császár halála után politikai fordulat következett be, Iustinus számára ugyanis a chalchedoni ortodoxia visszaállítása teljes mértékben megfelelt. A császár

764 GuIdOBALDI 1986, 207-208, COATES-STEPHENS 1996, 246, lokalizációs vita: PALMER 1990, 49, 181 lj.

765 CASS. CHRON. 514. „Me etiam consule in vestrorum laude temporum adunato clero vel populo Romanae ecclesiae rediit optata concordia."

766 COLL. AVELL. 173.

767 RiCHARDS, 97, 104-108. Az eredetileg alexandriai származású Dioscorus 530 szeptember 22-e és október 14-e között ellenpápaként tünik fel. Rómába 506 környékén érkezett. Kiváló szervezőnek tartották, IV. Felix pontifikátusa (526-530) volt az ún. bizánci párt vezetője. Felix halála közeledtével már érezte, hogy utódlása körül problémák adódhatnak, ezért kiadott egy palliumot, melyben megnevezte utódját Bontifatius személyében. 522. szeptember 22-én azonban mindkettőjüket felszentelték. 531-ben kiközösítették Dioscorust.

768 RICHARDS 1979, 103-104. 
engedett a pápai igényeknek, így 518. július 15--16-án a Hagia Sophia székesegyházban ünnepélyes keretek közt visszaírták az Anastasius által letett patriarchák nevét, valamint Leo pápa nevét a diptychonokba. Ezt követően császári rendeletben követelték meg mindenkitől, hogy hitet tegyenek a chalchedoni dogma mellett. Iustinianus és Konstantinápoly pátriárkája ezt követően levélben tudatta a döntést Hormisdas pápával, aki további szigorú feltételeket szabott. A pápa véleménye szerint mindenkit ki kell törölni a diptychonokból, akiket a Henotikon kihirdetése óta kiátkoztak (még azokat is, akiket éppen most írtak vissza), illetve valamennyi keleti püspököt, akik ez idő alatt hivatalban voltak. Ioannes pátriárka, mielőtt aláírta volna a dokumentumot, kijelentette, hogy a régi és az új Róma széke egy szék, ezzel továbbra is Chalchedon 28. kánonja mellett tört lándzsát, ami ugyan elismerte Róma tiszteletbeli elsőbbségét, de minden másban egyenlőnek deklarálta öket. ${ }^{769}$

Hormisdas Dioscorusnak írt levele szerint Albinus éppen ezt a folyamatot segítette azzal, hogy egy olyan összeállításon dolgozott, amely megkülönböztette egymástól azokat, akik írásban itélik el a chalcedoni dogmát, azoktól, akik csak szóban teszik azt. ${ }^{770}$ Mivel az osztrogótok arianizmusa Jézus isteni voltát és a Szentháromságot is tagadta, Albinus tevékenysége gyakorlatilag azt jelentette, hogy listázni kezdte azokat a gót vezetőket, akik nyíltan állást foglaltak chalcedoni rendelkezések és így Iustinianus egyházpolitikai törekvései ellen. Tevékenységén hamar megütköztek a ravennai udvar vezető gót tisztségviselöi, ami közvetve Boëthius vesztét is okozta.

Anonymus Valesianus beszámolója szerint a gót származású Cyprianus, ${ }^{771}$ aki ravennai udvar referendariusa, majd comes sacroruma és magistere volt, pénzéhségtől vezetve bevádolta Albinus patriciust, amiért az Theoderich uralma elleni leveleket küldött Iustinus császárnak. A Collectio Avellana tükrében a senator büne minden bizonnyal egyházpolitikai elkötelezettsége volt, de természetesen a politikai motiváció sem zárható ki. Amikor beidézték Albinust a ravennai udvarba meghallgatásra, váratlan támogatóra talált Boëthius magister officiorum személyében, aki a király jelenlétében Albinus védelmére kelt. Boëthius érvelése szerint a Cyprianus által támasztott vádak hamisak, hiszen ha a bevádolt senatort ebben a tettében bünösnek vélik, akkor nem csak ö,

769 MEYENDORFF 2001, 279-281.

770 Coll. AVELL. 173. "De laboris tui, quem cum dei omnipotentis iunamine suscepisti, pro ea parte, quae acta est, gratulamur effectu et indicamus ut, quemadmodum reuocandi sint hi, qui exscripto constituta Chalcedonensis concilii damnauerunt, debeas cogitare ne forsitan tales non scismatici sed magis haeretici uideantur an certe una sit causa tam eorum qui sermonibus, quam eorum qui conuincuntur scripto damnasse, quia per hanc distantiam filius noster uir illustris Albinus religiosus uidetur facere quaestionem. et cogita, utrum et scribentes contra Chalcedonense concilium per illum generalem libellum tantum suscipi debeant an certe aliquid amplius adicere."

771 PLRE2 332-333, "Cyprianus 2". 
hanem az egész senatus bünös, ${ }^{772}$ ami összhangban van Cassiodorus korábbi megjegyzésével. ${ }^{773}$ Úgy gondolom, hogy Boëthius ezzel utalhatott arra, hogy a senatus egyértelműen támogatta a iustinianusi politikát, elsősorban az Akakios-féle skizma lezárását. Boëthius kiállása miatt Cyprianus már nem csak Albinust, hanem annak védelmezőjét is megvádolta. Az ariánus Cyprianus minden bizonnyal nem személyes ellentét miatt vádolta meg Albinust, hanem egyszerủen azért jelentette az esetet, mert referendariusként ez volt a dolga, ugyanakkor az ariánus vallás követőjeként saját maga számára is sérelmesnek érezhette a dolgot. ${ }^{774}$

Ugyanez azonban nem mondható el Boëthiusról, aki saját beszámolója szerint is már régtől fogva ellentétben állt a ravennai udvar több magas rangú tisztségviselőjével. A Filozófia vigasztalása c. munkájában megemlíti, hogy semmi más, csakis a közjó elősegítése miatt vállalta ravennai hivatalát, ám éppen ebből származott a legtöbb súlyos összetüzése az udvar gót vezető tisztségviselőivel. Többször összetüzésbe került egy bizonyos Conigastusszal, aki gyámoltalanokat próbált meg kiforgatni vagyonából, de hasonlóképpen útját állta Triwila ${ }^{775}$ praepositus cubiculi mesterkedéseinek is. ${ }^{776}$ De a harmadik személy, akit az események érintettek, Symmachus (cos. $485)$ volt. A senator nem csupán Boëthius apósa volt, hanem egyben a senatus legidősebb tagja és vezetője is, ${ }^{777}$ aki a skizma lezárásának idején Konstantinápolyban tartózkodott a római senatus követeként. ${ }^{778}$

Anonymus szerint Theoderichben uralkodása végén megváltozott valami, gyülölte a senatorokat és alkalmat keresett meggyilkolásukra, ${ }^{779}$ végül sikerrel járt, Albinus tevékenysége elegendő bizonyítékot szolgáltatott, hogy fellépjen a senatus vezető tisztségviselőivel szemben. Boëthius fejére hamarosan kötél került, amit addig csavartak, amíg szemei ki nem pattantak helyükröl és kínok között végül egy doronggal verték agyon. ${ }^{780}$ Symmachus sem kerülhette el sorsát, az uralkodó hamarosan őt is kivégeztette. ${ }^{781}$ Anonymus beszámolójával van azonban egy probléma, nevezetesen, hogy éppen az ügyet kirobbantó Albinus haláláról nem számol be. De nem csak ő van így ezzel. Konstantinápolyban Prokopios is csak Boëthius és Symmachus kivégzéséről

2 ANON. VAL. 14.83, 86-86.

773 CASS. CHRON. 514.

774 ANON. VAL. 14.83, 86-86.

775 PLRE2 1126-1127, "Triwila".

776 Boeth. Cons. Phil. 1.4.8-35, Procop. De Bellis. 5.1.33. Boëthius bukásának egyik okát Prokopios is abban látja, hogy túlzottan erôs volt az igazságérzete és irigyei is szép számmal akadtak.

777 ANON. VAL. 15.92.

778 CASS. CHRON. 519. Erre enged következtetni Cassiodorus bejegyzése, ami Symmachust 519-ben keletről érkező követként írja le.

779 ANON. VAL. 14.85.

780 ANON. VAL. 14.85.

781 ANON. VAL. 15.92. 
és javainak elkobzásáról ír. ${ }^{782}$ A keleti auktor szerint kivégzése után néhány nappal ebéd közben a senatus első emberének levágott fejét szolgálták fel. ${ }^{783} \mathrm{~A}$ lefejezés a felségárulók bevett büntetése volt. III. Valentinianus is így büntette nővérének eunuchját, aki a történet szerint Honoria levelét és gyürüjét vitte Attilának, hogy a birodalom ellen vonuljon. ${ }^{784}$ Theoderich példát statuált azzal, hogy lefejezte a senatori ellenzéket. 523-ban Albinus ellen világos bizonyíték állt rendelkezésre, Boëthius maga mondja ki, hány ellenséget szerzett az udvarban és azt is, hogy a senatus is támogatta az egységet. Minden bizonnyal éppen úgy, ahogyan tette azt a Laurentius-féle skizma idején.

De akkor mégis miért nem szerepel Albinus a kivégzettek között? Az arisztokrácia tárgyalása során láthattuk, hogy a senatorok keresték annak a lehetőségét, hogy idősebb korukban is befolyással bírjanak, aminek egyik útja az egyházi szolgálat lett. Minden bizonnyal consulsága és praefectus praetoriói pozíciója után Albinus is erre törekedett. A 6. század elején 30-40 éves lehetett, bevádlásának idejében pedig már a hatvanas éveiben járhatott. Halála utána vagyona automatikusan az egyházra szállt, így lett a Szentszéké az a villa, ahonnan közel száz évvel korábban még III. Sixtus pápát seprüzték ki, s amely alapjaira később a SS. Quirico et Giulitta épült. ${ }^{785}$

A szakirodalomban elsősorban Momigliano nyomán terjedt el, hogy az 523-525-ben kivégzett senatorok az Anicius család tagjai vontak. A kutató egészen pontosan csak Symmachust és Boëthiust említette, hiszen nem használta Anonymus Valesianust. ${ }^{786}$ Ezzel szemben mi annyiban már biztosak lehetünk, hogy a történetben csak egyetlen Anicius volt biztosan: Albinus (cos. 493). Symmachus és Boëthius Anicius vérvonalát egyébiránt abból "vezette le" a Momigliano, hogy Symmachus lányát Probának nevezték, amit tipikus Anicius névnek gondolt. ${ }^{787}$ Cameron ezzel szemben bizonyította, hogy Proba nemhogy nem tipikus Anicius név, de még nem is Symmachus lánya, ráadásul az Anicius név sem Symmachus, sem Boëthius felmenöi között nem bukkan fel. ${ }^{788}$ Momigliano mindenesetre éppen emiatt gondolta, hogy az Ordo Generis Cassiodorumban (Anecdoton Holderi $^{789}$ található senatorok valamennyien az Anicius család tagjai, hiszen ha Symmachus lánya Anicius, akkor az apja is az és a veje, azaz Boëthius, illetve az Ordót készítő Cassiodorus is. A probléma Momigliano ezen állításával az, amint az első fejezetben is láthattuk,

782 Procop. DE Bellis. 5.1.32-34.

783 PROCOP. De Bellis. 5.1.35-36.

784 I. ANTIOCH FR. 223.2, PRISC. FR. 17, 20

785 Guidobaldi 1986, 207-208, COATES-STEPHENS 1996, 246, lokalizációs vita: PALMER 1990, 49, 181 lj.

786 MOMigLiANO 1966, 205.

787 MOMigLiano 1966, 185.

788 CAMERON 2012, 156-157.

789 A szöveget 1977-ben publikálta A. Holder, így kiadójáról gyakran Anecdoton Holderiként is nevezik. 
hogy az Ordo szövege éppen azon a ponton sérült, amelyből megállapítható lenne a tényleges rokonság, ezért a kutatás ugyan valamilyen kapcsolatot feltételez az Ordóban említésre kerülö személyek között, de nem rokonit. ${ }^{790}$

\subsubsection{A harminc szerencsés év}

Iordanes szerint Theoderich 30 évig uralkodott, Anonymus Valesianus viszont 33 évig, de csak 30 számított szerencsésnek. ${ }^{791}$ A szerencsétlenségek sora 523-ban kezdődött Albinus bevádolásával, amelynek alapját az ariánus gótok számbavétele jelenthette. Az Anicius családhoz tartozó senator megpróbáltatásait azonban Anonymusnál megelőzte egy szokatlan esemény. Mielőtt sor került volna a vádra, Theoderich utasításba adta, hogy a Verona külvárosában található Szent István imaház oltárát földig rombolják. ${ }^{792}$ Anonymuson kívül egy forrás sem említi ezt az eseményt. Az oltárban minden bizonnyal Szent István protomártír ereklyéi lehettek, aki 36-40 körül szenvedett vértanúhalált, amikor a jeruzsálemi zsinagóga vezetője bíróság elő állította, mert a diakónus nyilvánosan hirdette Jézus tanítását. A felbőszült zsidók kihurcolták Istvánt a városon kívülre és agyonkövezték. Érdemes alaposabban megvizsgálni a két esemény kapcsolatát, mert úgy gondolom, hogy a történetírók a 6. században társítani kezdik az Aniciusokhoz a protomártír ereklyéit és nem mellékesen az osztrogótok itáliai legitimációját is ez a kérdés magyarázhatja.

Orosius tárgyalása kapcsán már láthattuk, hogy a lélekkel kapcsolatos kérdései annyira összetettek voltak, hogy Szent Ágoston inkább Jeromosra bízta azok megválaszolását. ${ }^{793}$ Orosius ezért Betlehembe indult szent ajánlásának kíséretében, ${ }^{794}$ ahol megkapta Szent István protomártír néhány csontját (ossa solida) ${ }^{795} \mathrm{Az}$ ereklyéket Avitus Bracarensis bízta rá azzal, hogy miután végzett Jeromosnál, vigye őket hispániai szülővárosukba, Bracara Augustába. Orosius mindjárt Betlehembe érkezésekor furcsa dologról számol be. Az ariánus Athaulf csodás pálfordulásának elbeszélésére ugyanis éppen a protomártír ereklyéjének jelenlétében került sor. Orosius közli olvasójával, hogy személyesen hallotta, ahogy Betlehemben egy korábban Theodosius alatt

\footnotetext{
790 Momigliano 1966, 205, O’Donnell 1979, 262, Gallonier 1996, 305.

791 ANON. VAL. 12.59, JORD. ROM 349.

792 ANON. VAL. 14.83, 86-86.

793 JER. EP. 131.2-3. (Ágoston levele Jeromosnak): "Orosius Nam inde ad nos usque ab oceani littore properavit, fama excitus, quod a me posset de his, quae scire vellet, quidquid vellet audire. [...] Accipe igitur quae mihi, peto, aperire ac disserere non graveris. Quaestio de anima multos movit, in quibus et me esse confiteor."

794 August. EP. 166.2.

795 VANDERLINDEN 1946, 179-180.
} 
szolgáló jámbor és istenfélő katona Athaulf szavait tolmácsolja a szerzetesnek. ${ }^{796}$ Athaulf, felesége, Galla Placidia hatására áttért és már nem csak a a római törvények megtartásához ragaszkodik, hanem alkalmazni is akarta őket, uralma alatt egyesülhetnének a gótok és rómaiak. ${ }^{797} \mathrm{~A}$ dolog jelentősége abban áll, hogy Orosius ebben az esetben egyes szám első személyű szerkezetet használ, következésképpen az eseményeket úgy kell értelmeznünk, hogy azok a protomártír ereklyéinek jelenlétében történtek. A jelenetsor központi eleme az ereklye valamint Athaulf csodás áttérése. A hallottak után Orosius hajóra szállt és Hispánia felé vette útját. A protomártír csontjai azonban már sohasem érkeztek meg Bracarába. A szerzetes ugyanis Menorca szigetén értesült a várost érintő vandál támadásokról, ezért egy darab ereklyét elhelyezett a helyi templomban, majd visszaindult Észak-Afrikába. ${ }^{798}$

Orosius felajánlása egy röpirat kiindulópontjául szolgált. Az apokrif keresztény hagyomány zsidóellenes propagandája szorosan kapcsolódik a kortárs eseményeket feldolgozó röpiratirodalomhoz, ilyen volt az Epistula Severi, ${ }^{799}$ amely a menorcai zsidók kényszerített áttérítéséről szól és melyet István ereklyéinek megérkezése indított el. ${ }^{800}$ Menorca püspöke Orosius távozása után olyan eseményekről számol be, amelyek számos ponton párhuzamot mutatnak az itáliai senatorok kivégzését megelőző eseményekkel, amelyeket Anonymus Valesianus őrzött meg. Témánk szempontjából azonban csak öt caputnak ${ }^{801}$ van relevanciája. Anonymus leírása szerint

796 OROs. 7.43.4. "Nam ego" kezdetű mondat Orosius hétkötetes munkájában csak ebben az egy esetben fordul elö: "nam ego quoque ipse uirum quendam Narbonensem inlustris sub Theodosio militiae, etiam religiosum prudentemque et grauem, apud Bethleem oppidum Palaestinae beatissimo Hieronymo presbytero referentem audiui, se familiarissimum Athaulfo apud Narbonam fuisse ac de eo saepe sub testificatione didicisse, quod ille, cum esset animo uiribus ingenioque nimius, referre solitus esset" Az alábbi idézeten kívül saját magát összesen hét alkalommal (1.13, 2.2.11, 3.3.2 3.20.6, 3.23.1, 6.15.32, 7.35.12) említi meg a szerző.

797 OROS. 7.40.2... ,ab Athaulfo [...] capta atque in uxorem [Galla Placidia] adsumpta, quasi eam diuino iudicio uelut speciale pignus obsidem Roma tradiderit, ita iuncta potentissimo barbari regis coniugio multo reipublicae commodo fuit." [...] vö. 7.43.5: ,se [Athaulf] inprimis ardenter inhiasse, ut oblitterato Romano nomine Romanum omne solum Gothorum imperium et faceret et uocaret essetque, ut uulgariter loquar, Gothia quod Romania fuisset et fieret nunc Athaulfus quod quondam Caesar Augustus".

798 EP. SEVERI. 4.1-2. Severus nem nevezi nevén Orosiust, de a leírás alapján minden kétséget kizáróan róla van szó.

799 BRADBURY 1996, 15-17. Az Epistula Severi egy levél, amit Menorca püspöke Severus készített 418-ban, azért hogy megörökítse a helyi zsidók áttérését. A Revelatio Sancti Stephani igen elterjedt volt a latin világban, gyakran más munkákkal együtt terjedt, ilyen volt az Epistula Severi is, amely leírja a Szt. István ereklyéinek felfedezését és az általa életre hívott csodákat.

800 DiLley 2010, 605.

801 ANON. VAL. 14.80-83, 85. Eredetileg a narratíva részét képzi a 84. caput is, ami baljós elöjelek sorozatából áll, ezek azonban érdemi többletet nem adnak az értelmezéshez. A 14.84 párja Epistula Severiben a 9.4-nél található Severus álom. Egyúttal szeretném megjegyezni, hogy véleményem szerint az Epistula Severiben található álomleírások alapján megfejthető a Pars Posterior valamennyi anekdotája. Fontos megjegyeznem azt is, hogy ha figyelembe vesszük az Epistula Severi és a Pars Posterior vonatkozó része közötti párhuzamot, akkor tekintettel kell lennünk arra is, hogy Severus saját történetét írja le munkájában, éppen ezért a Pars Posterior vonatkozó részében szereplö püspök (Petrus) 
Itália belpolitikai problémái Eutharicus consullá (519) választásával kezdődtek. Noha a szerző elhallgatja, de ezzel egy időben két fontos esemény is történt. Egyrészt Iustinus fegyverrel fiává fogadta Eutharicust, ezzel kijelölve öt Itália következő uralkodójának, ${ }^{802}$ továbbá az Akakios-féle skizma lezárásával helyreállt az egység a keleti és nyugati egyház között. ${ }^{803}$ Cassiodorus ezzel az évvel kapcsolatban érdekes bejegyzést tesz "ebben az évben Róma sok csodát látott" jobbára Symmachus keletről érkezett követ révén, ami mind a rómaiakat, mind a gótokat gazdagította. ${ }^{804}$ Symmachus minden bizonnyal azonos a később kivégzett consullal (cos. 485), hiszen ebben az időben már ő volt a senatus vezető embere. ${ }^{805}$ Noha a szerző expressis verbis nem nevezi meg az Szent István ereklyéjét, valószínüsíthető, hogy az Akakios-féle egyházi szakadás lezárásának tiszteletére ekkor kerülhetett Itáliába.

Anonymusnál nyoma sincs csodáknak és elégedettségnek, sokkal inkább a helyzettel kapcsolatos elégedetlenséget érzékelteti, amikor megjegyzi, hogy ez az Eutharicus roppant durva és katolikus vallással szemben ellenséges volt. ${ }^{806}$ Majd azzal folytatja, hogy amíg Theoderich Veronában tartózkodott addig az uralkodó székhelyen összetűzés támadt keresztények és zsidók között, mert a zsidók nem akartak megkeresztelkedni és az erre a célra kapott szenteltvizet gyakran a folyóba öntötték. A zsidók tevékenységét ferde szemmel nézte Ravenna keresztény lakossága, csakhamar iszonyatos haragra lobbantak, nem tisztelve sem Theoderichet, sem Eutharicust, de még Petrus püspököt sem és a zsinagógákra támadva felégették azokat. ${ }^{807}$ A zsidók erre Veronába siettek a királyhoz, de nevében a praepositus cubiculi, Triwila járt el, aki Anonymus szerint maga is „eretnek” volt, így pártfogásába véve a zsidókat, és azt javasolta a királynak, hogy lépjen fel a keresztényekkel szemben. Theoderich feltételezte, hogy gyújtogatás történt, ezért utasításba adta, hogy az egész római lakosság adakozzon, amiből majd helyre tudják állítani a leégett ravennai zsinagógát. ${ }^{808}$ A Pars Posterior szerint nem sokkal később az uralkodót már teljesen elragadta az ördög, pedig ez idáig jól és panasz nélkül kormányozta az államot, utasításba adta, hogy a Verona

valójában a Pars Posterior eddig azonosítatlan szerzője, így vagy II. Petrus (494-519), vagy III. Petrus (569-578) ravennai püspökről lehet szó.

802 CASSIOD. VAR. 8.1.3.

803 CASS. CHRON. 519

804 CASS. CHRON. 519. "Eo anno multa vidit Roma miracula, editionibus singulis stupente etiam Symmacho Orientis legato divitias Gothis Romanisque donatas".

${ }^{805}$ CASS. Chron. 519 vö. PLRE2 1044-104, „Q. Aurelius Memmius Symmachus iunior 9”. Az adott szócikk szerkesztője, valószínüleg figyelmen kívül hagyta a Cassiodorust, hiszen maga is megjegyzi, hogy a senator követséget vezetett Konstantinápolyba, azt azonban nem tudja, hogy mikor. A dolgozatban korábban látott követségeket, amelyeket Theoderich küldött Konstantinápolyba kizárólag caput senatusok vezették.

806 ANON. VAL. 14.80.

807 ANON. VAL. 14.81. A történetíró szerint hasonló eseményekre került sor Rómában is.

${ }_{808}$ ANON. VAL. 14.82. Rendeletének végrehajtásával Eutharicust és Petrus püspököt bízta meg. 
külvárosában található Szent István imaház oltárát rombolják le. ${ }^{809}$ Bizonyos, hogy kényszerített áttérítésröl van szó, így akár az egyházi szakadás következményeire utal az esemény. Erre nem csak Cassiodorus tudósítása alapján következtethetünk, hanem az elkövetkező eseményekböl is, amelyekről Anonymus Valesianus számol be. Látni fogjuk, hogy mind az Epistula Severiben, mind a Pars Posteriorban leírt történet nagyfokú hasonlóságot mutat, hiszen az előbbi esetben biztosan tudjuk, hogy konfliktust a püspök szerint az ereklye érkezése okozta.

Az Epistula Severi története Maiorca szigetén, két helyszínen játszódik: ${ }^{810}$ Magonában (Mahón) és Jamonában (Ciudadela), előbbi helyen él a sziget összes zsidósága, mivel más helyeken képtelenek voltak megmaradni. ${ }^{811}$ A püspök beszámolója azzal kezdődik, hogy Jeruzsálemből egyszer egy pap (Orosius) érkezett, de mivel képtelen volt átkelni Hispániába, ezért visszatért a Szentföldre, azonban mielőtt útnak indult volna, Szt. István néhány ereklyéjét a helyi templomban helyezte el. ${ }^{812}$ A történet szerint távozása után egyre feszültebbé vált a helyzet a két felekezete között.

Az Epistula Severi szerint a zsidók és a keresztények közötti nézeteltéréseket kezdetben Theodorusnak, a magonai zsinagóga vezetőjének sikerült elhárítania, aki mind gazdagságban, mint tisztségei miatt általános elismertségnek örvendett a város mindkét felekezete körében. ${ }^{813}$ Ezek a tulajdonságok Theoderichre is érvényesek, aki Anonymus szerint soha semmi helytelent nem tett, így igazgatta a rómaiakat és gótokat egyszerre, és bár eretnek (ariánus) volt, soha nem támadt a katolikus vallás ellen. ${ }^{814} \mathrm{~A}$ feszültség kirobbanásához Magonában az vezetett, hogy Theodorus elhagyta a várost, hogy maiorcai birtokát ellenőrizze. ${ }^{815}$ Hozzá hasonlóan Anonymus Valesianusnál is akkor következett be összetüzés a keresztények és a zsidók között, amikor Theoderich elhagyta Ravennát Verona városáért, ahonnan öt is, akárcsak Severus Theodorusát egy követségnek kellett

809 ANON. VAL. 14.83.

810 EP. SEVERI. 2.5-6. Magona a sziget keleti oldalán, míg Jamona (Ciudadela) a nyugati szegletében volt.

811 EP. SEVERI. 3.1-2. Jamonában egyszerüen képtelenek voltak megmaradni, különböző bajok sújtották őket a városban (villámcsapás, hirtelen halál, betegség).

812 EP. SEVERI. 4.1-2., Dilley 2010, 605.

813 EP. SEVERI. 6.1. "Iudaeorum populus maxime cuiusdam Theodori auctoritate atque peritia nitebatur, qui non solum inter Iudaeos verum etiam inter Christianos eiusdem oppidi, et censu et honore saeculi praecipuus erat".

814 ANON. VAL. 12.60; 14.83. "Nihil enim perperam gessit. Sic gubernavit duas gentes in uno, Romanorum et Gothorum, dum ipse quidem Arrianae sectae esset, tamen nihil contra religionem catholicam temptans"; "Ex eo enim invenit diabolus locum, quem ad modum hominem bene rem publicam sine querella gubernantem subriperet".

815 EP. SEVERI. 7.1-2. "Iudaeis id magnopere expetentibus ut scilicet Theodorus, in cuius se omnis synagoga viribus acclinabat, ex Maioricensi insula reverteretur, ad quam tunc forte visendae possessionis gratia perrexerat. Qui quidem statim ut ad eum missa legatio est, remeans auctoritate sua multos terruit et non extinxit sed paululum sopivit contentionis incendium." 
visszahívnia a városba. ${ }^{816}$ Veronában nem közvetlenül a király vette pártfogásába a követeket, hanem Triwila (Symmachus vádlója), aki maga is eretnek (ariánus) ${ }^{817}$ volt. Anonymus szerint Theoderich az ö biztatására kezdett fellépni a keresztényekkel szemben. ${ }^{818}$

A követek érkezése után mind Theodorus, mind Theoderich visszatért a saját városába. Az Epistula Severi szerint a zsinagóga vezetőjének gyors visszatérése és személyes hatalma (auctoritas) révén mindenesetre igyekezet gátat szabni a keresztények buzgólkodásának, de a két felekezet közötti ellentéteket nem tudta megoldani. ${ }^{819}$ Theodorushoz hasonlóan Theoderich is próbálja elejét venni az elégedetlenségének. Severus szerint Theodorus saját népének patronusa volt, ${ }^{820}$ akárcsak Anonymusnál Theoderich, aki a szerző szerint az eretnekeket vette pártfogásba. ${ }^{821}$ ő azonban már nem csupán tekintélye révén éri ezt el, hanem kollektív büntetést szab ki. Az Anonymusnál megőrzött történet szerint nem a keresztényeket bünteti, hanem a rómaiakat, ${ }^{822}$ akiknek adakozniuk kellett a ravennai zsinagóga helyreállítására.

Jól látható, hogy Anonymus Valesianus teljes mértékben ugyanazt az eseménytörténetet adja vissza, mint az Epistula Severi. Néhány lényegi különbséggel. Ezek közül az első, hogy a történetben szereplő egyik gót sem zsidó vallású, hiszen Theoderich és Triwila is az ariánus vallás követője volt. Feltünő ugyanakkor, hogy Theoderich nem a keresztények ellen cselekszik, hanem kollektívan a rómaiak ellen, a szöveg ezen része mentes a vallási színezettől. Ehhez kapcsolódik, hogy Anonymus szerint csak Rómában és Ravennában történt ilyen eset, ${ }^{823}$ tehát az osztrogótok és a senatori arisztokrácia központjában, vagy ha úgy tetszik a gótok és a rómaiak fővárosában. Éppen ezért úgy gondolom, hogy az Anonymus történetében szereplő személyekben nem zsidókat kell látnunk, hanem ariánusokat. Erre mutat, hogy más kortárs krónikában semmi jel nem mutat a két felekezet közötti összecsapásokra, ugyanakkor a Variae-ban sem találunk utalást a ravennai zsinagóga újjáépítésére, ami felettébb furcsa, hiszen az uralkodói központról lévén szó mindenképpen említést érdemelne.

A Variae csupán néhány levelében szerepelnek zsidók, ezek azonban jól látható mögöttes tartalmat hordoznak, ha szem elött tartjuk, hogy a zsidó helyeket ariánus gótra cseréljük. A

816 ANON. VAL. 14.81-82. "Post haec Theoderico Verona consistente propter metum gentium facta est lis inter Christianos et Iudaeos Ravennates. [...] Mox Iudaei currentes Veronam".

817 ANON. VAL. 14.82. Anonymus ez esetben ügyel rá, hogy a gótokat következetesen eretneknek nevezze, így a szerző szemében az ariánusok és a zsidók is eretneknek számítanak.

818 ANON. VAL. 14.82

819 EP. SEVERI. 7.2.

820 EP. SEVERI. 6.3. "In civitate autem cunctis curiae muniis exsolutis, et defensor iam extiterat et etiam nunc patronus municipum habetur."

821 ANON. VAL. 14.81.

822 ANON. VAL. 14.82. Itt már nem a felekezettel jelöli a rómaiakat.

823 ANON. VAL. 14.81. 
gyüjtemény mindössze négy datálatlan ${ }^{824}$ levelében szerepelnek izraeliták, ${ }^{825}$ ezekből azonban csak egy beszél az őket ért „támadásról”. Ráadásul ezt a levelet nem is a zsidó hitközösségnek, hanem a római senatusnak címezték. ${ }^{826}$ A maradék három levél közül kettő a genovaiaknak, egy pedig milánóiaknak szól. Ez utóbbit Theoderich a civilitas hangsúlyozásával kezdi, amely az itáliai osztrogót kormányzat központi ideológiája volt, amely a félsziget társadalmát etnográfiai irányvonalak mentén rendezte, funkciójukban megkülönböztetve egymástól a gótokat (katonák) és a rómaiakat (közszolgák), akik mégis képesek egymás melletti békés együttélésre. ${ }^{827}$ Az uralkodó fontosnak tartja a civilitas megőrzését és az igazságos elbánást még azok esetében is, akikről úgy gondolják, hogy eltávolodtak az igaz hit útjáról. A milánói zsinagóga vezetője ugyanis arról tájékoztatta az udvart, hogy időről-időre inzultálják. A Variae felhívja a figyelmet, hogy a két közösség elkülönülését tiszteletben kell tartani, hiszen a harminc éves elöírás szokása mindenkire vonatkozik. A genovai zsidók egy kéréssel fordultak a ravennai udvarhoz, azt szeretnék ugyanis, hogy zsinagógájuk régi falai végre egy új tetőt tarthatnának. Theoderich engedélyezi a genovaiak kérését, de legnagyobb sajnálatára kiköti, hogy az új tető nem terebélyesedhet túl a régi határain és nem kaphat semmiféle díszítést. Mindezt azzal egyetértésében, hogy a zsidók tevékenysége nem ütközik össze a harminc éves rendelkezéssel. ${ }^{828}$ Az ugyancsak genovaiaknak írt levelében

824 KRAUTSCHICK 1983, 74-77, Krautschick egyik levelet sem tudta datálni, a 4.43-as levelet 509 környékére helyezte minden bizonnyal azért, mert egy ismert gót tisztségviselő (Arigern) is szerepel benne.

825 CASSIOD. VAR. 2.27. (Genova), 4.33 (Genova), 4.43. (Róma), 5.37. (Milánó)

826 CASSIOD. VAR. 4.43. (incidens) vö. 3.45. (Simplicius pápa háza). A levél minden bizonnyal egy allúzió a Laurentius-féle skizmára. A levél tanulsága szerint Arigern arról tájékoztatta az udvart, hogy Rómában csődület alakult ki és a lakosok porig égették a zsinagógát. mert néhány keresztényt korábban megbüntettek azért, mert megölték zsidó mestereiket. Arigern 502. augusztusában két másik góttal, Gudilával és Bedeulffal mediátori szerepet töltött be az két pápa ellentábora között. LIB. PONT. 53. 5.12 13, A Liber Pontificalis szerint még az év őszén, a gyülések között rátámadtak Symmachus pápára és több papot is megöltek, lehetséges, hogy a levél által említett zsidók/gótok is ekkor vesztették életüket. A Variae másik Arigernnek címzett levele (3.45) ugyanis arról számol be, hogy egy magánházat, amelyet korábban még Simplicius pápa vásárolt „Eufraxius acolitustól” megkörnyékezték a zsidók/gótok és maguknak követelik. Az oltárszolga utalás a kortárs Euphrasius-bazilika híres mozaikegyüttesére, ami a vallásszabadság és a korai kereszténység szimbólumának tekinthető. Ezt „vásárolta meg „Simplicius, akinek a pontifikátusa vége felé tört ki az Akakios-féle skizma, aminek egy fejezetét jelentette a Laurentius-skizma.

827 CASSIOD. VAR. 5.37.1.: „Libenter annuimus quae sine legum iniuria postulantur, maxima cum pro servanda civilitate nec illis sunt neganda beneficia iustitiae [...]"A civilitas kiterjedt irodalommal rendelkezik, ehhez lásd. AMORY 2003, 43-46. CASSIOD. VAR. 5.37.3.: „Tricennalis autem humano generi patrona praescriptio eo, quo cunctis vobis iure servabitur".

${ }^{828}$ CASSIOD. VAR. 2.27.1.-2.: [2] „Et noveritis vos severitatem minime defugere veteris sanctionis, si rebus non abstineatis illicitis. in ipsis vero parietibus cooperiendis vel fulciendis tantum licentiam damus, si vobis tricennalis non potest obesse praescriptio. quid appetitis, quae refugere deberetis? damus quidem permissum, sed errantium votum laudabiliter improbamus: religionem imperare non possumus, quia nemo cogitur ut credat invitus." 
Theoderich újfent hangsúlyozza a civilitas megtartásának fontosságát, amelynek legnyilvánvalóbb jele, ha betartják a törvényeket (az elődökét is). ${ }^{829}$

A levelekben szereplő tricennalis praescriptiót megtaláljuk a Variae egy másik levelében is, eszerint, ha egy barbár elbitorolta volna egy római földjét azt követően, hogy az osztrogótok átlépték az Isonzót (489) és az illető nem tud semmiféle hiteles dokumentumot felmutatni arról, hogy ö a jogos tulajdonos, akkor a területet vissza kell juttatni a korábbi tulajdonosnak. Azonban, ha az illető már a fent említett időpont előtt is birtokolta a területet, akkor a harmincéves elévülési szabály kell figyelembe venni és mindenféle területre vonatkozó fellebbezést el kell vetni. ${ }^{830}$

Ennek tükrében érdekes egybeesésnek tartom, hogy az Epistula Severi szerint a menorcai zsidók az erőszakos áttérítésük ellen tiltakoznak, Anonymus Valesianusnál pedig az Akakios skizma lezárása után ugyancsak zsidókat próbálnak erőszakosan áttéríteni. Csakhogy ezek a „zsidók” egymást buzdították vallásuk védelmére és a gyilkosságtól sem riadtak volna vissza. Bújták szent könyveiket és gyüjtötték a fegyvereiket annak érdekében, hogy erőszakkal nyomják el a keresztényeket. ${ }^{831}$ Éppen így tettek Theoderich udvaroncai is, elsőként az "eretnek" Triwila, aki maga buzdította a rómaiak ellen az uralkodót, de éppen így tett Cyprianus is, aki bevádolta Albinust, aki levelezést folytatott Iustinianusszal. ${ }^{832}$ Az Epistula Severi keresztényei Szt. István ereklyéihez fohászkodnak annak érdekében, hogy béke legyen a felekezetek között és a zsidók átkeresztelkedjenek, ami végül sikerül is. ${ }^{833}$ Anonymus Valesianusnál ellenben nem lesz vége a konfliktusnak, sőt mielőtt elkezdődnének a gyilkosságok, Theoderich éppen a protomártírról elnevezett imaház oltárát leromboltatja le. ${ }^{834}$ Az Anonymus Valesianusnál megörzött történet a

829 CASSIOD. VAR. 4.33.: ,[1] Custodia legum civilitatis est indicium et reverentia priorum principum nostrae quoque testatur devotionis exemplum [...] [2] Oblata itaque supplicatione deposcitis privilegia vobis debere servari, quae Iudaicis institutis legum provida decrevit antiquitas: quod nos libenter annuimus, qui iura veterum ad nostram cupimus reverentiam custodiri. atque ideo praesenti auctoritate censemus, ut quaecumque legum statuta moverunt, circa vos illibata serventur, quatenus quod ad civilitatis usum constat esse repertum, perpeti devotione teneatur."

830 CASSIOD. VAR. 1.18.2. „Si Romani praedium, ex quo deo propitio Sonti fluenta transmisimus, ubi primum Italiae nos suscepit imperium, sine delegatoris cuiusquam pittacio praesumptor barbarus occupavit, eum priori domino summota dilatione restituat. quod si ante designatum tempus rem videtur ingressus, quoniam praescriptio probatur obviare tricennii, petitionem iubemus quiescere pulsatoris."

831 EP. SEVERI. 8.4-5.

832 ANON. VAL. 14.85.

833 EP. SEVERI. 6.4. "Christiani autem, ut corde ita etiam et viribus humiles sed veritatis robore superiores, patroni Stephani auxilium deprecabantur".

834 ANON. VAL. 14.83-85, 87. "Nam mox iussit ad fonticulos in proastio civitatis Veronensis oratorium Santi Stephani, id est altarium, subverti. [...] Post haec coepit adversus Romanos rex subinde fremere inventa occasione..." 
gótok erőszakos áttérítésére tett kísérlet, amelyre az utolsó pillanatban, harminc évvel azt követően került sor, hogy birtokba vették Itáliát.

\subsubsection{Iuvenalia}

Malalas egyik anectodája szerint, Theoderich-et uralkodása kezdetén felkereste egy senator özvegye, egy bizonyos Iuvenalia és arra kérte, hogy szabadítsa meg egy jogügylettől, ami már 30 éve húzódik közte és egy patricius között. Az uralkodó engedett a kérésnek és küldetett mindkettőjük advocatusáért, akiket utasított, hogy két napon belül egyezzenek meg és döntsenek az ügyben, ha erre nem kerül sor, fejüket veszi. A fenyegetés hatott. A jogtudósok két nap múltán döntésre jutottak. Az asszony hálája jeléül gyertyát gyújtott és Theoderich-hez fordult, hogy köszönetet mondjon, hiszen megszabadította a nyomasztó jogügylettől. Az uralkodót azonban továbbra is bosszantotta az ügy, ezért újra magához hívatta az advocatusokat, akiket előbb megrótt, mert harminc év alatt nem tudtak megoldani egy ügyet, amire aztán két nap alatt is képesek voltak, majd lefejeztette őket. Ezután visszatért Ravennába, ahol haláláig élt, uralma ezt követően unokájára szállt. ${ }^{835}$

Az előzőekben említett Variae levelekben láthattuk, hogy harminc év után elévült a korábbi tulajdonjog, ha a területfoglaló három évtizedig zavartalanul birtokolt egy területet. Cassiodorus ezt az Isonzó (489) átlépéséhez igazította. Kikötötte ugyanakkor, hogy a területet harminc éven belül visszaszerezheti korábbi tulajdonosa, hacsak a területfoglaló nem tud hiteles dokumentumot (pittacium) felmutatni. ${ }^{836}$ A Variae leveleiben előforduló pittaciumot a Codex Theodosianusban is megtaláljuk. A joggyűjtemény szerint az adóbeszedők nem adhatnak ki ellátmányt, amíg nem kapták meg a hiteles igénylést (pittacium authenticum) a katonaság actuariusaitól, azaz a pittacium azt a pillanatot örökítette meg, amikor az adó fejadaggá változott, tehát egy juttatássá, amit egy katona már elvégzett szolgálataiért kapott. ${ }^{837}$ Ilyen lehetett Itália is, amelyet Theoderich kapott fáradozásaiért:

\section{„Zeno megjutalmazta Theoderichet szolgálataiért, patríciussá és consullá tette, sok pénzt adott neki, s igy küldte Itália ellen. Theoderich megállapodást kötött vele (pactuatus est), hogyha Odoacert legyözi, fáradozása jutalmaképpen addig uralkodhat Odoacer helyén, amíg Zeno meg nem érkezik. ",838}

835 JOH. MAL. 15.10. (384).

836 CASSIOD. VAR. 1.18.2.

837 CTH 7.4.11.

838 ANON. VAL. 10.49. „Zeno itaque recompensans beneficiis Thodericum, quem fecit patricium et consulem, donans ei multum et mittens eum ad Italiam. Cui Theodericus pactuatus est, ut, si victus 
Amikor Odoacer letaszította Romulus Augustulust, noha megölhette volna, inkább megkímélte életét, jövedelmet adott neki és övéivel együtt Campaniába, a Castellum Lucullanumba küldte, hogy szabad emberként éljen tovább. ${ }^{839}$ Romulus, akárcsak Theoderich, pittaciumot kapott, előbbi 476-os pittaciumát harminc év múltán éppen Theoderich erősítette meg. ${ }^{840}$ Az osztrogót uralkodó annyira fontosnak tartott a 30 éves szabály betartását, ${ }^{841}$ hogy edictumaiban több helyütt is említi, ${ }^{842}$ Az Edictum Theoderici kapcsán Lafferty figyelt fel arra, hogy a korábbiakhoz képest némileg módosított formában jelenik meg a rendelkezése ${ }^{843}$ pedig éppen ezek az általa ,jellegtelennek tünő" módosítással igyekeztek a gótok megtartani Itáliát.

Önmagában már az edictum hossza is beszédes, hiszen csaknem kétszer hosszabb, mint a legutóbbi joggyüjteményben található elbitorlásról szóló bejegyzés. ${ }^{844}$ A 12. edictum szerint azt követően, hogy valaki harminc éven át zavartalanul birtokolt egy területet már semmiféle bírósági eljárást nem von maga után, sem magánszemély, sem az állam részéről. Volt azonban egy újítás. Az edictum szerint ugyanis a jelenlegi birtokos javára be kell számítani a korábbi, vagy az azt megelőző birtokos tulajdoni időtartamát is. Abban az esetben, ha valaki harminc éven belül megtámadta volna a birtokviszonyt, de még mielőtt egyezségre jutnának, kezdetét veszi a negyedik évtized, akkor mindenféle jogkövetkezmény nélkül automatikusan le kell zárni a felperes eljárását. A jogalkotó hozzáteszi, hogy harminc évnek mindenképpen elegendőnek kell lennie bármilyen ügylet végigjárásához, ha megfelelő módon indították. Egy terület harminc év elteltével elidegeníthetetlenné vált. ${ }^{845}$ Az Edictum Theoderici egyik újítása abban rejlett, hogy az elődöket is

fuisset Odoacar, pro merito laborum suorum loco eius, dum adveniret, tantum praeregnaret." DE CER. 1.70 (R345) A győztesek jutalma a De Ceremoniisban is megjelenik éppen az actuarius kapcsán. Az $\dot{\alpha} \kappa \tau o v \alpha ́ \rho ı o \varsigma$ adja át a kocsiverseny győztesének jutalmát.

839 ANON. VAL. 8.37.

840 CASSIOD. VAR. 3.35. „ex nostra ordinatione patricium Liberium tibi matrique tuae per pittacium constiterit deputasse, in suo robore debeat permanere, nec a quoquam metuas irrationabilem quaestionem, qui nostri beneficii possides firmitatem." KRAUTSCHICK 1983, 75. Noha Krautschick Variae datálásáról készül munkájában kihagyta ennek a levélnek a keltezését, általánosságban elmondható, hogy a harmadik kötet 506 és 511 között kelt leveleket tartalmaz.

${ }^{841}$ A 30 éves elévülési szabály szorosan kapcsolódik az invasióhoz, ami eredeti formájában a Codex Theodosianusban szerepel, lásd CTh 4.22.3.

842 EDICTUM THEOD. 10; 69.

843 LAFFERTY 2010, 99-100. A szerzőnek elkerülte a figyelmét, hogy az Edictum Theoderici - többek között - már az állam szót is tartalmazza az elidegeníthetetlenséggel kapcsolatban.

844 EDICTUM THEOD. 12. vö. NVAL. 35.13.

845 EDICTUM THEOD. 12.: „Qui per triginta annos quamlibet rem iugiter possidere fuerit adprobatus, neque publico neque privato nomine patiatur aliquam penitus quaestionem. Tali autem possessori etiam auctorum proauctorumque suorum tempora secundum legem proficere debere censemus : illud adiicientes ut si intra triginta annos mota lis fuerit, nec finita, superveniens conclusio XXX annorum eandem sine aliqua dubitatione consumat: quia cuivis satis credimus abundeque sufficere, intra XXX annos et actiones suas rite componere et eas publico iudicio vel privata definitione peragere; ita ut 
beleszámította ebbe az időszakba. Korabeli krónikáink félszeg megjegyzései Theoderich ezen próbálkozását örökítették meg. Ilyen volt Marcellinus 519 környékén keletkezett bejegyzése, mely arra utalt, hogy Odoacer maga is gót volt, de ez őrződött meg Ióannés Antiocheus azon megjegyzésében is, amely arról számol be, hogy Theoderich és az idős szkír megegyezett abban, hogy együtt uralják Itáliát. ${ }^{846}$

Az edictum ugyanakkor egy jelentőségteles záradékkal is rendelkezett: Az ösi törvényekkel összhangban a gyámság alatt élőkre nem alkalmazható az elbirtoklás. A ravennai udvarra a precedenst III. Valentinianus Novellája jelentette, ami Theodosiusra hivatkozva ugyanezt írta elö. ${ }^{847}$ Ennek tükrében már értelmezni tudjuk Malalas kusza beszámolóját, ami az osztrogótok itáliai uralkodásáról és egy krízishelyzet megoldásáról szól. A történetben burkoltam minden fontos információ megtalálható, legföképpen az elbirtoklás harminc éves szabálya és a két advocatus halála. Amalasuntha 515-ben házasodott össze Eutharicusszal, aki egyesek szerint idősebb volt, ${ }^{848}$ míg mások, így a Konstantinápolyban alkotó Iordanes szerint igen fiatalnak (iuvenili aetate prudentia) számított. ${ }^{849} \mathrm{Az}$ asszonynak hamarosan két gyermeke is született a fiatal férfitöl, Athalarich és Matasuntha. Négy évig senkit sem zavart a „roppant durva és katolikus vallással szemben ellenséges" ${ }^{\$ 50}$ Eutharicus, ám miután 519-ben Iustinus fiává fogadta és consullá tette minden megváltozott. Az asszony már nem csupán egy gót herceg, de egy senator feleségévé vált, korai halála után pedig özvegyévé. Talán nem mellékes, hogy Tacitus szerint a Iuvenalia ünnepén mindenki korra, nemre való tekintet nélkül színpadra állhatott, hogy megcsillantsa latin vagy görög tudását, ${ }^{851}$ márpedig a iuvenilis özvegye mindkét nyelvet kitűnően beszélte és a művészeteket sem vetette meg. ${ }^{852}$ Egy forrásunk sem beszél Eutharicus halálának okáról és pontos idejéről, talán a Anonymus által is említett vallási összecsapások idején vesztette életét, hiszen az Epistula Severini

circa pupillarem aetatem privilegia antiquis vel novellis legibus concessa serventur, vel circa eos, qui ex quo competere poterant, post vicesimum et quintum annum intra tricesimum suas legibus proposuerint actiones. Cui casui quinquennii beneficium novella lege probamus adiectum." A későbbiekben Iustinianus kormányzata Theoderich saját fegyverét fordítja az osztrogótok ellen, hiszen a rendelkezés egyik kitétele éppen az, hogy a gyámság alatt élőkre a rendelkezés nem vonatkozik. Erről részletesebben a következő fejezetben lesz szó.

${ }^{846}$ MARC. COM. 476.2., I. ANTIOCH FR. 238.

847 „Sane sicut non coeptam intra tricennium quamlibet causam vetuimus incohari, ita quae contestate litis sumpsit exordium, excepto privilegio pupilaris aetatis, quod divae memoriae patris nostri Theodosii lege concessum est, intra eadem coeperat, contestata lis fuerit. Cui si is causus eveniat, emenso hoc tricennio, quod statutum est, aliud quinquennium prorogamus, intra quod debent negotia universa consumi"

848 CASSIOD. VAR. 8.1.3.

849 JORD. GET. 298.

850 ANON. VAL. 14.80.

851 TACiTUS ANN. 14.15. A római ifjúság ünnepét Nero (más néven Germanicus!) annak emlékére alapította, hogy férfikorba lépett és első ízben borotválkozott meg.

852 CASSIOD. VAR. 11.1.6. 
története sem mentes a halálesetektől. Erre utal, hogy Malalas történetében az özvegy asszony gyertyát gyújtott és hálát adott Theoderich-nek, miután az uralkodó megoldotta az asszony problémáját. Férje halála után Amalasuntha gyertyát gyújtott, apjához fordult és várta, hogy gyermeke uralkodását jóváhagyja. Ebben a formában nyerhet értelmet Prokopios Periklés-allúziója is, hiszen az athéni államférfi is jól, s kifogástalanul vezette az államot, s csak azt követően vált az állam első polgárává és bitorlójává, hogy társa, Ephialtés, egy évvel a háború kitörése előtt (i. e. 461) politikai gyilkosság áldozata lett. ${ }^{853}$ A Konstantinápoly és Ravenna közötti casus belli tehát nem Theodahad későbbi tevékenységéböl, hanem a császár által kijelölt örökös megöléséböl fakad. Theoderich szerencsés évei 519-ben véget értek, de számára és lánya számára az Athalarich feletti gyámság mentöövet jelentett. Theoderich ugyan uralkodott, de a görög szemében immár tyrannos volt, akárcsak Periklés.

Malalas történetében az uralkodó végzett két advocatusszal is, mert harminc évig képtelenek voltak megoldást találni az asszony jogi (helyesebben öröklésjogi) problémájára, de szorult helyzetükben napokon belül elöálltak a megoldással. Jól ismerjük ezt a két személyt, egyikük Boëthius, másikuk pedig apósa, Symmachus. A korábbi fejezetekhez hasonlóan azonosításukat ismét a források túlzott eltérései magyarázzák. Boëthius esete egyértelmü, hiszen kivégzése évében ő töltötte be a magister officiorumi tisztséget, ez pedig magában hordozza közvetlen érintettségét. Az Edictum Theoderici szerkesztése ugyanis a scriniához tartozott, ezt azonban a Variae tágabb értelmezésben használja, mindenféle hivatali adminisztrációra. Az udvarban a magister officiorum állt valamennyi hivatal felett lévén, hogy ö maga nem rendelkezett saját adminisztrációval. Kezében összpontosultak a legfontosabb méltóságok, ő felelt a provinciális kormányzókért, valamint ő nevezte ki a városi vezetőket, hozzá tartoztak a fontosabb követjárások. Számos elöjoggal rendelkezett, például egyetlen provincia kormányzóját sem iktathatták hivatalába, amíg bele nem egyezett, sőt megvétózhatta a kinevezéseket, de a fontosabb törvénykezés is hozzá tartozott. Ióannés Lydos a tisztség kapcsán megjegyzi, hogy az egész államszervezet sorsa a magister officiorum akaratától függött, befolyása döntö lehetett egyes krízishelyzetekben. ${ }^{854}$ De az udvar fegyelmi ügyei is hozzá tartoztak, így eshetett meg, hogy Boëthius Albinus védelmére kelt, hiszen ő vezette a senatort az uralkodó elé. ${ }^{855}$ Symmachus kivégzése pillanatában a senatus vezetője volt. Érintettségét a Chronicon Paschale fedi fel, a krónika összeállítója ugyanis maga is elmeséli az özvegy asszony történetét, ezt azonban némileg más adatokkal teszi. Ezek közül a legbeszédesebb, hogy a bejegyzés Symmachus (cos. 485) consuli

\footnotetext{
853 PLUT. PER. 10-11.

854 Not. Dign. OCC. 10., CASSiOd. VAR. 6.6., Lydus Mag. 3.62.3.

855 ANON. VAL. 14.85-86.
} 
évére helyezi és nem 30 éves pereskedésröl beszél, hanem csak háromról. ${ }^{856}$ A különböző történeti szálak így egybeforrnak, és új értelmet nyernek.

A kutatás az Ordo generis Cassiodororum alapján arra helyezkedett, hogy Boëthius és Symmachus az Anicius családhoz tartozott és az Ordo miatt már Cassiodorust is ebbe a családba sorolták. A korábbi fejezetekben szisztematikusan feltérképeztem az Anicius családot, a római Aniciusok tárgyalása esetében pedig láthattuk, hogy meddig terjednek a család határai. Az Ordo valójában a vezető rómaiak ravennai udvarában betöltött hierarchiáját vázolja, amit Cassiodorus szóhasználata árul el. Symmachust filozófusnak (vir philosophus) nevezi, Boëthiust szónoknak (orator), magát pedig igen müvelt férfinak (vir eruditissimus) nevezi. Ez utóbbi kifejezés azon túl, hogy egyértelmű felsőbbrendűséget fejez ki, csak egyetlen alkalommal fordul elő a teljes Cassiodorus korpuszban. De erre utal az is, hogy Cassiodorus Lélekröl írt értekezésében meglehetősen megvetően ír feltételezett rokonáról. A "Hogyan ismerd fel a rossz embert" c. fejezetének első mondata mindjárt azzal a felütéssel kezd, hogy az igaz hit nélkül az ember legalább olyan nyomorúságos, mint a filozófusok, akik a Szentírás helyett az emberi hibákban bíznak. ${ }^{857}$ Már ennek alapján is gyanítható, hogy a szerző elsősorban nem rokoni kapcsolatként tekint Symmachusra és Boëthiusra, hanem inkább az állam élén álló vezető tisztségviselők fejlődését szemlélteti az elnevezésekkel, annál is inkább, mert Boëthius magister officiorum helyét, kivégzése után, éppen Cassiodorus vette át. Ő pedig már elődeivel szemben túlélte valamennyi gót uralkodót, Konstantinápolyban pedig megírta a Variaet. ${ }^{858}$ Theoderich pedig, unokája gyámjaként uralkodhatott tovább, amit Konstantinápolynak is tiszteletben kellett tartania, hiszen az ősök (Theodosius és Valentinianus) törvényei ezt irányozták elő.

856 CHRON. PASCH. 485.

857 CASS. DE ANIMA 12.1. "Omnes igitur animae sine recta fide teterrimae sunt, ut philosophorum quae non creatoris legem sed humanum potius sequuntur errorem"

858 Noha szerkezeti elemzésére nem került sor, az előző oldalakon talált összefüggések ismeretében hajlok arra, hogy a Variae-t ne hivatali levélgyüjteményként értelmezzem, hanem egy olyan királytükörként, ami valós eseményeket keresztül, levélformában, a klasszikus 12 kötetes felépítést követve magyarázza azt, hogy hogyan is kellene uralkodnia az osztrogót uralkodónak. A szerző következetesen beszélt a harminc éves elévülésről, hangsúlyozta ezzel kapcsolatban a törvények betartásának fontosságát. A csonka, csak falakkal rendelkező zsinagóga új teteje, amely nem nyúlhat túl a régi határain túl minden bizonnyal egy utalás a sirmiumi háborúra, amely során az osztrogótok visszaállították az eredeti határokat. De erre jutunk abban az esetben is, ha végiggondoljuk Anastasius flottájának 506-os itáliai fosztogatását is, amire harminc évvel Romulus Augustulus eltávolítása után került sor. A sirmiumi háborúról részletesen: PROSTKO-PROSTYŃSKI 1994, 215-246. 


\subsection{Theoderich utódai}

Ahogyan a dánieli narratívában a világvége irányába halad a történet, ${ }^{859}$ úgy elevenedett meg a gótok egyre romló itáliai uralkodásának képe Prokopios történetében, aki a gót háború harmadik évének (538) eseményeit elbeszélve kitér a Neapolis főterén található mozaik leírására. ${ }^{860}$ Dániel próféciája némileg módosított formában Prokopios mozaikleírásában jelenik meg, ám ezek a változtatások rengeteg dolgot elárulnak a Iustinianus korabeli politikai gondolkodásról és megerősítik a korábban látottakat, mindenekelőtt azt, hogy visszaszámlálás Theoderich idejében indult. Prokopios azonban nem véletlenül alkalmazta geta szót előbb a 410-ről szóló rész bevezető szakaszában, majd 538-ban, a mozaik leírása kapcsán. Theoderich ugyanis 511-ben gyámság alá vette a gyermek Amalarich-ot ${ }^{861}$ és régensként elkezdett uralkodni a vizigótok felett. ${ }^{862}$ A családi kapcsolatok szempontjából korántsem mellékes, hogy Amalarich II. Alarich gyermeke volt, akinek viszont a Rómába betörő Alarich volt a dédapja ${ }^{863}$ Theoderich és Alarich között tehát rokoni kapcsolat volt. Prokopios szóhasználata arra utal, hogy ami kezdetét vette 410-ben, az az 530-as évek végén Theoderich utolsó életben maradt leszármazottjának Konstantinápolyba hurcolásával zárul.

Prokopios leírása szerint, a mozaikot még Theoderich idejében emelték, az uralkodó halálának pillanatában megrepedt, majd minden egyenes ági leszármazottjának halálakor egy újabb darab szakadt le belőle. Nyolc évvel ezután a gyomorrész is levált, éppen akkor, amikor Athalarich meghalt, nem sokkal később, Amalasuntha megölése pillanatában az ágyék is megsemmisült, végül pedig, amikor a gótok Róma ostromára készültek, mozaik fennmaradó részei, a lábak is az enyészeté lettek. ${ }^{864}$ Prokopios mozaikleírása azonban különleges abban, hogy csak az egyenes ági leszármazottakat jeleníti meg, így Theoderichet, Athalarichot, akit Amalasuntha követ, ${ }^{865}$ illetve a mozaik teljes megsemmisülése során utal Matasunthára is, aki ekkor Witiges feleségeként az éppen a Rómát ostromló gótok táborában tartózkodhatott. ${ }^{866} \mathrm{Az}$ ószövetségbeli próféciában szereplő szobor négy fő részből (fej, mell, ágyék, lábak) és az agyag talapzatból áll. ${ }^{867}$ Prokopios azonban kihagyja Theodahad uralkodását, aki ugyan az Amal-dinasztia tagja volt, ám nem volt Theoderich

859 DAN., lásd még MAGDalino 1993, 4-5.

${ }_{860}$ Procop. De Bellis. 5.24.22-27.

${ }^{861}$ PLRE2 64-65, "Amalaricus".

862 Procop. De Bellis. 5.12.45-46, JoRD. Get. 302.

863 JORD. GET. 298.

864 PROCOP. De Bellis. 5.24.22-27.

865 Procop. De Bellis. 5.24.22-27.

866 Procop. De Bellis. 5.11.27, 6.10.11.

867 DAN. 2.31-2:43. 
egyenes ági leszármazottja. Ezt az értelmezést Anonymus Valesianus is alátámasztja, aki szerint Theoderich utódai alatt is béke honolt, ${ }^{868}$ a pergentibus többes száma mögött legalább két uralkodót, mindenekelött az ifjú Athalarichot és régens anyját, Amalasunthát gondolhatjuk, esetleg Matasunthát, azonban ebben az esetben is, ahogy Prokopiosnál is, kiesik Theodahad. Ha elfogadjuk, hogy Prokopios a nápolyi mozaikon és a thukydidési allúzión keresztül magyarázza a háború előzményeit, akkor biztosak lehetünk benne, hogy ha volt is valamilyen megállapodás az osztrogótok itáliai uralkodására vonatkozóan Theoderich és Zeno között, akkor az nem az Amaldinasztia tagjaira, hanem csak Theoderich-re vonatkozott, és rá is csak harminc évig. 537-ben Witiges követei azért érvelhettek Belisariusnak uralkodásuk legitimitásáról, mert az uralkodó felesége Theoderich Eutharicus nemzette unokája volt. ${ }^{869}$

Megfigyelhető, hogy a keletrómai auktor az ostrom alkalmával nem személyesíti meg a negyedik testrészt, helyette gyüjtőfogalmat (gótok) használ. Ennek értelmében Keleten csak Theoderich-et és Eutharicus leszármazottait ismerték el. A leírásból ugyanakkor kiolvasható az is, hogy Konstantinápoly szemszögéből a legjobb uralkodó Theoderich volt, a legrosszabb pedig az illegitim Theodahad és a lázadó gótok. Itália kormányzása a két uralkodó között folyamatosan romlott, Theoderich uralkodása végén elkövette a föbünt, de Amalasuntha alatt veszhetett el ténylegesen az irányítás. Prokopios, amikor mủvében bemutatja az osztrogót Itáliát, hasonlóan elnyújtott felépítést alkalmaz, mint Aspar vandálok elleni hadjáratának leírásakor. Az idő összepréselésével majd elnyújtásával rávilágít arra a folyamatra, amelynek végén az Amaldinasztia pusztulása áll, és ami Theoderich idején már felsejlik (origo), Athalarich és Amalasuntha alatt alakot ölt (átmenet, ok), Theodahad alatt pedig kiteljesedik (vég).

Az origót, a keletrómai szempontból jó uralkodó képét Theoderich jelenti. Míg az osztrogót uralkodó Itáliába küldésének körülményeit a szerző elhallgatja, annál inkább részletezi személyes tulajdonságait. Theoderich férfias, harcos férfi képében jelenik meg, miközben Prokopios, akárcsak Anonymus Valesianus, írástudatlannak írja le, ami tíz éves konstantinápolyi látszatfogság után nyilvánvaló ferdítés. ${ }^{870}$ Ugyanezt a képet alkalmazza Prokopios a szegény parasztcsaládból származó Iustinus esetében, aki egy kis balkáni faluból verekedte fel magát a konstantinápolyi palotaőrség (comes excubitorum) parancsnokságáig. ${ }^{871}$

\footnotetext{
${ }^{868}$ ANON. VAL. 10.49. “Cuius temporibus [Theoderich] felicitas est secuta Italiam per annos triginta, ita ut etiam pax pergentibus esset."

869 Procop. DE BELLIS. 5.11.27, 6.10.11.

870 ANON. VAL. 12.61; 14.79.

871 Procop. ARC. 2.6.2, ANON. VAL. 13.76.
} 
"Mint már emlitettem, Theoderich király tanulatlan, ily módon lassú észjárású volt, minthogy uralkodásának tíz éve alatt azt a négy betüt, amivel rendeleteit aláirta, teljesen képtelen volt megtanulni. Ennélfogva elrendelte egy áttört aranylemez készitését, amely a ,legi” (láttam) szó négy betüjét mintázta; ezt követôen, ha alá akart irni, a lemezt a papir fölé helyezte, s azon keresztül vezette tollát, így csak a kézjegye látszott." ${ }^{972}$

Ezek a tulajdonságok azonban Konstantinápoly szemszögéből egyáltalán nem negatív jelzők. Theoderich legalább annyira írástudatlan volt, mint Iustinus, viszont mindketten megbízható katonák voltak a császár közvetlen közelében ${ }^{873}$ Prokopios szerint éppen ezért mindent Proculus, Iustinus quaestora intézett, aki tanácsadóként mellé ültetett a véletlen. ${ }^{874}$ Legalább ekkora szerep juthatott a birodalom nyugati felében Theoderich quaestorának, Cassiodorusnak, aki végigszolgálta szinte valamennyi uralkodót. 526. augusztus 30-án meghalt Nagy Theoderich. A trónon az ösök törvényeinek megfelelően kiskorú unokája, Athalarich követte, de helyette régensként Amalasuntha uralkodott.

\subsubsection{Amalasuntha és gyermeke}

A katonáskodáson alapuló gót társadalomban Amalasuntha helyzete meglehetösen ingatag volt és ezen kezdeti döntéseivel sem segített sokat, apja nehéz örökséget hagyott rá. Az első fejezetben számos példa mutatta a stratégiai házasságok jelentőségét. Az 5. század során, amikor egy özvegy vagy egy bizonytalan helyzetü uralkodó került hatalomra, első dolga volt, hogy kapcsolatot keressen valamelyik nagyhatalmú magister militummal, aki hatalmának stabilitását biztosította számára. Amalasuntha azonban nem élt ezzel a lehetősséggel. Egyik első döntésével visszajuttatta az 523-ban kivégzett Symmachus és Boëthius gyermekeinek szüleik elkobzott földjeit, ${ }^{875}$ miközben Boëthius vesztét éppen részben a ravennai udvar nagyhatalmú gótjai okozták, halálos ítéletüket pedig Theoderich mondta ki. Önmagában ez a döntése visszatetszést kelthetett a gótok között.

Amalasuntha ráadásul megkövetelte fiától, hogy életmódjában kövesse a római uralkodók szokásait, és arra szorította, hogy már igen korán grammatikushoz járjon. Ezenkívül kiválasztott

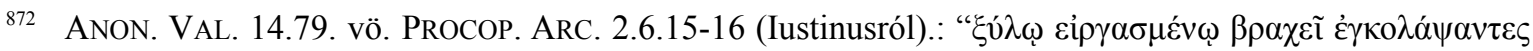

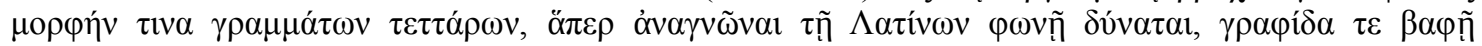

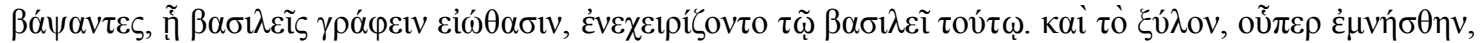

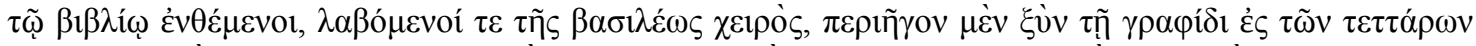

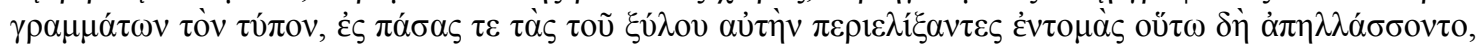

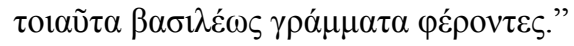

${ }^{873}$ Mindketten jó katonák voltak, legalábbis uralkodásuk kezdetén, akárcsak Periklés.

874 PROCOP. ARC. 2.6.13.

875 Procop. De Bellis. 5.2.5. Prokopios nem említi Albinus javait, ez a tény csak megerősíti a személyével kapcsolatok korábbi azonosítást. 
három öreg gót férfit, akikről tudta, hogy tisztességesek és körültekintőek, és arra utasította öket, hogy fiával éljenek, hogy az a gót szokásokkal is megismerkedhessen. Prokopios szerint a gótok korántsem voltak elégedettek ezzel a kettősséggel. Sokkal nagyobb hatást akartak gyakorolni a fiatal uralkodóra és elérni, hogy kizárólag gót szokások szerint nevelkedjen. ${ }^{876}$

Egy alkalommal Amalasuntha észrevette, hogy fia római neveltetéséhez nem méltó dolgot csinált. Az asszony megfenyítette, mire Athalarich sírva gót nevelői lakrészébe sietett. Prokopios szerint néhány gót erre szidalmazni kezdte az asszonyt és már ekkor azzal gyanúsították, hogy el akarja távolítani fiát az udvarból. Az udvar valamennyi gót előkelője összegyült és Amalasuntha elé járulva nyíltan a szemére hányta, hogy a fiút nem a gót szokásoknak megfelelően neveli, s mindezt olyan módon teszi, ami egyáltalán nem szolgálja Athalarich előnyét. Azt állították, hogy az irodalom tanulmányozása igencsak távol áll a férfiasságtól. Az idős nevelők pedig legtöbbször gyáva és alázatos szellemet kölcsönöznek egy fiatalnak. A gót előkelők szerint egy igazi férfi csak akkor tehet szert hírnévre, ha megszabadul attól a félelemtől, amit a könyvek olvasása ültet el benne, és fegyveres képzésnek veti alá magát. Ugyanakkor arra is felhívták Amalasuntha figyelmét, hogy még - a Konstantinápolyban nevelkedett - apja sem engedte egyetlen gót gyereknek sem, hogy grammaticushoz járjon.

"Mert ő [Theoderich] egyszer régebben még azt mondta mindannyiuknak, hogy ha egyszer beléjük férközik a félelem a korbácstól, akkor sohasem fogják megvetni a kardot, vagy a lándzsát. " 877

Ezért az egybegyültek azt kérték Amalasunthától, hogy úgy kormányozzon, ahogyan azt apja tette, aki jó gazdája volt a rá bízott területnek, s mert nem sokat foglalkozott irodalommal. ${ }^{878}$ Továbbá hogy, hagyja a fiút saját kortársai között nevelkedni, mert így hamarabb fog férfivá érni, és a barbár szokásoknak megfelelő tulajdonságokkal alakulnak ki benne. ${ }^{879}$

Ezek azonban nem csak a gót vezetők kritikája volt, hanem a konstantinápolyi udvari köröké is. Iustinianusnak ugyanis sok fejtörést okoztak a tanult emberek. A perzsa Kavād és Chosroés kis híján kijátszották az uralkodót egy örökbefogadással. Az ő ellenzékük a férfias és durva Zamasp volt. ${ }^{880} \mathrm{~A}$ császár seregeivel szemben álló gótok a háború kései szakaszában azzal

\footnotetext{
${ }^{876}$ Athalarich nevelőinek személye kérdéses, de nagy valószínűséggel Theoderich korábbi tisztségviselői közül kerülhettek ki. WOLFRAM 1990A, 336, Wolfram szerint Tuluin lehetett az egyik.

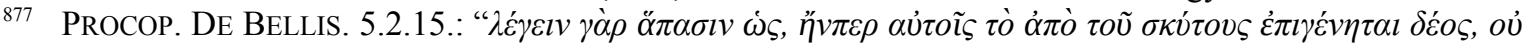

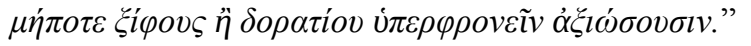

878 PROCOP. DE BELLIS. 5.2.16.

879 PROCOP. DE BELLIS. 5.2.1-17.

${ }^{880}$ Procop. De Bellis. 1.11.5.
} 
buzdították sajátjaikat, hogy a görögök természetüknél fogva férfiatlanok ${ }^{881}$ Theoderich unokája ebből a szempontból, ugyan még nem volt férfiatlan, de oktatása révén jó úton volt afelé, hogy maga is azzá váljon. Cassiodorus a következőt adja a fiatal uralkodó szájába:

"Nagyapámat [Theoderich] a városodban magas hivatalokba emeltétek; apámat [Eutharicus] Itáliában a pálmaág méltóságával ékesitettétek, az egyetértés iráni vágyából fegyverbe fogadott fiú lett, noha életkorban közel azonos volt veled." $\$ 82$

Athalarich ebben az időben már meg meri említeni a császárnak, hogy fiatal kora révén a fegyverrel történő fiúvá tétele (factus est per arma filius) már talán jobban illik rá, mint apjára, aki közel egykorú volt a császárral. A fiatal Athalarich bár finoman, de már meg meri említeni, hogy a császár a vele közel egykorú apját a fiának nevezte. A gót uralkodó azonban még nem merészkedett olyan messzire, mint egy évtizeddel korábban a burgund király. Anastasiusnak küldött levelében Sigismund (516-524) kifejti, hogy az általa birtokolt területet ugyan a császár nevében kormányozza, népét pedig a császár oltalmába helyezte. Köszönetét fejezi ki a császártól kapott magister militum és patricius címekért, de világosan megszabja a határt, amikor azt mondja, hogy elödei sokkal többre tartották azokat a dolgokat, amelyeket a császároktól (princeps) kaptak azoknál, mint amelyeket tulajdon apjuk (patres) adott nekik. ${ }^{883}$

Amalasuntha azonban nem fogadta meg a gót nemesek tanácsait. Prokopios szerint félt, és félelmében összeesküvést forralt ellenük, de hogy szándékát leplezze úgy tett, mint akinél a nemesek szavai értő fülekre találtak. Megtett mindent, amit a gótok kértek. Fia idős tanítóit elküldte, helyüket Athalarich-kal közel egykorú gót fiatalok vették át. Ahogyan a nemesek is kérték, Athalarich valamivel idősebb fiúk társaságában kezdte tölteni idejét, hogy korábban érjen. Amikor már serdültek, társai biztatására egyre inkább az alkohol rabságába esett, valamit romlott nőkkel intim kapcsolatba bonyolódott. A keletrómai auktor szerint társai egész jellemében olyanná tették, hogy ne fogadjon szót anyjának. Athalarich így lassanként elfordult anyjától. Amalasuntha ellenzéke kihasználva a helyzetet, nyíltan szervezkedni kezdett az asszony ellen, az Athalarich-kal élő fiatalok pedig már mondogatni kezdték neki, hogy talán ideje lenne elhagynia a palotát. 881 PROCOP. DE BELLIS. 8.23.25.

882 CASSIOD. VAR. 8.1.3. "vos avum nostrum [Theoderich] in vestra civitate celsis curulibus extulistis, vos genitorem meum [Eutharich] in Italia palmatae claritate decorastis. desiderio quoque concordiae factus est per arma filius, qui annis vobis paene videbatur aequaevus. hoc nomen adulescenti congruentius dabitis, qualia nostris senioribus praestitistis. in parentelae locum vester iam transire debet affectus: nam ex filio vestro genitus naturae legibus vobis non habetur extraneus."

883 Chrysos 1989, 16, AVIT. EP. 93.8: "Sub cuius fiduciae securitate atque laetitia gloriosissimo principi nostro qui corpore absumus, animo praesentamur. [...] Traxit illud a proavis generis mei apud vos decessoresque vestros semper animo Romana devotio, ut illa nobis magis claritas putaretur, quam vestra per militiae titulos porrigeret celsitudo, cunctisque auctoribus meis semper magis habitum est, quod a principibus sumerent, quam quod a patribus attulissent." 
Prokopios ezen a helyen több ízben is hangsúlyozza, hogy Amalasuntha "nő létére" egy pillanatra sem engedte magának, hogy gyengeségnek akárcsak szikráját is mutassa.

Majd hét év leplezett, vagy alig leplezett udvarbeli ellenségeskedés után a régensnő kiválasztotta azt a három férfit, aki a gótok között a legelőkelöbbek voltak, és akik a leginkább feleltek az őt ért inzultusokért. Azt remélve, hogy megszabadul tőlük, Itália határainak védelmére küldte mindhármukat. ${ }^{84}$ Ellenzéke azonban még távolról is képes volt folytatni az Amalasuntha elleni áskálódást. Prokopios szerint "a nő" a továbbiakban már nem volt képes elviselni ezt a terhet. ${ }^{885}$ Követeket küldött Konstantinápolyba Iustinianushoz és azzal a kéréssel állt elö, hogy el kívánja hagyni Itáliát. Iustinianus aligha leplezte elégedettségét, hiszen itt volt az alkalom, hogy korrigálja a tévúton járó nyugati birodalomrész életét. A császár biztatta Amalasunthát, hogy induljon csak útnak, Epidamnos (Durrës) házait pedig előkészítette az asszony és követsége érkezésére és megüzente, hogy addig marad, ameddig csak kedve tartja, de utána induljon tovább Konstantinápolyba a dolgok megvitatása véget. Iustinianus válaszára Amalasuntha tüstént megbízta a hozzá hűséges gótok egy csoportját, hogy azok megöljék a határvidéken ellene szervezkedő három gót nemest. Ezzel egy időben összekészítette minden értékét ${ }^{886}$ egy hajóra, és leghüségesebb követőivel útnak indult Epidamnosba. Miután kikötöttek, nem rakodták ki a hajót. Amalasuntha ugyanis abban bízott, hogy ha az ellene szövetkezö gótokat megölik, nyugodtan visszatérhet Ravennába. Erről a tervéről azonban elfelejtette tájékoztatni a császárt. Nem sok ideje volt még Epidamnosban, amikor megjött a hír, hogy követöinek sikerült megölnie valamennyi ellenfelét. Amalasuntha ezt követően, anélkül hogy értesítette volna Iustinianust, visszatért Ravennába. ${ }^{877}$

Amalasuntháról szóló leírásában Prokopios folyamatosan azt érzékelteti az olvasóval, hogy Theoderich halála után az asszony felelőtlen politikája vezette tévútra az osztrogótok itáliai uralkodását. Először szembement apja utolsó döntésével, amit megpróbált azzal jóvátenni, hogy visszajuttatta a kivégzett senatorok leszármazottainak az elítéltek birtokait. ${ }^{888}$ Ezt követően megpróbált egyedül kormányozni, anélkül, hogy egy befolyásos gót hadvezérrel összekötötte volna az életét. Döntései közül a legsérelmesebb az volt, hogy római mintára igyekezett neveli fiát, akiben a klasszikus irodalom olvasása és a grammaticusok tanításai elültették a kritikus

884 Az eseményre 533-ben kerülhetett sor, amikor a frankok elfoglalták Arlest.

885 PROCOP. DE Bellis. 5.2.22.

886 Procop. De Bellis. 5.2.26 vö. 1.22.3-4; 2.3.7; 2.5.29; 2.6.25; 2.8.4; 2.10.24; 2.12.34; 2.26.39; 2.27.46; $2.28 .10 ; 2.28 .44 ; 2.29 .29 ; 3.6 .2 ; 5.3 .26 ; 5.6 .19 ; 5.13 .14 ; 8.15 .3 ; 8.15 .17$. Prokopios megjegyzi, hogy 400 kentenaria aranyat is magával vitt. Ez az összeg Prokopios tükrében nagyon magasnak tünik, és azt az érzetet kelti, mintha Amalasuntha a teljes kincstárat magával vitte volna.

887 PROCOP. DE Bellis. 5.2.1-29.

888 Procop. De Bellis. 5.2.5. Prokopios nem említi Albinus javait, ez a tény csak megerősíti a személyével kapcsolatok korábbi azonosítást. 
gondolkodás csíráit. Athalarich elsősorban oktatása miatt merte megkérdőjelezni császárhoz füződő alárendeltségi viszonyát. A keletrómai szerző az egyes uralkodók müveltségén keresztül érzékelteti konstantinápolyi elismertségüket. Minél harciasabb valaki, annál kedvezőbb az udvar számára, a mủveltség fokával ez az elismertség arányosan csökken. Athalarichon azonban már nem segíthetett semmi, hiszen az idő ellene dolgozott, amint férfivá érik, a birodalom elidegeníthetővé válik.

\subsubsection{Theodahad}

A Ravennába visszaérkezett Amalasuntha a korábbi események fényében átértékelte helyzetét és felismerte, hogy támogatásra van szüksége. Minderre csaknem egy évtizednyi kötélhúzás után szánta el magát, azonban most is rosszul döntött. Egy katona helyett egy tanult, irodalomkedvelő és a hadakozásban teljesen járatlan gót nemes mellett kötelezte el magát. Theodahad Theoderich nővérének, Amalafridának a gyermeke volt, aki ebben az időben már igencsak koros volt. Cassiodorus szerint Amalasuntha dicsérte Theodahad tudását, amikor 534-ben maga mellé emelte uralkodónak. Prokopios szerint járatos volt nemcsak a latin irodalomban, de Platón filozófiájában is ${ }^{889}$ Véletlen vagy sem, de éppen ebben az évben jelent meg a Codex Iustinianus második kiadása, ami tartalmazta az athéni neoplatonikus akadémia bezárásáról szóló rendelkezéseket. ${ }^{890}$ Minden bizonnyal nem véletlen, hogy a történetírók közöl egyedül Prokopios köti össze Theodahadot Platónnal. Prokopios ezzel összemossa Theodahadot mindazzal a bủnnel (pederasztia, csillagjóslás, pogányság, filozófia), amelyeket Iustinianus iskola bezárásával kapcsolatos rendeletei beszélnek. Amalasunthának azonban imponált a férfi intellektusa, de igyekezett megzabolázni saját vágyait, amelyeket viszont Theodahad felismert és ki is használt. ${ }^{891}$ Ezzel azonban mind Prokopios, mind Cassiodorus azt mondja ki, hogy az itáliai politikai helyzet romlásáért egyedül Amalasuntha tehető felelőssé, akinek, bár meglett volna a lehetősége a békülésre, az utolsó pillanatban hátat fordított a császárnak. Ö volt, aki klasszikus nevelésre szorította fiát és ő volt, aki egy hadvezér helyett egy irodalmárt vett maga mellé.

Prokopios szerint annak ellenére, hogy Theodahad egyáltalán nem volt járatos a háborúban,

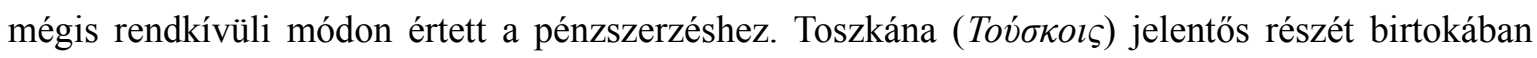
tartotta, de a többit is meg akarta szerezni. ${ }^{892}$ A keletrómai auktor - aligha hihető módon - azt állítja, hogy Theodahad maga is azt tervezte, hogy Itáliát - de legalábbis Toszkánát - senatori

889 CASSIOD. VAR. 10.3.4. Beiktatásakor Theodahad maga intézte proklamációját a római senatushoz.

890 BLUMENTHAL 1978, 384, WATTS 2004, 179

891 Erre utal Cassiodorus CASSIOD. VAR. 10.4.4, illetve PROCOP. DE BELLIS. 5.3.2; 5.4.1-3.

892 CASSIOD. VAR. 4.39; 5.12. Theodahadot már korábban arra utasította Theoderich, hogy szolgáltasson vissza olyan földet, amelyet erőszakosan vett birtokba. 
címért és konstantinápolyi menedékért cserébe átadja Iustinianusnak. Prokopios kusza leírásából az elkövetkező események időrendje a követjárásokon keresztül határozható meg. Ekkortájt érkezett Rómába két klerikus Hypatius és Demetrius személyében. Előbbi Ephesos papja, utóbbi pedig macedóniai Philippoiból érkezett azzal a céllal, hogy megvitassák azokat a hitbéli kérdéseket, amelyek vita tárgyát képezték kelet és nyugat között. ${ }^{893}$ Prokopios megemlíti, hogy bár jól ismeri a vitatott pontokat, még véletlenül sem tenne róluk említést, mert egyfajta “őrült ostobaságnak" tartja az "Isten természetéről" szóló vitát. ${ }^{894}$ Prokopios ezzel is csak azt éri el, hogy olvasója akarva akaratlanul az órigenizmusra asszociáljon. Órigenés (184-254) és követöi ugyanis éppen Platón visszaemlékezés elméletére ${ }^{895}$ építve azt vallották, hogy az örökkévalóságot megelőzte egy másik valóság, ami eretnek gondolatnak számított a korban. Theodahad tehát nem csak - klasszikus értelemben - művelt, de kapzsi és még eretnek tanoknak is hódol. Ezt csak elmélyíti a szerző, mikor megjegyzi, hogy Theodahad titokban találkozott is a pápához érkezett követséggel, akiknek elő is adta nagyszabású tervét: szívesen átadja Itáliát a császárnak, ha konstantinápolyi senator lehet belőle. ${ }^{896}$

Theodahaddal párhuzamosan Amalasuntha is arra jutott, hogy át kell adni Iustinianusnak Itáliát. Az asszony elhatározását nem a kapzsiság, hanem a félelem vezette. Athalarich ugyanis haldoklott, minden bizonnyal józannak korántsem nevezhető életmódja miatt. ${ }^{897}$ Amalasuntha bizonytalanságát az okozta, hogy nem bízott fia iránta tanúsított hủségében, másrészt úgy gondolta, ha beleavatkozik fia társasági életébe, akkor azzal csak magának árt. 534-ben - miközben a másik két követ Rómában volt - megérkezett a császár követe egy konstantinápolyi senator, bizonyos Alexandros személyében. Prokopios szerint a követ érkezését az indokolta, hogy a császár kíváncsi volt az Amalasunthával kapcsolatos helyzetre, hiszen miután kikötött Epidamnosban, mégsem ment hozzá Konstantinápolyba ${ }^{898}$ Nem jóindulatú kíváncsiság volt ez a császár részéről, ahogy azt Prokopios írja, hanem inkább nagyfokú bizalmatlanság. Alexandros, miután találkozott az egyházi

893 Hypatius a chalcedoni oldalt képviselte azon a zsinaton, amit Iustinianus hívott össze a fövárosban 533ban. Hypatius és Demetrius egy levelet hoztak a császártól a II. János pápának (533. június 6-án), amire egy évvel később tavasszal érkezett válasz (március 25). Mindkét dokumentumot tartalmazza a CoD. IUST. 1.1.8.

${ }^{894}$ Procop. De Bellis. 5.3.6. Lásd Procop. ARC. 18.29. Iustinianus kísérlete arra, hogy megértse "Isten természetét".

${ }^{895}$ Plat. MENO. Platón visszaemlékezés elméletében azt vette alapul, hogy a lélek az olyan összetett fogalmakat, mint a gondolat, vagy a szépség nem merítheti érzékelésből, ezért ezek nem érzékelésből származnak, hanem a lélek visszaemlékezése útján.

896 Procop. De Bellis. 5.3.9. vö. 1.24.25-31. Prokopios az olvasó szeme elött fonja össze Itália sorsát és jövöjét a Nika-felkeléssel és a konstantinápolyi senatus szerepével (Origenes "senator" beszéde)!

897 A betegség oka minden bizonnyal a túlzott alkoholfogyasztás volt, ami májzsugorodást okozhatott.

898 Alexandros azzal az ürüggyel érkezett, hogy a császár felzaklatták a lilybaeumi események. Az 534-es lilybaeumi eseményekre lásd PROCOP. DE BELLIS. 4.5.11-25. 
követekkel, Ravennába indult Amalasunthához, akivel titkon megállapodott, ${ }^{899}$ hogy az asszony átadja Itáliát a császárnak, akárcsak Theodahad. Nem sokkal később a követek visszatértek Konstantinápolyba és jelentést tettek a császárnak. Alexandros Amalasuntha döntéséről számolt be, Demetrius és Hypatius pedig Theodahad szándékát közölte.

Eközben a ravennai udvarba sorra érkeztek be a Toszkána lakosainak panaszai Theodahad visszaélései miatt. ${ }^{900}$ Amalasuntha megalapozottnak találta a panaszosok bejelentéseit és arra kötelezte Theodahadot, hogy valamennyi birtokot szolgáltassa vissza, de egyúttal azt is közölte a férfival, hogy társra van szüksége, mert fia hamarosan meg fog halni. Amalasuntha tehát annak ellenére vette maga mellé Theodahadot, hogy a férfi sem a rómaiak, sem a gótok között nem örvendett népszerüségnek. ${ }^{901}$ Prokopios szerint, amikor Theodahad felismerte Amalasuntha házassági szándékát, szinte mindenre megesküdött, amit az asszony kért, de esküje csalárd volt, mert emlékezett mindarra, amit Amalasuntha korábban vele tett. Miután megnyerte magának azoknak a gótoknak a hozzátartozóit, akik Amalasuntha ítélete alapján vesztették életüket, megölte Amalasuntha néhány hủ emberét, majd bebörtönözte az asszonyt. ${ }^{902}$

Amalasuntha a toszkánai Bolsena tó közepén lévő kicsiny szigetre került, amin egy igen tekintélyes erősség állt. Theodahad félt, hogy tettével kivívja a császár haragját, ezért Liberiust, Opiliót más senatorokkal együtt követségbe küldte Konstantinápolyba. Arra utasította öket, hogy tettére találjanak mentséget a császárnál, és biztosítsák afelől, hogy Amalasuntha nem szenvedett semmilyen sérelmet, annak ellenére sem, hogy az asszony helyrehozhatatlan kárt okozott neki. ${ }^{903}$ Theodahad követségével egy időben Iustinianus is indított egy újabb követet, immár a rendkívül képzett tárgyaló Petrus személyében, aki maga is illír születésű volt, meggyőzőereje pedig páratlannak számított. ${ }^{904}$ A császár ekkor még semmit nem tudott Athalarich haláláról, Theodahad uralkodásáról, vagy Amalasuntha helyzetéről. A két követség az Adriai tenger partján fekvő Aulon városánál találkozott. Petrus megtudta Liberiustól és Opiliótól, hogy Theodahad magához ragadta a hatalmat, Amalasuntha pedig Bolsena szigetén raboskodik. Egy futár segítségével gyorsan

899 PROCOP. DE BELLIS. 5.3.28. Alexandros átnyújtotta a császár titkos levelét, amiben az uralkodó kérdőre vonta a lilybaeumi események miatt.

900 Procop. DE BELlis. 5.3.1-7. Theodahad rekvirálásai nem csak magánbirtokokat érintettek, hanem az uralkodói patrimoniumokat is.

901 PROCOP. DE BELLIS. 5.3.1-7. A rómaiak a birtokelkobzások miatt nehezteltek rá. A gótok pedig talán egy összeesküvés miatt. Theodahad családja ugyanis Theoderich alatt elnyomásban élt.

902 PROCOP. DE BELLIS. 5.3.12-14.

903 Procop. DE BELlis. 5.4.12-21.

904 PROCOP. DE BELLIS. 5.3.30. Prokopios Petruson kívül még két alkalommal vonultat fel rendkívül képzett tárgyalókat, de valamennyien fontos eseményeket döntenek el. Lásd PROCOP. DE BELLIS. 2.24.4.: Constantinus és Sergius esete; PROCOP. DE BELLIS. 5.8.22: Pastor és Asclepiodotus tevékenysége. 
jelentette az itáliai eseményeket a császárnak és további utasításig a helyén maradt. ${ }^{905}$ Időközben Theodahad követei is befutottak Konstantinápolyba, és tájékoztatták a császárt az itáliai eseményekről. Kettejük közül azonban csak Opilio mesélte el Theodahad kérésének megfelelően a történteket, míg Liberius az igazságot mondta. ${ }^{906}$

Prokopios szerint, amikor Iustinianus ezeket megtudta, elsődleges célja az lett, hogy zavart keltsen a gótok között. A császár egy levelet küldött az Aulon városában várakozó Petrusnak azzal, hogy kézbesítse Amalasunthának. Ugyanakkor utasította a követet, hogy a levél tartalmát egyáltalán ne titkolja mások előtt, amikor Itáliába ér. A levélben ugyanis a császár kijelentette, hogy bármilyen segítséget hajlandó megadni az asszonynak, amire csak szüksége van. ${ }^{907}$ A Titkos történet szerint azonban egy másik - vagy éppen ugyanaz a - futár is befutott Aulonba egy másik vagy éppen ugyanazzal a - levéllel, melyben a császárnő arra utasította Petrust, hogy ölje meg Amalasunthát és nem marad hálátlan. ${ }^{908}$ A "meggyőzőerejében páratlannak számító követ" 535 tavaszán érkezett Itáliába és már egy ideje itt volt, amikor Amalasunthát április 30-án megölték. Petrus tiltakozott a gyilkosság miatt, de még a "harcias" gótok többsége is kijelentette, hogy a királynő megölése bizony háborús ok. Miközben Theodahad váltig állította, hogy a gótok az ő akarata ellenére cselekedtek. ${ }^{909}$ Prokopios ezúttal sem hazudik, csak éppen nem említ meg minden részletet. Petrus minden bizonnyal nem rögtön tiltakozott Amalasuntha megölése miatt, Theodahadot ugyanis kelepcébe csalhatták. A Variae egyik májusban kelt levelében, melyet Theodahad küldött Theodorának, a gót nemes mintegy mellékesen megjegyzi, hogy intézkedett annak a bizonyos személynek (Amalasuntha?) az ügyében, akire Theodora célzást tett. ${ }^{910}$ Egy másik levél pedig, amelyet Theodahad felesége küldött Theodorának kifejti, hogy férjével milyen sietve igyekeztek a császárné kegyébe férkőzni. ${ }^{911}$ Az ezt követő levél pedig már Petrus szerepét emeli ki, akit Theodahad kérésére küldött a császár a fennálló helyzet rendezése érdekében. ${ }^{912}$

905 PROCOP. De Bellis. 5.4.12-21.

906 Procop. De Bellis. 5.4.22-25.

907 PROCOP. DE BELLIS. 5.4.22-25.

908 PROCOP. ARC. 16.1-5.

909 Procop. De Bellis. 5.4.27-28.

910 CASSIOD. VAR. 10.20.4. "Nam et de illa persona [Amalasuntha?], de qua ad nos aliquid verbo titillante pervenit, hoc ordinatum esse cognoscite, quod vestris credidimus animis convenire. desiderium enim nostrum tale est, ut interveniente gratia non minus in regno nostro quam in vestro iubeatis imperio."

911 CASSIOD. VAR. 10.21.1. "Aestimare te convenit, Augustarum prudentissima, quantis cupiam nisibus gratiam vestram quaerere, quam etiam domnus iugalis meus magno studio desiderat optinere."

912 CASSIOD. VAR. 10.22.1. "Retinetis, sapientissimi principum, et per legatos nostros et per virum disertissimum Petrum, quem nuper ad nos vestra pietas destinavit, quo studio concordiam Augustae serenitatis optemus." 
Lehetett két levél, de két cél aligha, hiszen Prokopios korábban maga említi, hogy Petrus Itáliába küldésének célja, hogy zavart okozzon. ${ }^{913}$ Hogy a királynő felett őrködő gótok Theodahad hallgatólagos beleegyezésével és Petrus sugalmazására végeztek volna Amalasunthával, nagyon is valószínü, de egyértelműen nem kimutatható. Prokopios 5. könyvének többszöri elolvasása is csak erősíti azt a képzetet, hogy Theoderich halála után az osztrogót Itália minden problémája Amalasuntha tevékenységében gyökeredzett: Az ö ötlete volt fiának klasszikus nevelése, aki később már csaknem megkérdőjelezi Iustinianus hierarchiában betöltött szerepét. Az ő ötlete volt Theoderich egykori - és legprominensebb - gót hadvezéreinek megölése. És ő volt az is, aki nem egy erős katonát, hanem egy férfiatlan irodalmárt vett maga mellé, akinek esetében már kiteljesedett az, ami Athalarich oktatása esetében még csak felsejlett. Annyi azonban bizonyos, hogy Konstantinápolyba való visszatértekor Petrus megkapta beígért jutalmát, hiszen magister officiorum lett. ${ }^{914} 535$ tavaszán pedig elkezdődött a császár gótok ellen vívott háborúja. ${ }^{915}$

\subsection{A tiltott házasság}

Prokopios szerint Theodahad az ifjú Athalarich-kal szemben már kiművelt irodalomkedvelőnek és a platóni filozófia mủvelőjének számított. ${ }^{916}$ Tökéletes ellentéte volt a "szerfelett harcias és erős" Theoderich-nek, ${ }^{917}$ annál is inkább, mert míg Theoderich-nek megadatott egy Anicia, ámbár nem élt vele, ${ }^{918}$ addig Theodahad már legitimációját akarta egy Anicius révén elérni. Ez volt az a megoldás, ami a kétségek között őrlődő Amalasuntha számára is megoldást jelenthetett volna.

535 szeptemberében Amalasuntha már rég halott volt, Theodahad ingatag helyzete pedig már számára is egyre nyilvánvalóbbá vált, felesége halálával a tényleges irányítás azonban hozzá került, amely lehetőséget biztosított uralkodásának legitimációjára. 535 őszén egy illusztris kinevezésre került sor a ravennai udvarban. Egy korábbi tisztségviselőt, az 523. év consulát a primicerius bizalmas pozíciójába iktatták be, ${ }^{919}$ ami azt jelenti, hogy egyfajta személyzeti vezető lett, aki az uralkodói lakosztályok és palota föbb termeinek örei felett állt, ${ }^{920}$ de az uralkodói

\footnotetext{
913 PROCOP. DE BELlis. 5.4.22.

914 PLRE3A 994-998, "Petrus 6".

915 PROCOP. DE BELLIS. 5.5.8-9. Amelyhez elsőként a frankokat hívja segítségül a császár.

916 Procop. De Bellis. 5.4.1-3, 5.6.8-10, Prokopios két helyen is társítja Theodahadot Platónnal.

917 ANON. VAL. 12.58

918 MALCH. 18.3.

919 CASSIOD. VAR. 10.11.3.: "primiceriatus, qui est domesticatus". A tisztség azonosítása a szakirodalomban bizonytalan, azonban Cassiodorus gyakran azonosítja a comes sacrarum largitionummal. COD. IUST. 12.40.10.5. Iustinianus rendeleteinek tükrében a tisztségviselő speciális kiváltsága volt, hogy egy házra kapott beszállásolás alóli mentességet, örökösei pedig fél házuk tekintetében maradnak mentességben.

920 COD. THEOD. 6.33.1.
} 
díszruha is hozzá tartozott. ${ }^{921}$ Ebben a bizalmi pozícióba 535-ben Maximus ${ }^{922}$ (cos. 523) került, aki úgy tünik, korábban semmilyen udvari tisztséggel nem rendelkezett.

Maximus magas udvari pozícióját házasságának köszönhette, ugyanis egy gót hercegnőt vett feleségül, minden bizonnyal Theodahad valamelyik rokonát, talán éppen a lányát. ${ }^{923}$ Theodahad a senatusnak írt levelében erőteljes szavakkal biztatja a képviselőket, hogy fogadják be Maximust soraik közé, örüljenek házasságnak, hiszen ezzel ő is csak közelebb kerül hozzájuk. ${ }^{924} \mathrm{~A}$ Variae-ban található levélből az is kiviláglik, hogy melyik római nemzetséggel kötött házasságot Theodahad családja.

“Anicius: az egész földkereségen felmagasztalt család, melyet méltán neveznek elökelönek." ${ }^{925}$

A férfiatlan, ám művelt Theodahad tehát megfordította korábbi tendenciát. A korábbi fejezetekben már szó volt róla, hogy a Theodosius-dinasztia kihalása utána a család vérvonala az Aniciusokban élt tovább. Azonban, míg addig minden esetben egy barbár rabolt el és vett feleségül egy római hercegnőt, most fordult a kocka, egy barbár nő házasodott össze egy Aniciusszal. Nem csupán legitimációs kísérletről van szó, Theodahad valósággal gúnyt üz a császárból. A Maximus kinevezéséről szóló levél egyfajta antitézise a keletrómai udvar alávetési gyakorlatának (fegyverrel örökbefogadás), amit a barbárokkal szemben alkalmaztak. Theodahad Maximushoz írt levele meglepően hosszú a többi beiktatási levélhez képest.

Már rögtön a levél elején kiemeli, hogy csak az arra méltó uralkodók (princeps) (26 $^{926}$ kiváltsága kitüntetések osztogatása az alattvalók között. ${ }^{927}$ Ezt követően rátér az Anicius család dicsőítésére, amelyben újfent felfedezhető a család Theodosiusokkal történő azonosítása, amikor az író megjegyzi, hogy a nemzetség jelentősége majdnem uralkodókkal megegyező (Anicios quidem paene principibus pares). Ez a nemzetség most, felmenőinek ${ }^{928}$ hála, most Maximus vérében él

921 CASSIOD. VAR. 6.7.4.

922 PLRE2 539-40, "Heraclianus 3."

923 CASSIOD. VAR. 10.11.3: "cuius tempore [Theodahad] meruisti coniugem regiae stirpis accipere".

924 CASSIOD. VAR. 10.12.4: "exultate generaliter et has nuptias laetitia profusa celebrate. unde profecit nomen omnium, vota debent esse cunctorum. quae preces a me exigere potuerunt"

925 CASSIOD. VAR. 10.12.2: “Anicius: familia toto orbe praedicata, quae vere dicitur nobilis".

926 A Variae-ben a princeps szó csak Theodahad levelei között jelenik meg. Lásd még LYDUS MAG. 1.3.5.

927 CASSIOD. VAR. 10.11.1.: "Si gloria est bonorum principum incognitas honoribus clarificare personas, dum quicquid a subiectis proficitur regnantum laudibus applicatur, quanto nobis praestantius est nobilissimae familiae reddere, quod eam cognoscimus etiam nascendi sorte meruisse! sic enim iustitiam sequimur, si bonis heredibus parentum praemia non negemus. decet enim etiam priores suos vincere, qui ad nostra meruerunt tempora pervenire."

928 A távolabbi felmenők is felsejlenek a levélben, eszerint a Marius és Corvinus nemzetség egyesüléséből született Maximus. Cassiodorus ezzel igazolja a korábbi feltételezést, miszerint Gennadius Avienus (cos. 
tovább. ${ }^{929}$ Ezt követi a tényleges beiktatás, a pozíció megnevezése (primicerius), ami ugyan Maximus származásához képest rangon alulinak (mediocritas honoris; hic honor quamvis tantis natalibus videatur inferio) számít, de viselője kiteljesedhet a tisztség biztosította kereteken belül, de csakis azon belül. A primiceriusnak, az uralkodó legfőbb ajtónállójának bizony uralkodói kegyben van része, hiszen királyi vérből származó feleséget Theoderich uralkodása alatt még csak nem is remélhetett. Ez egy nyílt utalás arra, hogy Theoderich nem házasodott össze Anicia Iulianával, így a császár alattvalójaként igazgatta Itáliát. ${ }^{930}$ Ezt követően meglehetősen szokatlan hangvételt vesz fel a levél, ahhoz képest, hogy egy egyszerü beiktatásról van szó. Maximusnak úgy kell viselnie magát új tisztségében, hogy az minden tekintetben elfogadható legyen Theodahadnak, hiszen azzal, hogy egy hercegnőt kapott feleségül, hatalmas uralkodói kegyben volt része. Az Anicius családba ugyan nemesnek született, de ez Theodahad rokonaként már mit sem ér. Fel kell nőnie új helyzetéhez: alázatosnak és jótékonynak kell mutatkoznia mindenkivel szemben és legfőképpen szerénynek, ami az arrogancia ${ }^{931}$ ellentétpárja. ${ }^{932}$ Minden erény felett azonban Maximus "pozíciójában" a türelem a legfontosabb, amit folyamatosan gyakorolnia kell. A házassági kapcsolat a levél végén is visszatér, bár az Aniciusok nemesek, de még öket sem díszítette olyan kötelék, mint amilyet a Theodahad vérével való rokonság jelent. ${ }^{933}$

450) elvette Anicius Acilius Glabrio Faustus (cos. 434) lányát. A pontos személyazonosság azonban az adatok hiányában meghatározhatatlan.

929 CASSIOD. VAR. 10.11.2.: "Anicios quidem paene principibus pares aetas prisca progenuit: quorum nominis dignitas ad te sanguinis fonte perducta collectis viribus hilarior instaurata rutilavit. quis ergo relinqueret in posteris minus honoros, quos tamdiu constat fuisse praecipuos? accusarentur saecula, si talis potuisset latere familia. atque utinam nobis Marios vel Corvinos annosior vita servasset! vix satiaretur principis votum, si nos contingeret personas illas talium possidere meritorum. quemadmodum nunc profecto neglegamus inventa, qui desideramus habere praeterita?"

930 CASSIOD. VAR. 10.11.3.: "Atque ideo, quod feliciter dictum sit, primiceriatus, qui et domesticatus nominatur, ab indictione quarta decima tibi conferimus dignitatem. usurus es omnibus titulis qui ad eius pertinent actionem. hic honor quamvis tantis natalibus videatur inferior, cunctis tamen fascibus tuis videtur esse felicior: cuius tempore meruisti coniugem regiae stirpis accipere, quam in tuis curulibus nec praesumpsisses optare."

931 Prokopiosnál az uralom ellen lázadók legfőbb attribútuma az arrogancia.

932 CASSIOD. VAR. 10.11.4.: “Age nunc, ut sicut tibi est votivus, ita nobis reddatur acceptus. considera quid merueris et dignum te nostra affinitate tractabis. nam qui familiae regnantis adiungitur, in laudum gremio collocatur. nunc maior opera mansuetudini detur: nunc omnibus communio benigna praebeatur, ut talem probemur elegisse, quem nulla possit prosperitas immutare. humilis age rem gloriae, quia de modestia laus sumitur, de elatione odium concitatur. provectibus quidem proxima est indubitanter invidia, sed tolerantia melius vincitur, quae contentione semper augetur."

933 CASSIOD. VAR. 10.11.5.: "Supra ceteras virtutes amicam sapientibus ama patientiam: erectus ex nobis sustinendo potius quam vindicando laudaberis. iram vince: benigna dilige: cave, ne maior videatur esse felicitas moribus tuis, sed qui nostro iungeris generi, proximus gloriosis actionibus comproberis. laudati sunt quidem hactenus parentes tui, sed tanta non sunt coniunctione decorati. nobilitas tua non est ultra quo crescat. quicquid praeconialiter egeris, proprio matrimonio dignissimus aestimaris." 
Anicius Maximus házasságának jelentőségét a konstantinápolyi udvar szemszögéből Prokopios emeli ki, aki a Háborúkban egyszerüen összemossa Magnus Maximust, Petronius Maximust és Anicius Maximus személyét, azt az érzetet keltve, hogy a három személy rokona volt egymásnak. ${ }^{934}$ Látni fogjuk azonban, hogy a nevükön túl vérségi kapcsolat nem volt a három személy között. Hármójuk közös vonása abban nyilvánul meg, hogy az udvar szempontjából valamennyien trónbitorlók voltak és valamennyien a Theodosius-dinasztia tagjainak, vagy azok örököseinek ártottak.

A hispániai származású Magnus Maximus (383-388) 383-ban kelt fel Gratianus ellen a britanniai légiók élén, majd a császárt megölve elfoglalta birodalomrészét. Végső soron az ő tevékenységének az eredménye, hogy II. Valentinianus és családja Theodosius thessalonikéi udvarában keresett menedéket, ami végül Theodosius és Galla házasságához és a dinasztia folytatásához vezetett. Trónbitorlásának végül 388-ban Theodosius vetett véget. ${ }^{935}$

Prokopios felsorolásában a következő rokon egy újabb trónbitorló, akivel 455 kapcsán már találkoztunk. Petronius Maximus az 5. század közepén a Theodosius-dinasztia nyugati ágának vesztét okozta, ráadásul a kortársak szerint azzal igyekszik legitimálni hatalmát, hogy házasságra kényszeríti a császár özvegyét. A császárgyilkosság okát egyedülálló módon magyarázza Prokopios. A keleti auktor szerint Maximusnak gyönyörü felesége volt, akire Valentinianus szemet vetett. A császár vágyainak kielégítésére - mivel az asszony házas volt - nem kínálkozott semmilyen törvényes lehetöség, így hát istentelen tettre vetemedett. A palotába idézte Maximust, hogy pénzben dámajátékot játsszon vele, de kikötötte, hogy a vesztesnek egy meghatározott összeget kell fizetnie. A császár megnyerte a játékot és elérte, hogy Maximus átadja neki jegygyưrüjét mintegy zálogként, amíg a nyertesnek járó összeget át nem adja. A császár ekkor egy futárt küldött a senator feleségéhez azzal, hogy a császárnő bekérette a palotába. Az asszony a mellékelt jegygyürüből úgy ítélte meg, hogy az üzenetet férje küldte, ezért gyanútlanul indult az udvarba. A palotába érve Maximus feleségét a császárhoz hű emberek egy félreeső terembe vitték, ahol Valentinianus újra és újra megerőszakolta. A gyalázat után az asszony könnyek között ment haza, a házban pedig átkozni kezdte férjét, öt okolva, hogy ez a szégyenletes esemény megtörténhetett. Petronius Maximus ekkor határozta el, hogy merényletet követ el a császár ellen. ${ }^{936}$

\footnotetext{
934 Procop. De Bellis. 3.4.16 vö. 5.25.15.

935 Procop. DE BELlis. 3.4.16. Prokopios idősebb Theodosiusként azonosítja a császárt.

936 Procop. De BeLLIS. 3.4.17-24.
} 
A trónbitorló tágabb családja fián, Palladiuson ${ }^{937}$ kívül ismeretlen. Feltételezett felmenőiről Olympiodóros egy kurta töredékén kívül nem tesznek említést a források. ${ }^{938}$ A történetíró szerint egy bizonyos Maximus egyike volt annak a három senatornak az 5. század elején, aki a legtöbbet költötte fia praetori beiktatási játékaira. A beszámoló szerint hármójuk közül 4000 fontnyi arannyal Maximus fiának költségei rúgtak a legmagasabbra, miközben ez az összeg sok római háztartás egész éves jövedelmének felelt meg. Ráadásul ez az összeg nem tartalmazza a gabona, bor és más termékek eladásából származó bevételeket. Mindössze a név alapján több kutató úgy gondolta, hogy a történetírónál szereplő Maximus azonos lehet Petronius Maximus apjával. ${ }^{939}$ Ehhez az azonosításhoz éppen Prokopiost vették alapul, aki szerint Petronius Maximus a trónbitorló Magnus Maximus leszármazottja volt. ${ }^{940}$

A gyér forrásadottságok ellenére Petronius Maximus feltételezett leszármazási vonalát több dolog is meglehetősen kétségessé teszi. ${ }^{941}$ Egyrészt Cassiodorus, aki Maximus (cos. 523) senatusi beiktatása alkalmával egy szóval sem említi Petronius Maximust, pedig kétségtelen, hogy felmenői dicsőitése során megemlített volna egy korábbi császárt, még ha trónbitorló is volt. ${ }^{942}$ Erre a problémára már Hodgkin is felhívta a figyelmet a 19. század végén. ${ }^{943}$ De talán ami még fajsúlyosabb, hogy a Variae egy másik leveléből az is kiderül, hogy az 523. év consula korántsem volt olyan tehetős, mint amilyennek feltételezett öseit Olympiodóros leírja. ${ }^{944}$ Harmadrészt pedig Petronius Maximus egyetlen, korábbi házasságából született fiát Gaudentiusnak hívták. ${ }^{945}$ Cameron szerint ez a név sem előtte, sem utána nem lelhető fel a környező családfákban. ${ }^{946}$ Végül pedig számos forrás egyetért abban, hogy Petronius Maximust alig néhány hónapos uralkodás után menekülés közben megölték, ahogyan egyetlen fiát is, így tehát már a 455-ben megszakadt Petronius Maximus leszármazási vonala. ${ }^{947}$

937 PLRE2 821, "Palladius 10.” vö. HYD. CHRON. 155 (162). Palladiusról, a nevén, valamint azon kívül, hogy Petronius Maximus előző házasságából született jóformán semmilyen információval nem rendelkezik a kutatás.

938 OLYMP. FR. 41.1-2.

939 Többek között WES 1967, 52, TWYMAN 1970, 500, ZECCHINI 1981, 127.

940 Procop. De Bellis. 3.4.16-18.

941 A keleti források meglehetősen mostohán bánik Petronius Maximusszal. PrisC. Fr. 30.1 = I. ANTIOCH Fr. 201.1, Marc. Com. 455, Jord. Rom. 334, Jord. Get. 235, Procop. De Bellis. 6.4.24-28.

942 CASSIOD. VAR. 10.12.2-4.

943 HODGKIN 1886, 424, 2. 1j.

944 CASSIOD. VAR. 5.42.

945 HYD. CHRON. 160 (167).

946 CAMERON 2012, 146.

947 Forrásokra: PLRE2 821, "Palladius 10" vö. HYD. CHRON. 155 (162). A PLRE feltételezése szerint Palladius is ekkor veszthette életét, Hydatius ellenben nem említi a fiú halálát. 
Anicius Maximus (cos. 523) helyzete egészen különleges, ő ugyanis nem a Theodosiusdinasztia uralkodójának ártott, hiszen egy vérhez tartoznak. Anicius Maximus puszta létezésével segíti, vagy veszélyezteti azt, aki a Theodosius-dinasztia örököseként akart tetszelegni. Petronius Maximus feleségének története nemcsak III. Valentinianus gyilkosságára igyekszik magyarázatot adni, hanem allúzióként szolgálhat Anicius Maximus (cos. 523) ravennai udvarba kerülésére is. Maximusnak, aki a húszas évek elején töltötte be a consulságot, ekkor már mindenképpen házasnak kellett lennie. A gót hercegnővel 535-ben kötött házassága kapcsán a Variae nem említi korábbi feleségét, így talán akkor már özvegy lehetett. A senator anyagi helyzete azonban már korántsem volt mérhető elődei gazdagságához, Theoderich ugyanis levélben fordult a Maximushoz, hogy consullá avatása miatt cirkuszi játékokat rendezzen, amely kötelezettségre korábban egyik elődjét sem kellett emlékeztetni. ${ }^{948}$

Prokopios szerint 552-ben, amikor a Narses győzelme már biztos volt, Totila és gótjai menekülőre fogták. Prokopios szerint útjuk során válogatás nélkül kaszabolták az útjukba kerülő rómaiakat. Totila döntése értelmében ekkor a senatus több tagja Campaniában volt őrizetben. A zürzavarban - és minden bizonnyal, mert őreik is elmenekültek - több senatornak sikerült kereket oldania. Amikor a gótok tudomására jutott a dolog, az egész országban a szökevények kutatására eredtek és minden patriciust megöltek. A keleti auktor szerint Maximus is az áldozatok között volt. ${ }^{949}$ A senatorok után induló gót katonák kitartó keresésének leírásával Prokopios csak még inkább kiemeli Anicius Maximus fontosságát, halálának leírásával pedig biztosította, hogy a lázadó gótok utolsó önálló legitimációs próbálkozása is zátonyra futott, hiszen Maximus halálával az utolsó nyugati Anicius is meghalt.

A fejezetet során láthattuk az osztrogótok itáliai berendezkedésének keretrendszerét, legitimációjuk törékeny voltát. Aspar döntései még a magister militum halála után is komoly problémákat okoztak a későbbi uralkodóknak leginkább Theoderich Strabo és az osztrogót Theoderich miatt. Zeno ugyan egy kelepcével megpróbált megszabadulni mindkét hadvezértől, terve azonban kudarcba fulladt, ami számára sérelmes megegyezésre kényszerítette. Malchos szerint az osztrogót uralkodó romanitasa révén még Anicia Iuliana kezét is megszerezhette volna. A történetíró minden bizonnyal túlzott ezzel, hiszen Konstantinápolyban Geiserich példáján keresztül már jól tudták mit jelent ez. Theoderich nyomásgyakorlása elegendőnek bizonyult, hogy még a rendes consuli címet is elérje. Hogy mennyire problematikus volt Zeno és Theoderich

\footnotetext{
948 CASSIOD. VAR. 5.42.11.: "sed vobis, quibus necesse est talia populis exhibere, largitate manus fundite praemia, ut haec miseris faciatis esse votiva."

949 Procop. De Bellis. 7.9.6-19; 7.26.2. vö. 8.34.4-7.
} 
megállapodása, azt Prokopios Thukydidés azon szöveghelyére utalva magyarázta, amely éppen a peloponnésosi háború előzményeit ismertette. Mindezek árnyalták az osztrogótok és a konstantinápolyi udvar kapcsolatát. Prokopios tudatosan alkalmazta a periklési allúziót Theoderichre, hiszen az athéni államférfihez hasonlóan uralkodása végén Theoderich is az állam ellen cselekedett. Theoderich itáliai uralkodásának alapját az osztrogót uralkodó Zenóval kötött azon megegyezése alkotta, amely Odoacer megölésére vonatkozott. Az uralkodó ezt követöen harminc évig zavartalanul uralkodhatott, hiszen ha uralkodása túlnyúlt volna a három évtizeden, a gótok a maguk részére megtarthatták volna Itáliát, ezt elkerülendő új várományos érkezett a trónra az ifjú Eutharicus személyében, halála azonban átrajzolta az eseményeket. Kiskorú gyermekei révén az uralkodás biztosítottá vált Theoderich és Amalasuntha számára is, hiszen a kiskorú feletti régensség automatikusan érvénytelenítette az elbirtoklás megtámadásának lehetőségét.

Anonymus Valesianus úgy igyekezett elfedni ezt a megállapodást, hogy Odoacer halálát Zeno uralkodásának idejére helyezte, így a forrás szerint Anastasius immár más feltételt támaszthatott az osztrogót uralkodó elfogadására. A császár új feltétele a Henotikon pápai elfogadására vonatkozott, ami végső soron egy újabb skizmába sodorta a római klérust. A skizma eseményei között azonban felfedezhettünk egy olyan összefüggést, ami a nyugaton maradt Aniciusok leszármazását magyarázta. A leszármazáson keresztül világossá vált, hogy a családhoz tartozó Albinus aktív egyháztámogató tevékenységet folytatott, ami az Akakios-féle skizma lezárásának idején mutatkozott meg. Ez utóbbi tevékenysége okozta Albinus vesztét is, amelybe csak jóformán csak a véletlen sodorta bele Boëthiust és Symmachust, melynek nyomán a szakirodalom társítani kezdte őket. Az nyugaton maradt Aniciusok családjának rekonstruálásán keresztül látható vált, hogy nem csak Albinus független az előbb említett prominens senatoroktól, de a PLRE is hibát követett el, amikor öt és testvérét a Decius család tagjaként tüntette fel. A prosopográfiai gyüjtemény hibája több tucat tanulmány végkövetkeztetését befolyásolta negatívan, hiszen éppen a PLRE hibája miatt nem figyeltek fel arra, hogy az Anicius nyugati ága kihalt.

A Pars Posterior és a Epistula Severi összevetéséből láthatóvá vált Anonymus sorainak egy másik értelmezése, éppen azoknak a soroknak, amelyek a senatori arisztokrácia prominens tagjainak kivégzését előzte meg. A kivégzések Albinus bevádolásával vették kezdetüket, az Anicius-nemzetség tagjának szerencsétlen helyzetét azonban megelőzte a Szt. István imaház oltárának lerombolása, ahol minden bizonnyal az 519-ben keletről érkező szent ereklyéjét tárolták, de legalábbis utalt az Akakios-féle egyházi szakadás lezárására, amelybe a szerző a gótok erőszakos áttérítésének lehetőségét látta. A 6. századi történetíró leírásában az Anicius családhoz tartozó Albinus bukása szorosan kapcsolódott a Szt. István imatemplomhoz, a következő fejezetben 
látni fogjuk, hogy a történetírók valójában az ereklyékhez társítják a család tagjait. Theoderich uralkodásának szerencsétlen évei is ezen a ponton vették kezdetüket és folyamatosan romlottak egészen Theodahad uralkodásáig. Ennek a romlásnak a központjában az oktatás állt, hiszen míg Theoderich egyszerü magister militumként, a császár küldötteként érkezett Itáliába, ráadásul úgy, hogy nem vett magához Anicius nemzetségbeli feleséget, addig Athalarich már fel merte hánytorgatni a császárnak, hogy a vele közel egykorú apját a császár alávetési gyakorlatában a fiának nevezte. Amire Athalarich még csak utalt, az valóssággá vált Theodahad uralkodása idején, aki éppen egy Anicius révén igyekezett elérni a legitimációját. Malchos így mégsem véletlenül említette meg Theoderich kapcsán Anicia Iulianát, hiszen a házasság elutasításában éppen a hüség és a birodalom iránti alázat tükrözödik. Ezzel szemben Theodahad már semmiben sem különbözött azoktól az „elődeitől”, elsősorban Petronius Maximustól, akik erőszakkal kényszerítettek valakit házasságra csupán a legitimáció érdekében. A következő fejezetben látni fogjuk, hogyan fordítja Iustinianus Theoderich egykori fegyverét a gótok ellen. 


\section{551, ANICIUSOK ÉS A CSÁSZÁRI UDVAR}

A dolgozat elején az Aniciusok legitimációs szerepére, valamint Szt. István ereklyéjének feltételezett szerepére láttunk példát. A második fejezet során említettem, hogy 410 után Konstantinápoly fokozatosan kezdte megfosztani Rómát az új Jeruzsálem szerepétől, azonban ahhoz, hogy elérje ezt nem csupán templomokra és aktív hitéletre volt szüksége, hanem magába kellett olvasztania mindazokat a dolgokat, amelyeket a korabeli történetírók 410-hez társítottak. Láthattuk, hogy Orosius már nem arra törekedett, hogy függetlenítse a mennyei királyság gondolatát a testi és a földi léttől, hanem Galla Placidia és Athaulf házasságán keresztül igyekezett magyarázni az eseményeket. A házassággal párhuzamosan azonban csak egy materiális, Konstantinápoly számára is transzferálható dolog jelent meg, ez pedig Szt. István ereklyéje volt, ami expressis verbis ebben a fejezetben fog megjelenni az Aniciusokkal és így a Theodosiusdinasztiával kapcsolatban.

Theoderich a névtelen szerző szerint tanulatlan, s ily módon lassú észjárású volt. ${ }^{950}$ Esetében ezt annak tudtuk be, hogy elsősorban katona volt, ilyenformán pedig a hadakozásnak élt. Bár lehetősége lett volna arra, hogy Anicius-nemzetségbeli feleséget szerezzen magának mégsem élt a lehetőséggel, nem úgy, mint a mủvelt Theodahad. Prokopios hasonlóról tudatlanságról számol be Iustinus esetében is, ${ }^{951}$ így talán az ő esetében is van elhibázott Aniciusokkal kapcsolatos lehetőség, amit nem ö, hanem - akárcsak Theoderich esetében - az unokaöccse fog érvényesíteni. A következő oldalakon előbb bemutatom Iustinus és Iustinianus hatalomra jutásának körülményeit, melynek során rávilágítok egy közös pontra. Ezt követően ismertetem Anicia Iulianának, a város egyetlen nobilissimájának tevékenységét és alapításait, valamint felfedem Szt. István ereklyéjének Konstantinápoly életében betöltött szerepét, hiszen ezek elengedhetetlenek a későbbi belpolitikai folyamatok, így a Nika-felkelés mozzanatainak megértésében.

\footnotetext{
950 ANON. VAL. 14.79.

951 Procop. ARC. 2.6.15-16 (Iustinus).
} 


\subsection{Iustinus és Iustinianus hatalomra kerülésének körülményei}

A bederianai születésủ Iustinus 470 -es évek végén innen került a fővárosba, ahol társaival a palotaőrség tagjaivá vált, ${ }^{952}$ későbbi császárrá választásáról két történet is kering. Egy kevésbé realisztikus Anonymus Valesianus tollából, és egy hitelesnek tünő beszámoló Evagrios tolmácsolásában. A fejezet végére látni fogjuk, hogy Anonymus elbeszélése nagyobb történeti értékkel bír, mint bármely más auktoré.

A névtelen krónikás szerint az idős Anastasius számára komoly problémát jelentett az utódlás. Gyermeke nem lévén, egyetlen lehetősége az volt, ha unokaöccsei valamelyikére bízza a birodalmat, de hármójuk között (Hypatius (cos. 500), ${ }^{953}$ Pompeius (cos. 501), ${ }^{954}$ Probus (cos. $502)^{955}$ ) nem tudott dönteni, ezért a sorsra bízta magát. Egy napon beidézte őket a palotába, hogy vele reggelizzenek, szolgáinak pedig meghagyta, hogy a gyermekek részére egy-egy ágyat vessenek, hogy pihenőjüket is a palotában tölthessék.

"Utasitásba adta, hogy az egyik ágyon a fejrészhez az uralkodói jelvényt helyezzék el, és amelyikük a megjelölt ágyat választja aludni, öbenne kell elismernie a hatalom örökösét. Egyikük az elsö ágyon feküdt le, míg a másik kettő, testvéri szeretetböl egy másikban tért nyugovóra. Így esett, hogy egyikük sem aludt abban az ágyban, amelyben a királyi jelvényt elrejtették." 956

Az Anonymus Valesianusnál megőrzött hagyomány szerint a monofizita császár ebből megértette, hogy egyikőjük sem uralkodhat, ezért Istenhez kezdett fohászkodni kinyilatkoztatásért, hogy még életében megtudhassa, halála után ki veszi át uralmát. Egyik éjjel egy embert látott álmában, aki a következőt mondta neki:

"Akit holnap elsöként jelentenek be a hálószobádba, az fogja elnyerni utánad hatalmadat".957

Másnap reggel a praepositus cubiculi elsőként Iustinus comes excubitorumot jelentette be. A császár hálálkodni kezdett, hogy Isten még életében méltónak találta rá, hogy felfedje neki

\footnotetext{
952 Procop. Arc. 6.2., Ps.-ZaCh. Rhet. Chron. 8.61.

953 PLRE2 577-581, "Fl. Hypatius 6".

954 PLRE2 898-899, "Pompeius 2".

955 PLRE2 912-913, "Probus 8".

956 ANON. VAL. 13.74. "Et in uno lecto iussit ad capitem regium insigne poni, et quis de ipsis in eodem lecto elegisset dormire, in hoc se debere cognoscere cui regnum postea traderet. Unus quidem in uno lecto se iactavit, dum enim in alio, amore fraterno, se collocaverunt. Et ita contigit, ut in illo lecto ubi regium insigne positum erat nullus eorum dormiret."

957 ANON. VAL. 13.75.
} 
utódját. ${ }^{958}$ Míg Anonymus isteni sugallatnak tulajdonította Iustinus hatalomra kerülését, addig Evagrios szerint megválasztásában számottevőbb szerepet töltött be a pénz és a leleményesség. A császár belső köréhez tartozó Amantius ${ }^{959}$ praepositus cubiculi és társa, Andreas ${ }^{960}$ cubicularius azt tervezték ugyanis, hogy Anastasius halála esetén barátjukat, Theocritus ${ }^{961}$ domesticust teszik császárrá. Tervüket a testőrség lefizetésével akarták sikerre vinni, így az erre szánt pénzt Iustinusnak adták és megbízták, hogy fizesse le a scholarii-t és más katonai egységeket, hogy azok Theocritus mellé álljanak majd. Iustinus azonban nem Theocritus elönyére költötte el a rá bízott pénzt, hanem a sajátjára, ${ }^{962}$ így 527 . augusztus 1 -jén a palota környéki csapatok császárra kiáltották ki.

Iustinusnak azonban egy idő után hasonló problémával kellett szembenéznie, mint elődjének, ugyanis ő is gyermektelen volt, ráadásul hatalmának átörökítését is Anastasiushoz hasonlóan remélte. Olyannyira hasonló volt a helyzete Anastasiuséval, hogy az egyik ágon neki is három unokaöccse volt, ugyanis míg Petrus Sabbatius (a későbbi Iustinianus) nővérétől született, addig másik testvérének három gyermeke volt Boraïdes, ${ }^{963}$ Iustus ${ }^{964}$ és Germanus ${ }^{965}$ személyében. Iustinianus unokatestvérei azonban mintha nem is léteznének, hármójuk közül a Nika-felkelésig csak Germanus tủnik fel halványan a forrásokban.

Az 518 augusztusa utáni hetekben Anastasius rokonai és kedvezményezettjei valamennyi pozícióból kiszorultak. ${ }^{966}$ Egészen pontosan csak Hypatius és Pompeius, ugyanis csak ők szerepelnek a forrásokban. Az alacsony sorból származó császárnak különösen fontos volt, hogy a kulcspozíciót jelentő tisztségekben saját embereit lássa. ${ }^{967}$ Diogenianus ${ }^{968}$ váltotta a már-már örökös magister militumnak számító Hypatiust. Pompeiust pedig éppen Iustinus Germanus nevü unokaöccse váltotta Thracia magister militumi pozíciójában. ${ }^{969}$ Mielőtt Germanus elhagyta volna

958 ANON. VAL. 13.75.

959 PLRE2 67-68, "Amantius 4".

960 PLRE2 67-68, "Andreas qui et Lavsiacvs 10".

961 PLRE2 1065, "Theocritvs".

962 PS.-ZACH. RHET. CHRON. 8.61, EvAGR. HE. 4.2.

963 PLRE3A 245-246, "Boraides".

964 PLRE3A 758-759, "Iustus 2".

965 Procop. De Bellis. 1.24.19 vö. 1.24.53.

966 LYDUS MAG. 3.51.5, Iustinus hatalma biztosítása érdekében félreállította valamennyi lehetséges trónkövetelöt is. Lydos egy bizonyos Marinust név szerint is említ.

967 PLRE2 111-112, “Apion 2", PLRE2 1171-1176, "Fl. Vitalianus 2", PLRE2 840-842, "Fl. Patricius 14". Iustinus elsősorban olyan tapasztalt tisztségviselőket helyezett hatalomba, illetve hívott vissza, akiket korábban még Anastasius üldözött el. A praefectus praetoriói szék Apionhoz került. Philoxenus került a comes domesticorumi pozícióba. A Konstantinápoly védelméért felelős magister militum praesentalis tisztségbe pedig a korábban Anastasius ellen lázadó Vitalianus került, aki Patriciust váltotta a tisztségben.

968 PLRE2 362, "Diogenianus 4".

969 Procop. DE BeLLIS. 7.40.5-6. Germanus hamar katonai sikerekre tesz szert a Dunán éppen átkelő antok legyőzésével az 520-as évek elején. 
Konstantinápolyt, neve feltünik Hormisdas pápa levelei között. Iustinus ugyanis már hetekkel a megválasztása elött levelet küldött a pápának, melyben kifejezte szilárd elköteleződését az egyházi kérdések rendezése mellett, és támogatását kérte nemcsak az egyházi ügyekben, de saját személyét és családját illetően is. ${ }^{970}$ Hormisdas válaszában biztosította a császárt, hogy elkötelezett a családja iránt. ${ }^{971} \mathrm{~A}$ pápa azonban nemcsak Iustinusnak írt, hanem a császár másik unokaöccsének, Germanusnak is, melyben a mi fiunknak, valamint vir illustrisnek nevezi Iustinianusszal együtt. ${ }^{972}$ Az egyházfő 518-519-ben még egyértelmúen egy szinten kezeli Iustinus két unokaöccsét, ám ezt követően jó ideig nem hallunk Germanusról, minden bizonnyal 520-ra már elhagyta Konstantinápolyt.

Miközben Germanus az antokkal hadakozott a Duna vidéken, ${ }^{973}$ addig Iustinianus egyike volt annak a negyven embernek, aki Iustinus biztonságáért felelt. A testörgárda (scholae palatinae) candidatusként a palotán belül kezdte meg szolgálatát, a magister officiorum felügyelete alatt. ${ }^{974}$ 519-ben már a tiszteletbeli comes cím birtokosaként bukkan fel egy levélben, melyet Hormisdas pápa küldött Iustinus unokaöccsének. ${ }^{975}$ Minden bizonnyal Celer magister officiorum beleegyezésével kezdett egyházi ügyekkel foglalkozni, mint a consistorium segédszemélyzetének tagja. ${ }^{976}$ Innen egyenes út vezetett ahhoz, hogy magister officiorum legyen, ami 520-ban végül be is következett kinevezésével. ${ }^{977}$ A császár unokaöccsének karrierje így a már megszokott hivatali úton ívelt felfelé, befolyása pedig egyre csak növekedett.

Iustinianus kinevezésével furcsa dolgok vették kezdetüket Konstantinápolyban. Elöbb gyilkosság, majd városi zavargás tört ki, ami még több véráldozattal járt. 520 júliusában Vitalianus magister militum praesentalist többedmagával ${ }^{978}$ lemészárolták a palotában. Marcellinus elhallgatja

970 Coll. Avell. 141.2-3. (Iustinus), Coll. Avell. 147.2. (Iustinianus) Ezt követően 518. szeptember 7-én kelt levelében Iustinianus ismét megerősíti szándékukat az Akakios-féle skizma rendezését illetően. A levelek datlálása a consuli évek alapján történik, ehhez lásd CLRE.

971 Coll. Avell. 148 (Iustinianusnak). Coll. Avell. 149. Egy évvel későbbi levelében Hormisdas már hosszasan fejtegeti a Chalcedoni zsinat rendelkezéseit és arról ír, hogy hajlandó támogatni Leo tomusát.

972 Coll. Avell. 210.2.: “illustes magnificos uiros Iustinianum atque Germanum filios nostros.” Az ezt követő levélben is feltünik Germanus COLL. AVELL. 211.

973 PROCOP. DE BELLIS. 7.40.5-6.

974 VICT. TONN. 518.2. Iustinianus ezt megelőzően nem bukkan fel a forrásokban, így kétséges, hogy már ekkor ismerte Theodorát, aki foglalkozását tekintve aligha kerülhetett a palotakapun belülre.

975 Coll. Avell. 162, CROKE 2008, 21. Néhány feltételezés szerint Iustinianus már ekkor comes domesticorum, ennek azonban ellentmond, hogy ebben a korszakban, sőt korábban is több Hormisdashoz köthető levél is felbukkan, amelyben felbukkan a tisztségviselő vö. CoLL. AvELL. 111, 120, PLRE2 1023, "Flavius Theodorus Philoxenus Soterichus Philoxenus", ugyanakkor ebben az időben Philoxenus birtokolta a tisztséget.

976 A magister officiorum kiterjedt befolyására lásd PóKECZ KOVÁCs 2016.

977 VICT. TONN. 520.2. Az auktor szerint candidatusból lett magister officiorum, ami megerösíti, hogy a consistorium környékén szolgált ebben a korábbi időben.

${ }^{978}$ Celerianus és Paulus. 
a felbujtókat, de Tunnunai Victor tudni véli, hogy Iustinianus keze volt a gyilkosságokban, ${ }^{979}$ annyi mindenesetre bizonyos, hogy Iustinianus váltotta Vitalianust a valamennyi katona vezetőjét jelentő magister militum praesentalis tisztségben. A császár unokaöccse kétségtelenül kihasználta a tisztségben rejlő lehetőségeket, mert néhány évvel később semmit sem tett Konstantinápoly nyugalmának biztosításáért, miközben háborúkban jártas ${ }^{980}$ unokatestvérét is a fővárostól távol tarthatta. ${ }^{981}$

523-ban ugyanis a Hippodrom kék pártjának tagjai változatos gyilkosságokat követtek el Konstantinápoly különbözö pontjain, és más városokban. Ióannés Nikiu szerint a kékek Iustinianus utasításainak megfelelően jártak el. ${ }^{982}$ Iustinus a helyzet rendezése érdekében magához hívatta Theodotust, ${ }^{983}$ a város praefectusát és megbízta, hogy mindenféle részrehajlás nélkül kell felkutatnia a tetteseket. A császár megbízottja kisvártatva elóállította Theodosiust, a város egyik leggazdagabb polgárát, akit hamarosan ki is végeztetett. ${ }^{984}$ A eseményeket elbeszélő Malalas ugyan elhallgatja, de Nikiu tudni véli, hogy Iustinianus is őrizetbe került, ahonnan csak betegsége miatt engedték el. Theodotus mindenesetre javasolta a császárnak, hogy hasonló büntetést kapjon, hiszen ő is a felbujtók között volt. ${ }^{985}$ Amikor Iustinus meghallotta a praefectus urbi javaslatát, hirtelen felindulásból megfosztotta Theodotust valamennyi tisztségétől és számüzte Konstantinápolyból. ${ }^{986}$ A városi praefectusszal szembeni eljárás mélyen megrendítette a konstantinápolyi katonákat és összegyülve megtagadták a császárnak tett hűségesküjüket. Az idős császár korántsem volt egyszerü helyzetben, hiszen többek között a "megvesztegethetetlen" és köztiszteletben álló ${ }^{987}$ Proculus, ${ }^{988}$ a quaestor sacri palatii is Theodotus oldalára állt. Iustinusnak mindenesetre sikerült megbékíteni az ellenszegülöket, ${ }^{989}$ amit jelez az is, hogy a következő évben hatalomra kerülése után ismét ö töltötte be a consuli tisztséget. ${ }^{990}$ Konstantinápoly egykori praefectusa viszont már soha

\footnotetext{
979 Marc. COM. 520, Vict. TonN. 523.3 vö. I. NikiU. Chron. 90.11-12. A gyilkosságra 520. júliusában került sor.

980 Germanus tekintélyére PROCOP. DE BELLIS 7.39.17-20.

981 PLRE2 505-507, “Germanus 4".

982 I. NIKIU. CHRON. 90.16.

983 PLRE2 1104-1105, "Theodotus qui et Colocynthius 11".

984 JOH. MAL. 17.12 (416) vö. I. NIKIU. CHRON. 90.17.

985 I. NiKIU. CHRON. 90.17.

986 I. NIKIU. CHRON. 90.19.

987 Lydus Mag. 3.20, Procop. De Bellis. 1.11.11.

988 PLRE2 924-925, "Proculus 5".

989 I. NikIU. Chron. 90.20-23., PLRE2 1096, "Ephraemius”, PLRE2 1096, “Theodorus qui et Teganistes 57”, Ephraemius és Theodorus megválasztása hütötte le a kedélyeket.

990 CLRE 524, MARC. COM. 524. I. NikiU. CHRON. 90.24-29, Nikiu ezt követően sorozatos természeti csapásokat említ.
} 
nem tért vissza a fővárosba. ${ }^{991}$ Iustinianus viszont maradt, bár szavahihetősége talán megcsappant nagybátyja szemében. A másik keletrómai krónikás, Marcellinus is hallgat az eseményekről, ami aligha meglepő annak tükrében, hogy ebben az időben már Iustinianus alatt szolgált cancellariusként. ${ }^{992}$

525-ben az udvaroncok véleménye ellenére Iustinianus ismét elörébb lépett egyet a ranglétrán, Tunnunai Victor szerint azonban a császár akarata ellenére tette caesarrá unokaöccsét. ${ }^{993}$ Vélhetően a császár végül azért döntött Iustinianus kinevezése mellett - annak ellenére, hogy bizalma valószínúleg megrendült az 523-as események után -, mert másik tehetséges unokaöccsét, Germanust nem tudta kinevezni, hiszen lekötötték a thraciai harcok. A császár csak így tudta biztosítani, hogy a caesar a családjából való legyen.

Az eseményekkel egy időben ${ }^{994}$ Prokopios beszámol egy követjárásról a perzsa és konstantinápolyi udvar között, amelyben különös hangsúlyt kap az örökbefogadás kérdése. ${ }^{995} \mathrm{~A}$ keletrómai auktor története elsősorban a barbár és a római adoptio közötti különbségekre és jogkövetkezményeire hívta fel az Iustinus figyelmét.

Prokopios anekdotázó leírásban tudatja olvasójával, hogy Kavād perzsa uralkodó, szembeszállva népe szokásával, nem legidősebb fiát szánta maga után, hanem Chosroést. ${ }^{996}$ Prokopios azzal igyekszik érzékeltetni a még csírájában rejlő konfliktust, hogy érzékelteti az idősebbik fiú, Zamasp férfiasságát, ${ }^{997}$ harcedzettségét, valamint azt a tényt, hogy a perzsák között ezen erényei miatt számított igen népszerünek, ${ }^{998}$ bár keveset tudunk róla, de ezek az erények Zamasphoz hasonlóan Germanusban is megvannak. ${ }^{999}$

A történet szerint Kavād attól tartott, hogy az idősebbik fiú népszerüsége és férfias tekintélye miatt lázadás törne ki országában, ezért követek útján egy levelet küldött Konstantinápolyba, melyben felajánlotta, hogy hajlandó szemet hunyni a rómaiak perzsák ellen

991 I. NiKIU. CHRON. 90.16. A praefectus attól félt, hogy az életére fognak törni, ezért Jeruzsálemig meg sem állt.

992 vö. MARC. COM. 523.

993 VICT. TONN. 525a.

994 CROKE 2008, 43 160. $1 \mathrm{j}$.

995 PROCOP. DE BELLIS. 1.11.13-18. A fegyverrel örökbefogadást Prokopios nem gót szokásként értelmezi, hanem olyan eljárásként, ami “illik a barbárokhoz”, tehát ahogy Konstantinápolyban eljárnak a barbárokkal szemben, ami keletrómai szempontból nem csak a gótokat jelenti. A fegyverrel történő örökbefogadás Prokopios tükrében egy alávetési gyakorlat római és nem római között, egyenes hierarchiát tükrözve.

996 Procop. De BELlis. 1.11.3-4

997 PROCOP. DE BELLIS. 1.11.5

998 A férfiasság, férfiatlanság szembeállítása roppant sok helyen feltűnik Prokopiosnál, már ennek jelölésével is pozicionálja a történetet, melyet éppen mesél. Lásd: PROCOP. DE BELLIS. 1.14.33, 1.25.16, 4.22.2, 5.9.1, 7.4.13, 7.32.5, 8.3.7, 8.12.4.

999 PROCOP. DE BELLIS 7.39.17-20, 7.40.9. 
elkövetett atrocitásai felett, ha Iustinus hajlandó örökbe fogadni Chosroést. ${ }^{1000}$ Prokopios beszámolója szerint a császár és unokaöccse nagyon felbuzdultak a perzsa levelén, és sürgetni kezdték a "keményfejü és megvesztegethetetlen" Proculust, aki ekkor a quaestori hivatal vezetöje volt, hogy mihamarabb intézkedjen az örökbefogadással kapcsolatban. Prokopios szerint Proculus azonban közel sem volt olyan bizakodó az örökbefogadással kapcsolatban, ezért aggodalmait egy hosszú levélben ismertette a császárral. A quaestor szerint a "korábbi gyakorlathoz" képest radikális váltás lenne a római módon történő örökbefogadása, hiszen ez nem szólna másról, mint a Római Birodalom megszerzéséről, ugyanis, mint mondja, Iustinus halála után az örökbefogadott fiú örökölte volna a birodalmat. ${ }^{1001}$ Proculus figyelmeztette a császárt, hogy az örökbefogadás visszafordíthatatlan folyamat, ami komoly következményekkel jár. ${ }^{1002}$

Úgy gondolom, hogy a történetben Prokopios Proculus ellenállásán keresztül utal Iustinianus örökbefogadásának körülményeire, amire caesarrá avatásával és a perzsa követséggel egyidejüleg került sor. ${ }^{1003}$ Iustinus gyermektelen volt, élete telén pedig kiemelt jelentőségúvé vált számára, hogy biztosítsa vagyonát és hatalmát is a római joggyakorlatnak megfelelően adoptio útján. ${ }^{1004} \mathrm{Az}$ 525-ös adoptio tényét támasztja alá az is, hogy 521-es consuli diptychonjában még Petrus Sabbatius néven bukkant fel. Iustinianus örökbefogadásával és caesarrá avatásával biztosítottá vált az utódlás. A császár halála után 527. augusztus 1-jén Iustinianust választották a következö uralkodónak. Az elöbbiekben láthattuk a Iustinus és Iustinianus hatalomra kerülését nehezítő tényezőket, amelyek egy ponton különös egyezést mutattak, hiszen mind Iustinus, mind Iustinianus hatalomra kerülése elött felbukkan az éppen regnáló uralkodó három unokaöccse, akik közül az egyik eltérő módon, de kiemelésre kerül. Anastasius esetében az, aki egyedül hajtotta álomra a fejét, míg Iustinianus esetében Germanus, akit még Hormisdas pápa is említésre méltónak talált. Úgy gondolom, hogy ezek a hasonlóságok nem véletlenek. De mielőtt ennek a gondolatnak a jelentősége kontextusba kerülne, előbb meg kell ismernünk az Aniciusok konstantinápolyi alapításait, amelyek kiemelt szerephez jutnak a későbbiekben.

\footnotetext{
1000 Procop. De BELLIS. 1.11.6-9.

1001 PROCOP. DE BELLIS. 1.11.13-18.

1002 PROCOP. DE BELLIS. 1.11.13-18.

1003 A datálásra: GREATREX 1998, 139, CROKE 2008, 43 160. lj.

1004 Iustinianus Iustinus általi örökbefogadását igazolja a császári névben felbukkanó -ianus végződés. A jellegzetes végződés megfigyelhető több adoptált császár és római hadvezér nevében. Amikor L. Aemilius Paulus (cos. i. e. 168) örökbe fogadta P. Cornelius Scipiót, annak neve P. Cornelius Scipio Aemilianusra változott, Octavius neve pedig, miután Caesar örökbe fogadta, Octavianusra változott.
} 


\subsection{Az Aniciusok Konstantinápolyban}

Noha 527. augusztus 1-jén Iustinianust császárrá választották, közvetlen dinasztikus kapcsolatot továbbra sem tudott felmutatni a Theodosius-dinasztiával. Nem is kellett, hiszen a 6. századi Konstantinápolyban ebben az időben Anicia Iuliana személyében még élt a császár családjával közösségben egy nobilissima, akit ráadásul Malalas a város egyetlen patrikiájaként aposztrofál. ${ }^{1005}$ Nobilissima címe a Húsvéti krónika bejegyzésében lelhető fel, ${ }^{1006}$ melynek korábban I. Leo esetében már láthattuk a jelentőségét. A Chronicon Paschale bejegyzései alapján, mint említettük, úgy tủnik, hogy a Theodosius-dinasztia nőtagjai, férfitársaikkal ellentétben nem kinevezés útján jutottak a cím birtokába, hanem születésüktől fogva viselték azt, ${ }^{1007}$ így volt ezzel Anicia Iuliana is.

A korabeli Konstantinápolyban az asszony kitűnt az egyházat támogató tevékenységével. Anicia Iuliana különleges gondossággal ápolta szülei örökségét, de talán a család korábbi leszármazottainak alapításai miatt is felelősséget érzett. Minden bizonnyal nemcsak szülei, nagyszülei, de dédszülei, vagyis a Theodosius-dinasztia alapításai miatt is felelősséget érezhetett.

\subsubsection{Szt. István ereklyéi és az Aniciusok alapításai Konstantinápolyban}

Az 5-6. században a konstantinápolyi arisztokrácia lakhelyének középpontjában, a város 10. kerületében Constantinus fürdője (thermae Constantianae) állt. A nobilissima a 6. század elején összefogta ősei valamennyi egyházi alapításait és magántulajdonait. ${ }^{1008}$ Előbbiek gyakorlatilag három templomban merülnek ki, ezek a Szt. Laurentius, Szt. Euphemia és a Szt. Polyeuctus őse.

A kutatás csak az utóbbi időben kezdett figyelmet szentelni annak a ténynek, hogy a késő bizánci történetírók munkájában jobbára túlságosan kedvező kép uralkodik Iuliana rokonáról, Pulcheriáról. A 20. század második felében Kenneth Holum nyomán még az a nézet uralkodott, hogy a császárnő jámborsága alapvetően meghatározta uralkodásának módszereit. Holum szerint Pulcheria szüzességi fogadalma, társítva szent ereklyékkel, olyan eröt kölcsönzött neki, amellyel jogot formálhatott a hatalomra. ${ }^{1009}$ Az asszony egyházi alapításaival kapcsolatos mítoszgyártás már életében megkezdődött Sózomenos egyháztörténeti munkájával, aki ugyan megemlékezett arról, hogy a császárnő számos imaházat, szegényházat és templomot alapított, a pontos

1005 JOH. MAL. 16.19 (407)

1006 JOH. MAL. 16.19 (407), CHRON. PASCH. 517.

1007 Arcadius valamennyi gyermeke a nobilissima/nobilissimus cím birtokosa volt. CHRON. PASCH. 397 (Flaccilla), 399 (Pulcheria), 400, 414 (Eudocia, Arcadia), 401 (Theodosius), 403 (Marina). Anicia Iuliana előtt az utolsó említésre kerülő nobilissima Ariadne.

1008 ANTH. GR. 1.10.7-13.

1009 HoLUM 1989, 98-111. 
elhelyezkedésüket azonban elfelejti közölni. ${ }^{1010}$ A probléma jelentősége abban rejlik, hogy Rómával szemben Konstantinápolyban alig van feltárt épület, illetve vagy megsemmisültek, vagy más épületeket építettek rájuk. A török időszakban csak két épülettípus maradt meg: a templomok és a ciszternák. Ezek is kizárólag praktikus okokból. A templomok többségét mecsetté alakították, a ciszternák pedig továbbra is a város vízellátásának gerincét adták. A nem kortárs források sok egyházi épület alapítását tulajdonítják Pulcheriának, közös vonása ezeknek a kútfőknek, hogy valamennyi a halála után keletkezett. ${ }^{1011}$ Több kutató jelezte már, hogy ebben inkább a későbbi korok elvárásai jelennek meg. Jellemző példa erre a trieri Szent Péter-dóm elefántcsont faragványa, ami megörökíti, ahogyan II. Theodosius uralkodása alatt ünnepélyes keretek között Konstantinápolyba érkezik Szt. István ereklyéje. Elsősorban Theophanés nyomán terjedt el a szakirodalomban az a nézet, hogy erre az adventusra 421-ben került sor, ennek azonban aligha van történelmi hitelessége. ${ }^{1012}$

Az ereklyék Konstantinápolyba kerülésének van egy másik története is. Iuliana dédanyja, a pogány Athenais, aki a keresztségben az Eudocia nevet kapta, meglehetősen meseszerủ módon lett II. Theodosius felesége. ${ }^{1013}$ Megtérése szinte valamennyi bizánci krónika témája. ${ }^{1014} \mathrm{~A}$ keletrómai krónikásoknak azonban tévedtek abban, hogy Eudocia már házassága pillanatában, mintegy varázsütésre az államvallás elkötelezett követöjévé válik. ${ }^{1015} \mathrm{Az}$ asszony ugyanis szinte egész életében meggyőződéses monofizita volt és minden bizonnyal csak 455-ben, Megas Euthymios apát szorgalmazására térhetett át a hivatalos államvallásra, de az ezzel kapcsolatos információ is meglehetősen ingatag lábakon áll. ${ }^{1016}$ A történetről beszámoló Kyrillos Skythopolités ugyanis csak

$\overline{1010}$ SOZOM. HIST. ECCL. 9.1

1011 ANGELOVA 2014, 88.

1012 THEOPH. AM. 6119 vö. WORTLEY 1980. A faragvány részletes leírásához lásd: HoLUM 1979.

${ }^{1013}$ Malalas számol be arról elsőként, hogy Eudocia Athénban született egy pogány görög család gyermekeként. Apja, Leontius a később bezáratott athéni akadémiának megbecsült tanára volt. Nem csoda hát, hogy Pallas Athéné tiszteletére lányának az Athenais nevet adta. Gyermekkorában Athenais az athéni akadémiai közeg tudásának legjavát: retorikát, irodalmat és filozófiát szívott magába. Apja halála után azonban testvérei kiforgatták örökségéböl, így húszas évei elején nagynénje unszolására Konstantinápolyba ment. A legenda szerint ebben az időben a fiatal Athenaisszal szinte egykorú II. Theodosius házasodni készült, ezért arra kérte nővérét, Pulcheriát, hogy keressen számára megfelelő jelöltet. Keresés közben Pulcheria fülébe jutott az örökségéből kiforgatott lány története, aki szerény 100 solidusszal volt kénytelen a városba érkezni. Mindenképpen meg akarta ismerni öt, így rögtön magához hívatta. A találkozó során Pulcheriát lenyügözte Athenais szépsége és intellektusa. Miután visszament bátyjához, rögtön jelentette, hogy megtalálta számára a megfelelő jelöltet. Placidia olyan élénken mesélte el Athenais tulajdonságait testvérének, hogy az rögtön szerelembe esett. Házasságukra sem kellett sokat várni, 421. június 7-én összekötötték életüket. A történetíró szerint ekkor, a keresztséget követően vette fel Athenais az Eudocia nevet.

${ }^{1014}$ Evagrios, a Chronicon Paschale, Ióannés Nikiu, Theophanés, Zónaras, Niképhoros munkájában.

1015 EVAGR. HE. 1.20.

1016 CYR. SCYTH. V. EUTH, 35. 
tíz évvel később került Euthymios monostorába, Khan al-Ahmarba. Ellenben sokkal érdekesebb Marcellinus comes beszámolója.

Marcellinus szerint 439-ben Eudocia elzarándokolt Jeruzsálembe, ahonnan a fővárosba vitte Szent István protomártír ereklyéit, ${ }^{1017}$ amelyeket Orosius már egyszer elvitt Jeruzsálemből, hogy aztán Menorca szigetén felejtse őket. Marcellinus beszámolója szerint Eudocia elhelyezte az ereklyét a Szt. Laurentius bazilikában, ${ }^{1018}$ majd visszatért Jeruzsálembe, ahol 460-ban meg is halt. ${ }^{1019}$ A korábbi fejezetekben már láthattuk a protomártír maradványainak szerepét. Előbb Galla Placidia szabadulása és Athaulf csodás pálfordulása során volt szerepe, majd a dinasztia kihalása után az ereklyék átkerültek a Theodosius-dinasztia vérrokonaihoz, az Aniciusokhoz, és a későbbi történetírók már velük társítják azokat. Anonymus Valesianus leírásában Theoderich, mielőtt perbe fogna egy Anicius családhoz tartozó senatort, előbb “megzavarodik” és lerombolja a közeli Szent István imaházat. ${ }^{1020}$

Marcellinus törekszik arra, hogy kiterjessze az ereklyék szerepét azzal, hogy előbb leírja, hogy Szt. István maradványait II. Theodosius felesége helyezi el az általa alapított bazilikában, ${ }^{1021}$ egy későbbi caputban pedig már azt írja, hogy az Eudocia által alapított Szt. Laurentiust Pulcheria fejezte be, ${ }^{1022}$ hogy aztán - már egy epigramma tanulsága szerint - Anicia Iuliana díszítse tovább. ${ }^{1023}$ Szent István ereklyéi és a Theodosius-dinasztia tagjainak egyházi alapításai így kerültek az Aniciusokhoz.

A Szt. Laurentiuson kívül Anicia Iulianához kerültek gyermektelen nagynénjének, Arcadiának, továbbá szüleinek és dédszüleinek a tulajdonai is. Constantinus fürdőjének egyik oldalán a Szt. Euphemia temploma állt, a másik oldalán pedig a Szt. Polyeuctus-templom épült. Az asszony birtokai gyakorlatilag körülölelték a fürdő területét. ${ }^{1024}$ Konstantinápoly legimpozánsabb épülete ekkoriban a Szent Polyeuctus templom volt. A régi Hagia Sophia ugyanis, amelyet még 415. októberében II. Theodosius avatott fel, korántsem az az épület volt, amelyet ma ismerünk. A 6. század elején már nem is ez a palotakörzetben álló épület volt Konstantinápoly legimpozánsabb temploma, hanem az, amelyet a jóval távolabbi, arisztokraták által sürün lakott 10. kerületben, Marcianus császár győzelmi oszlopának szomszédságában emeltek, és a melitenei (ma Malatya)

1017 MARC. COM. 439.2.

1018 Cyr. Scyth. V. Euth, 35, Evagr. HE. 1.22. A jeruzsálemi Szent István templomban lelt végső nyugalomra.

1019 EVAGR. HE. 1.20.

1020 ANON. VAL. 14.83, 85.

1021 MARC. COM. 439.2.

1022 MARC. COM. 453.2.

1023 ANTH. GR. 1.10.7-13.

1024 Magdalino 2001, 64-65. 
vértanú tiszteletére szentelték fel. A templomot még Anicia Iuliana kezdte építeni, így folytatva a családi hagyományt, amelyet szülei és nagyszülei kezdtek el. Egy alapítási epigramma szerint ugyanis nem sokkal azt követően, hogy Licinia Eudoxia és lánya, Placidia kiszabadultak Geiserich fogságából, 464-ben egy templomot alapítottak Placidia újdonsült férjének, Olybriusnak a körzetében, a 10. kerület szívében. ${ }^{1025}$ Az épületet Szt. Euphemia tiszteletére szentelték fel, aki a chalcedoni zsinat alkalmával az ortodoxia javára ítélt. ${ }^{1026}$ Az épületnek nemcsak Licinia Eudoxia, Placidia és Olybrius, hanem még Anicia Iuliana is gondját viselte. Az ajánló epigramma szerint ugyanis szülei halála után az asszony tovább szépítette az épületet. ${ }^{1027}$

\subsubsection{A Szt. Polyeuctus és Iustinianus}

Egy másik epigramma, ami már a Szent Polyeuctus alapításáról számol be, jelzi, hogy Iuliana egy már álló kicsiny templomból építette fel a Polyeuctus gyönyörü épületét, ${ }^{1028}$ amelybe az 520-as évek végén egy Tours-i Szent Gergely által megőrzött történet szerint maga Iustinianus is ellátogat. ${ }^{1029}$

A Szt. Polyeuctus Constantinus fürdőjének északi oldalán kapott helyet. Bardill elemzése kimutatta, hogy a templom alapozásához használt téglák többségét 508/509. és 511/512. között készítették, a felépítményhez szükséges téglák pedig 517/518. és 520/521. között készültek. Az épület egy része már 518-ban, az Akakios-féle skizma lezárásakor állhatott, ${ }^{1030}$ de teljesen csak az 520-as évek végére készülhetett el. A téglák datálása mutatja, hogy az építkezés kezdetei éppen a monofizita Anastasius uralkodására esnek. Már önmagában ez a tény is rávilágít arra, hogy mekkora tisztelet övezte Konstantinápolyban Iuliana családját, hiszen egy nyíltan nicea-chalcedoni vallással rokonszenvező asszony kezdett egy monumentális építkezésbe.

A templom ajánló epigrammája szerint az épület Salamon templomának mása kívánt lenni. ${ }^{1031}$ Kétségtelenül ambiciózus terv volt, hiszen az i. e. 6. században elpusztult templom korának egyik legkiemelkedőbb építészeti szimbólumának számított. Ráadásul legbelsőbb helységében örizték a Frigyládát, benne a Tízparancsolattal. A templom alapköve a közeli Béthel

1025 CHRON. PASCH. 594.

1026 ODB 747-748, "Euphemia of Chalcedon".

1027 ANTH. GR. 1.12.

1028 ANTH. GR. 1.10.10. A templom alaprajza és rekonstrukciós képe, valamint jelenlegi állapota megtekinthető az alábbi oldalon: http://www.thebyzantinelegacy.com/polyeuktos Megtekintés dátuma: 2017.03.01. 15:32.

1029 Greg. TUR. Glor. MART. 102.

1030 BARDILL 2004, 125-26.

1031 ANTH. GR. 1.10.47-49. 
városából származott, ahol Jákob a nyitott eget láthatta, így olyan pontot szimbolizált ahol az ég és a föld találkozik. ${ }^{1032}$ Ezékiel a templom pusztulásában Isten büntetését látta, babiloni fogsága idején viszont egy látomásában már felismerte, hogy Salamon temploma egy napon újra felépül, és így Isten dicsősége visszaköltözik a Földre. ${ }^{1033}$ Később a keresztények is magukévá tették azt a nézetet és elterjedt, hogy az Új Jeruzsálem ott lesz, ahol az Új Temploma állni fog. ${ }^{1034}$ Salamon temploma egyszerü formákból és terekből állt. Méreteit tekintve 29 méter hosszú, 9,5 méter széles és 14,5 méter magas volt. A templomhoz udvar, csarnok és számos melléképület kapcsolódott. Belsejét faburkolat borította, a mennyezetet cédrusgerendák és deszkák alkották. Közelében épültek Salamon palotái is.

A Szt. Polyeuctus feltárási munkálatai ${ }^{1035}$ alátámasztották az ajánló epigramma célkitűzését. Tours-i Szent Gergely beszámolója szerint a templom Iuliana rezidenciája mellett épült fel. ${ }^{1036} \mathrm{~A}$ régészeti feltárások bebizonyították, hogy a Szt. Polyeuctus számos külső díszítő eleme több ponton emlékeztet a Salamon templom bibliai leírására. ${ }^{1037}$ A korai kutatásban ugyan még figyelmen kívül hagyták az epigrammát: nem a Salamon templom leírásával keresték az azonosságot, így Tours-i Szent Gergely beszámolóját is félreértelmezték. Mango és Sevcenko még úgy gondolta, hogy Iuliana templomának kökupolával kellett rendelkeznie, mert Gergely leírásában a camera szót használja, ${ }^{1038}$ ez azonban bármilyen födémet jelenthet. ${ }^{1039}$ A kutatók feltételezése alapján többen abba az irányba indultak el, hogy a Szt. Polyeuctus mintaként szolgálhatott Iustinianus számára a Hagia Sophia építésekor. A történetnek azonban szempontunkból más érdekessége van.

Tours-i Gergely meséli el az idős Anicia Iuliana és a hatalomra kerülő Iustinianus (intellegens imperatoris) kapcsolatát, amire így 527. augusztusa után, esetleg 1-2 évvel később kerülhetett sor, amit a felépítményhez készítette téglák datálása, illetve a az alábbi történet is alátámaszt. Gergely szerint egy napon, amikor Iustinianus már sokadjára hallotta az Anicia Iuliana gazdagságáról szóló beszámolókat, palotájából az asszony villájához sietett. A császár terve az volt, hogy pénzt kérjen tőle az állam céljaira, indoklásként pedig azt adta elö, hogy a barbárok békéltetése (gentes nobis placamus) hatalmas összegeket emészt fel, ráadásul a kincstár is kong az

\footnotetext{
1032 1Móz. 28:10-22, 35:9.

1033 EZ. 9.3-5, 10.4-5, 11.23.

1034 BARDILL 2006, 342.

1035 HARRISON 1989. A Szt. Polyeuctus feltárásai munkálatai az 1960-as évek második felében kezdődtek az isztambuli Saraçhane negyedben Harrison és Fairath régészek vezetésével.

1036 GREG. TUR. GLOR. MART. 102.

1037 HARRISON 1989, 137-39.

1038 MANGO-ŠEVČENKO 1961, 245.

1039 BARDILL 2006, 346-48.
} 
ürességtől. Iustinianus arra kérte Anicia Iulianát, akinek az isteni méltóság ereje rendkívül sok aranyat adott, kölcsönözne neki egy jelentékenyebb összeget a következő adóbegyüjtésig. A császár szerint a jótékony segítségét egész Konstantinápolyban megénekelnék. A történet szerint Iuliana ekkor azt mondta a császárnak, hogy nagyon csekély bevétellel rendelkezik, ezért várnia kell, amíg begyüjti járandóságait, de amint azzal meglesz, értesíteni fogja. A császár boldogan vonult vissza a palotába és már-már azt gondolta, hogy Anicia Iuliana vagyona a kincstárában van. A császár talán még vissza sem ért a palotába, amikor Iuliana mestereket hívott és utasításba adta nekik, hogy aranyát előbb olvasszák be, majd azzal díszítsék a Szt. Polyeuctus mennyezetét, így akarta ugyanis elkerülni, hogy a kapzsi császár akár a kezével is megérinthesse azt. Mikor a kézművesek végeztek feladatukkal, Theodosius dédunokája üzent a császárnak, hogy összegyült a pénz, jöjjön csak, nézze meg a saját szemével. A hír hallatára Iustinianus rögtön elindult, annak tudatában, hogy már elhozhatja az aranyat. Iuliana már várta, és a templomba invitálta imádságra. A császár betámogatta (adprehensam imperator manum mulieris) az idős asszonyt a templom belsejébe. Ekkor az asszony kérte, hogy a császár tekintsen fel és értékelje szegénységét (paupertas mea) és tegyen azt, amit csak jónak lát, nem fog ellenállni. Iustinianust lenyügözték a látottak, és szégyenében serényen dicsérni kezdte a mennyezetet, és már menni készült, amikor Anicia Iuliana lehúzta az egyik gyürüjét, és a kezébe rejtve a császár felé nyújtotta, arra kérve, hogy fogadja el tőle ezt az apróságot. A gyürüben azonban egy nagyobb ékkő (lapis Neronianus mirae) volt, zöldjében pedig ismét megcsillant a mennyezetbe olvasztott arany. A császár köszönetet mondott, dicsérte az asszonyt, majd visszavonult palotájába.

Tours-i Szent Gergely leírásában az Aniciánál pénzért esdeklő császár képe Anastasius adóreformjának tükrében igencsak valószíntütlen. Anastasius halálakor ugyanis 3200 kenténarion (105 $280 \mathrm{~kg}$ ) arany nyomta a kincstárat. ${ }^{1040}$ Ebböl az összegből csaknem harmincszor újra lehetett volna kötni a perzsákkal az 532-es ún. "örökös” békét. ${ }^{1041}$ A császár elsősorban nem az asszony gazdagságára irigykedhetett, hiszen a gyürü legalább annyit ért, mint a beolvasztott arany. Gergely szerint ugyanis a gyürüben Nero köve volt, ami a nevét id. Plinius leírása után kapta, aki megemlékezett arról, hogy Nero a Colosseumban egy smaragdon át nézett egy gladiátorviadalt. ${ }^{1042}$ Ahogyan az első századi császárnál a zöld smaragdban tükröződtek az egymásnak feszülő

$\overline{1040}$ PROCOP. ARC. 19.7. Anastasius gazdálkodásáról lásd HAARER 2006, 184-185, 190-192, 197-202. Ugyan Prokopios szerint is eltékozolta Iustinianus az Anastasius által összegyüjtött aranyat, de erre a látogatásra a császár és Anicia Iuliana között még az 520-as évek elején sor kerülhetett.

1041 PROCOP. DE BELLIS. 1.22.3. Az 532-es béke is csak 110 kenténarionba került.

1042 PLIN. HN. 37.26.63-65.: "Nero princeps gladiatorum pugnas spectabat in smaragdo" vö. GREG. TUR. GLOR. MART. 102.: "Erat enim in eo lapis Neronianus mirae viriditatis ac splendoris; qui cum fuisset ostensus, omne aurum quasi in viriditate visum est convertisse a pulchritudine gemmae. 
gladiátorok, éppen úgy láthatta magát Iustinianus is, ahogyan Anicia Iuliana kezét tartva a smaragdban visszatükröződik. ${ }^{1043}$

A császár tehát, a történet értelmében nem az asszony pénzére vágyott, hanem származására és legföképpen dinasztiájára. Ezt támasztja alá a 6. század elején keletkezett Baalbek orákulum, ami egyúttal a Szt. Polyeuctus Salamon imitációjára is magyarázatot nyújt. A jövendölés szerint Anastasius után elérkezik a világvége. A nappalok egyre csak rövidülnek, lassan erőszak, kapzsiság és barbárság lesz úrrá az embereken, megjelenik a négy eszkatologikus király, őket a Kelet királya követi, az Antikrisztus aki - Palesztinát is beleértve - helyreállítja a keleti területek egységét. A király nevét is megemlíti a jövendölés, bár romlott alakban maradt fenn. A három különböző kézirat eltérő neveken: Hiolbos, Olibos, vagy Ioulibos néven említi kelet királyát, ami lehet mitológiai, de akár történelmi személy is. A 19. század végén 20. század elején ezt a nevet kapcsolták össze az Olybrius olvasattal, így Seeck már a 472. év császárát, vagy azonos nevü unokáját látta benne. ${ }^{1044}$ A Baalbek orákulum tehát Iuliana fiát, Anicius Olybriust (cos. 491), vagy azonos nevet viselő unokáját (cos. 526) jövendölte Anastasius után a következő uralkodónak, aki helyreállítja az elszakított területek egységét. Elmondhatjuk tehát, hogy az Aniciusok a 6. század elején a birodalom integritásának szimbólumaivá váltak. ${ }^{1045}$ Iustinianus azonban nem csak Anicia Iulianára irigykedhetett, hanem Anastasius unokaöccseire is, vagy legalábbis valamelyikükre. Anastasius három unokaöccsével ugyanaz lehetett a problémája Iustinianusnak, mint ami Anicia Iuliana családjával: a vér. Azonban míg Anicia Iuliana és utódai leszármazásukat egészen a Theodosiusig vissza tudták vezetni, addig Anastasius unokaöccsei - legalábbis a szakirodalom tükrében - nem rendelkeztek ilyen adottságokkal. Iustinianus valamiért mégsem száműzte őket. Úgy gondolom, hogy az általános vélekedéssel ellentétes képet jelenít meg Evagrios, aki szerint Anastasius családjának valamennyi tagja úgy házasodott, hogy minél nagyobb hatalomra és gazdagságra tegyenek szert, ${ }^{1046}$ márpedig, ahogyan az előző oldalakból nyilvánvalóvá vált, a leggazdagabbnak az Anicius számítottak Konstantinápolyban, így feltételezhető, hogy házassági kapcsolatban álltak egymással. Ezek a kapcsolatok a Nika-felkelés során válnak kitapinthatóvá.

1043 Ez. 28:13 vö. JEL. 4:3.: A Jelenések könyvében, akárcsak Ezékielnél az alaktalan Isten széke körül megjelenő szivárvány smaragdzöld színt vesz fel.

1044 RE 2196-2208, “Anicius.”

1045 AlEXANDER 1967, 137, 158-159, RE 2196-2208, “Anicius.”, Mivel az orákulum Anastasius uralkodásának második felével kapcsolatban pontatlan információkat tartalmaz, azért a kutatás úgy tartja, hogy 502 és 506. között keletkezhetett. Alexander ugyanakkor bevonná a névvel kapcsolatos lehetséges azonosítások közé a Priskosnál és Ióannés Antiocheusnál található Oullibost, akit Anthemius és I. Leo uralkodása alatt megöltek Thraciában.

1046 EVAGR. HE. 4.1. 


\subsection{A Nika-felkelés}

532. január 10-én, egy szombati napon a császár ellen irányuló általános elégedetlenség az egyre nyomasztóbbá váló adóterhek és vagyonelkobzások miatt végül a Nika-felkelésben öltött testet, ami a kortárs beszámolók szerint másfél hétre anarchiába taszította a várost. A felkelésről készült legutóbbi elemzésben Geoffrey Greatrex arra jutott, hogy Iustinianus elődeihez képest egyáltalán nem következetesen járt el, bizonytalansága végül 35000 ember halálát okozta. ${ }^{1047}$

Malalas szerint a felkelés gyújtópontját az jelentette, hogy Eudaemon ${ }^{1048}$ városi praefectus őrizetbe vett néhány bajkeverőt a cirkuszi pártok tagjai közül. Január 10-én, egy szombati napon zajlott a gyanúsítottak tárgyalása. Gyorsan döntés született, Eudaemon hét személyt bünösnek talált és elrendelte kivégzésüket. A halálraítéltek közül kettő, egy zöld párti és egy kék párti személy túlélte a kivégzést, mert a rögtönzötten felállított installáció összeomlott. A túlélőket a kivégzés helyszínéhez közeli Szt. Konon monostor szerzetesei mentették meg, majd levitték őket az öbölbe és csónakon a Szt. Laurentiusba küldték, hogy ott leljenek menedékre. A templomot Marcellinus szerint még Eudocia kezdte építeni, de halála miatt befejezése Pulcheria császárnőre maradt. A templom nagy becsben volt a városban, hiszen mint láthattuk itt helyezték el Szent István protomártír ereklyéit. ${ }^{1049}$ Eudaemon, mit sem törődve az egyház vagy védnökének patrociniumával, katonákat küldött a szökevények elfogására. ${ }^{1050}$ Mindez ugyanakkor azt is jelentette, hogy közvetlenül egy Anicius dominiumot sértett meg. A tüntetés is ezt követően erősödött fel.

Az elégedetlenség a levegőben volt. Kedden, három nappal Eudaemon hajtóvadászata után kocsiversenyt rendeztek a Hippodromban. Mindkét párt tagjai arra kérték a császárt, hogy tanúsítson kegyelmet az elítéltekkel szemben. Egészen a huszonkettedik versenyig kántálták kérésüket, de nem kaptak választ a császártól. Ezt követően vette kezdetét a “Hosszú életet az

1047 GREATREX 1997. A Nika-felkelésről a legutóbbi részletes összefoglalót Geoffrey Greatrex készítette. Szintetizáló írásában kimutatta, hogy a Nika-lázadás tipikus és atipikus jegyeket hordozott magán, mivel a korábbi felkelésekhez viszonyítva rutinszerüen kezdődött: Tisztségviselők elbocsátása, elítéltek szabadon bocsátása, még az első rajtaütés a Hippodromban is a korábbi sémáknak megfelelően történt. Ami viszont szokatlan volt, az a féktelen öldöklés. A tömeg és az uralkodó majd minden tettére léteznek precedensek a múltból, még a lázadás hossza és tettei is szokványosnak mondhatók. Greatrex kimutatta, hogy a lázadás eseményeinek láncolata egyedi és véletlenszerü volt: Iustinianus állandóan különböző jeleket adott a lakosságnak: az egyik pillanatban engedékenynek tünt, egy másikban pedig már rendíthetetlennek. Ezért a lázadók számára úgy tünt, hogy a kezdeti nemből könnyen lehet igen, és ez folytatódott hosszú időn keresztül, de miután a lázadók megtagadták az utolsó békéltetési kísérletet a császár már nem bírta tovább tolerálni a helyzetet. Hasonló véleményen van: CAMERON 1976A, 280, CAMERON 1978, 264. A Nika-felkelés eseménytörténetének részletes tárgyaláshoz lásd GREATREX 1997, 81.

1048 PLRE3A 455, "Eudaemon 1".

1049 MARC. COM. 439.2, 453.2.

1050 JOH. MAL. $18.71(474)$ 
irgalmas kékeknek és zöldeknek" rigmusa. A kocsiversenyt követöen a kékek és a zöldek szövetkeztek egymással és a praefectusi hivatalhoz vonultak, hogy ott kérjék az elítéltek szabadon bocsátását. Ekkor adták szájról szájra egymás kötött a Nika (Győzz!) jelszót annak érdekében, hogy megakadályozzák a a titkos ügynökök beszivárgását soraik közé. Mivel a praefectusi hivatalnál sem kaptak választ, betörtek az épületbe, kiszabadították a foglyokat, majd felgyújtották az épületet, a hivatalnokokat pedig leöldösték. A zavargások egész este tartottak, a felkelők szinte a teljes várost lángba borították. Az éjszaka folyamán a tüz martalékává lett a Hagia Sophia székesegyház, a Zeuxippos-fürdő és a császári palota egy része, valamint a Constiantinus-forum mentén húzódó árkádsor. A császár és a senatus néhány tagja a palotába zárkózott. ${ }^{1051}$

Szerdára virradóan Iustinianus utasításba adta, hogy a versenyeket folytatni kell, de a pártok tagjai a verseny elkezdésének pillanatában tüzet gyújtottak a Hippodrom különböző szintjein. A császár utasítására Mundo, Constantiolus és Basilides is kivonult és megpróbálta jobb belátásra bírni a zavargókat, hiába. Prokopios szerint, amíg csak egymással voltak elfoglalva a pártok, ügyet sem vetettek Ioannes ${ }^{1052}$ praefectus praetorio és Tribonianus ${ }^{1053}$ államellenes tevékenységére, de miután kiegyeztek, azonnal rájöttek, hogy ők a felelösek minden bajért. ${ }^{1054}$ Városszerte nyíltan szidalmazták őket, valamint Eudaemon városi praefectust, és a legszívesebben maguk végeztek volna velük. Iustinianus annak érdekében, hogy kifogja szelet a lázadók vitorlájából, menesztette őket, és Phocast tette meg az udvar eparchosává. ${ }^{1055}$ Phocas az igazságszolgáltatás helyreállítása érdekében elrendelte, hogy a quaestori tisztséget Basileides patricius viselje. Ezt követően Belisarius kivonult egy csapat góttal, akik tisztázatlan okból harcba bonyolódtak a lázadókkal. A feldühödött tömeg erre városszerte válogatás nélkül gyújtogatni és gyilkolni kezdett. ${ }^{1056}$

1051 JOH. MAL. 18.71 (474), Procop. DE BELlis. 1.24.7-10.

1052 PLRE3B 627-635, "Fl. Ioannes 11".

1053 PLRE3B 1335-1339, "Tribonianus 1".

1054 Ioannes és Tribonianus jelleméröl: PROCOP. DE BELLIS. 1.24.11-16.

1055 Prokopios csak Ioannes és Tribonianus menesztéséről számol be, Malalas szerint viszont ekkor váltották le Eudaemont is.

1056 Joh. MAL. 18.71 (474), Procop. De Bellis. 1.24.17-18. 


\subsubsection{2. január 15: "A felkelők éljenzik Probust"}

A lázadás következő napján a tüntetők éljenezték Probust és a házához vonultak, hogy császárrá tegyék, legalábbis a kutatói rekonstrukciók szerint, amelyek Theophanés és a Chronicon Paschale beszámolójára építenek. ${ }^{1057}$ A kortársak azonban nem tesznek említést az eseményről, talán okkal.

Theophanés, aki minden bizonnyal a Chronicon Paschale vonatkozó passzusát dolgozta át, ${ }^{1058}$ összefüggésbe hozza Probus személyét a Nika-felkeléssel. A 8. századi auktor szerint a felkelők egy csoportja a házához sietett azért, hogy császárrá tegye Probust. A lázadók terve azonban kútba esett, mert Anastasius unokaöccsét nem találták a villában. Csalódottságuknak azzal adtak hangot, hogy felégették a senator házát. ${ }^{1059}$ A Nika-felkelés ezen jelenete csak a későbbi történetírónál fordul elő. Az eseménysor ugyanakkor erős párhuzamot mutat az 512-es Anastasiusellenes felkeléssel, mikor is a tüntető tömeg Areobindus (cos. 506) házához vonult azzal a céllal, hogy császárra tegyék a férfit. Az eseménysor tökéletesen megegyezik a Nika-felkelés alatti leírtakkal. A tüntetők nem találták otthon a magister militumot, ezért inkább felgyújtották az épületet. ${ }^{1060}$

Az 512-es esemény Theophanésnál is megjelenik, ${ }^{1061}$ ám nála a tömeg nem Areobindust, hanem - tisztség-tisztség alapon - Vitalianus ${ }^{1062}$ magister militumot akarta császárrá tenni. Az utóbbi magister militum azonban csak egy évvel később, 513-ban lázadt fel Anastasius ellen, Theophanés tehát összemossa a két eseményt. Vitalianus felkelésének zászlajára a chalcedoni dogma védelmét tüzte ki. ${ }^{1063}$ A 451-es rendelkezések melletti elkötelezettsége a későbbiekben is megmutatkozott, ugyanis tevékeny szerepet játszott az Akakios-féle skizma lezárásában is. A keletrómai auktor leírásával elsősorban ezt társítja az épülethez.

Areobindus, Vitalianus és Probus között szemmel láthatóan nincs közös vonás. A 4. fejezetben láthattuk, hogy Theophanés a Ioannes nevü római trónbitorlót is összekötötte az azonos nevü vandál magister militummal, így feltételezhető, hogy ebben az esetben is hasonlóképpen járhatott el. Világos, hogy a történet Marcellinus comes 512-re vonatkozó leírásából táplálkozik. Theophanés követi Marcellinust, amikor ö is egy magister militummal helyettesíti be Areobindust, Probusra azonban ez a párhuzam nem alkalmazható, mert Anastasius unokaöccse csak consul volt.

\footnotetext{
1057 Chron. Pasch. 622, Theoph. AM. 6024. Greatrex 1997, Heather 2014, 131-143, Potter 2015, 150.

1058 MANGO 1997, 281.

1059 Chron. PASCH. 622, TheOPH. AM. 6024

1060 MARC. COM. 512, JOH. MAL. 16.19 (407).

1061 THEOPH. AM. 6005.

1062 PLRE2 1171-1176, "Fl. Vitalianus 2".

1063 MARC. COM. 514.
} 
512-ben egyébiránt azért robbant ki felkelés a császár ellen, mert Anastasius idős korára egyre inkább kezdett szembehelyezkedni a 451-es chalcedoni zsinat rendelkezéseivel. Konstantinápoly lakosságának elégedetlensége akkor érte el a kritikus pontot, amikor 512 novemberében a Hagia Sophia székesegyházban felcsendült a theopaszkhita Háromszorszent liturgikus éneke. ${ }^{1064}$ A császárellenes tüntetők több konstantinápolyi épületet is felgyújtottak. Evagrios szerint ezek között volt egy szíriai szerzetes, bizonyos Marinus háza is, akinek ráadásul a tömeg a fejét is lecsapta. A kegyetlen gyilkosság oka, hogy a szerzetes az ének bevezetését szorgalmazó Severus legföbb támogatója volt. ${ }^{1065}$

Nem valószínü, hogy az 512-es tömeg vallási támogatás miatt vonult volna a magister militumhoz. Minden bizonnyal nem a magister militum tekintélye vonzotta őket az épülethez, hanem felesége, Anicia Iuliana. ${ }^{1066} \mathrm{Az}$ asszony legalább olyan aktívan szerepet vállalt az Akakiosféle skizma rendezésében, mint Vitalianus. A Collectio Avellana tanulsága szerint 519-ben Hormisdas pápa kérésére több ízben segítette a Konstantinápolyba érkező pápai követeket. ${ }^{1067} \mathrm{~A}$ kései források minden bizonnyal nem csak a neve miatt kapcsolták össze Anastasius unokaöccsének, Probusnak a személyét az épülettel, hiszen Anicia Iuliana - forrásokban legtöbbet említett - ősét is (cos. 371) ugyanígy hívták. A fejezet elején idézett forrás, amely Anastasius utódlásának sikertelenségét igyekezett magyarázni valójában a Nika-felkelés alatti összefonódásokra utalhat. Ugyan a forrás nem nevezi meg, hogy melyik fiú melyik ágyba feküdt, annyit azonban elárul, hogy ketten egy ágyba, míg Anastasius harmadik unokaöccse egyedül egy másik ágyon tért nyugovóra. Probus egy másik család sarja volt, bár azonosítása kétséges, neve alapján feltétezhető egy Anicius szál.

Prokopios szerint a lázadás nem akart veszíteni az erejéből, és a zendülést kezdetétől számító ötödik napon ${ }^{1068}$ Iustinianus gyanakodni kezdett Hypatiusra és Pompeiusra, hogy

1064 MEYENDORFF 2001, 261, 268. A Henotikon szövege óvatosan bár, de megtartotta Cyrill Krisztus egységéről vallott tanítását a theopaszkhizmussal együtt: “azt állítjuk, hogy a csodák és a szenvedés ugyanazé az Egyé." Valamivel később Konstantinápolyban az Anastasius császár pártfogását élvező Antiochiai Severus azon fáradozott, hogy theopaszkhita Háromszorszent ("Szent Isten, Szent Erős, Szent Halhatatlan, aki miérettünk keresztre feszítettél, irgalmazz nekünk”) az ún. Triszágion liturgikus ének bevezetésre kerüljön, ami végül 512-ben teljesült is. A Henotikon zavargásoknak végül Anastasius jámbor fellépése vetett véget. A Hippodromba vonulva szerény öltözetben felajánlotta lemondását. A császár alázatossága megnyugtatta a lázongó városiakat és a császár még bő fél évtizedig, halála napjáig hatalmon maradhatott.

1065 Evagr. HE. 3.43-44., MARC. COM. 512.4. Marcellinus comes tudni véli, hogy egy másik ember, bizonyos Plato házát is felgyújtotta a tömeg, erről azonban csak ő tesz említést.

1066 I. NIKIU. CHRON. 89.65, Theophanésszal szemben a 7. századi egyiptomi szerzetes, Ióannés Nikiu már biztos is benne, hogy Anicia Iuliana miatt mentek a házhoz.

1067 COLL. AVELL. 164; 179; 198.

1068 Prokopios ebben az esetben említ először időhatározót. Bár nem a vasárnapi kivégzéstől kezdi a Nikafelkelés mesélését, érdekes egybeesés, hogy ha origónak a vasárnapot tekintjük, akkor Anastasius 
merényletet terveznek ellene, ezért arra utasította őket, hogy a lehető leghamarabb hagyják el a palotát. Anastasius unokaöccsei vonakodtak, amitől a császár csak még inkább gyanút fogott és eltávolította őket az udvarból. Hypatius és Pompeius este tértek haza. ${ }^{1069}$ Másnap reggel híre ment a városban, hogy egyikük sincs már a palotában. A tömeg Hypatiushoz ment, hogy a fórumra vigyék és császárrá tehessék, de felesége, Maria belekapaszkodott férjébe és próbálta visszatartani, hiába. A tömeg a Constantinus fórumra ment Anastasius unokaöccsével, ahol jobb híján egy aranyláncot tettek a fejére korona vagy diadém gyanánt. Néhányan ugyan a palotában maradtak, de a senatus már gyülekezett az újonnan megválasztott uralkodó miatt. ${ }^{1070}$

\subsubsection{A senatusi ülés: Origenes beszéde}

A senatorok ezúttal nem a palota melletti üléstermükben sereglettek össze, hanem a város 6 . kerületében, a Constantinus fórum északi oldalán. ${ }^{1071}$ A Synklétos épületében egy Origenes nevü senator intézett beszédet társaihoz, melyben az események mérlegelésére szólította fel a képviselőket:

„Rómaiak, ezt a helyzetet csak háborúval lehet megoldani. A közvélemény azt tartja, hogy valamennyi emberi dolog közül a háború és a császári hatalom a legfontosabb. [...] a lenézett hatalom szerte szokott foszlani, amint ereje napról napra csökken. Mármost, vannak nekünk más császári palotáink is: a Plakillianai, meg az ún. Helené palotája. Onnan kiindulva kell ennek a mi császárunknak a háborút végigharcolnia, s a többi ügyeket is úgy intéznie, hogy jóra forduljanak." ${ }^{1072}$

Ennyit mondott Origenes. Társai azonban, legfőképpen Hypatius unszolására gyors és kíméletlen megoldást javasoltak. Az ülésteremben zajló jelenet középpontjába Prokopios egyetlen eseményt helyez: A senator beszédét, akinek legföbb célja a közös ellenség, Iustinianus eltávolítása. Kaldellis világított rá, hogy a senator beszéde emlékeztet egy korábbi, a Háborúkban elbeszélt eseménye, amikor a perzsa előkelök összegyülnek annak érdekében, hogy döntsenek uralkodójuk, Kavād eltávolításáról és megválasszák helyette nagybátyját Blasest. A két ülés számos

unokaöccseinek különböző említései egy napra esnek.

1069 Procop. De Bellis. 1.24.19-21.

1070 PROCOP. DE BELLIS. 1.24.23, 25.

1071 Két senatusi épület volt a városban. Az egyiket Nagy Constantinus építette még a város alapításakor, Iustinianus pedig helyreállította. Ez az Augustaion keleti oldalán kapott helyet közel a palotához. A másik épület a Constantinus forumának északi oldalán kapott helyet. ProCOP. DE BELLIS. 1.24.23, 25. Mivel Prokopios azt írja, hogy Hypatiusszal Constantinus fórumára mentek ezért valószínúleg a senatus is itt ült össze.

1072 Procop. De BelLis. 1.24.30. 
hasonlóságot mutat, így mindkettő Prokopios eszköze arra, hogy dramatizálja a Nika-felkelés alatt történő eseményeket. Mindkét esemény központi szereplöje egy-egy szónok, aki megosztja tanácsait az egybegyültekkel: a perzsáknál Gousanastades, a rómaiaknál pedig Origenes. A perzsák esetében Gousanastades azt javasolja, hogy addig öljék meg a zsarnokot, amíg lehetőségük van rá. A perzsák úgy döntenek, hogy egy olyan emberrel fordulnak szembe, akinek az ereiben királyi vér folyik. A szónokok tanácsát mindkét esetben követik, és éppen ez vezet a romlásba. ${ }^{1073}$

A senator minden bizonnyal fiktív felszólalása és a köré szövődő személyek és helyszínek különös jelentőséggel bírnak. A perzsa eseményekkel párhuzamosan a senatusi ülésteremben zajló esemény központi kérdése a jogos uralkodó kiléte és a királyi vér. A beszámoló azonban két olyan utalást is tartalmaz, amely felett elsiklott a kutatás. Az egyik Origenes személye, a másik pedig a senator által említett két palota. Előbbi a politikai helyzetre történő indirekt utalás, utóbbi pedig az utódlás szimbolikája.

Prokopios már a Rómába induló egyházi követségek kapcsán kikelt magából, amikor kénytelen volt szóba hozni a "Isten természetéről" szóló vitát, ${ }^{1074}$ praktikusabbnak gondolta hát megszemélyesíteni. ${ }^{1075}$ Prokopios minden bizonnyal az ókeresztény íróra utal, aki a 4. század végéig müködő alexandriai iskola teológusa volt. ${ }^{1076}$

Órigenés a keresztény dogmatika rendszerezését adta a Peri arkhón c. munkájában. Latin nyelvü átültetésére Tyrannius Rufinus (345-410) vállalkozott De principiis címmel, de pontatlanságai és a körülötte kialakuló viták véget vetetettek Jeromossal kötött évtizedes barátságának. A munka a gnoszticizmus és a neoplatonizmus nézeteit mentette át a keresztény tanokba. A Iustinianus-korabeli gondolkodás szemszögéből Krisztus természetének megítélése kiemelt jelentőségü volt, hiszen a Római Birodalom születése pillanatában rendkívüli kapcsolatba került vele. Krisztus első eljövetele Octavianus uralkodása alatt történt az egységes birodalom

1073 PROCOP. DE Bellis. 1.5.1-8, KALDELlis 2004, 124-125. Kavād fogsága tükröződik Iustinianusnak és udvarának önkéntes palotabeli száműzetésében is. Az igazság pillanata akkor érkezik el, amikor Kavād megszökik a börtönből és lemészárolja ellenségeit. Iustinianus pedig - Theodora tanácsa miatt felülkerekedik pillanatnyi gyengeségén és ugyancsak lemészárolja ellenségeit.

1074 Procop. De Bellis. 5.3.6., Procop. ARC. 18.29. Prokopios következetesen "Isten természetét említi, a Krisztus természetéről szóló vitát. 532-ben Órigenés megszemélyesítése minden bizonnyal Szent Sabbas konstantinápolyi látogatásával volt kapcsolatban. A Szent 530-532. közötti látogatásának oka ugyanis éppen a kolostorában kitört órigenista lázadás volt. Iustinianus és Órigenés viszonyára lásd BAÁN 1997, 41-61.

1075 A prosopográfiák és a kortárs források nem tesztnek említést Origenes nevű senatorról. A név kizárólag Prokopiosnál bukkan fel. GREATREX 1997, 75, 80, PLRE3B 957, “Origenes”. Greatrex a szöveghely kapcsán arra jutott, hogy Origenes más forrásban nem lelhető fel, így minden bizonnyal marginális szereplö. A PLRE azonban éppen Prokopios említése miatt valós személyt lát benne.

1076 Jeromos maga is aktív kapcsolatban volt az iskolával, illetve rajta keresztül Orosius is. Saját beszámolója szerint ugyanis Orosius 415-ben felkereste Jeromost Betlehemben, ahonnan bizalmas információkkal tért vissza, valamint Szent Ágoston leveleivel és a vértanú Szent István relikviáival. 
területén fekvő Palesztina területén és ugyancsak a birodalom határain belül érte a halál. Ebből kifolyólag már a Római Birodalom első császárára megkülönböztetett szerep hárult a kereszténység gondviselöjeként. ${ }^{1077}$

A platóni alapokra építkező Órigenés viszont úgy gondolta, hogy a test csupán az anyagtalan szellem ideiglenes tárolója. A test halála utána lélek életben marad, de ez visszafelé is igaz, vagyis a lélek a test előtt is létezik. Órigenés szerint volt olyan kor, amikor még nem volt testünk, tiszta szellemként éltünk egységben az Istennel. Ebből következik, hogy az örökkévalóságot megelözte egy másik valóság, amelyben a teremtés történt, ezért minden lélek elemi közösségben él a teremtővel, tehát a lélek hamarabb jött létre, mint ahogy az egyes lelkek testet ölthettek volna az anyagi világban, beleértve Krisztust is, noha ő volt az egyetlen, aki botlásoktól mentes, ezért benne a tökéletes emberség lakozik. Mivel a lelkek világa kezdetektől való, és a lelkek az isteni lényegben egyesülnek, ezért a végítélet után a lelkek visszanyerik eredeti állapotukat Istenben, az örök kárhozat így semmissé lesz. Krisztus második eljövetele során, minden ember szellemi testben támad fel. ${ }^{1078}$ Órigenés nézetrendszerében a világ teremtése folyamatos. A jelenlegi világ előtt is léteztek világok és ezt követően is lesznek újabbak. ${ }^{1079}$ A korábban létező lelkek gondolata erősen kapcsolódik az apokalipszis gondolatához és az ehhez kapcsolódó irodalmi mủfajokhoz vagy éppen a csillagjósláshoz, jövendöléshez, ${ }^{1080}$ amit Prokopios elöszeretettel társít a senatushoz. ${ }^{1081}$

A konstantinápolyi udvarnak még jó tíz évre volt szüksége ahhoz, hogy gátat szabjon az órigenizmusnak. Menas pátriárka csak 543-ban adta ki azt az értekezését, melyben elítélte Órigenést és követőit, ${ }^{1082}$ a konstantinápolyi zsinat pedig hosszú listában részletezte az órigenizmus téveszméit, ${ }^{1083}$ ami gyökeres szakítást jelentett az ókori vallási és filozófiai hagyománnyal. Órigenés megszemélyesítésével Prokopios rámutat, hogy a Nika-felkelés idején nem csak az órigenizmus nézetei körül folytak viták, hanem a Platón tanai körül is. A Synklétos senatorai,

${ }_{1077}$ Ez a kép Caesareai Eusebios (265 k.-339) nyomán terjedt el. Lásd még MACGILLIVRAY 2008.

${ }^{1078}$ DE PRINC. 1.6.1

1079 DE PRINC. 3.5.3.

${ }^{1080}$ A jelen látható világot egy másik elözte meg. A preexisztens emberi lelkek olyan szellemi létezők, akik elestek Istentől az előző világban, és ezért most anyagi testhez vannak kötve. A léleknek az előző világban elkövetett bünei magyarázzák Istennek kegyelmének különböző mértékét, melyet itt a földön mindenkire külön-külön kiterjeszt. Órigenés tanítása szerint Isten a lelket a szellemi szabadság miatt teremtette, a bün miatt azonban a test fogságában nevelődési és tisztulási folyamatra ítélte. Ez a nézet a bün jelenségének tekinti az emberi élet egyszeri és megismételhetetlen voltát.

${ }^{1081}$ Lásd. ProCop. De BeLlis. 5.7.6, 5.14.3, 5.24.28.

${ }^{1082}$ MEYENDORFF 2001, 303, 306. Menas javaslata alapján 10 anatémában kell elítélni őket, ezek között volt a lelkek korai létezésének tanítása is, amely szerint Krisztus az Istenszülőtől csak a testét kapta.

${ }^{1083}$ Meyendorff szerint Órigenés zsenialitása abban rejlett, hogy érthetően fogalmazta meg a bibliai hét lényeges elemeit a neoplatonikus műveltségủ értelmiségiek számára. 
akárcsak egykor Rómában a közjót képviselik. ${ }^{1084}$

\subsubsection{A két palota}

Origenes senator szerint a közjót pedig nem Iustinianus, hanem két másik császári palota képviseli:

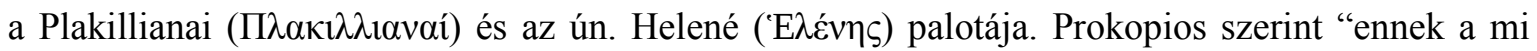
császárunknak" ezek valamelyikéből kell kiindulnia, és végigharcolnia a háborút úgy, hogy minden más dolog is jóra forduljon. ${ }^{1085}$ Origenes nem nevezi meg az uralkodót, ugyanakkor a kifejezés is arra utal, hogy nem feltétlenül Hypatiusról van szó. A senator általánosságban mondja, hogy a mi császárunk, tehát olyan császár, aki a senatus, az arisztokrácia érdekét képviseli.

A két épület közül csak a Plakillianai bukkan fel a forrásokban, ráadásul eltérő névalakokban, melyek közül talán a legbeszédesebb a Flaccillianae, ami véleményem szerint Nagy Theodosius császár első feleségére és szerelmére, Aelia Flaccillára utal. A Chronicon Paschale tudni véli, hogy a torquest, ami Prokopiosnál aranyláncként szerepel a tüntető tömeg éppen ebböl a palotából hozta és helyezte Hypatius fejére. ${ }^{1086}$ A Helenát nem említik a források, feltételezések szerint azonban Constantinus anyjára, Helenára utalhat. ${ }^{1087}$

Nem feltétlenül kell Constantinus császár anyját látni a név mögött, közelebbi analógia is létezik. A Nika-felkelés után, a Iustinianust másodikként követő II. Tiberius (574-582) császár idején ismét felbukkan a Helena név. 578-ban a császár friss házasként egy kocsiversenyt tekintett meg a Hippodromban, ${ }^{1088}$ amelyről a szír származású Ephesosi Ióannés (507-588) emlékezett meg. A történetíró szerint a cirkuszi pártok képviselői képesek voltak olyan hevesen összevitatkozni az új császárné megszólításán, hogy a verseny végül lázadásba torkollott. Az összeütközéshez az vezetett, hogy a kékek Anastasiának, a zöldek pedig Helenának nevezték Tiberius feleségét. ${ }^{1089}$ A császárnőnek a születési neve azonban nem tartalmazta sem a Helenát, sem az Aeliát. A Feketetengeri Daphnusia szigetéről a származó császárnő ugyanis születésekor a Ino nevet kapta. ${ }^{1090}$

578-ban a kocsiverseny éppen Ino császárnővé válását ünnepelte, ekkor vette fel az Aelia Anastasia nevet. A császárnők neve elött álló Aelia még a 4. század végén, I. Theodosius uralkodása alatt vált az uralkodói nomenklatúra részévé. Az Aelia név Nagy Theodosius első feleségének, Aelia Flaccillának a nevében szerepelt. A császár második feleségének nevében nem

1084 Boeth. CONS. PHIL. 1.4.8-35.

1085 PROCOP. DE BELLIS. 1.24.30.

1086 Chron. PASCH. 624.10.

1087 Procop. De Bellis, 64, 150. lj.

1088 THEOPH. AM. 6071.

1089 JOH. EPH. HE. 3.9.182

1090 PLRE3A 60-61, “Aelia Anastasia (Ino) 2”. 
található meg, hiszen Valentinianus lánya volt, ellenben Arcadius és Honorius feleségének nevében már ismét felbukkan. Theodosius fiai minden bizonnyal anyjuk iránti tiszteletből vezették be a gyakorlatot, amit utánuk minden keleti uralkodó folytatott. Véleményem szerint tehát a név státuszjelzővé vált. A jelenség nem példa nélküli. Hadrianus (117-138), vagy ahogy Aurelius Victor nevezi, a görögöcske (graeculus), ${ }^{1091}$ trónra lépése előtt a P. Aelius nevet viselte. Hadrianus császárrá választását követően az égei városok arisztokratáinak nevében megjelenik a P. Aelius prefixum, Salway szerint az arisztokraták ezzel jelezték, hogy a császárt patronusuknak tartják. ${ }^{1092}$

A Theodosius-dinasztia bukásáig valamennyi császárnő viselte a nevet, de 455 után is megtalálható valamennyi keleti uralkodó feleségének nevében, sőt nyugaton is újra megjelenik egy pillanat erejéig Anthemius feleségével, aki ugyancsak keletről érkezett. Az Aelia megtalálható Leo, Zeno és Anastasius feleségeinek nevében, de még a trónbitorló Basiliscus is tiszteletben tartotta a praenoment, hiszen az szerepelt felesége, Aelia Zenonis nevében is. ${ }^{1093}$ Elmondható tehát, hogy Theodosius első feleségének praenomenje a későbbi császárnők nevében egyfajta státuszjelző szerepet vett fel, ami kifejezte a Theodosius-dinasztiához való erős kötődést. Az Aelia névelem használata több mint egy évszázadon keresztül töretlen volt, egészen Iustinus uralkodásáig. A császár szakított a gyakorlattal, így Euphemia császárné nevében már nincs jelen a praenomen. Az alacsony sorból származó Iustinus és felesége talán nem mérte fel kellőképpen hagyomány jelentőségét, vagy sokkal inkább saját dinasztiájának önállóságát igyekezett hangsúlyozni. ${ }^{1094}$ Ez utóbbi érhető tetten azon, hogy Lupicina a keresztségben az Euphemia nevet kapta, ami közvetlen utalást jelentett a 451-es Chalcedoni zsinatra. Euphemia példáját Theodora is követte, hiszen az ő nevében sem szerepel a praenomen. Érdekes módon Iustinianus halála után azonban a császárok visszatérnek a korábbi gyakorlathoz. II. Iustinus feleségének, Sophiának (530-601) az esetében az Aelia ismét a császárnők hivatalos névhasználatának részét képzi.

A 8. századra Ephesosi Ióannéshez képest már lényegesen szürt kép alakult ki a történetírók fejében az eseményekröl. Theophanés ezúttal előnyünkre alakította át a szöveget. A történetíró szerint a Hippodromban valóban skandáltak a kékek és a zöldek, de nem Helenát és nem is az Anastasiát. A történetíró szerint rigmusok kérdés formáját öltötték. Az új császárnő hivatalos nevére voltak kíváncsiak, Tiberius kérdésként adta meg a választ a pártoknak. A történetíró szerint azt kérdezte, hogy mi a neve annak a templomnak, ami a Dagistheus nyilvános fürdőkkel szemben

1091 AUR. VICT. CAES. 15.

1092 SALWAY 1994, 138. A Valerius és Flavius nevek is hasonló utat futottak be, lásd részletesebben Salway remek cikkét.

1093 PLRE2 1156, “Aelia Verina”, PLRE2 140-141, “Aelia Ariadne”, PLRE2 1203, “Aelia Zenonis”.

1094 PLRE2 423-24, "Lupicina quae et Euphemia 5". PROCOP. ARC. 6.17. Prokopios szerint Lupicina egy barbár származású szolga volt. 
helyezkedik el, mert a császárné ugyanazt a nevet viseli. ${ }^{1095}$ A pártok erre egyszerre kezdték skandálni az Anastasia nevet. Az esemény tehát megörződött, de már csak egy névvel. Mindenesetre a történetíró az ezt követő sorokban már a másik aspiráns - a korábbi augusta - Aelia Sophia csalódottságát tudatja, aki továbbra is augusta akart maradni. Az Ephesosi Ióannés és Theophanés elbeszélése közötti különbség megmutatja, hogy a pártoknak egyáltalán nem volt mellékes, hogy a császárnő milyen keresztény nevet vesz fel. Prokopios és a többi forrás összevetése azonban egy sokkal lényegesebb nézőpontra tereli a figyelmet.

Origenes senator Flaccillianae-ja az Aelián keresztül Theodosius-dinasztia kontinuitására tett világos utalás, ami kiviláglik abból is, hogy Ino Ephesosi Ióannésnál végül nem a Hel ena nevet, hanem az Augustát kapja, és nevében az Aelia is visszatér. A Helenát Ephesosi Ióannésnál a zöldek skandálják, ami korántsem mellékes, Theodora apja ugyanis éppen ennek a pártnak volt az állatgondozója. ${ }^{1096}$ Origenes Helenája tehát nem más, mint Theodora császárnőé. ${ }^{1097}$ A senator beszéde így a jelenleg regnáló hatalom és a Theodosius-dinasztia szellemi örökségét folytatni kívánók közötti szembenállást szimbolizálja.

Az a tény, hogy II. Tiberius uralkodása alatt kis híján lázadás tört ki a császárnő neve miatt, világosan mutatja a dolog jelentőségét. Iustinus és Iustinianus lábbal tiporta Theodosius emlékét, nem tisztelték sem a korábbi szokásokat, sem a törvényeket. A Háborúkban Prokopios egy szóval sem említi Helenaként Theodorát, hacsak nem Origenes beszédén keresztül utal rá, ami igencsak visszafogott eljárásnak tekinthető, hiszen férje kénytelen volt törvényt módosítani, hogy az asszony egyáltalán átléphesse a palota márványküszöbét, ${ }^{1098}$ mentségére szól, hogy ezt az engedékenységét a Titkos történetben bőven ellensúlyozza. Iustinianus Helenájával szemben Konstantinápoly lakossága és a senatus többsége viszont a Theodosius-dinasztia politikai örökségét kívánta folytatni mind tettekben, mind külsőségekben. 532 januárja mutatta meg Iustinianusnak elhibázott politikáját, minden, amit ez után tett, pálfordulásának részét képzi. A politikai fordulat még uralkodása alatt teljessé vált, amit mi sem bizonyít jobban, hogy Iustinianus után éppen Sophia, Theodora testvére veszi fel elsőként az Aelia praenoment.

\footnotetext{
1095 THEOPH. AM. 6071.

1096 PROCOP. ARC. 9.2.

1097 ACO 2.155; 156. Pulcheriát ugyancsak császárnőként a 451-es zsinaton egybegyült atyák több alkalommal Helenának nevezték. ACO 3.27. Az Akakios-féle skizma lezárásakor Iustinus feleségét, Euphemiát is új Helenaként ünnepelték.

1098 COD. IUST. 5.4.23.
} 


\subsection{4. "A megtorlás"}

Origenes beszéde alatt a palotában tanácskoztak, Theodora erélyes kiállása bátorságot ébresztettek még a tétovázókban is. A palota környezetében állomásozó katonák a kivárásra játszottak, ezért a Iustinianus minden bizodalma a nemrég megérkezett két hadvezérében volt: Mundóban és Belisariusban, akik mindketten nagyszámú fegyveres élén tértek vissza a városba. Eközben a tömeg a Hippodromba vonult Hypatiusszal, ahol a senator felment a császár szokott helyére, és leült az uralkodó számára kijelölt helyre. ${ }^{1099}$

Iustinianus utasítására mindkét hadvezér kivonult a palotából. Belisarius először egyenesen akart feljutni Hypatiushoz. A palota őrségét ellátó katonák azonban elhatározták, hogy egyik félnek sem segítenek, így Belisarius visszatért a palotába, és azt bizonygatta, hogy ügyük elveszett. Erre Iustinianus az ún. Chalkéhoz küldte, és a hadvezérnek így sikerült is eljutni a Hippodromba. Besliarius az elönytelen adottságok miatt úgy döntött, hogy inkább a lázadókra tör, semmint hogy katonáival egy szük átjáróba préselje magát, ahol könnyen levágnák öket. Kardját kivonva a népre tört, az emberek felismerték Belisarius embereit és futásnak eredtek, Mundo, amikor ezt meghallotta, hogy maga is betört a Hippodromba a Halottnak nevezett kapun keresztül. A lázadó tömeg így a két hadvezér katonái közé szorult, akik halomra ölték őket. Miután csaknem 30000 embert lemészároltak, Belisarius kirángatta Hypatiust Iustinianus székéböl és testvérével, Pompeiusszal együtt átadta a császárnak. ${ }^{1100}$

Malalas beszámolója szerint a palotában a földre borulva előadták, hogy azért mentek a Hippodromba, hogy oda tereljék össze a lázadókat. Iustinianus halálra ítélte öket, az ítéletet pedig másnap végre is hajtották. Hypatius és Pompeius testét a tengerbe dobták. Az Anonymus Valesianusnál egy ágyban alvó testvérek története minden bizonnyal erre az eseményre reflektált. Ezt követően Iustinianus kinyilvánította győzelmét a város és a lázadók felett és kötelezettségek vállalt a leégett épületek helyreállítására. ${ }^{1101}$

\footnotetext{
1099 JOH. MAL. 18.71 (475).

1100 JOH. MAL. 18.71 (476-477). Prokopios szerint a császár unokatestvérei fogták el Hypatiust és testvérét, ez azonban minden bizonnyal egy történetírói fogás, amelyben az egykori császár és a jelenlegi császár unokatestvérei feszülnek egymásnak, így keretezve a történetet.

1101 JOH. MAL. 18.71 (476-477), CLRE 533. Diadalát jelezte, hogy a következő évben ismét ő viselte a consuli címet.
} 


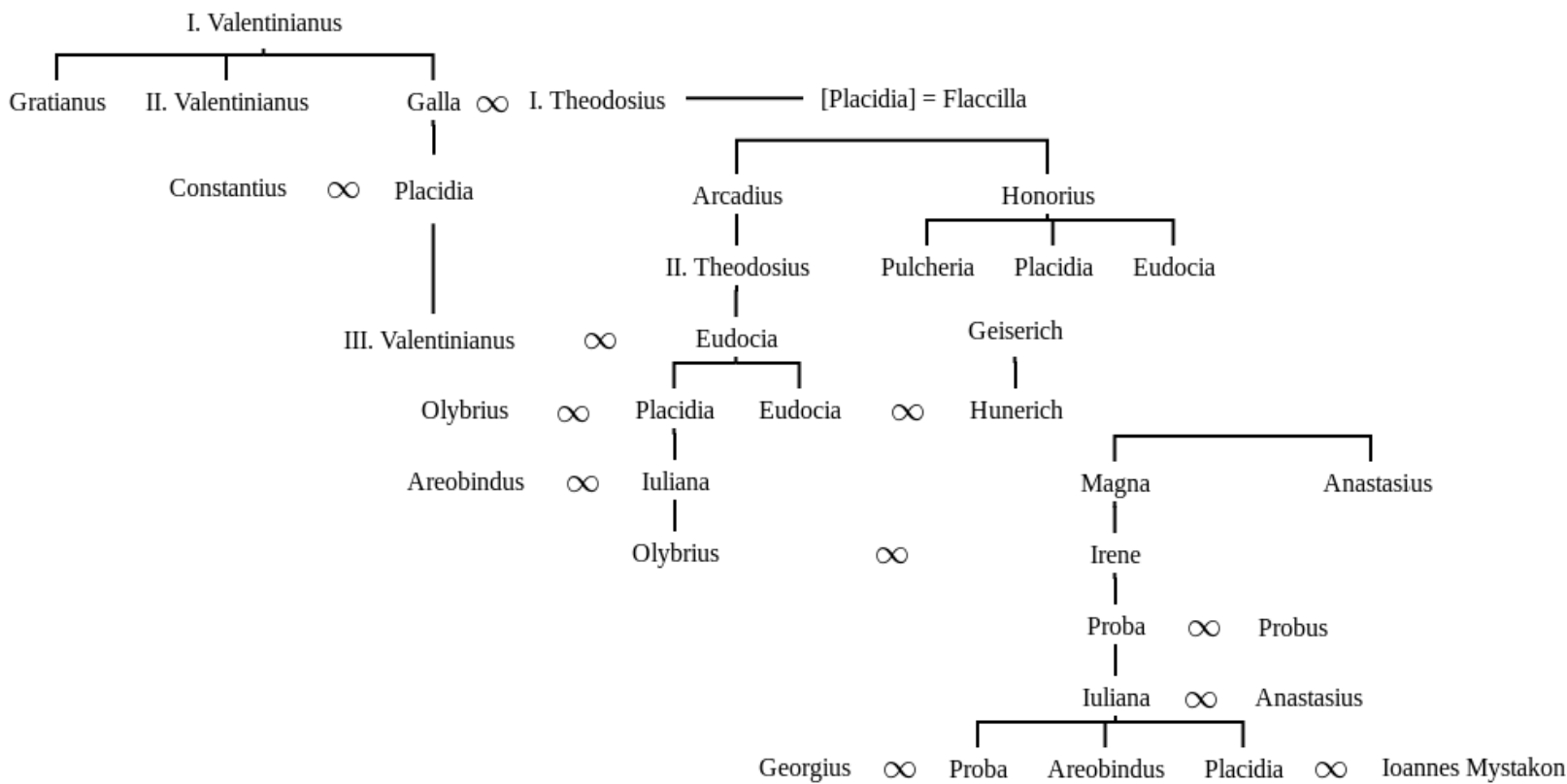

6. Stemma: A Theodosius-dinasztia Niképhoros alapján ${ }^{1102}$

A kivégzések mellett számüzetésekre is sor került, Malalas pár sorral később csak annyit közöl, hogy alig néhány hónappal a felkelés leverését követöen két patriciust, bizonyos Probust és Olybriust a császár visszahívta Konstantinápolyba és visszaadta nekik korábban elkobzott javaikat. ${ }^{1103}$ Minden bizonnyal Anastasius harmadik unokaöccséről és Anicius Olybriusról (cos. 491) lehet szó. Iustinianusnak alig pár hónapra volt szüksége csak ahhoz, hogy felismerje a Nikafelkelés mögött húzódó szálakat és hazahívja azt a két férfit, akik mindketten kötődtek az Anicius családhoz. A század elején a balbeeki jóslat úgy tartotta, hogy Anicia Iuliana gyermeke lesz a következő uralkodó, de később is úgy jelenik meg a család a forrásokban, mint akiknek az ereiben uralkodói vér folyik. ${ }^{1104}$ Anicius Olybrius ugyanis, Anicia Iuliana gyermekeként III. Valentinianus dédunokája volt. Úgy gondolom, hogy a Nika-felkelés rádöbbentette a császár korábbi elhibázott politikájára, néhány hónappal a felkelést követően pedig már keresi a lehetőségét annak, hogy az arisztokráciához és legföképpen az Aniciusokhoz kösse magát. Legalábbis ezt támasztja alá a

\footnotetext{
1102 NiCEPH. ChrON. SYNTH. 103-104. (de Boor)

1103 JOH. MAL. 18.80 (478).

1104 Coll. Avell. 170.2 (Hormisdas pápa Anicia Iulianának küldött levele). “imperialis sanguinis vena”.
} 
Niképhoros pátriárka leírása alapján készített stemma, amelyből kiolvasható, hogy Anicia Iuliana menye Anastasius unokahúga volt, ráadásul Probus éppen az ő lányát vette el, ${ }^{1105}$ így esetükben unokatestvérek közötti házasság történt.

Anonymus Valesianus külön ágyban alvó unokaöccseinek történetét és így az eltérő családok elméletét Cameron más megközelítésből történő elemzése is alátámasztja. A szerző Priscianus Anastasiushoz írt panegyricusának elemzésén keresztül kimutatta, hogy a PLRE állításával szemben Probus (cos. 502) nem lehetett Pompeius és Hypatius testvére. ${ }^{1106}$ Azonban, mivel Anonymus Valesianus és Prokopios is Anastasius unokaöccseként szerepelteti ${ }^{1107}$ kétségtelen, hogy a császár valamelyik testvérének gyermeke volt. 510 elött valamivel Theophanés szerint az eretnek Severusszal szemben egy alexandriai szerzetes érkezett, akit Dorotheosnak neveztek. Az alexandriai terjedelmes munkában állt ki a chalcedoni zsinat rendelkezései mellett, amit Anastasius sógornőjének, Magnának adott ajándékba, mivel ő is az ortodoxia híve volt. Az asszony aztán ajánlani kezdte a könyvet Anastasiusnak azt remélve, hogy vallási kérdésekben megváltozik a véleménye. ${ }^{1108}$ Anastasius családjában Magna lehetett az egyetlen asszony, aki az ortodoxia érdekeit képviselte, Probus (cos. 502) így minden bizonnyal az ö fia volt. ${ }^{1109}$ A Probus/Proba név szinte kizárólag az Anicius családban bukkan fel.

Az Anthologia Graeca szerint Anicia Iulianának egy fia és legalább két lányunokája volt. ${ }^{1110}$ A lányok azonban nem jelennek meg a forrásokban, mindenesetre ennek az információnak az ismeretében a család akár három irányba is folytathatta útját. Figyelembe véve, hogy Iuliana férje Areobindus (cos. 506) magister militum volt, a férfi katonatársai lehetséges vőjelöltként tủnhettek fel. Areobindus hosszú időn keresztül szolgált Patriciusszal (cos. 500) és Hypatiusszal (cos. 500), így mindketten lehetséges aspiránsok voltak. ${ }^{1111}$ Prokopios szerint egy alkalommal Areobindust hazahívják a perzsa hadszíntérröl, ${ }^{1112}$ ugyanakkor az is kiderül, hogy források között nem uralkodik egyetértés abban, hogy Areobindust vagy Hypatiust hívta-e haza Anastasius. ${ }^{113}$ Lehetséges, hogy egy házasság jóváhagyása miatt kerültek mindketten Konstantinápolyba akár

1105 CAMERON 1978, 272. Ezzel szemben Cameron úgy gondolja, hogy Probus (cos. 502) ismeretlen nevü fia Theodora ismeretlen nevü és törvénytelen lányát vehette el.

1106 COYNE 1988, 242 vö. MARC. COM. 523 Ezt egyébként Marcellinus comes consobrini kifejezése is megerösíti, amelyet a Anastasius unokaöccsei vonatkozásában használ.

1107 ANON. VAl. 13.74 (Pompeius, Probus, Hypatius), Procop. De Bellis. 1.12.6 (Probus).

1108 THEOPH. AM. 6002.

1109 MARC. COM. 523 Ezt egyébként Marcellinus comes consobrini kifejezése is megerősíti, amit Probus vonatkozásában használ

1110 ANTH. GR. 1.10.39.

1111 JOH. MAL. 16.9 (398), MARC. COM. 503. Ugyanazt az eljárást alkalmazta Aspar is.

1112 Procop. De Bellis. 1.9.1.

1113 PLRE2 143-144, “Fl. Areobindus Dagalaiphus Areobindus 1". 
együtt akár külön-külön, ezt jelzi, hogy Prokopios a Nika-felkelés alatt hosszasan védi Hypatius feleségét, az óvatos ${ }^{1114}$ Mariát, aki minden áron megpróbálta visszatartani férjét a tömegtôl, amely császárrá akarta koronázni. ${ }^{1115}$ Ezt az azonosítást támaszthatja alá Ióannés Nikiu, aki már az 512-es lázadás kapcsán megemlítette, hogy Anicia Iuliana Anastasius családjához tartozik, bár ezt a feltételt már Olybrius és Irene házassága is kielégíti. Nikiu ugyan nem említi a kapcsolat jellegét, de feltételezhető, hogy az asszony egyik ismeretlen unokája éppen Maria volt. ${ }^{1116}$ Ez az elgondolás illeszkedik az eddigi császárrá koronázási próbálkozások sorába, hiszen 512-ben is egy Anicia férjét akarta a tömeg megkoronázni és a Nika-felkelés alatt is ez lehetett a cél. Ugyanakkor, akár hitelt adunk Probus 532-es császárrá választási kísérletének, akár nem, a történetírók tévesztése világosan abba az irányba mutat, hogy Anicius rokonsággal rendelkeztek.

\subsection{Germanus}

Láthattuk, hogy az Akakios-féle egyházi szakadás lezárásának idején Hormisdas pápa még szinte egyenlőként kezelte Iustinianus és Germanust, később mégis Iustinianus örökölte nagybátyja után a trónt. Iordanes szerint Germanus az Anicius családhoz tartozott, minden bizonnyal apja vehetett el egy Anicius családhoz tartozó asszonyt, ez azonban nem mutatható ki egyértelmüen. A források azonban számos ponton alátámasztják a feltételezést.

Azt, hogy Germanus potenciális alternatívaként volt jelen Iustinus után, az is mutatja, hogy a Nika-felkelés leírása során Prokopios meglepő állításokat tesz. A lázadás egész leírása során szóba sem hozza Anastasius Pompeius nevü unokatestvérét, a lázadás leverésekor viszont már feltünik testvére, Hypatius mellett. Ennél azonban sokkal lényegesebb, hogy Malalasszal és más történetírókkal szemben ő nem Belisariusnak és Mundónak tulajdonítja a felkelés leverését és Anastasius unokaöccseinek elfogását, hanem Iustinianus unokatestvéreinek Boraïdesnek ${ }^{1117}$ és Iustusnak $^{1118}$, miközben megfeledkezik a harmadik testvérröl, Germanusról. ${ }^{1119}$ Prokopiosnak a

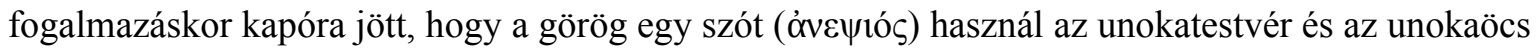

\footnotetext{
1114 Procop. De Bellis. 1.24.23 vö. 2.4.15, Maria fia, Anastasius örökölte anyja legföbb tulajdonságát az óvatosságot, amit Prokopios az teljes korpuszban csak kettejük esetén hangsúlyoz, ráadásul ugyanúgy. 539-ben Iustinianus követségebe küldte Chosroéshez, hogy megpróbálja elhárítani a háborút. Egy levelet (tartalma: PROCOP. DE BELLIS. 2.4.14-25) is küldött, amit miután elolvasta az uralkodó nem engedte el egyböl Anastasiust.

1115 Procop. De Bellis. 1.24.23-24.

1116 I. NiKIU. CHRON. 89.65.

1117 PLRE3A 245-246, "Boraides".

1118 PLRE3A 758-759, "Iustus 2".

1119 Procop. De Bellis. 1.24.19 vö. 1.24.53.
} 
számára, ezzel tehát nyelvileg is tökéletesen egymással szembeállítja a régi császár és az új császár "unokaöccseit." ${ }^{1120}$ Az új rend leszámol a régivel, végérvényesen. Ez az eljárás azonban egy rejtett utalást is hordozott, amit korábban már láthattunk Anonymus Valesianusnál és az 512-es felkelés kapcsán is. Prokopios megfeledkezik a harmadik testvérröl, Germanusról, az 512-es Probusról, akihez a császárral szemben álló tömeg azért vonul, hogy ellencsászárt állítson. Prokopios teszi ezt annak ellenére, hogy a tisztségviselő ekkor minden bizonnyal Konstantinápolyban volt, hiszen a thraciai megbízatása legkésőbb 527-ben véget ért, legközelebb pedig már magister militum praesentalisként bukkan fel. Prokopios tehát, akárcsak Anonymus Valesianus külön kezeli az egyik testvért, így jelezve lehetséges ellencsászár szerepét.

Prokopios egy másik helyen is érzékelteti Germanus kiemelt szerepét. A perzsa örökbefogadás leírása nem csupán a szerződések különböző fajtáinak, vagy éppen Iustinianus Iustinus általi adoptiójának a leírása. A keletrómai auktor perzsa történetében, akárcsak Iustinianus és Germanus esetében, két aspiráns pályázott Kavād örökségére. A perzsa uralkodó a szokások ellenére Chosroést szánta a Perzsa Birodalom uralkodójának, de félő volt, Zamasp, aki rendkívül férfias volt, és a katonák körében igen népszerünek számított, fel fog lépni Kavād döntése ellen. Prokopios szerint Zamasp nem is uralkodhatott volna, mert testi fogyatékossága ezt nem tette lehetővé. A perzsa ugyanis egy hadakozás során elveszíttette fél szemét, így a törvények

${ }^{1120}$ Prokopiosnál nehéz megállapítani a családi kapcsolatokat, elsősorban az unokatestvér és unokaöcs között

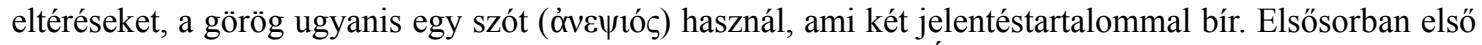
unokatestvért jelent, viszont második jelentése lehet unokaöcs is. Éppen ezért Prokopiosnál átfogóan kell átvizsgálni egyes családok esetében a kapcsolati viszonyt. A modern fordítások többnyire tévesen adják vissza a rokonsági fokokat. A következőekben a ? helyettesíti az unokatestvér/unokaöcs (ơveqiós) szót zárójelben pedig a Kaldellis által visszaadott fordítás szerepel vö. PrOCOP. DE BELlis. Boraïdes esetében: Procop. De Bellis. 1.24.53. (532k): Boraïdes és Iustus Iustinianus ? (unokatestvére). Procop. DE BELLIS. 7.32.17-18. (548k): Boraïdes, aki Iustinianus Germanus nevü ? (unokaöccsének) a testvére. Iustus esetében: Procop. De Bellis. 1.24.53. (532k): Boraïdes és Iustus Iustinianus ? (unokatestvére). PROCOP. DE BELLIS. 2.28.1. (543k): Iustus halála (betegség), aki Iustinianus ? (unokaöccse). Germanus esetében: Procop. De Bellis. 2.6.9. (540k): Germanus Iustinianus? (unokaöccse). Procop. De Bellis. 4.16.1. (536k): Germanus Iustinianus ? (unokaöccse). Procop. DE Bellis. 4.23.23. (540k): Germanus Iustinianus? (unokaöccse). PROCOP. De BeLlis. 7.12.11. (545k): Germanus Iustinianus ? (unokaöccse). Továbbá közli, hogy Ioannes házasságot kötött Germanus lányával. PROCOP. DE BELlis. 7.32.10.: Germanusnak két fia van. PROCOP. DE Bellis. 7.32.13. (540): Germanusnak egyik fiát Iustinusnak nevezik, nagyon fiatal, most sarjadt ki az első szakálla. PROCOP. DE BELLIS. 7.38.24. (550k): Germanus Iustinianus ? (unokaöccse). PROCOP. DE Bellis. 7.39.9. (550k): Germanus patricius Iustinianus ? (unokaöccse). PROCOP. DE BELLIS. 7.40.10. (550k): Vitalianus unokatestvére/unokaöccse Ioannes Germanus veje és Germanus két fia közül az egyik Iustinianus. PROCOP. DE Bellis. 8.25.11. (552k): Germanus fiai Iustinus és Iustinianus. Az adatok összevetésből megállapítható, hogy Boraïdes és Germanus testvérek voltak. Germanusnak két fia volt Iustinus és Iustinianus személyében és egy lánya, akit Ioannes vett el. Ugyanakkor Prokopios nem említi konkrétan, de a névalakból valószínüsíthető, hogy az 532-ben Nika-feleklésnél feltűnő, ám korai halált halt Iustus, Boraïdes és Germanus testvérek voltak, következésképpen a modern fordítások pontatlanul járnak el, amikor bármelyiküket is Iustinianus unokaöccseként definiálják. 
értelmében nem uralkodhatott a perzsák felett. ${ }^{121}$ Germanust magister militum praesentalisként még maga Iustinianus küldte a thraciai hadszíntérre. Könnyen lehet, hogy Germanus is hasonló sérülést szenvedett, mint Zamasp. Iustinianus az 510-es évek végén maga dönthetett Germanus kinevezéséről és Thraciába küldéséről. Az allúziót alátámaszthatja, mint ahogyan azt már láthattuk, hogy a perzsa követség és Iustinianus örökbefogadására egy időben kerülhetett sor, ahogyan az is, hogy ebben az időben Germanus magister militumként szolgált Thraciában.

A Germanus felmenőivel kapcsolatos féltékenység a Titkos történetben is megjelenik. Prokopios szerint Theodora császárné is mindent megtett annak érdekében, hogy megakadályozza Germanus gyermekeinek házasságát. Prokopios szerint Iustinianus felesége annyira gyülölte Germanust, és ezt olyannyira ki is mutatta, hogy senki sem mert házassági kapcsolatra lépni a férfi családjával. Gyermekei egészen addig nem tudtak megházasodni, amíg Theodora meg nem halt. Germanus lánya már 18 éves volt és még mindig nem házasodhatott Theodora miatt. Ioannes magister militum egy alkalommal Belisarius megbízásából Konstantinápolyba ment, ahol Germanus megkereste, hogy házassági kérdésekben egyeztessenek, annak ellenére, hogy a férfi rangban messze Belisarius alatt állt. Ioannes rangon felüli kapcsolatra törekedett, Germanus pedig "rászorult a kérőkre". Theodora amikor megtudta a tervet, mindent megtett, hogy megakadályozza a házasság létrejöttét. Miután az ármánykodása hatástalannak bizonyult, nyíltan megfenyegette Ioannest, hogy megöleti. ${ }^{122}$ Nem csak Theodora viselkedett ellenségesen Germanus családjával. 544-ben utód nélkül meghalt Germanus Iustus nevü testvére, ${ }^{1123}$ néhány évvel később pedig Germanus második, Boraïdes nevű testvére is eltávozott az élők sorából. Iustus örökösök nélkül halt meg, Boraïdest azonban felesége és lánya is túlélte. Végakarata szerint birtokait és egyéb ingóságainak nagy részét testvérére, Germanusra és annak gyermekeire hagyta. Végrendeletében pedig kikötötte, hogy felesége és lánya csak a törvényben rögzített minimális járadékra jogosultak. Iustinianus viszont, Germanus rosszallása ellenére, a hátramaradók védelmére kelt. ${ }^{1124} \mathrm{Ez}$ nem meglepő, hiszen Iustinianus másodunokahúga ügyében igyekezett érvényesíteni befolyását, miközben a legközelebbi élő férfi hozzátartozó Germanus volt. A császár minden bizonnyal a Novellae Constitutiones 538-ban kiadott 18-as rendeletére hivatkozva legalább a javak egy harmadát követelte a lánynak és az özvegynek. ${ }^{1125}$ Noha ezt nem tehette volna, mindenesetre ez is mutatja, hogy Iustinianus és felesége mennyire féltékenyen tekintettek az Anicius felmenőkkel rendelkező családtagjaikra, akik közül ekkor már csak Germanus élt.

\footnotetext{
1121 PROCOP. DE BELLIS. 1.11.4.

1122 PROCOP. ARC. 1.8-13.

1123 PROCOP. De BELlis. 2.28.1.

1124 Procop. De BELLIS. 7.31.17.

1125 NOV. 18.
} 
Iustinianus tudatosan igyekezett távol tartani unokatestvérét Konstantinápoly környékétől. 536-ban Észak-Afrikába küldte, ahol három éven keresztül teljesített szolgálatot. ${ }^{1126}$ 540-ben már Antiochiában volt, mindössze 300 ember élén. ${ }^{1127}$ Tíz évvel később pedig már az osztrogótok ellen vonuló erők élén állt. A császár nem adott mellé sereget, helyette Thraciába küldte, hogy maga verbuváljon csapatokat a rábízott arany segítségével. Vele tartott veje, Ioannes is. Prokopios szerint hatalmas ambícióval érkezett, úgy gondolta, hogy Lybia után Itáliát is visszahódíthatja a birodalom számára. Első lépésként, miután felesége, Passara már rég eltávozott az élők sorából, Iustinianus indíttatására feleségül vette a nála csaknem harminc évvel fiatalabb Matasunthát, az utolsó élő személyt az Amal-dinasztia sorából. Úgy gondolta, hogy ha a Theoderich unokája vele tart, akkor a gótok, emlékezve első itáliai királyuk szavára nem mernek majd fegyvert fogni ellene. A rómaiak közül a tapasztalt harcosok mind vele tartottak. A Duna mellékéről barbárok érkeztek, akik már ismerték Germanus érdemeit. ${ }^{1128}$ A sereg azonban már nem indulhatott el Germanusszal, a hadvezér élete telén egy betegségben saját katonai táborában hunyt el, ott ahol az elmúlt három évtizedet töltötte. ${ }^{1129}$

"[Matasuntha és Germanus] házasságából, az apa, Germanus halála után (postumum) született egy szintén Germanusnak nevezett fiú. Öbenne egyesült az Anicius-nemzetség az Amallal, s ö most mindkét nép reménysége, ha az Út élteti."

A császár az osztrogótok ellen fordította Theoderich és Theodahad fegyverét. A kis Germanus postumius törvényes gyámja felnőtt férfi rokona lett, ${ }^{1131}$ Iustinianus, aki két évvel (554) a gyermek születése után kiadta a Pragmatica sanctio pro petitione Vigilii rendeletet, melyben megerősítette Itália visszafoglalását és törvényei érvényességét az itáliai területen. A császár kifejezetten elismerte az Amal-dinasztia uralkodói, a rómaiak vagy a senatus által létesített valamennyi jogi ügyletet egyetlen kivétellel. Csupán egyetlen dolgot nyilvánított érvénytelennek. Azt a birtokadományozását, amelyet Theodahad juttatott Anicius Maximusnak a gót hercegnővel kötött házassága - és legitimációs kísérlete - alkalmával. ${ }^{1132}$

1126 MARC. COM. 536.2.

1127 MARC. COM. 540.

1128 Procop. DE BELlis. 7.39.9-20, JoRD. Get. 314.

1129 Procop. De Bellis. 7.40.9.

1130 JORD. GET. 314.

${ }^{1131}$ INST. 13, 14. vö. PROCOP. DE BelLIS. 7.32.13., Ezt azonban nem tölthette be örült vagy huszonötödik életévét betöltött személy, így Germanus első házasságból született fia sem lehetett jogosult gyámságra, hiszen Prokopios tükrében még első szakálla sem sarjadt ki.“

1132 Nov. Appendix 7. 


\section{7. ÖSSZEGZÉS}

A dolgozat első oldalain még nem tudhattuk, hogy mi indokolta Iustinianus számára, hogy idő előtt győzelmi szobrot emeljen magának, de az ezt követő oldalakon a különböző történetírók imitatisós gyakorlatának értelmezésén keresztül fokozatosan feltárult azoknak a történeti összefüggéseknek a sürü és szövevényes hálózata, amely a dinasztikus legitimáció töretlen fontosságát mutatta. A birodalomegyesítő Iustinianusnak céljai elérése érdekében világos kapcsolatot kellett felmutatnia az őt megelőző egyeduralkodóval, aki Nagy Theodosiusszal. Az összeköttetést a Rómában és Konstantinápolyban is jelen lévő Anicius család jelentette, nem csak Iustinianus, de Theodahad számára is.

A fejezetek során láthatóvá vált annak a mitológiai és egyházi/eszkatológiai értelmezésnek a sajátos keveredése, amely az elmúlt évtizedek történeti értelmezéseire jelentős hatást gyakorolt. A Konstantinápolyban alkotó történetírók mindenekelött Hérodotos munkájából merítettek. Iustinianus emlékmüvének mitológiai utalása is ebbe az irányba vitte a narratívát, azon belül is az asszonyrablás motívuma figyelemre méltó, hiszen ezek számukban is megegyeznek a hérodotosi mintával. A trójai harcokra tett allúzió Iordanes Geticájában is megjelenik, amikor a szerző Fritigern népét Vergilius Aeneisén keresztül az új hazát kereső trójaiakkal azonosította, akik Rómába érve szinte azonnal nőrablásba bonyolódtak. Ez azonban csak Iordanes értelmezése volt, Prokopios ezzel szemben Hérodotos leírására támaszkodott, amely Babilon elfoglalása alapján mintázta a történetet. A lényegi mondanivaló azonban ebben az esetben is ugyanaz volt, hiszen a Babilon ellen felvonuló perzsa sereg már a gótok őseivel, a getákkal kiegészülve állt neki az ostromnak, miközben ezek az ostromlók egyike sem vetette meg más asszonyának elrablását. A különböző leírások számos ponton párhuzamot mutatnak a babiloni fogság történetével, ennek figyelembevételével további értelmezések készíthetőek.

A történeti szakirodalomban a klasszikus asszonyrablás motívumának direkt értelmezése sok esetben megzavarta a vegyes házasságok értelmezését, amelyek meglehetősen szokványosak voltak a birodalomban a Constitutio Antoniniana kihirdetését követöen. Azok a rendeletek, amelyek valamilyen tiltást vagy szankciót helyeztek kilátásba a vegyes házasságokkal kapcsolatban, elsősorban nem a házasságok ellen irányultak, hanem inkább a határ menti kémkedés lehetőségét igyekeztek minimalizálni. Theodosius császár lányának elhurcolására nem is egy cselt követően került sor, mint Paris esetében, hanem majd két éves ostromzárat követően. Athaulf és Galla Placidia házasságára pedig még később, csak az elhurcolást követő negyedik évben került sor. Ennek ellenére Iordanes úgy alakította művének belső kronológiáját, hogy azt a nézetet 
erősítse, hogy Róma kifosztására és a házasságra még 410-ben sor került. Nem csak a gót krónikás élt ezzel a lehetőséggel, hanem az esetről elsőként beszámoló Orosius, aki Szent Ágostonnal szemben már egy merőben új magyarázattal élt a 410-es események kapcsán. A bragai szerzetes Jeromossal folytatott gyakori eszmecseréi folytán maga is tisztában lehetett azzal, hogy Rómát gazdag hitélete miatt gyakran Jeruzsálemhez hasonlították. Éppen azért Ágoston és Jeromos ellentétét azzal oldotta fel, hogy egyszerüen összemosta Róma kifosztását a házassággal, így a város sorsát így össze tudta kötni Placidia sorsával. A Jeromosnál hosszabb-rövidebb ideig tartózkodó egyháziaknál rendre megjelent az ószövetségi Dániel könyvének értelmezése, ami a történeti eseményeket eszkatológiai értelmezésbe helyezte. A kiindulópontot Galla Placidia és Athaulf házassága jelentette. Az asszony hatására a barbár uralkodó, népének szokásaival szembefordulva tisztelni kezdi a római törvényeket. Orosius egyedülálló módon azzal erősítette meg a történet hitelességét, hogy saját magát helyezte az elbeszélő szerepébe. Athaulf csodás pálfordulásáról éppen akkor értesült, amikor Szent István ereklyéit szállította, akit zsidók köveztek halálra. Orosius azonosítása több történetírónál is megjelent, mivel keresztény hagyomány zsidóellenes propaganda kapcsolódott a röpirat-irodalomhoz így az Epistula Severihez is, amelynek eseménytörténetét Anonymus Valesianus következetesen átvette, ebböl vált világossá, hogy a korabeli egyházi irodalom a gótokat következetesen zsidóként jeleníti meg. Ennek figyelembevételével a Variae alig néhány ,zsidó” levelén keresztül értelmezhető a gót tisztségviselök Laurentius-skizma során betöltött szerepe, Theoderich alkotmányos berendezkedésének néhány aspektusa is (pl. határkérdés), továbbá a korabeli felekezeti kérdések is, annál is inkább, mert a szakirodalom ezeket a leveleket kivétel nélkül szó szerint értelmezte.

Athaulf és Galla Placidia házassága jelentette a mintát a későbbi történetírók számára. Prokopios szerint nem a véletlennek köszönhették a vizigótok, hogy 410-ben bejutottak a városba, hanem az Anicius család egyik tagjának. A nemzetség rekonstruálása során világossá vált, hogy Róma leggazdagabb családjának számítottak és őseik révén jelentős észak-afrikai birtokállománnyal rendelkeztek. Az Aniciusokat tárgyaló fejezet fontos megállapítása volt, hogy Probus (cos. 371) 4. század végén bekövetkező halála követően gyors hanyatlás figyelhető meg a család életében. 410-es évekre pedig egész egyszerüen eltűnnek a történetírók szeme elől. Anicius Hermogenianus Olybrius (cos. 395) családjának vizsgálata megmutatta, hogy 414-ben, Anicia Faltonia Proba eladta római birtokait, és lányával, unokájával, valamint az ekkor nagyjából 10 év körüli Olybriusszal, a későbbi nyugatrómai császárral Észak-Afrikába távozott. Az Anicius család ezzel két részre szakadt: Anicius Auchenius Bassus (PVR 382) azonos nevet viselő fia és unokája továbbra is Rómában maradt, ők alkották a család nyugati ágát. A keleti ágat pedig az 
elvándoroltak leszármazottai alkották. A család ezen ágának római birtokai, így a Salaria kapu szomszédságában található domus Pinciana az állam tulajdonába kerültek.

Az Anicius család szerepében III. Valentinianus 455-ben bekövetkező halála okozott változást. Fiú örökös híján - a keleti ág után - Valentinianus halálával vége szakadt a Theodosiusdinasztia nyugati ágának is, annak a dinasztiának, amely I. Theodosiusszal, még ha rövid időre is, de vallási és területi egységet teremtett. Aëtius és Valentinianus halálával a vandálokkal kötött $442-$ es megállapodás érvényét vesztette. Geiserich hamarosan Róma felé indult csapataival, ugyanis III. Valentinianus idősebbik lánya Eudocia már jó ideje jegyben járt Hunerich-kel. A várost azonban nem csak fiával és annak jegyesével hagyta el, hanem magával vitte Valentinianus özvegyét, valamint a császár kisebbik lányát, Placidiát is. A problémák is inkább Placidia köré csoportosultak, akivel kapcsolatban a keletrómai történetírók tendenciózusan igazolni igyekeznek egy 455 elötti házasságot, miközben 455-ben még alig volt tizenkét éves. A konstantinápolyi auktorok eljárásának célja ezzel elsősorban az volt, hogy Placidia és Olybrius házasságának időpontját Marcianus halálánál korábbi időpontra tegyék, hiszen míg Marcianus felesége révén kapcsolatban állt a Theodosius-dinasztiával, addig Leo nem rendelkezett dinasztikus kapcsolattal. Uralkodói legitimációjának fontos eleme volt, hogy a Theodosius-dinasztia nőtagjait ismét Konstantinápolyban láthassa. A dolog jelentősége a nobilissima címben rejlett, amelyet a dinasztia nőtagjai már születésük pillanatában birtokoltak. A nobilissimus beiktatására vonatkozó protokoll zárósoraiból ugyanis kiderül, hogy a nobilissimus az augustus és az augusta családjának részévé válik, így beiktatás során a dinasztikus kapcsolattal nem rendelkező uralkodó a dinasztia tagjává válhatott egy formális eljárás keretében. Ennek jelentőségére Marcellinus comes világított rá, aki krónikájában csak egyetlen egyszer, éppen Placidia visszatérésének évében (462) nevezi Leót augustusnak. Leo feleségének, Verinának a solidusán is ezzel egyidejűleg jelenik meg az isteni kéz által tartott korona, amely korábban a Theodosius-dinasztia nőtagjainak érméin már uralkodásuk első évében megjelent. A cím Verina gyermekein keresztül hagyományozódott tovább, így az Anastasiusszal házasságot kötő Ariadne is rendelkezett vele.

A “müveletlen” Iustinus azonban nem tulajdonított különösebb jelentőséget a legitimáció ezen módjának, amit jelzett, hogy sem az ő, sem Iustinianus feleségének nevében nem bukkant fel az időközben státuszjelzővé váló Aelia név, amely I. Theodosius uralkodása alatt vált a császárnők nomenklatúrájának részévé. A 6. században Anicia Iuliana is a nobilissima cím birtokosa volt, akivel az osztrogót Theoderich házasságot köthetett volna, de nem tette. Anonymus Valesianus jobbára ezért nevezhette "műveletlennek" az osztrogót uralkodót, aki így a császár magister militumaként érkezett Itáliába, amit Odoacer legyőzése után harminc szerencsés éven keresztül 
birtokolt. Legalábbis a Iordanes és Anonymus Valesianus szerint, a szerencsés évek vége ugyanis szorosan kapcsolódott egy Anicius sorsához. A családfa rekonstrukció során világossá vált, hogy a PLRE adataival szemben a senator nem a Decius nemzetséghez tartozik. A gondok az Akakios-féle skizma lezárását követően jelentkeztek az 520-as évek elején, amikor Albinus (cos. 493) egy olyan összeállításon dolgozott, amely gyüjtötte chalcedoni dogma elítélőit, ami nyilvánvalóan sérelmes volt az ariánus osztrogótok számára. Bevádlása, magával rántotta a senatus két vezető tagját is, Boëthius és Symmachust. A családok vizsgálata során kiderült, hogy a három senator közül csak Albinus (cos. 493) tartozott bizonyíthatóan az Anicius családhoz. Ez az azonosítás segített megérteni, hogy Boëthius és Symmachus halálát alaptalanul társították egy esetleges senatori ellen frakcióhoz. 519-ben az Akakios-féle egyházi szakadás lezárása vallási összetüzéseket okozott Itáliában, a dátum azonban talán nem is véletlenül, de egybeesett az osztrogót uralkodóváltás szükségességével, hiszen a római joggyakorlat szerint egy-egy uralkodó csak harminc évig rendelkezhetett egy terület felett anélkül, hogy elbitorolta volna. A keletrómai kormányzat ennek ment elébe Eutharicus 519-es ünnepélyes örökbefogadásával. Az ifjú trónörökös korai halála és hátrahagyott gyermekei lehetőséget biztosítottak az elkövetkező uralkodók számára, hogy továbbra is birtokolják Itália területét. Ez azonban csak korlátozott ideig élhetett, hiszen a gyámság meghatározott életkorig szólt. Theodahad ezt a problémát igyekezett orvosolni azzal, hogy egy Aniciust vont családjába. Az elbitorlás alapján mindenképpen továbbgondolásra érdemes a keletrómai flotta 506. évi itáliai portyázása, hiszen erre éppen harminc évvel Romulus Augustulus eltávolítása után került sor. Marcellinus minden bizonnyal azért homogenizálta Theoderich-et és Odoacert, mert a krónika első kiadásának idején, az 510-es évek elején ez volt a hivatalos álláspont. Ez a kérdés ugyanakkor alátámaszthatja azokat a kutatásokat, amelyek azt igyekeznek alátámasztani, hogy Odoacer nem szkír származású volt, hiszen ez akár egy keletrómai propaganda is lehet a elbitorlás kiküszöbölésére.

A Veronában található Szt. István imaház oltárának lerombolása minden bizonnyal propaganda. A szent ereklyéjének jelenlétét expressis verbis nem közlik a források, erre csupán az imaház nevéből és a körülményekből lehet következtetni. Mindazonáltal a protomártír ereklyéinek vándorlásáról szóló beszámoló, valamint az Anonymus Valesianus által megőrzött eseménytörténete nagyfokú hasonlóságot mutat. A szent ereklyéje nem ekkor jelent meg először a Theodosius dinasztia, illetve az utódaiknak számító Aniciusok vonatkozásában, hiszen Galla Placidia házasságának, majd szabadulásának idején is szerepe lehetett. Konkrét említésére azonban csak Iustinianus idejében kerül sor, amikor a Nika-felkelés elött néhány elítélt a Szt. Laurentius bazilikában keresett menedéket, ahol az ereklyéket tárolták, és ami ekkor az Anicius család 
dominiumának számított. Az ereklye csak az utóbbi esetben jelenik meg az Aniciusokkal kapcsolatban, mindenesetre jó okunk van sejteni, hogy mindegyik esetben megfigyelhetö a protomártír ereklyéjének befolyásoló szerepe az Aniciusokkal kapcsolatban. A kérdés azonban további alaposabb vizsgálatot igényel.

Albinus bukását követően az osztrogótok uralkodásának fokozatos hanyatlása figyelhető meg a forrásokban, amit Prokopios az egyes uralkodók müveltségi fokával indokol. Míg Theoderich müveletlen katonának számított, így könnyüszerrel teljesítette az udvar parancsait, addig lánya már különösen fontosnak tartotta gyermeke római nevelését. Athalarich ugyan még csak kettős nevelést kapott, rómaiaktól és gótoktól egyaránt, máris képessé vált arra, hogy bár finoman, de megkérdőjelezze a császár alávetési gyakorlatát. Ez a folyamat Theodahad uralkodása idején érte el a csúcsát, aki Theoderich-kel szemben már roppant müveltnek, számított és ily módon már arra is képes volt, hogy Amalasuntha megölése utáni legitimációját egy Anicius házassággal próbálja elérni: lányát összeadta Anicius Maximusszal (cos. 523). Theodahad tettének jelentőségét Prokopios azzal fejezi ki, hogy Maximust pusztán névazonosság alapján két korábbi trónbitorló (Magnus Maximus, Petronius Maximus) rokonaként állítja be. A három személyt azonban mint láttuk, nem füzte rokoni kapcsolat egymáshoz.

Az Anicius-nemzetség tagjai Iustinianus uralkodására alatt is kiemelt szerephez jutottak. Iustinus uralkodása alatt Anicia Iuliana, a "császárral közösségben élő" nobilissima még életben volt, 530 körüli halála azonban legitimációs problémákhoz vezetett, hiszen Anastasius unokaöccsei közül legalább egyiküket házasság füzte Anicia Iuliana családjához. Iustinus unokaöccsei közül Germanus és Iustinianus tűnt potenciális utódként. Germanus előnyére szólt, hogy apja egy egyelőre azonosítatlan - Aniciusszal kötött házasságából született, azonban a császár még Anicia Iuliana halála előtt örökbe fogadta és utódjává tette Iustinianust. Theodosius-dinasztia utáni vágyakozása őrződött meg Tours-i Szent Gergely leírásában. Anicia Iuliana halála után azonban a császár már bármiféle dinasztikus kapcsolat nélkül uralkodott. A Theodosius-dinasztia utáni vágyakozás öltött testet a 532-es Nika-felkelésben. A felkelés azt követően eszkalálódott, hogy a városi praefectus emberei néhány elítélt nyomába eredtek, mit sem törödve a Szent Laurentius bazilika menedékjogával. Az épület, a benne elhelyezett Szent István ereklyék miatt a Theodosiusdinasztia, majd az Anicius család dominiumának számított. A Nika-felkelés kezdete és vége is az Aniciusokhoz kötődött. Az Anicius dominium megsértését követően a senatusi ülésen is felmerült Theodosius-Anicius-ház szembenállása az éppen regnáló hatalommal.

A Nika-felkelés leveréséről szóló elbeszélésekből Iustinus másik unokaöccsének, Germanusnak lehetséges trónigénye is megjelent. Prokopios ugyanis nem Belisariusnak tulajdonítja 
Hypatius elfogását, hanem Iustinus két unokaöccsének, Germanus testvéreinek, Boraïdesnek és Iustusnak. A történetíró ezzel hasonló képet alkalmaz, mint Anonymus Valesianus, aki ugyancsak párban szerepeltette Anastasius unokaöccseit. A három ágy közül Pompeius és Hypatius egy ágyban aludtak, míg Probus a harmadik ágyban, így történt meg, hogy senki sem aludt abban az ágyban, ahogy a felségjelvényeket elhelyezték. Így lett Anastasius után Iustinus az uralkodó, és így lett Iustinus után - és annak unokaöccsei félreállítása után - Iustinianus az uralkodó. Anonymus Valesianus Anastasius utódlásáról szóló leírása egyúttal a Nika-felkelés allúziója is. A császár továbbra sem rendelkezett dinasztikus felmenőkkel, erre akkor nyílt lehetősége, amikor Iustinus unokaöccsei kezdtek meghalni és kiskorú utódaikat Iustinianus védelmébe tudta venni. Erre elöször akkor nyílt lehetősége, amikor Boraïdes halála utána az árva és az özvegy védelmében fel tudott lépni. Nem sokkal később felállították Konstantinápoly föterén azt a lovas szobrot, amely egykor Theodosiusé volt. Iustinianus így közösségbe került az egykori császár dinasztiájával, amit minden idők legnagyobb emlékművével rögtön kifejezésre is juttatott. Germanus halála után a császár Germanus postumus gyámja lett, aki Germanus Matasunthával kötött házasságából született, így vérében egyesült az Amal és az Anicius vér. Iustinianus kihasználva gyámságát, kibocsátotta az itáliai helyzet jogi rendezését rögzítő Pragmatica Sanctiót, így a félszigetet uralma alá vonhatta. Iustinianus így mind Theoderich, mind Theodahad módszerét felhasználta uralkodása stabilizálására. 


\section{Felhasznált irodalom}

\section{Források}

ACO = Acta Conciliorum Oecumenicorum. Vol. 1-4. Ed. Schwartz, Eduard, és Johannes Straub. Berlin: Walter de Gruyter, 1914.

ACTA SYNHOD.HABIT. ROM. = „Acta Synhodorum habitarum Romae”. In Cassiodori Senatoris Variae, 393-455. Monumenta Germaniae Historica Auctores Antiquissimi 12. Ed. Mommsen, Theodor. Berlin: Apud Weidmannos, 1894.

$\mathrm{AE}=$ L'Année Épigraphique. Paris, 1888-

AMM. MARC. = History. Vol. 1-3. Loeb Classical Library 300, 315, 331. Trans. Rolfe, J. C. Cambridge, MA: Harvard University, 1939. Magyar fordítása: Ammianus Marcellinus. Róma története. Fordította Gyula Szepesy. Budapest: Európa, 1993.

ANON. VAL. = „Anonymi Valesiani Pars Posterior”. In Chronica minora saec. IV. V. VI. VII. (I), 306-40. Monumenta Germaniae Historica Auctores Antiquissimi 9. Ed. Mommsen, Theodor, Berlin: Apud Weidmannos, 1882.

ANTH. GR. = The Greek anthology. Vol. 1-5. Loeb Classical Library 67. Ed. Paton, W. R., \& Michael A. Tueller. Cambridge MA - London: Harvard University, 2014.

ANTH. LAT. = Anthologia Latina . Bibliotheca scriptorum Graecorum et Romanorum Teubneriana. Ed. Shackleton, Bailey, és R. David Berlin: de Gruyter, 1982.

August. Conf. $=$ Sancti Augustini Confessionum libri XIII. Corpus Christianorum Series Latina 27. Ed. Verheijen, L. Turnhout: Brepols, 1981.

August. De Bon. Viduit. = „De Bono Viduitatis liber unus”. In S. Aurelii Augustini Opera Omnia, 429-50. Patrologia Latina 40. Ed. Migne, Jacques-Paul. Bonn: apud Garnier fratres, 1865.

August. De CIV. D. = De civitate Dei. Corpus Christianorum Series Latina 47. Ed. Dumbart, B., és A. Kalb. Turnhout: Brepols, 1955.

Aur. Vict. Caes. = Pseudo-Aurélius Victor. Abrégé des Césars. Collection des Universités de France. Série latine 353. Ed. Festy, Michel. Paris: Les Belles Lettres, 1999.

Auson. GRAT. ACT. = Ausonius. „The Thanksgiving of Ausonius for his Consulship, Addressed to the Emperor Gratian”. In Volume II: Books 18-20. Paulinus Pellaeus: Eucharisticus, Trans. Evelyn-White Hugh G., 219-70. Loeb Classical Library 115. Cambridge, MA: Harvard University, 1921.

Avit. EP. = Alcimi Ecdicii Aviti viennensis episcopi Opera quae supersunt. Vol. 2. Monumenta Germaniae Historica. Auctores Antiquissimi 6. Ed. Peiper, Rudolf. Berlin: Apud Weidmannos, 1893.

Boeth. Cons. PhiL. = Boethius. Theological Tractates. The Consolation of Philosophy. Trans. H. F. Stewart, E. K. Rand \& S. J. Tester. Loeb Classical Library 74. Cambridge MA: Harvard University, 1973. Magyar fordítás: Boethius. A filozófia vígasztalása. Ford. György Hegyi. Budapest: Magyar Helikon, 1979.

CASS. DIO = Cassius Dio. Roman History. Trans. Earnest Cary. Loeb Classical Library. Cambridge, MA: Harvard University, 1914.

CASsiod. Chron. = „Cassiodori Senatoris Chronica”. In Chronica minora saec. IV. V. VI. VII. (II), 109-60. Monumenta Germaniae Historica. Auctores Antiquissimi 11. Ed. Mommsen, Theodor, Berlin: Apud Weidmannos, 1894. 
Cass. De Anima = Magni Aurelii Cassiodori Senatoris Liber de Anima. Ed. Halporn, James W. New York: Fordham University, 1960.

Chron. PASCH. $=$ Chronicon Paschale. Vol. 1-2. Corpus Scriptorum Historiae Byzantinae 11-12. Ed. Dindorf, Ludwig August. Bonn: Impensis Ed. Weberi, 1832. Angol fordítása: Chronicon Paschale 284-628 AD. Translated Texts for Historians 7. Ed. Whitby, Michael, \& Mary Whitby. Liverpool: Liverpool University, 1989.

CIC = Corpus Iuris Civilis. Vol. 3.: Novellae. Ed. Schoell, R., és G. Kroll. Berlin: Apud Weidmannos, 1912.

Cic. FAM. $=$ Cicero. Letters to Friends. Trans. D. R. Shackleton Bailey. Vol. 1-3. Loeb Classical Library 205, 216, 230. Cambridge MA: Harvard University, 2001.

$\mathrm{CIL}=$ Corpus Inscriptionum Latinarum. Ed. Mommsen, Theodore et al. Berlin, 1853 -.

COD. IUST. = „Codex Iustinianus”. In Corpus Iuris Civilis, 2:1-56. Ed. Kruger, Paul. Berlin: Apud Weidmannos, 1888.

COD. THEOD. $=$ Theodosiani libri XVI cum Constivtionibvs Sirmondianis et Leges novellae ad Theodosianvm pertinentes. Vol. 1. Ed. Mommsen, Theodor, és Paul M. Meyer. Berlin: Apud Weidmannos, 1905. Angol fordítása: Codex Theodosianus The Theodosian Code and Novels, and the Sirmondian Constitutions. Ed. Pharr, Clyde Princeton: Princeton University, 1952.

COLL. Avell. = Epistulae imperatorum pontificum aliorum inde ab a. CCCLXVII usque ad a. DLIII datae Avellana quae dicitur collectio. Vol. 1-2. Corpus Scriptorum Ecclesiasticorum Latinorum 35. Ed. Guenther, Otto. Prága - Bécs - Lipcse: Hoelder - Pichler - Tempsky, 1895.

CYR. SCYTH. V. EUTH. = „Leben des Euthymios”. In Kyrillos von Skythopolis, 2:3-84. Texte und Untersuchungen zur Geschichte der altchristlichen Literatur 49. Trans. Schwartz, Eduard. Leipzig: J. C. Hinrichs, 1939.

DAn. STYL. = Three Byzantine Saints: Contemporary Biographies of St. Daniel the Stylite, St. Theodore of Sykeon and St. John the Almsgiver. Trans. Dawes, Elizabeth. London, 1948.

DE CER. = Constantine Porphyrogennetos. The Book of Ceremonies. Trans. Ann Moffatt és Maxeme Tall. Byzantina Australiensia 18. Canberra: Australian Association for Byzantine Studies, 2012.

DE PRINC. = „Peri Archon (De Principiis)”. In Origenis Opera Omnia, 99-412. Patrologiae Cursus Completus, Series Graeca 11. Ed. Migne, Jacques-Paul. Bonn, 1887.

Dig. = „Iustiniani Digesta”. In Corpus Iuris Civilis, Vol. 1. Ed. Mommsen, Theodor \& Paul Krüger, Berlin: Apud Weidmannos, 1899.

ENNOD. Ep. = Magni Felicis Ennodi Opera. Monumenta Germaniae Historica. Auctores Antiquissimi 7. Ed. Vogel, Friedrich. Berlin: Apud Weidmannos, 1895.

ENNOD. PAN. $=$ „Panegyricvs dictvs clementissimo regi Theoderico ab Ennodio dei famvlo”. In Magni Felicis Ennodi Opera, 203-14. Monumenta Germaniae Historica Auctores Antiquissimi 7. Ed. Vogel, Friedrich. Berlin: Apud Weidmannos, 1885.

ENNOD. VITA EPIPH. = Vita Beatissimi Viri Epifani Episcopi Ticinensis Ecclesiae. Monumenta Germaniae Historica. Auctores Antiquissimi. Ed. Vogel, Friedrich. Berlin: Apud Weidmannos, 1885.

EP. AUSTRAS. = „Epistolae Austrasiacae”. In Epistolae Merowingici et Karolini aevi (I), 3:110-53. Monumenta Germaniae Historica. Epistolae. Ed. Gundlach, Wilhelm \& Ernst Dümmler. Berlin: Apud Weidmannos, 1892.

EP. SEVERI = „Severi Epistola ad omnem Ecclesiam, de virtutibus in Minoricensi insula factis per reliquias sancti Stephani”. In S. Aurelii Augustini Opera Omnia, 41:821-32. Patrologia Latina. Ed. Migne, Jacques-Paul. Bonn: apud Garnier fratres, 1864. 
EugIPP. V. SEV. = Eugippii Vita sancti Severini. Monumenta Germaniae Historica. Auctores Antiquissimi, 1.2. Ed. Sauppe, Hermann. Berlin: Apud Weidmannos, 1877.

EUNAP. FR. = „Eunapius”. In The Fragmentary Classicising Historians of the Later Roman Empire, 2:2-151. ARCA: Classical and medieval texts, papers and monographs 10. Trans. Blockley, Roger C. Liverpool: F. Cairns, 1983.

EVAGR. HE = Evagrius Scholasticus. Historia ecclesiastica - Kirchengeschichte. Fontes Christiani 57. Ed. Hübner, Adelheid. Turnhout: Brepols, 2007. Angol fordítása: The Ecclesiastical History of Evagrius Scholasticus. Translated Text for Historians 33. Trans. Whitby, Michael. Liverpool: Liverpool University, 2000.

FREDEGAR $=$ Krusch, Bruno, Ed. Fredegarii et aliorum Chronica. . Vitae sanctorum. Monumenta Germaniae Historica. Scriptores rerum Merovingicarum (SS rer. Merov.) 2. Hannover: Impensis Bibliopolii Hahniani, 1888.

GAI. INST. = Gaius Institutiones. Ed. Manthe, Ulrich. Darmstadt: WBG, 2010.

GELASIUS EP. = Thiel, Andreas, szerk. Epistolae Romanorum pontificum genuinae et quae ad eos scriptae sunt A.S. Hilaro usque ad Pelagium II. Tomus I. A.S. Hilaro ad Pelagium. Ann. 461523. Braunsberg: Eduardi Peter, 1868.

GREG. TUR. GLOR. MART. = „Gloriam Martyrum Gregory of Tours”. In Gregorii Turonensis Opera, 2.: Miracula et opera minora. Editio nova lucisope expressa:34-111. Monumenta Germaniae Historica. Scriptores rerum Merovingicarum. Ed. Krusch, Bruno. Hannover: Impensis Bibliopolii Hahniani, 1885.

GrEG. TUR. HF. = Gregorii Turonensis Opera . Vol. 1.: Gregorii Episcopi Turonensis Decem Libri Historiarum. Monumenta Germaniae Historica. Scriptores rerum Merovingicarum 1. Ed. Krusch, Bruno. Hannover: Impensis Bibliopolii Hahniani, 1937.

G. S. = „Gesta senatus Romani de Theodosiano publicando”. In Theodosiani libri XVI cum Constivtionibvs Sirmondianis et Leges novellae ad Theodosianvm pertinentes, Vol. 1. Ed. Mommsen, Theodor \& Paul M. Meyer. Berlin: Apud Weidmannos, 1905.

HDT. = Herodotus. The Persian Wars. Trans. A. D. Godley. Loeb Classical Library 117-120. Cambridge, MA: Harvard University, 1920. Magyarul: Hérodotosz: A Görög-Perzsa Háború. Ford.: Muraközi Gyula. Budapest: Osiris, 2000.

Hom. IL. = Homer. Iliad. Trans. A. T. Murray. Vol. 1-2. Loeb Classical Library 170-171. Cambridge MA: Harvard University, 1924.

HYd. Chron. = The Chronicle of Hydatius and the Consularia Constantinopolitana: two Contemporary Accounts of the Final Years of the Roman Empire. Trans. Burgess, R. W. Oxford: Clarendon, 1993. Magyar fordítása: Hydatius. Chronica (379-469). Fordította Széll Gábor. Documenta historica 68. Szeged: JATEPress, 2005.

I. ANTIOCH FR. = Ioannis Antiocheni fragmenta quae supersunt omnia . Corpus Fontium Historiae Byzantinae. Series Berolinensis 47. Ed. Mariev, Sergei. Berlin, New York: Walter de Gruyter, 2008.

I. NikiU. Chron. = The Chronicle Of John, Bishop Of Nikiu. Trans. Charles, R. H. London: Williams \& Norgate, 1916.

INST. = „Iustiniani Institutiones”. In Corpus Iuris Civilis, Vol. 1. Ed. Kruger, Paul. Berlin: Apud Weidmannos, 1899.

JER. ADV. RUFIN. = Hieronymus. Contra Rufinum. Corpus Christianorum Series Latina 79A. Turnhout: Brepols, 1982.

JER. C. IOA. $=$ S. Hieronymus presbyter Contra Iohannem. Corpus Christianorum Series Latina 79A. Ed. Feiertag, J.L. Turnhout: Brepols, 1999. 
JER. DAN. = Hieronymus. Commentariorum in Danielem Prophetam Liber Unus. Ed. F. Glorie. Corpus Christianorum Series Latina 75A. Turnhout: Brepols, 1964.

Jerom. EP. = Jeromos. Select Letters. Loeb Classical Library 262. Cambridge MA: Harvard University, 1933. Magyar fordítása: Szent Jeromos Levelek. Ford. Takács László \& Puskely Mária. Vol. 1-2. köt. Budapest: Szenzár, 2005.

JOH. EPH. HE = Joannis episcopi Ephesi Monophysitae Scripta historica quotquot adhuc inedita supererant. Anecdota Syriaca 2. Leiden: Lentner, 1868. Angol fordítása: Payne Smith, R., Ed. The third part of The ecclesiastical history of John, Bishop of Ephesus. Ed. Land, Jan Pieter Nicolaas. Oxford: Oxford University, 1860.

JOH. MAL. = Ioannis Malalae Chronographia. Corpus scriptorum historiae Byzantinae 6. Ed. Ludwig August Dindorf. Bonn: Impensis Ed. Weberi, 1831. Angol fordítása: The Chronicle of John Malalas. Ford. Elizabeth Jeffreys, Michael Jeffreys, Roger Scott \& Brian Croke. Byzantina Australiensia 4. Australian Association for Byzantine Studies, 1986.

JORD. GET. = „De origine actibusque Getarum”. In Iordanis Romana et Getica, 53-138. Monumenta Germaniae Historica. Auctores Antiquissimi, 5.1. Ed. Mommsen, Theodor. Berlin: Apud Weidmannos, 1882. Magyar fordítása: Iordanes. Getica: A gótok eredete és tettei. Ford. A PTE Ókortörténeti és Régészeti Tanszékének hallgatói munkaközössége Kiss Magdolna vezetésével. 4. kiad. Budapest: L’Harmattan, 2005.

JORD. ROM. = „De summa temporum vel origine actibusque gentis Romanorum”. In Iordanis Romana et Getica, 1-52. Monumenta Germaniae Historica. Auctores Antiquissimi, 5.1. Ed. Mommsen, Theodor. Berlin: Apud Weidmannos, 1882. Magyar fordítása: Iordanes. Romana: Az idők rövid összefoglalása, avagy a római nép eredete és tettei. Ford. Horváth Szilvia. Vivarivum Fontivum 7. Kaposvár - Pécs: Rippl-Rónai Múzeum - GeniaNet, 2014.

LIB. GEN. = „Liber genealogus”. In Chronica minora, 1:154-96. Monumenta Germaniae Historica. Auctores Antiquissimi 9. Ed. Mommsen, Theodor. Berlin: Apud Weidmannos, 1892.

LIB. OR. = Libanii Opera . Vol. 1-4.: Orationes. Ed. Foerster, Richardus. Leipzig: Teubner, 1903.

LiB. PONT. = Liber Pontificalis. Vol. 1. Monumenta Germaniae Historica. Gesta pontificum Romanorum. Ed. Mommsen, Theodor. Berlin: Apud Weidmannos, 1898.

LiBAnIUS, Ep. = Libanius. Autobiography and Selected Letters. Trans. A. F. Norman. Loeb Classical Library 478-479. Cambridge MA: Harvard University, 1992.

LiV. = Livy. History of Rome. Trans. B. O. Foster, Evan T. Sage, Alfred C. Schlesinger \& Frank Gardner Moore. Loeb Classical Library 114, 133, 172, 191, 233, 355, 367, 381, 295, 301, 313, 332, 396, 404. Cambridge, MA: Harvard University, 1919.

MALCH. = „Malchus”. In The Fragmentary Classicising Historians of the Later Roman Empire, 2:402-63. ARCA: Classical and medieval texts, papers and monographs 10. Trans. Blockley, Roger C. Liverpool: F. Cairns, 1983.

MARC. COM. = „Marcellini V.C. comitis chronicon”. In Chronica minora saec. IV. V. VI. VII. (II), 37-106. Monumenta Germaniae Historica. Auctores Antiquissimi 11. Ed. Mommsen, Theodor. Berlin: Apud Weidmannos, 1894.

Men. PROT. $=$ The History of Menander the Guardsman. ARCA: Classical and medieval texts, papers and monographs 17. Trans. Blockley, Roger C. Liverpool: Francis Cairns, 1985.

Merobaud. CARM. = „Fl. Merobaudis reliquiae”. In Fl. Merobaudis reliquiae. Blossii Aemilii Dracontii Carmina. Eugenii Toletani episcopi Carmina et epistulae, 1-20. Monumenta Germaniae Historica. Auctores Antiquissimi 14. Ed. Vollmer, Fridericus. Berlin: Apud Weidmannos, 1961. Magyar fordítása: Olajos, Terézia. „Merobaudes müvei”. Antik Tanulmányok: Studia Antiqua 13, sz. 1 (1966): 172-88.

Nic. CALl. HE. = Nicephori Callisti Ecclesiasticae Historiae. Vol. 145-147. Patrologiae Cursus Completus, Series Graeca. Ed. Migne, Jacques Paul. Paris: apud Garnier fratres, 1904. 
NiCEPH. Greg. HiST. BYZ. = Nicephori Gregorae Byzantinae Historiae. Vol. 148-149. Patrologiae Cursus Completus, Series Graeca. Ed. Migne, Jacques Paul. Paris: apud Garnier fratres, 1904.

Niceph. Chron. Synth. $=$ Nicephori Archiepiscopi Constantinopolitani Opuscula Historica. Ed. De Boor, Carl. Leipzig: Teubner, 1880.

Nonnus. Dion. = W. H. D. Rouse. Vol. 1-3. Loeb Classical Library 344, 354, 356. Trans. Nonnos. Dionysiaca. Cambridge, MA: Harvard University, 1940.

Not. Dign. OCC. $=$ Notitia dignitatum et administrationum omnium tam civilium quam militarium in partibus Occidentis. Ed. Böcking, Eduard. Bonn: Marcus, 1839.

NOT. DiGN. OR. = Notitia dignitatum et administrationum omnium tam civilium quam militarium in partibus Orientis. Ed. Böcking, Eduard. Bonn: Marcus, 1839.

Nov. = Iustiniani Novellae. Vol. 3.: Novellae. Corpus Iuris Civilis. Ed. Schoell, R. \& G. Kroll. Berlin: Apud Weidmannos, 1912.

NOV. THEOD. $=$ Theodosiani libri XVI cum Constivtionibvs Sirmondianis et Leges novellae ad Theodosianvm pertinentes. Vol. 1. Ed. Mommsen, Theodor, és Paul M. Meyer. Berlin: Apud Weidmannos, 1905.

NVAL. = „Novellae Valentiniani”. In Theodosiani libri XVI cum Constivtionibvs Sirmondianis et Leges novellae ad Theodosianvm pertinentes, 2:69-154. Ed. Mommsen, Theodor \& Paul M. Meyer. Berlin: Apud Weidmannos, 1905.

OLYMP. FR. = „Olympiodorus”. In The Fragmentary Classicising Historians of the Later Roman Empire, 2:152-221. ARCA: Classical and medieval texts, papers and monographs 10. Trans. Blockley, Roger C. Liverpool: F. Cairns, 1983.

Oros. = Pauli Orosii Historiarum adversum paganos libri VII. Corpus Scriptorum Ecclesiasticorum Latinorum 5. Ed. Zangemeister, Karl. Bécs: Apud C. Geroldi filium, 1882.

PACAT. PANEG. = „Panegyricus Pacati Theodosio dictus”, 471-520. Patrologiae Cursus Completus, Series Latina 13. Ed. Migne, Jacques-Paul. Paris: Excudebat Vrayet, 1845. Angol fordítása: Pacatus Panegyric to the Emperor Theodosius. Trans. Nixon, C. E. V. Liverpool: Liverpool University, 1987.

PAUl. Diac. Hist. LANG. = „Pauli historia Langobardorum”. In Scriptores rerum Langobardicarum et Italicarum saec. VI-IX, 12-192. Monumenta Germaniae Historica. Scriptores rerum Langobardicarum et Italicarum 1. Ed. Waitz, Georg Hannover: Impensis Bibliopolii Hahniani, 1878. Magyar fordítása: Paulus Diaconus. A Langobardok története. Fordította György Galamb. Medievalia. Budapest: L'Harmattan, 2012.

Paul. Mediolanensis, V. Ambrosi = Paulinus, Mediolanensis. „Vita Sancti Ambrosii Mediolanensis Episcopi”. Patrologia Latina 20. Ed. Jacques-Paul Migne. Bonn: apud Garnier fratres, 1845. 711-52.

PHILOSTOR. HIST. ECCL. = Philostorgios Kirchengeschichte. Vol. 1-2. Kleine und fragmentarische Historiker der Spätantike 7. Trans. Bleckmann, Bruno \& Markus Stein, Paderborn: Ferdinand Schöningh, 2015. Angol fordítása: Philostorgius. Philostorgius: Church History. Ford. Philip R. Amidon. Writings from the Greco-Roman World 23. Atlanta, GA: Society of Biblical Literature, 2007.

Plat. Meno. = Platón. Menón. Ford. Bárány István. Budapest: Atlantisz, 2013.

Plin. HN = Pliny. Natural History. Trans. H. Rackham. Loeb Classical Library 330. Cambridge, MA: Harvard University, 1938.

PolYB. = Polybius. The Histories. Trans. W. R. Paton. Loeb Classical Library 128, 137, 138, 159, 160, 161. Cambridge, MA: Harvard University, 2010. 
PRISC. FR. = „Priscus”. In The Fragmentary Classicising Historians of the Later Roman Empire, 2:222-401. ARCA: Classical and medieval texts, papers and monographs 10. Trans. Blockley, Roger C. Liverpool: F. Cairns, 1983.

Procop. Aed. = Procopius. On Buildings. Trans. H. B. Dewing. Loeb Classical Library 343. Cambridge MA: Harvard University, 1940.

Procop. Arc. $=$ Procopius. The Anecdota or Secret History. Trans. H. B. Dewing. Loeb Classical Library 290. Cambridge, MA: Harvard University, 1935. Új angol nyelvü kiadása: Prokopios. The Secret History with Related Texts. Ed. Anthony Kaldellis. Indianapolis Cambridge: Hackett, 2010.

ProcoP. DE BELLIS = Procopius. History of the Wars. Trans. H. B. Dewing. Loeb Classical Library 48, 81, 107, 173, 217. Cambridge, MA: Harvard University, 1914. Új angol nyelvü kiadása: Kaldellis, Anthony, Ed. The Wars of Justinian. Trans. H. B. Dewing. Indianapolis Cambridge: Hachette, 2014.

PROSP. TIRO = „Prosperi Tironis epitoma chronicon”. In Chronica minora saec. IV. V. VI. VII. (I), 342-485. Monumenta Germaniae Historica. Auctores Antiquissimi 9. Ed. Mommsen, Theodor, Berlin: Apud Weidmannos, 1892.

Prudent. C. Symm. = Prudentius. Against Symmachus 2. Crowns of Martyrdom. Scenes From History. Epilogue. Trans. H. J. Thomson. Loeb Classical Library 398. Cambridge, MA: Harvard University, 1953.

Ps.-ZACh. Rhet. Chron. = The Chronicle of Pseudo-Zachariah Rhetor: Church and War in Late Antiquity. Trans. Robert R. Phenix és Cornelia B. Horn. Translated Text for Historians 55. Ed. Greatrex, Geofferey. Liverpool: Liverpool University, 2011.

SHA QUAD. TYR. = „The Lives of Firmus, Saturninus, Proculus and Bonosus”. In Historia Augusta, 3.: The Two Valerians. The Two Gallieni. The Thirty Pretenders. The Deified Claudius. The Deified Aurelian. Tacitus. Probus. Firmus, Saturninus, Proculus and Bonosus. Carus, Carinus and Numerian:386-415. Trans. Magie, David. Loeb Classical Library 263.

SHA TYr. Trig. = „The Thirty Pretenders”. In Historia Augusta, 3.: The Two Valerians. The Two Gallieni. The Thirty Pretenders. The Deified Claudius. The Deified Aurelian. Tacitus. Probus. Firmus, Saturninus, Proculus and Bonosus. Carus, Carinus and Numerian:64-151. Loeb Classical Library 263. Trans. Magie, David. Cambridge, MA: Harvard University, 1932.

SiD. Apoll. CARM. $=$ Gai Solii Apollinaris Sidonii Epistulae et carmina . Monumenta Germaniae Historica. Auctores Antiquissimi 8. Ed. Lütjohann, Christian. Berlin: Apud Weidmannos, 1887.

SOCRATES, HIST. ECCL. = Socratis Scholastici Historia Ecclesiastica. Patrologiae Cursus Completus, Series Graeca 67. Ed. Migne, Jacques Paul. Paris: Imprimerie Catholique, 1864.

Suet. Aug. = Suetonius. Lives of the Caesars. Trans. J. C. Rolfe. Vol. 1.: Julius. Augustus. Tiberius. Gaius. Caligula. Loeb Classical Library 31. Cambridge, MA: Harvard University, 1914.

SYMm. Ep. $=$ Q. Aurelii Symmachi quae supersunt. Monumenta Germaniae Historica. Auctores Antiquissimi, 6,1. Ed. Seeck, Otto. Berlin: Apud Weidmannos, 1893.

SyN. EP. = Synésios de Cyrène. Trans. Denis Roques. Vol. 2-3: Correspondance: Lettres I-CLVI. Collection des universités de France Série grecque. Paris: Les Belles Lettres, 2000.

Tacitus Ann. = Tacitus. The annals. Trans. J. Jackson. Loeb Classical Library 249, 312, 322. Cambridge, MA: Harvard University, 1931-1937. Magyar fordítása: Publius Cornelius Tacitus. Tacitus összes müvei. Ford. Borzsák I. Budapest: Európa, 1980. 
Tacitus Germ. = Tacitus. Agricola. Germania. Dialogue on Oratory. Trans. M. Hutton. Loeb Classical Library 35. Cambridge, MA: Harvard University, 1914. Publius Cornelius Tacitus. Tacitus összes müvei. Fordította István Borzsák. Budapest: Európa, 1980.

THEM. OR. = Themistii Orationes quae supersunt. Ed. Downey, G. \& A. F. Norman. Leipzig: Teubner, 1974.

THEOD. LeCT. EPIT. $=$ Theodoros Anagnostes. Epitome Historiae Tripartitae. Ed. Christian Hanson Guenther. Theodoros Anagnostes Kirchengeschichte. Berlin: Akademie, 1971.

THEOPH. AM = Theophanis Chronographia. Ed. De Boor, Carl. Leipzig: Teubner, 1883.

Thuc. = Thucydides Historiae. Ed.: Karl Hude, Vol 1-2. Leipzig: Teubner, 1913-25. Magyar fordítása: Thuküdidész. A Peloponnészoszi Háború. Ford. Muraközi Gyula. Budapest: Osiris, 1999.

Tzetzes ChIL. III. Hist. = Ioannis Tzetzae Historiarum Variarum Chiliades. Ed. Kiessling. Leipzig: Teubner, 1826.

Verg. Aen. = „Vergilius Aeneis”, In Vergilius összes müvei. Ford. Lakatos István. Budapest: Helikon, 1967.

Vict. TonN. $=$ „Victoris Tonnennensis Episcopi Chronica”. In Chronica minora saec. IV. V. VI. VII. (II), 163-224. Monumenta Germaniae Historica. Auctores Antiquissimi 11. Ed. Mommsen, Theodor. Berlin: Apud Weidmannos, 1894. Magyar fordítása: Tunnunai Victor. Chronica: 444-565. Fordította Gábor Széll. Documenta historica 80. JATEPress, 2008.

V. Mel. Gr. = Vie de sainte Mélanie. Sources Chrétiennes 90. Ed. Gorce, Denys. Paris: Les Études du Cerf, 1976.

ZON. = Ioannis Zonarae epitome historiarum. Vol. 1-6. Bibliotheca scriptorum Graecorum et Romanorum Teubneriana. Ed. Dindorf, Ludwig August. Leipzig: Teubner, 1868. Angol fordítása: Banchich, Thomas, és Eugene Lane. The History of Zonaras: From Alexander Severus to the Death of Theodosius the Great. Routledge Classical Translations. London New York: Routledge, 2011.

Zos. = Zosimus: new history. Byzantina Australiensia 2. Trans. Ridley, Ronald T. Leiden - Boston, MA: Brill, 1982.

\section{Szakirodalom}

ADAMIK 2009 = Adamik, Tamás. Római irodalom: a kezdetektöl a Nyugatrómai Birodalom bukásáig. Pozsony: Kalligram, 2009.

ADAMIK 2001 = Adamik, Béla. „A Római Birodalom hivatalos nyelvhasználatának történetéhez: A iustinianusi reform". Antik Tanulmányok: Studia Antiqua 1-2 (2001): 177-88.

AleXANDER 1967 = Alexander, Paul J. Oracle of Baalbek: The Tiburtine Sibyl in Greek Dress. Dumbarton Oaks Studies 10. Washington: Dumbarton Oaks, 1967.

ALFÖLDI 1934 = Alföldi, Andreas. „Die Ausgestaltung des monarchischen Zeremoniells am römischen Kaiserhofe". Mitteilungen des Deutschen Archäologischen Instituts. Römische Abteilung (1934): 1-118. 
AMORY 2003 = Amory, Patrick. People and Identity in Ostrogothic Italy, 489-554. Vol. 33. Cambridge Studies in Medieval Life and Thought 4. Cambridge: Cambridge University, 2003.

Angelova 2015 = Angelova, Diliana. Sacred Founders: Women, Men, and Gods in the Discourse of Imperial Founding, Rome through Early Byzantium. Oakland: University of California, 2015.

ANGELOVA 2014 = Angelova, Diliana. „The Stamp of Power: The Life and Afterlife of Pulcheria's Buildings". In Byzantine Images and Their Afterlives: Essays in Honor of Annemarie Weyl Carr, Ed. Annemarie Weyl Carr, Lynn Jones, \& Kathleen Maxwell, 83-103. Burlington: Ashgate, 2014.

Ast - LougovayA, $2015=$ Ast, Rodney - Lougovaya, Julia „The Art of the Isopsephism in the Greco-Roman World”. In Ägyptische Magie und ihre Umwelt, Ed. Andrea Jördens, 2015., 82-98. Wiesbaden: Harrassowitz, 2015.

BAÁN 1997 = Baán, István. Justinianus császár teológiája. Varia Byzantina Bizánc világa 2. Budapest: Bizantinológiai Intézeti Alapítvány, 1997.

BARDILL 2006 = Bardill, Jonathan. „A New Temple for Byzantium: Anicia Juliana, King Solomon and the Gilded Ceiling in the Church of St Polyeuktos in Constantinople". In Social and Political Life in Late Antiquity, Ed. William Bowden, Adam Gutteridge, \& Carlos Machado, 1:339-72. Late Antique Archaeology. Leiden - Boston: Brill, 2006.

BARDILL 2004 = Bardill, Jonathan. Brickstamps of Constantinople: Two Volumes. Oxford - New York: Oxford University, 2004.

BARNES 1993 = Barnes, Thimothy David. Constantine and Eusebius. Cambridge: Harvard University, 1993.

BARNISH 1983 = Barnish, Samuel J. B. „The »Anonymus Valesianus« II as a Source for the Last Years of Theoderic". Latomus 3 (1983): 572-96.

BARnwell 1992 = Barnwell, Paul S. Emperor, Prefects and Kings: The Roman West, 395-565. London: Duckworth, 1992.

BENEDICTY 1960 = Benedicty, Róbert. Hogyan foglalta el Alarich Rómát? Antik Tanulmányok, 9 (1960): 75-81.

BERGMÜLlER 1903 = Bergmüller, Ludwig. Einige Bemerkungen zur Latinität des Jordanes. Augsburg: Pfeiffer, 1903.

Beschaouch 1969 = Beschaouch, Azedine. „Uzappa et le proconsul d'Afrique Sex. Cocceius Anicius Faustus Paulinus". Mélanges d'archéologie et d'histoire 1 (1969): 195-218.

BLOCKLEY 1982 = Blockley, Roger C. „Roman-Barbarian Marriages in the Late Empire”. Florilegium, 4 (1982): 63-79.

BlOCKLEY 1983 = Blockley, Roger C., Trans. The Fragmentary Classicising Historians of the Later Roman Empire: Eunapius, Olympiodorus, Priscus and Malchus. ARCA: Classical and Medieval Texts, Papers and Monographs 10. Liverpool: Francis Cairns, 1983.

Blois 1976 = Blois, Lukas de. The Policy of the Emperor Gallienus. Studies of the Dutch Archaeological and Historical Society 7. Leiden: Brill, 1976.

Blumenthal 1978 = Blumenthal, Henry J. ,529 and Its Sequel: What Happened to the Academy?" Byzantion: Revue Internationale Des Études Byzantines (1978): 369-385.

BOYANCÉ 1972 = Boyancé, Pierre. Le culte des muses chez les philosophes grecs: études d'histoire et de psychologie religieuses. Bibliothèque des Écoles Françaises d'Athènes et de Rome. Paris: Boccard, 1972.

BÓNA 1993 = Bóna, István, szerk. Hunok-gepidák-langobardok. Magyar östörténeti könyvtár 6 . Szeged: József Attila Tudományegyetem, Magyar Östörténeti Kutatócsoport, 1993. 
BRADBURRY 1996 = Severus of Minorca: Letter on the Conversion of the Jews. Ed. Scott Bradbury. Oxford: Clarendon Press, 1996.

BRENK 1987 = Brenk, Beat. "Spolia from Constantine to Charlemagne: Aesthetics versus Ideology." Dumbarton Oaks Papers 41 (1987): 103-109. doi: 10.2307/1291549.

BROwn 1971 = Brown, Peter. The World of Late Antiquity: From Marcus Aurelius to Muhammad. London: Thames and Hudson, 1971.

BRown 2013 = Brown, Peter. The Rise of Western Christendom: Triumph and Diversity, A.D. 2001000. 10th anniversary reviewed edition. The Making of Europe. Chichester - Malden: Wiley-Blackwell, 2013.

BURY 1923 = Bury, John Bagnell. A History of the Later Roman Empire: From the Death of Theodosius I. to the Death of Justinian. Reprint. Vol. 1-2. London: Dover, 1923.

BuRGESS 1993 = Burgess, Richard W. The „Chronicle of Hydatius” and the „Consularia Constantinopolitana": Two Contemporary Accounts of the Final Years of the Roman Empire. Oxford: Clarendon, 1993.

CAMERON 1976 = Cameron, Alan. Circus Factions: Blues and Greens at Rome and Byzantium. Oxford: Clarendon, 1976.

CAMERON 1978 = Cameron, Alan. „The House of Anastasius”. Greek, Roman and Byzantine Studies, 19 (1978): 259-76.

CAMERON 1984 = Cameron, Alan. „Anicius Claudius (I.Cret. Iv. 322)”. Zeitschrift Für Papyrologie Und Epigraphik (1984): 147-48.

CAMERON 1988 = Cameron, Alan. „Flavius: A Nicety of Protocol”. Latomus, 1 (1988): 26.

CAMERON 2012 = Cameron, Alan. „Anician Myths”. The Journal of Roman Studies 102 (2012): $133-71$.

CAmeron 2012B = Cameron, Alan. „Basilius and His Diptych Again: Career Titles, Seats in the Colosseum, and Issues of Stylistic Dating”. Journal of Roman Archaeology 1 (2012): 51330 .

CAmeron - ConRAD - King 1995 = Cameron, Averil, Lawrence I. Conrad, és Geoffrey R. D. King, Ed. The Byzantine and Early Islamic Near East: States, Resources, and Armies. Studies in Late Antiquity and Early Islam 1. Darwin, 1995.

CAPIZZI 1997 = Capizzi, Carmelo. Anicia Giuliana: La Committente (c. 463 - c. 528). Donne d'Orient e d'Occidente 4. Milano: Jaca Book, 1997.

ÇETINKAYA 2009 = Çetinkaya, Haluk. „An Epitaph of a Gepid King at Vefa Kilise Camii in. Istambul". Revue Des Etudes de Byzantines, 67 (2009): 225-229.

Chastagnol 1956 = Chastagnol, André. Les Fastes de la Préfecture de Rome au Bas-Empire. Etudes Prosopographiques, II. Paris: Nouvelles Editions Latines, 1956.

Chastagnol 1960 = Chastagnol, André. La Préfecture urbaine à Rome sous le Bas-Empire. Publications de la Faculté des Lettres et Sciences Humaines D'Alger 34. Paris: Universitaires de France, 1960.

Chastagnol 1966 = Chastagnol, André. Le Sénat romain sous le règne d'Odoacre: Recherches sur l'Épigraphie du Colisée au Ve siècle. Antiquitas. Reihe 3, Abhandlungen zur Vor- und Frühgeschichte, zur klassischen und provinzial-römischen Archäologie und zur Geschichte des Altertums 3. Bonn: Rudolf Habelt, 1966.

Christie 1998 = Christie, Neil. The Lombards: The Ancient Longobards. Oxford: WileyBlackwell, 1998.

Christol 1986 = Christol, Michel. „À propos des Anicii: le IIIe siècle”. Mélanges de l'Ecole française de Rome. Antiquité 1 (1986): 141-64. 
Chrysos 1989 = Chrysos, Evangelos K. „Legal Concepts and Patterns for the Barbarians” Settlement on Roman Soil". In Das Reich Und Die Barbaren, Ed. Evangelos K. Chrysos, Reprint 2016., 13-24. Veröffentlichungen Des Instituts Für Österreichische Geschichtsforschung 29. Berlin - Boston: De Gruyter, 1989. doi:10.7767/9783205102977003 .

Clover $1971=$ Clover, Frank M., Trans. „Flavius Merobaudes: A Translation and Historical Commentary". Transactions of the American Philosophical Society, New Series 1 (1971): 178.

ClOver 1978 = Clover, Frank M. „The Family and Early Career of Anicius Olybrius”. Historia: Zeitschrift Für Alte Geschichte 1 (1978): 169-96.

CLRE = Bagnall, Roger Shaler, Alan Cameron, Seth R. Schwartz, és Klaas A. Worp. Consuls of the Later Roman Empire. Philological Monographs of the American Philological Association 36. Atlanta: American Philological Association, 1987.

COATES-STEPHENS 1996 = Coates-Stephens, Robert. „Housing in Early Medieval Rome, 500-1000 AD." Papers of the British School at Rome (1996): 239-59.

CoATES-STEPHENS 2003 = Coates-Stephens, Robert. "Attitudes to Spolia in Some Late Antique Texts.” Late Antique Archaeology 1 (2003) 339-358. doi: 10.1163/22134522-90000014.

COURTOIS 1955 = Courtois, Christian. Les Vandales et l'Afrique. Reprint (1964). Aalen: Scientia, 1955.

CoYne 1988 = Coyne, Patricia. „Priscian’s De Laude Anastasii Imperatoris”. PhD disszertáció, McMaster University, 1988.

CROKE 1983 = Croke, Brian. „A.d. 476: The Manufacture of a Turning Point”. Chiron 13 (1983): $81-119$.

CROKE $1987=$ Croke, Brian. „Cassiodorus and the Getica of Jordanes”. Classical Philology 2 (1987): 117-34.

CROKE $1990=$ Croke, Brian. „Theodor Mommsen and the Later Roman Empire”. Chiron. Mitteilungen Der Kommission Für Alte Geschichte Und Epigraphik Des Deutschen Archäologischen Instituts, 20 (1990): 159-89.

CROKE 2001 = Croke, Brian. Count Marcellinus and His Chronicle. Oxford - New York: Oxford University, 2001.

CROKE $2010=$ Croke, Brian. „Reinventing Constantinople: Theodosius I's Imprint on the Imperial City". In From the Tetrarchs to the Theodosians: Later Roman History and Culture, 284-450 Ce, Szerk. Scott McGill, Cristiana Sogno \& Edward Jay Watts, 241-64. Yale Classical Studies 34. Cambridge - New York: Cambridge University, 2010.

DAHN $1865=$ Dahn, Felix. Prokopius von Cäsarea: ein Beitrag zur Historiographie der Völkerwanderung und des sinkenden Römerthums. E. S. Mittler und Sohn, 1865.

DAHN 1866 = Dahn, Felix. Die könige der Germanen: Das wesen des ältesten königthums der germanischen stämme und seine geschichte bis auf die feudalzeit. Würzburg: E. A. Fleischmann, 1866.

DAHN $1881=$ Dahn, Felix. Urgeschichte der germanischen und romanischen Völker. Berlin: G. Grote'sche, 1881.

DEMANDT 1969 = Demandt, A. „Der Tod des älteren Theodosius”. Historia: Zeitschrift für Alte Geschichte 5 (1969): 598-626.

DEMANDT 1969A = Demandt, A. „M. A. Wes, Das Ende des Kaisertums im Westen des Römischen Reichs. Aus dem Holl, übertragen von K. E. Mittring”. Byzantinische Zeitschrift 1 (1969): 96-101. 
DEMANDT 1989 = Demandt, Alexander. „The Osmosis of Late Roman and Germanic Aristocracies". In Das Reich Und Die Barbaren, Ed. Evangelos K. Chrysos, Reprint 2016., 75-86. Veröffentlichungen Des Instituts Für Österreichische Geschichtsforschung 29. Berlin - Boston: De Gruyter, 1989.

DEMANDT 1989A = Demandt, Alexander. Die Spätantike: römische Geschichte von Diocletian bis Justinian, 284-565 n. Chr. München: C. H. Beck, 1989.

DEWING 1940 = Dewing, Henry Bronson. „Appendix I.: The Equestrian Statue of Justinian in the Augustaeum (Buildings, I.2.5-12)". In On Buildings, 7:395. Loeb Classical Library 343. London: Harvard University, 1940.

DeY 2012 = Dey, Hendrik. "Spolia, Milestones and City Walls: The Politics of Imperial Legitimacy in Late Third-Century Gaul." In Patrons and Viewers in Late Antiquity, szerk. S. Birk Toft and B. Poulsen. Aarhus: Aarhus University, 2012. 298-307.

DIESNER 1963 = Diesner, Hans-Joachim. Orosius und Augustinus. Budapest: Magyar Tudományos Akadémia, 1963.

Dilley 2010 = Dilley, Paul C. „The Invention of Christian Tradition: “Apocrypha,” Imperial Policy, and Anti-Jewish Propaganda". Greek, Roman, and Byzantine Studies 50 (2010): 586615.

DöLgER 1953 = Dölger, Franz. Byzanz und die europäische Staatenwelt: Ausgewählte Vorträge und Aufsätze. Reprint (1976). Darmstadt: Wissenschaftliche Buchgessellschaft, 1953.

DöLGER 1940 = Dölger, Franz. „Die »Familie der Könige« im Mittelalter”. Historisches Jahrbuch (1940): 397-420.

ENSSLIN 1947 = Ensslin, Wilhelm. Theoderich der Grosse. München. Münchner, 1947.

ERRINGTON 1996 = Errington, R. Malcolm. „Theodosius and the Goths”. Chiron (1996): 1-27.

ERRINGTON $2006=$ Errington, R. Malcolm. Roman Imperial Policy from Julian to Theodosius . Chapel Hill: University of North Carolina, 2006.

EvANS-GRUBBS 1989 = Evans-Grubbs, Judith. „Abduction Marriage in Antiquity: A Law of Constantine (CTh IX 24.1) and Its Social Context". Journal of Roman Studies (1989): 5983.

FABBRINI 1979 =Fabbrini, Fabrizio. Paolo Orosio uno storico. Roma: Storia e Letteratura, 1979.

FREY 2016 = Frey, Jon M. Spolia in Fortifications and the Common Builder in Late Antiquity. Mnemosyne, Supplements. History and Archaeology of Classical Antiquity 389. Leiden, Boston: Brill, 2016.

FRÖHLICH 1989 = Fröhlich, Thomas. „The Study of the Lombards and the Ostrogoths at the German Archaeological Institute of Rome, 1937-1943”. Fragmenta 2 (2008): 183-213.

GALDI $2010=$ Galdi, Giovanbattista. „Late Sparsa Collegimus: The Influence of Sources on the Language of Jordanes". In Colloquial and Literary Latin, Ed. Eleanor Dickey \& Anna Chahoud, 357-75. Cambridge: Cambridge University, 2010.

GALONNIER 2010 = Galonnier, Alain. „Anecdoton Holderi ou Ordo generis Cassiodororum, Introduction, édition, traduction et commentaire". Antiquité Tardive 4 (1996): 299-312.

GAUDENZI 1888 = Gaudenzi, Augusto. Sui rapporti tra l'Italia e l'impero d'Oriente fra gli anni 476 e 554 D. C.: studio storico e giuridico. Bologna: Tip militare, 1888.

GEARY 1988 = Geary, Patrick J. Before France and Germany: The Creation and Transformation of the Merovingian World. New York: Oxford University, 1988.

GEARY 2014 = Geary, Patrick J. A nemzetek mitosza: Európa népeinek születése a középkorban. Budapest: Atlantisz, 2014. 
Georgacas 1947 = Georgacas, Demetrius John. „The Names of Constantinople”. Transactions and Proceedings of the American Philological Association (1947): 347. doi:10.2307/283503.

Gerola 1931 = Gerola, Guiseppe. Le vedute di Costantinopoli di Cristoforo Buondelmonti. Studi bizantini e neoellenici. Vol. III. Roma: R. Garroni. 1934.

GIBBON 1776 = Gibbon, Edward. The History of the Decline and the Fall of the Roman Empire. Ed. John Bagnell Bury. Vol. 1-6. London: Strahan \& Cadell, 1776.

Gillett $2004=$ Gillett, Andrew. Envoys and Political Communication in the Late Antique West, 411-533. Cambridge Studies in Medieval Life and Thought: Fourth Series. Cambridge: Cambridge University, 2004.

Goetz 1980 = Goetz, Hans-Werner. Die Geschichtstheologie des Orosius. Darmstadt: Wissenschaftliche Buchgesellschaft, 1980.

GOFFART 1988 = Goffart, Walter. The Narrators of Barbarian History (A.D. 550-800): Jordanes, Gregory of Tours, Bede, and Paul the Deacon. Princeton: Princeton University, 1988.

GOFFART 2010 = Goffart, Walter. „The Technique of Barbarian Settlement in the Fifth Century: A Personal, Streamlined Account with Ten Additional Comments". Journal of Late Antiquity 1 (2010).

GRABAR 1936 = Grabar, André. L'empereur dans l'art byzantine. Recherches sur l'art officiel de l'empire d'Orient. Vol. 75. Publications de la Faculté des Lettres de l'Université de Strasbourg. Paris, 1936.

GREATREX 1997 = Greatrex, Geoffrey. „The Nika Riot: A Reappraisal”. The Journal of Hellenic Studies (1997): 60-86. doi:10.2307/632550.

GREATREX 2011 = The Chronicle of Pseudo-Zachariah Rhetor: Church and War in Late Antiquity. Trans. Robert R. Phenix és Cornelia B. Horn. Translated Text for Historians 55. Ed. Greatrex, Geofferey. Liverpool: Liverpool University, 2011.

GUIDOBALDI 1986 = Guidobaldi, Frederico. „L'edilizia abitativa unifamiliare nella Roma tardoantica". In Societa Romana e Impero tardo antico II. politica, economia, paesaggio urbano, Ed. Andrea Giardina, 165-237. Roma - Bari: Laterza, 1986.

GuRLITT 1912 = Gurlitt, Cornelius. Die Baukunst Konstantinopels. Berlin: Ernst Wasmuth. 1912.

HAARER 2006 = Haarer, Fiona K. Anastasius I: Politics and Empire in the Late Roman World. Leeds: Francis Cairns, 2006.

HALLETT 2014 = Hallett, Judith P. Fathers and Daughters in Roman Society: Women and the Elite Family. Princeton: Princeton University, 2014.

HARLOW-LAURENCE 2001 = Harlow, Mary, és Ray Laurence. Growing Up and Growing Old in Ancient Rome: A Life Course Approach. London - New York: Routledge, 2001.

HARPER 2012 = Harper, Kyle. „Marriage and Family”. In The Oxford Handbook of Late Antiquity, Ed. Scott Fitzgerald Johnson, 667-718. Oxford - New York: Oxford University, 2012.

HARRISON 1989 = Harrison, R. M. A Temple for Byzantium: The Discovery and Excavation of Anicia Juliana's Palace-Church in Istanbul. Austin: University of Texas, 1989.

HARRISON 1981 = Harrison, R. M. „The Emperor Zeno's Real Name”. Byzantinische Zeitschrift 1 (1981): 27-28. doi:10.1515/byzs.1981.74.1.27.

HEATHER 1989 = Heather, Peter. „Cassiodorus and the Rise of the Amals: Genealogy and the Goths under Hun Domination”. The Journal of Roman Studies, 79 (1989): 103-28.

HEATHER 1991 = Heather, Peter, és John F. Mathisen. The Goths in the Fourth Century. Translated Text for Historians 11. Liverpool: Liverpool University, 1991.

HEATHER 1991B = Heather, Peter J. Goths and Romans, 332-489. Oxford Historical Monographs. Oxford - New York: Oxford University, 1991. 
HeAther $1996=$ Heather, Peter. The Goths. Ed. James Campbell és Barry Cunliffe. The Peoples of Europe. Leichester: Blackwell, 1996.

HEATHER 1997 = Heather, Peter. „Late Antiquity and the Early Medieval West”. In Companion to Historiography, Ed. Michael Bentley, 65-82. London - New York: Routledge, 1997.

HeAther 2006 = Heather, Peter. The Fall of the Roman Empire. Oxford: Oxford University, 2006.

HEATHER 2014 = Heather, Peter. The Restoration of Rome: Barbarian Popes and Imperial Pretenders. Oxford: Oxford University, 2014.

Heather-Moncur 2001 = Themistius. Politics, philosophy, and empire in the fourth century: select orations of Themistius. Trans. David Moncur. Vol. 36. Translated texts for historians. Liverpool, 2001.

HodGKIN 1886 = Cassiodorus. The Letters of Cassiodorus Being A Condensed Translation of the Variae Epistolae of Magnus Aurelius Cassiodorus Senator 1886. Ford. Thomas Hodgkin. London: Henry Frowde, 1886.

HOLDER-EGGER 1877 = Holder-Egger, Oswald. „Die Chronik des Marcellinus comes und die oströmischen fasten". Neues Archiv 2 (1877): 59-109.

Holum 1989 = Holum, Kenneth G. Theodosian Empresses: Women and Imperial Dominion in Late Antiquity. The Transformation of the Classical Heritage 3. Berkeley: University of California, 1989.

Holum 1979 = Holum, Kenneth G., és Gary Vikan. „The Trier Ivory, »Adventus« Ceremonial, and the Relics of St. Stephen”. Dumbarton Oaks Papers (1979): 113.

ISBELL 1994 = Isbell, John Claiborne. The birth of European romanticism: truth and propaganda in Staël's „De l'Allemagne”, 1810-1813. Cambridge studies in French 49. Cambridge - New York: Cambridge University, 1994.

JANIN $1950=$ Janin, Raymond. Constantinople byzantine. Développement urbain et Répertoire topographique. Archives de l'Orient latin 4. Paris: Institut Français d'Études Byzantines, 1950.

JONES 1964 = Jones, Arnold Hugh Martin. The Later Roman Empire, 284-602: A Social, Economic, and Administrative Survey. Vol. 1-3. Oxford: Basil Blackwell, 1964.

JONG 1996 = Jong, Mayke de. Johann Friedrich Böhmer (1795-1863): Romanticus en rijkspatriot. De Middeleeuwen in de negentiende eeuw. Hilversum: Verloren, 1996.

KALDELLIS 2004 = Kaldellis, Anthony. Procopius of Caesarea: Tyranny, History, and Philosophy at the End of Antiquity. Philadelphia: University of Pennsylvania, 2004.

KALDELLIS 2011 = Kaldellis, Anthony. Hellenism in Byzantium: The Transformations of Greek Identity and the Reception of the Classical Tradition. Cambridge - New York: Cambridge University, 2011.

KALDELLIS $2017=$ Kaldellis, Anthony. „The Social Scope of Roman Identity in Byzantium: An Evidence-Based Approach". Byzantina Symmeikta 27 (2017): 173-210.

KAUFMANN 1884 =Kaufmann, G. „Die Fasten von Constantinopel und die Fasten von Ravenna”. Philologus 42 (1884): 471-510.

KERÉNYI 1977 = Kerényi, Károly. Görög mitológia történetek az istenekröl és az emberiségröl; hérósztörténetek. Budapest: Gondolat, 1977.

KINNEY 2001 = Kinney, Dale. "Roman Architectural Spolia." Proceedings of the American Philosophical Society 145 (2001) 138-161.

KISS 2014 = Kiss, P. Attila. ,„»...ut strenui viri...« A gepidák Kárpát-medencei története”. PhD disszertáció, Szegedi Tudományegyetem, 2014. 
KISS 2015 = Kiss P., Attila. „...ut strenui viri...” A gepidák Kárpát-medencei története. Szeged: Szegedi Középkorász Mühely, 2015.

KöPKE 1859 = Köpke, Rudolf. Die Anfänge des Königtums bei den Goten. Berlin: Weidmann, 1859.

KraUtSCHICK 1983 = Krautschick, Stefan. Cassiodor und die Politik seiner Zeit. Habelts Dissertationsdrucke: Reihe Alte Geschichte 17. Bonn: Dr. Rudolf Habelt, 1983.

KuLIKowski 2007 = Kulikowski, Michael. Rome's Gothic Wars: From the Third Century to Alaric. New York: Cambridge University, 2007.

LEERSSEN 2006 = Leerssen, Joseph Theodoor. National Thought in Europe: A Cultural History. Amsterdam: Amsterdam University, 2006.

LieBesChUeTZ 2011 = Liebeschuetz, Wolfgang. „Why Did Jordanes Write the Getica?” Antiquité Tardive 19 (2011): 295-302.

LAFFERTY 2010 = Lafferty, Sean D.W. „The Edictum Theoderici: A Study of a Roman Legal Document from Ostrogothic Italy". PhD disszertáció, University of Toronto, 2010.

LIM 1999 = Lim, Richard. „People as Power: Games, Munificence and Contested Topography”. In The Transformations of Vrbs Roma in Late Antiquity: Proceedings of a Conference Which Took Place on February 13 - 15, 1997, in Part at at the American Academy in Rome and in Part at the University of Rome „La Sapienza”, Ed. William Vernon Harris \& Javier Arce, 265-82. Journal of Roman Archaeology: Supplementary Series 33, 1999.

LIPPOLD 1952 = Lippold, Adolf. „Rom und die Barbaren in der Beurteilung des Orosius”. PhD disszertáció, Universität Erlangen, 1952.

LiVERANi 2004 = Liverani, Paolo. "Reimpiego senza ideologia. La lettura antica degli spolia, dall'Arco di Costantino all'età di Teodorico." Mitteilungen des Deutschen Archäologischen Instituts. Römische Abteilung 111 (2004): 383-434.

LLEWELLYN 1976 = Llewellyn, Peter. „The Roman Church during the Laurentian Schism: Priests and Senators". Church History 4 (1976): 417-27. doi:10.2307/3164345.

LUTTWAK 2011 = Luttwak, Edward N. The Grand Strategy of the Byzantine Empire. Cambridge Massachusetts - London: Belknap, 2011.

MacGillivraY 2008 = MacGillivray, Nicol Donald. „Byzantine Political Thought”. In The Cambridge History of Medieval Political Thought c. 350 - c. 1450, Ed. J. H. Burns, 49-80. Cambridge: Cambridge University, 2008. 10.1017/CHOL9780521243247.006.

MACHADO 2012 = Machado, Carlos. Two Romes: Rome and Constantinople in Late Antiquity. Ed. Lucy Grig és Gavin Kelly. Oxford Studies in Late Antiquity. Oxford University, 2012.

MAENCHEN-HeLfen 1973 = Maenchen-Helfen, Otto. The World of the Huns: Studies in Their History and Culture. Berkeley: University of California, 1973.

MAGDALINO 2001 = Magdalino, Paul. „Aristocratic Oikoi in the Tenth and Eleventh Regions of Constantinople”. In Byzantine Constantinople, Ed. Nevra Necipoğlu, 53-69. Leiden: Brill, 2001.

MAgdalino 1993 = Magdalino, Paul. „The History of the Future and Its Uses: Prophecy, Policy and Propaganda". In The Making of Byzantine History: Studies Dedicated to Donald M. Nicol on His Seventieth Birthday, Ed. R. Beaton \& C. Roueché, 3-34. Aldershot, 1993.

MAIER 2007 = Meier, Hans-Rudolf. Die Anfänge des neuzeitlichen Spolien- begriffs bei Raffael und Vasari und der Konstantinsbogen als Paradigma der Deutungsmuster für den Spoliengebrauch. Das Münster 60 (2007), 2-8.

MAISCHBERGER 1997 = Maischberger, Martin. Marmor in Rom: Anlieferung, Lager- und Werkplätze in der Kaiserzeit. Wiesbaden: Reichert, 1997. 
MALJESKA 1984 = Maljeska, George P. Russian travelers to Constantinople in the fourteenth and fifteenth centuries. Dumbarton Oaks Studies, 19. Washington, D.C: Dumbarton Oaks Research Library and Collection, 1984.

MANGO 1985 = Mango, Cyril A. Le développement urbain de Constantinople, IVe-VIIe siècles. Travaux et mémoires du Centre de recherche d'histoire et civilisation de Byzance 2. Paris: Diffusion de Boccard, 1985.

MANGO 1997 = Mango, Cyril, és Roger Scott. The Chronicle of Theophanes Confessor: Byzantine and Near Eastern History, AD 284-813. Ed. Geoffrey Greatrex. Oxford: Clarendon, 1997.

MANGO-ŠEVČEnKo 1961 = Mango, Cyril, és Ihor Ševčenko. „Remains of the Church of St. Polyeuktos at Constantinople". Dumbarton Oaks Papers, 15 (1961): 243-47.

MARCHAND 1975 = Marchand, Suzanne L. Down from Olympus Archaeology and Philhellenism in Germany, 1750-1970. New Jersey: Princeton University, 1996.

Mathisen 2012 = Mathisen, Ralph W. „Clovis, Anastasius, and Political Status in 508 C.E.: The Frankish Aftermath of the Battle of Vouille'". In The Battle of Vouillé, 507 CE Where France Began, Szerk. Ralph W. Mathisen és Danuta Shanzer. Millennium-Studien Zu Kultur Und Geschichte Des Ersten Jahrtausends n. Chr. 37. Göttingen: De Gruyter, 2012, 79-110.

Matthews 1975 = Matthews, John. Western Aristocracies and Imperial Court, A.D. 364-425. Oxford Reprints. Oxford: University of Oxford, 1975.

MCCORMICK 1990 = McCormick, Michael. Eternal Victory: Triumphal Rulership in Late Antiquity, Byzantium and the Early Medieval West. Cambridge: Cambridge University, 1990.

MeIGGS 1973 = Meiggs, Russell. Roman Ostia. Oxford: Clarendon, 1973.

MEYENDORFF 2001 = Meyendorff, John. Birodalmi egység és keresztény szakadások: Az egyház 450 és 680 között. Trans. Gergely Utry. Varia Byzantina - Bizánc Világa 4. Budapest: Bizantinológiai Intézeti Alapítvány, 2001.

MiLlar 1977 = Millar, Fergus. The Emperor in the Roman World. London: Duckworth, 1977.

Mierow 1908 = Mierow, Charles C. Jordanes: The Origin and Deeds of the Goths. New Jersey: Princeton University, 1908.

Momigliano 1910 = Momigliano, Arnaldo. „Cassiodorus and Italian Culture of His Time”. In Studies in Historiography, 181-210. London: Weidenfels \& Nicolson, 1966.

MOMMSEN $1910=$ Mommsen, Theodor. Gesammelte Schriften. Vol. VI: Historische Schriften III. Berlin: Weidmann, 1910.

MOORHEAD 1978 = Moorhead, John. „The Laurentian Schism: East and West in the Roman Church". Church History 2 (1978): 125-36. doi:10.2307/3164729.

MOORHEAD 1983 = Moorhead, John. „The Last Years of Theoderic”. Historia: Zeitschrift für Alte Geschichte 32 (1983): 106-120.

MOORHEAD 1984 = Moorhead, John. „The Decii under Theoderic”. Historia: Zeitschrift für Alte Geschichte 33 (1984): 107-115.

MOORHEAD 1992 = Moorhead, John. Theoderic in Italy. Oxford: Clarendon, 1992.

MuHLBerger 1990 = Muhlberger, Steven. The Fifth-Century Chroniclers: Prosper, Hydatius, and the Gallic Chronicler of 452. ARCA, Classical and Medieval Texts, Papers, and Monographs 27. Leeds: F. Cairns, 1990.

MÜLLER-WIENER 1977 = Müller-Wiener, Wolfgang, Renate Schiele, és Wolf Schiele. Bildlexikon zur Topographie Istanbuls: Byzantion, Konstantinupolis, Istanbul bis zum Beginn d. 17. Jh. Tübingen: Wasmuth, 1977. 
NIQUET 2000 = Niquet, Heike. Monumenta virtutum titulique: Senatorische Selbstdarstellung im spatantiken Rom in Spiegel der epigraphischen Denkmaler. Heidelberger Althistorische Beiträge und Epigraphische Studien 34. Stuttgart: Franz Steiner, 2000.

NOVAK 1980 = Novak, David M. „Anicianae Domus Culmen, Nobilitatis Culmen”. Klio 2 (1980): 473-93. doi:10.1524/klio.1980.62.62.473.

NOVAK 1976 = Novak, David M. „Cirta and the Anicii of Uzappa: A Note”. Klio 1-2 (1976). doi:10.1524/klio.1976.58.12.21.

NOVAK 1979 = Novak, David M. „The Early History of Anician Family”. In Studies in Latin Literature and Roman History, Ed. Carl Deroux, Vol. I. Collection Latomus. Bruxelles: Latomus, 1979.

NTDAR $=$ A New Topographical Dictionary of Ancient Rome. Ed. Richardson, Lawrence jr. Baltimore: John Hopkins University, 1992.

Nuffelen 2012= Nuffelen, Peter van. Orosius and the Rhetoric of History. Oxford early Christian studies. Oxford: Oxford University, 2012.

O'DALY 1990 =O'Daly, Gerard. Augustine's City of God: A Reader's Guide. Oxford: Oxford University, 1990.

O'Donnell 1979 = O'Donnell, James J. Cassiodorus. Berkeley: University of California, 1979.

OlAJos 1966 = Olajos, Terézia. „Merobaudes müvei”. Antik Tanulmányok: Studia Antiqua 1 (1966): 172-88.

Oost 1968 = Oost, Stewart Irvin. Galla Placidia Augusta: A Biographical Essay. Chicago: Chicago University, 1968.

ORLANDI 2004 = Orlandi, Silvia. Epigrafia anfiteatrale dell'Occidente romano: anfiteatri e strutture annesse con una nuova edizione e commento delle iscrizionidel Colosseo. Vetera 15. Roma: Quasar, 2004.

ORLANDI 2006 = Orlandi, Silvia. „Le iscrizioni del Colosseo come base documentaria per lo studio del senato tardoantico". In Le trasformazioni delle élites in età tardoantica: atti del convegno internazionale, Perugia, 15 - 16 marzo 2004, Ed. Rita Lizzi Testa, 311-24. Saggi di storia antica 28. Roma: L'Erma di Bretschneider, 2006.

OSTROGORSKY 1936 = Ostrogorsky, Georg. „Die byzantinische Staatenhierarchie”. Seminarium Kondakovianum, 8 (1936): 41-61.

OSTROGORSKY 1956 = Ostrogorsky, George. „The Byzantine Emperor and the Hierarchical World Order". The Slavonic and East European Review 84 (1956): 1-14.

OSTROGORSKI 2003 = Ostrogorski, Georg. A Bizánci Állam története. ford. István Lénárd Magyar, Ferdinánd Németh, és Péter Prohászka. Budapest: Osiris, 2003.

PALMER 1990 = Palmer, Robert E. A. „Studies of the Northern Campus Martius in Ancient Rome”. Transactions of the American Philosophical Society 2 (1990): 1-64.

PASCHOUD 1989 = Paschoud, François. „Zosime, Eunape et Olympiodore, Témoins des Invasions Barbares". In Das Reich und die Barbaren, szerkesztette Evangelos K. Chrysos, Reprint 2016., 181-202. Veröffentlichungen des Instituts für Österreichische Geschichtsforschung 29. Berlin - Boston: De Gruyter, 1989.

Pensabene-PAnella 1993-94 = Pensabene, P - Panella, C. „Reimpiego e progettazione architettonica nei monumenti tardo-antichi di Roma, I". Atti della Pontificia accademia romana di archeologia 66 (1993-94): 111-283.

PLRE1 = Martindale, Jhon Robert, Arnold Hugh Martin Jones, és John Morris, Ed. The Prosopography of the Later Roman Empire A.D. 260-395. Vol. 1. The Prosopography of the Later Roman Empire. Cambridge: Cambridge University, 1971. 
PLRE2 = Martindale, Jhon Robert, Ed. The Prosopography of the Later Roman Empire A.D. 395527. Vol. 2. The Prosopography of the Later Roman Empire. Cambridge: Cambridge University, 1980.

PLRE3A = Martindale, Jhon Robert, Ed. The Prosopography of the Later Roman Empire A.D. 527641. Vol. III A. The Prosopography of the Later Roman Empire. Cambridge: Cambridge University, 1992.

PLRE3B = Martindale, Jhon Robert, Ed. The Prosopography of the Later Roman Empire A.D. 527641. Vol. III B. The Prosopography of the Later Roman Empire. Cambridge: Cambridge University, 1992.

POHL $1980=$ Pohl, Walter. „Die Gepiden und die Gentes an der Mittleren Donau nach dem Zerfall der Attillareiches". In Die Völker an der mittleren und unteren Donau im fünften und sechsten Jahrhundert: Berichte des Symposions der Kommission für Frühmittelalterforschung 24. bis 27. Oktober 1978, Stift Zwettl, Niederösterreich, 4:239305. Veröffentlichungen der Kommission für Frühmittelalterforschung. Bécs: Österreichischen Akademie der Wissenschaften, 1980.

POHL 1997 = Pohl, Walter. Kingdoms of the Empire: The Integraton of Barbarians in Late Antiquity. The Transformation of the Roman World 1. Leiden - New York: Brill, 1997.

PÓKECZ KovÁcs 2016 = Pókecz Kovács, Attila. „A magister officiorum”. Scriptura, 1 (2016): $138-56$.

POTTER 2015 = Potter, David S. Theodora: Actress, Empress, Saint. Women in Antiquity. New York: Oxford University, 2015.

ProstKo-Prostyński 1994 = Prostko-Prostyński, Jan. Utraeque Res Publicae: The Emperor Anastasius I's Gothic Policy (491-518). 2. Publikacje Instytutu Historii UAM 1. Poznań: Instytut Historii UAM, 1994.

RANKE 1883 = Ranke, Leopold von. Weltgeschichte: Die Römische Republik und ihre Weltherrschaft. Berlin: Duncker \& Humblot, 1883.

Rawson 1999 = Rawson, Beryl, Ed. The Roman Family in Italy: Status, Sentiment, Space. Oxford: Oxford University, 1999.

RichaRdS 1979 = Richards, Jeffrey. The Popes and the Papacy in the Early Middle Ages, 476-752. Boston - London: Routledge \& Kegan Paul, 1979.

$\mathrm{RE}=$ Paulys Realencyclopädie der classischen Altertumswissenschaft. Ed. Georg Wissowa, Wilhelm Kroll, and Karl Mittelhaus, 83 vols, x, supplemental volume, cols 957-92. Stuttgart: Alfred Druckenmüller, 1890-1980.

RoBerts 2003 = Roberts, Walter E. A Study of Concordia: Changing Conceptions of Imperial Power and Responsibility in Late Antiquity. PhD disszertáció, Emory University, 2003.

RUGGINI 1988 = Ruggini, Lellia Cracco. „Gli Anicii a Roma e in provincia”. Mélanges de l'Ecole française de Rome. Moyen-Age 100 (1988): 69-85.

SALWAY 1994 = Salway, Benet. „What's in a Name? A Survey of Roman Onomastic Practice from c. 700 B.C. to A.D. 700". The Journal of Roman Studies (1994): 124-45. doi: $10.2307 / 300873$.

SARTORIUS 1811 = Sartorius, Georg Friedrich. Versuch über die Geschichte der Ostgothen während ihrer Herrschaft in Italien. Hamburg, 1811.

SEECK 1889 =Seeck, Otto. „Studien zur Geschichte Diocletians und Constantius II. Idacius und die Chronik von Constantinopel". Neues Jahrbucher für Philologie und Pädagogik 35 (1889): 601-35. 
SETtIPANi $2000=$ Settipani, Christian. Continuité gentilice et continuité familiale dans les familles sénatoriales romaines à l'époque impériale: mythe et réalité. Boston - Oxford: University of Oxford, 2000.

SHEPARD 2006 = Shepard, Jonathan. „Manners Maketh Romans? Young Barbarians”. In Byzantine Style, Religion and Civilization: In Honour of Sir Steven Runciman, Szerk. Elizabeth Jeffreys, 135-58. Cambridge: Cambridge University, 2006.

SHERWIN-WHITE 1973 = Sherwin-White, Adrian Nicholas. The Roman Citizenship. Reprint (1996). Oxford: Oxford University, 1973.

SHORTER 1991 = Shorter, Edward. Women's Bodies: A Social History of Women's Encounter with Health, Ill-Health, and Medicine. New Brunswick: Transaction, 1991.

SORACI 1974 = Soraci, Rosario. Ricerche sui conubia tra Romani e Germani nei secoli IV-VI. Catania: Muglia, 1974.

SPEIDEL 1998 = Speidel, Michael P. „The Slaughter of Gothic Hostages after Adrianople”. Hermes 4 (1998): 503-6.

SPINETOLI 1986 = Spinetoli, Ortensio da. Lukács: A szegények evangéliuma. ford. Alfréd Turay. Luca: Cittadella Editrice, 1986.

STALLKNECHT 1969 = Stallknecht, Bernt. Untersuchungen zur römischen Aussenpolitik in der Spätantike (306-395 n. Chr.). Rhein. Frieddr.-Wilh.-Univ., 1969.

STEIN 1949 = Stein, Ernst. Histoire du Bas-Empire. Ed. Jean-Rémy Palanque és Ernst Stein. Vol. 2. Paris: Desclée de Brouwer, 1949.

SuNDWALL 1919 = Sundwall, Johannes. Abhandlungen zur geschichte des ausgehenden Römertums. Öfversigt af Finska Vetenskaps-Societetens Förhandlingar. Helsingfors: Helsingfors Centraltryckeri och Bokbinderi Aktiebolag, 1919.

SwAIN 2010 = Swain, Brian. „Jordanes and Virgil: A Case Study of Intertextuality in the Getica”. The Classical Quarterly 1 (2010): 243-249.

SYME 1971 = Syme, Ronald. Emperors and Biography: Studies in the „Historia Augusta”. Clarendon, 1971.

SzÉLL 2005 = Hydatius. Chronica (379-469). Fordította Széll Gábor. Documenta historica 68. Szeged: JATEPress, 2005.

THOMPSON 2002 = Thompson, Eduard A. Romans and Barbarians: The Decline of the Western Empire. Wisconsin Studies in Classics. Madison: University of Wisconsin, 2002.

TREITINGER 1956 = Treitinger, Otto. Die oströmische Kaiser- und Reichsidee nach ihrer Gestaltung im höfischen Zeremoniell. Darmstadt, 1956.

TwYMAn 1970 = Twyman, Briggs L. „Aetius and the Aristocracy”. Historia: Zeitschrift Für Alte Geschichte 4 (1970): 480-503. doi:10.2307/4435155.

VÁCZY 1935 = Váczy, Péter. „Haldokló Antik Középkor”. In Egyetemes Történet, Ed. Bálint Hóman, Gyula Szekfü, \& Károly Kerényi, Vol. 2.: A Középkor Története. Budapest: Magyar Szemle Társaság, 1935.

VANDERLINDEN 1946 = Vanderlinden, S. „Revelatio Sancti Stephani (BHG 7850-6)”. Revue des études byzantines 1 (1946): 178-217.

VÁRADY 1976 = Várady, László. „Jordanes-Studien. Jordanes und das »Chronicon« des Marcellinus Comes - Die Selbständigkeit des Jordanes". Chiron: Mitteilungen der Kommission für Alte Geschichte und Epigraphik des Deutschen Archäologischen Instituts, 6 (1976): 441-87.

VÁRADY 1984 = Várady, László. Epochenwechsel um 476: Odoaker, Theoderich d. Gr. und die Umwandlungen. Anhang: Pannonica. Budapest: Akadémiai Kiadó, 1984. 
VASILIEV 1932 = Vasiliev, Alexander Aleksandrovic. „Was Old Russia a Vassal State of Byzantium”. Speculum (1932): 350-60.

WARD-PERKINS 1984 = Ward-Perkins, Bryan. From Classical Antiquity to the Middle Ages: Urban Public Building in Northern and Central Italy, AD 300-850. Oxford Historical Monographs. Oxford, New York: Oxford University, 1984.

WARD-PERKINS 1999 = Ward-Perkins, Bryan. Re-using the architectural legacy of the past, entre idéologie et pragmatisme. In The Idea and Ideal of the Town. Leiden, Boston, Köln: Brill, $225-244$.

WARD-PERKINS 2006 = Ward-Perkins, Bryan. The Fall of Rome and the End of Civilization. Oxford: Oxford University, 2006.

WATTS 2004 = Watts, Edward. ,Justinian, Malalas, and the End of Athenian Philosophical Teaching in A.D. 529". The Journal of Roman Studies (2004): 168-82. doi: $10.2307 / 4135014$.

WeBER 1987 = WeBER, Max. Gazdaság és társadalom: A megértő szociológia alapvonalai. Budapest: Közgazdasági és Jogi K., 1987.

WeBER 1989 = Weber, Ronald J. „Albinus: The Living Memory of a Fifth-Century Personality”. Historia: Zeitschrift Für Alte Geschichte 4 (1989): 472-97.

Wenskus 1961 = Wenskus, Reinhard. Stammesbildung und Verfassung. Das Werden der frühmittelalterlichen gentes. Köln: Böhlau, 1961.

Wes 1967 = Wes, Marinus Antony. Das Ende des Kaisertums im Westen des römischen Reichs. Studiën van het Nederlands Historisch Instituut te Rome 2. Hague: Staatsdrukkerei, 1967.

WhitBy 1989 = Whitby, Michael, és Mary Whitby, Ed. Chronicon Paschale 284-628 AD. Translated Texts for Historians 7. Liverpool: Liverpool University, 1989.

WiLKES 1992 = Wilkes, John. The Illyrians. Oxford: Blackwell, 1992.

WIRBELAUER 1993 = Wirbelauer, Eckhard. Zwei Päpste in Rom: der Konflikt zwischen Laurentius und Symmachus (498-514): Studien und Texte. Quellen und Forschungen zur antiken Welt 16. München: Tuduv, 1993.

WIRBELAUER 1992 = Wirbelauer, Eckhard. „Zwei Päpste in Rom. Die Auseinandersetzungen um den römischen Episkopat in der Spätantike. Mit einer kritischen Edition der Symmachianischen und Laurentianischen Dokumente". Albert Ludwig Universität, 1992.

WOLFRAM 1979 = Wolfram, Herwig. Geschichte der Goten. Entwurf einer historischen Ethnographie. München: C. H. Beck, 1979.

WOLFRAM 1997 = Wolfram, Herwig. Die Germanen. München: C.H. Beck, 1997.

Wolfram 1990 = Wolfram, Herwig. History of the Goths. Trans. Thomas J. Dunlap. Berkeley Los Angeles - London: University of California, 1990.

WoOD 2008 = Wood, Ian. „Barbarians, Historians, and the Construction of National Identities”. Journal of Late Antiquity 1 (2008): 61-81.

WooD 2013 = Wood, Ian N. „The Uses and Abuses of Barbarian Invasions in the Nineteenth and Twentieth Centuries". In Manufacturing Middle Ages Entangled History of Medievalism in Nineteenth-Century Europe, szerk. Patrick J. Geary és Gábor Klaniczay, 51-69. National Cultivation of Culture 6. Leiden - Boston: Brill, 2013.

WORTLEY 1980 = Wortley, John T. „The Trier Ivory Reconsidered”. Greek, Roman and Byzantine Studies 21 (1980): 381-94.

ZacCagnino-Bevan-Gabov 2012 = Zaccagnino, Cristiana, G. Bevan, és A. Gabov. „The Missorium of Ardaburius Aspar: New Considerations on Its Archaeological and Historical Contexts". Archeologia Classica, 63 (2012): 419-54. 
ZECCHINI 1981 = Zecchini, Giuseppe. „La politica religiosa di Aezio”. In Religione e politica nel mondo antico, Ed. Marta Sordi, 250-77. Milánó: Vita e Pensiero, 1981.

ZECCHINI 1981A = Zecchini, Giuseppe. „La politica degli Anicii nel V secolo”. In Atti del Congresso Internazionale di Studi Boeziani (Pavia, 5-8 ottobre 1980), Ed. Luca Orbetello, 123-138. Roma: Herder, 1981.

ZECCHINI $2003=$ Zecchini, Giuseppe. „Latin Historiography: Jerome, Orosius and the Western Chronicles". In Greek and Roman Historiography in Late Antiquity: Fourth to Sixth Century A.D., Ed. Gabriele Marasco, 317-45. Leiden: Brill, 2003. 